UNIVERSIDADE DE SÃO PAULO

FACULDADE DE EDUCAÇÃO

LINGUAGEM E EDUCAÇÃO

\title{
O CINEMA NA ESCOLA: ASPECTOS PARA UMA (DES)EDUCAÇÃO
}

Daniel Marcolino Claudino de Sousa

São Paulo

2017 



\author{
UNIVERSIDADE DE SÃO PAULO \\ FACULDADE DE EDUCAÇÃO \\ LINGUAGEM E EDUCAÇÃO
}

\title{
O CINEMA NA ESCOLA: ASPECTOS PARA UMA (DES)EDUCAÇÃO
}

\author{
Daniel Marcolino Claudino de Sousa
}

Versão Corrigida

Tese apresentada ao Programa de PósGraduação em Educação da Faculdade de Educação da Universidade de São Paulo como requisito parcial para obtenção do título de Doutor em Educação.

Linha de Pesquisa: Linguagem e Educação

Orientador: Celso Fernando Favaretto

São Paulo

2017 
AUTORIZO A REPRODUÇÃO E DIVULGAÇÃO TOTAL OU PARCIAL DESTE

TRABALHO, POR QUALQUER MEIO CONVENCIONAL OU ELETRÔNICO, PARA FINS

DE ESTUDO E PESQUISA, DESDE QUE CITADA A FONTE.

Catalogação na Publicação

Serviço de Biblioteca e Documentação

Faculdade de Educação da Universidade de São Paulo

371.364 Sousa, Daniel Marcolino Claudino de

S725c O cinema na escola: aspectos para uma (des)educação / Daniel

Marcolino Claudino de Sousa; orientação Celso Fernando

Favaretto. São Paulo: s. n., 2017.

$355 \mathrm{p}$.

Tese (Doutorado - Programa de Pós-Graduação em Educação. Área de Concentração: Linguagem e Educação) - Faculdade de Educação da Universidade de São Paulo.

1. Experiência 2. Pedagógico 3. Cinema 4. Escola 5. Imagem

6. Benjamin, Walter I. Favaretto, Celso Fernando, orient. 


\title{
O CINEMA NA ESCOLA: ASPECTOS PARA UMA (DES)EDUCAÇÃO
}

\author{
Tese apresentada ao Programa de Pós- \\ Graduação em Educação da Faculdade de \\ Educação da Universidade de São Paulo \\ como requisito parcial para obtençãodo \\ título de Doutor em Educação.
}

Aprovada em:

\section{Banca Examinadora}

Professor:

Instituição:

Julgamento:

Assinatura:

Professor:

Instituição:

Julgamento:

Assinatura:

Professor:

Instituição:

Julgamento:

Assinatura:

Professor:

Instituição:

Julgamento:

Assinatura:

Professor:

Instituição:

Julgamento:

Assinatura: 

Este trabalho é dedicado àqueles que fomentam a dimensão de justeza da coisa pública, $e$ àqueles que sonham com os cinemas nacionais do chamado Terceiro Mundo. 
"Por mi parte, yo nunca he sido partidário, cuando se trata de aproximarse al arte, de la exhortación pedagógica de decirlo todo"

(Alain Bergala, 2007, p. 80)

"A mentalidade colonial dessa gente torna-a incapaz de imaginar sequer que uma situação normal exigiria que pelo menos 50\% dos filmes exibidos no Brasil fossem brasileiros"

(Paulo Emílio Sales Gomes, 1986, pp. 258-259)

"Mas há de chegar o dia em que deixaremos de ser mercadorias" (Jogador de futebol Daniel, personagem de Rio, 40 graus, de Nelson Pereira dos Santos) 


\section{AGRADECIMENTOS}

$A$

Adilson Citelli, pelo prazer de assistir a suas aulas na graduação e na Pós-graduação. Rinaldo Voltolini, pela honra e prazer das aulas na graduação e na Pós-graduação e pela clareza e importância do tema "educação" estudado por meio da psicanálise. Leandro de Lajonquière, pela discplina em que os alunos tiveram a oportunidade de ler os trabalhos uns dos outros e de comentá-los; pela disponibilidade em me receber para supervisão fora do país. Amaury César Moraes, pela participação no Exame de Qualificação, pelas sugestões e pelo empréstimo do conjunto de textos da FDE que antecederam o projeto $O$ cinema vai à escola. Rogério de Almeida, pelas importantes sugestões no Exame de Qualificação e pelo texto sobre Rashômon, cuja leitura me rendeu muito prazer. Sandro Francisco Detoni, pelos infinitos cafés que, em sua densidade, couberam partilhas inestimáveis de amizade, das políticas que surgiam entre um e outro dos muitos goles de cafeína e de álcool, além das referências a paternidades nebulosas e a Grandes Momentos; à irmandade inestimável. Diego, Dimas, Carolina, Joana, pelo carinho "uberabiano". Dimas, pela viagem cantada e repleta de verde que nunca esquecerei. André Felipe e Fernanda Souza, pela ternura, leveza, preguiça, e rodoviárias. Mari-Nilva, pelas cartas e sentimentos brindados, nascidos da sintonia de crenças em um mundo mais justo, ao humor dolorido de momentos ternos, fraternos; à irmandade e generosidade em baldes. César Moreira, pelo mel, pelos cafés, pelas janelas com vista para o coração. Carlos Vernillo, pelo olhar sempre generoso. Cleide Sousa, pela fortaleza gentil. Eveline da Silva, pelo sorriso e quereres atravessados, escondidos dentro de dois ou três livros. Felipe Passos, pelos pingue-pongues, almoços e pelas partilhas generosas; pelas nuanças psicanalíticas e à amizade que se constitui como um quadro, como a vida. Roger Buono, pelos pan-africanismos e iorubás que saltam com concretude urgente. Ao pessoal da Secretaria da Pós-Graduação, pela compreensão e orientação generosa quanto aos prazos e procedimentos; Francisca Raquel, pelos medos e efusões e ao que no fundo não sabemos e partilhamos desde sempre, com ou sem legendas. A Mohammad Reza Salehi, pelo humor maior que a vida. A Guilherme Torres, pela partilha de cafés e pelas generosas leituras, além das cervejas brindadas em discussões (im)puras; pela partilha de projetos, pela sensibilidade contida, pelo sorriso amigo, pelo desejo de revolução partilhado. Camila Guedes, pela gentileza nos 
dados sobre prazos, prorrogações e pelos bares e a vontade de mais. Iolanda, pelo sorriso e simpatia, Ailton, pela simpatia, Marquinho, pela gentileza costumeira, Didi, Pereira, Seu Maurício, Nilton, Rodrigues, Esther, pela simpatia e sorriso, Naldo. Jailton Oliveira, pela partilha de impressões de política, filmes, peças de teatro e pela sensiblidade em tudo isso. Jany Canela, pela vivacidade na partilha de ideias que salvariam o mundo pelo carinho sempre a postos. Josemar Marcolino, pela irmandade aprendida, pelos encontros nos desencontros. Juliana Maia, pela leitura e sugestões deste trabalho, pelos tempos de cafés e festivos encontros, pelos medos, anseios e alegrias partilhados. Maria Diomar de Souza Oliveira, pela saudade adiada e a vontade de estarmos juntos. Marilda Conceição, pela inocência e carisma, além da leitura atenciosa em certo momento da escrita. Miguel Fernandes, pelas músicas de sempre, pelos cordéis, e pelo trabalho que lhe tirou a infância, cujas marteladas sempre me lembraram as dolorosas de mestre José Amaro, de "Fogo morto", o melhor romance já escrito no mundo ("Ouvia o gemer da filha. Batia com mais força na sola."). Priscila Grycia, pelos acordes atonais que saltaram das cordas, pelo sorriso. Tia Izabel, Tia Maria, Tio Napoleão, Tio Miguel, Cassinha. Maria Stello, Mariana, Nathalia e à viagem que fizemos juntos a São João Del Rei. José Miguel de Souza, pela delicadeza e amizade. A Vicente Gonçalves de Oliveira Neto, pelo carinho imenso, irmandade, amizade fraterna e companheira de sempre, pelo humor, pela música, pelo tanto que não se diz e, no entanto, partilha-se; à Nara Lee, pela entrega inteira. Vicente Junior, pelo passado que se estende para frente. Laerte e Kátia Fedrigo, pela partilha de sonhos, que se derramam, juntos. Ivan Vieira, pela amizade.

À FAPESP, cujo amparo financeiro a este trabalho abrandou as disposições da dureza próprias à pesquisa. Ao/À parecerista da FAPESP, que, no anonimato que lhe cabe, fez intervenções fundamentais para a melhora do trabalho desde a análise inicial do projeto desta pesquisa.

A Celso Favaretto, que não apenas tornou possível este trabalho, mas atribuiu a precisão dos conceitos que, por ventura, encontrem-se aqui; a seu olhar cirúrgico e reiterado; pelas muitas leituras e generosas colaborações, além do encanto que me gerou, dentre outras, a menção aos convites que fizera a Paulo Emílio Sales Gomes e 
a Roberto Santos (O grande momento e A hora e a vez de Augusto Matraga) para participarem de suas aulas quando, na ocasião, era professor do ensino básico; à dureza da escuta (que suscitou este trabalho) da qual não pude escapar; à dimensão de experiência benjaminiana partilhada nas reuniões de orientação. À Sônia, pela torcida e simpatia constante, além das partilhas de bolos e cafés.

À FDE, nas pessoas de Lizete Freire Onesti e Devanil Tozzi, pela prontidão generosa quanto ao fornecimento de informações importantes sobre o projeto O cinema vai à escola, tanto pessoalmente, em entrevista, quanto por e-mail ou telefone. À Casa de Referência Mário Covas - CRE, nas pessoas de Nana e Nieko que, com toda presteza, me doaram dois dos quatro volumes da coleção Lições com Cinema. Marco Napolitano, pela entrevista concedida.

A Ferdinando Crepalde Martins, pelo carinho, pelas leituras, sugestões, amizade e irmandade inestimáveis, irãs, alemanhas, segredos, fraquezas/fortalezas partilhados; pelo humor de dentes e da alma, desde sempre.

À Ana Paula Nunes Chaves, pela companhia, carinho, críticas aos primeiros textos e torcida desde o projeto inicial; à amizade, à irmandade, aos chiles, minas, rios $e$ augustas partilhados, à tristeza que nos espreitou aqui, ali, à alegria, à inestimável presença e delicadeza, à grande e fraterna amizade. 


\section{RESUMO}

SOUSA, Daniel Marcolino Claudino de. O cinema na escola: aspectos para uma (des) educação. 2017. 326p. Tese (Doutorado em Educação). São Paulo: Faculdade de Educação da Universidade de São Paulo, 2017.

O projeto "O cinema vai à escola", da SEE-SP/FDE (de 2008 a 2015), é objeto de estudo do presente trabalho, que o examina aproximando as perspectivas do cinema e da educação. Para tanto, parte da questão benjaminiana do empobrecimento da experiência e, de algum modo, da adorniana do empobrecimento do repertório de imagens, buscando identificar modos de uso do cinema na escola e investigando se e em que medida o referido projeto provoca o empobrecimento da experiência em razão dos meios aplicados na oficialização da entrada do cinema na escola. Em geral, o cinema na escola é sustentado por um discurso pedagógico oficial que especifica e atribui o lugar do cinema no universo escolar. Interessa a esta pesquisa identificar e analisar esses lugares. Cinematografias, tais como a de Godard, a do Neo-realismo italiano e a do Cinema Novo brasileiro confrontam e se colocam como referências a esse lugar atribuído ao cinema pela escola. Entende-se aqui que a perspectiva desses cinemas, bem como nossa concepção de escola, cuja função primordial tem a ver com o deslocamento das referências estabilizadas dos sujeitos, não se constituem de elucubrações desconectadas da chamada realidade do universo escolar atual. Ao contrário, entendem que o presente em que parece se constituir o filme opera aí encaminhamentos sem solução definitiva. Contudo, ao se utilizar de modo ilustrativo do cinema, o discurso pedagógico hegemônico nas escolas, a despeito da discussão sobre a diluição do sujeito - isto é, da perda da perspectiva histórica unitária -, fortalece esse lugar do "sujeito", entendido como oposição ao "objeto". Assim, promove um modo de aprendizagem que toma o "conteúdo" da obra, a "mensagem do filme", como objeto central, moralizando-o. Dessa forma, não o considera obra de arte ou mesmo objeto de vivência, reduzindo-o a recurso pedagógico que pode "facilitar" os estudos de teor cientificizantes. Nesse sentido, faz-se importante a investigação sobre a ideia de currículo e o lugar que nele ocupa a arte e mais especificamente o cinema, em virtude da urgência uníssona quanto ao tratamento das mídias e do cinema na escola. Para tanto, este trabalho analisa textos oficiais da SEE-SP (os “Cadernos de cinema do professor" e os vídeos sobre o Projeto), que regulamentam a entrada do cinema na escola, dentre vários outros. Em tempo, tomamos como parâmetro a experiência francesa transposta em livro por Alain Bergala (2007), além de conceitos importantes no estudo da arte como "indústria cultural", de Adorno e Horkheimer. 
Palavras-chave: Experiência. Pedagógico. Imagens. Cinema. Walter Benjamin. Escola. Theodor Adorno. 


\begin{abstract}
SOUSA, Daniel Marcolino Claudino de. The cinema in school: aspects for a (des) education. 2017. 326p. Thesis (Doctorate in Education). São Paulo: Faculty of Education, University of São Paulo, in 2017.

The project 0 cinema vai à escola ("Cinema goes to school"), from SEE-SP / FDE (2008 to 2015), is the subject of study of the present work, which examines it by approaching the perspectives of cinema and education. Thus, begins from the Benjaminian question of the impoverishment of experience and, in some way, of the embellishment of the impoverishment of the repertoire of images, seeking to identify ways of using cinema in school and investigating if and to what extent the said project causes the impoverishment of experience through the ways of the entrance of the cinema in school. In general, cinema at school is supported by an official pedagogical discourse that specifies and attributes the place of cinema in the school universe. This work identifies and analyzies these places. Cinematographies, such as Godard's, Italian Neo-realism and Brazilian Cinema Novo, confront and place themselves as references to this place attributed to cinema by school. It is understood here that the perspective of these cinemas, as well as our conception of school, whose primary function has to do with the displacement of the stabilized references of the subjects, do not constitute of lucubrations disconnected from the socalled reality of the current school universe. On the contrary, they understand that the present in which the film appears to constitute the film operates there with no permanent solution. However, in using illustrative cinema, hegemonic pedagogical discourse in schools, in spite of the discussion about the dilution of the subject - that is, of the loss of the unitary historical perspective - strengthens this place of the subject. Thus, it promotes a mode of learning that takes the "content" of the work, the "message of the film", as the central object, moralizing it. In this way, it does not take it as a work of art or even as an object of experience, reducing it to a pedagogical resource that can "facilitate" scientific studies. In this sense, it is important to investigate the idea of curriculum and the place that art occupies in it, and more specifically the cinema, because of the unanimous urgency regarding the treatment of media and cinema in school. In order to do so, this work analyzes the official texts of the SEE-SP (Cadernos de Cinema do Professor - "Teacher's Film Schedules" - and the videos about the Project), among others, which regulate the entrance of cinema to school. In time, we took as a parameter the French experience transposed in book by Alain Bergala (2007), as well as important concepts in the study of art as "cultural industry", by Adorno and Horkheimer.
\end{abstract}


Keywords: Experience. Pedagogical. Images. Movie theater. Walter Benjamin. School. Theodor Adorno. 


\section{SUMÁRIO}

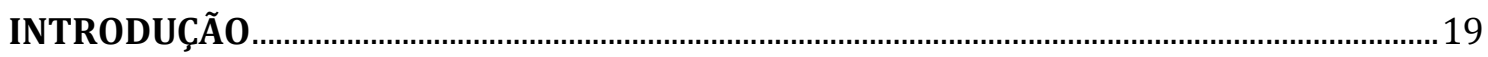

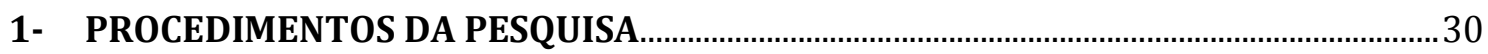

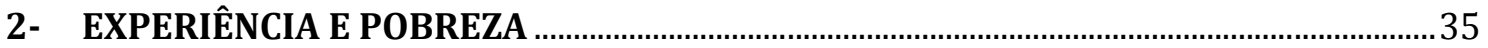

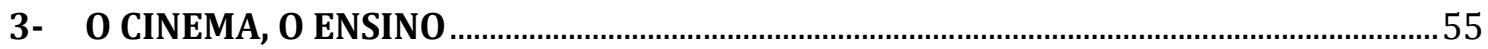

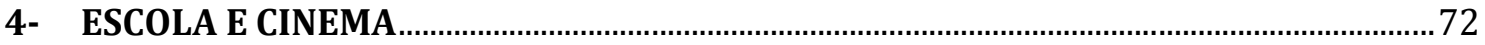

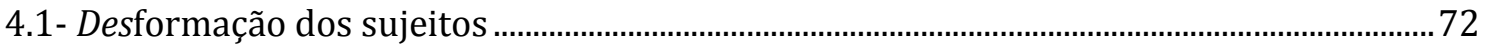

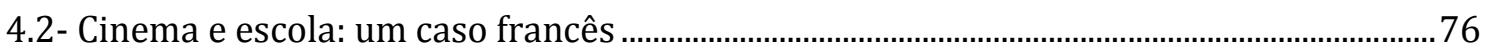

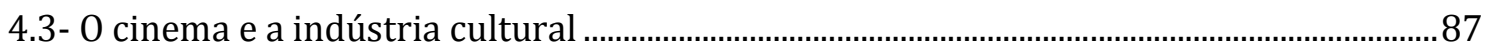

4.5- A escola como lugar da polifonia e o deslocamento do sujeito ............................................ 103

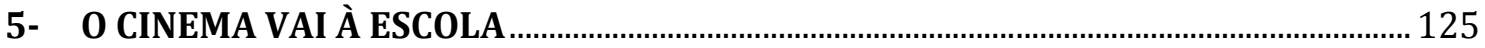

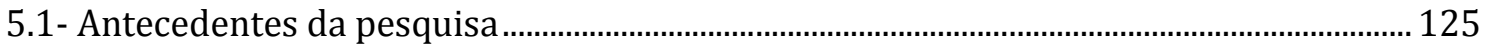

5.2- Antecedentes históricos da relação do cinema com a escola no Brasil ........................... 139

5.3- Aparelhagem para a projeção de filmes na escola ................................................................... 158

5.4- A ideia de currículo subjacente à Proposta Curricular do Estado de São Paulo ............ 167

5.5- A Disciplina Arte na Proposta Curricular e no Currículo do Estado de São Paulo ........ 189

5.6- Caderno do Professor: a disciplina Arte ..................................................................................... 218

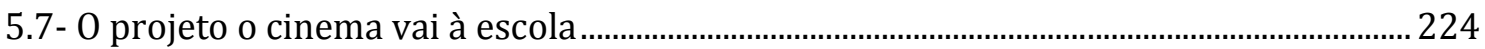

5.8- Os Cadernos de Cinema do Professor do projeto 0 cinema vai à escola............................ 286

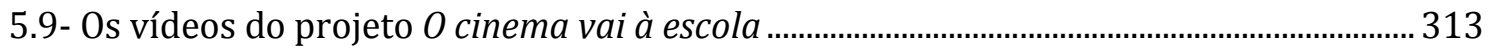

CONCLUSÃO

REFERÊNCIAS 


\section{Lista de Siglas}

ABE - Associação Brasileira de Educação

ANCINE - Agência Nacional do Cinema

APAE - Associação de Pais e Amigos dos Excepcionais

CENP - Coordenadoria de Estudos e Normas Pedagógicas

CEU - Centro Educacional Unificado

DE - Diretotia de Ensino

EaD - Ensino a Distância

ECA - Escola de Comunicações e Artes

DIP - Departamento de Imprensa e Propaganda

ENEM - Exame Nacional do Ensino Médio

FDE - Fundação para o Desenvolvimento da Educação

IACC - Instituto de Arte e Cultura do Ceará

IDEB - Índice de Desenvolvimento da Educação Básica

IDESP - Índice de Desenvolvimento da Educação no Estado de São Paulo

INCE - Instituto Nacional de Cinema Educativo

LDB - Lei de Diretrizes e Base da Educação

MASP - Museu de Arte de São Paulo

MEC - Ministério da Educação

MPPC - Motion Picture Patents Company

PAN - Panorâmica (movimento de câmera)

PCN - Parâmetros Curriculares Nacionais

PCNP - Professores Coordenadores de Núcleo Pedagógico

PCOP - Professor Coordenador Pedagógico

PDM - Plano de Diretrizes e Metas para o Audiovisual

PNLD- Programa Nacional do Livro Didático

PPP - Projeto Político Pedagógico

SAEB - Sistema Nacional de Avaliação Básica

SARESP - Sistema de Avaliação de Rendimento Escolar do Estado de São Paulo

SIEC - Sistema do Escola em Cena

SISVIC - Sistema de Distribuição de Vagas às Instituições Culturais

SOCINE - Sociedade Brasileira de Estudos de Cinema e Audiovisual 
SSE-SP - Secretaria de Educação do Estado de São Paulo

UNESCO - Organização das Nações Unidas para a Educação. 


\section{INTRODUÇÃO}

A história da inserção do cinema $^{1}$ na educação formal tem início já na primeira infância da chamada "sétima arte". De acordo com Serrano e Filho (1930, p. 27-28), o chamado cinema educativo, ou cinema educador ${ }^{2}$, teve sua primeira ocorrência em 1898, ocasião em que um médico e professor chamado Doyen, em Paris, teve uma de suas operações filmada a fim de ser usada em sala de aula com seus alunos. Sem entrar no mérito de afirmar se tal filmagem pode ser considerada (a rigor) cinema ou não, o episódio é ilustrativo, no sentido de afirmar que já havia, naquela época, a preocupação de sua utilização como recurso pedagógico.

No III Congresso Internacional de Educação realizado em Bruxelas, em 1910, o cinema foi destaque porque, segundo os organizadores, havia filmes que ameaçavam os bons costumes com algumas cenas "inconvenientes". Em 1916, Edouard Herriot, membro da comissão extraparlamentar, criada na Universidade de Bruxelas para pensar a utilização do cinema com fins educativos, emite parecer denunciando a "sugestão criminosa de cenas cinematográficas. Roubos, assassinatos, reproduzidos na tela, ficam fortemente gravados na mente infantil ou adolescente. É uma perigosa instigação." (SERRANO \& FILHO, 1930, p. 27-28).

Pelo argumento do autor, ainda que nos filmes os criminosos fossem presos e que ficasse evidente a vitória do bem sobre o mal, a simples figuração (representação) desses personagens e das situações de crime na tela, induziria as pessoas (crianças e adolescentes) a praticar os mesmos atos na vida cotidiana.

A lógica desse pensamento, ainda muito comum hoje em dia $^{3}$, além de pressupor que a intermediação do professor seja pouco eficaz, concebe o

\footnotetext{
${ }^{1}$ Ainda que consideremos importantes os vários projetos desenvolvidos nas escolas do estado de São Paulo com o audiovisual relacionados a games e novas tecnologias (celulares, ipod etc.), objetivamos aqui, conforme título de nosso trabalho, tratar do cinema como a arte de produção de longas e curtas-metragens a serem exibidos para uma coletividade (considerando que a escola utiliza o cinema em formato DVD) na escola, e não do audiovisual de modo geral. Quando mencionarmos "audiovisual", estaremos enfatizando a dimensão orgânica, quase "fisiológica" do cinema, que se utiliza da imagem e da palavra, em articulação, não apenas sobre ou justapostas. ${ }^{2}$ Cinema educador, aqui como mera inserção do cinema no campo educacional, como ilustrador de conteúdo.

${ }^{3}$ Basta que tomemos como exemplo a indicação de idade mínima trazida nos cartazes para os filmes, que se utiliza frequentemente de parâmetros moralistas para tal indicação, sendo que um nu frontal, mesmo não sensualizado, pode elevar a idade mínima para 18 anos.
} 
espectador como inapto para a recepção crítica dos elementos apresentados pelos filmes, parecendo desconsiderar que "o público estabelece o contrato entre a obra de arte e o mundo." (DUCHAMP, apud FAVARETTO, 2014, p. 07). Os filmes, pois, seriam educativos apenas na medida em que confirmassem os valores oficiais defendidos pela escola, esta marcada fortemente por uma vertente moralista.

No Brasil, o Manifesto dos Pioneiros da Escola Nova, de 1932, também marcará a relação do cinema com a educação formal, uma vez que o documento defende expressamente a entrada do cinema no ambiente escolar: "A escola deve utilizar, em seu proveito, com a maior amplitude possível, todos os recursos formidáveis, como a imprensa, o disco, o cinema e o rádio" (AZEVEDO, 2010, p. 62). Consequência dessa efervecência e concepção será a criação do Instituto Nacional de Cinema Educativo - INCE, em 1937.

Anteriormente ao Manifesto dos Pioneiros da Escola Nova, já em 1927, antes do início da Segunda República, havia menção à participação do cinema na educação por ocasião da I Conferência Nacional de Educação, realizada em Curitiba, cujo objetivo maior, expresso nas 111 teses publicadas em decorrência de tal evento, parecia ser o de fazer convergir esforços para a implementação dos ideários positivistas, que tinham o progresso como baluarte.

É curioso que a concepção do uso de cinema na educação desses dois documentos citados acima encontre ainda hoje, mesmo que de maneira mais sofisticada e mais desenvolvida (como veremos mais adiante), indícios de uso ilustrativo do cinema e, portanto, auxiliar no bojo do que efetivamente movimenta a escola - a saber, o currículo, que é fundamentalmente disciplinar. A potência do cinema como arte, pois, parece frequentemente arrefecida pelos documentos e propostas pedagógicas que formalizam a entrada desta arte no universo escolar.

Ao longo deste trabalho, procuraremos analisar vários documentos, sobretudo, o projeto $O$ cinema vai à escola - a linguagem cinematográfica na educação, concebido e realizado pela SEE-SP/FDE 4 a partir de 2008, que aponta

\footnotetext{
${ }^{4}$ Secretaria de Educação do Estado de São Paulo - SEE-SP - e Fundação para o Desenvolvimento da Educação - FDE. A FDE é subordinada à SEE-SP, mas em determinados momentos fica claro o papel que cada uma desempenha, por vezes antagônicos, caso da suspensão (não renovação do programa Cultura é Currículo) do projeto $O$ cinema vai à escola, ocorrida em 2015 por meio de ofício expedido pela SEE-SP em 03 de agosto de 2015, segundo a própria FDE, em razão de corte no orçamento do governo do Estado. A suspensão do projeto se deu por deliberação da SEE-SP em contrariedade às 20
} 
diferentes concepções quanto ao uso do cinema no universo escolar, como é possível constatar em diversas propostas efetuadas em publicações de congressos importantes que discutiram a questão, como aquele realizado pela SOCINE (Sociedade Brasileira de Estudos de Cinema e Audiovisual). É o caso de A Intuição Democrática no Ensino Audiovisual de Jovens para Jovens, de Moira Toledo Dias Guerra Cirello (SOCINE, 2009), que aposta no ensino do cinema enquanto expressão artística e como profissionalização dos alunos como se tratasse de um curso específico de cinema e não situado no contexto escolar de ensino básico, com todas as dificuldades que lhe são próprias. A autora fala no surgimento de "novos talentos", que seriam absorvidos pelo mercado. 0 fazer cinema, nessa perspectiva do mercado, serviria para aprimorar a convivência em grupo, uma vez que se trataria de uma arte produzida coletivamente.

O trabalho Filme histórico: novas formas de circulação e ampliação de público, de Bruno Hingst (SOCINE, 2010), busca investigar projetos no plano do governo paulista realizados entre 1995 e 2009, que apresentassem semelhanças com a "Programadora Brasil" (projeto da central de acessos para filmes brasileiros da Secretaria de Educação do Governo Federal) que disponibiliza filmes em DVD para exibição não-comercial em circuitos alternativos, como escolas, universidades, cineclubes, pontos de cultura e centros culturais, "bem como os resultados obtidos com esta nova forma de se ampliar a circulação de filmes." (SOCINE, 2010).

O autor pretende comparar tais iniciativas contemporâneas com ações desenvolvidas durante o Estado Novo (1937-1945), que tinha à época a preocupação com "o desenvolvimento de políticas culturais que gerassem um conceito de nação, com fortalecimento natural de sua história." (SOCINE, 2010, Bruno Hingst). Para tanto, naquele período, o Estado buscou em filmes como Pátria e bandeira (1917), de Simões Coelho, Tiradentes (1917), de Perassi Felice, e Caçador de diamantes (1932), de Vittorio Capellaro, evidências de um projeto nacional. Em um momento de acentuado viés ufanista, a exibição de filmes nas escolas promoveria certa predisposição à formação de um espírito de nacionalidade. Nos filmes exibidos atualmente através do projeto "Programadora 
Brasil", do Governo Federal, os títulos transmitem visões muito diferentes daquelas expostas nos títulos exibidos pelo Estado Novo. São os casos de Xica da Silva (1976), de Cacá Diegues, e Carlota Joaquina (1995), de Carla Camurati, em muito distintos principalmente no que concerne ao tratamento de termos nacionalistas. Tais filmes são, antes, deboche, sátira à idealização da aristocracia do Brasil imperial e também à idealização geral de Brasil, no tocante à sua formação. Os filmes de Simões Coelho e de Perassi Felice, citados anteriormente, ao contrário, são sérios e afirmam um projeto de nacionalidade.

0 trabalho $A$ escola documentária - A dimensão visual do real, de Alexandre Buccini, analisa a produção de documentários em escolas a fim de tentar perceber como tal atividade interfere na "qualidade da educação e de libertação do pensamento" (BUCCINI, SOCINE, 2010), parecendo crer que a produção de documentários pelos próprios alunos mudaria o quadro comum nas escolas brasileiras de "indisciplina" e de "desinteresse" dos alunos pelos estudos, uma vez que tal estratégia conferiria poder aos "oprimidos". Trata-se, a nosso ver, de uma visão romântica do cinema como recurso pedagógico, que desconsidera as causas da indisciplina e do desinteresse, apresentando o cinema como "distração", brinquedo para entretenimento, além de o diagnóstico do autor ser reducionista, já que ele elege a "indisciplina" e o "desinteresse" dos alunos como os principais problemas da escola atual, tomando o efeito pela causa.

Considerando os exemplos acima, identificamos duas vertentes de um mesmo problema. De um lado, a abordagem que não prioriza o cinema como gênero artístico, tomando-o como ilustração de assuntos mais "nobres" do currículo. De outro, o ensino do cinema como instrumento de profissionalização (ou ainda, a proposta de fazer cinema na escola, "colocar a mão na massa"). Por consequência, de acordo com tais abordagens, o cinema promoveria o gosto, inclusive, pelos estudos, contribuindo para a mudança no quadro de indisciplina, fenômeno comum nas escolas brasileiras e, ao que tudo indica, também no mundo. Entre um e outro, a noção de cinema como entretenimento é a tônica.

Essas vertentes parecem contribuir para a despotencialização do uso do cinema no Ensino Básico pela submissão da estrutura espectatorial do cinema ao conteúdo das disciplinas. No segundo caso, pelo excesso, em virtude de o professor 
transferir a condução da atividade fazer cinema para os alunos, supondo que essa participação se constitui em protagonismo juvenil, enfraquecendo sua mediação e apequenando o papel da constituição de uma espectatorialidade ${ }^{5}$.

O projeto $O$ cinema vai à escola, em princípio, aposta na produção da espectatorialidade, na medida em que fornece material impresso e audiovisual (filmes e vídeo didático) para a formação do público jovem em ambiente escolar. Investigaremos esse material a fim de procurar perceber se as concepções de cinema que eles manifestam permitem (e em que medida) uma entrada na experiência estética específica propiciada por esta forma de arte.

Se a presença do cinema na educação formal no Brasil apresenta uma trajetória que remonta já desde 1898, a consolidação dessa relação nas escolas é relativamente tardia. Assim, há uma lacuna no que diz respeito à inserção estrutural do trabalho com o cinema na escola através de uma regulamentação formal como ocorreu com as demais disciplinas. Para se ter ideia do retardamento da incorporação de um trabalho mais estrutural, apenas no ano de 2014 é aprovado e sancionado (Lei 13.006, de 26 de junho de 2014), pela presidenta Dilma Rousseff, um parágrafo de autoria do senador Cristovam Buarque (PDT-DF), acrescido ao Art. 26 da LDB, Lei No. 9.394/96, que torna obrigatória a exibição de filmes brasileiros nas escolas de, no mínimo, duas horas mensais ${ }^{6}$. Mas, apesar de tal medida, a exibição de filmes integrada à proposta pedagógica da escola ainda é bastante frouxa. Trata-se, todavia, de uma indicação de que há preocupação quanto à inclusão do cinema entre as necessidades escolares. É compreensível, pois, que a entrada do cinema na escola esteja se dando segundo critérios optativos, ficando a cargo de cada unidade escolar o trabalho de incluí-lo em seu currículo, uma vez que se trata de um "componente curricular complementar" (§ $\left.8^{\circ}\right)$.

\footnotetext{
${ }^{5}$ Espectatorialidade é aqui usada quanto à relação do espectador com a obra, não apenas aos aspectos que envolvem a "personalidade psíquica" (SOURRIAU apud AUMONT, 2003, p. 107) do espectador, mas quanto às reações que duram depois da projeção e que têm a ver com a lembrança do filme ou com uma "espécie de impregnação produtora de comportamento", conforme Étienne Souriau (ver verbete espectatorial em AUMONT, 2003, p. 107).

6"§ 8‥ A exibição de filmes de produção nacional constituirá componente curricular complementar integrado à proposta pedagógica da escola, sendo a sua exibição obrigatória por, no mínimo, 2 (duas) horas mensais." (http://presrepublica.jusbrasil.com.br/legislacao/125304834/lei-1300614, acesso em 25 de Novembro de 2014).
} 
Sendo o filme, portanto, um "componente curricular complementar" aplicado ao livre arbítrio de cada unidade escolar, é de se perguntar por que a indicação do cinema nessa lei e não outra linguagem artística. Por que o cinema e não o teatro ou a música? Na tentativa de responder a esta questão, veremos como isso ocorre no caso específico de O cinema vai à escola - a linguagem cinematográfica na educação.

Esta tese pretende investigar no projeto da SEE-SP as implicações do uso de filmes como elementos que dariam suporte pedagógico ao professor, bem como averiguar o processo de eleição das obras e quais são os atores imbuídos neste processo.

Nesse sentido, procuraremos pensar a espectatorialidade do cinema na escola e não onde essa arte se apresenta "originalmente" (salas de cinema, cineclubes ou mesmo em casa, seja por meio do DVD, celular ou do computador). Pretende ainda identificar os critérios de escolha dessa arte e a expectativa do que se pretende atingir com ela.

Dentre vários outros aspectos a serem analisados, levaremos em conta as condições técnicas das unidades escolares para a projeção de filmes e que finalidades específicas esperam-se atingir. Procuraremos verificar se o cinema apresentado pelo projeto O Cinema vai à escola continua cinema (isto é, se em alguma medida ele continua arte, considerando as necessidades de transformação da obra em recurso pedagógico). Pensamos que o modo como o cinema aparece no discurso do professor e de que modo este o convoca para compor sua aula seja determinante para a configuração do tipo de recepção que se pretende formar. Destas escolhas (com todas as limitações a que o professor é submetido) decorrerá a avaliação que constará se o cinema será tomado em sua dimensão de arte (ou um esforço nesse sentido) ou se ele comporá o cenário apenas como um recurso pedagógico auxiliar nas disciplinas. Não temos, contudo, a expectativa de que o cinema se transporte para a escola e permaneça exatamente aquele da sala comercial $^{7}$ de cinema, com todo o ritual e aparelhamento que lhe é próprio, mas

\footnotetext{
${ }^{7}$ Entendemos aqui como sala comercial de exibição de filmes aquelas em que se almeja o lucro, sendo, portanto, pouco comum a exibição de um filme que não atenda ao objetivo de atrair o chamado grande público. Nesse sentido, centros culturais como o Centro Cultural São Paulo ou a Galeria Olido (ambos administrados pela Prefeitura de São Paulo), não são salas comerciais. Há, contudo, salas comerciais em que são projetados filmes que, a princípio, não seriam elencados para 24
} 
procuraremos pensar se algo do imponderável próprio à arte resiste em sua transposição para a sala de aula.

Não estamos salientando essas questões a fim de mensurar em que situações, no caso do projeto da SEE-SP, o cinema seria ou não desrespeitado como arte, como se fosse possível aplicar uma escala ou um padrão de respeitabilidade ao uso que se faz do Cinema, com "c" maiúsculo. Com a concepção de arte da modernidade ${ }^{8}$, sobretudo, a partir do aparecimento dos ready made de Duchamp, fica claro que não se pode mais se referir a uma Arte com "a" maiúsculo. Considerando as mudanças na concepção de arte contemporânea, procuraremos verificar se o cinema ainda mobiliza a sensibilidade e o pensamento no contexto escolar, requisitos básicos a serem efetivados nas disciplinas de arte.

No intuito de aprofundar tal investigação, estabeleceremos aproximações entre o cinema e a educação, buscando atentarmos para singularidades desses dois regimes de produção de signos. A dificuldade de estabelecimento de uma crítica do cinema (a educação voltada para o cinema não pode prescindir da crítica de cinema) advém, como diz Deleuze (2004, p. 75), do duplo obstáculo: o de que a crítica não pode se restringir a uma descrição dos filmes, mas também não pode tão simplesmente aplicar-lhe conceitos que não vêm do cinema. Assim, de acordo com esse autor, o cinema está fadado a esse diálogo com outras expressões do pensamento:

A tarefa da crítica é formar conceitos, que evidentemente não estão 'dados' no filme, e que, no entanto, só convêm ao cinema [...]. Conceitos próprios ao cinema, mas que só podem ser elaborados filosoficamente. Não são noções técnicas [...], mas a técnica não é dada se não serve a fins que ela supõe e que ela não explica (DELEUZE, 2004, p. 75).

Em carta comentando o livro A Rampa, de Serge Daney (2007), publicada na Cahiers du Cinéma, em 1986, Deleuze afirma que “o cinema não tem nenhuma necessidade da crítica para encher as salas nem para preencher sua

uma sala puramente comercial, caso do Espaço Itaú de Cinema, mantida pelo banco Itaú, e o Cine Caixa Belas Artes, mantido por particular em parceria com a prefeitura de São Paulo e com a Caixa Econômica Federal, ambos situados também em São Paulo.

8 Temos em vista a diferença entre modernidade e modernismo proposta por vários autores, dentre eles, Marilena Chaui (1992), para quem a modernidade surge no final do século XVI e se estende até fins do século XIX, quando dá lugar ao modernismo, que se estende até os anos 1960. 
função social.” (DELEUZE, 2004, p. 94). Contudo, para a televisão, continua ele, antes de tudo, a função social supera a busca de uma função estética, "onde reina o plano médio, que recusa toda aventura da percepção em nome do olho profissional." (DELEUZE, 2004, p. 94). A formação profissional do olho de que fala Deleuze supõe o mundo constituído de controladores e controlados, mediados pela admiração e vontade do contato com a técnica, o zoom-contact, como ele diz. Técnica e mais nada além da técnica, sobrepondo-se a pedagogia da percepção.

Essa vontade de contato com a técnica de que fala o filósofo francês parece jogar luz sobre a ilusão de autonomia conferida às atividades nas escolas com o fazer-cinema - "o colocar a mão na massa", que atribuiria autonomia crítica aos estudantes.

Escapando ao canto da técnica, a postura de Daney no referido livro, segundo Deleuze, é a da crítica a um só tempo estética e poética, o que o distancia daqueles que acreditam na restrição a um "formalismo lingüístico, a fim de salvar o caráter sério da crítica." (DELEUZE, 2004, p. 91). Contudo, há ainda aqueles, como Pasolini (PASOLINI, 2006), que acreditam que a crítica e o cinema nada têm em comum, exatamente porque cada um deles pertence a regimes tecnológicos distintos (palavra e imagem) e que só muito pobremente um poderia se referir ao outro. Isso porque o texto do filme seria "não encontrável" (Raymond Bellour apud AUMONT, 2007, p. 209), não citável, pois

as combinações entre imagem e som produzem, muitas vezes, impressões que não são traduzíveis em palavras e em frases, cujas significações são alcançadas com a utilização de outras regras de análise e de exposição distintas das utilizadas no estudo de documentos escritos (NOMA, 2006, p. 260).

Assim, em última instância, um filme só teria legitimidade de referir-se a outro filme na medida em que o suporte-imagem é o mesmo, da mesma forma que um texto, também pelas mesmas razões técnicas, somente poderia referir-se a outro texto, nunca um texto a um filme nem o contrário.

A despeito da tensão entre as opiniões diversas acima, considerando que nos encontremos licenciados para falar sobre o cinema, devemos lembrar aqui da existência de, ao menos, dois tipos de cinemas. Aquele visto em salas de cinema ao qual nos referíamos acima, e o visto em casa ou em outro ambiente privado. 
Este, como a confirmar o cinema na forma de exibição individual inventada por Thomas Edison, dentre outros aspectos, diferencia-se daquele visto em salas de cinema em razão de que, sendo manipulado pelo espectador, pode ser parado ou adiantado a qualquer momento.

Considerando as primeiras exibições públicas dos filmes dos irmãos Lumière como o nascimento do cinema, observamos que aquela experiência deu-se no período áureo do naturalismo no teatro. Ao transformar o cinema em linguagem, Méliès e Porter tomam emprestado desse naturalismo suas formas privilegiadas de exibição: a plateia sentada sob a luz apagada, a tela como um palco italiano e quarta parede, o filme como espetáculo a ser contemplado. Não por acaso, Marshal McLuhan (2009) irá considerar o cinema como um meio quente, saturado de informações, e a televisão um meio frio, exigindo esta, assim como o telefone - também um meio frio - maior participação das pessoas para a compreensão do que é veiculado. 0 controle remoto da televisão exercerá sobre o espectador o fascínio da busca da satisfação que faz correrem as imagens quando elas não lhe parecem importantes, quando lhe parecem descartáveis. Devido a esse controle é possível que o espectador em casa não termine de ver o filme ou o termine saltando as partes que não têm diálogo, "os vazios semânticos" que não lhe comunicam nada (não o afetam).

Nesse sentido, a seleção de filmes feita pela escola, que é focada especialmente nos temas recorrentes entre os alunos, não reforçaria a formação de seu mundo privado? Devido a essa ênfase, poderia a escola tomar como pressuposto que o acesso à dita “cultura de elite" (literatura, artes plásticas, música, teatro ou cinema) possa ser de uso comum, principalmente em escolas públicas? Para a investigação destas questões que relacionam o cinema e a educação, além daquelas apotandas anteriormente, nos reportaremos às proposições de Theodor Adorno e Max Horkheimer sobre indústria cultural $^{9}$ (ADORNO \& HORKHEIMER, 2006), buscando identificar e analisar, neste importante texto, o funcionamento da escola no papel de formadora da espectatorialidade frente ao fenômeno da indústria cultural. Para tanto, serão

\footnotetext{
${ }^{9}$ A noção de indústria cultural, cunhada por Adorno e Horkheimer, contrapõe-se à de cultura de massa (Lazarsfeld), que frequentemente remetia a uma produção supostamente espontânea, autêntica (Pra ver mais: ADORNO, 2009).
} 
importantes dois textos de Adorno que tratam da relação entre ideologia e televisão (1969a \& 1969b), que reforçam não apenas o cinema, mas também a televisão como instrumentos ideológicos. Assim, perguntamo-nos pelo papel da escola na formação do gosto e dos hábitos relacionados ao consumo cultural e se ela pode provocar o salto do gosto à experiência estética. Pergunta, na verdade, feita por nós aos documentos e ao projeto $O$ cinema vai à escola, na expectativa de verificar se tais documentos e o projeto em questão consideram essa hipótese.

Ainda que trabalhe em outro registro crítico, nos valeremos de Michel Foucault (1979, 2007, 2009, 2011), de Gilles Deleuze (2007a, 2007b, 2004, 1990) e também da psicanálise, por entendermos que nos ajudará a configurar lugares de saber no contexto escolar, importantes para compreendermos como se dá a entrada do cinema na escola. Com Sigmund Freud (1997) e Jacques Lacan (1992, 1998, 2005, 2008), que nos ajudarão a identificar e analisar os lugares atribuídos pelo Projeto ao cinema na escola. Além disso, interessam-nos autores como Rinaldo Voltolini $(2009,2011,2012)$ e Leandro de Lajonquière $(1998,2010)$, que estabelecem diretamente a relação entre psicanálise e educação, bem como Maria Rita Kehl (2002, 2009, 2015a, 2015b, 2015c), dentre outros, cujas abordagens contribuirão para a análise da questão do sujeito e da escola como sistematizadora do trabalho pedagógico.

Alguns textos nos interessaram pontualmente, caso de $O$ Pensamento do Exterior (1966), de Michel Foucault. Deste autor, tomaremos também alguns outros como A Ordem do Discurso (2011), ainda que a obra se constitua, em grande medida, num texto indicial, que antes aponta que sistematiza noções de lugares de poder, modos de subjetivação etc., que, sabemos, serão detidamente desenvolvidos em outras obras. Para melhor compreensão dessas questões, recorremos a outros escritos anteriores em que as noções de sujeito foram mais largamente delineadas. Assim, tomamos As Palavras e as coisas (1966) e $O$ que é um autor? (1969) para buscarmos entender que discursos legitimam a entrada do cinema na escola e seu ordenamento nessa instituição. Também tomaremos Foucault e a Crítica do Sujeito, de Inês Lacerda Araújo e $O$ Discurso Filosófico da Modernidade, de Jürgen Habermas. Neste, Habermas discute questões importantes para a filosofia contemporânea e oportunas para repensarmos as do próprio Foucault, de Bataille, 
dentre outros. De Walter Benjamin tomaremos vários textos reunidos no volume Magia e técnica, arte e política (1996) como suporte para pensarmos a questão da experiência e da obra de arte.

Quanto aos autores "do cinema", e que lidam mais especificamente com esta arte, teremos como referência Jean-Luc Godard em suas obras fílmicas, além de entrevistas e textos de sua autoria. Além destes, serviremo-nos também de autores importantes que pensaram a relação do cinema com a educação, tais como Alain Bergala, principalmente o seu La Hipótesis del Cine (2007); Phillipe Dubois, com seu Cinema, Vídeo, Godard (2004); Serge Daney, com A Rampa (2007); Antoine Baecque, com Cinefilia (2010), dentre outros.

Com referência a essas leituras, estaremos atentos ao conjunto de documentos oficiais, principalmente o projeto $O$ cinema vai à escola, que engendram um modelo de escola, procurando analisar aí como se dá o pensamento da SEE-SP/FDE sobre a entrada do cinema no ambiente escolar, oportunidade para pensarmos como o imponderável da arte é acolhido por essa instituição e em que condições. 


\section{1- PROCEDIMENTOS DA PESQUISA}

A presente pesquisa tem sido desenvolvida de acordo com o modelo de análises qualitativas, sendo a base de nossa investigação a interpretativa. No que diz respeito ao aspecto teórico, este projeto guarda proximidades com a perspectiva pós-crítica, enunciada anteriormente nos autores e no modo de articulação dos discursos.

A análise dos materiais do projeto $O$ cinema vai à escola se beneficiará de referências internacionais como as representadas pelo British Film Institute (BFI): Using Films in Schools: a practical guide (2010) e as da Organização das Nações Unidas para a Educação (UNESCO): Alfabetização Midiática e Informacional (2013) para que possamos estabelecer parâmetros de análise com os de outros órgãos com funções similares aos da SEE-SP/FDE.

A partir do material da SEE-SP/FDE (Caderno de cinema do professor e os vídeos) enviado às escolas, junto com os filmes, foram preliminarmente identificadas e analisadas as concepções de cinema a fim de detectar que uso se pretende fazer desta forma de arte em contexto escolar e, por consequência, o tipo de experiência estética que se pretende proporcionar a alunos e professores, não desconsiderando, é claro, o imprevisível que acompanha tal experiência.

Classificamos o material a partir de uma pré-análise. Assim, são eles: matérias publicitárias sobre o desenvolvimento de projetos nas escolas da rede estadual de ensino; documentos oficiais do estado de São Paulo, como a Proposta Curricular do Estado de São Paulo e o Currículo do Estado de São Paulo (e neste, o Currículo de Arte); o projeto $O$ cinema vai à escola e material usado para formação de professores (dentre eles, os Cadernos de Cinema do Professor e os vídeos). Além da publicação Lições com cinema, também editada pela SEE-SP/FDE (série de artigos e entrevistas sobre cinema), que antecedeu o projeto $O$ cinema vai à escola.

A classificação e a análise do material tiveram como objetivo entender o propósito (e efeitos na prática) de seu uso na escola, a exemplo das matérias sobre os projetos em escolas que visam divulgar elogiosamente iniciativas que incluem o cinema no rol de interesses das instituições educativas. No horizonte da análise e 
da classificação consideramos, nesta pesquisa, que a ideia de empobrecimento da experiência possibilita pensar a entrada do cinema no contexto escolar para identificar o que na escola, de acordo com os documentos de análise, possibilita a eficácia da experiência.

0 material em questão permite perceber que lidar com o cinema na escola é sempre transitar entre o uso do filme como arte e o uso "garantido" de filmes com boa probalidade de aprovação prévia dos alunos, como é o caso de filmes do cineasta Charles Chaplin, um dos contemplados na lista de filmes enviados às escolas pela FDE. As escolhas implicam uma intenção: que a receptividade seja fácil, agradável e instrutiva.

Em grande medida, as escolhas pedagógicas em relação aos filmes não procuram atender à exigência estética das obras, mas aos objetivos das disciplinas, promovendo assim, uma inadequação no modo de tratar os filmes na escola. Tanto a postura que superestima a possibilidade de o filme por ele próprio ser suficiente para realizar a atividade em sala de aula, provocando o que chamamos de experiência estética, na relação pura e simples com a obra de arte. Assim, dispensaria a mediação do professor e, por consequência, da escola e, por outro lado, representaria a aposta no efeito messiânico da palavra do professor que, por si só, seria capaz de reorganizar o pensamento e a sensibilidade para experimentála. Nesse sentido, dispensaria a preocupação com o tipo de filme a ser exibido e, por consequência, toda a rede de possibilidade de articulações que ele poderia suscitar.

Faz parte do projeto $O$ cinema vai à escola a distribuição de filmes às escolas de Ensino Médio da rede estadual de ensino de São Paulo. Dessa lista de filmes, alguns como Cinema, aspirinas e urubus (2005), de Marcelo Gomes, e Terra de ninguém (No man's land, 2001), de Danis Tanovic, em alguma medida, fogem a temáticas que seriam de aplicação fácil e direta em sala de aula como Crash (2004), de Paul Haggis, que trata claramente do uso de drogas, de violência e racismo, ou Billy Elliot (2000), de Stephen Daldry, que trata de preconceito a homossexuais. Por isso, estes são facilmente adequados ao formato escolar. No Caderno de Cinema do Professor (vol. 1), as atividades com Cinema, aspirinas e urubus, por exemplo, vão no sentido de pedir ao aluno que tente detectar o que há de mais significativo 
no filme e que pesquise o ano de 1942 (ocasião em que se dá o enredo da obra), além de verificar que imagens chamam a sua atenção, abrindo possibilidades de o aluno voltar ao filme, buscando novas relações com ele. Já no caso de Crash, as atividades indicadas são claras quanto à questão central: o preconceito racial ${ }^{10}$. Ao selecionar um filme por seu uso temático, a FDE acaba por especificar a inserção da arte no campo escolar.

Com a sistematização dos diferentes materiais (documentos, vídeos, roteiros), passamos à detecção de elementos de duas naturezas: a) os que subsidiam propostas de pensar o filme como objeto autônomo na escola, isto é, o cinema tomado como arte e não como auxiliar de disciplinas do Currículo, como prática (des)educativa. Nesta vertente, os filmes podem ser apresentados na escola como eventos culturais, independente das disciplinas, visando à geração de repertório e para provocar a experiência do pensamento e da sensibilidade; b) elementos da abordagem oficial respaldada pelas orientações que constam no projeto e nos Cadernos de Cinema do Professor. Seria possível uma conciliação entre esses dois modos de uso do cinema na escola, entre a e b? A análise dos textos e vídeos do projeto $O$ cinema vai à escola foi efetivada levando em conta a concepção geral do projeto, os roteiros de atividades que constam nos Cadernos de Cinema do Professor e a indicação do uso dos filmes na sala de aula, vinculados às disciplinas. Essa dissonância representada por a é percebida na fala de alguns cineastas e críticos entrevistados pela FDE e que constam no material disponibilizado em site ${ }^{11}$.

Para o desenvolvimento da pesquisa nos utilizamos dos textos que fazem parte do projeto da SEE-SP como as palestras (de críticos de cinema convidados) publicadas nos Cadernos de Cinema do Professor e que apontam caminhos inclusive dissonantes em relação ao direcionamento oficial do projeto. Assim, lançamos atenção para entrevistas com alguns especialistas que

10 Assim, lê-se: "Explore trechos do filme [Crash] onde o preconceito se apresenta de forma implícita. (...) pesquise a questão racial nos EUA. (...) Pergunte aos alunos o que eles sabem sobre a Declaração Universal dos Direitos Humanos. (...)" (Caderno de Cinema do Professor, vol. 1).

${ }^{11} \mathrm{http}: / /$ www.fde.sp.gov.br

32 
contribuíram com a formação do projeto: Devanil Tozzi (Organização do Programa Cultura é currículo), Lizete Freire Onesti (Gerência de Educação e Cultura) e Marcos Napolitano (Consultoria do Projeto). Acreditamos que o material e essas entrevistas configuram um corpus coerente para análise, adequado para responder às questões sobre o uso que se faz do cinema na escola. Interessa-nos saber se o cinema é ferramenta ilustrativa apenas em primeira instância ou se, pela concepção de cinema e de educação manifestos nos documentos investigados, o projeto $O$ cinema vai à escola possibilita ao aluno saltar do gosto ou da procura e satisfação narcísica para a experiência estética.

Procuramos investigar se as orientações dos materiais pedagógicos do projeto já mencionados anteriormente para o uso do cinema nas escolas não guardariam relação com a vontade de encontrar na arte uma simples representação da realidade. Investigamos, pois, se não seria essa a expectativa gerada em torno da entrada do cinema na escola. Daí a importância da escolha dos filmes. Averiguaremos se essa escolha se dá pela possibilidade de o filme espelhar a chamada realidade, inclusive com intenções moralizantes.

A primeira caixa de filmes distribuídos às escolas da rede estadual de Ensino de São Paulo pela FDE apresenta uma primeira resposta. 0 roteiro de atividades proposto no Caderno de Cinema do Professor (vol. 1) para o primeiro filme da lista ("A Cor do Paraíso", 1999, Irã), de Majid Majidi, sugere que, depois de exibido o filme, o professor retorne a ele, por meio dos capítulos do DVD, buscando relembrar com os alunos "os principais momentos do filme". Sugere ainda que o professor explore alguns desses momentos, fazendo com que os alunos percebam situações típicas de inclusão e de exclusão. Aqui, sente-se claramente a subordinação do filme ao tema abordado. Já o roteiro de atividades do segundo filme da lista, A Rosa Púrpura do Cairo (1985), de Woody Allen, sugere que a abordagem do professor em sala de aula considere a relação entre ficção e realidade a partir do filme. Como se sabe, nesta história a personagem Cecília (Mia Farrow) é apaixonada por filmes hollywoodianos ${ }^{12}$. Em especial, ela assiste 
seguidas vezes a um deles em que surprendentemente o galã (Jeff Daniels) sai da tela e se dirige a ela para quem declara seu amor, tirando-a da dureza de seu mundo cotidiano, que é acentuada pela recessão por que passam os EUA. O Roteiro de atividades sugere ainda que essa relação da ficção com a chamada realidade seja estabelecida pela compreensão da narrativa do filme dentro do filme. Para tanto, sugere o estudo de figuras de linguagem, que provocam "mudança de sentido das palavras". Dentre as figuras de linguagem apropriadas para a ocasião, sugere a "alegoria", a "metáfora" e a "metonímia". Voltaremos a essas análises no capítulo sobre o projeto $O$ cinema vai à escola. Por ora, retomaremos Walter Benjamin para procurarmos entender sua noção de empobrecimento da experiência e em que medida ela nos pode ser útil.

no final dos anos 1960 e que tem seu término em fins de 1970), conhecido como um hiato na produção consagrada à narrativa da transparência desse estúdio, que teve obras ousadas e importantes como Bonnie e Clyde - uma rajada de balas (Bonnie and Clyde, 1967), de Arthur Penn, Os Maridos (Husbands, 1970), de John Cassavetes, Corrida sem fim (Two-lane blacktop, 1971), de Monte Hellman, O Poderoso Chefão (The Godfather, 1972), de Francis Ford Coppola, Taxi Driver (Taxi Driver, 1976), de Martin Scorsese, dentre outras. 


\section{2- EXPERIÊNCIA E POBREZA}

Experiência e Pobreza (1996b), de Walter Benjamin, foi publicado no ano de 1933 e sua apreciação sobre experiência será reconsiderada pelo autor em escritos mais tardios, como em Sobre o Conceito de História (1996c), de 1940. Contudo, a importância daquele texto está em considerar o fenômeno do alastramento do empobrecimento da experiência, que passa da esfera privada para a pública como sinal do estabelecimento de uma crise. Estamos mais pobres do ponto de vista da experiência, constata Benjamin. Em Experiência e Pobreza (1996b), o pensador parece não vislumbrar um reverso do empobrecimento, anunciando a instalação da barbárie. Podemos aí pensar numa postura nostálgica de Benjamin, como diz Jeanne Marie Gagnebin (1996).

Já em Sobre o Conceito de História (1996c) o filósofo alemão aponta para uma renovação autêntica da história, avaliando a possibilidade do reconhecimento da imagem do passado em um aqui, agora, pela apropriação das reminiscências desse passado. Essa relação se dá pela experiência com o passado, na elaboração do passado, mas não uma relação com um passado que se eterniza incólume (BENJAMIN, 1996c, p. 224).

Aqui, vale o comentário de Zizek sobre Heidegger quanto à concepção de repetição do passado. Esta noção é cara a Benjamin para quem o futuro está contido no passado, no sentido de que este é impregne de potenciais "não realizados, e o futuro autêntico é a repetição/recuperação desse passado, não do passado como foi, mas daqueles elementos do passado que o próprio passado (...) traiu, sufocou, deixou de realizar." (ZIZEK, 2012, p. 153). Na esteira de Benjamin, Gagnebin afirma ser o passado

realmente passado (...), ele não volta enquanto tal, mas só pode ressurgir, diferente de si mesmo, e, no entanto, semelhante, abrindo um caminho inesperado nas camadas do esquecimento. Se há uma retomada do passado, este nunca volta como era, na repetição de um passado idêntico: ao ressurgir no presente, ele não é o mesmo, ele se mostra como perdido e, ao mesmo tempo, como transformado por esse ressurgir; o passado é outro, mas, no entanto, semelhante a si mesmo (GAGNEBIN, 2005, p. 100). 
A impossibilidade da restauração de um passado tal qual que se repetiria indefinidamente no presente gera nos sujeitos uma sensação de perda de referenciais. Para Benjamin, os trabalhos do belga James Ensor são os que melhor expressam essa perda de referenciais, a decadência da experiência na modernidade. Seus trabalhos Entrada de Cristo em Bruxelas, de 1888 (Figura 1), e Máscaras Confrontando a Morte, de 1888, para ficarmos com dois, representam uma cidade que aposta no carnaval uma alegria que não há mais. Verifica-se tal aposta nas roupas espalhafatosas e nos rostos disformes, lambuzados de farinha branca, enquanto nas máscaras de olhos grandes e vazios constata-se a ausência de vida. De acordo com Benjamin, talvez por isso elas confrontem a morte, no caso do segundo trabalho. Há antes a manifestação de desespero, uma fantasmagoria assustadora que, não sendo mais da ordem do privado (visto ser generalizante e pública), caracteriza o que o autor chamou de barbárie. Essa desvinculação do sujeito de suas referências produz sujeitos melancólicos (ou deprimidos).

A configuração de melancolia, que passava despercebida na Idade Média, como diz Maria Rita Kehl (2009b), já que havia certa dignidade no sofrimento, dentre outros aspectos, em virtude dos discursos religiosos em voga, não passa mais despercebida na sociedade moderna (sociedade de consumo) a partir da segunda metade do século XX. Sociedade voltada para o prazer e caracterizada pelo consumo desenfreado (ato que produziria o gozo intenso e constante), nossas formas contemporâneas de vida compreendem a melancolia, que aparece como sintoma individual, ao contrário do gozo (entendido aqui como pulsão de morte, categoria psicanalítica), que é perseguido incessantemente; um problema, pois, a ser eliminado. 0 que essa sociedade faz? Intensifica a medicalização desse sofrimento pela autorização do próprio sujeito que, atendendo aos apelos de autodiagnóstico, entende que está deprimido e procura um médico. Empobrecimento da experiência aí implica também empobrecimento da subjetividade. 


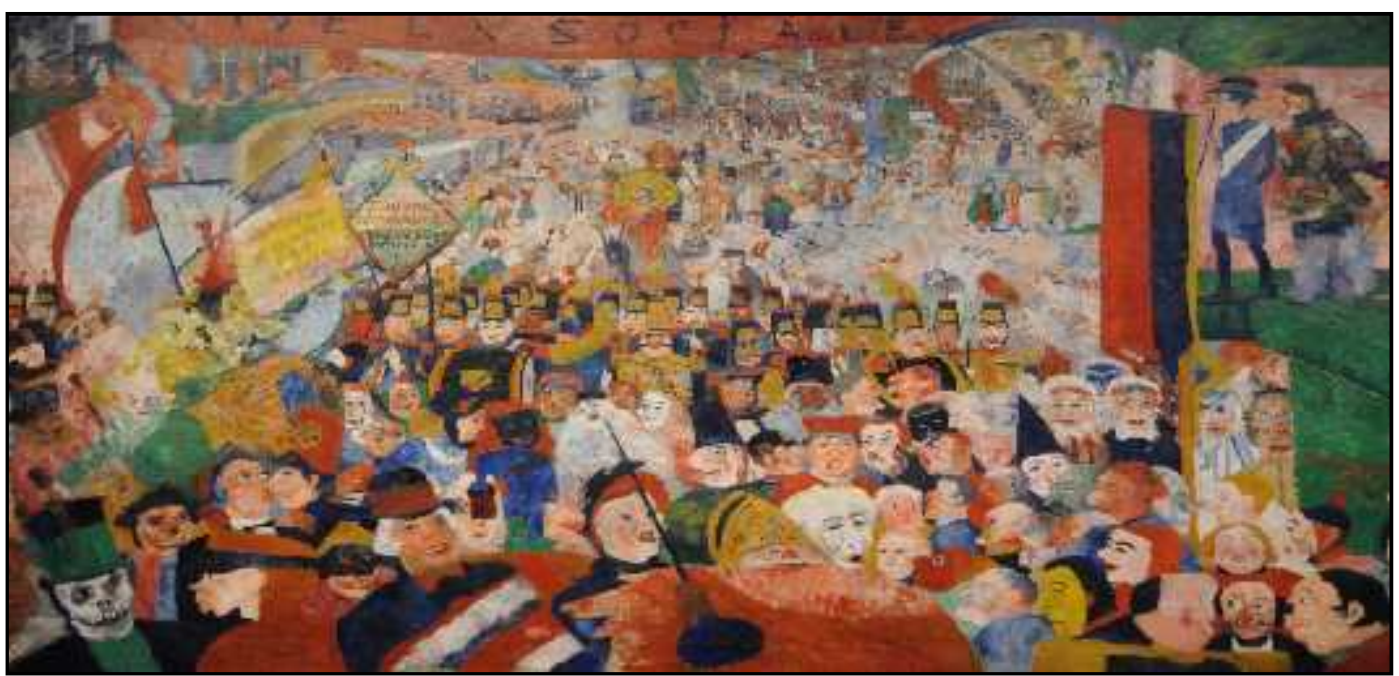

Figura 1- Entrada de Cristo em Bruxelas- 1888 (Museu J. Paul Getty, Califórnia, EUA), 258 cm x $430 \mathrm{~cm}$, óleo sobre tela.

Ao contrário de James Ensor (que ironiza a alegria em seus quadros), tanto Paul Klee, quanto Adolf Loos, vai dizer Benjamin, referem-se a um novo homem ${ }^{13}$, moderno, e que, por isso, não carregaria em si manifesta anterioridade; não carregaria, numa palavra, o peso do tradicional. Eles se dirigem ao homem contemporâneo, nu de todo um passado que o caracterizaria: “[...] contemporâneo nu, deitado como um recém-nascido nas fraldas sujas de nossa época" (BENJAMIN, 1996b, p. 116). Isso impressiona Benjamin e é para ele a manifestação da celebração do vazio. No capitalismo, para o pensador, a técnica intensifica a alienação dos sujeitos, fazendo com que eles não se reconheçam (BENJAMIN, 1996e, p. 162).

A passagem da nostalgia de Experiência e pobreza para pensar o presente de modo mais crítico já se deu em Benjamin antes mesmo de Sobre o conceito de história. Em 1936, em A Obra de Arte na Era de sua Reprodutibilidade Técnica (1996a), ele apresenta o cinema como a arte moderna por excelência. Importante, dessa forma, para pensarmos que configuração o cinema assume no contexto escolar. Também em 1936, em O Narrador (1996d), ele acentua o

13 O imaginário movimentado por essa ideia do homem novo é antigo e apresenta-se em várias elaborações discursivas, desde o marxismo (novo tempo, um novo homem, que se daria com a instalação da ditadura do proletariado), até a Bíblia (1985), que apostava num tempo vindouro em que não haveria mais dores: "Vi também descer do céu, de junto de Deus, a Cidade santa, uma Jerusalém nova (...).". O anjo descido do Céu teria falado para João, autor do texto: "Ele enxugará toda lágrima de seus olhos, pois nunca mais haverá morte, nem luto, nem clamor, e nem dor haverá mais. Sim! As coisas antigas se foram." (Ap.: 21, 2-4). 
empobrecimento da experiência no mundo moderno e contemporâneo pela morte da narração, ainda que teça elogios a Nicolai Leskov ${ }^{14}$ como uma espécie de artesão da palavra, pois guardaria tradições no seu texto, diferente do romancista, cujo trabalho é fruto de empenho solitário, desvinculado das tradições.

Benjamin nos lembra que, diferente da pintura ou do romance, para os quais a reprodução técnica é extrínseca, no cinema ela é intrínseca (BENJAMIN, 2013, p. 07), estrutural. Para o autor, “o filme é uma forma cujo caráter artístico é em grande parte ${ }^{15}$ determinado por sua reprodutibilidade” (1996d, p. 175). Assim, fica clara a despedida de um tipo de experiência ligada à tradição. Com tal constatação, Benjamin, nesse caso, não é nostálgico, como se poderia pensar, pois ele não localiza no passado um tempo feliz que não volta mais, o que imobilizaria seu pensamento. Compreende, sim, que aquela experiência da tradição deu lugar a outras como a do romance, por exemplo, que é caracterizado por ser uma atividade solitária (Cf. BENJAMIN, 1996a, p. 54) e desligada da oralidade, típica ao sujeito moderno; e também à outra experiência, como a do cinema, cujo cinegrafista faz às vezes de médico, que opera esteticamente ao se aproximar da realidade como o cirurgião se aproxima do paciente. Porém, permite "ver não tanto coisas novas, mas outra maneira de ver velhas coisas (...)" (MARTÍN-BARBERO, 2008, p. 83). Essa nova representação oferecida pelo cinema é para o homem contemporâneo a mais significativa, exatamente pela possibilidade de maior intervenção no mundo contemporâneo (BENJAMIN, 1996d, p. 187). Ao contrário do procedimento historicista, desse movimento que se despede da tradição por completo, trata-se de reconhecer em grandes acontecimentos e nos pequenos os restos, as reminiscências e apropriar-se desses vestígios como a "verdadeira imagem do passado." (BENJAMIN, 1996c, p. 224).

A tendência à eliminação das tradições ${ }^{16}$ é intensificada em tempos de capitalismo moderno. Nesse sentido, o lugar do ensino se torna desprovido do lodo

\footnotetext{
${ }^{14}$ Vale lembrar, a exemplo de Georg Otte (2012, p. 61), que o texto "O narrador", de Benjamin, não é uma análise literária da obra de Leskov. A referência a este é, antes, ilustrativa.

${ }^{15} \mathrm{Em}$ grande parte, pois como se sabe, há filmes que são lançados com poucas cópias cujo público esperado é restrito a especialistas, a princípio, mas que, ao ganhar notoriedade na história do cinema ou adquirindo sucesso de bilheteria, pode obter mais cópias.

16 No capitalismo avançado, as tradições não são exatamente eliminadas, mas convertidas em mercadoria a ser consumida por um público ávido de participação histórica com um passado "nobre". Ao se dar ao consumo, a mercadoria é assumida como identificação. 0 consumidor se 38
} 
do tempo e se converte em um "trabalho humano" previsível. Essa atividade previsível parece lançar também o cinema e os espectadores na esteira do plano da experiência restrita à vivência individual (Erlebnis). Trata-se do "vazio dessa experiência individual [que ] é engendrado por uma ação que se limita a si própria; a qual não faz outra coisa senão repetir a história e reificar a ordem." (PIRES, 2014, p. 818).

A contraposição que Benjamin tem em vista frente ao empobrecimento da experiência é a figura do artesão da Idade Média (a quem corporações ofereciam determinadas vantagens, como a detenção sobre os meios de produção e certa garantia de liberdade de trabalho), que produzia objetos com finalidade social (JIMENEZ, 1999, p. 39). Essa é a referência de Benjamin para detectar mudanças estruturais na experiência. Na Renascença, o artesão configura-se como artista, que passa a assinar suas obras e a ser contratado pelo grau de criação, digamos, e de notoriedade autoral, não mais apenas pelo dispêndio que poderia custar determinado trabalho. Para Marc Jimenez, a primeira mudança nessa passagem de artesão a artista é que este deixa de produzir algo que seja útil socialmente, fazendo o valor de uso da obra passar a um valor de troca. Nesse momento, o artista torna-se um assalariado, pago por cada trabalho realizado.

Essa passagem, junto com a técnica de reprodução em massa da obra de arte, já característica dos tempos em que os artigos de Benjamin foram escritos, e mais ainda atualmente, será, segundo ele, o entrave que impossibilitará a experiência com o passado como elaboração. A técnica tira das pessoas o convívio e, com a tradição oral, a possibilidade de organizar expectativas coletivas de um "aqui-agora". Com a técnica, que aparelhou guerras nunca antes tão destruidoras e que mudou substancialmente a configuração social, aumentando o nível de pobreza e de exposição ao mundo do trabalho, encontra-se o "frágil e minúsculo corpo humano" (BENJAMIN, 1996b, p. 115). Frágil, principalmente pela perda das referências antigas, pela narração que já não contempla experiências, uma vez que se constitui em apreensão individual e solitária do ser no mundo, em detriment da tradição.

identifica com ela, "espelho espetacular de sua vida empobrecida." (BUCCI \& KEHL, 2009, p. 44), não apenas como contemplação de algo que desperta os olhos. 
É como se estivéssemos privados de uma faculdade de intercambiar experiências. Uma das causas desse fenômeno é óbvia: as ações da experiência estão em baixa, e tudo indica que continuarão caindo até que seu valor desapareça de todo (BENJAMIN, 1996d, p. 198).

Tal processo é certamente acompanhado por um "indescritível empobrecimento do repertório de imagens [...], o empobrecimento da linguagem e toda a expressão". (ADORNO, 2006b, p. 146).

Como dissemos, o apagamento do legado da tradição é a condição eixo para a identificação do que Benjamin chama de empobrecimento da experiência. Ele toma uma frase de Brecht para situar o sintoma de celebração do novo em detrimento do antigo, do apagamento do passado. Ei-la: "Apaguem os rastros!" (BRECHT apud BENJAMIN, 1998b, p. 118). Esta celebração caracteriza a aspiração dos homens a um mundo em que ele possa ostentar sua experiência empobrecida. Benjamin vê essa aspiração refletida no movimento modernista da arquitetura Bauhaus e no romance de Scheerbart, que exaltam a cultura de vidro, ou do aço, materiais, por excelência, desprovidos de vestígios, de traços. Nesse sentido, os homens não aspiram a novas experiências, "eles aspiram a libertar-se de toda experiência, aspiram a um mundo em que possam ostentar tão pura e tão claramente sua pobreza externa e interna, que algo de decente possa resultar disso.” (BENJAMIN, 1996b, p. 118). A constatação de Benjamin: “(...) ficamos pobres. Abandonamos uma depois da outra todas as peças do patrimônio humano, tivemos que empenhá-las muitas vezes a um centésimo do seu valor para recebermos em troca a moeda miúda do 'atual'” (BENJAMIN, 1996b, p. 119).

Essa discussão empreendida pelo autor parte de sua observação dos soldados da I Guerra Mundial que voltavam mudos para suas casas ${ }^{17}$. Antes, as pessoas que iam lutar, se voltavam, podiam contar histórias que agregavam e faziam laço, pois o sujeito havia adquirido autoridade experiencial (diante da morte). Mas esses soldados da I Guerra Mundial não se sentiam à vontade para

\footnotetext{
${ }^{17}$ Do mesmo modo, Paulo Emílio Sales Gomes lembra que "depois da batalha do Marne [na I Guerra Mundial], houve uma brusca mudança de tom nos artigos de Almereyda [pai do cineasta Jean Vigo]. Ele visitara os campos de batalha e, em seus artigos relatando suas impressões, já não tratava dos bárbaros, dos boches ou do heroísmo dos soldados franceses. Só falava dos cadáveres de homens jovens e dos horrores da guerra." (GOMES, 2009, p. 25-26). 
contar uma história. Trata-se de uma experiência que não gera uma narrativa. Ela engendra o silêncio (DUNKER, 2012).

Para Benjamin, essa pobreza de experiência é a nova barbárie (BENJAMIN, 1996c, p. 115). No mesmo sentido, Adorno e Horkheimer entendem que a "sociedade burguesa encontra-se subordinada de um modo universal à lei de troca" (ADORNO, 2006b, pp. 32-33), processo este engendrado pela produção em série que representa uma "imagem terrível de uma sociedade sem memória" (ADORNO, 2006b, p. 32), “uma nova espécie de barbárie” (ADORNO, 2006a, p. 11). Nos dois casos, trata-se de empobrecimento da subjetividade.

Se Benjamin e Adorno/Horkheimer concordam em apontar o empobrecimento da experiência na modernidade, eles diferem quanto às possibilidades de saída desse estágio de barbárie. Diferem ainda num ponto específico que nos interessa mais particularmente aqui, que é quanto à noção de cinema. Enquanto para Adorno e Horkheimer a experiência cinematográfica está completamente enquadrada na lógica do capital, produzindo alienação, qualquer que seja o filme, para Benjamin, conforme podemos notar em seu texto de 1935/1936, A obra de arte na era de sua reprodutibilidade técnica (1996a), é possível que determinados filmes, como os de Charles Chaplin, por exemplo, fujam a essa lógica. Benjamin vê nos filmes de Chaplin a possibilidade de o espectador sair de sua inércia, de seu ensimesmamento. As contribuições de Adorno e Horkheimer sobre o reinado absoluto da indústria cultural, por um lado, são fundamentais para entender a desubjetivação a que a indústria cultural submete as pessoas, mas também, por outro, a abertura dessa relação, em Benjamin, para o uso criativo do cinema é, segundo Gagnebin, importante para

(...) entender as tentativas de práticas culturais e artísticas contemporâneas que se caracterizam muito mais pela 'experimentação' do que pela criação de uma 'obra' acabada e singular. Penso notadamente em todas as práticas como instalações, performances, atividades teatrais ou circenses ou cinematográficas lúdicas e efêmeras. A partir notadamente de suas reflexões sobre o teatro 'épico' de Brecht, mas também sobre o teatro de crianças proletárias (que ele conheceu a partir de sua amiga Asja Lacis), Benjamin tentou pensar mais em termos de 'ordenação experimental' (Versuchanordnung) do que em termos mais clássicos de 'obra de arte' (Kunstwerk) (GAGNEBIN, 2015). 
Essa abertura para pensar o experimental a que teria se voltado Benjamin parece ser uma experiência estranha ao ambiente escolar, que se acostumou com o suposto conforto dos formatos bem acabados, com as obras, com o uso sem remorsos da função-autor, citando e usando os autores como entidades canônicas. Nesse sentido, a exibição de filmes (ainda que apenas trechos) cujos diálogos desencontrados sem importância para personagens esvaziados de certo realismo, como em $O$ ano passado em Marienbad (L'année dernière a Marienbad, 1961), de Alain Resnais, parece impensável no ambiente escolar, tal a formatação que seguem os formatos bem acabados de um mostruário pedagógico.

No entanto, não se trata de sugerir que um curso ou um projeto de cinema na escola seja composto predominantemente de filmes como $O$ ano passado em Marienbad ou Terra em Transe (1967), de Glauber Rocha, por exemplo. Contudo, chama atenção que haja pouca viabilidade de exibição desses filmes mesmo entre os professores, o que parece indicar que a preferência de professores e de alunos esteja voltada para o cinema de tipo comercial. Aceitando tal formatação, a escola reforça essa condição, eliminando, com isso, a pluralidade das obras exibidas e trabalhadas.

A esse propósito, o da pluralidade, Jimenez (1999), na esteira de Adorno, lembra que "a forma é também um conteúdo" (p. 357). Por isso, chamamos atenção da preocupação do projeto $O$ cinema vai à escola de utilizar-se do critério "pedagógico"18 para seleção dos filmes. Nesse sentido, não seria importante que a escola expusesse alunos e professores a filmes distintos dos apenas comerciais? Pois a forma é um lugar privilegiado de resistência “à liquidação realizada pela indústria cultural" (JIMENEZ, 1999, p. 356). Não se pode esquecer que "a comunicação e a cultura constituem hoje um campo primordial de batalha política." (MARTÍN-BARBERO, 2008, p. 15). 0 mercado domina esse campo. Com

\footnotetext{
${ }^{18} 0$ termo pedagógico aqui resume uma série de critérios que busca ver no filme selecionado sua utilidade em sala de aula. A ideia é que ele deva servir pedagogicamente ao professor que fará uso dele em sala de aula. Assim, sobre o filme é considerada a indicação de faixa-etária, pois um filme que tenha indicação para maiores de 16 anos de idade restringiria seu uso. Também se deve considerar o ritmo do filme, pois um filme lento poderia ser pouco atraente para os alunos. Quanto à possibilidade de chamar a atenção dos alunos o projeto $O$ cinema vai à escola também considera se o filme é em preto e branco, documentário ou ficção, de difícil compreensão, tendo em vista a habilidade do filme de proporcionar identificação e debate.
} 
larga entrada no social, o mercado, no entanto, não sedimenta as tradições, ao contrário, desmancha-as no ar (MARTÍN-BARBERO, idem).

A atmosfera na escola é, a princípio, pouco favorável à exibição de filmes experimentais ou daqueles que fujam ao simples esquema comercial, seja longa ou curta. Também é escassa a realização de curtas-metragens nas escolas em que se possa perceber um ensaio de composição mais singular, em que se resista à necessidade de aplicação de uma gramática oficial do cinema que submete todo o resto ao afã de contar uma história. Isso, em virtude de que a promoção de espaços como festivais de cinema nas escolas, com o planejamento de cursos voltados para o manuseio e para a formação de repertório de filmes pouco mobiliza a produção de subjetividades dos participantes, evitando lançá-los na experiência do estranhamento. Do mesmo modo, nas escolas, quanto à literatura, esse estranhamento é impossibilitado pela raridade nos estudos de autores com invólucro menos "clássico", a chamada literatura marginal (ou mesmo certa literatura canonizada, mas que é considerada de difícil uso na escola em razão da presença de palavrões e de personagens marginalizados como prostituta, ladrões etc., caso de Dalton Trevisan, com Em busca de Curitiba perdida, Continhos galantes, Orígenes Lessa, com Beco da Fome ou Caio Fernando Abreu, com Os dragões não conhecem o paraíso, Morangos mofados). São nomes como Ferréz (Capão pecado, Literatura marginal), Carolina de Jesus (Quarto de despejo) ou Márcia Denser (Diana caçadora). A ausência desses autores "menores" nas escolas é sintoma de certo culto exclusivo aos autores "maiores".

No tocante à citação de Gagnebin (p. 40) sobre abertura de Benjamin para pensar o experimental no cinema, vale lembrar que Adorno e Horkheimer não partilhavam dessa ideia, além do francês Georges Duhamel, em 1931, para quem o cinema deformava as referências literárias conforme a seguinte passagem: "E ninguém gritou assassinos! ... Todas as obras que desde a juventude sussurramos em nosso coração muito mais que com nossos lábios (...) viram-se desmanteladas, mutiladas, reduzidas a pedaços". (DUHAMEL apud STAM, 2003, p. 83). Duhamel talvez fosse o crítico mais voraz do cinema, pois para ele essa modalidade não era arte, apesar de emocionar e divertir (ou talvez exatamente por emocionar e divertir especialmente o grande público). É “um passatempo para escravos, um 
entretenimento para analfabetos, pobres criaturas estupificadas pelo trabalho e pela ansiedade (...)." (DUHAMEL apud STAM, 2003, p. 84). Mas certamente não era uma voz dissonante. Ao contrário, encontrava receptividade no meio intelectual. Robert Stam também cita o alemão Herbert Jhering, que em 1926 prevenia que “o cinema norte-americano era mais perigoso que o militarismo prussiano: milhões de pessoas estavam sendo 'cooptadas pelo gosto norte-americano; elas tornam-se iguais, uniformes'” (STAM, 2003, p. 83).

A partir desse panorama desfavorável ao cinema na formação do espírito crítico, pode-se ter noção da importância do posicionamento discordante de Benjamin. Para ele, o novo impacto causado pelo cinema não era negativo; ao contrário, tratava-se de um impacto de natureza epistemológica, de modo que o cinema e a fotografia "construíam novos paradigmas artísticos que refletiam as novas forças históricas; não poderiam, portanto, ser julgadas pelos antigos padrões" (STAM, 2003, p. 84). Para Benjamin era por meio da montagem que

o cinema administrava efeitos de choque instauradores de uma ruptura com as circunstâncias contemplativas do consumo da arte burguesa. Graças à reprodutibilidade técnica, também a interpretação cinematográfica perdeu a presença literal do ator característica do teatro, mitigando, assim, a aura do indivíduo (STAM, 2003, p. 85).

Benjamin fazia notar as mudanças acrescidas pelo cinema. Dentre elas, sem dúvida, era seu caráter de reprodutibilidade técnica. 0 filme podia ser visto por uma multidão simultaneamente e em tempos diferentes (reproduzível), em lugares diferentes, sem prejuízo de haver desfalque na qualidade do produto apresentado. A distração ${ }^{19}$ causada no espectador tão criticada no cinema por tornar o espectador passivo, na verdade, "não implicava passividade; era, em lugar disso, uma manifestação liberatória da consciência coletiva, um sinal de que o espectador não estava 'enfeitiçado na escuridão'” (STAM, 2003, p. 85). 0 cinema era parte das condições criadas pelo capitalismo que gerariam sua destruição.

\footnotetext{
${ }^{19}$ Em carta a Benjamin, Adorno (2012, p. 210-211) deixa clara sua discordância quanto à "teoria da distração" de Benjamin e acusa-o de anarquismo romântico por "depositar fé cega no poder espontâneo do proletariado", sem dar-se conta de que o proletariado é ele próprio um produto da burguesia.
} 
Benjamin faz das palavras de Franz Werfel as suas: "Seu sentido [do cinema] está na sua faculdade característica de exprimir, por meios naturais e com uma incomparável força de persuasão, a dimensão do fantástico, do miraculoso e do sobrenatural" (WERFEL apud BENJAMIN, 1996a, p. 177), o que nos faz pensar que talvez a dureza do cotidiano escolar caracterizada por matizes cientificizantes $^{20}$ não tenha, de modo geral, até hoje, acentuado a contribuição da dimensão do fantástico possibilitado, tanto pelo cinema, quanto pela literatura. Ao contrário, não deixa de ser espantoso como a escola tem sido especular desse quadro a que se referem Adorno e Horkheimer ou Benjamin, quando expurga a experiência estética ao procurar homogeneizar, generalizar o saber, ao modo da ciência. Dessa maneira, procastina a experiência própria à arte: "O discurso da ciência tem por ofício uma pretensão universalizante, quer dizer, pretende ter a boa resposta para todos [...]." (LEBRUN, 2004, p. 110).

Tal generalização promovida pelos discursos cientificizantes apagaria os gostos distribuídos circunstancialmente no conjunto de alunos e professores de

\footnotetext{
${ }^{20}$ Com sentido cientificizante, entendemos a tendência dos discursos que circulam no contexto escolar a converterem as disciplinas na escola em divulgadoras de pesquisas das várias ciências. Tal processo se dá mais fortemente a partir da Escola Nova, sendo o professor de cada disciplina responsável por apresentar aos alunos durante o ano letivo os resultados compilados por livros consagrados e oficializados, valendo aí as definições de Geografia, História, e assim por diante, que esses livros trazem (já as atividades com os filmes usufruem de uma espécie de isenção de responsabilização dos professores quanto aos resultados "pedagógicos" junto aos estudantes, como se a responsabilidade fosse, na verdade, da SSE-SP, por esta ter selecionado os filmes, entendendo que os filmes seriam unidades de sentido pronto, independentes de outras disciplinas cujo sentido não se apreende senão por determinado esforço de cada professor e que é expresso nos planos de aula). Dessa forma, mesmo a disciplina "Arte" é apresentada em termos lógico-racionais, e frequentemente voltada para trabalhos manuais para feitura de objetos artesanais, divididos em etapas. Esse espírito cientificizante, como um movimento "natural", organiza as vidas não apenas no espaço escolar, mas naqueles em que sua ocupação, em tese, se daria de modo espontâneo. Assim, em São Paulo, pode-se perceber que, em espaços que as pessoas frequentam para a prática de atividades físicas, como o amplo e arborizado interior da Universidade de São Paulo, no Butantã, por volta das imediações da praça do Relógio. Detendo um pouco o olhar sobre essas pessoas, notamos que elas se juntam em grupos distintos. Para cada grupo, há, por vezes, mesas com frutas montadas próximas dos carros em volta dos quais os grupos se aglutinam, geralmente vinculados a uma empresa ou a um personal trainner. As pessoas não andam a esmo para cá, correndo para lá ou fazendo os antigos "apoios" e flexões ao gosto aleatório. 0 que observamos é que essas atividades passaram, a partir de certo tempo, a serem organizadas por esses profissionais. São fisioterapeutas, nutricionistas, professores de educação física, engenheiros de corpos, enfim. Olhando de fora, parecem tribos pelo modo padronizado que se vestem, malhas coladas ao corpo, e pela forma em que se distribuem conforme as atividades. Em seus pulsos, com frequência, se vêem cronômetros ou medidores de pressão. Ainda em relação a essa questão da pedagogização do dia a dia, apresento a seguir, uma passagem que elucida o uso pedagógico do esporte: “(...) quanto ao esporte, percebese não só que perde a dimensão de lazer e de manifestação relativamente autônoma para converter-se em parte da pedagogia, à maneira fascista ou à ascese protestante, que faz do esporte um purificador e uma obrigação moral." (CHAUI, 1985, p. 90).
} 
determinado tempo e lugar. Distante dessa prática generalizante, a ideia de acontecimento destacada por Deleuze em Lógica do Sentido nos ajudará a pensar o discurso cientificizante de muitas práticas pedagógicas do universo escolar. Para Deleuze, acontecimento tem pouco a ver com substância. 0 acontecimento está fora do reino da causalidade. Portanto, podemos, em alguma medida, dizer que o acontecimento está fora da relação de causalidade ensino-aprendizagem, o que não significa que a escola deva descuidar do ensino, abandoná-lo.

Consciente das limitações de controle dos efeitos educativos na formação dos estudantes, a fim de promover a entrada na experiência estética, no entanto, é forçoso admitir que tal experiência passa pela questão do gosto. Contudo, ao contrário do que comumente se pratica na escola, a partir de obras consideradas clássicas, como na literatura, o gosto não se forma necessariamente a partir das obras-primas, mas através de uma experiência com as obras (inclusas aí as obras-primas), eventos, acontecimentos, que não pertencem necessariamente ao cânone. A questão é conseguir o salto disso que é banalizado na indústria cultural, usando o cinema como intervenção nesse gosto produzido massivamente. Forma-se ou se faz ressonância ao gosto para explodi-lo em tensão com referências heterogêneas. 0 salto do gosto homogeneizado, disseminado pela indústria cultural, para a produção da marca do singular, a nosso ver, necessita de "efeitos de choque instauradores de uma ruptura com as circunstâncias contemplativas do consumo da arte burguesa" (FAVARETTO, 2013, p. 72). Tal ruptura não é produzida com fórmulas prontas de antemão, previstas pelo receituário comumente encontrado em práticas pedagógicas no ambiente escolar.

Nesse sentido sugerido por Favaretto, cabe uma menção à ruptura provocada pela concepção de história de Benjamin em relação à da tradição. Para Benjamin, a história "é tratada como processo aberto, descontínuo e não-teológico dos sistemas artísticos e culturais" (FAVARETTO, 2013, p. 72), não como formação. Segundo Kracauer, “o próprio Benjamin denomina o seu procedimento de monadológico. Ele é a antítese do sistema filosófico que quer garantir o seu alcance no mundo por meio de conceitos universais e, sobretudo, a antítese da generalização abstrata." (KRACAUER, 2009b, p. 280). Postura intelectual fundamental para pensar as condições da experiência no ambiente escolar, pois 
essa é exatamente a contramão dos sistemas pedagógicos predominantes, situando-se na via daquilo que nesta tese estamos chamando de deseducação.

Ao contrário da ideia de ruptura mencionada anteriormente, no dia a dia da escola brasileira, flagra-se quase em sua totalidade o uso convencional de filmes que respondem ao propósito de uma prática de pretensão cientificizante. Não devemos nos admirar, como diz Lajonquière, que a matriz pedagógica seguida amplamente por essa escola e, caracterizada pelo discurso pedagógico hegemônico, "é a mesma matriz da catequese conquistadora e/ou colonial." (LAJONQUIÈRE, 2010, p. 83).

Noutra perspectiva, para educar, parece imprescindível partir do pressuposto de que os alunos se constituem como sujeitos pela confrontação e possibilidades da (re)elaboração de seus desejos, o que nos faz lembrar que em Antígona (SÓFOCLES, 1999), Hémon, insatisfeito com o modo com que seu pai Creonte estava tratando o caso em que Antígona reivindicava as honras fúnebres de seu irmão morto, lembra-o de que o governante não governa um deserto. Da mesma forma, o professor não fala sozinho, não fala para um deserto de almas, nem para almas desertas.

Assim, a constatação do empobrecimento da experiência, mas também o da experiência autêntica (Erfahrung), conforme Benjamin, são duas dimensões em tensão, não estanques, que nos mobilizam quanto à entrada do cinema na escola. Não estanques, porque o que se ventila aqui de experiência pode se dar durante a projeção de um filme, num instante de segundos e, em seguida, nada do filme dizer ao espectador. Tal experiência ainda pode depender da geração de uma certa nuvem de predisposição para que determinada fruição aconteça. Dessa maneira, o espectador pode estranhar determinado filme ou determinada cena deste, contudo, pela repetição da exibição de obras "similares", pode desenvolver uma predisposição para tal obra ou cena, chegando até mesmo a conceber nuances e elementos distintos dos filmes comumente assistidos. Não se trata de acumulação departamentalizada. Estaria mais próximo do que se passa com o estudo de línguas estrangeiras, em que num determinado momento as informações às quais o estudante foi exposto seguidamente de repente passam a fazer sentido. 
Diante disso, perguntamo-nos se em que medida o cinema promove o enriquecimento ou o empobrecimento da experiência nos alunos e professores. Nesta tese, procuramos indicar possíveis respostas a essa questão. É necessário, no entanto, que atentemos para as sutilezas na relação que se estabelece entre objetivos pedagógicos, "conteúdo" do filme e a experiência de ver um filme na escola. Sutilezas ainda quanto à recepção estética de alunos e professores, mas também quanto à concepção do projeto $O$ cinema vai à escola, orientando o uso do material constante das caixas dos DVDs. 0 que se pode dizer estritamente sobre o que chega a uns e a outros? Isto é, o que se ensina e o que se transmite? Como é estabelecida para cada espectador sua relação com a obra fílmica? Nesse sentido, depois das vanguardas históricas, depois de Duchamp, é relevante a pergunta:

Que tipo de experiência se procura na arte, desde que a arte deixou de oferecer conhecimento e beleza para apresentar-se como um contínuo exercício de desorientação, que repercute sobre uma estetização orientada para as maneiras de viver, de habitar espaços, de viajar. A tal ponto, que também já faz bastante tempo que é na vida mesma, não nas suas representações, que se situa o trabalho de arte (FAVARETTO, 2015, p. 24).

$\mathrm{Na}$ esteira dessa passagem acima, perguntamo-nos de que modo a escola opera nessa relação com uma arte deslocada e que já não apresenta o belo, nem o conhecimento. Nesse contexto, como decidir sobre o repertório de filmes a ser projetado na escola? Um filme predominantemente comercial poderia também efetivar uma experiência estética? Ou deveria ser abolido em razão de apenas supostamente evocar referências que repetiriam o mesmo sem propor uma participação mais ativa do espectador, como diz Tomaz Gutierrez Aléa (1984)?

Dizer que a escola parece vocacionada ao ensino, a princípio soa estranho, porque parece tautológico (escola e ensino). De que modo uma escola não estaria voltada para o ensino? No entanto, pelo menos no tocante à arte contemporânea, que, como vimos, deixa de ser portadora de conhecimento e do belo, as respostas não estão mais dadas no objeto estudado. Chama atenção, contudo, que na escola seja dado quase absoluto destaque ao ensino e pouco ou quase nada à transmissão, expressão esta que consta em Bergala quando o autor fala em educação artística contrapondo-se a ensino artístico (BERGALA, 2007, p. 33). Assim, ainda que criticamente, ao tematizar o ensino sem a ponderação do 48 
estabelecimento de limites a ele, entra-se na lógica que o coloca em evidência, na maratona para a codificação excessiva de tudo o que é previsto no currículo. Não é a isso que se refere Deleuze, quando afirma sobre "a lei da sobrecodificação despótica." (DELEUZE, 2004, p. 33)? Nesse mar de codificação, a abordagem do cinema que se pretenda resistente a tal tendência é também recusado. Busca-se apreender o virulento da arte, domesticá-lo. Para Bergala, há que se conservar a contradição da tensão da contradição entre a tendência à normatização da instituição escolar e a alteridade fornecida pela arte (BERGALA, 2007, p. 35). Os filmes, que pela proposta original alimentariam essa tensão, terminam entrincheirando-se (BERGALA, 2007, p. 35) em festivais e nas poucas salas de cinema de "arte", reservando-se a um público habitué, universitário, já iniciado. Esses filmes não contemplam as expectativas pedagógicas predominantes, porque a supercodificação destas pressupõe a figuração como elemento principal da obra, longe da noção de acontecimento de que trata Deleuze e para quem a arte figurativa "não é simplesmente perigosa por ser figurativa, mas porque pretende reinar sobre a visão (...)." (DELEUZE, 2007b, p. 19).

Esse perigo indicado por Deleuze não é moral, religioso ou místico, como se o autor sugerisse que as coisas se apresentam desmembradas, desvinculadas umas das outras, sem nenhuma relação de implicação e, em algum nível, sem nenhuma causalidade, apenas submetida a uma vontade divina, arbitrária, casual e caótica. Ele chama atenção para os estoicos, que promovem a divisão entre "corpos" e "incorporais", sendo "os corpos" causas uns em relação com os outros e os "incorporais" movimentos, efeitos, acontecimentos. Os acontecimentos não são substâncias; eles não podem existir, mas antes subsistem, insistem, e são seres apenas, no mínimo, indispensáveis, num nível anterior à conformação de uma coisa ao nível da substância (DELEUZE, 2007a, p. 05). 0 acontecimento é da ordem do "entre-coisas". Ele se dá entre as coisas, entre os corpos. Não qualifica a substância, nem é substância, é verbo. Essa imaterialidade não se presta à fixação ao modo de uma fotografia descritiva que documentaria 
uma determinada época ou ao modo de um filme narrativo ${ }^{21}$. Ela é antes um espectro, mancha.

Nosso interesse nessa concepção de acontecimento apresentada por Deleuze é, pois, a cisão da relação causal que regeria os corpos a fim deproporcionar subversão das concepções que circulam no ambiente escolar. Para Deleuze, tal concepção compreende uma subversão da filosofia tradicional, calcada na relação causal entre corpos e coisas. Foucault também partilha dessa concepção quanto a uma relação causal explicar os fenômenos. Amparado nas discussões foucaultianas, Júlio Groppa Aquino nos lembra que "no prisma genealógico foucaultiano, estaríamos diante da acontencimentalização de determinada prática com vistas à sua desmultiplicação causal [...]“ (AQUINO, 2014, p. 96) ou ainda na esteira de Foucault, "precisamos instalar o acaso em seu lugar correto na história." (ROSE, 1988, p. 41).

O fundamental da linguagem humana é incontrolável, e esse fundamental foge à adequação de categorias da causalidade aristotélica, fundada na substância e que apresenta os estados de coisas como acidentes (DELEUZE, 2007a, p. 08). Para os estoicos, segundo Deleuze, os estados de coisas participam do mesmo status de ser e não de um extra-ser. Assim, para os estoicos, ser e não-ser se fundiriam na expressão intencionalmente imprecisa de Deleuze alguma coisa em vez de Ser.

Deleuze (2007a, p. 292) cita os livros de Pierre Klossowski como aqueles que possuem personagens cuja identidade é diluída. Os tempos atuais, mais que nunca, ainda que fluidos, parecem ter a dificuldade de diluir os discursos, de retirar-lhes o invólucro de verdade, de diluir a verdade de suas referências em razão de seu aferramento a elas, à certeza e conforto que proporcionam. Está em jogo um narcisismo defensivo em primeira instância como qualquer um que se defende do estranho que o ameaça, como o mergulho do eremita em si mesmo, que

\footnotetext{
${ }^{21}$ Narrativo aqui no sentido de que o filme se detém em "contar" uma história em detrimento de "mostrá-la", com forte apelo para a voz over, por exemplo. Contudo, convém destacar que é praticamente impossível, a rigor, um filme não ser em alguma medida narrativo, pois para tanto "seria preciso que ele fosse não representativo, isto é, que não se possa perceber relações de tempo, de sucessão, de causa ou de consequência entre os planos ou os elementos." (AUMONT, 1994, p. 93). Narrar parece estar na contracorrente de sua impossibilidade a partir de Benjamin para quem a narração tem a ver principalmente com a transmissão oral. 
se refugia na solidão. Trata-se, numa expressão, de economia psíquica. Para Christopher Lasch o narcisismo está associado ao consumo. Diz ele:

A cultura organizada em torno do consumo de massa estimula o narcisismo que podemos definir [...] como a disposição de ver o mundo como um espelho; mais particularmente, como uma projeção dos próprios medos e desejos [...] (LASCH, 1986, p. 24).

A escola sente os efeitos dessa cultura, parecendo não haver nela possibilidade da existência de fronteiras, de hesitação, de suspensão da certeza dos discursos de que é investido o ensino. Busca-se a anulação do diferente pela insolação autoirradiada de um eu discursivo grande ou alto demais, tão alto, que não olha no olho, estando acima dos outros discursos como os vários produzidos na informalidade da comunidade escolar que seriam, por consequência, mais baixos, inferiores.

0 gigantismo em que se constituem as versões oficiais da pedagogia atual não se dobram sobre si, não flexionam seu olhar para os outros, impossibilitando "uma reflexão das palavras, uma reflexão nas palavras para que apareça enfim liberada de tudo o que a recobre, de tudo o que lhe esconde o caráter flexional da língua." (DELEUZE, 2007a, p. 295). Aqui vale lembrar a reflexão de Deleuze quanto à noção de dado, que ele elabora a partir de Hume em seu livro sobre Empirismo e subjetivismo (DELEUZE, 2012). Diferente da crítica transcendental kantiana, “o dado não é mais dado a um sujeito, o sujeito se constitui no dado." (apud SAFATLE, 2012, p. 16, 2ª aula).

Pode-se seguramente inferir as implicações dessa noção constituidora do dado para a educação. Pois como pensar conceitos como experiência, vontade, escolha etc. sem a implicação do sujeito no contexto? Daí a conclusão de Deleuze: “que a 'experiência' é o nome que damos para um processo de constituição (...), de produção da subjetividade." (SAFATLE, 2012, p. 16, 2ª aula).

É sabido que um indivíduo, para constituir-se como sujeito, precisa aderir e reconhecer-se numa ideologia. “Todo e qualquer 'sujeito' só pode existir em um contexto social, de relacionamento, onde ele possa ser reconhecido e reconhecer a si próprio, orientando sua prática cotidiana desde seus atos mínimos até os mais significativos." (GALLO, 1998, p. 139-140). Assim, "o ato de tornar-se 
sujeito é pois um ato de 'libertação' e um ato de 'sujeição' ao mesmo tempo.” (1998, p. 140). Contudo, lembra Sílvio Gallo, que, se não é a sociedade (em nosso caso, o sistema escolar) que instaura a representação e a coisificação no processo de produção das subjetividades, "ela se utiliza e se beneficia amplamente disso" (idem, p. 143). Assim, a escola se utiliza do cinema como mais um campo de ideologização, visto ser o que a própria sociedade espera dela. Nesse sentido, a pressão ruidosa do gosto dos alunos passa a se constituir em uma demanda a ser atendida e fomentada.

A noção de dado de Deleuze mencionada anteriormente contrapõe-se à outra ideia bastante corrente no meio educacional e midiático, a saber, a informação e sua produção. Ideia da mesma família da "mensagem do filme", uma vez que parece ser mais uma base de sustentação dos discursos dominantes no meio escolar a contribuir para a produção de subjetividades. 0 projeto $O$ cinema vai à escola deixa de tocar nesse aspecto importante para a educação, que é a da produção da informação (e do filme), isto é, o momento anterior à circulação da informação e da utilização que se faz dela, quando pronta, como produto. Não se trata aqui de ressaltarmos a velocidade da informação, na qual cairíamos em discussão um tanto estéril de admitir ou negar a utilidade dos avanços tecnológicos, mas de sua natureza. Essa informação responderia mais pelo nome de Informação com "i" maiúsculo, que organiza os eventos segundo uma interpretação que responde à noção nostálgica de restauração da unidade perdida. A Informação é a própria unidade, portanto, manifesta prova de que não há unidade perdida. Com isso, expropria o destinatário dos contextos raramente democráticos de constituição da informação já que ela permanece indecifrável e gratuita para o cidadão comum. E, no entanto, essa expropriação é intencional. Sobre essa questão, vale a pena acompanhar a seguinte passagem:

A Informação não se reduz ao aspecto do consumo nem ao da persuasão (como mostra a Teoria da Recepção, o consumo depende da reinterpretação das mensagens, e a persuasão pode falhar), mas se assenta no desejo de sedução. Esta decorre da capacidade dos meios para nos convencerem de que estamos vendo e ouvindo a produção coletiva de idéias ou de valores (...). A 
sedução é tanto maior porque responde a uma exigência real do espaço democrático, isto é, a circulação pública das informações e a formação de uma opinião pública informada que possa julgar e decidir (CHAUI, 1985, p. 35 apud SARAIVA et al, 1982, p. 70).

As pessoas ditas comuns (dentre elas, os estudantes do Ensino Médio) se apropriam da produção supostamente coletiva e democrática da informação veiculada pelo noticiário sem noções básicas sobre a produção e funcionamento das notícias. A Informação aparece com força de verdade pela ocupação sistemática dos espaços midiáticos, que acabam por ditar formas de pensar, agir e sentir. A justaposição de enunciados é a característica de funcionamento da maioria dos programas televisivos, implicando, pois, a forma de pensar das pessoas que, ao argumentarem, produzem pouca articulação de ideias.

Esse modo de circulação da Informação entrava a livre circulação do debate e, com isso, limita o acesso a discursos mais consistentes que, por sua vez, se não impossibilita a experiência (nos moldes benjaminianos), ao menos a torna mais rarefeita. Nesse contexto, a nosso ver, a escola acaba se tornando mais um espaço em que esse modo de funcionamento da Informação impera. Na escola há poucos trabalhos consistentes sobre televisão e jornais. Aliás, pouco se vê TV e pouco se lê jornais com fins de compreender a produção ou invenção da Informação. A análise do que se passa na televisão, isto é, a janela pela qual a maioria das pessoas costuma equacionar seus valores, é, pois, matéria pouco estudada. Seguindo o raciocínio por ora apresentado, podemos constatar que o mesmo se dá com o cinema.

Nesse sentido, não seria exagero afirmar que a informação impossibilita a experiência. Pela lógica de produção da informação, exige-se que ela seja renovada constantemente. De acordo com Benjamin, "a informação só tem valor no momento em que é nova." (BENJAMIN, 1996d, p. 204). Por isso, há uma circulação maciça de pequenos dados fragmentados de informação. "Muito diferente é a narrativa. (...) Ela conserva suas forças e depois de muito tempo ainda é capaz de se desenvolver." (idem, p. 204). A narrativa, continua Benjamin, "não está interessada em transmitir o 'puro em-si' da coisa narrada como uma informação ou um relatório." (idem, p. 205). 


\section{3- O CINEMA, 0 ENSINO}

No início de seu $A B C$ da Literatura (2013), Ezra Pound anuncia que os leitores a que ele se destina são aqueles que não estão mais na escola ou que nem passaram por ela. Uma advertência tão forte, a ponto de ser escrita em letras garrafais, não pretende enganar o leitor: o caminho de estudos da literatura será longo e fastidioso, e o estudante, cuja satisfação do gosto não é imediato, terá frequentemente de suportá-lo (POUND, 2013, p. 23).

Ao contrário, o projeto $O$ cinema vai à escola da SEE-SP/FDE, no uso que faz do cinema na escola, convoca os destinatários com a promessa de prazer $^{22}$. Resta-nos perguntar se nesse uso do cinema a promessa de chegada ao conhecimento - de que é auxiliar - é cumprida. Esse aprendizado, no entanto, não se dá pela exposição simples aos filmes. Na verdade, o aluno, cujo olhar encontrase largamente codificado pelo cinema dito comercial, teria que passar por um desaprendizado - ou por uma deseducação. Trata-se da reeducação do olhar.

Perguntamos se o cinema na escola possibilitaria essa reeducação do olhar. Nesse sentido, o trabalho com o cinema de Bazin em fins da década de 1940 é modelar. Ele indica que na ocasião poucos intelectuais escreviam sobre cinema (ver BAECQUE, 2010, p. 63), pois era considerado arte menor. Não é por outra razão, que Éric Rohmer, professor de literatura, começa suas atividades sobre cinema com esse pseudônimo. Ao contrário, para Bazin, “o cinema é a pedra angular da nova 'educação popular' oferecida aos homens que se reerguem dos infortúnios da guerra (...)” (BAECQUE, 2010, p. 57).

No entanto, o trabalho com o cinema não garante respostas diretas. Sabe-se o quanto a relação do espectador com a obra fílmica pode se dar de modos diversos, a depender do lugar e das condições em que um determinado filme é exibido. Bazin, por exemplo, praticava a chamada "santa trindade": apresentação

22 O Caderno de Cinema do Professor (vol. 1), da FDE, anuncia que, com o cinema, "alunos e professores poderão desfrutar e aprender com muita emoção, suspense e aventura!" (2008, p. 06); no volume 2, que se trata de "um caminho muito interessante e prazeroso." (2009, p. 05). E, no volume 4, que "a sétima arte nos instiga a ir além, a viajar por muitos outros universos. E, assim, quando retornamos, sempre trazemos na bagagem um olhar ampliado e enriquecido sobre todas as coisas e, acima de tudo, sobre nós mesmos." (2010, p. 03). Essas citações ressaltam a impressão de leveza e de prazer que seria trabalhar com o cinema e como ele nos tornaria pessoas melhores. 
do filme, projeção e discussão (BAECQUE, 2010, p. 62). Ele era o crítico religioso que pregava o cinema em cineclubes. 0 caso de nossa pesquisa é em muito diferente. A exibição de filmes em ambientes especializados para tais exibições como o circuito comercial, cineclubes ou mesmo no ambiente caseiro, guarda características próprias distintas da projeção numa escola cujo aluno-espectador, para citar algumas diferenças, não escolhe o filme que será exibido como alguém escolhe quando vai a uma sala comercial de cinema ou a um cineclube. Assim, para pensar a configuração que adquirem as experiências com o cinema na escola, há que se considerar todo um conjunto de fatores, dentre eles, as referências culturais dos alunos, seleção dos filmes, condições técnicas de projeção.

Bazin tem algumas razões para crer no cinema como "ferramenta" pedagógica. Segundo ele, o fato de o cinema mostrar em vez de indicar faz dele veículo privilegiado da verdade. Diferente do pintor ou do escritor, que são atravessados pela subjetividade no manejo de seus instrumentos de trabalho (a pena e o pincel), o cineasta registraria a materialidade de seu trabalho pela objetividade de seu instrumento, que é a câmera, embora supondo-se que aí intervenha o "inconsciente ótico", como indica Benjamin (BAECQUE, 2010, p. 65). Baecque tem em vista o texto de Bazin Ontologia da imagem fotográfica, presente em O cinema (1991), que identifica o instrumento de registro mecânico da realidade (a câmera) como veículo de verdade maior entre as artes. Por princípio, poder-se-ia registrar a realidade independentemente do sujeito. Sabe-se que Baecque e Bazin não são ingênuos em desconsiderar o trabalho de composição da imagem do cinema ou da fotografia antes, durante e depois da realização da imagem. No entanto, a prova de que o princípio aí é maior que o resultado é, como atesta Bazin, que as primeiras fotografias eram inferiores às pinturas quanto à "reprodução" mimética dos objetos exteriores, visto que elas eram pouco nítidas e em preto e branco. Mas é aí que Bazin identifica a pintura, paradoxalmente, como um mau sucedâneo dos procedimentos de reprodução: "não passa de uma técnica inferior da semelhança." (BAZIN, 1991, p. 22). Mas a pintura não se restringe à arte da reprodução. 0 que estava em questão no caso da fotografia e do cinema era o princípio de "transferência de realidade da coisa para a sua reprodução." (BAZIN, 1991, p. 22). 
Essa noção de cinema é fundamental para a discussão sobre as possibilidades de sua presença na escola na constituição das condições da experiência. Ao modo kantiano, pergunta-se sobre o que pode o cinema na escola. Se considerado procedente o parecer de Bazin quanto à capacidade de ele representar mais fielmente a realidade exterior que as outras artes ou que ele é "especialmente sensível para captar e nomear a gramática do sofrimento social" (DUNKER, 2015, p. 15), tem-se aí um poderoso recurso para a representação de situações interessadas - de ordem política, ética, e estética - e perfeitamente previstas nos conteúdos curriculares.

Assim, considerando que a verossimilhança é fundamento das imagens do cinema, vale destacar que é possível servir-se dessa marca de representação sem se restringir à ilustração tão somente a fim de confirmar expectativas do gosto codificado dos alunos-espectadores. A verossimilhança se dá mesmo em uma sequência que inclua o sobrenatural, caso de Gritos e sussurros (Viskningar och rop, 1972), de Ingmar Bergman, em que Maria (Liv Ullman), depois de morrer de câncer, volta a viver, gerando em seu retorno uma situação em que se dá um ajuste de contas com as irmãs. 0 retorno à vida da personagem atribui a ela novas condições que desencadeiam o diálogo. A ressurreição não é fim, mas meio para que o diálogo que não havia se dado antes da morte da personagem se dê em seu retorno.

O tratamento da questão do ensino implica, ao mesmo tempo, pensar o que a escola pode ensinar ou o que é possível ensinar, isto é, o que seria necessário ensinar. Não se pode perder de vista que a dimensão educativa é ampla e diluída, e que se aprende mesmo quando não se tem intenção de ensinar. É o caso da televisão que, a rigor, não ensina, mas o que se aprende por ela, como se sabe, não é pouco ${ }^{23}$. Com o cinema se passa o mesmo.

Contudo, a escola parece ainda estruturada para atender a expectativa de que as atividades principais de seu funcionamento se deem por responsabilidade de professores nas salas de aula, a partir de cada disciplina, separadamente. 0 cinema, nessa perspectiva, é inserido em sala de aula para auxiliar no cumprimento de tal expectativa. Assim, a propósito do título do projeto

${ }^{23}$ Quanto a essa questão da consideração da televisão como instância educativa, a entrevista de Guillermo Orozco-Gómez é oportuna. (Cf. CITELLI \& COSTA, 2011, pp. 239-253). 
O cinema vai à escola, talvez, para ser mais preciso e ciente de seu escopo e consequências, ele devesse se chamar $O$ cinema vai à sala de aula. Por isso, a perspectiva de Bazin, que é a do cineclube, a de exposição do filme sem preocupação com um determinado currículo, é tão contrastante. De modo geral, o valor cultural de uso do filme se destacava. A nossa questão, ao contrário, exige a contextualização do cinema em ambiente escolar.

A despeito do problema sobre o que é ensinável, vale a pena mencionar o caso da Academia de Ciências, Artes e Belas-Letras de Dijon, na França, que lançou em 1750 o concurso para resposta à seguinte questão: “O restabelecimento das ciências e das artes terá contribuído para aprimorar os costumes?". Com tal pergunta, a Academia acreditava haver implicação direta entre cultura, educação e bons costumes. Como se sabe, Jean-Jacques Rousseau ganha o prêmio com uma resposta negativa, ainda que se esperasse pela confirmação, pois vivia-se a crença no Iluminismo, que tinha na Renascença (denominada de "restabelecimento", termo presente na questão da academia de Dijon) a expressão de orgulho de uma nova era. Rousseau opõe-se a essa aposta na razão, privilegiando o papel da emoção (ARBOUSSE-BASTIDE \& MACHADO, 1988). Ele critica, nesse discurso, na verdade, o processo civilizatório que, por meio das artes, tornará seu "gosto mais fino", sofisticando os costumes numa uniformização "desprezível e enganosa", de modo que não se "ultrajará grosseiramente o inimigo, mas jeitosamente o caluniaremos." (ROUSSEAU, 1988, p. 140).

Mais tarde, em $O$ mal-estar na civilização, Freud dirá que "a atitude estética em relação ao objeto da vida oferece muito pouca proteção contra a ameaça do sofrimento (...)" e que "a beleza não conta com um emprego evidente; tampouco existe claramente qualquer necessidade cultural para ela" (FREUD, 1997, p. 32).

Ainda que se trate de diferentes momentos do pensamento voltado para a crítica do processo civilizatório, Rousseau e Freud estão tecendo ponderações sobre a racionalidade e o investimento no utilitarismo das artes e das ciências. Eles não celebram a implicação direta entre arte e ciência, valores e felicidade. Contudo, atualmente, para a maioria dos discursos circulantes nas escolas e para os materiais que visam à entrada do cinema nessas instituições - e vários exemplares 
da literatura que trata do cinema na educação - ele é veículo privilegiado de transmissão de valores. É o caso do livro Cine y Educación (2007), de Alma Ambròs e Ramón Breu. Para esses autores, o cinema está condicionado a uma "educación en valores [que] pasa a ser uno de los contenidos que integra la asignatura de la educación para el desarrollo personal y la ciudadanía [...]." (AMBRÒS \& BREU, 2007, p. 26), com fins de "aprender a vivir en el sentido más amplio de la expresión." (idem, p. 26). Para os autores, assim como o projeto $O$ cinema vai à escola, o cinema contribui "para a formação crítico-reflexiva do jovem e do adulto" (São Paulo, 2008. Site da SEE-SP) 24 .

Nesse sentido de formação para a cidadania e de um bem-viver, os autores dizem ser o cinema indubitavelmente "elemento neutral, no intervencionista. No es un discurso de los padres o del tutor o la tutora, sino un relato con personajes que tienen contradicciones, problemas y conflictos que pueden ayudar a tener elementos de reflexión personal." (AMBRÒS \& BREU, 2007, p. 27). Quanto ao que os autores atribuem ao longo do livro, essa passagem é índice do cinema como uma espécie de lugar neutro da enunciação como veículo para a circulação da multiplicidade, fazendo-nos entender que seria distinto dos processos que se têm em casa e mesmo na escola. Ainda de acordo com Alma Ambròs e Ramón Breu, o cinema seria a própria vida, melhorada, porque problematizada a partir de personagens que não estariam de acordo quanto às questões em jogo e, por esse motivo, os alunos teriam um panorama diverso para tomadas de decisão.

Deduz-se daí que tal panorama seja apresentado por um jogo de ideias, o que coloca o filme nessa condição de apresentador de ideias e não propriamente como obra de arte. Assim, Ambròs e Abreu parecem crer no cinema não como arte, mas como um lugar de ensaio de ideias de uma multiplicidade tal de ideias que não encontraria paralelo na vida cotidiana, não importando a que filme se refere. Aliás, quanto a esse ponto, concorda com o documentarista brasileiro Eduardo Coutinho, para quem não importa o filme a ser exibido na escola, desde que o "animador" (COUTINHO, 2009, p. 33) saiba o que fazer com o filme, como se os filmes a priori portassem disparadores capazes de apresentar a experiência da crítica a seus

${ }^{24}$ http://culturaecurriculo.fde.sp.gov.br/cinema/cinema.aspx. Acesso em 10 de agosto de 2015. 
espectadores. O cinema, para esses autores, é portador da possibilidade de transmitir e produzir valores.

Nesse sentido, podemos pensar o quanto essa preocupação com a produção dos valores pode determinar a seleção de filmes a serem exibidos aos alunos e o crivo pelo qual passam para serem considerados filmes dignos de integração ao contexto escolar. Referimo-nos à dimensão reflexivo-crítica que se adivinharia nos filmes a fim de que tenham efeitos "reflexivo-críticos" nos alunosespectadores. A entrada do cinema na escola, então, serve a interesses pedagógicos, mas também, éticos, políticos e até estéticos. É dessa forma que um filme confirma na exibição e na discussão o que já se esperava dele. 0 filme, como um curinga, serviria ao propósito de ínterim, do enquanto isso, não sendo tomado segundo sua especificidade ${ }^{25}$. Ele não responde por si próprio; está no contexto escolar como se não fosse o seu habitat.

Confirmam esse cenário a ausência de um lugar próprio para o cinema como disciplina na escola, a falta de um calendário de exibição de filmes e de outras atividades a serem desenvolvidas com o cinema, ficando a cargo de cada professor lançar mão dele para auxílio de atividades de sua disciplina, ainda que a Lei 13.006, de 26 de junho de 201426, de autoria do senador Cristovam Buarque, obrigue as escolas no Brasil a exibirem duas horas mensais de produção cinematográfica brasileira. De qualquer maneira, considera-se essa lei um passo na concretização da importante relação do cinema com a educação, mesmo que seja notória sua fragilidade quanto aos meios para viabilização dessa relação.

Igualmente, o projeto $O$ cinema vai à escola é, sem dúvida, uma tentativa de consolidação da entrada do cinema na escola, na medida em que disponibilizou 71 filmes em DVD para todas as escolas da rede estadual de São Paulo, além de material didático para auxílio ao professor no uso dos filmes. 0 projeto funcionou do ano 2008 a 2015, quando foi suspenso. Além dessa proposta, havia ainda outras

\footnotetext{
${ }^{25}$ Apesar de a literatura ocupar um lugar nobre no currículo escolar, para Todorov (2009) ela não se constitui na escola em um fim em si mesmo já que em vez do sentido da obra, procura-se nela os elementos que justificariam sua apreensão ao modo das ciências. Ele está se referindo ao estudo da metáfora, elipse etc. Contudo, o caso do cinema é peculiar já que ele não é justificado nem como disciplina.

${ }^{26}$ Falaremos dessa lei mais adiante, no item "4.1- I Conferência Nacional de Educação", mas sugerimos a leitura do texto "Da obrigatoriedade do cinema na escola, notas para uma reflexão sobre a Lei 13.006" (FRESQUET \& MIGLIORIN, 2015), que trata das limitações e das lacunas que tal lei evidencia.
}

60 
duas, sendo que as três faziam parte do programa Cultura é currículo. No entanto, ao considerar a aplicação das noções de espectatorialidade e de sujeito faltou-lhe a tensão dos efeitos do cinema como arte no currículo em que a ciência ocupa lugar privilegiado. 0 cinema, aliás, entra no currículo como "complementar".

A despeito da discussão sobre a diluição do sujeito, que remete à questão da perda da perspectiva histórica única de que tratam Lyotard, Deleuze, Foucault, dentre outros, a escola parece cristalizar o lugar do sujeito consciente quando eleva a ciência a posto maior. A perda da perspectiva histórica única significa "abandonar as metanarrativas [o que] implica, então, puxar o tapete sobre o qual se assenta a escola moderna ou se assentam, pelo menos, nossos discursos sobre o que é e para que serve a educação escolarizada." (VEIGA-NETO, 1995, p. 13). No mesmo sentido diz Zizek: "A era das grandes explicações acabou, precisamos do 'pensamento fraco'” (ZIZEK, 2012, p. 19). Na contramão desse movimento, a escola promove modos de aprendizagem que tomam o "conteúdo" como objeto central. Para tanto, precisa tomar o aluno, não como um sujeito clivado, mas consciente e autônomo, capaz de apreender as matérias ensinadas. Esse propósito é percebido não apenas com o gênero de filmes "documentais", mas também com os filmes de "ficção livre". Tenta-se extrair deles mensagens que interessem "pedagogicamente" a um ensinar-aprender (o binômio cuja preocupação encontra-se tão assustadoramente presente nas práticas pedagógicas. Essa preocupação, antes, revela o sintoma de conversão a que se constitui a intenção do ato pedagógico. Assim, instrumentaliza-se o professor para que ele seja veículo da verdade para que convença do melhor modo o aluno. A ênfase é dada ao ensino para que este se converta em aprendizado).

A expressão "mensagem do filme" responde a esse propósito. Pode-se flagrá-la travestida em outras tais como "o diretor do filme quis passar isso", "o filme fala disso" etc., que, com frequência, constitui-se numa leitura redutora da obra com fins moralizantes, pois a toma como parte instrumental extraída do filme - aquilo que é codificável - considerando o filme, no fim de contas, reprodução mimética. A função primordial do filme na escola, pois, passa a ser a de naturalizar a realidade. 
O uso de uma expressão como "mensagem do filme", como resumo da obra, que encerra um enunciado e, por consequência, um destinatário, ainda que guarde a boa intenção de assegurar algo do filme para os alunos e relacioná-lo com um assunto estudado em dada disciplina, pode fechar a obra para outros sentidos. Assim, em determinado momento de seu livro Como usar o cinema na sala de aula, Marcos Napolitano (2003, p. 94) diz: "Quando o filme for utilizado numa atividademeio, é muito importante o professor estimular um debate sobre a chamada 'mensagem' principal da obra". Se a atividade, como o texto indica, é meio, isto é, se o filme é usado como ilustração na apresentação de uma determinada disciplina, talvez o professor devesse antes estar atento a mensagens no filme e questionar os alunos sobre aquela que lhes interessa para a aula em questão.

Essa busca pela "mensagem do filme", pela redução do apresentado pelo registro fílmico a uma mensagem - uma espécie de paráfrase - não seria da mesma ordem da crítica de Deleuze (1990, p. 165) à busca nos filmes pelo "mundo verdadeiro"? Esse mundo, diz ele, não existe. Os filmes clássicos ${ }^{27}$, isto é, aqueles

\footnotetext{
270 termo "clássico" aqui está no sentido de "clássico de massa", expressão utilizada por Jacques Aumont (2008, p. 31). 0 termo clássico relacionado ao cinema é controverso, já que o cinema nasce na modernidade e alimenta-se dela (AUMONT, 2008). Contudo, tal termo é mais comumente usado para obras hollywoodianas até o final da década de 1950 (AUMONT, 2003, p. 54), enquanto o seu início é mais difícil de determinar, como atesta Aumont, sendo, no entanto, apontado o momento em que a indústria de Hollywood se estabelece com hegemonia e seu estilo já se encontra fixado, sobretudo pelo ideal da transparência. Isto se deu na década de 1920. Mas clássico também tem o sentido apontado por Deleuze, quando este identifica o funcionamento dos filmes por meio de binômios, como "pobre/rico", "bem/mal", "exterior/interior" (GUÉRON, 2011, p. 34), ou ainda, como o próprio Deleuze especifica, são aqueles cuja narração é "orgânica", que "consiste no desenvolvimento dos esquemas sensório-motores segundo os quais as personagens reagem a situações, ou então agem de modo a desvendar a situação. É uma narração verídica, no sentido em que aspira ao verdadeiro, até mesmo na ficção." (DELEUZE, 1990, p. 157). Tal narração, pois, é dependente de eventos que se justificam pelo desencadeamento causal, que justifica as ações seguintes. Quanto ao termo modernidade, este é comumente utilizado quando há referências ao cinema que começa a se constituir a partir do Neo-realismo italiano, com Roberto Rossellini, Antonioni, dentre outros, que, ao contrário da continuidade dos planos no cinema clássico, propõem a descontinuidade, por exemplo (RANCIĖRE, 2000), com desdobramentos em vários outros movimentos como a Nouvelle Vague francesa e no Cinema Novo, de Glauber Rocha e Nelson Pereira dos Santos, por exemplo. É difícil a demarcação de tal modernidade, quando, na verdade, com Sob os tetos de Paris (Sous les Toits de Paris, 1930), de René Clair, já se tem prerrogativas que serão características do Neo-realismo italiano, como na sequência inicial em que uma câmera desce dos telhados até chegar a um grupo de pessoas de uma comunidade qualquer em Paris. Enquanto as pessoas cantam, seguindo a condução de um homem, outros tentam pequenos furtos nos desatentos participantes. Eisenstein defendeu "uma montagem que interrompe o fluxo de acontecimentos e marca a intervenção do sujeito do discurso através da inserção de planos que destroem a continuidade do espaço diegético, que se transforma em parte integrante da exposição de uma ideia. No seu cinema, a sucessão de eventos não obedece a uma estrita causalidade linear e não encontramos uma evolução dramática do tipo psicológico. Eisenstein prefere falar em 'justaposição de planos', ao invés de encadeamento" (XAVIER, 2005, p. 130).
} 
cujo móvel é "o verdadeiro", “a informação”, na verdade, têm esse mundo verdadeiro como motivo. Pois se este mundo existisse, engendraria um "homem verídico". No fundo dessa busca da redução do filme a uma mensagem paira uma verdade que se apresentaria portentosa, incólume, que é bem expressa nos filmes clássicos, de narração orgânica, para usar os termos de Deleuze. São filmes cuja narração apresenta descrições calcadas em razões sensório-motoras, uma espécie de esconde-esconde da verdade.

Vale a pena lembrar que Deleuze fala da Nouvelle vague como um bloco homogêneo, faltando, a nosso ver, precisão quando aponta o avanço desse movimento na ruptura com "o mundo verdadeiro" dos filmes clássicos. Ruptura também com a revolução que havia realizado o Neo-realismo italiano, pois que este “ainda mantinha a referência a uma forma do verdadeiro" (DELEUZE, 1990, p. 165) e que só a Nouvelle vague teria rompido "deliberadamente com a forma da verdade para substituí-la por potências de vida, potências cinematográficas consideradas mais profundas" (DELEUZE, 1990, p. 168). Esquece de pontuar, no entanto, que vários filmes de cineastas da Nouvelle vague como os de François Truffaut, tais como Atirem no pianista (Tirez sur le pianiste, 1960), Um só pecado (La peau douce, 1964) e A noiva estava de preto (La mariée était em noir, 1968), por exemplo, mas também de outros, como Ascensor para o cadafalso (Ascenseur pour l'échafaud, 1958) ${ }^{28}$, de Louis Malle, aspiram ao verdadeiro, cujo encadeamento rígido das

\footnotetext{
${ }^{28}$ Há nesses quatro filmes citados eventos que geram forçosamente outros, que justificarão seus enredos cuja narração Deleuze denominaria de "narração orgânica", aquela que caracteriza os filmes chamados clássicos ou que destes guardam tal característica. Assim, por exemplo, em Ascensor para o cadafalso o personagem Julien Tavernier (Maurice Ronet), já na rua, percebe (ação 2) que esqueceu (ação 1) a corda que usara para escalar o andar superior onde se encontrava seu patrão, que ele matou. Na volta, entra no prédio sem ser visto (ação 3) pelo segurança. Tal ação servirá a seguir para que o segurança do prédio desligue (ação 4) a energia elétrica quando o senhor Tavernier já estará no elevador, ficando ali preso (ação 5) para que, então, outras ações sejam desencadeadas como a do casal de jovens que se aproveita para tomar (ação 6) o carro do senhor Tavernier, que ficara estacionado com as chaves na ignição. Por sua vez, este casal de jovens conhecerá (ação 8) um outro casal (de turistas alemães) e o matará. A polícia suspeita do proprietário do carro e dos pertences encontrados ali, dentre eles, o casaco e um revólver, ambos do senhor Tavernier. Antes, o casal de jovens passara (ação 7) pelo lugar onde a esposa do patrão de Tavernier e amante deste, a senhora Florence Carala (Jeanne Moreau), haviam combinado de se encontrar, depois que Tavernier tivesse matado o senhor Carala (Jean Wall). Florence Carala reconhece o carro que passa (ação 9) por ela e vê (ação 10) do lado do passageiro uma moça jovem, dando a impressão de que Tavernier desistiu de matar seu marido e de seu encontro com ela, trocando-a pela jovem (ação 11). A jovem é bonita, o que acentua a impressão de traição sentida por Florence Carala, o que a faz perambular pelas ruas em profunda melancolia, levando-a (ação 13), por fim, à delegacia, em decorrência de confusão (ação 12) num bar. Na delegacia, travará (ação 14) contato com o investigador do crime do casal alemão, que pergunta a ela se ela conhece o
} 
ações engendra as consequências que estabelecem uma relação de causa-efeito que atravessa todo o filme. Dentre os exemplos citados, talvez Ascensor para o cadafalso seja o mais emblemático quanto à aspiração ao verdadeiro.

Cientes das nuanças desse debate, lembremos da perspicácia de Federico Fellini em seu Os palhaços (I clowns, 1970). Ao ser perguntado sobre qual seria a mensagem do documentário que é realizado dentro do filme Os palhaços, ele próprio, que faz um personagem que dirige o documentário sobre palhaços dentro do filme, não consegue responder. Não tem tempo, porque logo um balde vindo de qualquer lugar lhe cai na cabeça, a exemplo de uma animação e, em seguida, um outro balde também cai na cabeça do jornalista que havia dirigido a pergunta ao diretor.

Fellini parece calar diante da pergunta em questão, porque está ciente de que não se trata de reduzir o filme a uma mensagem. 0 filme é polissêmico, diria Fellini, pois ainda que pareça em determinado momento defender a tese sobre o desaparecimento de um determinado tipo de palhaço ${ }^{29}$, as questões estão postas no circo, digo, em círculo. Jean-Paul Sartre não é de outra opinião. Respondendo a provocações de seus adversários, ele enxota do círculo artístico aqueles para quem a função da arte era "passar mensagens a seus leitores" (SARTRE, 2015, p. 32).

Por outro lado, na ânsia de absolver a vida de qualquer forma de julgamento para a apresentação de sua tese de inexistência de um "mundo verdadeiro", seguindo aí passos de Nietzsche (inexistência, inacessibilidade ou

senhor Tavernier, suspeito do assassinato do casal estrangeiro. É ela quem descobrirá que não fora Tavernier quem matara o casal alemão, mas outro casal, o de jovens, chegando a seguir (ação 16) o rapaz até o laboratório de revelação de fotografias que havia num motel onde ele teria ficado por algumas horas com a moça cúmplice. Ele se dirige ao local (ação 15) a fim de eliminar o que julga ser a única prova do assassinato dos alemães: o filme da máquina fotográfica que se encontrava no carro de Tavernier e da qual fizera uso para fazer algumas fotos de si, de sua cúmplice e do casal de alemães. Chegando lá, a polícia o prende no momento da revelação (o rosto do rapaz surge no papel fotográfico exatamente no momento em que ele adentra a sala) das fotos e é levado preso. Quase ao mesmo tempo, a senhora Carala entra na sala do laboratório e também é surpreendida pelas fotos de sua relação de intimidade com o amante no material que é revelado no exato instante de sua chegada como acontecera com o rapaz. Atônita, ainda sob o impacto da descoberta aliviada de que não havia sido traída por seu amante e assassino de seu marido, desliza sua mão sobre as fotos mergulhadas na água da bacia de revelação como se o tocasse e revivesse os momentos de intimidade que surgiam nas fotos. Como se pode perceber, uma ação leva à outra, não podendo uma ser antecipada por outra, pois há uma cadeia muito rígida de eventos para justificar o enredo do filme.

${ }^{29} \mathrm{O}$ filme considera as duplas de palhaços formadas por um tipo denominado de Augusto, que é aquele mais lúdico e atrapalhado, e o denominado Branco, que é o "escada", aquele que prepara situações para que o outro diga ou faço algo que provoque o riso. 
inutilidade da verdade), para Deleuze, Orson Welles (e também Fritz Lang) "não parou de lutar contra o sistema de julgamento" (DELEUZE, 1990, p. 168). Sem indicar cenas, ou mesmo os filmes onde elas poderiam estar, Deleuze faz generalizações ao apresentar este cineasta, interpretando-o como se toda a sua obra respondesse a esse caráter que representaria a luta contra o sistema de julgamento. Dos poucos momentos que Deleuze especifica cenas ou sequências a que se refere quando se trata de exemplificar suas teses, utilizando-se de filmes, ele o faz para apresentar Fritz Lang, como aquele que, em vez de dicotomizar a questão de bem e mal,

faz do mal uma dimensão humana e não mais faustiana quer sob forma de um gênio hipnótico (Mabuse), quer sob a de uma impulsão irresistível ( $O$ vampiro de Dusserdorf). Com isso a questão da verdade, quer dizer, do tribunal e do julgamento, vai revelar toda a sua ambiguidade: $M$ é submetido a um tribunal de delinquentes que não tem a verdade como móvel (...) (DELEUZE, 1990, p. 168).

“Mensagem do filme” é, enfim, a expressão mais acabada da expectativa de encontrar no filme verdades postas junto a razões-motoras, sem as quais o filme perderia suas motivações. Tudo no filme existe em função das ações desencadeadoras. Objetiva-se espremer a laranja para se extrair seu suco, como se o bagaço fosse descartável, como se raspas e restos não interessassem. Procura-se, assim, construir determinado sentido que, em geral, na verdade, projeta-se forçosamente do exterior para a obra. No entanto, preferimos manter a desconfiança com Hermenegildo Bastos de que "o específico do trabalho artístico é que nele os fins práticos que estão na mira do trabalho humano são postos em suspensão." (BASTOS, 2013, p. 137). No entanto, os discursos pedagógicos circulantes nas escolas, em geral, constituem seu trabalho de modo a atender a uma expectativa de "mensagem", desprezando a multiplicidade em que se constituem as artes, intraduzíveis no registro fixo e redutível de uma mensagem.

A busca pela mensagem nos filmes acaba por restringir a seleção de filmes àqueles que possibilitem a redução do artístico a um código, o que nos remete ao dilema popularizado de quem teria vindo primeiro, se o ovo ou a galinha. Na verdade, essa dependência moral, que torna os filmes produtos todos muito 
parecidos entre si, é frequentemente alimentada em via dupla: o público espera a moral da história e o filme é formatado de tal modo a que se extraia dele, uma moral. Sobre esse aspecto da homogeneidade dos filmes, Kracauer lembra que "as tentativas de alguns diretores e autores de se distanciarem dessa homogeneidade estão de antemão condenadas”, pois “a sociedade é muito poderosa para tolerar películas diferentes daquelas que lhe convêm." (KRACAUER, 2009a, p. 312).

Preocupado com esse papel assumido pelo cinema, para Kracauer, "os numerosos filmes históricos que ilustram meramente o passado (...) são tentativas que têm a finalidade de iludir o público." (KRACAUER, 2009a, p. 313). É nesse sentido que a incorporação das tecnologias da imagem proposta pelo programa Cultura é currículo exige determinada atenção. Não compreenderia o cinema uma especificidade, de maneira que sua matéria em geral funciona pouco numa tradução codificada, não se prestando bem à formatação, visto serem as imagens "mais aleatórias" do que o texto escrito, além de se constituir num registro outro, impossibilitando ajustes diretos como se dá, por exemplo, entre ensaio e literatura, quando num ensaio citam-se passagens de um texto literário? Entre ensaio e um texto literário o registro é o da palavra. Entre ensaio (palavra) e o filme (imagem/som), não. Trata-se de um outro modo de pensar os eventos, modo que talvez demande menos palavras e mais silêncio. Nesse sentido, qual profissional na escola se responsabilizaria por colocar essas questões em evidência? Que professor lidaria com as questões do cinema? Como colocá-las em evidência na escola?

Perguntaríamos ainda se, na ausência da colocação dessas questões, Agamben não falaria de dessubjetivação do espectador a exemplo daquele "que passa as suas noites diante da televisão [pois que] recebe em troca da sua dessubjetivação apenas a máscara frustrante do zappeur ou a inclusão no cálculo de um índice de audiência." (AGAMBEN, 2012b, p. 48). Ele diz ainda que:

Se a todo dispositivo corresponde um determinado processo de subjetivação (ou, neste caso, de dessubjetivação), é totalmente impossível que o sujeito do dispositivo o use 'de modo correto'. Aqueles que têm discursos similares são, de resto, o resultado do dispositivo midiático no qual estão capturados. (AGAMBEN, 2012b, p. 48). 
Na esteira de Foucault, Agamben chama "de dispositivo qualquer coisa que tenha de algum modo a capacidade de capturar, orientar, determinar, interceptar, modelar, controlar e assegurar os gestos, as condutas, as opiniões e os discursos dos seres viventes." (AGAMBEN, 2012b, p. 40).

Fazendo uso desses lugares comuns como "mensagem do filme", por exemplo, e deixando à boa sorte de cada zappeur (em seu mundo privado) decidir sobre o que melhor lhe convém, as pedagogias circulantes em contexto escolar parecem seguir também o espírito normativo cuja expressão de controle são os dispositivos. Por isso, a seleção interessada do professor que toma mão de um filme numa locadora (e mesmo, em certa medida, a da relação de filmes do projeto O cinema vai à escola) indica que a intervenção em sala de aula objetiva ressaltar, por assim dizer, o conteúdo "disciplinar" de que o filme seria portador. A justaposição do filme ao conteúdo disciplinar abordado em sala de aula é justificado e reforçado pela mensagem do filme, que o ilustra. A escola, assim, parece forçar a transformação do cinema em televisão, esta que é, como se sabe, vocacionada para a comunicação, quando se sabe que a preocupação em detectar no "texto" fílmico a moral da história, o sentido único, numa palavra, a mensagem; busca-se no texto "fonte" o sentido prévio a que se referem as perguntas, a partir de sentidos que teriam sido fixados pelo texto fílmico, quando, noutra via, Barthes havia assinalado que "já não se considera as obras como simples mensagens, ou mesmo enunciados, como produtos acabados, mas como 'produções perpétuas, enunciações pelas quais o sujeito continua a se debater'”. (BARTHES apud AUMONT, 1995, p. 208). O superlativo dessa ideia é a de que não existe discurso "sobre" a obra, mas que a elaboração discursiva que pretende referir-se a uma determinada obra é já "um outro texto, de estatuto equivalente, 'que entra na proliferação indiferenciada do intertexto'”. (AUMONT, 2007, p. 208).

Essa concepção de Barthes de "produções perpétuas" talvez contribua para a impressão de que estamos advogando pela eleição indiferenciada de filmes para o trabalho dos professores em sala de aula, como se fosse necessário abolir os critérios de seleção de filmes para uso pedagógico, apostando todas as fichas na mediação do professor e na idealização da recepção. Como se a ideologia operasse sozinha na escolha do cinema como recurso pedagógico. 0 filme passaria a se 
constituir como facilitador da fixação (como "exercícios de fixação") dos conteúdos científicos e que gozam de prestígio curricular.

$\mathrm{Na}$ contramão do cumprimento da promessa dos filmes do cinema comercial de fornecerem mensagens, o papel do cinema na escola não só não seria o de "facilitar o aprendizado" como ele poderia ser um complexificador, um instalador de hipóteses, um problematizador.

Os filmes que circulam no mercado também fazem seleção e recortes conceituais. Por isso, um filme, a rigor, deve ser tomado como ficção e não veículo da verdade, cabendo perguntar-se a que público determinado filme se refere. A maioria das pessoas no filme é branca? Qual o tratamento dado a essas pessoas? Há negros e qual o seu papel no filme? São questões dessa natureza que se faz o sociólogo e cineasta Noel dos Santos Carvalho em entrevista ao vídeo $A$ formação do olhar ${ }^{30}$. Da mesma forma, ele nos lembra que poderíamos nos questionar por que sabemos tanto de Revolução Francesa ou da Revolução Russa e, por outro lado, sabemos tão pouco da História dos povos pré-colombianos, da História da África, o processo de independência de Moçambique e de Angola, países lusófonos, por exemplo. Existe, pois, um catalisador - um catalisador ético ou moral, estético ou político? -, que faz determinada família de assuntos serem predominantes nos currículos de escolas e de universidades.

O livro não está isento dessa operação ideológica, e também ele se constitui como comunicador de "verdades". Todavia, a credibilidade de que goza o livro coloca o filme em plano inferior. No fim de contas, o filme confirma a "superioridade" do livro na medida em que é convocado segundo a demanda das disciplinas. Essa realidade, contudo, não é apenas brasileira. Para Jack Lang, “'Education nationale [da França] était alors indifférente à la création artistique. L'art et la culture n'appartenaient pas aux domaines nobles, dignes de la

\footnotetext{
${ }^{30}$ Vídeo da entidade sem fins lucrativos Cinema e Educação - CinEdu - A formação do olhar - "é um documentário que se propõe a refletir sobre a relação entre a educação e o cinema no Brasil, tomando como eixo transversal a importância do ensino da história e cultura afro-brasileira nas escolas. O documentário conta com depoimentos de profissionais que fazem parte da cinematografia contemporânea brasileira e da educação como o cineasta Jefferson De, a professora e pesquisadora Ana Lúcia", o sociólogo e cineasta Noel dos Santos Carvalho. Texto e vídeo disponíveis em https://www.youtube.com/watch?v=KXIsiTBgOU4. Acesso em 6 de fevereiro de 2016. 68
} 
construction d'un savoir comme les mathématiques ou le français."31 (LANG, 2000). Lang, como ministro da educação na França, junto ao Ministério da Cultura, lança o Plan de Cinq $\mathrm{Ans}^{32}$, que visava, a exemplo do projeto $O$ cinema vai à escola, fornecer filmes em DVD e cadernos de sugestões de uso pedagógico dos filmes para facilitar a relação do professor com esse material.

No entanto, sabe-se que, ao ver um filme, o espectador não identifica apenas o que está posto na tela, na verdade, ele vê mais que seus olhos veem (AUMONT, 1995, p. 226), ele "se perde" nas várias referências apresentadas pelo filme. 0 fato de chamarmos atenção para certa disposição patológica da escola em "pedagogizar" ou codificar tudo que adentra o espaço escolar como obrigatoriamente "pedagógico", não implica que estejamos advogando pela descodificação indiscriminada. 0 acesso à cultura não se dá apenas ao proporcionar o contato do sujeito com a arte, isentando a escola de mediar essa relação. Não é por outra razão que Aumont (1995, p. 224) diz se interessar pelo espectador como sujeito imerso numa experiência individual, psicológica, estética, subjetiva, e não pelo espectador como um dado estatístico, imaginário, depositário do produto audiovisual, um espectador abstrato. Desse modo, há entre a hipercodificação dos processos educacionais e a ausência generalizada de codificação um ponto a ser definido que passa pela codificação, mas também pela vivência de práticas escolares abertas à compreensão crítica da eficácia de processos científicos e artísticos.

Compreende-se a dificuldade que a escola apresenta no trabalho com o cinema, dada a sua tendência a codificar também o filme não comercial. Em apresentação de livro de Jacques Aumont (2007), Rubens Machado Junior admite ser mais fácil para ele, e em toda parte, associar cinema e literatura. Diz ser a relação teórica do cinema com a literatura muito mais comum do que a relação do cinema com a pintura, por exemplo, em virtude de as estruturas narrativas da literatura se aproximarem mais às do cinema do que daquelas do campo visual, caso da pintura. Isso devido à "maior acessibilidade no plano das racionalizações a

\footnotetext{
31 “A educação nacional [francesa] era, então, indiferente à criação artística. A arte e a cultura não pertenciam ao domínio nobre, não eram dignas da construção de um saber como as matemáticas ou o francês." (tradução nossa).

32 Plano de Cinco Anos, projeto que visou à sistematização da entrada das artes no ensino formal básico na França, inclusive o cinema.
} 
que podemos lançar mão para compreender e discutir um filme, tal como ele se dá socialmente no circuito de exibição." (MACHADO JUNIOR In AUMONT, 2007, p. 16). E continua: "As grandes narrativas tomam o lugar de destaque pela sua maior comunicabilidade com os grandes públicos." (MACHADO JUNIOR In AUMONT, 2007, p. 16). É muito mais fácil para o professor perceber as temáticas e falar delas a partir de acontecimentos do enredo do filme. Por isso, compreende-se que a SEESP/FDE lance mão também desse critério para a escolha de filmes.

Outro critério para a escolha dos filmes a serem exibidos na escola tem a ver com sua forma fácil e dinâmica, de modo que possa prender a atenção dos alunos, ponto caro no contexto escolar atual. Mas, sobretudo, porque conta uma história. Assim, "o cinema torna-se efetivamente uma instituição de efeito moral." (ADORNO \& HORKHEIMER, 2006, p. 126). 0 filme é escolhido já em função de sua "vocação" para contar uma história, caso do filme A partida (Okuribito, 2008), de Yôgirô Takita, constante da lista de filmes da FDE e de muitos outros. A entrada do cinema na escola se dá, pois, segundo uma trama de interesses políticos, morais e estéticos de que está impregnada.

Acrescentem-se a isso as condições técnicas de reprodução do filme, pois se espera de uma sala de cinema que ela possua determinadas características sem as quais a projeção da obra seria prejudicada. De outro, o filme se esforçaria inutilmente para cumprir sua parte na satisfação mínima das expectativas do espectador. Da mesma forma que nos parece ser incoerente considerar jovens e crianças usuários - como uma clientela - tal como consta nos documentos oficiais como $\mathrm{LDB}^{33}$, sendo comum ouvir professores referindo-se aos alunos, da mesma forma, o espectador é paradoxalmente tomado como sujeito pronto a ser satisfeito, narcísico, contribuindo para sua infantilização, sendo alimentada a ideia de uma identificação fixa, em vez de procurar lançar o jovem no sopro de um "devir-louco",

\footnotetext{
${ }^{33}$ Lei no 9.394, de 20 de dezembro de 1996, caput do "Art. 26ㅇ. Os currículos do ensino fundamental e médio devem ter uma base nacional comum, a ser complementada, em cada sistema de ensino e estabelecimento escolar, por uma parte diversificada, exigida pelas características regionais e locais da sociedade, da cultura, da economia e da clientela." (destaque nosso). E no "Capítulo V, Da Educação Especial, Art. 58으, § 1ํ․ Haverá, quando necessário, serviços de apoio especializado, na escola regular, para atender às peculiaridades da clientela de educação especial." (destaque nosso). Na LDB N. 12.796/2013, além de acrescentar os currículos da educação infantil ao §2º do Art. 26, o termo "clientela" é substituído por "educandos": "Os currículos da educação infantil, do ensino fundamental e do ensino médio devem ter base nacional comum, a ser complementada, em cada sistema de ensino e em cada estabelecimento escolar, por uma parte diversificada, exigida pelas características regionais e locais da sociedade, da cultura, da economia e dos educandos." 
"devir-ilimitado" (DELEUZE, 2007a, p. 08), de uma identificação nômade, pois "o interessante nunca é a maneira pela qual alguém começa ou termina. 0 interessante é o meio, o que se passa no meio". (DELEUZE apud FAVARETTO, 2014, p. 18). Este é o lugar do devir; "é no meio que há o devir, o movimento, a velocidade, o turbilhão", enfim, "o intempestivo". (FAVARETTO, 2014, p. 11).

É nesse sentido que Adorno reforça a ideia de que aquilo que não é definido claramente e sobre o qual não se possa falar racionalmente é insuportável. "Lo distinto es insoportable, pues sirve para recordar lo que le está prohibido." (ADORNO, 1969, p. 67). Para Adorno, a imagem da televisão parece pertencer ao telespectador, parece participar das pequenas propriedades (“[...] los siente como cosas de su propriedad, sobre las quales puede disponer, sientindóse superior a ellos.", p. 65) tal como um "cinematográfico doméstico". Essa falta de distância da imagem em relação ao espectador parece impossibilitar a experiência já que se trata do comum, do trivial de todo dia. "Ni siquiera tiene que moverse para ir al cine [...]." (ADORNO, 1969, p. 67). A esse respeito, diz Godard:

Levei tempo para compreender por que há cenas curtas na televisão, nas reportagens. É simplesmente porque isso se torna difuso ao cabo de 4 segundos e assim, eles cortam por causa da imagem difusa e não por que as cenas estejam terminadas ou maçantes. Da mesma forma, as cenas são cada vez mais curtas no cinema, porque os técnicos da tomada de cena não sabem mais determinar as coordenadas [...] (GODARD, 1986, p. 216).

Essa imagem apequenada, fugidia, envergonhada, responde à ânsia de um espectador ensimesmado em prazer suicida como Narciso, ávido por imagens que se sucedem freneticamente. Imagens que se referem a uma realidade que elas pretendem criar sem correspondência ao que lhes seria exterior, imagens-objeto elas mesmas. Essa discussão é feita por Kátia Maciel (1993) em um pequeno texto, em que condensa ali a tensão entre um cinema que se converte em virtual, porque seduzido, tragado pela tecnologia, e outro, que se utiliza do virtual, da tecnologia, e continua sendo cinema, cuja imagem "secreta uma certa heterogeneidade que nos lembra que não estamos sós; a imagem é então a condição de possibilidade da própria alteridade." (MACIEL In: PARENTE, 1993, p. 257). Eis do que se recente a introdução do cinema na escola. 


\section{4- ESCOLA E CINEMA}

\section{1- Desformação dos sujeitos}

Ponto fundamental para o funcionamento de um projeto de cinema na escola é, sem dúvidas, a seleção de filmes. No entanto, há uma dificuldade na indicação das obras, pois frequentemente é impraticável a distinção exata entre o chamado filme comercial e o dito filme de arte. Isso em razão de que um mesmo filme pode tanto fazer concessões ao público a partir de um conjunto de clichês que o colocariam no rol de filmes comerciais como apresentar elementos que o aproximariam de um filme de arte. Assim, mais apropriado talvez fosse atentar para a maior ou menor identificação do filme com os chamados lugares comuns (abundância de plano e contra-plano a fim de mostrar o desenvolvimento de um diálogo, introdução de música a fim de emocionar e direcionar a sensibilidade do espectador, por exemplo, entre outros) próprios do cinema dito comercial sem enquadrá-lo definitivamente numa dessas duas categorias e ao que ele apresenta de inventivo, evitando tais lugares comuns.

Quando pouco traduzível em termos de procedimentos pedagógicos, na medida em que evita os lugares comuns, o filme pode gerar desconforto pedagógico na lógica escolar em razão (também) do escasso uso dessas obras na escola. Assim, diante desses dois caminhos, pergunta-se qual a escola deve seguir. Há quem diga que é indiferente, desde que o tratamento dado aos filmes seja crítico. Outros acreditam que a experiência com o filme por si só "fala" ao espírito do aluno, sendo inócua a interferência do educador e, por vezes indesejada. Por fim, há aqueles que se situam entre uma e outra estratégia, compreendendo que os alunos não são tabula rasa nem autônomos para guiarem-se sozinhos pelas obras.

Pensando, por exemplo, no caso do ensino de Filosofia, como lembra Lyotard, “(...) uma leitura não é filosófica apenas porque os textos são tidos por filosóficos (...) uma vez que se pode ler textos filosóficos sem filosofar e ler textos considerados artísticos, políticos, jornalísticos filosoficamente." (LYOTARD, 1993, p. 117), de modo análogo um filme não precisaria ser considerado arte para ser 
utilizado no contexto escolar, de modo que também poderia cumprir os objetivos de "formação do pensamento crítico" (LDB, 1996, Sessão IV, Art. 35, Inciso III). Contudo, como ressalta Celso Favaretto, a leitura filosófica não dispensa os próprios textos filosóficos, mesmo que em fragmentos:

O simples contato com essa linguagem mais resistente em relação à linguagem comum pode ser formativo e isso é a dificuldade dos professores: como trabalhar com uma linguagem tão resistente como a da filosofia com alunos que, de certa forma, demandam uma linguagem mais comum, do dia-a-dia (FAVARETTO, 2001).

Da mesma forma, a ausência de filmes propriamente artísticos em uma determinada seleção pode indicar uma aposta no que Bergala chama de "ilusão pedagógica" (BERGALA, 2007), que diz respeito à crença de que a escola pode prescindir da diversidade de filmes, uma vez que o trabalho de evidenciação dos processos fílmicos pelo professor já garantiria um modo crítico de ver filmes. Assim, bastaria que algumas vezes no ano o professor viesse a fazer um trabalho com os alunos decifrando algumas passagens de filmes e indicando o que estaria por trás das imagens para que os alunos nunca mais "voltassem a ver uma tela como antes".

Para além do investimento na palavra do professor quanto à "ilusão pedagógica", a diversificação dos filmes entre comerciais e aqueles fora do mainstream pode favorecer um panorama representativo para o professor, que tem aí papel fundamental não só na seleção dos filmes (ainda que dentro de uma seleção previamente apresentada a ele, como no projeto $O$ cinema vai à escola, que, ao todo, enviou às escolas 71 filmes) como também na mediação continuada junto aos alunos.

No sentido contrário da confirmação do lugar comum, de que qualquer que seja o filme, ele tem papel formativo, a ideia de desformação se afirma quando agentes detonadores acionam situações de fala e acontecimentos (no caso da projeção de filmes), que provoca deslocamentos na posição do aluno-espectador. 0 termo desformação é aqui acionado em razão da necessidade de ruptura com a formação de alunos e professores advinda de uma concepção abstrata da arte, cultura e educação. Apesar de um considerável avanço nas concepções 
pedagógicas desde o início do século XX, como a reforma promovida pela Escola Nova, inspirada em ideais iluministas, na LDB de 1961, dentre outros avanços, o lugar das artes e da cultura na escola vinham sendo apresentado de modo secundário em relação ao conhecimento científico. A escola, em geral, parece, em muito, ainda devedora demasiadamente das Luzes. Para Bergala (2007), ela resiste a qualquer mudança. Não por não ter propostas transformadoras, mas pelo hábito de conservar-se tal como está. Apesar disso, Jack Lang acredita ser a escola o lugar que pode promover o encontro com a arte:

Je voudrais en même temps dire qu'il n'y a pas d'autre lieu que l'École pour organiser la rencontre de tous avec l'art. Il n'y a pas d'autre lieu que l'École pour instaurer de manière précoce le contact avec les œuvres (LANG, 2000) ${ }^{34}$.

Assim, como promover a ruptura com essa forma de funcionamento da escola de que fala Bergala e incluir a ideia de deslocamento a ser provocado pelos acontecimentos? Nesse sentido dos deslocamentos do sujeito de seus lugares comuns, a exibição de filmes que fujam à estética do cinema comercial pode, com a veiculação de "filmes de arte", contribuir para estabelecer uma proposição estética, que seja uma alternativa à da TV aberta, resistindo, assim, à cristalização do olhar narcisista, ávido por novidades (facilmente descartáveis), produzido e reforçado pela indústria cultural. A exibição de filmes não comerciais pode ainda provocar situações como a da mãe de aluno de uma escola estadual, que ao final da sessão de O Cachorro (Bombón, El Perro, 2004), de Carlos Sorín, comentou: “Não sabia que se podia fazer filmes assim. Não acontece nada. Não sabia que podia terminar em nada. Quando não terminava era porque tinha uma continuação noutro filme"35. Esta fala é indicativa da importância de filmes pouco usuais, para a formação, que contam uma história, mas, ao mesmo tempo, por assim dizer, resistem em contá-la

\footnotetext{
34 "Eu gostaria de, ao mesmo tempo, dizer que não há outro lugar que a escola para organizar o encontro de todos com a arte. Não há outro lugar que a escola para instalar de maneira precoce o contato com as obras" (tradução nossa).

${ }^{35}$ De 2007 a 2009, período em que fui professor de Filosofia em escolas do Estado de São Paulo, projetei alguns filmes em caráter experimental. Dentre eles, O Cachorro (Bombón, El Perro, 2004), de Carlos Sorín. Na projeção, por acaso, uma mãe, que esperava que a secretaria da escola emitisse algum documento de seu filho, aceitou o convite para ver o filme. Ao término, fez o comentário que consta no parágrafo acima. 
ou ainda contam-na sem expô-la como se dissecasse um animal nalgum laboratório.

Desprendido de interesses pedagógicos, o caso dessa mãe faz pensar na constituição do gosto dos alunos-espectadores. Ao contrário da função-espectador, que é a mais usada para designar um espectador abstrato (AUMONT, 2003, p. 105), os alunos-espectadores não são consumidores sem rosto como a criança genérica de que tratam os discursos pedagógicos cientificizantes na escola, segundo Lajonquière (2010). Para Jack Lang, "longtemps en effet notre système éducatif [francês] est resté rétif, prisonnier d'une conception trop abstraite et trop historique de la culture." (LANG, 2000)36. Diferentemente da condição do anonimato do espectador do cinema comercial, os alunos-espectadores são espectadores específicos, sendo possível, pois, considerar suas reações, conversar com eles sobre o filme, levá-los a produzir textos e nesse processo promover uma relação interessada com o cinema.

A seleção de filmes e os trabalhos com estas obras em sala de aula, bem como os instrumentos apoiadores desses trabalhos, como os roteiros de atividades que motivam o uso dos filmes, tudo isso supõe concepções de sujeito, de cinema, de educação. A consideração do repertório prévio dos alunos-espectadores é outro ponto importante para a configuração de um trabalho com filmes, pois as referências que os alunos trazem abrem possibilidades de experimento de outras matrizes, de modo que a análise comparada possibilita a ampliação e diversificação do repertório. A análise das próprias referências é lembrada por Sartre como uma importante condição:

A consciência emocional é primeiramente irrefletida e, nesse plano, ela só pode ser consciência dela mesma no modo nãoposicional. A consciência emocional é, em primeiro lugar, consciência do mundo. (...) o sujeito emocionado e o objeto emocionante estão unidos numa síntese indissolúvel. A emoção é uma certa maneira de apreender o mundo (SARTRE, 2007, pp. 5657).

Uma das dimensões poderosas do trabalho com o cinema na escola é o de provocar e possibilitar o exercício do pensamento e da emoção sobre práticas

\footnotetext{
36 "há muito tempo, com efeito, nosso sistema educativo [francês] tem sido prisioneiro de uma concepção muito abstrata e muito histórica da cultura." (tradução nossa).
} 
irrefletidas, emocionais, considerando que essas práticas são, como diz Sarte, "uma certa maneira de apreender o mundo", conforme citação anterior. Porque o repertório prévio dos alunos geralmente se constitui de modo irrefletido, "espontâneo". Essa "espontaneidade" é sequestrada quando os filmes utilizados são apenas os comerciais (quase $90 \%$ do público em 2014, no Brasil, foram para filme comercial estrangeiro ${ }^{37}$ ) e em televisão aberta (quase $80 \%$ dos filmes são estadunidenses hollywoodianos ${ }^{38}$ ).

\section{2- Cinema e escola: um caso francês}

O projeto O cinema vai à escola, da SEE-SP/FDE, é um marco no que diz respeito a uma sistematização do uso do cinema na rede estadual de ensino público. Para nos auxiliar no trabalho de análise desse projeto e de outros documentos da SEE-SP/FDE, comentaremos um caso francês, projeto desenvolvido com as mesmas pretensões daquele que aqui nos ocupamos, cujo objetivo maior foi o de inserir formalmente o cinema no sistema escolar.

Em 2000, Alain Bergala foi convidado pelo então ministro francês da Educação Jack Lang (e que já havia sido ministro da Cultura na década de 1980) para, em parceria com o Ministério da Cultura e da Comunicação (cuja ministra era Catherine Tasca), desenvolver durante cinco anos um projeto que visava à formalização da entrada das artes nas escolas. Bergala coordenou a parte de cinema. 0 projeto chamava-se Mission de l'éducation artistique et de le l'action culturelle (Missão de Educação Artística e de Ação Cultural), ou simplesmente Mission (Missão), como ficou conhecido. Esse projeto fazia parte da política nacional da educação Le plan de cinq ans (Plano de Cinco Anos) e resultou em livro de autoria do próprio Bergala, intitulado L'hypothèse cinema. Petit traité de

\footnotetext{
37Fonte: ANCINE. Site:

http://oca.ancine.gov.br/media/SAM/Informes/2014/Informe_anual_preliminar_2014_Arquivode Publicacao.pdf. Acesso em 11 de maio de 2016.

${ }^{38}$ Esses dados serão melhor explorados no capítulo sobre o projeto $O$ cinema vai à escola.

76
} 
transmission du cinema a l'école et ailleurs (A Hipótese Cinema: pequeno tratado sobre a transmissão do cinema na escola e fora dela) ${ }^{39}$.

Logo nas páginas iniciais, Bergala fala de quão ingrato é o terreno da pedagogia e de como suas instâncias oferecem uma resistência silenciosa a mudanças. "Son las inercias más desesperantes, porque es imposible convercerlas" (BERGALA, 2007, p. 16). Não obstante, a aposta de Jack Lang no projeto - o que Bergala chama de a hipótese de Lang - era a de que, para este, a entrada do cinema na escola representaria a alteridade - ou a possibilidade de provocar nos alunos a percepção da alteridade - algo radicalmente outro, mas que não romperia necessariamente com as normas do ensino e das pedagogias clássicas (BERGALA, 2007, p. 33).

Para Bergala, no entanto, faltava um pensamento tático que coadunasse os objetivos da escola laica e os do cinema como arte, dadas as dificuldades operacionais da educação escolar. Mesmo quando funciona, se funciona, deve-se desconfiar dos resultados e métodos empregados com fins pedagógicos. A preocupação do autor se situa principalmente na adaptação que se faz do objeto estudado à dimensão pedagógica. Para ele deve haver "respeito ao cinema". 0 contrário disso acontece devido à responsabilidade do professor de lidar com uma matéria que desconhece. Assim, o filme é abordado como "produtor de sentido", em que o professor procura discorrer sobre o que julga serem as intenções do cineasta com tais cenas, angulação etc. (BERGALA, 2007, p. 30-32). Nesse sentido usual se coloca o ensino artístico. Diferentemente, Bergala propõe a concepção de uma educação artística, a exemplo de Godard, que estabelece a diferença entre regra e exceção. Para Godard a cultura é a regra, enquanto a arte se constitui como a exceção. Todo o texto de Bergala segue esse sentido, o de denunciar o perigo da domesticação da arte pela cultura escolar. Nessa concepção, a expressão "ação cultural" no título do projeto (Missão de Educação Artística e de Ação Cultural) responde à dimensão do cinema como evento cultural; isto é, como projeção de filme sem restringir-se ao ensino. A educação artística sugerida por Bergala, em contraste com a do ensino artístico, tem em vista que a arte resista à codificação promovida pela escola, não a restringindo ao ensino. Para Bergala "el arte, eso no

${ }^{39} \mathrm{~A}$ versão utilizada nesta pesquisa foi publicada na Espanha: La Hipotésis del cine: pequeño tratado sobre la transmissión del cine en la escuela y fuera de ella (BERGALA, 2007). 
se enseña, eso se encuentra, se experimenta, se transmite por vias diferentes al discurso del saber único, y a veces, incluso sin ningún tipo de discurso" (BERGALA, 2007, p. 34).

0 crítico francês pergunta-se pelas possibilidades de a escola fazer esse trabalho de acolhimento do cinema como produção de alteridade. Diz que a função da escola é exatamente essa, a de retirar o aluno do mundo privado a que se restringe, de modo a assimiliar a sua dimensão pública. A escola é a única possibilidade que grande parte dos estudantes tem para acessar um repertório cultural significativo - local ${ }^{40}$, nacional, mundial, em que o cinema está incluído. Ele toma sua própria trajetória como exemplo, quando diz ter sido "salvo" pela escola sem a qual teria ficado no campo, isolado culturalmente.

Quizás es necesario empezar a pensar la película - aunque no es lo más fácil pedagógicamente - no como un objeto, sino como la traza final de un proceso creativo, y el cine, como arte. Pensar la película como un gesto de creación. No como un objeto de lectura, descodificable, sino cada plano como la pincelada del pintor a través de la cual se puede comprender un poco su proceso de creación. Son dos perspectivas muy diferentes (BERGALA, 2007, p. 37).

Pensar o filme não como objeto, mas como processo não é senão pensar o filme numa dimensão do outro, o que não deixa de se configurar como público. Como disse Bergala, às vezes a arte dispensa mesmo o discurso. "Tiene que ser una experiencia de otra naturaleza que la de una asignatura particular, tanto para los alumnos como para los docentes.” (BERGALA, 2007, p. 34). Ao contrário, a escola tem uma tendência "a normalizar, amortiguar e intentar absorber esa parte de peligro que representa el encuentro con toda forma de alteridad para resguardarse a sí misma y a sus agentes." (BERGALA, 2007, p. 34).

Assim, como produzir as condições para a realização de tal experiência?

Será que a dificuldade de se pensar o encontro com a arte, idealmente, dar-se-ia

${ }^{40} 0$ Art. 26,§ 2․o., da LDB N. 9.394/1996, em que constava a seguinte redação: "O ensino da arte constituirá componente curricular obrigatório, nos diversos níveis da educação básica, de forma a promover o desenvolvimento cultural dos alunos." foi alterado na LDB N. 12.287/2010, ficando da seguinte forma: "O ensino da arte, especialmente em suas expressões regionais, constituirá componente curricular obrigatório nos diversos níveis da educação básica, de forma a promover o desenvolvimento cultural dos alunos" (destaque nosso). Essa alteração dá destaque às produções artísticas locais, mas não se restringindo a elas, como lembra Rosa Iavelberg (2012). 
por uma "plácida libertad individual"? (BERGALA, 2007, p. 36). No sentido de um possível encaminhamento para essa questão, Bergala promove o que chama de o "elogio ao fragmento". Pensando que o longa-metragem, tal como se constitui, como um bloco inteiriço, obriga o espectador a tomar parte no fluxo das imagens, preocupando-se com determinado enredo e não prestando atenção a outros detalhes, ele apresenta duas formas de lidar com fragmentos de filme. Uma delas é a que considera o fragmento como autônomo, independente do filme. 0 fragmento é tomado em si como uma unidade fechada sem relação com outras partes do todo de onde fora retirada. A outra forma é a de relacioná-lo com o todo do filme, um corte arbitrário, que gera "ligeira frustração" ao espectador, alimentando-o de vontade de ver mais do filme. A primeira é mais fácil de ser conduzida do que o filme inteiro. A segunda, como incitação ao desejo de ver o filme inteiro (BERGALA, 2007, p. 118). Ora, essa segunda estratégia sugerida por Bergala, de tomar o fragmento como parte, remetendo-o ao todo do filme, faz eco àquela preocupação, por sua vez, de não tomar a obra fílmica como um todo fechado, evitando buscar nele quase que exclusivamente a moral da história.

É por entender que esse processo de entrada do cinema na escola é mesmo complexo que Alain Bergala não acredita que ele deva ser "suavizado" com obras mais comerciais, que façam uso de lugares comuns como concessão ao público. "Esto ya es una pedagogia de la mirada: aceptar ver las cosas, con su parte de enigma, antes de taparlas com las palabras y los sentidos." (BERGALA, 2007, p. 98), pois

mirar una tela planteándose las preguntas del pintor e intentando compartir sus dudas y sus emociones de creador, no es lo mismo que mirar el quadro limitándose a las emociones del espectador (BERGALA, 2007, p. 38).

Esta estratégia é interessante para que a discussão na sala de aula não se limite às "impressões" dos alunos.

Diferente de Bergala, vale ressaltar novamente, Eduardo Coutinho (COUTINHO In TOZZI, 2009, p. 33), ao ser perguntado sobre que filmes ele indicaria para que professores da escola básica não deixassem de ver com seus alunos, ele diz que qualquer um serve ao propósito pedagógico a depender do 
"animador", bastando que este saiba o que quer e como discutir é o que importa. Para Coutinho, o importante é que “(...) ele [o animador] sempre tem que motivar as discussões." (COUTINHO, 2009, p. 33).

Ainda, ao contrário de Coutinho, Bergala parece partidário de uma pedagogia do desconforto, em que o professor acredite na inadequação dos discursos sobre os assuntos do filme e, com isso, leve os alunos sistematicamente a prepararem-se para lidar com tal desconforto sem a necessidade de resolver os "vazios" da arte. Eis o objetivo maior: não evitar esses vazios da arte que acontecem na escola. Assim, atribuir ontologia à imagem fílmica é já um grande desafio.

Bergala chama atenção para o modo tradicional de acolher o cinema na escola. Fala de "imperialismo linguístico". Eis a razão da recorrênica deste fato ser predominante: na França, o cinema é tomado como objeto de atenção no momento de hegemonia das ciências da linguagem, como a linguística, a semiologia e a semiótica. Além disso, Bergala destaca o medo dos professores diante de um objeto pouco conhecido em que se constitui o filme, o que os teria levado a "aferrarse a modelos de análisis más familiares, que ya practicaban, especialmente en literatura." (BERGALA, 2007, p. 41). Para Bergala, o linguisticismo tira do cinema "una de sus dimensiones esenciales, que lo distingue de las otras artes, la de 'representar la realidad a través de la realidad." (BERGALA, 2007, p. 42). Isto é, sua peculiaridade em mostrar em vez de dizer. O"imperialismo linguístico" ou "linguisticismo" e a já citada "ilusão pedagógica" também são aspectos inerentes ao tratamento do cinema na escola brasileira.

Antes de a cena nos chegar na tela como algo desde sempre dado, teria o cineasta (e sua equipe) hesitado entre um tipo e outro de flores? Seguindo o método que Bergala (2007) chama de "pedagogia da criação", ele incita professores e alunos a pensarem na condição dos filmes antes de se tornarem ato. Para tanto, segue o sentimento trazido à tona por George Bataille quando este se refere a Manet:

Nos cuesta imaginar el cuadro que admiramos suspendido como estuvo entre la incertidumbre que era en un primer momento para el pintor y la certidumbre que es para nosostros... ¡Cómo nos equivocaríamos sobre ellas si no situáramos de nuevo bajo la luz 
dudosa del nacimiento de estas telas tan diversasi (BATAILLE apud BERGALA, 2007, p. 127).

Isso não significa que se deva buscar na tela os objetos como se tratasse de um quebra-cabeças em que pudéssemos tirar isso e colocar aquilo, testando peça por peça. A citação de Bataille chama atenção para a obra de arte como ato de criação e para sua não-naturalidade.

Conforme já mencionado, o projeto coordenado por Bergala fazia parte de uma política nacional de educação chamada Plan de cinq ans (Plano de Cinco Anos). Como sugere o título, tinha cinco anos para ser desenvolvido. Foi interrompido, no entanto, por redução no orçamento. Apenas 32 dos 100 DVDs da coleção L'Éden Cinema do projeto La Mission (A Missão) chegaram às escolas francesas. Diferentemente, $O$ cinema vai à escola definia os filmes e a quantidade deles a serem distribuídos às instituições a cada ano e o projeto não tinha prazo para acabar ${ }^{41}$.

A postura de Bergala frente ao projeto parece ser aquela que, antes de indicar esse ou aquele cineasta como próprio ao contexto escolar, apesar dos DVDs entregues às escolas, é possível assumir, principalmente por parte dos professores, uma espécie de espírito investigador ou experimentador. Assim, como a um livro que pode ser abandonado sem pudor pelo leitor em razão de outro, também o filme poderia ser abandonado em prol de outro ou de uma busca inserida num projeto como "Filmes Pós-Segunda Guerra Mundial", por exemplo, em que os alunos veriam vários filmes da mesma época, tentando perceber características comuns ou diferenças entre eles.

A propósito da importância da geração do repertório de filmes na formação de alunos e professores, Bergala dá destaque a dois textos, um escrito por Jacques Rivette ${ }^{42}$ e o outro, por Serge Daney ${ }^{43}$ (BERGALA, 2007, p. 43-48), em que ambos tratam do filme Kapo (1960), de Gilles Pontecorvo. Para Bergala, as relações e comparações de planos que os dois autores fazem só foram possíveis

\footnotetext{
${ }^{41}$ Segundo Lizete Freire Onesti e Devanil Tozzi, membros da coordenação do projeto $O$ cinema vai à escola, em entrevista concedida ao autor (30 de setembro de 2015), conforme já salientado, o projeto foi interrompido pela SEE-SP por tempo indeterminado. Atualmente, os filmes são aproveitados pelo programa Escola da Família, que acontece aos finais de semana. Nesse caso, o público não se restringe a alunos, uma vez que é aberto à comunidade.

420 texto de Jacques Rivette é De l'abjection, Cahiers du cinéma, núm. 120, junho de 1961.

430 texto de Serge Daney é Le travelling de Kapo, Trafic, núm. 4, outono de 1992, Pol.
} 
porque eles já haviam visto muitos filmes. Esse seria um meio de dessacralizar a relação com a obra de arte. O texto de Jacques Rivette é uma crítica feroz e contundente à cena em que a atriz Emmanuelle Riva se mata lançando-se a uma cerca elétrica. Para Rivette, o diretor do filme que roda uma cena dessas com especial atenção a detalhes, como o de um travelling antes do desfecho e a seguir, o posicionamento das mãos, merece seu profundo desprezo ${ }^{44}$.

Todavia, não se está sugerindo que o filme deva atender aos requisitos do império do prazer imposto pelo aluno-espectador ao querer que se abandone uma obra por outra, mas que ele possa se sentir à vontade para constituir seu percurso fílmico sem ter que se culpar por não gostar ou não reconhecer tal ou qual filme como canônico. Deve, ao contrário, ser estimulado a estabelecer articulações entre os filmes, como no exemplo do texto de Jacques Rivette ou a relação de planos presentes no texto de Serge Daney, que compara o plano do suicídio de Kapo, que fora criticado por Rivette, com um de Contos da lua vaga (Ugetsu Monogatari, 1953), de Kenji Mizoguchi. O plano deste tem a duração de um minuto e mostra o marido Genjurô retornando, depois de abandonado a casa por um certo tempo para viver uma vida de prazeres. Ao chegar, percebe tudo vazio, mas ao contornar a casa, enquanto se mantém no enquadramento (acompanhado por uma PAN, da direita para a esquerda e, a seguir, uma PAN, da esquerda para a direita) volta ao lugar por onde acabara de passar. No lugar que estava imediatamente antes vazio, agora encontra-se a esposa Miyagi, cozinhando. A emoção toma conta dos dois. A seguir, a cena continua com outras sequências, quando ao fim se saberá que a mulher já havia morrido e que o encontro não passou de um delírio do personagem. Assim, para Bergala, a relação entre planos de filmes diferentes ou a indicação moralizante de um travelling só é possível de ser feita por quem possua um repertório amplo e diversificado de filmes. É o que se

\footnotetext{
${ }^{44} \mathrm{~A}$ Passagem no original: "Voyez cependant, dans Kapo, le plan où [Emmanuelle] Riva se suicide, en se jetant sur les barbelés électrifiés; l'homme qui décide, à ce moment, de faire un travelling avant pour recadrer le cadavre en contre-plongée, en prenant soin d'inscrire exactement la main levée dans un angle de son cadrage final, cet homme n'a droit qu'au plus profond mépris." In: http://www.slate.fr/story/113377/travelling-kapo-rivette-shoah, consulta em 06 de maio de 2016. "Veja, no entanto, em Kapo, o plano em que [Emmanuelle] Riva comete suicídio, atirando-se sobre o arame farpado eletrificado; o homem que decide nesse momento de fazer um travelling antes de retomar o cadáver em contra-plongé, tendo o cuidado de incluir exatamente a mão levantada em um canto do enquadramento final, este homem não tem direito senão ao profundo desprezo" (tradução nosa).
} 
espera de um professor que trabalhe com cinema, como se espera que sejam feitas relações entre textos das várias disciplinas, como em Geografia ou em História.

Dessa forma, a presença do cinema na escola, segundo Bergala, não visa à simplificação do processo ensino-aprendizagem. Ao contrário, visa à complexificação, tornando possíveis novas relações com o mundo. Tal processo parece exigir a implicação do aluno - e do professor, com a obra, que, convocado, joga(-se) no jogo. Jogar (ou jogar-se), mexer as peças do tabuleiro, parece ser fundamental para a ação de qualquer aprendizado. Como diz Philippe Arnaud, só o desejo ensina. Assim,

Toda la película [referindo-se ao filme $O$ Boulevard do Crime (Les Enfants du Paradis, 1945) de Marcel Carné] es la exposición de la condición vital de cualquier transmisión que opere: El deseo inicial del hijo, pues es el quien aprende, no la enseñanza." (ARNAUD apud BERGALA, 2007, p. 79).

Neste filme, o pai, que é mímico, recusa-se a ensinar ao filho sua arte, proibindo-o mesmo de reproduzir ou usar seu nome como referência, de modo que a lição que o pai Deburau dará ao filho será uma única: que ele o veja atuando, mas "no copies los que yo hago" (ARNAUD apud BERGALA, 2007, p. 78).

Algo parecido se passa em Andrei Rublev (1966), de Andrei Tarkovski, em que o pai, que fazia sinos, cuja técnica todos desconheciam, foi supostamente passada ao filho. Por ocasião da morte do pai, o adolescente Boriska diz ter tido ensinamentos, que este antes de morrer lhe passara o segredo e então, o garoto, com arrogância nervosa, comanda o processo de fabricação de um grande sino. Espera-se que ao final seu tilintar soe de modo poderoso a ser ouvido longe. Boriska aguarda nervosamente ao teste, em que se movimenta o pêndulo para que bata nas bordas e produza o som característico. A resposta é positiva e o sino produz o som esperado. Quando todos se dispersam, Andrei Rublev encontra o garoto chorando desesperadamente. Nesse momento, Boriska surpreendemente confessa ao pintor que seu pai nunca lhe havia passado o segredo. Como ele teria aprendido o "segredo" senão por transmissão?

Retomando Benjamin, trata-se aí de mais um caso de transmissão e não de ensino ou de decodificação das técnicas para se fazer um sino. Assim, trata-se da 
ideia de experiência de Benjamin, em que o que se trasmite de geração a geração não é algum ponto específico, uma técnica, mas um eterno presente. De onde Boriska teria aprendido senão pelo pai (e não do pai), com o convívio? Parece-nos que o possível da arte aí se deu em razão do desejo do garoto Boriska de ser digno de carregar um traço do pai, dessa dignidade de certo "pertencimento", de filiação.

Em que pese a dimensão da transmissão no tocante à arte na escola, contudo, há um aspecto prático para o qual Bergala chama atenção. A constituição da experiência com filmes na escola depende de vários aspectos, estando dentre eles, a constituição do hábito de ver filmes. Bergala chama atenção também para que a escola não fuja aos verdadeiros desafios, devendo a escola "confrontarse a las verdaderas dificultades del acto de creación en el cine” (BERGALA, 2007, p. 177).

Para Bergala, esse aspecto do "ato de criação no cinema" seria frequentemente negligenciado nas atividades práticas com o cinema na escola. Isso fica evidente nos curtas-metragens de tipo "cartão de visitas", feitos já com a preocupação de seduzir canais de televisão, de inserir-se no mercado, digestivamente. Tais curtas-metragens são, em grande medida, diz Bergala, hipercodificados, de modo que passam a sensação de "já vistos" tal sua formatação para o mercado. Essas obras sentem-se impelidas a parecerem brilhantes, com um giro final e movimentos sofisticados de câmera etc. Nesse modelo dominante de curta-metragem, dentre alguns problemas, Bergala aponta a falta do sentimento do tempo, "que tampoco debería depender de la duración de la película." (BERGALA, 2007, p. 178). Para essas produções, o objetivo maior é o de contar uma história e de significar, isto é, "una voluntad exclusiva de enunciación" (BERGALA, 2007, p. 178).

Ao contrário, no contexto pedagógico da escola, é preciso colocar a questão do que deve ser priorizado, se o produto ou o processo. Pois importa saber como professores e alunos se colocam diante da questão: o que enquadrar, como, por quanto tempo; quando cortar, selecionar, montar. Para Bergala, a busca pelo sentido acaba por controlar todas as etapas da produção dos curtas-metragens que, em tese, seria o lugar de respiro da linguagem cinematográfica, já que os curtas-metragens ainda não estão inseridos no circuito fechado de exibição de filmes. Por isso, ele se coloca a questão de como "introducir en pedagogía que lo 
importante es que haya vida en un plano, y que la vida no se deja captar tan facilmente como se produce el sentido (...)" (BERGALA, 2007, p. 179).

Assim, a exibição na escola de filmes de cineastas como Jean-Luc Godard ou Abbas Kiarostami, por exemplo, acaba não acontecendo pela pressuposição da instituição de que não há possibilidade de estabelecimento do sentido a partir de tais filmes, quando, a rigor, uma matriz de filmes não inviabilizaria a outra. É certo que se trata de projeções com procedimentos bem distintos. Assim, à diferença da projeção da de um filme já formatado para televisão, o de Godard ou o de Kiarostami revelaria, de saída, que a relação com o olhar codificado dos alunos não se daria de modo suave e agradável como a relação com qualquer coisa que fuja ao estritamente figurativo ou narrativo. Por isso, para promover a transição desse olhar a um olhar mais errante dever-se-ia anteceder um Godard por toda uma sequência de filmes mais "leves"? Como diz Bergala, deve-se começar com Pokemon para se chegar a um Carl Dreyer? No entanto, seria exatamente a partir de um Godard (Kiarostami, Carl Dreyer, Bergman etc.) que parecem surgir aberturas para tratar o cinema na escola como alteridade. Godard, por exemplo, imprime uma marca própria ao cinema, dentre outros aspectos, ao tirar o peso do enredo. Seu cinema é a manifestação de uma concepção menos presa ao figurativo, menos fechada e menos preocupada em contar uma história, ainda que em algum nível, conte, caso também de Kiarostami, Dreyer e tantos outros como Bergman e Tarkovski, por exemplo. Lembremo-nos que Piaget destaca o equívoco dos pedagogos de reduzir os objetos concretos a um processo figurativo (PIAGET, 1970, p. 72). Da mesma forma, as escolas elegem os filmes figurativos ou narrativos por servirem de ilustração às disciplinas e pela facilidade de incluí-los em seus discursos, pela facilidade em explicá-los.

O desejo de encontrar figuração nas artes parece sintetizar a obsessão da escola pela produção do sentido a que se refere Bergala. Com isso, não se trata de propor que os filmes busquem o apagamento total da figura. Tais figuras continuam semelhantes ao mundo em que vivemos. Para fazermos uma comparação com a pintura, tomemos como exemplo o quadro de Paul Cézanne $A$ floreira azul (1885-1887, Museu d'Orsay, Paris, França). As figuras que compõem a 
tela não correspondem à realidade objetiva, mas não deixamos de reconhecer ali os objetos. Suas linhas não procuram reproduzir a floreira que imaginamos ter servido de modelo. No quadro, a floreira está inclinada para a esquerda, como se fosse tombar. As linhas retas se concentram nas bordas da mesa e no jarro à esquerda. E ainda nos perguntamos se o arranjo de flores não estaria preste a derrubar a floreira. Os vasos e mesas, que por ventura figuram nos filmes de Godard, são aqueles mesmos que encontramos na realidade exterior. 0 que está diluído são a história, os personagens, o emolduramento.

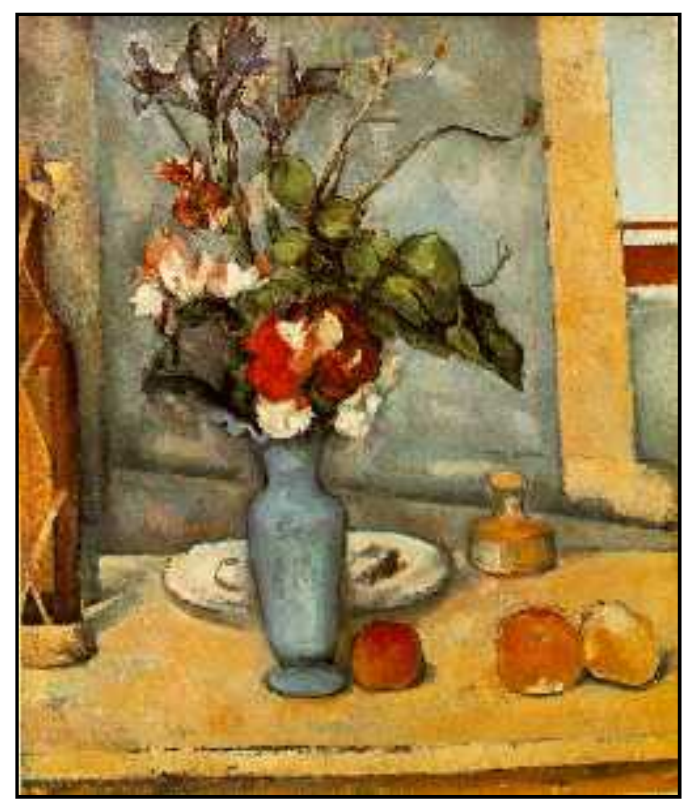

Figura 2 - A floreira azul (Le vase bleu), Paul Cézanne, 0,612 x 0,5, óleo sobre tela, Museu d'Orsay, Paris, 1889-1890.

Enfim, para escapar à armadilha da busca pelo sentido promovida a todo custo pelos curtas "festivaleiros", Bergala chega a sugerir que, em vez de vinte minutos, o aluno faça apenas um plano, mas com experiência íntima, em prol do ato de criação. Essa experiência tem que mobilizar o desejo do aluno e suas capacidades para com o cinema. 


\section{3- 0 cinema e a indústria cultural}

A discussão sobre a indústria cultural promovida por Adorno e Horkheimer aparece como capítulo, sob o título "A indústria cultural: o esclarecimento como mistificação das massas", em texto maior denominado Dialética do esclarecimento (ADORNO \& HORKHEIMER, 2006), publicado em 1947. Tal escrito é uma crítica à concepção de emancipação por meio da razão, tese do Iluminismo condensada no texto célebre de Kant, Resposta à pergunta: que é o esclarecimento? (KANT, 1985). Como se sabe, Kant via na razão o meio pelo qual os sujeitos sairiam "progressivamente" da menoridade e passariam à maioridade. Para ele, o estado de menoridade é a incapacidade de se fazer uso de seu próprio entendimento sem a direção de outra pessoa, sendo a permanência neste estado de responsabilidade do próprio sujeito "menorizado". A saída da menoridade é, segundo Kant, o ponto principal do Esclarecimento (KANT, 1985). A razão iluminista tomou uma forma particular na sociedade moderna, identificada por Adorno e Horkheimer como razão instrumental, isto é, como instrumento de dominação técnica.

Apesar de o problema sobre essa transformação da razão iluminista em razão instrumental apontado por Adorno e Horkheimer estar presente também no fascismo e nazismo, neste texto, os autores estão se referindo à sociedade moderna e industrial de forma geral, cujo exemplo ítalo-germânico é um consequente paroxismo. São concepções políticas que expressam uma razão com respeito a fins, isto é, uma razão que administra as vidas, regulamenta-as, controla-as, eliminando “(...) o horizonte sombrio do mito [que] é aclarado pelo sol da razão calculadora, sob cujos raios gelados amadurece a sementeira da nova barbárie." (ADORNO \& HORKHEIMER, 2006, p. 38). Contudo, é no capitalismo contemporâneo, sobretudo, impulsionados pela experiência nos EUA, que eles identificam que "a cultura converteu-se totalmente numa mercadoria (...)" (ADORNO \& HORKHEIMER, 2006, p. 162, destaque nosso), e que o pensamento teria perdido o fôlego e se limitado à apreensão do factual isolado (ADORNO \& HORKHEIMER, 2006, p. 162). A conclusão de Adorno e Horkheimer não é outra senão a de que a razão, que, em termos kantianos, apontaria para a superação de um estado de menoridade, na 
verdade, intensifica tal estado. Em vez de libertar, aprisiona. Para Barbara Freitag, o texto representa, pois, "a morte da razão kantiana, asfixiada pelas relações de produção capitalista" (FREITAG, 2004, p. 21).

Essa posição de Adorno e Horkheimer é tomada por muitos autores como pessimista. 0 pessimismo justificar-se-ia pela necessidade de explicar o advento do fascismo, do nazismo, do regime stalinista e, ao mesmo tempo, a revolução que não veio no Ocidente. Isto é, explicar "o fracasso dos prognósticos marxistas, sem romper, no entanto, com as intenções marxistas.” (HABERMAS, 2000, p. 166). No intuito de libertar a humanidade do jugo da repressão, da ignorância e da inconsciência, os dois autores teriam colocado a razão em aporias, dentre elas, a de criticar a razão instrumental pela própria razão.

Habermas, herdeiro do legado do Instituto de Pesquisa Social, que identifica tais aporias, tenta salvar a razão desta encruzilhada e do referido pessimismo. Para ele, Adorno e Horkheimer eram perfeitamente conscientes das contradições perfomativas da crítica totalizada (HABERMAS, 2000, p. 170). No prefácio de 1944 do referido texto, Adorno e Horkheimer reconhecem que a autodestruição do esclarecimento é uma aporia: "A aporia com que defrontamos (...) a autodestruição do esclarecimento." (ADORNO \& HORKHEIMER, 2006, p. 13). O seguinte trecho de Habermas dá uma indicação de sua crítica.

Como podem os dois iluministas, pois nunca deixaram de sê-lo, subestimar o conteúdo racional da modernidade cultural, de tal modo que em tudo percebem apenas uma aliança entre razão e dominação, poder e validade? Não se deixam inspirar por Nietzsche (...), valendo-se de uma experiência fundamental autonomizada da modernidade estética? (HABERMAS, 2000, p. 172).

Para Freitag, assim como Habermas, Adorno e Horkheimer também preservam, "em sua essência, a crença iluminista: usar a razão como instrumento de libertação para realizar a autonomia, a autodeterminação do homem." (FREITAG, 2004, p. 41).

O termo indústria cultural aparece no bojo dessa discussão, mas já estava presente em "Arte e Cultura de Massa", artigo de 1941, de Horkheimer (FREITAG, 2004, p. 66). Em “A indústria cultural: o esclarecimento como 
mistificação das massas", Adorno e Horheimer querem demonstrar que a "arte, fundida com o divertimento, teria sido paralisada em sua força inovadora e esvaziada de todo conteúdo crítico e utópico." (ADORNO/HORKHEIMER apud HABERMAS, p. 160). 0 texto procura denunciar o predomínio da identidade - "a eterna repetição do mesmo" - que se apresenta com a ideia de certa liberdade criativa que se potencializaria pela livre circulação das obras e que poderiam ser acolhidas ou não pelo público conforme o julgamento sobre o valor destas.

A ideia de livre circulação das obras é defendida por Paul Lazarsfeld (1971). O sociólogo austríaco sustenta a ideia de espontaneidade e de democratização dos produtos da chamada cultura de massa como um movimento espontâneo a que o mercado se adequaria. Para Adorno e Horkheimer, na verdade, essa circulação "espontânea" de obras responderia ao "poder absoluto do capital" (ADORNO \& HORKHEIMER, 2006, p. 99). As cifras que envolvem os projetos industriais, incluindo aí o cinema, são já uma suspeita de que não se trata de algo espontâneo como parece muitas vezes ser entendido: "A racionalidade técnica hoje é a racionalidade da própria dominação" (ADORNO \& HORKHEIMER, 2006, p. 100). Já no início da implantação do rádio, a indústria cultural cumpria o destino de submeter a audiência a uma mesma programação. Igualmente, para Adorno e Horkheimer, o cinema apassivaria a percepção dos espectadores.

0 cinema-mercadoria existe em função do mercado consumidor, que o retroalimenta. Para se ter ideia dessa relação de reciprocidade, no Brasil, o público que foi a cinema em 2014, por exemplo, aumentou em 4,1\% em relação a 2013, rendendo R\$1,96 bilhão ${ }^{45}$. Tais cifras têm implicação na dimensão de controle da indústria cultural sobre a suposta espontaneidade do público. A exemplo dos curtas-metragens "festivaleiros" mencionados por Bergala (2007), que se esforçam para fazer um produto voltado para o mercado, Adorno e Horkheimer destacam os programas de caça aos talentos - existentes aqui e alhures, que consiste em

\footnotetext{
45 "Diferente do que aconteceu em 2013, o propulsor do crescimento do mercado brasileiro de cinema em 2014 foi o filme estrangeiro, particularmente o norte-americano. Os filmes estrangeiros reverteram a tendência de queda observada em 2013 com um crescimento de 12,2\%. No total, 16 obras dos EUA ultrapassaram a marca de três milhões de ingressos. Em 2013, foram dez. Destaca-se também o aumento da quantidade de grandes campanhas de lançamento de títulos estrangeiros. Durante o ano, nove filmes estrangeiros foram lançados em mais de mil salas, contra seis em 2013 e quatro em 2012". Fonte: ANCINE.http://oca.ancine.gov.br/media/SAM/Informes/2014/Informe_anual_preliminar_2014_Ar quivodePublicacao.pdf. Acesso em 11 de maio de 2016.
} 
concurso de canto na televisão ou no rádio, em geral, para pessoas até então sem projeção profissional -, como manifestação já de um formato mercadológico preconcebido. No caso, os autores se referem a programas de rádio, cujo público atraído, a despeito de se constituir de pessoas novas, uma vez que não trabalham para nenhuma gravadora, no entanto, “(...) já pertencem à indústria muito antes de serem apresentados por ela: de outro modo não se integrariam tão fervorosamente." (ADORNO \& HORKHEIMER, 2006, p. 100). Essa busca intensa pelo reconhecimento já é, segundo Adorno e Horkheimer, sinal de que são eles mesmos uma produção da indústria cultural. Dimensão controladora, que regulamenta o consumo e que é regulamentado por ele. 0 consumidor impõe sua demanda, que é atendida pelo filme. Impõe-se pela força consumidora da coletividade.

\begin{abstract}
Outrora, o sujeito que olhava, escutava, li uma obra, devia se esquecer, se fazer indiferente. Hoje a obra é objeto do desejo pequeno-burguês que espera que a obra lhe traga algo. A obra-dearte se torna a 'coisa' que satisfaz esse desejo, sendo sentida como necessidade. A arte, na medida em que corresponde a uma necessidade social, se torna uma empresa movida pelo lucro: duplamente rentável, já que permite manter o status quo e satisfazer necessidades perpetuamente recriadas e condicionadas no consumidor, que nem mais toma consciência de que no interior da falsa totalidade não pode existir satisfação autêntica. A exploração econômica com fins ideológicos contribui para o que Adorno chama a 'Entkunstung [perda do caráter artístico da arte ou desertificação da arte] da arte'. (JIMENEZ, 1977, p. 86).
\end{abstract}

Elogiado por Benjamin, esse aspecto coletivo constitutivo da relação com a produção do filme como obra de arte na modernidade é um problema para Adorno:

a coletividade é algo que penetra até o íntimo do filme. Os movimentos que ele representa são impulsos miméticos. Antes de qualquer conteúdo e conceito eles animam os espectadores e os ouvintes a se movimentarem juntos, como num trem. Nessa medida, o filme é semelhante à música, assim como nos primeiros tempos do rádio a música era parecida com as películas. Dificilmente chega a ser um desvio considerar o sujeito constitutivo do filme como um 'nós' (...). À medida que o olho é arrastado nesse fluxo, ele cai na corrente de todos aqueles que seguem o mesmo apelo." (ADORNO In COHN, 1994, p. 105). 
Na mesma direção, Freitag afirma que

A cultura fornecida pelos meios de comunicação de massa não permite que as classes assalariadas assumam posição crítica face a sua realidade, já que ela mistura os planos da realidade material com as suas formas de representação e progressivamente anulam os mecanismos de reflexão e crítica para acionarem a percepção e os sentidos (visão e audição)." (FREITAG, 2004, p. 73).

Os meios de comunicação de massa não só não permitem o conhecimento dos processos de produção como reforçam a posição das classes trabalhadoras como meros consumidores. Os produtores a serviço da indústria cultural, lembra Kracauer, não se deixarão seduzir em fomentar espetáculos que, de algum modo, ataquem os fundamentos da sociedade. Por isso, "os filmes feitos para as classes mais baixas da população são sempre mais burgueses do que aqueles para o público mais refinado, precisamente porque eles tocam em pontos de vista subversivos sem explorá-los." (KRACAUER, 2009, p. 311). Isso permite a Kracauer decifrar "o cinema [...] como ideologia."46 (ADORNO, 2009, p. 12), como instrumento desse processo de alienação. Alienação que não se apresenta como defeito na comunicação de massa. Ela é, na verdade, pressuposta.

A ideologia é também uma questão para a escola. Para Barbara Freitag, “a atuação da ideologia na escola não se daria tanto na transmissão de conteúdos ideológicos, mas sim através do próprio instrumento de transmissão (de quaisquer conteúdos), ou seja, da linguagem" (FREITAG, 1980, p. 09-10). Igualmente, para Adorno e Horkheimer, o cinema serviria como instrumento de alienação em sua imposição como produto industrial atendendo ao propósito ideológico como linguagem.

Visto que a presença desse cinema comercial ideológico na sociedade é massiva, e que ele se constitui, em grande medida, como reprodução do mesmo em suas palavras, "arte (...) paralisada em sua força inovadora e esvaziada de todo

\footnotetext{
46 Preciosa a observação de Terry Eagleton sobre o suposto desaparecimento do termo ideologia dos artigos e textos acadêmicos em geral numa época em que se nota a organização ideológica de grupos em torno de questões polêmicas, como declaração de guerra a países, a reunião do chamado eixo do mal etc. (Cf. EAGLETON, Terry. Ideologia. São Paulo: ed. UNESP, 1997).
} 
conteúdo crítico e utópico" -, como fazer a escola escapar à intensa (e quase exclusiva) imposição da narratividade fílmica, frequentemente reforçada pelo excesso de imagens e falas que tudo explicam, o que contribui para a manutenção da posição do espectador como consumidor de imagens "esvaziadas" e procurar marcar o ambiente escolar com uma multiplicidade fílmica mais significativa?

Em “A indústria cultural..." e em vários outros textos, Adorno e Horkheimer já teriam dado o tom da resposta a essa pergunta. Apesar das sugestões de determinadas ações para a contenção do domínio da alienação produzida pela indústria cultural, sua crítica é por demais estrutural para contentar-se com reformas. 0 tom da resposta à pergunta acima é, pois, pela negação, isto é, que não é possível escapar ao império da indústria cultural. "La industria de la cultura pasa por alto su moralismo (...). La enfermedad no está en los individuos de malas intenciones, sino en el sistema mismo." (ADORNO, 1969b, p. 82). Não se trata de moralizar a observação sobre o fenômeno da indústria cultural senão de reconhecer que há uma estrutura que antecede a produção da arte e que a absorve tão logo ela surja.

Em dois textos sobre televisão Adorno reafirma sua posição em não ver saída para a autenticidade no audiovisual: "El vocabulario de la escritura de imágenes no es sino estereótipos." (ADORNO, 1969a, p. 72). Neste mesmo texto ele diz:

Así como toda imagen o cuadro pretende suscitar en el observador lo que en ellos está enterrado y con lo cual ofrecen analogías, los cuadros del cine o la televisión, breves como un centelleo y fluidos, se parecen más a una escritura. Son leídos y no observados. El ojo es arrastrado por líneas, como al leer, y en la plácida suceción de las escenas, es como si se diera vuelta a una página. En cuanto imagen, la escritura ideográfica es un medio regresivo en el que vuelven a encontrarse el productor y el consumidor; se trata de una escritura que pone a disposición del hombre moderno imagénes arcaicas. Una magia sin encanto no comunica ningún enigma, sino que corresponde a modelos de comportamiento conformes no sólo al peso del sistema total, sino también a la voluntad de quienes lo controlan (ADORNO, 1969a, p. 71).

Para Adorno a semelhança entre as obras é uma indicação de direcionamento e controle estético. "La similitud de las películas es prueba de la 
unidad de la industria de la cultura: es casi indiferente por donde se aborde." (ADORNO, 1969b, p. 76). O cinema é produto “de una planificación comercial, no conoce esa riqueza de estratos." 47 (ADORNO, 1969b, p. 76).

0 ar de familiaridade dos filmes ditos comerciais confirma 0 prognóstico de Adorno, pois “(...) tudo o que se lhe oferece é tão semelhante ou idêntico (...)." (ADORNO, 1991, p. 79). Essa sememelhança é verificável no uso recorrente de clichês ${ }^{48}$, por exemplo. “(...) a obra medíocre sempre se ateve à semelhança com outras, isto é, ao sucedâneo da identidade. A indústria cultural acaba por colocar a imitação como algo de absoluto." (ADORNO/HORKHEIMER apud HABERMAS, p. 161).

Adorno critica aqueles que defendem que a padronização da estética do cinema mencionada pelo autor dar-se-ia em razão da atenção dispensada pelo cinema à produção da informação. Por sua vez, em uma entrevista sobre Godard concedida à Cahiers du cinema (DELEUZE, 2004), Deleuze confirma esse parecer de Adorno, chamando atenção para a disseminação do uso funcional da linguagem na televisão, no cinema e na literatura, com a expulsão das linhas de fuga e do desequilíbrio na linguagem ou da gagueira em sua própria língua. "Não ser gago em sua fala, mas ser gago da própria linguagem." (DELEUZE, 2004, p. 52). Dado o uso funcional generalizado da linguagem na televisão, para Deleuze, Godard - que fez dois programas e que foi ao ar por seis vezes - teria sido o único caso de quem não se deixou enganar por esse meio de comunicação. "Em geral já perdemos antes de começar." (DELEUZE, 2004, p. 52). Do mesmo modo, para Adorno, a discussão em torno da televisão (como também do cinema ou do rádio) não deve ser tomada de modo isolado, pois para ele a televisão é

um momento no sistema conjunto da cultura de massa dirigista contemporânea orientada numa perspectiva industrial, a que as pessoas são permanentemente submetidas em qualquer revista,

\footnotetext{
47 Adorno se refere ao conceito de multiplicidade de estratos estéticos: "[...] el hecho de que ninguma obra de arte comunica de manera unívoca y de per sí su contenido. Se trata siempre de algo complejo, que no puede ponerse estrictamente en un casillero y que sólo se abre en un proceso histórico." (ADORNO, 1969, p. 77).

48 Clichê aqui no sentido de Deleuze, segundo Rodrigo Guéron: "esquema de controle e interiorização dos instintos." (GUÉRON, 2011, p. 138). Vale notar que em alguns filmes o clichê pode aparecer de forma involuntária, contudo, nos chamados filmes comerciais, ao contrário, ele é condição de sua existência.
} 
em qualquer banca de jornal, em incontáveis situações da vida, de modo que a modelagem conjunta da consciência e do inconsciente só pode ocorrer por intermécio da totalidade desses veículos de comunicação de massa (ADORNO, 2006b, p. 88).

A televisão e o cinema e todo o conjunto de meios de comunicação estariam comprometidos em sua própria ontologia com a sociedade (ADORNO, 2006b, p. 81). Os fins de sua reprodução respondem aos interesses dos próprios produtores, lançando-se incansavelmente "contra el espectador 'mensajes' abiertos o encubiertos. Posiblemente estos últimos, por ser psicológicamente los más efectivos, tengan preeminência en la planificación." (ADORNO, 1969b, p. 77).

Esse comprometimento ou controle da sociedade em relação à televisão - a despeito da discussão sobre que função ela deveria desempenhar: se informar, entreter ou a de formação -, para Adorno, ela serve mais àquela do que a esta, pois entende que a formação exige certos cuidados a que a televisão, a princípio, não se detém. Nesse sentido, sugere que seja ensinado às pessoas como ver televisão, de modo que elas não se sintam iludidas nem subordinadas a ela como ideologia, isto é, como "tentativa de incutir nas pessoas uma falsa consciência e um ocultamento da realidade, além (...) de procurar-se impor às pessoas um conjunto de valores." (ADORNO, 2006b, p. 80).

Segundo Adorno, a potência que Benjamin viu no cinema negligencia essa dimensão da indústria cultural. Ele, por exemplo, "não tratou de quão profundamente várias de suas categorias postuladas para o cinema - valor de exposição, teste - estão comprometidas com o caráter da mercadoria, contra o qual sua teoria se volta." (ADORNO In COHN, 1994, p. 104). Prossegue: "A durabilidade do método voltado para o choque [no sentido de Benjamin] desperta dúvidas." (ADORNO In COHN, 1994, p. 105). Isto é, Benjamin, ao combater o caráter de mercadoria do cinema, estaria, na verdade, reforçando-o como tal, pois para Adorno, "qualquer realismo estético hoje" (ADORNO In COHN, 1994, p. 104) está preso à lógica da mercadoria. Considerando que esse texto - "Notas sobre o filme" (1994) - foi publicado em 1967, é certo que não passaram despercebidos por Adorno vários movimentos importantes no cinema, dentre eles, o Neo realismo italiano, e o aparecimento de muitos cineastas que, no mínimo, causariam certa suspensão da assertiva de que tratar-se-iam de trabalhos restritos a produtos da 
indústria cultural. No entanto, Adorno sugere que o cinema reforce nele próprio outras linguagens, como a música, caso de um filme do compositor Mauricio Kangel, Antithese (1965). Essa seria a forma de potencializar o cinema. Cita A Noite (La notte, 1961), de Michelangelo Antonioni, como o antifílmico, por apresentar imagens estáticas. Para ele, este filme expressa pelo antifímico "o tempo vazio com olhos vazios." (ADORNO In COHN, 1994, p. 102). Seria o caso de incluir esse filme entre aqueles que são como "um resto de art nouveau (...) que querem fazer nuvens peregrinas e lagos sombrios falarem por si." (ADORNO In COHN, 1991, p. 104)?

A partir do que até aqui foi dito, vale notar o quanto Adorno e Horkheimer parecem tratar a indústria cultural como unidade, um bloco homogêneo que se instalou nos poros da vida social de modo que não só a divulgação das obras, mas o próprio processo de produção artística já estaria condenado à sua lógica. Tratar-se-ia de uma espécie de agente que submete a produção cultural a um formato fechado.

Como dissemos, segundo Habermas, essa crítica de Adorno e Horkheimer é niveladora, pois "desconsidera os traços essenciais da modernidade cultural." (HABERMAS, 2000, p. 163). Esquece, por exemplo, a riqueza da contribuição das vanguardas. (HABERMAS, 2000, p. 162-163). Para Jesús MartínBarbero, o modo de Adorno mobilizar a discussão sobre a arte é aristocrático. Afirma ainda que Adorno privilegia a "arte maior" em detrimento de outra, por consequência, "menor". Retomando o conceito de indústria cultural, ressalta que ele desconsidera a importância da arte popular. Mais: impossibilita pensá-la. "E se na origem da indústria cultural, mais que a lógica da mercadoria, estivesse de fato a reação frustrada das massas ante uma arte reservada às minorias?" (BARBERO, 2008, p. 77). Quanto a essa concepção de arte pura e hierarquizada de Adorno, Barbero destaca que na era da comunicação de massa "a arte permanece íntegra precisamente quando não participa da comunicação" (ADORNO apud BARBERO, p. 79).

Adorno e Horkheimer parecem ter se enredado "nas teias do aparentemente icônico, repetitivo e massificador." (CABRERA, 2013, p. 80), limitando sua visão do cinema àquele cinema convertido em virtual, nos termos de Kátia Maciel, porque seduzido e tragado pela tecnologia (MACIEL, 1993). 
Não obstante, contrariamente à semelhança que caracterizaria as obras de arte submetidas à indústria cultural de que tratam Adorno e Horkheimer, é possível apontar toda uma linhagem de filmes cuja dessemelhança é a marca maior. Assim, dentre muitos exemplos, A Palavra (Ordet, 1957), de Carl Dreyer, escaparia à reprodução do mesmo ao traduzir a ideia de milagre em acontecimento humano. A Palavra, nesse sentido, não seria mero produto industrial. Do mesmo modo, filmes da juventude do cinema como Paris Adormecida (Paris qui dort, 1924), Sob os Tetos de Paris (Sous le toits de Paris, 1930) e A Nós a liberdade (A Nous la liberté, 1931), de René Clair, para citar apenas um cineasta. Benjamin vai ser aquele que percebe esse potencial do cinema para além de sua condição de repetição do mesmo. Há nesses filmes citados algo muito diferente do esquema sensório-motor. Seus "personagens não 'sabem' mais reagir às situações que os ultrapassam (...). Nasce uma nova raça de personagens. Mas, sobretudo, nasce a possibilidade de temporalizar a imagem cinematográfica (...)” (DELEUZE, 2004, p. 78). Deleuze aí está se referindo principalmente aos filmes de Yasujiro Ozu e aos do Neo realismo italiano.

Com a Nouvelle vague francesa, essa perspectiva muda ainda mais. Mesmo que em muitos filmes desse movimento a literatura estivesse fortemente imbricada, os enredos, em grande medida, não respondiam mais às demandas do texto, chegando ao ponto ideal (de escritura) de utilização da câmera como caneta (DUBOIS, 2004), o que se constitui em outro nível de infidelidade a um referente ou à diluição de uma figuração ou transposição de um modelo original. Nem tudo que se apresenta na tela está justificado diegeticamente. Godard, por exemplo, faz farto uso de recursos como o salto, em Acossado (À bout de souffle, 1959), e o falsoraccord ${ }^{49}$, em Week-end à francesa (Week end, 1967).

É divergindo do sentido de submissão ou da colonização da imagem pela palavra, no sentido de Godard, que o cinema não-narrativo - ou o cinema não

\footnotetext{
${ }^{49}$ Em contraposição ao raccord (continuidade), o falso-raccord sugere um corte na continuidade, como o faz diversas vezes Godard já desde Acossado, seu primeiro longa, quando corta "sem necessidade" (do ponto de vista da montagem de planos). Corte, esteticamente falando, pois não chega a prejudicar a continuidade sugerida pelo raccord. Vale lembrar que o falso-racord já era fartamente utilizado por Eisenstein e também por Roberto Rossellini. Aumont cita como exemplo Viagem à Itália (1953). Para ver mais: AUMONT \& MARIE, 2003, verbete Falso-raccord. 96
} 
submetido exclusivamente ao narrativo -, deseduca o olhar, na medida em que não repete a fórmula do cinema comercial, ao contrário, subverte-a.

Godard se pergunta pelas possibilidades do próprio cinema, reconfigurando-o como lugar do pensamento e da sensibilidade. Nesse sentido, trata-se de um cinema deseducativo, na medida em que contraria a concepção de educação levada a cabo na predominância pela busca do sentido dos discursos pedagógicos cientificizantes, a exemplo dessa mesma busca pelos curtasmetragens "festivaleiros", como diz Alain Bergala (2007). O falso-raccord é um indicador de que o exercício cinematográfico ganha autonomia frente à função de contar algo, de reprodução naturalista, tônica das produções hollywoodianas, pois esse recurso não contribui para a transparência nem para a progressão da história "contada"; ao contrário, chama atenção para os processos fílmicos e, frequentemente, como diz Nana (Anna Karina) em Viver a vida (Vivre sa Vie, 1962), de Godard, "quanto mais falamos, menos as palavras significam." (ver Figura 3). A obra de Godard aí situa-se como arte conceitual. Ao fazer cinema, Godard pensa o próprio cinema.

Assim, em vários enquadramentos de seus filmes, Godard deixa elementos de fora que, a princípio, seriam importantes para a compreensão da história ou que satisfariam o voyeurismo do espectador. É o caso da cena inicial em Viver a Vida, que se passa num café (Ver Figura 3), em que Nana conversa com Paul (André Labarthe). Nana é vista de costas, no centro do quadro, enquanto Paul não é enquadrado apesar de sua voz ser ouvida. A cena tira o espectador de seu lugar uma vez que ele está habituado a tudo ver e ouvir. 0 espectador se impacienta, porque não quer perder nada para que não lhe faltem elemenos para compreensão da história. Contudo, as falas do casal não ajudam muito na compreensão do diálogo. Mais uma vez, é como Nana diz: as palavras perdem sua significação.

Algo acontece aí, pois não se trata de deixar de fora do quadro alguma coisa como a uma peça de quebra-cabeça a fim de que o espectador o monte, nem de apresentar uma charada. Emblema disso é, por exemplo, o final de Acossado, em que o personagem Michel Poicard (Jean-Paul Belmondo), caído no chão, prestes a morrer, diz uma palavra que não é compreendida por Patricia Franchini (Jean Seberg), personagem que o delatou à polícia. Ela pergunta a um homem que se 
encontra na ocasião: "O que ele disse?". "Ele disse que você é mesmo asquerosa”. Em seguida, Michel Poicard passa os dedos sobre os próprios olhos como se faz com os moribundos (ver Figura 4). Ironia. Godard está satirizando os clichês. Nesse momento, desnorteada, Patricia olha para a câmera e, ao mesmo tempo, passando o polegar pelos lábios (ver Figura 5) - gesto que Michel fizera algumas vezes no filme, pergunta retoricamente o que significa "asquerosa". Continua a olhar para o espectador (Benjamin diria que ela olha para o aparelho) como a perguntar por sua opinião: eu sou asquerosa? Não espera pela resposta, dá-lhe as costas. Termina o filme.

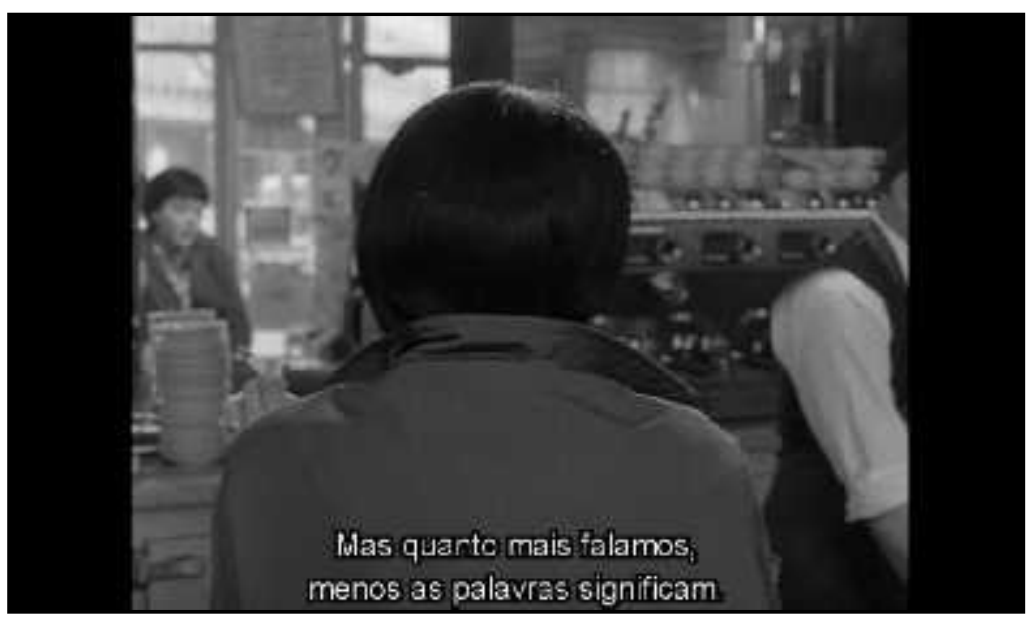

Figura 3: Viver a vida(Vivre sa vie, 1962). Nana, de costas, em diálogo com Paul, fora de quadro.

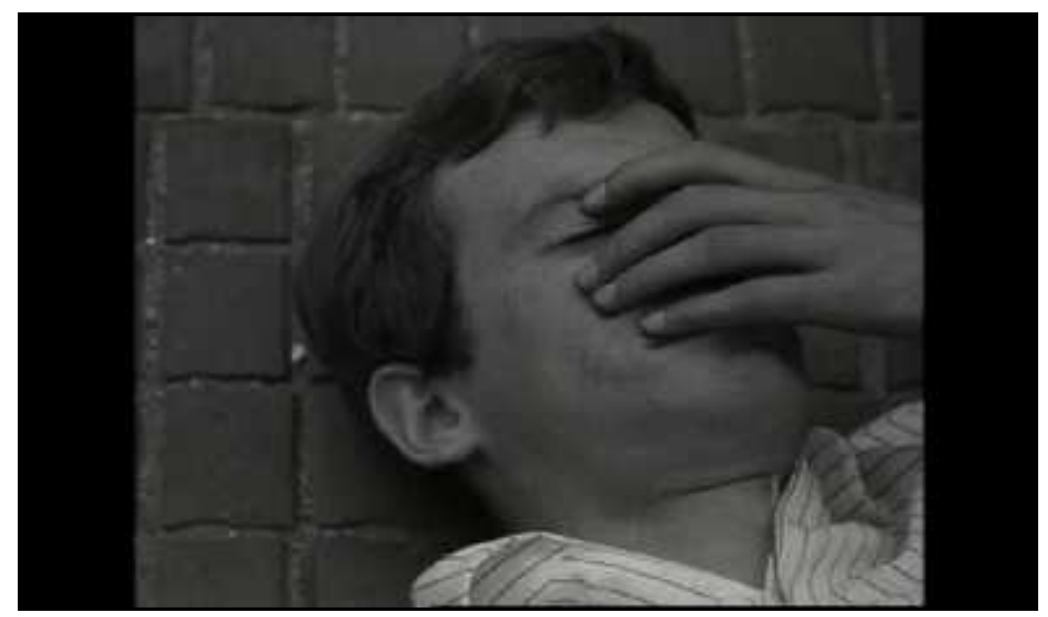

Figura 4: Acossado (À bout de souffle, 1959). Michel Poicard fecha os próprios olhos "antes" de morrer. 


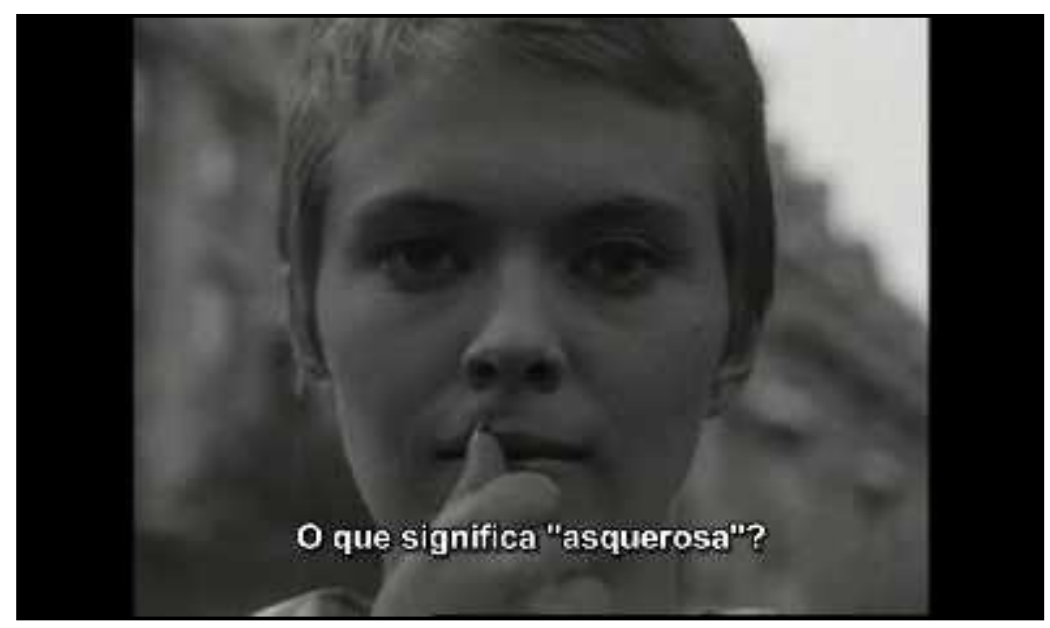

Figura 5: Acossado (À bout de souffle, 1959). Patricia Franchini passa o polegar nos lábios, imitando o gesto de Michel Poicard.

Tanto em Viver a Vida quanto em Acossado, Godard não deixou de contar uma história. Neste, por exemplo, o espectador é informado sobre a vida de dois personagens que, de um modo bastante singular, apaixonam-se um pelo outro e sobre os acontecimentos que levam à morte de um deles. No entanto, no desenvolvimento dessa história, há a economia de informações, de diálogos, de fatos causais que levariam a outros. Em passagens discretas (como ao responder à pergunta que lhe fazem se ela é bonita), o filme nos informa que Michel gosta de Patricia. Ele responde: "Ela é estranha, mas eu gosto dela". Além disso, perseguido por ter matado um policial, poderia ter saído do país, mas espera convencer Patricia a ir com ele. Para provar a si mesma que não estava apaixonada por Michel, Patricia o denuncia à polícia e diz isso a ele: "Não quero estar apaixonada por você! Por isso telefonei para a polícia. Fiquei porque queria ter a certeza se estava ou não apaixonada por você. $\mathrm{O}$ fato de ser tão má para você prova que não estou apaixonada.”. "Repete isso”, diz Michel. Patricia repete palavra por palavra. E ouve de Michel: "Prova que não há amor feliz.". Patricia hesita.

Pode-se dizer que Godard resiste ao final melodramático em que, fácil seria que o espectador escutasse um violino e que a morte do personagem selasse uma redenção em que o amor prevaleceria. Ao contrário, tem-se uma atmosfera de inadequação, incompletude. Asquerosa, traidora, qual o adjetivo para Patricia? (ver Figura 5).

Tal cinema (em alguma medida não-narrativo) muda a referência estável do espectador fomentado pela "verborragia" (inclusive visual) do cinema 
clássico, que tudo explica e mostra. Se para muitos esse cinema aparece como a arte dos novos tempos, como aquela que poderia traduzir a angústia desse contexto, para alguns cineastas, caso de João Moreira Salles, ele não é. Segundo o documentarista, o atributo natural do cinema é a leveza - como é próprio a um produto da indústria cultural -, não o mergulho nas águas profundas da condição humana. "Penso que ele [o cinema] é deficiente, pode menos do que a literatura ou até mesmo do que a pintura" (SALLES, 2011, p. 84). Para ficar com o cinema de autor, como ele diz, faz críticas a Bergman, John Ford e a Godard. "Acossado (À Bout de Souffle, 1960) é puro deslize na superfície, nada de mergulhos. Godard não tenta ir para o fundo, prefere deslizar para os lados, na pura alegria de se deixar ir. [...]. Comédia, por exemplo, o cinema faz muito bem." (SALLES, 2011, p. 85). Para ele, Bergman é ambicioso demais, não em si mesmo, mas pelo meio [o cinema] que ele resolveu empregar para investigar. John Ford, "um grande entusiasta dos deslizamentos horizontais." (SALLES, 2011, p. 85).

Apesar dessas declarações incisivas sobre a natureza do cinema serem muito posteriores aos textos de Benjamin, elas não aparecem isoladas. São expressão de uma ideia disseminada, inclusive na escola, o que torna mais ousado por parte de Benjamin atribuir ao cinema a condição de arte, quando a concepção do que era arte estava concentrada naquelas já consagradas, caso da pintura e da literatura, por exemplo. No caso da fotografia e do cinema, o aparelhamento (achava-se) isentava o artista de implicação. Do mesmo modo, a pré-fabricação dos objetos, ready-made, como diz Thierry de Duve (2007), concorriam com o sentimento de alguns artistas de estarem perdendo terreno para o que é comum, os utensílios ordinários. Duve cita o exemplo de Don Judd, que se defende de Duchamp contra o vale-tudo. É como se Don Judd dissesse: "Não, não vale tudo. Os meus objetos não são objetos ordinários, são objetos específicos.'” (DUVE, 2007, p. 216). Ou ainda: eu sou artista. Don Judd assusta-se com a ideia de que todo mundo pode ser artista, como se o lugar do artista deixasse de existir, por consequência. "A arte está ameaçada a partir do momento em que qualquer coisa pode ser arte e qualquer um pode ser artista." (DUVE, 2007, p. 217). 0 ready-made conferiria essa condição a qualquer um por meio de qualquer objeto de uso cotidiano. Em alguma 
medida também o cinema e a fotografia. Esta, diz Duve, "é uma pintura readymade." (DUVE, 2007, p. 218).

É nesse sentido que o cinema representa o auge do abalo sofrido pela tradição (BENJAMIN, 1996a, p. 169), mas é também o reverso da crise, na medida em que representa a "renovação da humanidade." (BENJAMIN, 1996a, p. 169). Como antídoto que é feito do próprio veneno, a técnica, responsável pela perda ou empobrecimento da experiência, por meio do cinema pode incrementar a visão humana e também a experiência ${ }^{50}$. Para Benjamin, contrariamente a Adorno,

(...) atualmente, talvez apenas o cinema esteja acima desta tarefa [de representar a modernidade] - de qualquer modo, é ele que se encontra mais próximo dela que qualquer outra forma de arte. $\mathrm{E}$ quem reconhecer isto estará inclinado a rebater as pretensões do filme abstrato, por mais importantes que sejam seus experimentos. Ele solicitará um período de resguardo, uma proteção natural para aquele kitsch que encontra no cinema seu lugar providencial. Somente o cinema pode detonar as substâncias explosivas que o século XIX acumulou nesta matéria estranha, talvez desconhecida anteriormente, que é o kitsch. Mas, assim como para a estrutura política do filme, a abstração pode também se tornar perigosa para os outros meios modernos de expressão (iluminação, técnica de construção etc.) (BENJAMIN, 2007, p. 440).

Como se percebe na citação ("o cinema [está] acima desta tarefa", "Somente o cinema pode detonar as substâncias explosivas"), Benjamin declara sua aposta no cinema como a grande arte da modernidade, pois por meio do cinema

O espaço se amplia com o grande plano, o movimento se torna mais vagaroso com a câmara lenta. É evidente, pois, que a natureza que se dirige à câmara não é a mesma que a que se dirige ao olhar. A diferença está principalmente no fato de que o espaço em que o homem age conscientemente é substituído por outro em que sua ação é inconsciente. Se podemos perceber o caminhar de uma pessoa, por exemplo, ainda que em grandes traços, nada

\footnotetext{
50 Benjamin está aqui se referindo ao alcance do olho mecânico em que se constitui a câmera e as possibilidades a partir dela da manipulação da imagem, como a câmera lenta, zoom, travelling etc., ou a montagem própria do cinema. Nesse sentido, em Signos, Merleau-Ponty diz em relação a um experimento de filmagem do pintor Matisse, enquanto este pintava um quadro: "O mesmo pincel que a olho nu saltava de ato em ato, parecia meditar, num tempo dilatado e solene, numa iminência de princípio do mundo, tentar dez movimentos possíveis, dançar em frente à tela, roçá-la várias vezes e lançar-se enfim, como relâmpago, sobre o único traçado necessário." (apud CARMO, 2000, p. 59).
} 
sabemos, em compensação, sobre sua atitude precisa na fração de segundo em que ela dá um passo. 0 gesto de pegar um isqueiro ou uma colher nos é aproximadamente familiar, mas nada sabemos sobre o que se passa verdadeiramente entre a mão e o metal, e muito menos sobre as alterações provocadas nesse gesto pelos nossos vários estados de espírito. Aqui intervém a câmara com seus inúmeros recursos auxiliares, suas imersões e emersões, suas interrupções e seus isolamentos, suas extensões e suas acelerações, suas ampliações e suas miniaturizações. Ela nos abre, pela primeira vez, a experiência do inconsciente ótico, do mesmo modo que a psicanálise nos abre a experiência do inconsciente pulsional. De resto, existem entre os dois inconscientes as relações mais estreitas. Pois os múltiplos aspectos que o aparelho pode registrar da realidade situam-se em grande parte fora do espectro de uma percepção sensível normal (BENJAMIN, 1996a, pp. 189190).

O cinema teria aberto uma grande janela e instalado para o olhar do espectador um espaço antes inacessível. Não se trata de uma imagem-objeto, autorreferente, mas de um nível de configuração do espaço e do tempo antes impossível. Não apenas no nível da percepção, no nível ótico, na medida em que o aparelho aumenta/diminui, acelera/retarda, foca/desfoca imagens, mas na produção de uma amálgama de conotação onírica ou mesmo no plano representacional em que se trata aí de um jeito próprio do cinema de apresentar/ocultar elementos e alterá-los.

No Brasil, há uma publicação, no início do século XX, que reconhece esse lugar que mais tarde Benjamin confereriria ao cinema, enaltecendo a contribuição dessa arte para a cultura e para a crítica. Trata-se da revista Klaxon, que tem por parte da redação a defesa do cinema como a arte "da nossa época": "A cinematographia é a criação artística mais representativa da nossa época. É preciso observar-lhe a lição." (In: Klaxon, no. 1, 15/05/1922, p. 02, apud XAVIER, 1978, p. 143). Na mesma página, um pouco antes, a redação manifesta sua preferência pela atriz Perola White em detrimento de Sarah Bernhardt, isto é, manifesta sua preferência pelo cinema em detrimento do teatro, nos seguintes termos: "Sarah é tragédia, romantismo sentimental e technico. Perola é raciocínio, instrucção, esporte, rapidez, alegria, vida.". Mais adiante, May Caprice dirá sob o título "KineKosmos": "Griffith genial americano". Ainda celebrará o cinema como "o riso, a força, o inverossímil scientifico.” E termina: “modernos. Modernos” (CAPRICE, May. “Kine-Kosmos". In: Klaxon, no. 1, 15/05/1922, p. 13). 
No entanto, estaria na condição de arte industrial em que se constitui o cinema, isto é, na eleição de objeto ordinário à arte por meio da técnica, o motivo maior que justificaria, diante das (outras) disciplinas, a secundarização do cinema na escola?

\section{5- A escola como lugar da polifonia e o deslocamento do sujeito}

Dentre os muitos temas abordados por Slavoj Zizek, característicos de sua escrita interessada e engajada, encontra-se o da ideologia. 0 filósofo retoma a discussão em torno do termo - que para muitos está em desuso devido ao pouco alcance teórico que poderia proporcionar ${ }^{51}$ - e amplia a sua abrangência, associando-o ao termo fantasia, o que o torna mais perceptível, inclusive nas relações de poder existentes no ambiente escolar. Essa operação foi assim comentada por Christian Dunker:

A fantasia ideológica não se opõe à realidade, mas estrutura a própria realidade social. 0 problema reside em saber o que, em cada momento, precisa ser excluído da realidade para que a própria realidade se mostre consistente (DUNKER, 2013, p. 44).

Slavoj Zizek dá ênfase à fantasia como a "matéria-prima" da ideologia. 0 destaque para a fantasia como basal na constituição da chamada realidade das relações sociais contrasta com o uso cru do termo ideologia para indicação de lugares de poder: dominador e dominado. Como se sabe, em termos marxianos, discurso ideológico é aquele promovido por uma classe dominante ao inverter o verdadeiro pelo falso a fim de manipular o pensamento de um determinado grupo social. Para Marx e Engels, por exemplo, em A ideologia alemã (2007), mesmo os "socialistas verdadeiros" tinham uma compreensão insuficiente da literatura socialista estrangeira, porque não a tomavam "como expressão e produto de um movimento real, mas como escritos puramente teóricos" (MARX \& ENGELS, 2007,

${ }^{51}$ Cf. EAGLETON, Terry. Ideologia. São Paulo: Ed. Boitempo e UNESP, 1997. Nesta obra, Eagleton aponta o filósofo italiano Gianni Vattimo como defensor da ideia de que o fim da modernidade coincidiria com o fim da ideologia. Para Vattimo, segundo Eagleton, tal termo está ultrapassado. Eagleton, ao contrário, apresenta vários exemplos que evidenciam a atualidade do termo. 
p. 437). Dessa forma, esvaziam essa literatura de sua dimensão real, uma vez que eles não se ocupam “com os homens reais” (MARX \&ENGELS, 2007, p. 438), promovendo a separação pré-hegeliana entre sujeito e objeto. Mas talvez a definição mais clara de ideologia seja a apresentação de uma interpretação dos processos sociais como única, promovendo, com isso, a naturalização dessa interpretação, o que vale dizer que a fantasia ideológica oculta "o antagonismo sobre o qual se funda qualquer campo social." (DUNKER, 2013, p. 42).

Para Christian Dunker e Ana Lúcia Rodrigues, a exemplo dos procedimentos dos "socialistas verdadeiros" criticados por Marx e Engels, "cada filme, no fundo, corresponde a uma espécie de experimento para produzir um 'eu' dotado de unidade, capacidade de antecipação e reconhecimento." (DUNKER \& RODRIGUES, 2015, p. 19). Dunker, em uma das analogias propostas em "Fazer cinema, fazer psicanálise" (2015, vol. I), está se referindo à teoria da interpelação de Louis Althusser utilizada por Jean Baudry para "pensar o cinema como um dispositivo de criação ideológica de individualizações, ou seja, de fixação de modalidades (...).". Contudo, a proposta de trabalho da relação entre cinema e psicanálise apresentada por Dunker acaba por promover uma separação entre a "reconstrução fílmica" e a posição do espectador diante do filme, entendida aqui como pura fruição; com a ideia einsensteiniana de que filmar é justapor imagens, tende a tomar o fílmico como onírico.

A "atualização" da discussão em torno do termo ideologia chama atenção para algo da ordem do desejo. A imbricação da ideologia com o termo fantasia mantém a dimensão política daquele e, deste, agrega um novo significado. Por isso, os sujeitos mobilizam-se em defesa apaixonada desse ou daquele aspecto em que acreditam. Como diz Zizek, a dimensão do "eles não sabem" é a marca da realização que se alimenta repetidamente a sensação de insatisfação logo depois de cada consumo, definindo a experiência ideológica e anunciando aí a posição do gozo (ZIZEK, 1990, p. 07).

$\mathrm{Na}$ escola, a fantasia ideológica nega evidências em função da manutenção de seu funcionamento já consolidado. Embora haja intensa indicação do próprio real - na medida em que os mais variados problemas da escola atual pululam - de que as escolas precisam ressignificar seus currículos em razão de sua 
pouca representatividade social e da pouca eficácia dos métodos utilizados no processo ensino-aprendizagem, tal evidência é, no entanto, "excluída da realidade", como disse Dunker, não encontrando acolhida por parte dos gestores escolares, ao contrário, oposição. A fantasia ideológica, assim, atribui o "fracasso escolar" a "professores não comprometidos" ou a alunos que "não querem nada". Desa forma, excluem da realidade o que lhes é próprio para que sua fantasia seja mantida. Contudo, "a fantasia não é obra de alguém, mas resultado, ao mesmo tempo, da ação do objeto e do corte do significante." (NASIO, 1993, p. 130).

Nasio está destacando a ideia de que o sujeito é destituído do poder que se diz que ele teria. Na verdade, a sociedade é regida por um sistema jurídico e de avaliação (frequentemente pensada para punir) no contexto escolar que pressupõe a todo ato, uma vontade deliberada. Contudo, "o sujeito em questão é o sujeito do inconsciente, isto é, o sujeito que é efeito da experiência inconsciente de produzir essa fantasia [...]." (NASIO, 1993, p. 130). 0 ato transforma o sujeito naquilo que ele pratica:

[...] o voyeur, por exemplo, não apenas olha, mas transforma-se em olhar, é o melhor meio de compreender o que significa a fantasia. [...] Do ponto de vista psicanalítico, somos, na fantasia, aquilo que perdemos (NASIO, 1993, p. 129).

Ao considerar que não "apenas" vemos, mas nos transformamos naquilo que vemos, ou melhor, em alguma medida, somos aquilo que vemos e desejamos, justificar-se-ia, mais uma vez, a necessidade de uma pluralidade mais significativa na composição dos filmes a serem exibidos na escola, não sendo nem de longe suficiente o "desvelamento" do que está "por trás" dos planos fílmicos, isto é, a ilusão pedagógica de que pelo discurso crítico pode-se injetar a criticidade nos alunos.

Nesse sentido em que aponta J.-D. Nasio, as pessoas seriam não apenas aquilo que veem em determinados filmes, mas, em certa medida, associando à espectatorialidade, elas seriam, na fantasia, o que se perderiam. Desse modo, quanto à negação da existência da necessidade do debate e de mudanças no currículo de uma determinada escola, não se trataria apenas de um ato ideológico no sentido de uso de estratégia classista (e consciente) nas relações de poder por 
parte de determinada gestão pedagógica, mas daquilo (a fantasia) que fundamenta ou mobiliza no jogo os sujeitos em ação. A despeito do funcionário que diz apenas estar "cumprindo ordens", a negação da necessidade do debate é exercida por quem acredita nela e não como simples estratégia (consciente) ideológica na relação de poder com os eventuais opositores.

Para Jacques Aumont, a ideologia no cinema visa à "regulagem dos jogos psíquicos do espectador e à circulação de uma certa representação social." (AUMONT et al, 2011, p. 99). Essa regulagem visa ao apagamento dos rastros (e, por consequência, apagamento também da enunciação) produzidos pelo aparato mecânico do cinema (quando o espectador se dá conta da presença física da câmera no plano, por exemplo, ele tende a rejeitar o filme já que ele prefere a continuidade entre os planos, isto é, a transparência) que caracterizou até hoje o chamado cinema mainstream. Trata-se da naturalidade promovida pelo raccord, preocupado em garantir certa continuidade visual (e sonora). Ainda que nada natural, uma cena configurada em plano e contra-plano, por exemplo, apresenta ao espectador os dois elementos principais num determinado diálogo, como se atendesse à avidez do espectador de "participar" do diálogo. Os dois rostos como fontes principais do diálogo são apresentados de forma seguida, ora um, ora o outro, apresentando o diálogo de modo inteiro. Assim, o espectador, como diz Aumont, submetido à linearidade do filme, não "terá a impressão de estar vendo unidades descontínuas" (AUMONT et al, 2011, p. 181). Os planos formam um todo, completando-se a todo instante; da mesma forma se passa com os diálogos.

Presume-se o quanto essa fórmula linear e contínua é empacotável e como ela é digestiva, caindo bem para um mercado ávido por comunicar. Contudo, são formas de suprimir o "inconsciente ótico" identificado por Benjamin (1996f) no clique fotográfico:

A natureza que fala à câmara não é a mesma que fala ao olhar; é outra, especialmente porque substitui a um espaço trabalhado conscientemente pelo homem, um espaço que ele percorre inconscientemente. Percebemos, em geral, o movimento de um homem que caminha, ainda que em grandes traços, mas nada percebemos de sua atitude na exata fração de segundo em que ele dá um passo. A fotografia nos mostra essa atitude, através dos seus recursos auxiliares: câmara lenta, ampliação. Só a fotografia 
revela esse inconsciente ótico, como só a psicanálise revela o inconsciente pulsional (BENJAMIN, 1996f, p. 94).

Utilizando-se de um exemplo, Benjamin distingue do artístico algo pertencente ao "real" que escapa ao controle do artista. Como exemplo, ele toma a foto Duas vendedoras de peixe de Newhaven (Two Newhaven fishwives, 19431947), de David Octavius Hill. O olhar recatado para o chão "tão displicente e tão sedutor" de uma das vendedoras é algo que escapa ao artístico do fotógrafo, "que não quer extinguir-se na 'arte'” (BENJAMIN, 1996f, p. 93). O registro fotográfico desse algo que escapa era acentuado nas primeiras fotografias, uma vez que as fotos eram apresentadas ao público sem legendas, em outros espaços, já que os jornais ainda não a haviam incorporado. Assim, "o rosto humano era rodeado por um silêncio em que o olhar repousava." (BENJAMIN, 1996f, p. 94).

Esse algo que escapa, a que se refere Benjamin, para Roland Barthes escapa a despeito de toda cultura. Sobre a fotografia Anormais em uma instituição (1924), de Lewis H. Hine, em que constam duas crianças anormais, Barthes diz: "desprezo todo saber, toda cultura...vejo apenas a imensa gola Danton do garoto, o curativo no dedo da menina..." (BARTHES, 1984, p. 79). Aqui subjaz sua definição de studium e de punctum. Ambos habitam a fotografia, mas aquele é caracterizado por uma ampla extensão de campo. 0 espectador reconhece os elementos da fotografia com seu saber de pessoa vivente: uma bandeira, um chapéu, um vestido etc. pode remeter o espectador ao ambiente em que se encontra determinado modelo e ter ideia do que se trata em geral, a fotografia. Diz-se que o studium é o que se apresenta de modo codificado na fotografia, o que se pode nomear. 0 punctum, ao contrário do studium, salta da fotografia como uma flecha que busca seu alvo. Em seu livro A câmara clara (1984), ele dá vários exemplos. Assim, na foto dos anormais, o punctum para Barthes é a gola Danton, a despeito daquilo que compõe o tema principal da fotografia que é a anormalidade dos modelos.

Ao contrário do discurso cientificizante das pedagogias circulantes na escola, e do cinema que encobre as descontinuidades e forja uma suposta transparência como a evitar tais descontinuidades como problema, a psicanálise 
toma o sintoma como central para a compreensão dos sujeitos. "O sintoma é, propriamente falando, um evento na análise, uma das imagens através das quais a experiência se apresenta." (NASIO, 1993, p. 11). Experiência analítica, o momento em que a linguagem tropeça. Diz-se aí, que a fala fracassa (NASIO, 1993, p. 11), trai o sujeito. “Onde a fala fracassa, aparece o gozo" (NASIO, 1993, p. 12). Por sua vez, o cinema de transparência procuraria limpar o filme dos ruídos (sintomas) causados pelas descontinuidades, pelos tropeços da linguagem, evitando, assim, a experiência.

Nesse sentido, fica claro que a idealização do aluno efetuada pela escola como sujeito abstrato, a princípio, interessado em assuntos das ciências pela curiosidade que lhe seria característica, procura evitar as descontinuidades e sintomas da vida escolar. A cientificação do currículo atende ao propósito de tomar os processos pedagógicos como eventos sigulares, mas esbarra no teor abstração dessa proposta.

Assim, tal ideal pedagógico é, em grande medida, resistente ao que, de modo interessado, circula cotidiana e subrepticiamente na escola. Como resistência, ele deixa de legitimarar vozes da comunidade escolar, não apenas a dos alunos, mas também a dos professores, que assumem o discurso das ciências em detrimento de suas trajetórias e singularidades.

Essa resistência se apresenta sob vários aspectos. Um dos modos de realizá-la é tomar a escola como um ambiente em que as atividades dão a ver tipos de controles objetivos. Assim, prioriza-se a suposta necessidade de controle do tempo de execução das tarefas pedagógicas dos professores e de seus desempenhos em sala de aula ${ }^{52}$. São também conhecidas as sofisticadas punições aos alunos, desde a convocação constrangedora de pais e mães para a escola à diminuição de notas. Enfim, procura-se exercer sobre estudantes e professores todo um conjunto de ações mobilizadas por uma intenção pedagógica que tem por finalidade torná-los dóceis, funcionais. A decência das palavras, diz Foucault, limpa a convivência, os discursos (FOUCAULT, 2007, p. 10), das possibilidades do

\footnotetext{
52 Veja-se a "proposta [de 2000] de se cronometrar as aulas, de sorte que o docente distribua os tópicos disciplinares e atividades didático-pedagógicas de acordo com determinações do relógio para o bom andamento dessa nova invenção tecnológica, são ofertados técnicos do banco Mundial, nos cursos de capacitação dos docentes, para que estes operem competentemente a sincronia entre o ritmo dos ponteiros e a organização da aula." (CITELLI, 2012, p. 10). 108
} 
genuinamente subjetivo. Assim, busca-se a homogeneização pelo discurso supostamente neutro da ciência que, aliás, ocupa lugar privilegiado no currículo escolar.

No controle daquilo que fugiria ao ponto neutro do discurso cientificizante, tem-se a expulsão, por exemplo, da literatura chamada "marginal", cujo discurso "fétido" poderia ferir narinas supostamente acépticas. Nesse rol de referências proibidas entra também o "mau" cinema, aquele, a princípio, impossível de ser pedagogizado, cujo potencial pedagógico ${ }^{53}$ é considerado baixo. Atendendo à ideologia da idealização do aluno, a escola está, assim, calcada no forte pressuposto daquilo que é legível a ela, sustentando sua vocação pela estabilidade, evitando a diferença.

Dessa forma, os discursos pedagógicos na escola, em geral, são tomados por uma funcionalidade que estabelece lugares estanques no ethos que relaciona os sujeitos em questão e distribui papéis sob essa funcionalidade. Os modos de controle ali estabelecidos partem do pressuposto de que haja uma hierarquização dos saberes, em que o grupo gestor, em última instância, é o condutor e quem assegura o valor desses saberes. 0 professor, no exercício de sua particularidade em sala de aula, cumpre no micro, a passagem do que se espera das abordagens ressoantes do currículo. Trata-se de uma espécie de prática teórica, isto é, o professor realiza em sala de aula, por meio da visibilidade de suas abordagens, os ideais cientificistas (e com isso, é eivado de silêncio quanto a questões fundamentais de gênero, racismo, identidades nacionais etc.) de que se impregnou o currículo.

Para que essa configuração apresente resultados satisfatórios, isto é, para que não haja grandes resistências por parte dos alunos à sua implementação, busca-se exercer todo um aparato de controle - de viés contratual: a escola ensina, o estudante aprende - da postura pressuposta do aluno. Assim, as notas diminuídas em virtude de mau comportamento, faltas, castigos em sala de aula, repreensões e

\footnotetext{
${ }^{53}$ Sobre o potencial pedagógico dos filmes, encontra-se a indicação nos Cadernos de Cinema do Professor (vol. 2) da SEE-SP/FED: "Assistir ao filme antes de qualquer outra atividade é condição básica, pois não se trata de ver o filme levando em conta apenas a relação do seu tema ou 'conteúdo', mas de avaliar o seu potencial pedagógico e de formação cultural, bem como a adequação à turma e ao trabalho que será realizado depois." (São Paulo, 2009, p. 23, destaque nosso).
} 
humilhações verbais, até o que se chama de "meia falta" etc., procuram ajustar o comportamento do aluno ao ser contratual que se espera dele, e fazer com que ele próprio estabeleça o seu "de acordo", isto é, que se autodiscipline, importando para o processo, na verdade, que ele seja vigilante das regras, cobrando de si e dos colegas a conduta considerada correta. Dessa forma, procura-se transitar das normas regulatórias características da sociedade disciplinar, de que tratara Foucault, para o estado de controle em que os estudantes e professores incorporariam tais normas como naturais.

Nesse sentido é que os chamados fracassos escolares dos alunos são compreendidos como pura resistência de "selvagens" ao processo "civilizatório" empreendido pelo sistema escolar. Esse tom moral é dado, em grande medida, pelos próprios professores. Sem considerar, enfim, a possibilidade de se encontrar aí um importante sintoma dos processos educativos.

A matriz que permeia essa perspectiva da escola é, em grande medida, a moderna, cuja aposta na razão possibilitaria a passagem da menoridade para a maioridade do pensamento. A confiança nessa dimensão da razão autoriza a ideia de contrato estabelecida pela escola com estudantes e professores, que por princípio, pressupõe partes contratantes e que essas partes, com responsabilidades próprias, devem sustentar seus papeis.

Infere-se daí que a escola pressupõe sujeitos já formados, com vontade própria e definida. Contudo, como lembra Voltolini, o contrato marca o laço social mais pelo que não se pode fazer. Como a ideia de autoria teria surgido com o propósito de se punir o autor 54 (FOUCAULT, 2009, p. 275) de determinada obra ou para anular o contrato (BAXANDAL, 1991) ${ }^{55}$, este estabelece papeis para responsabilizar os sujeitos em questão.

\footnotetext{
${ }^{54}$ Autoria aqui também no sentido da resistência subreptícia de que falamos anteriormente, daquilo que leva a marca subjetiva que surge no cotidiano escolar.

55 Nas letras, "os textos, os livros, os discursos começaram a ter realmente autores (diferente dos personagens míticos, diferentes das grandes figuras sacralizadas e sacralizantes) na medida em que o autor podia ser punido, ou seja, na medida em que os discursos podiam ser transgressores." (FOUCAULT, 2009, p. 275). Na pintura, o século XV é um marco na relação entre, de um lado, o pintor que realizava uma obra (ou ao menos a supervisionava) e, do outro, alguém que a encomendava, o cliente. A prova da formalização desse processo são os diversos contratos da época. Em um deles, o contratante, por escrito, e que é assinado por ambas as partes, "entrega e confia ao Domenico a pintura de um painel que o dito Francesco mandou fabricar e o forneceu; (...) e deve pintar o dito painel inteiramente com sua própria mão. (...) E se Domenico não entregar o painel no prazo previsto, estará sujeito a uma multa de quinze florins brutos; e o mesmo, se Messer 110
} 
As aquisições de direitos de minorias hegemômicas são, sem dúvida, importantes, mas, como lembra Voltolini, vale perguntar: "a reivindicação de um direito é ilustrativa da afirmação de uma posição de sujeito desejante?" (VOLTOLINI, 2004, p. 96). As demarcações de papeis, via contrato, efetivamente, contemplam o exercício desejante de docentes e estudantes? Parecem mais estabelecer uma relação entre fornecedor e cliente - "uma das dimensões constitutivas de nossa atualidade é a tentativa de tratar em termos jurídicos todos os problemas da cidade" (Roland CHEMAMA apud VOLTOLINI, 2004, p. 92) -, aliás, termo este utilizado na LDB para designar os estudantes. Vale lembrar que cliente (do latim cliens, plural, clientes) significava aquele que estava "sobre a proteção de" (FARIA, 1962), protegido, indivíduo da sociedade romana antiga de baixo poder aquisitivo e que era "protegido" por patrão (patronus), de poder aquisitivo superior. Aquele devia obediência a este. Hoje, designa principalmente o consumidor, o comprador ou usuário de determinado produto. Em qualquer dos casos, parece-nos estranho que os estudantes sejam convertidos em clientela.

Se há um desejo (negativo, não afirmativo) em questão é o da escola em abarcar a totalidade da obediência de sua clientela. Nessa configuração, compreende-se que, por extensão, não cabe ao aluno o lugar de sujeito desejante. Deixa, assim, de levar em conta o lugar de indeterminação que é característico da sala de aula e que para ela se "supõe uma competência que não é técnica, mas que requer um desempenho hábil e desenvolto para ver a realidade escolar em que vivemos." (FERRARA, 1993, p. 117). Tal indeterminação fica mais evidente na perspectiva de uma condição pós-moderna. Na esteira, pois, de Lyotard, Favaretto afirma que $o$

saber deixa de ser magnetizado por uma idéia, como aquela do projeto moderno de emancipação da razão e da liberdade humanas; desenvolve-se por uma dinâmica interna, assimilando o acaso e, através de novas mediações, transformando-se muitas vezes, em instrumento de circulação e de poder. Assim, o desafio moderno, de conferir um sentido às coisas, vê-se atingido pela indeterminação e heterogeneidade das atividades contemporâneas que criticam o ideal de progresso e o finalismo dos projetos modernos (FAVARETTO, 1991, pp. 121-122).

Franceso não efetuar os pagamentos mensais previstos, estará sujeito a uma multa igual ao valor total, ou seja, uma vez concluído o painel, terá que pagar completamente e na sua totalidade o saldo da soma devida." (BAXANDAL, 1991, p. 18). 
Trata-se ainda, segundo Favaretto, da constatação de "que uma certa concepção de modernidade fracassou, comprometendo a confiança na própria idéia de prática social emancipadora." (FAVARETTO, 1991, p. 123). Tal fracasso se instala na escola como um mal-estar, já que a condição de diluição das referências colocou em xeque a suposta principal função da escola, que seria emancipar os usuários de seus serviços. Tal mal-estar que se expressa no estado de ebulição em que se constitui a sala de aula parece rir dos projetos com vocação iluminista seu escárnio cotidiano dentro de paredes que, sintomaticamente, justapõem discursos de alunos e de professores no complexo universo escolar. Em reação a esse cenário não são poucos os casos de afastamento de professores de suas funções por problemas psíquicos ${ }^{56}$.

Esta separação entre o que assume importância jurídica da posição desejante é ela própria sintoma da responsabilização dos professores pelo bom desempenho nos 50 minutos que lhes são atribuídos para, a seguir, ele - o professor - ter que retomar o mesmo escopo na sala seguinte, com a mesma responsabilidade de desempenho. Repetição exigida pelo funcionamento da estrutura escolar, enquanto do professor, como se sabe, não é demandado algo apenas técnico. Seu papel, para além da técnica, tem a ver com reinvenção, o que nessas condições apresentadas constitui-se num impossível.

Com frequência, na esteira do que diz Roudinesco (2000, p. 14), a emancipação é mobilizada pela via da individualidade, isto é, por certa consciência do indivíduo, que busca sua própria singularidade em meio ao vazio da vida moderna, em detrimento de uma subjetividade (ROUDINESCO, 2000), que assumiria, por assim dizer, o seu desejo. 0 professor, em sua atividade solitária de sala de aula, perde-se diante da "inutilidade" daquilo que ele se propõe a falar ou que se submete ao falar, considerando que se o currículo determina sua fala, em grande medida, dessubjetiva-o. A escola parece se empenhar em aplacar a falta estruturante causada pela expulsão da subjetividade a fim de evitar a angústia daí

\footnotetext{
${ }^{56}$ Segundo Paula de Camargo (2015), 57\% dos professores paulistas se afastaram por motivo de depressão, enquanto o índice da população geral é de $9 \%$. O segundo maior motivo de afastamento entre esses professores é de Transtorno de ansiedade (49\%), enquanto o da população em geral é 11\%. Fonte: http://revistaescolapublica.com.br/textos/35/mal-estar-docente-300042-1.asp. Acesso dia 09 de junho de 2016.
} 
resultante que poria em xeque a funcionalidade de sua organização. 0 professor, assim, negocia o desejo em troca da funcionalidade de certo conforto em uma fala que, em grande medida, não o espelha. Dessa forma, esse/a homem/mulher, esse/a professor/a, teria se transformado "no contrário de um sujeito" (ROUDINESCO, 2000, p. 14).

A perspectiva apresentada por Maria Rita Kehl não é diferente da de Roudinesco. Apoiada na ideia de empobrecimento da experiência de Benjamin, ela diz: "Se a vida psíquica, premida pela necessidade de reagir a estímulos externos velozes e violentos, fica restrita ao trabalho (protetor) da atenção consciente, que experiência se produziria a partir de uma vivência dessas?" (KEHL, 2009, p. 155). Ao falar de guerra como o lugar de esvaziamento da experiência e da presença da técnica sobrepondo-se às formas tradicionais de narração, as análises de Benjamin recaem de cheio na escola. Ora, não estariam entrincheirados alunos e professores? Não estariam eles situados de tal forma que ao começar uma aula o professor desse início a uma guerra? O que ele "conta" de sua experiência diária em sala de aula senão o seu represado silêncio?

Assim, os discursos pedagógicos promovem a homogeneização do espaço escolar, mobilizada pela crença na totalidade de agenciamento único do saber com fins de promoção dos chamados grandes discursos de legitimação. A heterogeneização desse espaço, ao contrário, não convidaria o estudante a se implicar como espaço habitado, vivido?

A produção da homogeneização espacial no contexto escolar não leva em conta a descontinuidade sígnica como produtora de "cesuras que rompem o instante e dispersam o sujeito em uma pluralidade de posições e de funções possíveis." (FOUCAULT, 2011, p. 58), a partir do espaço vivido, em sala de aula e nos vários existentes na escola, bem como na comunidade. Tal redução do polissêmico ao comum inviabiliza a (re)consideração dos modos de ver e operar das ciências a partir da significação para os sujeitos que vivem os complexos contextos na escola, a fim, de no exercício teórico-político, integrar alunos, professores e comunidade do entorno na elaboração de concepções mais críticas (inclusive no sentido estético) de escola, de aprendizado, "fracasso escolar" etc., que lhe sejam significativos. 
Assim, a prática dessignificada, tanto para os professores, quanto para os alunos, esvazia o lugar nesse jogo, vivificando, todavia, o aspecto ideológico que atualiza a ilusão pedagógica contratual de que tratamos anteriormente. Sintoma desse não-lugar ocupado pelo professor são os sofisticados termos para indicar essa vacância, quais sejam, "facilitador", "intermediador", "ponte para o conhecimento", e assim por diante.

Caudatário desse não-lugar, a entrada do cinema na escola cumpre a função de auxiliar, uma vez que a obra fílmica seria autônoma como produto a ser exibido e, por assim dizer, dispensaria mediação. 0 professor, pois, não precisaria falar, conduzir o evento, precisaria apenas projetar o filme que, se bem escolhido, diz-se, proporciona a comunicação daquilo que se espera dele, isto é, a afirmação do mesmo - o que responde ao desejo de estabilidade da instituição escolar, servindo de veia para a disseminação de remédio moral. 0 outro modo de uso do filme prever a sagacidade do professor em extrair mensagens que poderão ser exploradas com fins gerais ou na ilustração de matéria de determinada disciplina. O que foge a um e a outro modo de usar o filme, depende de iniciativa do próprio professor, de tentar desvinculá-lo da relação restrita entre disciplinas e aos conteúdos excessivamente codificados, propondo uma terceira possibilidade.

Em geral, contudo, a hierarquização dos saberes na escola é bastante rígida para que haja uma terceira via - a do uso espontâneo do cinema - responda à necessidade de uma nova organização escolar, em que o aspecto vivencial seja integrado, de modo a atentar para a acessibilidade dos alunos aos bens culturais (teatro, música, cinema etc.). Pensa-se saber do que a criança precisa saber, o que justifica políticas educacionais que prescrevem os saberes infantis. Assim, a parte no jogo cabida a eles é a de apreender o que lhes for exposto nas aulas que, por sua vez, sabe-se, não fora produzido por uma dinâmica que procure incorporar a trajetória das atividades e saberes dos professores e alunos, mas por prescrição em currículo. Essa prescrição permite pouca abertura para o imponderável em que se constitui o ato educativo. "Educamos sempre na ignorância da criança que fomos" (Freud apud VOLTOLINI, 2011). Perde-se de vista que, ao eliminar o impossível ${ }^{57}$

\footnotetext{
${ }^{57}$ A questão do impossível na psicanálise é trazida à tona pelo livro Educação Impossível, de Maud Mannoni, mas, a despeito do que pode parecer pela sugestão do termo, como observa Lajonquière (1998, p. 121), essa impossibilidade da educação não se refere à sua anulação/inutilidade, mas às 114
} 
não-moldável do papel da educação, isto é, sem se dar conta de que educar é de certa forma impossível, que é impossível ou contraproducente o esforço de controle dos efeitos da educação, empobrece-se a experiência do pensamento, "porque situar o impossível na educação significa abrir suas possibilidades" (Freud apud VOLTOLINI, 2011). Quando a escola insiste num método científico de controle de resultados e, portanto, controle dos processos, avaliando não só desempenhos, mas modos de ser, em geral, avalia para punir ou para premiar, a depender da adequação ou não às normas reguladoras.

A instituição escolar tenta abarcar, explicar a totalidade da realidade em que está imersa, como dissemos, sem abrir portas ao imponderável que é o educar. Nesse sentido, Foucault lembra já quase no final de A Ordem do Discurso, que Jean Hypolite falava da impossibilidade de uma totalidade. Por isso, Foucault quer se perceber no meio do discurso e não como alguém que tomará suas rédeas, determinando-o, como seria próprio a um sujeito com "s" maiúsculo. Nesse sentido, o sujeito com "s" maiúsculo aspira à totalidade. Em vez disso, "é preciso aceitar introduzir a casualidade como categoria na produção dos acontecimentos." (FOUCAULT, 2011, p. 59). O sujeito é sempre barrado, sempre clivado, porque, como diria Lacan, perdeu o "objeto a"58 para sempre. Lacan, aliás, toma essa ideia de Freud, para quem a primeira satisfação do bebê gera nele um traço mnemônico que nunca mais será satisfeito (LAJONQUIÈRE, 1993, p. 155). Caio Fernando Abreu diz em seu famoso conto Dama da Noite algo que reflete essa ideia:

Mas anota aí pro teu futuro cair na real: essa sede, ninguém mata. Sexo é na cabeça: você não consegue nunca. Sexo é só na imaginação. Você goza com aquilo que imagina que te dar o gozo, não com uma pessoa real, entendeu? Você goza sempre com o que tá na sua cabeça, não com quem tá na cama. Sexo é mentira, sexo é loucura, sexo é sozinho, boy (ABREU, 1988, p. 96).

\footnotetext{
"ilusões pedagógicas que sustentam as educações escolares[...].", que "visam abortar, paradoxalmente, a possibilidade de que aconteçam efeitos educativos." Ainda que Mannoni tenha endereçado sua crítica principalmente ao sistema francês de educação é perfeitamente possível estender tais críticas ao sistema brasileiro. Se o sistema francês pecava pelo excesso, o brasileiro peca por defeito educativo (Cf. LAJONQUIÈRE: 1998, p. 121).

58 "a" é propositalmente minúsculo, já que nunca haverá um objeto "A", com a maiúsculo, que saciaria completamente o desejo humano.
} 
O objeto de desejo, na verdade, é um índice, um signo que nos remete ao primeiro objeto, "objeto a". Por isso Lacan vai dizer que "amar é dar o que não se tem a alguém que não o quer" (LACAN, 1992, p. 41). Dá o que não se tem porque no amor queremos ser "todo" para o outro, um sujeito com "s" maiúsculo. Além disso, o outro não quer porque é a completude que mata o amor ${ }^{59}$, pois o que desperta $o$ desejo é a falta, não a completude, como se sabe desde Platão, em $O$ Banquete. "Quando não há falta a falta é que há" (LACAN, 2005), diz Lacan. No entanto, o jeito de se dá por completo, de dar o que não se tem, é falando. "Eu sou todo seu!", ainda que a pessoa seja casada e que já ficara claro que ela não deixará o cônjuge. A expressão abre uma brecha significante.

Estendendo essas ideias para o campo da educação, ao contrário, como se habitasse um universo paralelo, ao desconsiderar essa chave de discussão,

\begin{abstract}
A Educação Continuada introduziu a crença de que é possível o sujeito se transformar sempre, aprender sempre. Mas, diferentemente do hardware do computador que se pode ser sempre trocado, as mudanças nos seres humanos esbarram em uma série de impasses. A principal delas é a barreira do corpo. 0 corpo em sua materialidade. 0 corpo como o Real que não pode ser ultrapassado (LENY, 2005, p. 20).
\end{abstract}

Desconsiderando os alunos reais, o modo de seus corpos ocuparem o espaço escolar e de se expressarem, sua língua, enfim, suas referências parecem não ser uma questão na escola. Estes são tomados como o protótipo receptor da aplicação do processo cientificista, cuja menoridade do pensamento deve ser abandonada em prol do exercício paradoxal e predominante da razão. Uma razão universal, que organiza o pensamento sobre a vida a partir de elementos transcendentais à experiência.

Isso nos remete à ideia de história para a psicanálise. Quanto a isso, Oscar Cirino diz: "A história não é o passado. A história é o passado na medida em que é historiado no presente - historiado no presente porque foi vivido no passado." (LACAN, 1986, [1953-54], apud CIRINO, 2001, p. 106). O sujeito aí se

\footnotetext{
${ }^{59}$ Quanto a essa questão, em um interessante texto ("Os que fracassam pelo êxito") Freud sugere que o desejo é para alguns insuportável (FREUD, 2015). 116
} 
situa na reconstituição do vivido e não de memórias intactas, fotográficas de seu passado, pois "se trata menos de lembrar do que reescrever a história" (LACAN, 1986, [1953-54], apud CIRINO, 2001, p. 106).

Nesse mesmo sentido, para Foucault, "reescrever a história" não pode estar desligado da noção de autoria. Para ele a produção da noção de autor, o "Haja Autor!” da tradição, implementado como dispositivo de controle, visa à substituição dessa presença inteira, linguagem e corpo, e busca solapar a ideia de sujeito clivado, barrado da psicanálise, substitui a presença hesitante e errante do sujeito dividido, que só de longe não exibiria fraturas.

Tal produção do autor, segundo Foucault, está ligada à necessidade de criminalização da autoria a partir do texto. Visa à domesticação da fala, na medida em que procura inibir o crime com a visibilidade da possibilidade da punição. Do mesmo modo, isto é, na perspectiva de ser responsabilizado pelo trabalho executado, um artista, no Renascimento, passa a ser contratado e obrigado a assinar suas obras na garantia de que outra pessoa não o fizesse ${ }^{60}$.

Já Freud discute a autoria numa outra chave. Ele descobre em seu próprio processo investigativo e de escrita a questão da diluição da autoria, na medida em que reconhece a voz de seus mestres no seu trabalho, ocasião em que atribuía indubitavelmente a eles determinado traço de autoria das ideias nas quais estava trabalhando, enquanto os supostos autores de tais ideias negaram a autoria, afirmando ainda que elas nem mesmo provieram deles. Freud será forçado a reconhecer que há na relação entre várias pessoas o que ele chamou de transmissão, algo que não é, nem totalmente de um, nem totalmente de outro. Não se trata de ensino 61 , que

se inscreveria mais do lado da articulação simbólico-imaginária, uma vez que pretende colocar em signos, comunicar, [por sua vez] a transmissão se colocaria mais do lado do Real, mais do lado do 'isso que se passa' (VOLTOLINI, 2008, p. 191).

Nesse sentido, o ensino tem a ver com conteúdo, com codificação desse conteúdo e, por isso, carregado de intencionalidade. Na transmissão, o papel da

\footnotetext{
60 Para ver mais, cf. BAXANDALL, Michael (1991).

61 Ensinar vem do latim, insignare, que quer dizer pôr em signos.
} 
elaboração é fundamental na aproximação de ideias e na combinação dessas ideias ao ponto de produzirem algo autêntico do qual alguém passa então a se sentir autor.

Assim, Freud, em A História do Movimento Psicanalítico, de 1914, diz:

A ideia pela qual eu estava me tornando responsável de modo algum se originou em mim. Fora-me comunicada por três pessoas cujos pontos de vista tinham merecido meu mais profundo respeito (...). Esses três homens me tinham transmitido um conhecimento, que, rigorosamente falando, eles próprios não o possuíam. Dois deles, mais tarde, negaram tê-lo feito quando lhes lembrei o fato (...). Mas essas três opiniões idênticas, que ouvia sem compreender, tinham ficado adormecidas em minha mente durante anos, até que um dia despertaram sob a forma de uma descoberta original (FREUD apud VOLTOLINI, 2008, pp. 185-186).

Foucault aponta algo nesse sentido da "geração" como apropriação de uma ideia:

\begin{abstract}
Durante muito tempo permaneci preso a um conflito mal resolvido entre minha paixão por Blanchot e Bataille, por um lado, e o interesse por certos estudos positivos, como os de Démeziel e Lévi-Strauss, por outro. Mas, na realidade, essas duas orientações, cujo único denominador comum talvez seja constituído pelo problema religioso, contribuíram igualmente para conduzir-me à idéia do desaparecimento do sujeito (FOUCAULT apud HABERMAS, 2000, pp. 333-334).
\end{abstract}

As ideais vão e vêm, são esquecidas, perdem sua nitidez, ganham-na em seguida, tomam formas diversas (DELEUZE, 1998b, 1h20'). Enfim, apresentam-se num longo percurso de "materialização" até conformar-se a um pensamento. Esse processo se dá, diz Freud, pela elaboração. Semelhante se passa com o aprendizado de uma língua estrangeira. Não se sabe exatamente o que se tem aprendido, pois as palavras e expressões orbitam como satélites que farão, pouco a pouco, sentido num universo linguístico. A apreensão do conjunto de signos aí se dá exponencialmente, pois há saltos que não são exatamente lógicos. Algo dessa ordem se dá com a ideia de autoria.

Essa ideia da geração de um saber a partir de uma configuração pouco definida considera a cultura e as circunstâncias em que uma pessoa esteja inserida para a constituição de uma marca pessoal. Ora, a compreensão da produção da ideia para além do ensino é fundamental para procurar considerar os processos na 118 
escola - particularmente aqueles que envolvem as artes. No entanto, a aposta dessa instituição parece se dar quase inteiramente no campo do ensino, uma vez que se procura didatizar tudo: o texto, o filme. Pensamos se não seria aí interessante que as escolas percebessem formas de promoção da autonomia dos sujeitos situados no universo escolar, procurando dividir o espaço dado às ciências com espaços de produção e exposição de artes, bem como fazer a escola, em algum nível, espelhar a vida a partir do que os alunos vivenciam em suas comunidades. Não é a isso que se refere Barbero, quando lembra o relato de Giroux, em que conta sobre a riqueza cultural nas ruas dos Estados Unidos? Contudo, ao conhecer as escolas, viu que elas não representavam essa pluralidade das ruas (MARTíNBARBERO. In: CITELLI \& COSTA, 2011, p. 210).

É no uso das palavras (ou em meio a elas) que o sujeito chega a entender-se como náufrago, como o fazem Freud, Lacan e Foucault. Este diz: "É preciso pronunciar palavras enquanto as há, é preciso dizê-las até que elas me encontrem" (FOUCAULT, 2011, p. 06). Trata-se de um exercício existencial, experimental, o de estar na linguagem e saber-se nela, linguajando e se ajustando a ela, nela. Ajustando-se, mas também criando, pois não se trata apenas de adequação de, num provador de linguagens, vestir a mais adequada. Ora, sendo o sujeito a condição de assujeitamento, da quase casualidade, da transversalidade, então é preciso exercitar a fala até que ela se ajuste ao objeto a que ela se refere, atravesse-o, até haver transitória satisfação de correspondência (ou "até que elas me encontrem", como disse Foucault).

Não é esse o caso de Viver a Vida (Vivre sa Vie, 1962), de Jean-Luc Godard, em que Nana fala inadequada e desajustadamente? Constata ela: "Quanto mais se fala mais as palavras perdem seu sentido", que é a tese de Rousseau em $A$ Origem das Línguas para quem, ao se falar muito uma palavra, seu sentido original é perdido. Em outro momento, Nana parece ironizar a tese de Sartre sobre a responsabilidade, afirmando que as pessoas são responsáveis por seus atos. Ela enumera uma série deles, dos mais complexos aos mais simples, como levantar a mão, olhar para o lado. Diz caber a qualquer pessoa escolher apenas as coisas boas da vida. Ora, como se depreende do filme, Nana teve que deixar o lugar onde morava por não pagar o aluguel. A seguir, torna-se prostituta, quando, na verdade, 
gostaria de ser atriz de cinema. Depois de proferir seu discurso com leveza e inconsequência, olha com seus olhos grandes e expressivos, flagrados pela câmera com desalento impressionante. Tal olhar para a câmera (e para o espectador) é a negação do que acabara de defender. Na verdade, ela não escolhera nada.

A despeito dessa discussão, isto é, da fragilidade do "pensamento fraco", vacilante, o professor fala como se seu público fosse composto de ouvidos dóceis, como se o aluno soubesse da necessidade ou tivesse a predisposição de procurar ajustar sua compreensão ao discurso proferido pelo professor. Há um desencontro entre o que se sente obrigado a dizer, discurso ao qual tenta se ajustar todos os dias antes de entrar em sala de aula, e as expectativas dos estudantes, do outro lado. Entre professor e alunos, o abismo, olhares que se cruzam cúmplices, mas imobilizados, antagônicos. Como disse Merleau-Ponty: "A ciência manipula as coisas e renuncia habitá-las.” (2004, p. 13). Nesse jogo destrutivo de hostilidade mútua os alunos estão amparados por certo anonimato da quantidade. Eles desconfiam que a escola, assim como todas as instituições na sombra das grandes narrativas, não cumpriram a promessa de segurança e de felicidade. Imbuída de fornecer aprendizado a bem do futuro de seus alunos, a escola encontra uma variedade complexa de problemas que tornam esse resultado inócuo.

Contrariando esse histórico de regularidade de problemas apontados, em que o não cumprimento do lugar que se espera dos alunos faz parte, é que se pode considerar que em novembro de 2015, reagindo a uma política costumeiramente impositiva do governo do estado de São Paulo, que fecharia aproximadamente 90 escolas de sua rede em razão de um plano para a educação, alunos da própria rede estadual reuniram-se e deram início a um movimento que foi bastante amparado e reconhecido por artistas e intelectuais, e que teve divulgação favorável também na grande mídia (ao menos não depreciativa, como é comum $)^{62}$, ao contrário daquilo que comumente se vê, pois "o discurso mediático elabora um ponto de vista padronizador da imagem do docente [e, por

\footnotetext{
${ }^{62} \mathrm{~A}$ matéria do grupo G1, da Rede Globo, como se sabe, costumeiramente crítica a manifestações populares contra o PSDB, publica matéria extensa em que apresenta posições contra e a favor das ocupações. Segundo a matéria, a Secretaria de Educação do Estado de São Paulo confirmou que eram 190 escolas ocupadas até o dia 27 de novembro de 2015. De acordo com o Sindicato dos Professores do Ensino Oficial do Estado de São Paulo (APEOSP), eram 194. http://g1.globo.com/sao-paulo/noticia/2015/11/ocupacoes-atingem-pelo-menos-190-escolasestaduais-de-sp-apos-18-dias.html 120
} 
consequência, da escola] que ao mesmo tempo sintetiza temas e figuras e os coloca em circulação social através dos diferentes veículos.” (CITELLI, 2012, p. 10). A despeito da cristalização dos possíveis estabelecidos como limites pelo discurso midiático, os alunos ocuparam as escolas e propuseram uma agenda de atividades possíveis num formato que surpreende pelo tão propagado ilusório "protagonismo estudantil" pelas pedagogias circulantes no meio escolar. Contudo, é notório o protagonismo estudantil no caso das ocupações das escolas mencionadas anteriormente.

De fato, os estudantes, a partir da ocupação dessas escolas marcadas para fechamento, chegaram a se dar conta de que o espaço escolar poderia cumprir o seu destino de formação por outras vias, desconhecidas por eles até então. Em várias delas eram sugeridas discussões sobre questões que interessavam à comunidade escolar como a própria política de reforma educacional do governo do Estado, que gerou o movimento, mas também temas mais amplos sobre uma política desejável, como vários previstos no currículo como a Revolução Francesa, por exemplo. 0 advogado Daniel Biral, integrante do Coletivo Advogados Ativistas, que fornece assessoria jurídica aos estudantes das ocupações, disse que no período da ocupação, houve 5 mil profissionais voluntários que deram aulas para os estudantes. Com a participação desses profissionais de fora da instituição escolar, Daniel Biral conclui que "a escola formal está falida e, este ano, não conseguiu cumprir com o planejamento pedagógico. Queremos que essa escola seja repensada." (BIRAL, 2015). ${ }^{63}$ A partir do exercício elaborado pelos próprios estudantes e profissionais nas escolas, durante o período da ocupação, Daniel Biral chega à conclusão de que é possível a proposição de um outro modelo de escola.

Depois das ocupações, isto é, "recuperada a normalidade", as sugestões e atividades implementadas nas escolas durante as ocupações parecem não ter marcado a instituição. Parece que sempre se começa do zero. 0 discurso cientificizante da escola parece ser não apenas predominante, mas totalizante, a ponto de não incorporar os acontecimentos que fogem de seu estrito interesse. Essa relação foi observada por Hanna Arendt. Para ela é a inscrição no discurso

${ }^{63}$ BIRAL, Daniel. Alunos de escolas ocupadas querem usar aula voluntária para abonar dias letivos. Entrevista concedida à Empresa Brasil de Comunicação S/A - ECB, disponível no endereço: http://agenciabrasil.ebc.com.br/educacao/noticia/2015-11/alunos-de-escolas-ocupadas-queremusar-aula-voluntaria-para-abonar-dias. Site consultado em 10 de dezembro de 2015. 
científico que faz com que o ser humano perca sua relação com o mundo, sua implicação, sua faculdade de julgar (Cf. LEBRUN, 2004, p. 71ss.). 0 professor, parece-nos, situando-o nessa caracterização do Homem geral, também perdeu sua faculdade de julgar, de selecionar, de olhar para o universo curricular e enxergarse ali, propor recortes, destacar aspectos que lhe pareçam mais importantes etc. Enfim, tomado por esse espírito cientificista, o professor afasta-se da experiência, vale dizer, do acontecimento singular. Esse sujeito que se destituiu do lugar de sujeito é a saída da condição humana (ARENDT Cf. LEBRUN, 2004, p. 71), incapaz de pensar, radicalmente falando. Sujeito modesto e tirânico, ele ensina algo que não lhe interessa (DANEY, 2007, p. 111).

0 professor, pois, desalojado do lugar do pensar vaga como fantasma sem tocar as coisas que deveriam constituir o seu mundo, sem falar das coisas de seu mundo, de dentro delas. Ao contrário, passa a se constituir como veículo do discurso científico, do enunciado científico que, na verdade, prescinde do enunciador. Esse não-lugar do professor não lhe confere condições de ser atravessado pelo singular da experiência estética (erfahrung). Por isso, procurará moldar as linguagens ao termômetro cientifizante do discurso lógico da Ciência. 0 mesmo se dará com o cinema, que será útil na medida em que fornecer possibilidade de mobilizar o cientifizável. Assim, "quando nos deixamos [...] levar pelo meio técnico, perdemos as referências [...]" (LEBRUN, 2004, p. 100).

Essa demissão do sujeito de seu lugar no pensamento tem implicação fundamental na dinâmica escolar, visto que tal condição é responsável por pensar a especificidade de cada escola, com nuanças que lhe são próprias e que o "conteúdo curricular", por consequência, resguardaria. À demissão do sujeito na produção do pensamento corresponde a elevação da técnica a esse lugar. Já se disse, onde não fala o sujeito é a técnica quem fala. Atualmente, sintoma maior dessa ocupação por parte da técnica em lugar do singular é o avanço vertiginoso dos cursos na modalidade EaD.

Vale dizer que essa demissão não é a mesma da ordem daquele que se dá conta de que nada sabe (Sócrates). Ao contrário, esse lugar do não-pensar é o lugar da arrogância discursiva, cujo discurso propõe a varredura do desvio, da gagueira à qual se refere Deleuze (2004, p. 52). Como diz Lebrun, ao comentar 
1984, livro de Georges Orwell, tomar a palavra aqui não se trata de um ato singularizado, autoral, por assim dizer, mas de "expressão automatizada de fórmulas pré-fabricadas, que se poderia denominar de língua coagulada" (LEBRUN, 2004, p. 104). Tomamos tal ideia de empréstimo para aplicá-la ao professor, que de tão ausente como sujeito, fala de seu dizer como uma "prática fonatória desumanizada" (LEBRUN, 2004, p. 105), como se ele fosse um ventríloquo cujas palavras não lhe pertencessem, nem ele a elas, mas fossem duas instâncias díspares, antagônicas.

Esses eventos relacionados à ocupação das escolas parecem lembrar a fala de Foucault em sua aula inaugural no Collège de France, em 1970: "Desejo não começar", diz ele, mas a instituição expulsa essa ideia como delírio e a impõe como necessidade em forma de poder. Nesse sentido, o texto "Crise na Educação" (ARENDT, 2013) é preciso quando aponta a sociedade estadunidense como constituída, mais que todas, da crença no marco zero, no início do novo homem, na liberdade como valor absoluto. Fala-se no início absoluto como se fala de zero absoluto para o frio, quando, sabe-se, trata-se de uma abstração, um ponto indicativo, ideal. Fala-se como se o início fosse a origem. Como se fosse possível, na origem, encontrar as coisas e nomeá-las. Foucault está na direção contrária da nomeação das coisas. Ele está dizendo que há uma produção polifônica do $\begin{array}{llll}\text { discurso. } & \text { No entanto, } & \text { essa } & \text { produção }\end{array}$ é controlada, selecionada, organizada e redistribuída, cuja ação é conjurada para "dominar seu acontecimento aleatório, esquivar sua pesada e temível materialidade" (FOUCAULT, 2011, p. 09). 0 discurso, pois, não é produto do acaso, ele surge (e se mantém) de relações de poder. E a escola é uma fonte de produção dessas polifonias.

Em alguma medida, Foucault e Arendt falam da mesma coisa. Aquele gostaria de tomar o discurso já em seu movimento, apresentando-se subrepticiamente, chegando à conclusão de que não há começo (FOUCAULT, 2011) e, no entanto, a instituição exige esse começo. Já Arendt aponta os equívocos em pensar que estamos começando algo, na medida em que não se leva em conta toda uma história que sempre antecederá o "novo". 
Assim, a experiência promovida nas escolas ocupadas parece contrapor-se à ideia de começo mítico, que tende a cristalizar as experiências institucionais, que se estendem como razão social de um modelo autoreferente. Com isso, desautorizam qualquer discurso exterior. No caso das ocupações das escolas aqui referidas, o discurso elaborado teve os sujeitos das próprias escolas como protagonistas. Os alunos - os sem luz, como sugere o termo -, eles próprios, motivados pelas descobertas no meio do caminho, perceberam que era possível se constituir outro tipo de instituição escolar. Essa experiência de ocupação das escolas, pois, parece um importante ensaio dessa possibilidade.

Este longo excurso pela psicanálise e pela experiência das ocupações nas escolas da rede estadual de São Paulo acrescenta à discussão um cenário de condições concretas de ocupação de lugar de sujeito por parte dos alunos a partir de mudanças na configuração escolar. Tal cenário incidirá na análise que promoveremos a seguir do lugar atribuído aos agentes que compõem a escola (alunos, professores, diretores, coordenadores pedagógicos) no material do projeto da SEE-SP e de seus antecedentes. 


\section{5- O CINEMA VAI À ESCOLA}

\section{1- Antecedentes da pesquisa}

De 2007 a 2008, atuei como professor de Filosofia no Ensino Médio da rede pública estadual de São Paulo em diferentes escolas, ocasião em que vi majorar o propósito inicial desta pesquisa de doutorado - o de entender como se dava o trabalho com o cinema no ambiente escolar. Pela vivência em escolas, eu saia que a imagem como suporte pedagógico - de qualquer registro, seja ele das artes plásticas, da fotografia ou do cinema -, era secundarizada diante da predileção do texto escrito. Por esta razão, fazia-se necessário notar que tal problema não se restringe ao cinema, pois como diz Rosa Iavelberg:

A ausência de práticas de criação nas escolas em diferentes linguagens da arte: teatro, música, dança ou artes visuais, cada qual tratada disciplinarmente em sua especificidade; a arte a serviço de projetos de meio ambiente, saúde, datas comemorativas do calendário escolar e à aprendizagem de outras disciplinas sem ênfase em seus conteúdos próprios; a desvalorização da área denotada pela ausência de proposta de aquisição de livros ${ }^{64}$ pelo Programa Nacional do Livro Didático (PNLD); a ausência de avaliação dos projetos desenvolvidos nas escolas como situações de aprendizagem; e a pouca visita cultural e estudo de arte brasileira ou de artistas regionais (IAVELBERG, 2012).

Na visão de Iavelberg, as escolas encontram-se privadas de práticas criativas, de modo que não soaria estranha a afirmação de que se trata de uma ocorrência generalizada. Ademais, assim como a autora descreve, também percebi que prevalece a pouca atenção de diretores, gestores e professores para com as

\footnotetext{
64 Iavelberg escreve o texto do qual foi retirada essa citação em 2012. Em 2015 é aberto edital pelo MEC, que contempla a disciplina Arte. Resolvemos manter a citação em razão de que continua sendo uma característica corrente a despreocupação em considerar as artes um campo específico. Cf.http://pesquisa.in.gov.br/imprensa/jsp/visualiza/index.jsp?data=13/04/2015\&jornal=3\&pagin $\mathrm{a}=53$ \&totalArquivos=212. Acesso em 19 de junho de 2016.
} 
$\operatorname{artes}^{65}$, havendo, provavelmente por consequência de desinteresse formal efetivo por esse campo, a desconsideração de seu tratamento como disciplina específica. A ausência de proposta por parte do PNLD de aquisição de livro didático de artes é provavelmente sintoma desses problemas apontados. Segundo Bergala, são problemas também da educação francesa:

Lo que más falta, en este campo de la pedagogía del arte, es un pensamiento táctico convecido de los grandes principios que lo guían - digamos los grandes objetivos de la escuela laica, que siempre, y ahora más que nunca, debe defenderse - y que permanezca alerta tanto a las dificultades en la traducción real de estas ideas generales a la práctica pedagógica, como a la validez de los discursos demasiado pragmáticos (BERGALA, 2007, pp. 3031).

Foi nesse cenário pouco criterioso quanto ao trabalho com as artes, exposto por Iavelberg e por Bergala - como pude averiguar em minhas experiências como professor -, que tomei conhecimento do projeto $O$ cinema vai à escola - a linguagem cinematográfica na educação, da SEE-SP/FDE. A partir de sua criação, em 2008, tal projeto passava a introduzir formalmente e a organizar o uso do cinema nas escolas da rede estadual de ensino de São Paulo. Além do fornecimento de filmes em DVD às escolas para formação de acervo, o projeto foi amparado por material66 impresso e digitalizado com o objetivo de sugerir sistematicamente orientações aos professores quanto à utilização dos filmes em sala de aula.

Interessante é notar que, a exemplo do que se passou com o projeto francês "Missão de Educação Artística e de Ação Cultural", coordenado por Alain Bergala, $O$ cinema vai à escola distribuiu o mesmo conjunto de filmes (no caso, 71 longas-metragens) e os mesmos roteiros de atividades - que se encontram nos Cadernos de Cinema do Professor - a todas as escolas da rede estadual.

Comparando o material do projeto $O$ cinema vai à escola com o do já mencionado programa coordenado por Bergala (e também com o Using films in

\footnotetext{
${ }^{65}$ Afirmação partilhada por Marcos Napolitano em entrevista concedida a este autor realizada em 16 de maio de 2016, em que ressalta que foi esse o problema maior do projeto $O$ cinema vai à escola, o de não ter dado atenção a "essa ponta do processo".

${ }^{66}$ Mais adiante, quando tratarmos especificamente do projeto $O$ cinema vai à escola, detalharemos os materiais que fazem parte desse projeto.
} 
schools: a practical guide, projeto desenvolvido na Inglaterra), constatamos semelhanças e diferenças. O programa coordenado por Bergala publicou o documento Le plan pour les arts et la culture à l'École 67 , contendo 64 páginas, que trata das artes na escola, com orientações e sugestões teóricas e procedimentos gerais em torno de uma página para cada arte (Música, Dança, Literatura, Teatro, Artes Plásticas, Cinema, Fotografia). No caso do cinema, há sugestões mais práticas, como o uso de câmera mini-DV para visualização por parte dos alunos da fabricação de uma imagem de cinema, por exemplo, e há também sugestões quanto à necessidade de exibição integral dos filmes, sugerindo (ainda que de modo impreciso ${ }^{68}$ ), que o professor devesse implementar uma pedagogia da criação ("Faire visionner des œuvres intégrales (...); Mettre en place une pédagogie de la création au cinema, où chaque élève sera amené à faire une expérience intime, concrète et pratique de l'acte de création (...)”69 (FRANÇA, 2001, p. 29). 0 texto não se detém em orientações de como usar os filmes em sala de aula, mesmo aqueles 32 da coleção L'Éden Cinema enviados às escolas francesas pelo projeto.

Por sua vez, a publicação Using film in schools: a practical guide ${ }^{70}$ (BARRANCE, 2010), em suas 50 páginas traz, principalmente, um passo a passo de como filmar ${ }^{71}$, utilizando-se do ambiente da própria escola, além de vários outros procedimentos pertinentes a filmagens, problemas de como estabelecer orçamento das filmagens e de como solicitar patrocínio, por exemplo. A ênfase dessa publicação é dada à filmagem na escola, de modo que seria mais preciso se ela se chamasse Filming in schools... Apesar disso, propõe a integração do cinema ao currículo formal da escola, sugerindo entradas específicas em algumas disciplinas

\footnotetext{
67 Plano para as Artes e a Cultura na Escola (tradução nossa), publicado no terceiro trimestre de 2001. Cf. www.education.gouv.fr/archives/2012/refondonslecole/wpcontent/uploads/2012/07/le_plan_pour_les_arts_et_la_culture.pdf. Acesso 16 de junho de 2016. ${ }^{68}$ De modo mais preciso, em La hipótesis... (2007, p. 37), quanto à ideia de uma pedagogia da criação, Bergala sugere: "Pensar la película como la traza de un gesto de creación. No como un objeto de lectura, descodificable, sino cada plano como la pincelada del pintor a través de la cual se puede comprender un poco su processo de creación.".

69 "Assistir integralmente às obras (...); Estabelecer uma pedagogia da criação do cinema em que cada aluno seja levado a vivenciar uma experiência íntima, concreta e prática do ato de criação (...)” (www.education.gouv.fr/archives/2012/refondonslecole/wp-

content/uploads/2012/07/le_plan_pour_les_arts_et_la_culture.pdf. Acesso 16 de junho de 2016, tradução nossa).

70 Usando o filme em escolas: um guia prático (tradução nossa). Diferentemente da publicação Plano para as Artes e a Cultura na Escola, esse guia é especificamente sobre cinema.

71 A rigor, "filmar" se refere à filmagem com câmera que usa filme e "gravar", à gravação digital.
} 
tais como Inglês, História, Geografia e Matemática, por exemplo, e por temas "transversais" como cidadania:

\begin{abstract}
English:
Use moving images as a stimulus for speaking and listening; Use short films to develop understanding of narrative and point of view [para o Ensino fundamental I]: use moving images as stimulus for writing, e. g. letters, news items, film reviews. View the opening scene from an adaptation before reading the book, and consider what it tells the viewer about genre, narrative and character. (...) [para o Ensino Secundário, primeiro ano].

History:

View archive film to develop understanding of an historical period [para o Ensino Fundamental I]: Use clay animation to depict an historical event; Make film documentaries incorporating archive footage. [para o Ensino Fundamental II]; Compare, analyse and discuss different (fictional or documentary) film representations of an historical period, event or character; Explore the techniques used in propaganda films; Write film scripts. [para o Ensino Secundário, primeiro ano].

Citizenship:

Use short films, children's films and feature films to stimulate discussion and writing about issues of citizenship. Using film can provide a way for children to address personal issues at one remove. [para o Ensino Fundamental I]; Explore the techniques which films use to present issues, groups, institutions or events in positive or negative ways. [para o Ensino Fundamental II] (BARRANCE, 2010, p. 05-07) ${ }^{72}$.
\end{abstract}

\footnotetext{
72 Inglês:

Use imagens em movimento como um estímulo para falar e ouvir; Use curtas-metragens para desenvolver a compreensão da narrativa e do ponto de vista [Para o Ensino Fundamental I]: use imagens em movimento, como estímulo para a escrita, e. g. cartas, notícias, resenhas de filmes. Veja a cena de abertura de uma adaptação antes de ler o livro, e considere o que diz o espectador sobre gênero, narrativa e personagem. (...) [Para o Ensino Secundário, Primeiro ano].

História:

Veja arquivo de filme para desenvolver a compreensão de um período histórico [Para o Ensino Fundamental I]: Use animação de barro para descrever um evento histórico; Faça documentários incorporando imagens de arquivo. [Para o Ensino Fundamental II]; Compare, analise e discuta diferentes (ficção ou documentário) representações cinematográficas de um período histórico, Evento ou personagem; Explore as técnicas usadas em filmes de propaganda; Escreva roteiros de cinema. [Para o Ensino Secundário, Primeiro ano].

Cidadania:

Use curtas-metragens, filmes infantis e filmes para estimular a discussão e escrever sobre questões sobre cidadania. 0 uso de filme pode fornecer uma maneira para as crianças a lidar com questões pessoais. [Para o Ensino Fundamental I]; Explore as técnicas que utilizam filmes a apresentar problemas, grupos, instituições ou eventos de modo positivo ou negativo. [Para o Ensino Fundamental II]. (tradução nossa).
} 
Além dessas sugestões de uso do filme na sala de aula, com inclusão no currículo, Using films in schools entende que o filme pode e deve ser usado em atividades informais, isto é, em sua dimensão estritamente cultural, quando sugere projeções aos finais de semana ou a participação dos alunos em cineclubes. Recomenda ainda uma série de procedimentos básicos para a sala de projeção, tanto para melhor visualização das imagens como o "blackout", quanto à distribuição das cadeiras, indicando a disposição delas em "camadas", em forma de meia lua. Recomenda também que as caixas de som fiquem próximas da projeção e não no alto como poderia parecer melhor.

Dessa dimensão prática da realização de filmagens e de projeções na escola, a partir de avaliação da atuação das várias escolas de cinema na Inglaterra, como menciona o texto, o guia Using films in schools estabelece três princípios da educação por meio do filme: 1) o crítico, que diz respeito à compreensão e à análise de filmes; 2) o cultural, que se refere ao aprofundamento da experiência de ver um filme, podendo ser exibidos filmes pouco usuais na televisão e nas salas de cinema do Brasil e 3) o criativo, referindo-se à importância de os alunos fazerem seus próprios filmes (BARRANCE, 2010, p. 09). Também diferentemente do projeto da SEE-SP e daquele coordenado por Bergala, não há a proposição de distribuição de filmes em formato DVD; o uso dos filmes se daria pela internet, lembrando o guia que cada escola deve tomar as providências para obter uso de banda-larga e de ter o devido cuidado com a não violação de direitos autorais.

Assim, percebe-se que o projeto $O$ cinema vai à escola se diferencia dos dois modelos estrangeiros, principalmente em razão de apresentar o conjunto de sugestões de uso específico para cada filme distribuído (além do fato de as obras serem encaminhadas fisicamente, em invólucros com mídia e material de apoio) materialmente para as escolas do projeto. São, pois, 71 Roteiros de atividades sugeridas para cada filme e dentre estes, 41 se encontram em dois dos quatro volumes dos Cadernos de Cinema do Professor, que são impressos como livros e também disponibilizados em site da SEE-SP; os 20 outros ficam disponibilizados para acesso apenas no site. Mas a principal diferença entre o projeto do governo paulista e seus similares europeus reside no fato de este centrar sua tônica na espectatorialidade, sobretudo, porque sua tônica é a da espectatorialidade a partir 
da projeção de filmes em sala de aula. Por isso, justifica-se um considerável número diversificado de filmes distribuídos às escolas e material para utilização desses filmes com orientações sobre a linguagem cinematográfica e palestras de especialistas. Não há nesse material nenhuma parte tratando especificamente de gravação ou filmagem na escola a fim de orientar a produção de curtas-metragens como no guia inglês e, em menor escala, no francês. Se no vídeo comentado ${ }^{73}$ do projeto da SEE-SP há a abordagem sobre a "gramática" do cinema, tal propósito visa apenas à instrumentalização de professores e alunos como espectadores, não como realizadores.

Vale ressaltar que este material vem suprir a falta quase absoluta de filmes em bibliotecas das escolas estaduais em São Paulo (falta esta que também inclui material escrito para orientação de professores e alunos quanto à linguagem do cinema). Nesse sentido, o kit se constitui em valioso recurso com textos e falas de especialistas, além de um diversificado conjunto de filmes. Esse material fornecido à escola oferece um importante apoio para que esta tome as rédeas da inserção do cinema em seu currículo (ou no seu dia a dia) que, como já dito, é geralmente tratado com informalidade.

Independentemente da qualidade desse material - que analisaremos mais adiante -, o que nos chama atenção é o foco de sua produção, que priorizou a experiência de especialistas na feitura do material, deixando em segundo plano a "ponta da educação", formada por professores, diretores, coordenadores pedagógicos e alunos. Nesse aspecto, tal processo de produção de um saber assemelha-se ao que ocorre com a produção dos livros didáticos das outras disciplinas. 0 material já chega à escola decantado e consolidado, pronto para ser aplicado, o que se constitui em um problema a ser observado se considerarmos que se trata de uma distribuição indistinta a alunos em diversas condições; seja quanto ao nível de escolaridade, idade ou condição social. Vale lembrar ainda que a rede estadual é bastante ampla, incluindo escolas situadas em grandes centros e em cidades pequenas. 
A produção desse material por especialistas exteriores aos propósitos educacionais específicos das unidades escolares pode ser já ela própria expressão de submissão de todo um conjunto heterogêneo em torno de 3,6 milhões de estudantes e de 230 mil professores (caso de São Paulo, que possui a maior rede de ensino do país), a um mesmo material, intensificando ainda mais a desconsideração das singularidades dos grupos envolvidos. Nesse sentido, tal material restringiria a potência do objeto em questão, o cinema. Como disse Bergala, parece mesmo faltar uma pedagogia que preveja e contemple alguma forma de "adaptação", ou seja, algo que leve em consideração a heterogeneidade dos grupos (sem prejuízo do objeto) aos quais tais programas se dirigem: "Si no respeta su objeto [o cinema], si lo simplifica o lo caricaturiza a ultranza, incluso con las mejores intenciones pedagógicas del mundo, está haciendo un mal trabajo." (BERGALA, 2007, p. 31).

Ademais, o projeto $O$ cinema vai à escola não partiu de necessidades próprias geradas nas escolas ou mesmo sequer foi fomentada por membro delas, o que é suficiente para modificar a sensibililidade para sua receptividade: trata-se de iniciativa de instâncias fora das escolas; isto é, não surge de uma demanda "natural”, "espontânea" do funcionamento da escola, mas como política de direito; não como "sintoma", como diz Voltolini, mas como iniciativa desvinculada do desejo de um público supostamente interessado.

É espantosa a dimensão do projeto em termos de números (ver Tabela 1, abaixo). A quantidade de filmes (71 títulos) entregues às 4.030 escolas estaduais de Ensino Médio ${ }^{74}$ contabiliza 286.130 unidades de DVD, mais 6 caixas de filmes para as 91 Diretorias de Ensino em todo o estado (6.461), totalizando 292.591 unidades. Com essa quantidade de filmes esperava-se poder gerar grande número de sessões nessas instâncias a fim de que o ato de acessar os filmes se tornasse um hábito. Contudo, alguns fatores, que serão vistos mais adiante, explicam as dificuldades de estabelecimento da geração desse hábito.

Tabela 1: Gastos gerais utilizados na compra e distribuição dos filmes, elaboração de materiais e contratação de especialistas.

\footnotetext{
${ }^{74}$ Dados extraídos do INEP. Os dados da SEE-SP apontam 3.200 escolas estaduais de Enino Médio sob a jusrisdição do Estado de São Paulo. De acordo com a tabela de gastos gerais, o número de escolas varia de 3.773 a 4.030 , de 2008 a 2014 .
} 


\begin{tabular}{|l|l|l|l|l|l|l|}
\hline OCVE* & 2008 & 2010 & 2012 & 2013 & 2014 & Total \\
\hline $\begin{array}{l}\text { Escolas } \\
\text { participante } \\
\text { s }\end{array}$ & 3.807 & 3.773 & 4.030 & 4.030 & 3.907 & \\
\hline $\begin{array}{l}\text { Alunos } \\
\text { atendidos }\end{array}$ & 1.753 .061 & 1.742 .782 & 1.798 .420 & 1.800 .000 & 1.695 .443 & \\
\hline $\begin{array}{l}\text { Municípios } \\
\text { (645 }\end{array}$ & 645 & 645 & 645 & 645 & \\
\hline $\begin{array}{l}\text { Recurso } \\
\text { (R) }\end{array}$ & 1.685 .471 & 1.896 .945 & 1.384 .471 & $555.888,48$ & 619.116 & $\mathbf{6 . 1 4 1 . 8 9 1 , 4}$ \\
\hline
\end{tabular}

Fonte: dados extraídos do SISVIC e SIEC, atualizado em 23/07/2015, enviados por e-mail em 09/03/2016 pela FDE (Lizete Freire Onesti e Devanil Tozzi) em resposta à solicitação por nossa parte.

*OCVE - Projeto O cinema vai à escola. Nos anos 2009 e 2011 não houve compra nem distribuição de filmes nem qualquer outro gasto com o Projeto.

0 valor total de $\mathrm{R} \$ 6.141 .891,40$ corresponde à soma de gastos referentes à compra, distribuição dos filmes e à contratação de pessoal especializado para a elaboração dos roteiros e para palestras nas Orientações técnicas e Videoconferências, todas disponibilizadas no site da SEE-SP.

A tabela abaixo refere-se apenas à compra dos filmes. 0 valor da unidade dos filmes variou de $\mathrm{R} \$ 9,90$ a $\mathrm{R} \$ 32,90$, sendo que um deles, Sobre o futebol e barreiras, 2011, de Arturo Hartmann, foi doado ao projeto.

Tabela 2: Gastos utilizados na compra e distribuição dos filmes

\begin{tabular}{|l|l|l|}
\hline Ano & Escolas & Investimento \\
\hline $\mathbf{2 0 0 8}$ & 3.849 & $1.331 .581,00$ \\
\hline $\mathbf{2 0 1 0}$ & 3.849 & $1.697 .986,00$ \\
\hline $\mathbf{2 0 1 2}$ & 3.932 & $681.573,00$ \\
\hline $\mathbf{2 0 1 3}$ & 3.796 & $592.594,00$ \\
\hline $\mathbf{2 0 1 4}$ & 3.923 & $311.722,00$ \\
\hline Total & & $\mathbf{4 . 6 1 5 . 4 5 6 , 0 0}$ \\
\hline
\end{tabular}


Fonte: dados extraídos do SISVIC e SIEC, atualizado em 23/07/2015, enviados por e-mail em 09/03/2016 pela FDE (Lizete Freire Onesti e Devanil Tozzi) em resposta à solicitação de nossa parte.

0 primeiro obstáculo que se impôs a esta pesquisa de doutorado foi o da impossibilidade prática de percorrer um número expressivo de escolas a fim de investigar como a utilização do material tem se dado nessas instituições a partir d'O cinema vai à escola, pois a rede estadual de ensino de São Paulo compreende, como já dito, cerca de 4.000 escolas $^{75}$. Ademais, com a leitura do material, os usos do cinema na prática me pareceram menos relevantes se comparados à forma de pensar a entrada do cinema pela SEE-SP/FDE. O modo que o cinema entra na escola e a definição de diretrizes do tipo de cinema a ser adotado são bastante significativos e determinantes para o papel do cinema que buscamos analisar.

No Brasil, alguns momentos históricos que antecederam ao lançamento de $O$ cinema vai à escola apresentam indicações de como se dava a relação entre o cinema e a educação. Dois desses momentos são a I Conferência Nacional de Educação, realizada em 1927, e a mobilização conhecida como Movimento dos Pioneiros (de 1932), que estabeleciam o cinema como auxiliar no processo de aprendizagem. Eles nos serviram de referência para o estudo do projeto $O$ cinema vai à escola - a linguagem cinematográfica na educação (2008) para verificar se houve mudança de expectativas em relação àquele cenário. Procuramos identificar se de 1927 a 2008 houve transformações significativas no que diz respeito aos objetivos da relação do cinema com a educação. Tentamos verificar, pois, se o cinema, que era pensado em termos instrumentais nesses dois momentos referidos, permanece como uso instrumental no projeto da SEE-SP/FDE, em prejuízo da experiência estética propriamente; se o cinema ainda seria uma

\footnotetext{
75 No Caderno de Cinema do Professor (vol. 4) consta que a primeira caixa de filmes foi entregue a "3.896 unidades escolares" (LIMA. In: TOZZI, 2010, p. 05), que é, conforme citação em texto e confirmação posterior em entrevista concedida pela FDE ao autor (30 de setembro de 2015), a quantidade de escolas estaduais com Ensino Médio em São Paulo. O Censo Escolar a que tivemos acesso mais próximo de 2008, ano de distribuição da primeira caixa, foi o de 2012, em que consta o número de 4.969 escolas estaduais, sem contar as 210 mantidas pelas universiddes estaduais e pelo Centro Estadual de Educação Tecnológica "Paula Souza". De acordo com o Censo Escolar de 2014, o mais recente produzido, o número de escolas estaduais é de 5.033, excetuando as 220 mencionadas anteriormente. De acordo com o site da SEE-SP (http://www.educacao.sp.gov.br/portal/institucional/a-secretaria/. Acesso dia 25 de janeiro de 2016) o número é de 5.300 escolas, ao todo.
} 
espécie de compensação ao desinteresse dos alunos cansados do processo de ensino-aprendizagem, como parecem sugerir esses documentos que confirmam o uso do cinema para "facilitar" o ensino-aprendizagem. Além disso, procuramos investigar se a dimensão prático-material, isto é, a realização das aulas com filmes, é melhor pensada no referido projeto, principalmente nos roteiros de atividades sugeridas pelos Cadernos de Cinema do Professor.

Não estamos, contudo, tomando por absolutos esses momentos que propuseram a entrada do cinema no contexto escolar, ou projetando neles poder determinante quanto às políticas educacionais (independentemente de outros agentes sociais) como o que atualmente talvez seja o de maior destaque na produção cultural do país - que é a grande mídia - como diz Michel de Certeau, ao se referir aos mass-media como uma "grande empresa de escolarização nacional" (CERTEAU apud SALIBA, 1993, p. 11).

Feita essa ressalva, consideremos agora que a entrada do cinema na escola encontra uma organização curricular bastante consolidada. As aulas dos professores estão sujeitas aos conteúdos e diretrizes gerais das disciplinas emitidos pela referida Secretaria de Educação por meio de material didático, em conformidade com o currículo oficial do estado.

Com o mesmo propósito de tornar o material didático mais acessível e interessante a alunos e professores, como no caso do cinema, a Proposta Curricular do Estado de São Paulo trouxe no mesmo ano de lançamento do projeto $O$ cinema vai à escola uma outra iniciativa que consistia na distribuição de jornais (denominados "Jornal do Aluno") com abordagens referentes aos conteúdos das disciplinas a fim de, por meio desse suporte, angariar maior empatia dos alunos com os tópicos apresentados, contrapondo-se, assim, à relação que estes mantinham com o livro didático. Tal suporte, somado às apostilas (chamadas de "revistas do professor"), em formato de cartilha, também com o mesmo propósito do Jornal do Aluno de tentar possibilitar maior acessibilidade dos professores e dos alunos a esse material. Contudo, a reação à proposta foi pouco favorável, já que o material mantinha o tom acadêmico, além de erros evidentes como falhas de transcrição de textos das obras originais, no caso da disciplina de Filosofia, por 
exemplo. Houve escolas em que o material foi queimado em manifestação de protesto.

Porém, antes de analisar o lugar do cinema na Proposta Curricular do Estado de São Paulo e no Currículo do Estado de São Paulo, para nos ajudar a pensar essas questões levantadas, tomaremos como parâmetro duas pesquisas que tratam dos temas cinema e a educação do estado. A primeira, de mestrado, de Marcelo Vicentin, denomina-se $O$ cinema vai à escola: um papel para diferentes personagens (relações entre currículos), cultura(s) e identidade(s), apresentada em 2013 na Universidade São Francisco, de Itatiba (SP), teve como objetivo tensionar o encontro entre linguagem cinematográfica e o currículo escolar. 0 estudo tem aporte teórico baseado em Michel Foucault e Nietzsche, e teve como objeto de análise a experiência de exibição de filmes em aulas de língua portuguesa no ensino básico proferidas pelo próprio pesquisador. Partilhamos com o autor as críticas à concepção do sujeito moderno empreendidas por Nietzsche e Foucault, que perdura na maioria das teorias pedagógicas que circulam no meio escolar. As críticas, em resumo, tem como alvo as ideias de História, Emancipação, Razão (VICENTIN, 2013).

Vicentin defende que

(...) os filmes vão ao encontro de mais uma característica fundamental do projeto [O cinema vai à escola], externado no primeiro caderno de cinema destinado aos professores: tornar mais interessante o tratamento de conteúdos curriculares, ou seja, motivar o aluno para que dentro do espaço e da perspectiva escolar reflita criticamente sobre o mundo que o cerca (2013, p. 117).

Na época em que foi escrita sua dissertação, a SEE-SP havia distribuído apenas 41 filmes. Para ele, esses filmes

representam o referencial de qualidade que o currículo e o conhecimento escolar propôs alcançar, além de encerrar em si ou em similares de acordo com a cultura cinematográfica do(s) professor(es) - a qualidade estética intrínseca, o potencial de interação com as disciplinas curriculares e a promoção de reflexão sobre o mundo que a SEE-SP propôs com a "nova" proposta curricular." (p. 116-117). 
Com tais constatações, Vicentin parece julgar ser completa a proposta da SEE-SP, no que diz respeito aos objetivos de se tomar o cinema como auxiliar às disciplinas e quanto à promoção da reflexão por meio dos filmes. Pensa a exibição de filmes na escola em consonância com o atendimento daquilo que a LDB lembra ser função da escola, qual seja, "o aprimoramento do educando como pessoa humana, incluindo a formação ética e o desenvolvimento da autonomia intelectual do pensamento crítico" (Art. 35 da LDB, citado por VICENTIN, 2012, p. 117).

Ainda segundo o autor, a aposta de que a projeção de filmes - parece não se importar com o filme em particular - tem por si só grande eficácia, por ser capaz de agregar à aula algo que a tornaria mais "interessante", uma vez que o aluno se sentiria "motivado" para refletir "criticamente sobre o mundo que o cerca". Todo esse trabalho de uso do filme seria feito a partir da submissão do aluno aos "conteúdos curriculares".

A segunda pesquisa que tomamos como referência é a tese de doutorado realizada por Claudia Mogadouro, intitulada Educomunicação e Escola: o cinema como mediação possível (desafios, práticas e propostas), defendida em 2011 na Escola de Comunicações e Arte (ECA) - USP. Nela, a pesquisadora analisa as várias iniciativas de uso do cinema na educação, dentre estas o projeto $O$ cinema vai à escola. Já no início, a tese considera a premissa defendida por Ismar Soares de que é preciso partir de dois pressupostos:

que a educação só acontece quando existe uma 'ação educativa', presente em todos os modos de formação do ser humano. E que a comunicação, enquanto produção simbólica e transmissora de sentidos é, sem (sic) si, uma 'ação educativa' (MOGADOURO, 2011, p. 15).

A ideia de comunicação, tal como enunciada, parece acentuar demasiadamente o papel da consciência para os destinos engendrados pela "ação educativa". Um verniz de consciência que, a nosso ver, minora a composição do inconsciente no fenômeno da ação educacativa. Mais: parece atribuir certo automatismo para a mesma ação educativa, que contradiz a ideia inicial de uma intenção educativa engendrada na noção de comunicação. A nosso ver, tal noção 
parece desprezar a potência da ideia de transmissão, que é inventariada em toda ação humana, fundada na cultura e não no indivíduo.

Diferentemente da tese de Morgadouro, não pretendemos acentuar o uso do cinema na educação como uma ferramenta mais ou menos eficaz, mas analisar como tal recurso é pensado ao adentrar as escolas da rede estadual. Que papel lhe é levado a cumprir. E, inevitavelmente, que concepções de cinema alimentaram o projeto.

O material do projeto $O$ cinema vai à escola apresenta noções de cinema, escola, sujeito e experiência estética, noções estas das quais nos servimos para pensar que lugar o projeto produz para o cinema. Conhecer o referido projeto em sua especificidade e abrangência nos permitiu, por exemplo, investigar como se deu a seleção dos filmes distribuídos pela SEE-SP/FDE, bem como a elaboração do material (impresso, vídeos) quanto aos critérios apresentados. Ademais, possibilitou investigar como se tem pensado o cinema dentro da perspectiva pedagógica do estado de São Paulo no âmbito da Secretaria de Educação, permitindo-nos atentar para a questão do empobrecimento da experiência no uso que aí se faz do cinema.

Para tanto, fez-se necessário também recorrer a outros documentos, tais como a Proposta Curricular do Estado de São Paulo, lançada em 2008, e sua conversão em Currículo do Estado de São Paulo, dois anos depois. Nosso interesse nesses dois documentos foi o de situar o cinema (e a Arte, de modo geral) na discussão que neles é feita para tentar entender o papel que lhe atribui o projeto $O$ cinema vai à escola. Além destes, também recorremos à análise dos artigos e dos roteiros de estudo do projeto, da seleção dos filmes distribuídos às escolas, assim como os vídeos dos debates realizados pela Secretaria junto com a FDE para obter mais informações quanto às questões próprias e atuais desse uso formal do cinema na escola.

Antes do lançamento do projeto base deste estudo, a SEE-SP/FDE já havia lançado uma série de artigos sobre cinema e educação sob o título Lições com cinema (São Paulo, 1993), publicada em seis volumes e, posteriormente, rearranjado em quatro, em 1993. Esses textos são resultados do seminário Cinema em Vídeo, também organizado pela SEE-SP/FDE, em 1991, que, a seguir, publicaria 
as falas dos participantes. Importante notar que não há aí, como haverá no projeto O cinema vai à escola, uma elaboração específica com objetivos articulados numa proposta única. Os textos em Lições com cinema são uma reunião de ideias de autores independentes entre si, que foram convidados a falar sobre a relação entre cinema e educação. No entanto, consideramos uma fonte importante, por se tratar de um antecedente do projeto $O$ cinema vai à escola, elaborado pela mesma fundação, ainda que por um grupo diferente de pessoas que nele atuava. Em alguma medida, ainda que com propósitos bem distintos, aquela primeira publicação contribuiu para instalar o debate sobre cinema e educação.

Diante dessas fontes documentais, a saber: a) o projeto $O$ cinema vai à escola - a linguagem cinematográfica na educação e o material que o compõe (roteiros, cadernos, filmes, vídeos); b) Proposta Curricular do Estado de São Paulo; c) Currículo do Estado de São Paulo e, por fim, d) Lições com cinema, pretendemos verificar e demonstrar que papel tem sido atribuído ao cinema e o lugar da experiência estética nesse processo.

Antes, porém, faremos a análise de um documento representativo de como se pensava a entrada do cinema na educação no início do século XX. Referimo-nos àquele emitido pela I Conferência Nacional de Educação ${ }^{76}$, evento que se deu de 19 a 23 de dezembro de 1927, em Curitiba, no Paraná. Tal evento é um marco no Brasil por pensar o papel da educação num projeto de unidade nacional em torno da reestruturação da educação formal. São 111 teses resultantes desse encontro, contudo, comentaremos apenas aquelas que nos interessam para o presente trabalho, isto é, aquelas cuja temática tem relação com a presente pesquisa. Além dessas teses também comentaremos o Código de Educação do Estado de São Paulo, de 1933, pioneiro no Brasil na consideração do cinema como instrumento educativo.

\footnotetext{
76 Para ter acesso ao documento original, favor consultar o site https://repositorio.ufsc.br/handle/123456789/123679. 


\section{2- Antecedentes históricos da relação do cinema com a escola no Brasil}

Fizemos buscas dos termos "cinema", "filme", "estética" e "arte" nas 111 teses da I Conferência Nacional de Educação para identificarmos aquelas em que houvesse ocorrências de tais palavras-chave; além disso, procuramos nos títulos das teses aquelas que tivessem pertinência com a nossa pesquisa. Dos dois procedimentos, selecionamos algumas que passamos a comentar. Segundo o autor da tese de n. 05, Necessidades da pedagogia moderna, Lindolpho Xavier, que apresenta Augusto Comte como "príncipe do pensamento", ao lado de São Paulo, S. Tomás, Kant, dentre outros, a missão da pedagogia é a de "desenvolver a fraternidade e o altruísmo (...). Fazer o homem sinérgico, mais simpático, mais enérgico, mais sábio (...), mais fraternal, mais republicano, mais religioso.". "Como conseguir?", pergunta-se o autor, que responde a seguir: "Ensinando-lhe a herança do passado, para que ele a use e a transmita melhorada aos seus sucessores." (Tese n. 5, I Conferência, 1997, p. 66). Sobre as cinco heranças que o autor elenca, encontram-se a literária, a científica, a institucional, a religiosa, sendo esta a mais elevada de todas. Quanto à herança estética, diz:

De posse daqueles instrumentos, penetra a criança no mundo de emoções da poesia; vem a música, os quadros, as telas, as formas esculturadas, a arte arquitetônica, o ritmo, expressão; surge a beleza das tintas, nas rimas, nos sons, nos conceitos edificantes, nos exemplos sublimes, na pureza das linhas, no movimento." (Tese n. 5, I Conferência, 1997, p. 66).

Para Lindolpho Xavier, arte está associada à Beleza, como se pode constatar pelas expressões "formas esculturadas", "surge a beleza das tintas". Contudo, o cinema não é mencionado, evidenciando que na Conferência em questão essa forma de expressão artística não era um assunto unânime.

$\mathrm{Na}$ Tese de n. 15, Organização dos Museus Escolares: sua importância, Nicephoro Modesto Falars ressalta que o fundamento da educação "consiste principalmente na apreensão e discernimento dos múltiplos e diversos objetos que, por sua natureza, são capazes de avantajar o aluno inteligente e aplicado nos diversos ramos do saber humano." (I Conferência, 1997, p. 116), com o intuito de “manter a integridade da nossa pátria, garantir-lhe o progresso (...)” (p. 117). 
Quando possível, o museu servirá, diz ele a seguir, para substituir os livros com suas gravuras pequenas (Tese n. 15, I Conferência, 1997, p. 118), denotando claramente o papel das obras dos museus como ilustração para os estudos escolares. Para Fernando Nereu de Sampaio, autor da Tese de n. 17, Pela educação estética, a iniciação estética tem sido "lastimavelmente imperfeita" em razão de uma "orientação pedagógica deficiente", sugerindo que esta se deva ser dada desde a escola primária. Ele se refere basicamente ao desenho, à literatura, à arquitetura, à escultura, às artes plásticas e à música, que seriam capazes de imprimir "costumes, embelezar os lares e circundar-se de objetos de bom gosto [...]" (Fernando Nerreu de Sampaio, Tese n. 15, p. 121).

A Tese de n. 23, 0 Cinematográfico escolar, de América Xavier Monteiro de Barros, é a única que se refere diretamente ao cinema em seu título, celebrandoo como a arte, por excelência, da atualidade, constituindo-se no "meio mais perfeito e completo para a representação de seres, fatos e coisas", sendo ainda o meio mais educativo e instrutivo, que desperta "o interesse das crianças, facilitando-lhes o esforço cerebral de maneira sedutora e agradável." ( $O$ Cinematográfico escolar, de América Xavier Monteiro de Barros, p. 131, destaque nosso). Os filmes a que Monteiro de Barros se refere são aqueles em que figuram "rios caudalosos", "cachoeiras opulentas", "plantio de algodão, de café”, isto é, produções com pretensão documental, no sentido mais estrito do termo. Para ele, países que cuidam zelosamente da educação incorporam o cinema como instrumento, dentre eles a França, que "desde 1913 tem instalado em várias escolas aparelhos de projeção." (O Cinematográfico escolar, de América Xavier Monteiro de Barros, p. 132). Para uso do filme, o autor da tese sugere que este seja projetado de modo mais lento, parando quando necessário. "Terminada a projeção, [o professor] faz um resumo do assunto explanado [no filme]". Para o autor, além de poupar o aluno de viajar para conhecer lugares longínquos, o cinema permitiria o acesso ao mundo invisível, tal como o bater de asas dos insetos ou a trajetória de um projétil.

J. P. Porto Carrero, com a Tese de ํㅜ 64, intitulada $O$ Caráter do escolar, segundo a psicanálise, relativiza várias das posições comuns à época (como a da chamada "escola antiga", como diz Carrero) de designar as crianças como seres 
inteligentes ou estúpidos, aptos ou não para os estudos de matemática ou de história etc. Para o autor, Freud "abriu novos horizontes para o estudo dessas pequeninas almas a quem se tem erradamente buscado meter no sapato chinês de métodos uniformemente absurdos." (p. 368). Destaca a "emotibilidade" como uma caracterísitca da criança a que a escola não pode deixar de levar em conta, lembrando que a quietude não é "normal" nessa fase da vida. Na sequência, lembra que o "professor mal-avisado" ressalta a dor da primeira proibição, da "primeira chinelada", ao promover punições e pouco estímulo ao aluno, o que gera um sentimento de culpa e, por consequência, a necessidade da punição, retroalimentando um círculo. A tese seguinte, a de $n^{\circ}$ 65, de Deodato de Moraes, $A$ Psicanálise na educação, em acordo com a anterior, antevê que chegará o dia em que será exigido de todo educador "certa familiaridade com a estrutura e o modo de funcionamento do espírito inconsciente" (Tese n. 65, p. 387). Esta tese, a exemplo da anterior, também relativiza os saberes estabelecidos sobre a infância. Estas duas teses que tratam da psicanálise parecem destoar das demais por questionarem o modelo de infância adotado pela escola, colocando em suspensão tal modelo a partir da ideia de Freud de que a infância é perdida; educa-se na ignorância da infância que se pensa ter tido.

Reunidas em Curitiba, "as elites do poder", como destaca Carlos Eduardo Vieira (2004), representadas pelo governador Caetano Munhoz da Rocha e pelo inspetor Geral de Ensino, o senhor Lysíamaco Ferreira da Costa, em parceria com a igreja católica, conseguem sediar um evento de importância nacional, pautando uma questão capital no cenário intelectual nacional: a educação. Apesar da dispersão das teses, há uma unidade, que é "produzir um padrão, um modelo de referência sintonizado como (sic) os tempos modernos." (VIEIRA, 2004). Essa uniformização, continua Vieira, "é um requisito da modernidade, pois à luz da razão teremos uma única verdade e uma única forma de alcançá-la." (VIEIRA, 2004).

Se a I Conferência Nacional de Educação, realizada pela ABE (Associação Brasileira de Educação) que, por sua vez, fora fundada em 1924, filia-se de modo geral a ideias moralistas, como se pode constatar pelas teses ("desenvolver a fraternidade e o altruísmo"), apoiando-se nas ideias de arte como objeto de bom 
gosto, de "melhoria" do caráter, do progresso ("manter a integridade da nossa pátria, garantir-lhe o progresso [...]") pela educação dos bons costumes ("costumes, embelezar os lares e circundar-se de objetos de bom gosto"), tal documento parece ser indicação de preocupação de organização da educação no país, na medida em que há nele o estabelecimento de discussões sobre parâmetros a serem seguidos, além do estabelecimento de uma orientação de unidade nacional da educação contra a descentralização que imperava no Brasil até então.

Desde 1823, na recém-proclamada independência do Brasil, já havia um caráter universalizante na concepção sobre a educação. Nesse sentido, Fernando de Azevedo lembra que no Art. 179, inciso xxxii, a Constituição de 1823, outorgada pela Coroa, garante "a instrução primária a todos os cidadãos" (apud AZEVEDO, 2010, p. 606). Essa é uma expressão da predominância liberal no Brasil, característica que vinha sendo a tônica desde a chegada da corte de Portugal em 1808, por ocasião da invasão das tropas de Bonaparte ao país lusitano. No mesmo ano de sua chegada ao Brasil, D. João VI decreta a abertura dos portos ao comércio estrangeiro, revoga o Alvará que havia sido ordenado para o fechamento de todas as fábricas e funda a Imprensa Régia, marcando o início do jornalismo brasileiro. Imprensa pela qual será impresso Basílio da Gama, de Tomás Antônio Gonzaga, dentre outros importantes textos literários. Tais iniciativas são de teor liberal, entretanto ainda não havia uma organização da educação e uma unidade mínima nacional. 0 poder antes se concentrava na corte portuguesa. Como nota Fernando de Azevedo (2010, p. 601), o governo português proibe o funcionamento da única oficina tipográfica no Brasil que se tem notícia antes da Imprensa Régia. A oficina foi fundada em 1747, no Rio de Janeiro, e fechada logo em seguida.

Se o Brasil não possuía exemplos práticos de uma educação não estritamente religiosa e de teor mais liberal, teria, no entanto, uma experiência inovadora com o Semináro de Olinda. Criado em 1798 pelo bispo do estado de Pernambuco, Azeredo Coutinho (nascido no Rio de Janeiro), o Seminário de Olinda implementaria um ensino inspirado na reforma pombalina, mudando o modelo jesuítico. No Seminário eram mantidas as disciplinas tradicionais - retórica, literatura e religião, gramática, poética, latim -, e acrescidas grego, francês, história, geometria, física, história natural, desenho. Além dessas, também uma que versava 
sobre estudos acerca dos "problemas econômicos criados pela mineração, pela industrialiazação, pelo declínio da economia baseada simplesmente na monocultura ou no monopólio." (Gilberto Freyre apud AZEVEDO, 2010, p. 600). Esses estudos voltavam-se para os problemas econômicos contemporâneos de então, perdendo, com isso, o caráter estritamente "abstrato" do ensino jesuítico.

O clima liberal era reforçado por experiências como a do Seminário de Olinda e pela vitória dos liberais na câmara dos deputados com a aprovação do "Ato Adicional" (o nome antigo para "emenda"), de 1834. Como aponta Azevedo (2010, p. 608), de acordo com Tavares Bastos, o governo da União se isentava “'do principal dos deveres públicos de uma democracia', que é o de levar a educação geral e comum a todos os pontos do território e de organizá-la em bases uniformes e nacionais.” (AZEVEDO, 2010, p. 609). 0 parágrafo 2o. do Art. 10 modificava a Constituição de 1824, transferindo "às assembleias provinciais o encargo de regular a instrução primária e secundária, ficando dependentes da administração nacional o ensino superior em todo o país (...)”. (AZEVEDO, 2010, p. 608). Essa vontade de descentralização da educação se deu entre os liberarais, provavelmente pelo receio de um retorno à centralização por parte de um governo monárquico, regime que o Brasil havia experimentado até então.

Havia, portanto, uma tensão entre uma política de cunho nacional com outra, descentralizada, que outorgava aos estados o poder de legislar sobre os seus interesses. Quase um século depois, a I Conferência Nacional de Educação é uma das expressões da preocupação das elites de encaminharem uma política nacional de educação, indicando que o que se passava no século XIX não era uma questão já superada.

Atualmente, na sociedadede de consumo em que, nas escolas, acabam sendo integrados instrumentos importantes de trabalho, como os livros didáticos e também os filmes em formato de DVD ou veiculados pela internet, entende-se claramente que as dimensões cultural, educacional e econômica estão fortemente imbricadas e que, portanto, a produção desse material é uma questão de caráter eminentemente nacional.

Nesse sentido, fica cada vez mais claro que o preceito liberal do laissez faire quanto ao privilégio da liberdade individual e da livre concorrência não 
atende à necessidade de conservação das economias e das expressões culturais nacionais. Expressão dessa percepção é o decreto n. 6.177 de 1o. de agosto de 2007, assinado pelo então presidente Luís Inácio Lula da Silva, que ratifica o texto da Convenção sobre a Proteção e Promoção da Diversidade das Expressões Culturais promovida pela UNESC077, esta assinada em Paris, em 20 de outubro de 2005. Nela, afirma-se que "a diversidade cultural é uma característica essencial da humanidade" e que ela constitui "patrimônio comum da humanidade, a ser valorizado e cultivado em benefício de todos". Tendo em vista estas prerrogativas, constituem-se objetivos da Convenção, dentre eles:

(1) proteger e promover a diversidade das expressões culturais; (2) criar condições para que as culturas floresçam e interajam livremente em benefício mútuo; (3) reafirmar a importância do vínculo entre cultura e desenvolvimento para todos os países, especialmente para países em desenvolvimento, e encorajar as ações empreendidas no plano nacional e internacional para que se reconheça o autêntico valor desse vínculo; (4) reafirmar o direito soberano dos Estados de conservar, adotar e implementar as políticas e medidas que considerem apropriadas para a proteção e promoção da diversidade das expressões culturais em seu território; (5) fortalecer a cooperação e a solidariedade internacionais em um espírito de parceria visando, especialmente, o aprimoramento das capacidades dos países em desenvolvimento de protegerem e de promoverem a diversidade das expressões culturais." (UNESCO, 2005, destaque nosso).

Para proteção e promoção da diversidade das expressões culturais, a fim de evitar, por exemplo, impacto predatório na formação das pessoas em termos de educação, de cultura, de gosto, em razão da presença esmagadora do filme estadunidense nos mercados nacionais e de grandes lançamentos de um mesmo título, a Convenção afirma como princípio de soberania que, em acordo com a Carta das Nações Unidas e com os princípios do direito internacional, "os Estados têm o direito soberano de adotar medidas e políticas para a proteção e promoção da diversidade das expressões culturais em seus respectivos territórios" (UNESCO, 2005, destaque nosso). Ressalta-se a importante atribuição conferida pela Convenção do aspecto de soberania à produção nacional do audiovisual.

\footnotetext{
77 No endereço eletrônico a seguir é possível conferir tanto o decreto assinado pelo Brasil quanto o texto da Convenção de Paris. http://www.planalto.gov.br/ccivil_03/_ato20072010/2007/decreto/d6177.htm. Acesso dia 08 de julho de 2016. 
Repercução desse importante documento (apenas EUA e Israel não o assinaram) para a contenção do domínio de produtos de uma determinada nacionalidade em um mercado estrangeiro ("os Estados têm o direito soberano de adotar medidas") é a aprovação de algumas leis no Brasil, que buscam legislar sobre as dimensões culturais, dentre elas, o audiovisual, que foram: (a) a Lei no. 12.485/2011, que no Capítulo V, Art. 16, estabelece a obrigatoriedade de veiculação de no mínimo 3 horas e meia por semana de produção de audiovisual nacional em horário nobre das TVs Pagas78; (b) a Lei no. 8.386/2014, em seu Art. $1^{\mathrm{o}}$, determina que

as empresas proprietárias, locatárias ou arrendatárias de salas ou complexos de exibição pública comercial ficam obrigadas a exibir, no ano de 2015 [na verdade, a partir de 2015], obras cinematográficas brasileiras de longa metragem no âmbito de sua programação, observado o número mínimo de dias e a diversidade dos títulos fixados em tabela constante do Anexo.

No Anexo referido, tal lei estabelece uma proporção de dias por ano em que devem ser exibidas obras cinematográficas brasileiras em relação ao número de salas de determinado complexo, além de limitar a exibição de um mesmo título em até $30 \%$ das telas de um complexo de salas de cinema. Com isso, busca-se conter o domínio de grandes lançamentos de filmes estrangeiros no país. Além disso, em consonância com o espírito da Convenção de Paris visa ao estabelecimento mínimo de exibição de filmes brasileiros nas salas de cinema do país. Por sua vez, a (c) Lei no. 13.006/201479 obriga as escolas a exibirem filmes de

780 texto da Lei no. 12.485/2011, Capítulo V, Art. 16, na íntegra, diz: "Nos canais de espaço qualificado, no mínimo $3 \mathrm{~h} 30$ (três horas e trinta minutos) semanais dos conteúdos veiculados no horário nobre deverão ser brasileiros e integrar espaço qualificado, e metade deverá ser produzida por produtora brasileira independente."

${ }^{79}$ A Lei 13.006, de 26 de junho de 2014, acrescenta o inciso 8ªo Artigo 26 da Lei 9.394, de 20 de dezembro de 1996, cujo autor do projeto foi o senador Cristovam Buarque. Em entrevista, ele afirma que por ele deveriam ser mais de duas horas de filmes brasileiros por mês, mas que para tanto necessitaria dessas exibições se darem em horário integral. Na mesma entrevista, afima que todo cineasta que receber financiamento público deveria disponibilizar cópia em DVD dos filmes para as escolas ou apenas autorizar o download (FRESQUET \& MIGLIORIN. In FRESQUET, 2015, p. 07). Fresquet e Migliorin acreditam que essa lei proporciona "pensar a escola como um espaço coletivo de contemplação, de intelectualização e sensibilização com as obras cinematográficas [e] é também apostar que, dessas leituras criativas do Brasil assim feito imagem, se cria matéria-prima para novas construções do país em território escolar." (p. 09). E pouco antes, na mesma página: "A Lei cria a possibilidade da (sic) escola garantir o acesso a toda criança - e famílias - escolarizada ao 
produção nacional em suas instalações. Ela acrescenta ao Art. 26 da LDB No. 9.394/96, o seguinte parágrafo: “§ 8 A exibição de filmes de produção nacional constituirá componente curricular complementar integrado à proposta pedagógica da escola, sendo a sua exibição obrigatória por, no mínimo, 2 (duas) horas mensais." (NR). Esta lei expressa uma preocupação que já é sentida quando o cinema era o meio de comunicação mais comum, depois da imprensa (SIMIS, 2015, p. 26), e que sua participação junto à escola é regulamentada em 1933, no Decreto Lei no. 5.884, de 21 de abril, que institui o Código de Educação do Estado de São Paulo.

Nesse Código o cinema era tomado como educativo. 0 documento previa a criação de quinze coordenadorias técnicas, dentre elas, uma denominada de "Serviço de Rádio e Cinema Educativo". O diretor Geral do Departamento de Educação nomeava as pessoas para os cargos de chefia desses serviços, devendo o chefe ser auxiliado por um professor, técnico em cinema. Exemplos de outros serviços: Serviço de Prédio e Instalações Escolares e Serviço de Música e Canto Coral, só para citar dois. 0 objetivo do Serviço de Rádio e Cinema Educativo era “colocar ao alcance da escola as conquistas da técnica moderna (...)” (BRASIL, Lei no. 5.884, Artigo 121), cabendo ao chefe desse serviço quanto ao cinema:

1-“organizar a filmoteca e coleções de dispositivos e diafilmes";

2-"fiscalizar a instalação de aparelhos projectores";

3-"elaborar plano de filmagens";

4-“orientar a parte educativa e instrutiva das projeções fixas e animadas";

5-“organizar e censurar filmes recreativos e discursos, conferências, palestras e comunicações a serem irradiadas".

O Código previa ainda, no Artigo 123, a instalação de projetor em toda escola ("primário e secundário"), quando as condições dos prédios das unidades escolares assim o permitissem, ainda que para tanto devesse ter autorização do Departamento de Educação, cabendo aos próprios estabelecimentos de ensino a aquisição desses projetores.

cinema, mas, mais do que isso, a possibilidade de acesso a sistemas de expressão e signos, blocos de ideias e estéticas marginalizadas pelo mercado e pelo sistema oligopolista de exibição." 
Na ocasião do referido Código, vale lembrar que o cinema brasileiro encontrava-se numa fase de expansão (entre 1923 e 1933), produzindo cerca de 120 títulos, o dobro da década anterior, percebendo-se também um novo impulso qualitativo das fitas, quando se pode falar em um movimento de cinema brasileiro. A imprensa ${ }^{80}$ já não era indiferente à produção nacional de cinema (GOMES, 1996, p. 51). Basta lembrar que Limite (1931), de Mário Peixoto, e Ganga Bruta (1933), de Humberto Mauro, são dessa época. De modo geral, eram produções que se davam em São Paulo e no Rio de Janeiro, mas também em Campinas, Recife, Belo Horizonte, Rio Grande do Sul e até no interior de Minas, em Pouso Alegre, com Almeida Fleming, e em Cataguases, com Humberto Mauro. Os chamados ciclos regionais, que se davam fora do grande eixo Rio de Janeiro-São Paulo, geralmente não projetavam seus filmes nacionalmente, salvo raras exceções, e menos ainda fora do país. Contudo, como nos lembra Paulo Emílio, “o problema não é aumentar o número de filmes a serem apresentados no exterior, mas sim diminuir o número de fitas estrangeiras aqui exibidas." (GOMES, 1996, p. 83). As leis mencionadas parecem ratificar essa prescrição.

Não se pode também esquecer que 1930 é o ano que coloca fim à primeira República no Brasil, com a chamada Revolução de 1930, em que Getúlio Vargas é elevado ao poder. Marco para a modernização industrial no país, uma nova classe substitui as elites do Café, em plena crise por vários fatores, dentre eles, pela quebra da bolsa nos EUA, em 1929. 0 cinema se apresenta como o meio de comunicação que mais convergia com os interesses desse novo momento, cujo estandarte era a industrialização. Confirmam esse movimento a criação dos sistemas de ensino SENAI e SESI, em 1942, e a própria Reforma Capanema, que entendia que a educação deveria ser oferecida em acordo com as necessidades da nação definidos os papéis sociais a partir das posições de classe. Mundialmente, a década de 1930 é aquela que apresentará a criação de vários órgãos oficiais para a inserção do cinema no meio escolar, e mesmo um pouco antes, caso da Itália, que desde 1928 já possuía um Instituto Internacional de Cinematografia Educativa, e o

\footnotetext{
80 Segundo Paulo Emílio Salles Gomes (1996), as revistas Paratodos e Selecta em 1923 eram no Brasil as que mais se interessavam por cinema cujos redatores principais eram Mário Behring e Paulo Lavrador, respectivamente, que eram implacáveis com a produção nacional. Mas esse fervor hostil, ainda segundo Gomes, contribuía para estimular o debate sobre os filmes produzidos em território nacional.
} 
da França, que cogitava a criação de um Ministério do Cinema (SIMIS, 2015, p. 32s.). De acordo com Serrano e Venâncio, segundo Anita Simis (2015, p. 33), "em março de 1931 foi instalado, em São Paulo, o primeiro aparelho de projeção animada em estabelecimento de ensino público, seguindo o exemplo de vários outros grupos escolares." (SIMIS, 2015, p. 33). Em 1935, o estado da Bahia criaria o Serviço de Rádio e Cinema Educativo nas escolas, lembrando ainda que o INCE seria criado em 1937.

Foi também na década de 1930 que houve a primeira Reforma Educacional de caráter nacional realizada pelo então Ministro da Educação e Saúde Francisco de Campos, conhecida como Reforma Francisco de Campos, que se formalizou pelo Decreto de Lei n. 19.890, de 18 de abril de 1931, e consolidado com alterações no ano seguinte, sob o Decreto de Lei n. 21.241, de 4 de abril de 1932.

A Reforma Francisco de Campos traz organicidade nacional ao que estava legado ao plano estadual, tanto sobre o ensino primário e secundário, quanto universitário. Além disso, acrescenta ao ensino básico dois anos, dividindo esse ensino em dois ciclos: Fundamental ( 5 anos) e Complementar ( 2 anos). 0 Fundamental era de formação básica e geral para todos. 0 segundo ciclo era propedêutico e específico para as diferentes áreas universitárias. 1) Direito era uma. Outra: 2) Medicina (englobando Odontologia e Farmácia). E por fim, 3) Engenharia e Arquitetura. Dependendo do curso escolhido, cada um desses três grupos possuía um conjunto de disciplinas específicas.

Tal reforma é controversa. Para Anísio Teixeira (1957, p. 104), por exemplo, quanto ao ensino secundário, ela não representou a consolidação dos ideais democráticos; ao contrário, teria acentuado "o espírito de nossa organização dualista de privilegiados e desfavorecidos. A escola secundária seria uma escola particular, destinada a ampliar a 'classe dos privilegiados'”. Teixeira se refere ao caráter elitista dessa Reforma, que privilegia o aspecto enciclopédico numa sociedade extremamente desigual.

Quanto ao caráter enciclopédico da Reforma Francisco de Campos, Otaíza de Oliveira Romanelli concorda com Maria Tetis Nunes, acentuando que, 
De fato, para um contexto social que começava a despertar para os problemas do desenvolvimento e da educação, numa sociedade cuja marioria vivia na zona rural e era analfabeta e numa época em que a população da zona urbana ainda não era totalmente atingida, nem sequer pela educação primária, pode-se imaginar a camada social para a qual havia sido elaborado um currículo assim tão vasto (ROMANELLI, 1986, p. 136).

Apesar de também criticar esse aspecto elitista da Reforma Francisco de Campos, Romanelli ressalta o espírito moderno da década de 1930, que teria favorecido a democratização do ensino.

Se antes, a estrutura oligárquica, as necessidades de instrução não eram sentidas, nem pela população, nem pelos poderes constituídos (pelo menos em termos de propósitos reais), a nova situação implantada na década de 30 veio modificar profundamente o quadro das aspirações sociais, em matéria de educação, e, em função disso, a ação do próprio Estado (ROMANELLI, 1986, p. 59).

Para a sustentação da tese de que a democratização do ensino aumenta a partir do estabelecimento de relações capitalistas, Romanelli cita as pesquisas de Lourenço Filho, quando este nota que

é fácil compreender que, em grupos de população muito dispersos, de economia incipiente, muitas vezes reduzida à prática de agricultura de subsistência ou pouco mais que isso, em regime quase geral de subemprego, as expectativas de melhoria dos padrões de vida são exíguas, não apresentando maior sentido prático a preparação formal que a escola passa a proporcionar. Nessas circunstâncias, a demanda é reduzida, ainda em face de mais ampla oferta (LOURENÇO FILHO apud ROMANELLI, 1986, p. 59).

Romanelli defende a ideia de que havia nessa década uma defasagem entre a demanda emergente por uma formação que a educação formal não podia atender. Para o autor, explica-se pela predominância do setor agrícola na economia brasileira, "aliada a formas arcaicas de produção e à baixa densidade demográfica e de urbanização (...)", com consequente ausência de "demanda social de educação." (ROMANELLI, 1986, p. 60). Defende ainda a relação direta do aumento da demografia com o aumento da escolaridade, convencido pelos dados de Lourenço 
Filho, que aqui apresentamos resumidamente. Em 1900, a população era de 17.438.434; em 1940, 41.236.315; em 1970, 94.501.554. 0 índice de analfabetismo era, respectivamente, $65,3 \%, 56,2 \%, 33,1 \%$.

Pela discussão até aqui empreendida, nota-se, pois, que a criação do INCE não aparece isolada. Ela é antecedida por uma sequência de atos que relacionam cinema e educação. A primeira delas, segundo Fernando de Azevedo (2010, p. 758), deu-se em 1910, quando o Museu Nacional inaugurou a sua filmoteca, no Rio de Janeiro. Dentre os primeiros filmes que compuseram esse acervo estavam aqueles sobre os indígenas Nambiquaras, produzidos por Roquete Pinto, em Rondônia, e os produzidos pela Comissão Rondon, que documentavam suas explorações geográficas, botânicas, zoológicas e etnográficas.

Além dessa iniciativa tomada pelo Museu Nacional, ainda segundo Fernando de Azevedo, houve várias outras em instituições escolares e de cultura. No entanto, uma lei (Decreto 3.281, de 23 de janeiro de 1928, arts. 296-297; Decreto 2.940, de 22 de novembro do mesmo ano, arts. 633-635) que legislasse sobre o cinema com fins escolares apareceria apenas em 1928. Na ocasião, o então Diretor Geral da Instrução Púbica do Distrito Federal era o próprio Fernando de Azevedo que, por meio dos referidos decretos, determinou e regulou a sua utilização em todas as escolas da capital do país. No ano seguinte, 1929, por iniciativa de Fernando de Azevedo, ainda Diretor Geral da Instrução Pública do Distrito Federal, tem-se a inauguração da Primeira Exposição de Cinematografia Educativa, que é coordenada por Jonathas Serrano. Em 1932, desta vez sob inspiração de Anísio Teixeira, o Decreto 3.763, de 1ํo. de fevereiro, cria a Divisão do Cinema Educativo, ano em que é regulamentado o serviço de censura dos filmes no país ${ }^{81}$ e estipulado cota para produções brasileiras na programação normal do exibidor e também de filmes educativos ${ }^{82}$. Em 1933, sob a orientação de Fernando

\footnotetext{
${ }^{81}$ Decreto N. 21.240, de 4 de abril de 1932. Disponível em http://www.ancine.gov.br/legislacao/decretos/decreto-n-21240-de-4-de-abril-de-1932. Acesso em 10 de dezembro de 2015.

${ }^{82}$ Seguem os artigos 12 e 13 do Decreto No. 21.240, de 4 de abril de 1932: "Art. 12. A partir da data que for fixada, por aviso, do Ministério da Educação e Saúde Pública, será obrigatório, em cada programa, a inclusão de um filme considerado educativo, pela Comissão de Censuras."

Art. 13. Anualmente, tendo em vista a capacidade do mercado cinematográfico brasileiro e a quantidade e a qualidade dos filmes de produção nacional, o Ministério da Educação e Saúde Pública fixará a proporção da metragem de filmes nacionais a serem obrigatoriamente incluídos na programação de cada mês.”. Disponível em 150
} 
de Azevedo, são criados em São Paulo (Decreto 5.884, de 21 de abril) os Serviços de Rádio e Cinema Educativo, que institui o Código de Educação. Teve ainda importância capital para ressonâncias da euforia por mundanças do Governo Provisório (de 1930 a 1934) a reforma na educação em São Paulo, promovida por Lourenço Filho. Apesar de curta duração (1930-1931) a experiência do referido intelectual, sua concepção de universalização da educação e sua relação com a cultura, especialmente o cinema, segundo Fernando de Azevedo (2010, p. 708), imprimiu "vigoroso impulso ao cinema educativo".

A própria criação do Ministério de Educação e Saúde, em 1930, ainda no primeiro ano do Governo Provisório, denota o desenvolvimento de uma consciência educacional atenta a diversas direções (AZEVEDO, 2010, p. 709). Desse período, a Reforma Francisco de Campos, com sua reorganização do ensino secundário para sete anos, é elogiada por Fenando de Azevedo, porque teria elevado o curso secundário, de um simples “'curso de passagem' ou de instrumento de acesso aos cursos superiores, a uma instituição de caráter eminentemente educativo (...)." (AZEVEDO, 2010, p. 710). No entanto, como diz Schwartzman (1984, p. 54), a geração de Francisco de Campos, em Minas, está "recristianizada no movimento católico jovem (...)”, estando, assim, "mais solidária às causas da Igreja do que seus pais, de pensamento mais livre.”, o que explicaria a adoção do Governo Provisório, de uma dupla frente: ao mesmo tempo progressista, quando assume a universalização como aspecto educativo predominante e a inclusão de aspectos da cultura na educação, e também, por outro lado, quando implementa o ensino religioso facultativo, abolido na Constituição de 1891, em resposta a pressões de católicos, especialmente da revista católica A Ordem, que chega a conclamar "os católicos para a luta pelo esforço da posição da Igreja na sociedade (...)." (SCHWARTZMAN, 1984, p. 55). Como lembra Romanelli, a Constituição de 1934, em seu artigo 153, recoloca o ensino religioso como facultativo:

O ensino religioso será de freqüencia facultativa, e ministrado de acôrdo com os principios da confissão religiosa do alumno, manifestada pelos paes ou responsaveis e constituirá materia dos

http://www.ancine.gov.br/legislacao/decretos/decreto-n-21240-de-4-de-abril-de-1932. Acesso em 10 de dezembro de 2015. 
horarios nas escolas publicas primarias, secundarias, profissionaes e normaes.

A Constitução de 1891, em seu Art. 72, § 6º , havia estabelecido que "Será leigo o ensino ministrado nos estabelecimentos publicos."

Fernando de Azevedo (AZEVEDO, 2010, p. 758) lembra ainda que o Decreto 24.651, de 10 de julho de 1934, que cria no Ministério da Justiça, o Departamento de Propaganda e Difusão Cultural que atribui, no Art. $2^{\circ}$, as competências para este Departamento. Das quatro alíneas, destacamos as três primeiras: a) "estudar a utilização do cinematógrafo, da radiotelefonia e demais processos técnicos e outros meios que sirvam como instrumento de difusão"; b) "estimular a produção, favorecer a circulação e intensificar e racionalizar a exibição, em todos os meios sociais, de filmes educativos" e, c) "classificar os filmes educativos, nos têrmos do decreto n. 21.240, de 4 de abril de 1932, para se prover à sua intensificação, por meio de prêmios e favores fiscais".

Diferentemente do Código do Estado de São Paulo, como se verá mais adiante, que em seu Art. 30 distingue as sessões realizadas nas escolas entre educativas e sessões recreativas, segundo as competências do Departamento de Propaganda e Difusão Cultural, deveriam ser estimuladas a produção e a difusão do filme educativo a tal ponto que, nos parece, tornar-se-ia cultural. 0 movimento proposto é de dentro da escola para fora, não restringindo o filme ao invólucro "educativo". Em vez de distinguir o recreativo do educativo, tal competência promove a fusão dessas duas dimensões.

Outro acontecimento que contribuiu para a criação do INCE ou que propiciou a demanda de sua criação foi o Manifesto dos Pioneiros da Escola Nova, de 1932. Escrito por Fernando de Azevedo e assinado por vários intelectuais, dentre eles Cecília Meireles e Edgar Roquette-Pinto, aponta que a escola deve se utilizar de quaisquer recursos que possam contribuir em seu benefício. Dentre tais meios, inclui o cinema: "A escola deve utilizar, em seu proveito, com a maior amplitude possível, todos os recursos formidáveis, como a imprensa, o disco, o cinema e o rádio" (AZEVEDO (1932), 2010, p. 62).

Contudo, em todo o texto do Manifesto encontram-se expressões que ratificam a lógica que se utiliza do cinema como ferramenta. Assim, consta ali, com 
força de modernidade e tons iluministas: “(...) devemos formar-nos princípios fixos e inabaláveis que sirvam para regular, de um modo firme, todos os nossos pensamentos e todas as nossas ações” (AZEVEDO (1932), 2010, p. 64). E aqui: “(...) trabalhando cientificamente nesse terreno [na educação], ele [o educador] deve estar tão interessado na determinação dos fins de educação, quanto também dos meios de realizá-los." (p. 34). E ainda:

Onde se tem de procurar a causa principal desse estado antes de inorganização do que de desorganização do aparelho escolar, é na falta, em quase todos os planos e iniciativas, da determinação dos fins de educação (aspecto filosófico e social) e da aplicação (aspecto técnico) dos métodos científicos aos problemas de educação. Ou, em poucas palavras, na falta de espírito filosófico e científico, na resolução dos problemas da administração escolar (AZEVEDO (1932), 2010, p. 34).

Assim, a prática educacional estava orientada pelo "espírito científico". O cinema também, portanto, aparece submetido a essa orientação. Nesse sentido, percebe-se que para o Movimento o cinema é tomado, antes, por instrumento educacional do que arte. É como consequência desse debate em que figuram momentos concretos da discussão dos rumos educacionais que deveriam tomar o país, dentre eles a criação do Museu Nacional, a I Conferência Nacional de Educação, o Movimento dos Pioneiros, o Código de Educação do Estado de São Paulo, que o então Ministério de Educação e Saúde, por meio da Lei n. 378, de 13 de janeiro de 1937, Art. 40, cria o Instituto Nacional de Cinema Educativo - INCE -, que se destinava "a promover e orientar a utilização da cinematographia, especialmente como processo auxiliar do ensino, e ainda como meio de educação popular em geral."83. Além disso, cabia ao Instituto,

organizar e edificar filmes educativos brasileiros; permutar cópias dos filmes editados ou de outros; editar e permutar discos ou filmes sonoros, com aulas, conferências e palestras; organizar uma filmoteca educativa para servir aos institutos de ensino, e publicar

83 Para conferir o texto na íntegra: http://www2.camara.leg.br/legin/fed/lei/1930-1939/lei-37813-janeiro-1937-398059-publicacaooriginal-1-pl.html, consulta feita no dia 18 de junho de 2015. Embora o INCE tenha sido criado oficialmente em 13 de janeiro de 1937, desde meados do ano anterior, a Comissão Instaladora, produzindo, adquirindo e adaptando filmes educativos para a exibição e distribuição à rede de ensino no país, em 1936, "já havia produzido 26 filmes científicos, de reportagens e de temática artística." (SIMIS, 2015, p. 33). 
uma revista consagrada ao cinema, ao fonógrafo e ao rádio, nas suas aplicações à pesquisa e à educação (AZEVEDO, 2010, p. 759).

O ministro Gustavo Capanema nomeia como diretor geral do INCE o professor e escritor, membro da Academia Brasileira de Letras de então, Roquette Pinto, para quem, em suas palavras, "o rádio é a escola dos que não têm escola. É o jornal de quem não sabe ler"84 (apud AMORIM, 2015, p. 28). E, ao mesmo tempo, pode ser usado "como fonte de regeneração para as massas" (ABEL, 2004, p. 233). O cineasta Humberto Mauro - já conhecido principalmente por Ganga Bruta (1933), que fez pela Cinédia, mas também por outros como Favella dos Meus Amores (1935) e Cidade Mulher (1936), que fez já na Brasil Vita Filme, fundada por Carmen dos Santos, atriz de vários de seus filmes - assume a direção executiva e viria a dirigir, sob a produção do instituto onde fez mais de 300 documentários, dentre eles Descobrimento do Brasil (1937), Acampamento Escoteiro (1939), Sabará (1956), São João Del Rei (1958), A velha a fiar (1964) (SOUZA, 1990). 0 Instituto funcionou até 1966. O Descobrimento do Brasil, como várias de suas obras sob a égide do INCE, foi uma empreitada que procurou unir arte e educação, atendendo ao propósito de tornar os aspectos da História do Brasil mais palatáveis aos estudantes, fazendo parte de um conjunto de filmes com destinação ao público escolar.

A atuação do INCE foi decisiva para a visualização e vigência de um órgão que não se limitava a parcos trabalhos e não se confundia com o DIP (Departamento de Imprensa e Propaganda). Para estabelecer tal distinção, Roquette Pinto (SCHWARTZMAN, 1984, p. 89), em 1942, prepara um longo relatório para apresentar os trabalhos do INCE. Segundo o relatório, o INCE chegou a realizar projeções de filmes em mais de mil escolas e institutos de cultura, além de ter organizado uma filmoteca, intercâmbios internacionais, elaboração de filmes documentais, além de trabalhar com filmes $16 \mathrm{~mm}$, aliás, curiosamente, pois o DIP trabalhava com filmes $35 \mathrm{~mm}$ etc.

Em Revisão Crítica do Cinema Brasileiro (2003), de Glauber Rocha, Humberto Mauro é alçado à posição de patrono do cinema brasileiro, desbancando

840 texto de Ruy Castro sobre Edgar Roquette-Pinto, cujo trecho é aqui citado por Paulo Henrique Amorim (2015), pode ser lido na íntegra em http://www.consciencia.net/2004/arquivo/roquettepinto.html, acesso em 15 de dezembro de 2015. 154 
o "hermético" Mário Peixoto, com seu aclamado Limite (1931). Ressalta como as principais obras de Humberto Mauro, Ganga bruta (1933) e Favela dos meus amores (1935). Naquele, Mauro teria apresentado o melhor do impressionismo de Renoir, "a audácia de Griffith, a força de Eisenstein, o humor de Chaplin, a composição de sombra de Murnau, mas, sobretudo, absoluta simplicidade, agudo sentido do homem e da paisagem, um lirismo (...)" (ROCHA, 2003, p. 45). Vai ser essa simplicidade de Mauro o principal elemento ressaltado em várias passagens de Glauber Rocha, como a seguinte em que o defende de uma crítica, que o teriam qualificado de primitivo: "Se primitivo em cinema for dirigir a câmera por intuição, antes de amordaçá-la pela razão, Jean Vigo, Robert Flaherty, Roberto Rossellini, Luis Buñel, o hindu Satyajit Ray e outros tantos, entre os maiores cineastas, são primitivos." (ROCHA, 2003, p. 50).

Contudo, Glauber comenta apenas de passagem filmes ideológicos como O descobrimento do Brasil. Para Eduardo Morettin (2013), enquanto os produtores de cacau na Bahia expulsavam os indígenas ou mesmo exterminavam-nos e se apropriavam de suas terras, o filme servia à ideologia de convivência pacífica e de troca cultural entre europeus e indígenas. Há cenas desfiguradoras (termo usado por Gracialiano Ramos em referência a outra cena que comentaremos a seguir) como a dos europeus ensinando um indígena a cumprimentar as pessoas com aperto de mão. 0 plano em detalhe é a evidência da consciência do filme. Outra cena emblemática que reforça o peso ideológico do título de $O$ descobrimento do Brasil é aquela em que, em determinado momento, Pedro Álvares Cabral e Frei Henrique acolhem alguns indígenas, protegendo-os do frio com cobertores e travesseiros e, a seguir, deixam o recinto na ponta dos pés para não acordá-los. Esse relato é lembrado por Eduardo Morettin (2013), que na mesma ocasião cita a crítica de Graciliano Ramos a esta cena: "E lamentamos que nesse trabalho de Mauro [O descobrimento do Brasil], trabalho realizado com tanto saber, se dêem ao público retratos desfigurados dos exploradores que aqui vieram escravizar e assassinar o indígena." 85.

\footnotetext{
85 Publicado em RAMOS, Graciliano. Linhas Tortas. Rio de Janeiro - São Paulo: Record - Martins, 1976, páginas 143-144. Tivemos acesso ao texto pelo site CinemaBrasileiro.NET: http://www.cinemabrasileiro.net/descobrimentobrasil.html. Acesso em 19 de setembro de 2016.
} 
A relação de outros filmes ideológicos, estes produzidos pelo INCE, também não são comentados por Glauber. É o caso de Os Bandeirantes (1940), Barão do rio branco (1944), o café - história e penetração no Brasil (1958), Acampamento escoteiro (1939), Dia da bandeira I (1936), Dia da bandeira II (1938), Dia da bandeira III (1939), Dia da pátria I (1937), Dia da pátria II (1951), O Estado Novo organiza a juventude (1942). Todos esses títulos demostram que o INCE servia fortemente a uma política estatal.

Se por um lado, o trabalho de Humberto Mauro é ideológico, por outro, inspiraria o movimento Cinema novo brasileiro, principalmente porque Mauro, na composição de seus filmes, volta-se para o Brasil. Mas também, como bem lembra Edgar Salvadori de Decca (apud SCHVARZMAN, 2004, p. 12), por sua modernidade, que não deve ser buscada "nos enredos de seus filmes, mas em sua técnica de produzir sentimentos fortes e contraditórios, por intermédio de uma linguagem, ao mesmo tempo, fluente e envolvente.". Tais filmes tensionam as margens entre a modernidade e um sentimento de nacionalidade do qual ele é caudatário e motivador.

Os muitos trabalhos de Humberto Mauro pelo INCE constituíram uma espécie de inventário do Brasil. Não é por outro motivo que Glauber Rocha vai considerá-lo "a substância maior que não foi percebida." (Glauber Rocha apud SCHVARZMAN, 2004, p. 16). Contudo, apesar de inspiração para o Cinema Novo, de certa forma, ele será negado por esse movimento. Mesmo o aspecto nacionalista de Mauro (no Cinema Novo) sofreu contestações. Com seu conhecido tom social questionador, é lançado o manifesto de 1973, Luz e Ação, assinado por Carlos Diegues, Glauber Rocha, Joaquim Pedro de Andrade, Leon Hirszman, Miguel Faria Jr., Nelson Pereira dos Santos e Walter Lima Jr. Para esses cineastas, foi nos anos 1960 "que a cultura cinematográfica do País se libertou finalmente dos padrões europeus e americanos, descolonizando-se e afirmando-se como representação de uma antropologia nova, de um homem novo." (ARANTES et al, 1979, p. 07). Eles reivindicam a reinvenção do cinema:

O cinema para nós só tem sentido enquanto invenção permanente, em todos os níveis de criação - prospecção de novos modos de produção, especulação de novas áreas temáticas, experimentação 
de novas articulações lingüísticas e sintáticas, utilização de novas técnicas etc. (ARANTES, 1979, p. 09).

Contudo, o movimento se arrefeceria. É assim que ao tempo em que criticava a dispersão do próprio Cinema Novo como movimento, o manifesto condenava a Neochanchada, que nascia e tomava o mercado nacional: “(...) o Cinema Novo disperso assistia ao nascimento de um novo cinema brasileiro. A neochanchada toma conta da praça com o pretexto do público e da indústria, incentivada pelos órgãos oficiais, controlada pela censura." (ARANTES, 1979, p. 08). Neste mesmo ano, em carta a Celso Amorim, na ocasião diretor-geral da EMBRAFILME, diz Glauber: “(...) a direita do Cinema Novo entrou nas neochanchadas (até com adesões do udigrúdi), ficando apenas um Vértice Glauber Rocha, Paulo Saraceni e Gustavo Dahl -, execrados à sanha das piranhas." (ROCHA In BENTES, 1997, p. 649).

Como se pode perceber, o tom é em muito distinto do espírito que conduzia os trabalhos do órgão oficial, que Humberto Mauro dirigia. Contudo, o movimento Luz e Ação demonstrava preocupação quanto ao estabelecimento de uma relação estável com o público, entendendo que sem ele, dizia o manifesto, não haveria cinema. Conclamava ainda cineastas e críticos a um trabalho conjunto, considerando o contato com o público, porque o Cinema Novo buscava sair do formato adquirido, que lhe rendia isolamento e se voltava para um estilo menos anticonvencional (XAVIER, 2001).

Recusamos a chantagem do 'público a qualquer preço'. Ela tem levado o cinema brasileiro às mais aberrantes deformações: o riso fácil à custa do mais fraco, o racismo, a sexualidade como mercadoria (...). E afirmamos essa recusa com toda a autoridade de quem muito tem trabalhado, cada vez mais, em direção a uma harmonia dialética entre espetáculo e espectador (ARANTES, 1979, p. 09).

Negação mais radical do nacionalismo de Humberto Mauro será aquela promovida pelo Cinema Marginal brasileiro, fazendo oposição a essa estabilização da relação com o público (XAVIER, 2001). O Cinema Marginal, por assim dizer, alopra, escarnece o público. Abandona a pedagogia pela experiência do choque, como diz Ismail Xavier, de acordo com Alexandre Figueirôa (2004, p. 35). É por 
princípio deseducativo, e, em alguma medida, antieducativo, se considerarmos as palavras de Ismail Xavier sobre o Cinema marginal, que apontam a associação desse movimento com o pós-estruturalismo, por exemplo:

0 aspecto destrutivo de sua prática conduz a associações com o underground e com a atmosfera teórica do pós-estruturalismo, quando se coloca como tarefa primordial do filme político a crítica radical da representação burguesa cristalizada no cinema (XAVIER, apud FIGUEIRÔA, 2004, p. 35).

\section{3- Aparelhagem para a projeção de filmes na escola}

Tendo em vista a discussão quanto à acessibilidade da população ao cinema no Brasil, nos utilizaremos de alguns dados que permitirão sua análise. Vale destacar que tal termo acessibilidade, aqui empregado, tem em vista o estudo realizado por Romeu Kazumi Sassaki86, citado na "Análise de Impacto", divulgada pela ANCINE (2015) ${ }^{87}$.

Na década de 1930, as escolas tinham, elas próprias, que adquirir seus aparelhos de projeção (no caso, projetores de $16 \mathrm{~mm}$ ou de $35 \mathrm{~mm}$, conforme mencionado no Código, Art. 126, "Os estabelecimentos de ensino poderão realizar, semanalmente, sessões cinematográficas, com exibição de filmes recreativos, mediante pagamento de entrada."). Estas eram as sessões recreativas, que eram pagas a fim de arrecadar fundos para a Caixa da Filmoteca, instuída pelo mesmo Código, Art. 30: "Fica criada a caixa de Filmoteca, para arrecadação das quantias aludidas", para a compra de material para projeção. 0 outro tipo eram as sessões educativas, gratuitas.

\footnotetext{
${ }^{86}$ Segundo o autor, para produzir inclusão pela acessibilidade há de se considerar que esta é constituída de seis tipos: arquitetônica (que os sujeitos possam se dirigir a uma sala para ver um filme ou em casa sem barreiras ambientais físicas), atitudinal (um ambiente que possibilite que as pessoas tenham acesso ao lugar sem se sentirem discriminadas), comunicacional (que as pessoas possam ser comunicadas, sendo, para tanto, preciso frequentemente o uso de vários veículos como internet, cartazes, revista, o uso de língua estrangeira, em braile etc.), instrumental (pressupõe ausência de barreiras dos instrumentos conceituais para acessar o espaço), metodológica (pressupõe a ausência de barreiras quanto aos métodos de estudos do objeto a ser acessado, no caso, o filme) e programática (ausência de barreiras normativas e de regulamentos que impedem o acesso das pessoas). Cf.: http://www.escoladegente.org.br/noticiaDestaque.php?id=459.

${ }^{87}$ ANÁLISE DE IMPACTO №. 1/2014/SEC (versão finalizada em fevereiro de 2015). Disponível em http://www.ancine.gov.br/sites/default/files/consultas-publicas/AIR-Acessibilidade-VersaoOstensiva.pdf. Acesso em 06 de julho de 2016. 
Interessante notar a distinção que o Código faz das sessões ao considerar uma "educativa", que era gratuita, e a outra, "recreativa", paga. Dicotomia sintomática ainda bastante presente na escola atual que, em grande medida, desconsidera o poder educativo do audiovisual exibido na TV e nos cinemas. Tal distinção parece entender que o recreativo não pode ser também educativo, nem o educativo, recreativo. 0 educativo parece reduzido ao que não tem preço; é apenas o que não se cobra. Aquilo que era cobrado não podia ser educativo. Como se exigisse da educação, nostalgicamente, o seu valor de uso, de modo que cobrar por ela seria perder esse valor, assumindo um valor de troca. Como já salientado por Marx, trata-se do fetiche da mercadoria: o sistema de troca é introjetado moralmente como valor. Se o filme é pago ele não é educativo. Não se percebe que a mercadoria é introjetada, ela é fantasma, fetiche. É por isso que o educativo "deve" ser gratuito, não como dimensão pública, por razões políticas, mas morais. Reflexo da falta de compreensão de como se dava a sociedade de consumo, que ainda não havia entrado com força na sociedade brasileira. Pagar era indecente. Vale ainda lembrar que no Brasil, nas décadas de 1940-50, estudar em escola privada significava certa desonra para o aluno, pois se dizia pejorativamente que essas instituições privadas funcionavam à base do "pagou-passou". Ao contrário, desde a Reforma Francisco de Campos, há um rígido controle de avaliação, de modo que se diz que se trataria de um sistema não de ensino, mas de "um sistema de provas e exames." (ROMANELLI, 1986, p. 137).

Para se ter ideia desse "sistema de provas e exames", elencamos três artigos da Reforma:

Art. 34. Haverá durante o ano letivo arguições, trabalhos práticos e, ainda, provas escritas parciais, com atribuição de nota, que será graduada de zero a dez.

Art. 35. Mensalmente, a partir de abril, deverá ser atribuida a cada aluno e em cada disciplina pelo respectivo professor, pelo menos uma nota relativa a arguição oral ou a trabalhos práticos.

$\S 1$ ㅇ A média das notas atribuidas durante o mês servirá para o cômputo da média anual que constituirá a nota final de trabalhos escolares.

$\S 2^{\circ}$ A falta da media mensal, por não comparecimento qualquer que seja o pretexto, inclusive por doença, equivale à nota zero.

Art. 36. Haverá anualmente em cada classe e para cada disciplina quatro provas escritas parciais, constituindo a média dessas quatro notas a nota final de provas parciais. 
Nas décadas seguintes, ainda era difícil a projeção de filmes. 0 aparecimento da TV, uma espécie de cinema doméstico, foi, a princípio, o fantasma do cinema, que ameaçava fazê-lo desaparecer. Depois, deu-se conta de que o cinema tinha uma abrangência social que demandava sua existência. Como a fotografia, que teria contribuído para a pintura adquirir seu lugar como arte, sua especificidade, o cinema teria que se desvencilhar da imagem domesticada do lar. Contudo, o que se passou, de modo predominante, foi que o espectador domesticado passou a procurar a imagem domesticada também nos cinemas. A TV é parte do sistema constituído para além do doméstico, tomando a dimensão privada no público. TV e cinema se retroalimentam: o filme comercial ganha uma amplitude inimaginável.

Com o aparecimento do vídeo em formato caseiro (VHS, Video Home System), no final da década de 1970, as escolas começaram a se aparelhar para a exibição de filmes, mas ainda com a utilização das TVs como tela. Curioso que a TV tenha servido de suporte para o cinema, quando é, de certa forma, sua negação. Ela é, por assim dizer, possuída momentaneamente pelo cinema, mas não deixa de exercer por meio de seu suporte a limitação da imagem que veicula, o seu apequenamento. Contudo, é preciso admitir que o vídeo representou o respiro frente à programação da TV, equacionada para um grande público como é próprio da programação de uma emissora privada ou estatal, que procura vender seus produtos para o maior número possível de pessoas de uma única vez. Para tanto, tem que generalizar sua linguagem a um grupo homogêneo.

Atualmente, o aparelhamento para projeção de filmes nas escolas é bem menos complicado. 0 Estado se encarrega das instalações básicas dos equipamentos necessários à projeção de filmes. Em 201288, das 4.969 escolas do estado de São Paulo, 4.930 (99,2\%) delas tinham televisão e 4.887 (98,3\%) tinham DVD. Em 2013, das 5.009, 4.906 (97,9\%) tinham televisores, 4.828 (96,4\%) tinham DVD. Em 2014, das 5.033 escolas, 4.876 (96,9\%) tinham televisores, 4.688 (93,1\%)

88 Censo Escolar do Estado de São Paulo. Secretaria de Educação, 2012, 2013 e 2014. http://www.educacao.sp.gov.br/noticias/saiba-como-funcionara-o-censo-escolar-2012, acesso em 03 de outubro de 2015. Os anos analisados foram os únicos disponibilizados no site da SEE-SP. 160 
tinham DVD. Para melhor visualização, apresentamos esses dados na Tabela 3 abaixo $^{89}$ e, a seguir, num gráfico:

Tabela 3 - Quantidade de escolas, de televisores e de DVDs nos anos de 2012, 2013 e 2014

\begin{tabular}{|c|l|l|l|}
\hline Ano & $\begin{array}{c}\text { Quantidade de } \\
\text { Escolas }\end{array}$ & $\begin{array}{l}\text { Quantidade de } \\
\text { Televisores }\end{array}$ & $\begin{array}{c}\text { Quantidade de } \\
\text { DVDs }\end{array}$ \\
\hline 2012 & 4.969 & 4.930 & 4.887 \\
\hline 2013 & 5.009 & 4.906 & 4.828 \\
\hline 2014 & 5.033 & 4.876 & 4.688 \\
\hline
\end{tabular}

Fonte: Censo Escolar: São Paulo, 2012, 2103 e 201490.

O Gráfico 1 nos permite visualizar melhor o decréscimo de aparelhos de televisores e principalmente de DVDs.

Gráfico 1 - Quantidade de escolas, de televisores e de DVDs nos anos 2012, 2013 e 2014

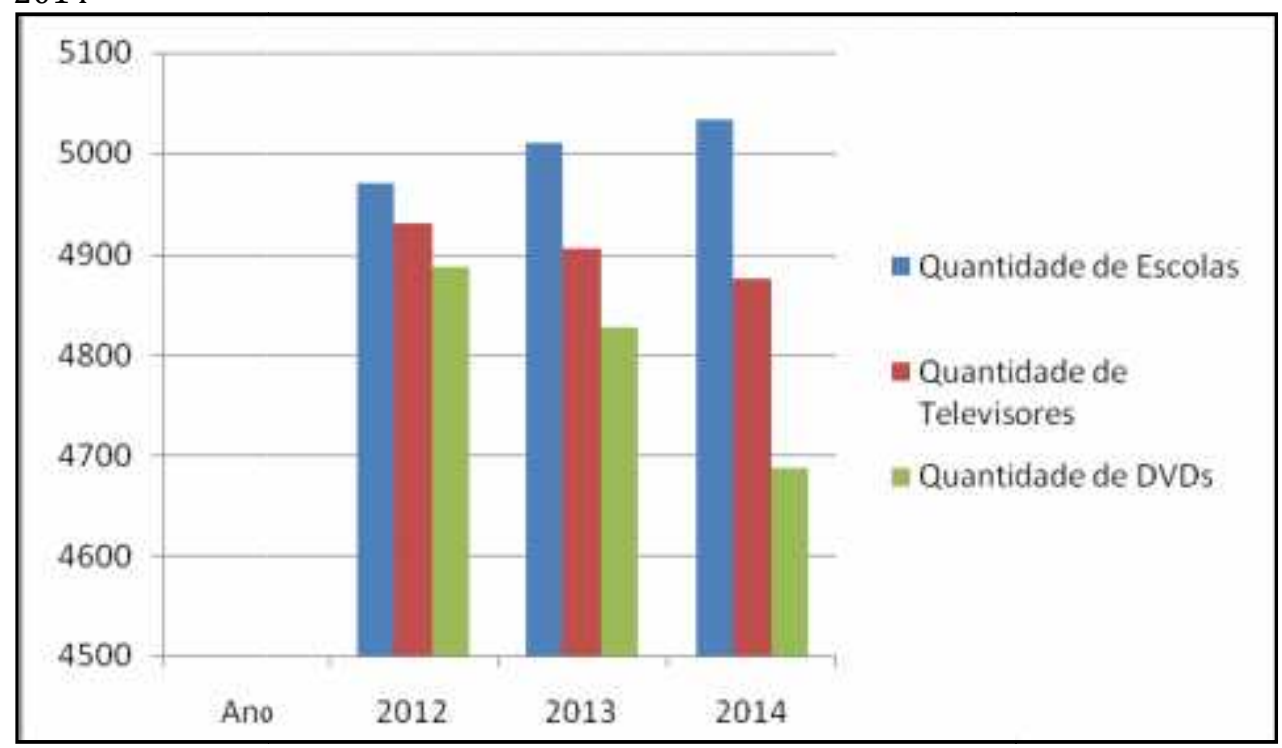

Fonte primária: Censo Escolar: São Paulo, 2012, 2013 e 2014.

${ }^{89}$ Infelizmente não chegamos a conhecer nenhuma estatística de mesma abrangência quanto a projetores como Datashow e similares. Imaginamos que, apesar de terem se passado dois anos desde essa pesquisa, os aparelhos de Datashow sejam rarefeitos nas escolas em razão de serem bem mais caros (em torno de $\mathrm{R} \$ 1.800,00$ ) que os aparelhos de DVD (em torno de R $\$ 100,00$ ) já, de certa forma, em desuso.

90 Para o total de escolas da rede estadual não foram contabilizadas aquelas estaduais mantidas e administradas pelas universidades estaduais paulistas (USP, UNESP, UNICAMP e Centro Estadual de Educação Teconológica Paula Souza). 
O VHS praticamente sai de circulação no ano de 2007, como se pode ver no gráfico da Pesquisa realizada pela Screen Digest e pelo Evolution of Home Entertainement, em 2010, e divulgado no Plano e Diretrizes e Metas para o Audiovisual $^{91}$ (2013. p. 63), ano em que não se tem registro significativo de aluguel de fita. De acordo ainda com o gráfico, o aluguel de fitas tem início em 1982 e tem seu auge em 1994. Segundo o mesmo estudo, o Brasil possui um número maior de habitantes por sala de cinema que a Argentina, Uruguai e Chile, isto é, possui menos salas de cinema por habitante.

Gráfico 2 - Índice nacional de habitantes por sala de cinema (em milhares de hab./sala)

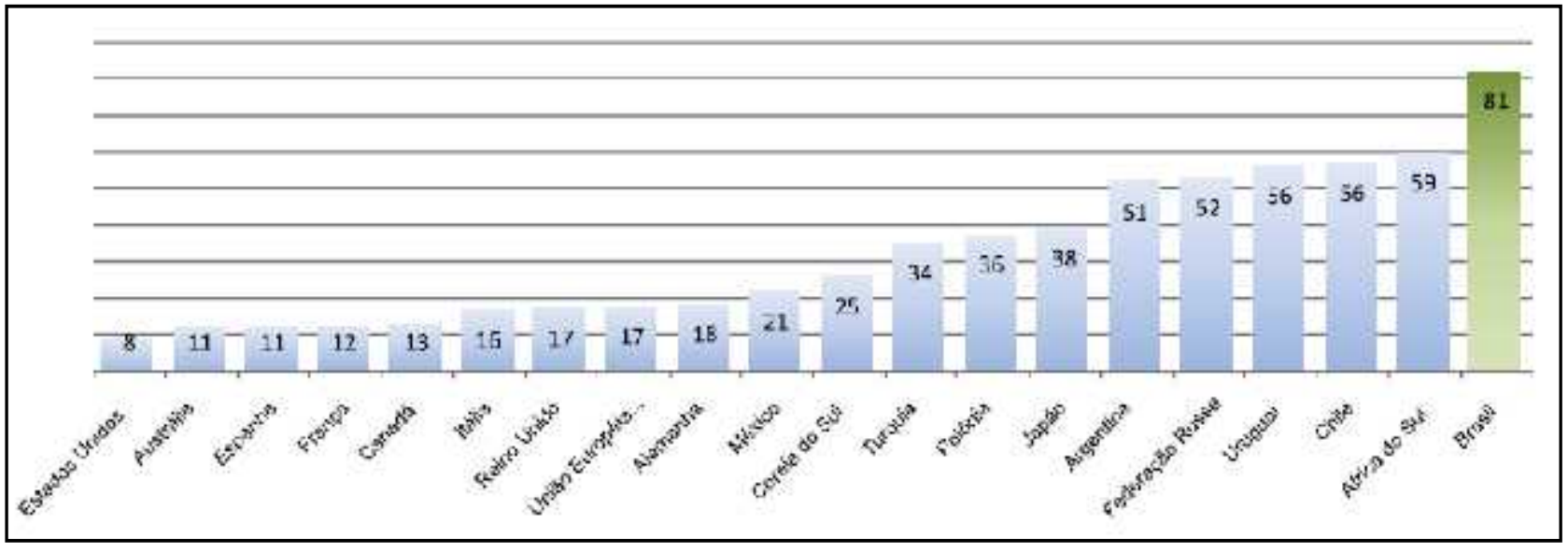

Fonte primária ANATEL e www.teleco.com (Balanço Huawei - projeções 2012 e 2014), acessível em: http://www.ancine.gov.br/sites/default/files/folhetos/PDM\%202013.pdf

O Gráfico 2 parece indicar um ostensivo primeiro lugar do Brasil, mas trata-se do inverso, a proporção de salas de cinema por habitante do Brasil, no gráfico, é a menor. Esse baixo número é um indicador de que há uma questão a ser debatida, certamente com implicações na educação, isto é, na formação de público para o cinema brasileiro. Há que se destacar, no entanto, que o Brasil tem aumentado o número de salas de cinema a cada ano: entre 2003 e 2010, por exemplo, a média foi de 71; entre 2011 e 2014, 153; e em 2015, foram 183, chegando ao número de 3.000 salas atualmente, segundo dados emitidos pelo diretor da ANCINE, Manoel Rangel ${ }^{92}$, caindo a proporção de 81 para 68 mil

\footnotetext{
${ }^{91} \mathrm{http}: / /$ www.ancine.gov.br/sites/default/files/folhetos/PDM\%202013.pdf

92 Cf.: http://www.ebc.com.br/cultura/2015/10/ancinebrasil-voltara-ter-3-mil-salas-de-cinemaainda-em-outubro. Acesso em 07 de julho de 2016. 162
} 
habitantes/sala, insuficiente ainda, contudo, para mover o Brasil da posição apresentada pelo Gráfico 2.

Os indicadores da Tabela 3 e do Gráfico 1 nos informam que as escolas, em sua maioria, possuíam televisores e DVDs para a projeção de filme nos anos indicados, ainda que esse número tenha diminuído de ano a ano. Infelizmente não tivemos acesso a nenhuma pesquisa que especificasse a situação das 3.896 escolas estaduais especificamente de Ensino Médio quanto à existência de televisores e de aparelhos de DVDs.

Há de se levar em conta que a projeção em televisores limita bastante, tanto a qualidade da projeção da imagem - considerando que a maioria das escolas funciona em período diurno, portanto, com forte concorrência de luz solar, o que exigiria das salas de projeção o recurso black-out - quanto da emissão de som, este limitado às caixas internas dos televisores, que ficam, pois, situados na frente, num único ponto. Raramente as escolas providenciam caixas de som laterais ou traseiras, condição generalizada das escolas da Rede estadual de Ensino de São Paulo.

Esses elementos técnicos são fundamentais para o envolvimento dos espectadores com o filme nas escolas, tanto pelos motivos óbvios de compreensão do que se vê e do que se fala (ainda que o filme seja falado em língua estrangeira, ouvir o que se diz, os ruídos e eventuais músicas, determina a ambientação do filme. Se o filme for legendado, o problema adicional será a dificuldade do acompanhamento das legendas numa tela pequena), quanto na "leitura" das imagens. É frequente que o professor que viu o filme em condições mais favoráveis (em casa ou numa sala de cinema) esqueça esse aspecto e espere que os alunos tenham sensibilidade prévia para dedicar-se ao ato de ver um filme.

Se para a leitura de textos escritos na escola necessita-se de silêncio além, é claro, de material (livros, revistas, jornais etc.) que comporta os textos - a projeção de filmes exige toda uma ambientação técnica (sala escura com cadeiras, projetor, filme), que possibilite que o público acompanhe a projeção a contento. 0 livro não precisa necessariamente ser de boa qualidade de impressão. Em alguns casos, chega-se a agregar um valor ao livro se ele for antigo. Não é o caso da projeção de filmes. 
Se o investimento quanto à aparelhagem para a exibição de filmes nas escolas é uma questão, investimentos na produção de audiovisual é também uma questão importante. 0 Conselho Superior de Cinema, órgão colegiado que pertence ao Ministério da Cultura, que foi criado em 2001 pela Medida Provisória 2.228/01, em 2012, elaborou um Plano de Metas ${ }^{93}$, estudo em que constam dados sobre vários aspectos do audiovisual no Brasil, além de fazer uma projeção para os anos seguintes até 2020. São medidas que visam à intensificação da exibição de filmes brasileiros nos cinemas. Desse plano, passamos a destacar alguns dados que nos chamaram a atenção.

No início da década de 2000, 29 longas-metragens brasileiros foram lançados em salas de cinema (2002). No ano seguinte, 30. Esse número começa a crescer significativamente a partir e 2004, tendo uma pequena queda no ano seguinte, mas que é retomada, chegando em 2011 a 99 filmes (BRASIL, Plano e Diretrizes e Metas para o Audiovisual, 2013, p. 31). Também o investimento federal na produção nacional de cinema teve vertiginoso crescimento. De $\mathrm{R} \$$ 89.357.303 em 2002, passa-se a R \$ 1.512.120.152 (BRASIL, Plano e Diretrizes e Metas para o Audiovisual, em 2013, p. 33), o que equivale a quase 17 vezes mais. Em 2015 foram R\$2,35 bilhões ${ }^{94}$.

A bilheteria para filmes brasileiros em 2002 foi de 7.299 .790 entradas. Em 2010 foi de 25.687.247, chegando em 2011 a 17.869.385. (BRASIL, Plano e Diretrizes e Metas para o Audiovisual, 2013, p. 41). No entanto, se essa comparação é feita com o filme estrangeiro, vê-se que o país, como dizia Paulo Emílio Sales Gomes (1996), está ocupado. Essa ocupação é muito nítida nos seguintes números: em 2002, de bilheteria, os filmes estrangeiros fizeram a marca de mais de 83 milhões de espectadores, terminando 2011 com a impressionante marca de mais de 126 milhões. Em 2015, das 20 maiores bilheterias, 17 foram dos EUA e 3, do Brasil. Assim, quando se fala em filme estrangeiro é necessário

\footnotetext{
93 Plano de Diretrizes e Metas para o Audiovisual (ANCINE, 2013). http://www.ancine.gov.br/sites/default/files/folhetos/PDM\%202013.pdf. Acesso em 10 de novembro de 2015.

94 Informe de Acompanhamento de Mercado. (ANCINE, 2015). Cf.: http://oca.ancine.gov.br/media/SAM/2015/DistribuicaoSalas/Informe_Distribuicao_Salas_2015.p df. Acesso em 07 de julho de 2016. 164
} 
salientar a marcante presença estadunidense e nela a dos filmes de Hollywood. No caso, os 17 filmes são dese estúdio.

Quanto à TV aberta, em 2009, a porcentagem de filmes longasmetragens dos EUA chega à impressionante porcentagem de 78\%, de outros países, 10,7\%, e de brasileiros, 11,4\%. (BRASIL, Plano e Diretrizes e Metas para o Audiovisual, 2013, p. 57). Em minisséries e seriados, EUA: 71,7\%, outros, 11,8\%, brasileiros: $16,5 \%$.

Ainda que os dados abaixo sejam referentes a programações de longasmetragens e séries em TV aberta, pode-se ter uma boa ideia da proporção da presença de filmes dos EUA no cotidiano do brasileiro, chegando a quase $80 \%$ do total, o que equivale a dizer que a cada 10 filmes, 8 são estadunidenses e apenas um é brasileiro $(11,4 \%)$.

Gráfico 3 - Origem dos longas-metragens exibidos nas redes de TV aberta (2009) - à esquerda Gráfico 4 - Origem das minisséries e seriados exibidos nas redes de TV aberta (2009) - à direita

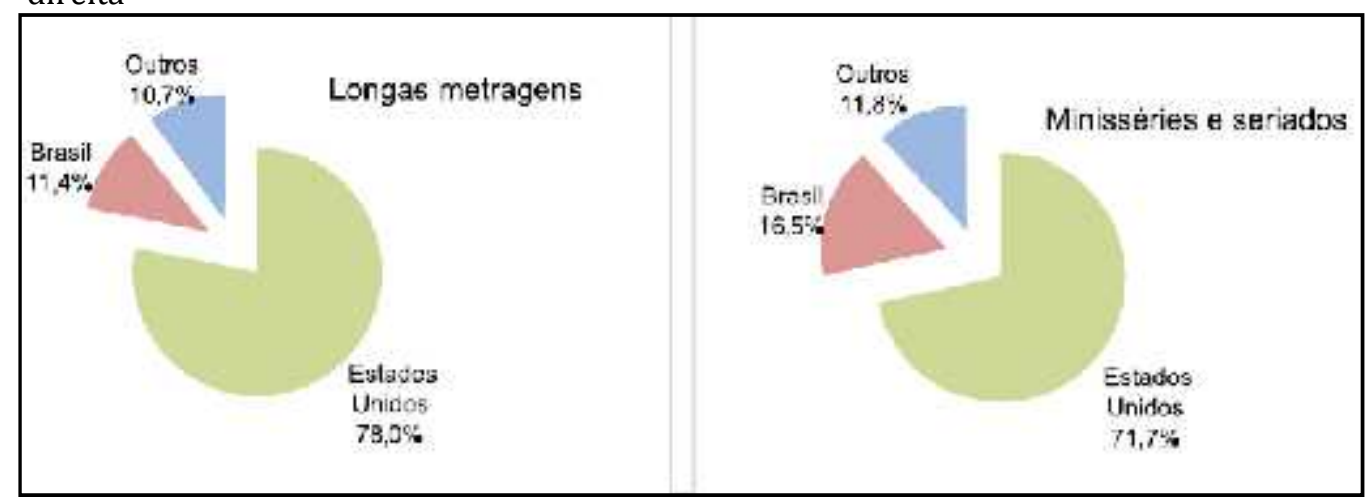

Fonte primária: http://www.ancine.gov.br/sites/default/files/folhetos/PDM\%202013.pdf. Sites das emissoras cabeças de rede (Band, SBT, Rede TVI, TV Cultura, TV Gazeta e TV Brasil)/grades de programação. Pesquisa: SAM/ANCINE. Obs.: dados de longasmetragens por número de títulos: minisséries e seriados por hora de exibição. 0 Plano de Diretrizes e Metas para o Audiovisual - PDM - foi publicado em 2013, ainda que os dados sejam de 2009, conforme indicação acima.

A "ocupação" majoritária das salas de cinema e do espaço na TV brasileira pelo produto audiovisual estrangeiro, na expressão de Paulo Emílio Gomes, parece ainda suscitar poucas ações efetivas se considerarmos a concepção de cinema no Currículo do Estado de São Paulo. Apesar da lei que obriga as escolas à exibição de duas horas mensais de produto audiovisual brasileiro, o cinema é ainda "componente complementar". 
O conteúdo de disciplinas do Currículo, portanto, não complementares, é matéria de exames externos (de nível estadual ou nacional), como Língua Portuguesa, Matemática e Ciências da Natureza, principalmente, caso do Sistema de Avaliação de Rendimento Escolar do Estado de São Paulo - SARESP, aplicada desde 1996, e usado no cálculo do Índice de Desenvolvimento da Educação do Estado de São Paulo - IDESP. Este foi criado em 2007 e tem sido referência para estabelecer metas ano a ano para as escolas, bem como para cálculo do bônus (financeiro fornecido ao professor), que cada escola deve receber pelo desempenho anual no exame. Além da estrutura de funcionamento atrelada a avaliações externas impostas em torno do currículo, que dá ênfase aos conteúdos das disciplinas, o professor encontra no bônus outro fator que o enreda nos objetivos pedagógicos que tem em vista o cumprimento de tais índices ${ }^{95}$. Nesse sentido, contribui para secundarizar mais ainda aqueles conteúdos considerados complementares, caso do cinema.

Em nível nacional, são aplicados anualmente a Prova Brasil e o Sistema Nacional de Avaliação Básica - SAEB, cujos exames tratam de Língua Portuguesa (com foco em leitura) e Matemática (com foco em resolução de problemas) para os 5․ e 9․ anos do Ensino Fundamental.

Tais exames contribuem para imprimir um modo de funcionamento em torno da instrumentalização dos professores, que acabam tendo que se mobilizar para atender às demandas dos exames, com consequente destinação de horas a mais por semana para essas disciplinas contempladas. 0 desempenho nessas avaliações subsidia o cálculo do Índice de Desenvolvimento da Educação Básica IDEB, que também, a exemplo do IDESP, referido mais acima, passa a determinar políticas a fim de que os desempenhos melhorem.

Nesse contexto, inconscientemente, é possível que um professor se pergunte sobre o que poderia levá-lo a estudar o cinema para incluí-lo como "matéria escolar" se este saber não apresenta em seu horizonte nenhuma "utilidade" pedagógica. Assim, a despeito do que se diz sobre a importância que tem tomado a imagem nas sociedades contemporâneas, a escola segue atribuindo à

\footnotetext{
950 recurso à bonificação é usado em políticas neoliberais, que buscam premiar aqueles que teriam o mérito em determinado momento, sem incorporar tal bonificação ao salário. Esse valor da bonificação, que seria de obrigação do Estado incorporá-lo ao salário é usado como moeda de troca. 166
} 
palavra (e aos números) o lugar principal. Confirmação disso que estamos dizendo é a presença reinante da palavra no livro didático e as aulas dos professores, em que basicamente são de formato oral-expositivo.

\section{4- A ideia de currículo subjacente à Proposta Curricular do Estado de São Paulo}

O projeto $O$ cinema vai à escola nasce inserido num contexto pedagógico. É criado diretamente pelo programa Cultura é currículo, em 2008, que procura atender a concepção de currículo da Proposta Curricular do Estado de São Paulo e do Currículo do Estado de São Paulo que, por sua vez, são derivados, ou se pretendem consonantes a documentos que os direcionam, como os PCN (Cf. Figura 6). Comentaremos neste trabalho prioritariamente a Proposta Curricular do Estado de São Paulo em razão de ela ter sido lançada no mesmo ano do projeto. 0 Currículo do Estado de São Paulo será citado quando trouxer uma particularidade ausente na Proposta (como os Cadernos do Professor). Os Cadernos do Professor diminuem o aspecto generalizante da Proposta, sugerindo intervenções diretas na sala de aula. Contudo, os dois documentos são, em grande medida, o mesmo, não apenas conceitualmente, mas também quanto à reprodução textual.

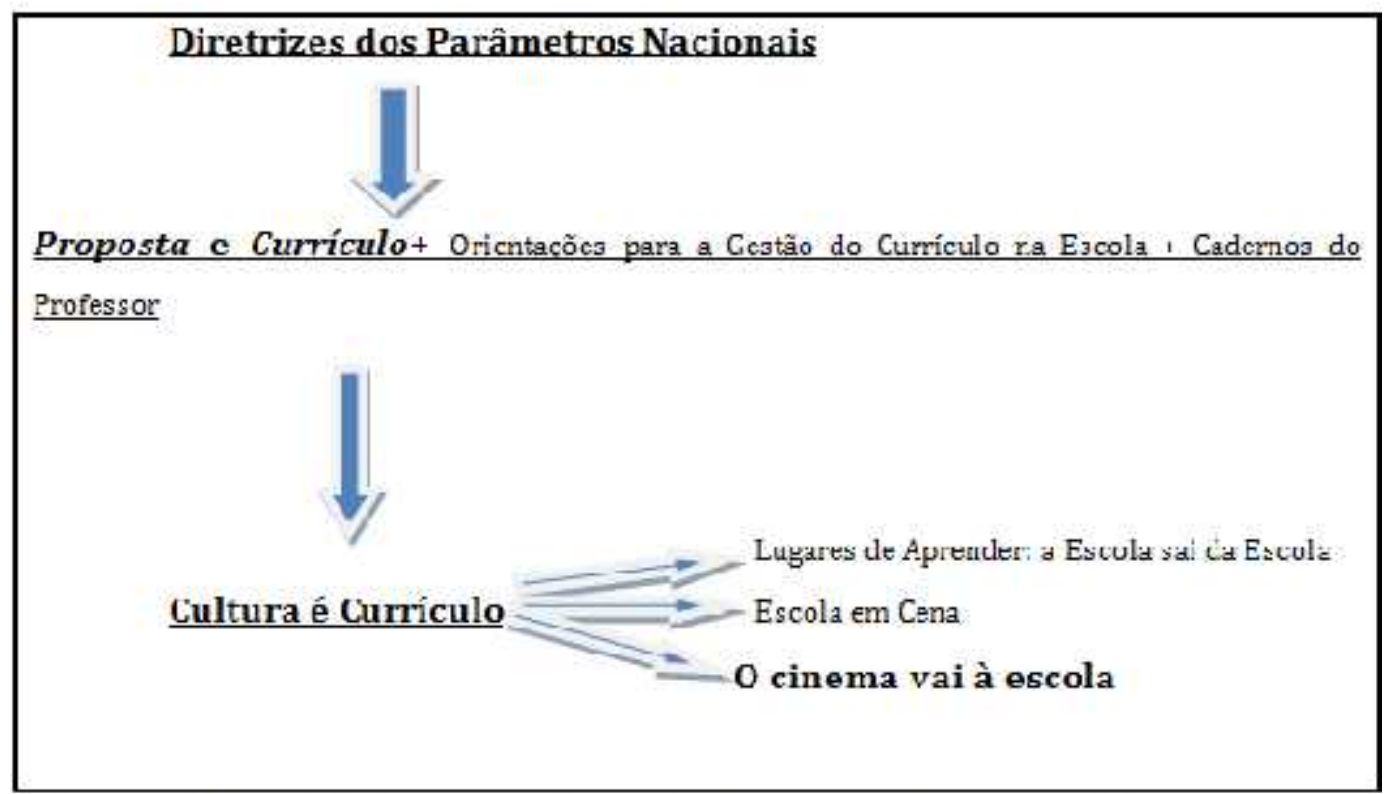

Figura 6: Fluxograma de composiçãc de Diretrizes dos Parámetros Nacionais eo Curriculo 
Currículo é um termo chave e recorrente nos discursos pedagógicos. Documento escrito a partir do qual ações pedagógicas de uma instituição educativa são orientadas, o currículo é expressão não definitiva da concepção de sistema escolar. Nesse sentido, as diretrizes que nele constam possibilitam que o legado ou a concepção de legado - de um determinado grupo oriente todo um conjunto de ações a partir daquilo que fora julgado importante (ou "pedagogicamente" mais importante) para servir de modelo a ser "reproduzido". Contudo, a depender da organização e das relações de poder de uma determinada instituição o modelo pode ser imposto de tal modo que a liberdade de criação e crítica de seus usuários sejam desautorizadas, gerando uma expectativa por parte da gestão de que as ações pedagógicas se deem de modo espelhado, reproduzido a partir do modelo.

O currículo reúne a base de temas julgados prioritários para a vida escolar dos estudantes a partir de uma base nacional comum e uma parte diversificada. Nesse sentido, há um perfil crítico-social de cada currículo que promove uma seleção constante de temas e modos de ensinar em detrimento de outros. O currículo, tal como se apresenta, procura orientar e disciplinar as atividades e mesmo as falas do professor em sala de aula. Serve, pois, de referência (prática e teórica) para que o professor organize seus planos de aula, mas também para que seja cobrado e sofra as punições no caso de não conformidade ${ }^{96}$.

\footnotetext{
${ }^{96}$ Uma das punições indiretas sentidas pelo professor é a de ele não receber bônus em razão dos baixos resultados da escola nos exames exteriores, dentre eles, o SARESP e a Prova Brasil. Vértice na configuração do ato de educar, isto é, o professor é aquele que mantém contato direto com o aluno e, por isso, é frequentemente responsabilizado pelos baixos índices. Quanto a punições diretas, vale lembrar que até 2008 vigorou no Brasil o Artigo 242 do Estatuto dos Funcionários Públicos (conhecido como "Lei da Mordaça"), criado no ano de 1968, que proibia o funcionário público de rereferir-se "depreciativamente, em informação, parecer ou despacho, ou pela imprensa, ou qualquer meio de divulgação, às autoridades constituídas e aos atos da Administração." Segundo o site "Observatório do Direito à Educação", a ONG Ação Educativa aponta que a categoria que teve maior registro de abuso por uso dessa lei foi a dos professores, sendo tantas as ocorrências que o Sindicato dos Professores do Ensino Oficial do Estado de São Paulo - APEOESP - junto com a citada ONG, lançaram uma campanha para revogação do artigo: "Fala, Educador! Fala, Educadora!". Essa lei é revogada por projeto de lei do então deputado estadual Roberto Felício (PT). Fonte: http://www.intervozes.org.br/direitoacomunicacao/?p=22261. Acesso em 27 de janeiro de 2016. Embora a "Lei da Mordarça" não faça referência à punição do professor quanto ao não cumprimento do currículo, ela serve para enterdermos como os professores como categoria são conformados a uma certa cultura de obediência. Mais recentemente, surge uma onda considerada de extrema direita, cujos membros têm feito circular um documento em que qualquer "cidadão de bem" pode acusar um professor que incorra em "doutrinação ideológica". Esta expressão é utilizada para temas que, em geral, são atribuídos a uma agenda de "esquerda". O grupo central impulsionador dessa onda neo-conservadora é o Movimento Escola Sem Partido, organização coordenada por Miguel Nagib, Procurador de Jusitça do Estado de São Paulo, no entanto, vinculada informalmente a partidos de direita, dentre eles, o DEM e o PSDB.
} 
O paroxismo da busca da adequação ao "currículo" pode ser notado no caso da atividade sobre homofobia sugerida por um professor do segundo ano do Ensino Médio do Centro Educacional no 6 de Ceilândia, no Distrito Federal, ocorrida em fins de junho de 2016. Segundo o site "Pragmatismo Político"97, a deputada Sandra Faraj enviou ofício à direção da escola solicitando esclarecimentos e "providências legais cabíveis". A queixa teria sido apresentada à deputada pela mãe de um aluno, que procurou seu gabinete. Em ofício, a deputada, que é evangélica, pede esclarecimento do teor abordado pelo professor, visto que teria ferido os "valores da família" e que as escolas não teriam "autorização para abordar temas dessa maneira.". Apesar de ter havido reação dos professores contra a tentativa de interferência na autonomia do professor, de acordo com o Conselho dos Direitos da Criança e do Adolescente do Distrito Federal, e contra o que o sindicato dos professores, quanto ao envio do ofício da deputada, chamou de "tentativa de intimidar e constranger os professores", ainda segundo a redação do site, como se pode perceber, a queixa é apresentada em caráter de denúncia e não de diálogo.

Assim, o cumprimento do currículo se impõe com força de lei na escola. Para a escola citada, o assunto está previsto no currículo. Qualquer sujeito da comunidade pode vir a questionar se determinado assunto abordado pelo professor, inclusive seus métodos, está previsto no Currículo. Por fim, este expressa uma espécie de acordo, geralmente não sem grande tensão, entre as várias partes responsáveis por sua constituição, incluindo a comunidade fora da escola.

Antes sugestivo, expresso pelo termo "proposta", do título Proposta Curricular do Estado de São Paulo é, hoje, obrigatório: "Currículo do Estado de São Paulo". A ausência da palavra "proposta" na versão atual do documento parece marcar essa transição.

Consequência do processo de massificação da escolarização e da intensa industrialização, o currículo moderno tem início, segundo Tomaz Tadeu da Silva, de acordo com Garcia (2011), a partir de 1920, nos Estados Unidos, e tinha como objetivo responder a algumas questões como o que os alunos deveriam

97 http://www.pragmatismopolitico.com.br/2016/07/deputada-evangelica-quer-punir-professorque-debateu-homofobia-na-aula.html. Acesso dia 28 de julho de 2016. 
aprender, o saber a ser considerado válido, o que deveria fazer parte do currículo e que conhecimento deveria ser ensinado.

Desde então, para Tomaz Tadeu da Silva há um avanço significativo nas pedagogias oficiais expressas pelos currículos, uma vez que estes, hoje, já reconhecem a dimensão do multiculturalismo e da diferença. Reconhecer sua existência significa atribuir estatuto de conhecimento. Contudo, acrescenta o autor, falta uma "teoria da identidade e da diferença" (SILVA, 2009, p. 73), pois o termo multiculturalismo é apresentado com frouxidão de sentido. Com essa menção ao multiculturalismo apela-se para o respeito e a tolerância à diferença.

Tomaz Tadeu da Silva (2009), porém, coloca-se criticamente nesse contexto. Diz que é preciso não perder de vista as limitações desse anúncio da existência da diferença. Para ele, é necessário realizá-la, apresentando uma teoria que a sustente. $\mathrm{O}$ sujeito enunciador do currículo parece preocupado em pontuar que o documento segue as tendências mais progressistas das pedagogias atuais, conforme Silva chama atenção, para quem é preciso entender a diferença como processo e não como identidades fixas. Respeito à diversidade tem esse sentido limitado de não tocar no diferente, no diverso. Respeitar o diverso, nesse caso, não significa promover a diversidade.

Calcados na identidade, os discursos circulantes e em evidência no contexto escolar promulgam uma espécie de pedagogia da hipercomunicação. Fazem coincidir signo e referente. Procura-se, assim, eliminar a brecha que toda relação linguística apresenta, que se dá por zona de aproximação do signo com a coisa. A identidade como elemento da comunicação não é um dado da natureza, uma essência, ela é produzida por relações de poder (SILVA, 2009, p. 96). O que Tomaz Tadeu da Silva discute nesse texto a que fazemos referência é que o currículo e uma pedagogia da diversidade centram-se no respeito a uma identidade essencialista. Ao contrário, para ele, um currículo precisa basear-se na diferença, "em toda experimentação que torne difícil o retorno do eu e do nós ao idêntico." (SILVA, 2009, p. 100). Para evitar a reprodução da mesmidade, o autor lembra a noção de performatividade de Judith Butler (que, por sua vez, fora tomada de Austin) para quem é necessário quebrar o ciclo de repetição e de afirmação do signo. Vale lembrar que a noção de repetição é destacada particularmente por 
Jacques Derrida. Diz ele ser o signo repetível, pois do contrário seria impossível a comunicação. Tal característica tende a produzir identidades que, se forem tomadas como definitivas, estáticas, cristalizar-se-iam as relações em pontos fixos. É nesse sentido, que Butler sugere a quebra da cadeia do signo, a interrupção de seu império.

Dessa forma, o currículo pode ser elaborado de modo que essas questões sejam centrais e não apenas enunciativas. Nesse sentido, a escola tem um papel fundamental na interrupção de afirmação do signo. Visto que as imagens são mais caóticas, menos encontráveis (Raymond Bellour apud AUMONT, 2007, p. 209) e até não citáveis, como falado anteriormente, seja pela maior presença da imagem pelas artes ou das ideias e dos textos ou ainda pela promoção sistemática de eventos culturais. As artes (e o cinema) podem propor para a escola outro tipo de relação com o evento cultural (filmes, peças de teatro, música etc.). Por isso, é importante que o professor acredite na proposta a ser desenvolvida por ele e por seus colegas que, ousando interromper a afirmação do signo expresso mesmo em programas televisivos e no cinema dito comercial, busque (des)orientar-se no pensamento sem desprezar a contribuição das artes num ambiente que é eminentemente dominado pelas disciplinas científicas.

De acordo com Lopes, a noção institucional de política - "o que concerne ao Estado e ao governo em detrimento de sua conceituação como relativa às decisões da vida coletiva num grupo de homens organizados" (LOPES, 2006, p. 35, destaque da autora) - é transposta para o debate curricular, "fazendo com que o debate nesse campo se constitua como uma extensão das análises de outras dimensões das políticas públicas do Estado." (LOPES, 2006, p. 35). As discussões em torno do currículo tendem, pois, a responder predominantemente à noção do Estado não como um coletivo de pessoas interessadas que decidem pela gestão da coisa pública, de planos educacionais respaldados pelo debate público junto às comunidades escolares, isto é, como propriamente política no sentido amplo do termo, mas como instância partidária.

Essa mesma relação, de unidades estanques entre si, pode ser flagrada entre currículo e cultura no Cultura é currículo, programa da SEE-SP que dá origem ao projeto $O$ cinema vai à escola. A vinculação estabelecida entre currículo e 
cultura, assim como se encontra expresso no nome do programa Cultura é currículo, parece ser sintomática de uma disfunção. Tal relação é de predominância, de antecedência, do currículo frente à cultura. Ora, apesar de toda política de currículo ser uma política cultural (LOPES, 2009, p. 37), não obstante o currículo, no caso desse programa, é usado como predicado para a definição de cultura. Essa relação, pois, parece invertida. Ao apresentar a relação entre essas duas dimensões, a SEE-SP parece defender a tese de que a cultura se resume ao currículo, deixando de tomá-la como referencial inapreensível, a rigor, por qualquer currículo. A cultura é, em certo sentido, inapreensível. Com tal percepção, pensamos se o currículo não poderia apresentar-se como cultura: Currículo é cultura. 0 currículo, neste caso, é ou se pretende, também, cultura, ou seja, o currículo não tem aí a pretensão de abarcar, de encerrar a dimensão cultural. Na expressão "currículo como espaço de cultura" (Proposta, p. 07), parece que a cultura encontra seu lugar, ainda que de forma tímida.

A própria Proposta alinha e embala evidências dessa inversão:

Currículo é a expressão de tudo o que existe na cultura científica, artística e humanista, transposto para uma situação de aprendizagem e ensino. Precisamos entender que as atividades extra classe não são 'extracurriculares' quando se deseja articular a cultura e o conhecimento (Proposta, p. 08, grifo nosso).

A ênfase na coincidência entre os termos currículo e cultura parece ser a tônica e não a defesa de que o currículo faça o movimento de se apropriar das expressões culturais como bens. Essa transposição da “cultura” para o currículo já aí parece ser tomada com a crença no procedimento adequado de salvaguardar a essência cultural no ambiente escolar, como se essa transposição, a exemplo dos museus quanto às obras de arte, consagrassem $o$ lugar da cultura.

O documento declara-se defensor e estimulador do "desejo de aprender" como uma instância de desenvolvimento de uma curiosidade genuína na humanidade, considerando que na nova escola, "o professor não se limita a suprir o aluno de saberes, mas é o parceiro de fazeres culturais, aquele que promove de muitas formas o desejo de aprender, sobretudo com o exemplo de seu próprio 
entusiasmo pela cultura humanista, científica, artística e literária." (Proposta, p. 08, destaque nosso).

A ideia do professor como parceiro parece indicar uma igualdade de condições impossível no processo de que aqui se trata. Como se os jovens já estivessem convencidos de seu papel nos processos que se dão na escola. Ademais, o "desejo" quanto ao aprendizado ("desejo de aprender") a nós não parece se dar de modo intransitivo, isto é, como desejo de aprender qualquer coisa. Parece fazer significativa diferença para o aluno o assunto a ser estudado por ele.

Contudo, ao mesmo tempo, refere-se aos jovens, maioria a quem se dirige o Currículo (público de 11 a 18 anos de idade), como estando em um momento entre a infância e a fase adulta, uma fase transitiva.

Paralelamente a essa conduta, é preciso considerar quem são esses alunos. Ter entre 11 e 18 anos significa estar em uma fase peculiar da vida, localizada entre a infância e a idade adulta. Neste sentido, o jovem é aquele que deixou de ser criança e se prepara para tornar-se adulto. Trata-se de um momento complexo e contraditório, que deve orientar nossa proposta sobre o papel da escola nessa fase de vida (Proposta, p. 14).

A referência feita aos jovens é a de que estes não são mais crianças, isto é, entende que eles deixaram de ser crianças e que se "preparam" para a vida adulta como se ações pedagógicas devessem estar voltadas para um futuro que lhes avizinha, derivando daí que o tempo presente dos jovens é secundário, pois importam para o ser escolar, ao menos na Proposta em questão, o exercício da cidadania e o uso responsável da vida social.

A noção sobre a vida humana expressa nessa passagem lembra o equívoco da pergunta corrente feita à criança sobre o que ela será quando crescer, negligenciando, desse modo, o que ela já é, ainda que provisoriamente.

Assim, a Proposta nos chama atenção quando reivindica identidades estanques. "As crianças realizam e compreendem ao falar, pensar ou sentir, mas não sabem ainda tratar o próprio agir, pensar ou sentir como uma forma de linguagem.". É apenas na "adolescência que isso se tornará possível e transformará o ser humano em um ser de linguagem, em sua expressão mais radical." (Proposta, p. 17). Parece que aí temos o reforço da ideia estanque das "idades": a infância e a 
adultição, e entre elas, a adolescência como fronteira do que já foi (criança) e do que será (adulto).

A Proposta considera a extensão dos anos que compreendem a adolescência nos tempos atuais, mais ainda assim, estanque: "um lugar privilegiado para o desenvolvimento do pensamento autônomo, que é condição para uma cidadania responsável”. (Proposta, p. 05). Chama atenção para a tecnologia, que imprime

um ritmo sem precedentes no acúmulo de conhecimentos e gera uma transformação profunda na sua estrutura e nas suas formas de organização e distribuição. Nesse contexto, a capacidade de aprender terá de ser trabalhada não apenas nos alunos, mas na própria escola, enquanto instituição educativa: tanto as instituições como os docentes terão de aprender.

(...)

Isso muda radicalmente nossa concepção da escola como instituição que ensina para posicioná-la como instituição que também aprende a ensinar.

(...)

Esse é o ponto de partida para o trabalho colaborativo, para a formação de uma "comunidade aprendente", nova terminologia para um dos mais antigos ideais educativos. A vantagem é que hoje a tecnologia facilita a viabilização prática desse ideal (Proposta, p. 07).

"A vantagem é que hoje a tecnologia facilita a viabilização prática desse ideal [a formação de uma comunidade aprendente]": mais uma vez a ideia de aprendizado está no horizonte dos vários recursos de que a escola dispõe, no caso, a tecnologia. Aqui a instituição escolar é apresentada como aquela que aprende a aprender. A enunciação desse discurso indica essa nova dimensão da instituição como um valor a ser levado a cabo: "a capacidade de aprender terá de ser trabalhada não apenas nos alunos, mas na própria escola" (Proposta, p. 12).

Ações como a construção coletiva da Proposta Pedagógica, por meio da reflexão e da prática compartilhadas, e o uso intencional da convivência como situação de aprendizagem fazem parte da constituição de uma escola à altura dos tempos atuais. Observar que as regras da boa pedagogia também se aplicam àqueles que estão aprendendo a ensinar é uma das chaves para o sucesso das lideranças escolares. Os gestores, como agentes formadores, 
devem aplicar com os professores tudo aquilo que recomendam a eles que apliquem com seus alunos (Proposta, p. 12).

Pode-se perceber a fixidez dessas identidades no destaque que se dá no Currículo à necessidade de "desenvolver o espírito crítico, reflexivo, tolerante e respeitoso perante as diferenças de opinião e de formas de ser e de pensar que se baseiam em diferenças socioculturais." (Currículo, p. 159, grifo nosso). Entendemos que essa interpretação não existe apenas na letra do texto, mas que é representativa do contexto escolar, que vai marcar as estratégias dos professores e suas atividades. Além do mais, infantilizam (no sentido apontado por Deleuze apud FOUCAULT, 1988, p. 73) os alunos quando dizem que as crianças não se sabem seres de linguagem.

Considerando as fases etárias dos estudantes, a SEE-SP lançou o Jornal do Aluno, que visava à maior acessibilidade de seu conteúdo. Segundo orientações da SEE-SP, o Jornal do Aluno foi elaborado para ser usado nos primeiros quarenta dias letivos, a ter início no dia 18 de fevereiro de 2008, e se estenderia até 30 de março, com o objetivo de promover a recuperação de conteúdos para os 3,6 milhões de alunos em todo o Estado ${ }^{98}$, com ênfase em português e em matemática, para só então, dar-se início aos estudos curriculares. Segundo a coordenadora do projeto de recuperação, Maria Inês Fini, outro objetivo da recuperação no início do ano era preparar o aluno para a nova Proposta curricular, que viria a seguir. Ora, parece sintomático que uma estratégia que seria usada para a preparação dos alunos para a chegada da Proposta curricular, na verdade, este já deveria apresentar uma proposta de "preparação", de ensino-aprendizagem, para usar o termo corrente.

Se por um lado a SEE-SP sugeria a maior acessibilidade do aluno ao conhecimento por meio de um dispositivo do cotidiano (que é o jornal), no caso o Jornal do Aluno, por outro, acentuava a posição do aluno como aquele cujo papel na escola é o de aprender: "Hoje, mais do que nunca, aprender na escola é o 'ofício de aluno', a partir do qual ele vai fazer o trânsito para a autonomia da vida adulta e profissional." (Proposta, p. 05).

98 Conforme site da SEE-SP: http://www.saopaulo.sp.gov.br/spnoticias/lenoticia.php?id=90789, acesso em 08 de janeiro de 2016. 
Ora, a princípio, o jornal poderia transmitir a ideia de certa leveza (determinados aspectos do conhecimento geralmente pouco abordados na escola) a que o aluno seria convidado a acessar por meio do jornal. Contudo, o material mantinha o conteúdo do livro, como se fosse um livro em formato de jornal, organizado por áreas de conhecimento, disciplinas e por séries. Nesse sentido, parece que não poderia ser de outro modo já que o Jornal do Aluno era o material que se propunha a "recuperar" conteúdos de uma aprendizagem que não teria acontecido anteriormente ${ }^{99}$.

Interessante é notar que na Proposta o radical "aprend", de aprendizagem, apresenta 71 ocorrências, ficando atrás apenas do radical "educ", de educação, significando, assim, que há aí uma importância nada desprezível dada ao fenômeno da aprendizagem. Já na apresentação da Proposta indica-se como objetivo melhorar a qualidade da aprendizagem dos alunos da Rede Estadual: "[A Proposta do Estado de São Paulo] Pretende apoiar o trabalho realizado nas escolas estaduais e contribuir para a melhoria da qualidade das aprendizagens de seus alunos." (São Paulo, 2008, p. 03).

Integra ainda a Proposta um segundo documento (Orientações para a Gestão do Currículo na Escola) com "a finalidade específica de apoiar o gestor para que seja um líder e animador da implementação desta proposta curricular nas escolas públicas estaduais de São Paulo" (Proposta, destaque itálico nosso, destaque negrito original, p. 03). No Currículo o documento mudará de nome, passando a se chamar Caderno do Gestor, com a mesma "finalidade específica" (Currículo, p. 09) da Proposta. Esta propõe

que a aprendizagem resulte também da coordenação de ações entre as disciplinas, do estímulo à vida cultural da escola e do fortalecimento de suas relações com a comunidade. Para isso, reforça e propõe orientações e estratégias para a educação continuada dos professores (Proposta, destaque itálico nosso, destaque negrito original, p. 04).

\footnotetext{
${ }^{99}$ Segundo a coordenadora, de acordo com site da SEE-SP, o projeto de recuperação tinha como objetivo "recuperar competências que o Sistema de Avaliação de Rendimento Escolar do Estado de São Paulo (Saresp) de 2005 mostrou que a maioria não tem. O Saresp indicou que 70\% dos alunos de 4 a série da rede estadual não dominam conceitos fundamentais de Matemática. Ou seja, têm dificuldade em operações de soma, subtração, multiplicação e divisão. A avaliação mostrou que 48,4\% dos alunos não sabem ler nem escrever apropriadamente."
} (http://www.saopaulo.sp.gov.br/spnoticias/lenoticia.php?id=90789). 
0 "estímulo à vida cultural da escola" deve servir, assim, prioritariamente, ao propósito de que o aluno aprenda. Aprender, mais uma vez como verbo intransitivo. Vale dizer, imperativo. Assim, o documento, respaldado pelos PCN e pela LDB, esta em sua versão mais atual, estabelece um caminho lógico que implica diretamente a cadeia: vida cultural estimulada-aprendizado-cidadania (lê-se: vida cultural estimulada implica aprendizado que, por sua vez, implica a formação de um cidadão). 0 que talvez seja uma formulação forçada.

Promovendo a ideia de que vivemos um novo tempo, para a Proposta a tarefa da escola é tornar-se apta a preparar os alunos para esse novo tempo. Para tanto, deve-se priorizar "a competência de leitura e escrita" ao tempo que "define a escola como espaço de cultura e de articulação de competências e conteúdos disciplinares." (Proposta, p. 03). Ressalta ainda as dificuldades de inserir os alunos num contexto artístico contemporâneo, lembrando que não é fácil para qualquer professor lidar com a pergunta "Isso é arte?". Nesse sentido, entende que a "mediação cultural"100 em espaços na própria escola ou fora (museus, cinemas, teatros etc.) é fundamental para o processo educativo.

Contudo, essa noção do essencial da cultura subordinada ao currículo, ao que se pensa ser a função da escola - a apreensão da cultura pelo currículo -, pertencente à missão da instituição de possibilitar que os alunos aprendam, parece colocar a cultura como "uma só cultura para todos" e "razão instrumental que contudo não poderá desvincular-se de seu estar constituída a partir da negação e da exclusão de qualquer outra matriz cultural não integrável na dominante." (MARTÍN-BARBERO, 2008, p. 140).

A Proposta anuncia a necessidade de acesso a bens materiais: "Na sociedade de hoje, são indesejáveis tanto a exclusão pela falta de acesso a bens materiais quanto a exclusão pela falta de acesso ao conhecimento e aos bens culturais." (Proposta, p. 04). Essa passagem foi mudada no Currículo para: "Na sociedadede hoje, é indesejável a exclusão pela falta de acesso tanto aos bens

100 Currículo de São Paulo para o Ensino Fundamental- Ciclo II - e Ensino Médio, Caderno de Arte, 2008, p. 42 42. Tecnologias: Alice Vieira. Autores: Geraldo de Oliveira Suzigan, Gisa Picosque, Mirian Celeste Ferreira Dias Martins e Sayonara Pereira. 
materiais quanto ao conhecimento e aos bens culturais". (Currículo, p. 10). Nesse sentido, justificar-se-ia aí a entrada do cinema no contexto escolar como um bem cultural de natureza imaterial, conforme Art. 216, da Constituição Brasileira de 1988101, o que o Decreto de Lei no. 25, de 1937, emitido pelo então empossado Getúlio Vargas, no Estado Novo, não tinha a compreensão dessa dimensão imaterial como patrimônnio, ainda que se referisse à produção de natureza humana ${ }^{102}$.

O quarto item da Proposta dedica-se a defender a prioridade do ensino escolar, voltada para a competência da leitura e da escrita, conforme passagem: "A humanidade criou a palavra, que é constitutiva do humano, seu traço distintivo. 0 ser humano constitui-se assim um ser de linguagem e disso decorre todo o restante, tudo o que transformou a humanidade naquilo que é." (Proposta, p. 11). A seguir, apresenta uma relação de benesses que a entrada progressiva na razão conferiria ao jovem estudante.

Do ponto de vista social e afetivo, a centralidade da linguagem nos processos de desenvolvimento possibilita ao adolescente aprender, pouco a pouco, a considerar suas escolhas em uma escala de valores. Viabiliza-lhe aprender a enfrentar as conseqüências das próprias ações, a propor e alterar contratos, a respeitar e criticar normas, a formular seu próprio projeto de vida e a tecer seus sonhos de transformação do mundo (Proposta, p. 12).

A Proposta parece traçar um caminho certo e seguro para os jovens. Desnecessário dizer da falibilidade dessa aposta, que acredita "educar para a vida" (Proposta, p. 13), sem se dar conta de dizer-se fora dela ao se utilizar da preposição "para", compreendendo-se, pois, fora dela.

Mais uma vez, pensamos não se tratar de preciosismo quanto ao "uso" da língua, mas de atentar para as significações implicadas na língua. As

\footnotetext{
101“Art. 216. Constituem patrimônio cultural brasileiro os bens de natureza material e imaterial, tomados individualmente ou em conjunto, portadores de referência à identidade, à ação, à memória dos diferentes grupos formadores da sociedade brasileira (...)". Disponível em http://www.planalto.gov.br/ccivil_03/constituicao/ConstituicaoCompilado.htm

102 "Art. 1․ $\S 2^{\circ}$ Equiparam-se aos bens a que se refere o presente artigo e são também sujeitos a tombamento os monumentos naturais, bem como os sítios e paisagens que importe conservar e proteger pela feição notável com que tenham sido dotados pelo (sic) natureza ou agenciados pelo (sic) indústria humana.". Disponível em http://www.planalto.gov.br/ccivil_03/decretolei/Del0025.htm. 
características do caminho seguro antes mencionado são confirmadas pelo uso da preposição, anunciando um movimento de dentro para fora, como se fosse possível preservar os jovens da vida para que eles possam apropriar-se dela apenas depois que estiverem transformados em seres de linguagem.

Admite em determinado momento que a escola não é a única instituição detentora da informação, mas atribui a ela a função de "preparar seu aluno para viver em uma sociedade em que a informação é disseminada em grande velocidade" (Proposta, p. 14).

Já chamamos atenção para a produção da informação no capítulo sobre experiência e pobreza, momento em que abrigamos a ideia de que a informação, tal como ela é mobilizada majoritariamente pelas mídias e mesmo pela instituição escolar, parece concorrer para a inviabilização da produção da experiência pela pretensão de transmissão de fatos puros, desarticulados, apresentados com prazo de validade quase instantâneo, dada a necessidade estimulada no público para o ávido consumo de nova informação.

A esse propósito, chamávamos também atenção para a necessidade de a escola incorporar a seus propósitos os dados e o modo de produzi-los midiaticamente, visto serem tão presentes na vida cotidiana de alunos e professores. Num mundo eivado pela massa de informações desconexas que alimenta as telas dos aparelhos domésticos e portáteis, jornais televisivos ou impressos, o cinema, as caixas de entrada de e-mail e os diversos perfis em sites e blogs ou whatsapps, que são consultados diariamente, em alguma medida, podemos mesmo crer que se dar conta da natureza da produção da informação seja condição fundamental para entrar na experiência. Mas não apenas dar-se conta. Parece aí que o trabalho da escola é o de também instrumentalizar os sujeitos de modo que possam tomar posse dos mecanismos de poder que estabelecem (ou como se diz em jornalismo, que "pautam") a agenda que nutrirá as discussões informais do dia seguinte.

O estudo dos meios de produção midiáticos pode proporcionar aos estudantes a visibilidade da fabricação dos fatos jornalísticos, da intenção jornalística, que frequentemente silencia, oculta o esssencial. Esse trabalho de apropriação dos meios de expressão está em consonância com as competências 
que a Proposta (p. 14-15) indicará como objetivo do trabalho docente. Tais competências são tomadas do Exame Nacional do Ensino Médio - ENEM, que são, em resumo:

1 - "Dominar a norma culta da Língua Portuguesa e fazer uso das linguagens matemática, artística e científica".

2 - “Construir e aplicar conceitos das várias áreas do conhecimento para a compreensão de fenômenos naturais, de processos histórico-geográficos, da produção tecnológica e das manifestações artísticas”.

3 - "Selecionar, organizar, relacionar, interpretar dados e informações representados de diferentes formas, para tomar decisões e enfrentar situaçõesproblema".

4 - "Relacionar informações, representadas em diferentes formas, e conhecimentos disponíveis em situações concretas, para construir argumentação consistente."

5 - "Recorrer aos conhecimentos desenvolvidos na escola para elaborar propostas de intervencão solidária na realidade, respeitando os valores humanos e considerando a diversidade sociocultural".

Contudo, anteriores a essas cinco competências, estão o ler e o escrever, dois pressupostos pelos quais, se cumpridos, todas as outras competências são consequências. Para se ter ideia da pressuposição do ler e do escrever, sobre a terceira competência, diz o texto:

Ler implica também - além de empregar o raciocínio hipotéticodedutivo, que possibilita a compreensão de fenômenos antecipar, de forma comprometida, a ação para intervir no fenômeno e resolver os problemas decorrentes dele. Escrever, por sua vez, significa dominar os muitos formatos que a solução do problema comporta." (Proposta curricular, p. 15).

Como se pode perceber, a Proposta aposta no ler e no escrever como as grandes habilidades e competências a serem desenvolvidas pela escola. Tais designações - habilidade e competência - parecem se referir a execuções mecanizadas que seriam adquiridas prematuramente e não tivessem a ver com a existência dos sujeitos que, como se sabe, não são dados a ler ou a escrever textos 
indiscriminadamente com o mesmo interesse. Ler e escrever estão aí estritamente ligados à decodificação da letra impressa, secundarizando "leituras" e "escrituras" em outros formatos, seja pela imagem em movimento, seja pela pintura, dentre outras.

A Figura 7 abaixo indica que da Proposta Curricular do Estado de São Paulo derivam as propostas referentes a cada disciplina, que com ela devem estar em consonância, do mesmo modo que a Proposta deve estar em consonância com a LDB e os PCN. Analisaremos a seguir a Proposta referente à disciplina de Arte a fim de procurar perceber e analisar a concepção que aí se tem de arte.

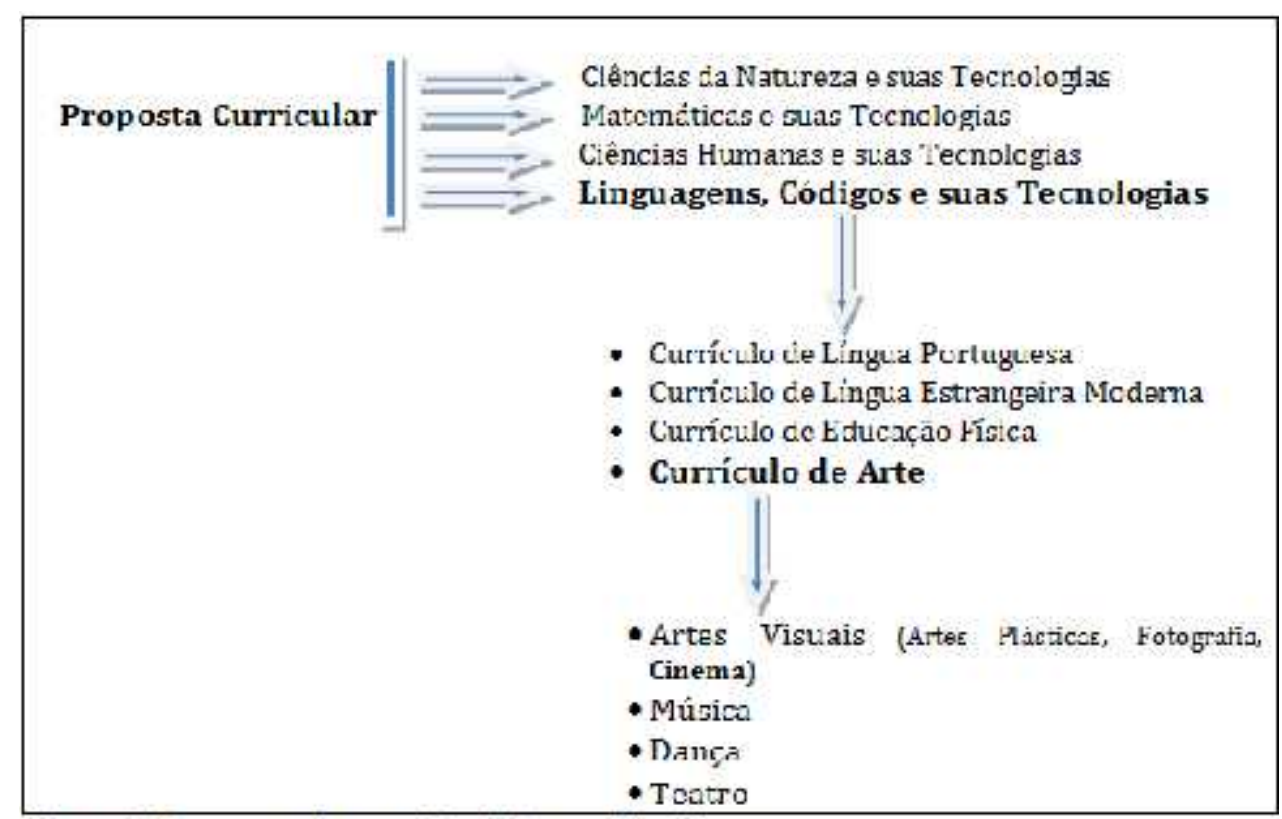

Figura 7: Fiuxograna Proposta Gurricular eas Disciplinas

Fazendo o percurso > Proposta Curricular do Estado de São Paulo > Linguagens, Códigos e suas Tecnologias > Currículo de Arte chegamos às quatro artes contempladas pelo documento (o mesmo se dá nos Cadernos do Professor do Currículo) que, como pode se ver na Figura7, são: as Artes Visuais, a Música, a Dança e o Teatro.

Apesar de o cinema ser considerado uma arte visual, tanto na Proposta, quanto nos PCN, ele não é abordado no Caderno de Arte nem citado. Nos PCN, ele é citado de passagem: 
A invenção do papel, das técnicas de impressão (xilo, calco, litogravuras) e posteriormente da prensa de Gutemberg são tecnologias que revolucionaram e ampliaram as possibilidades de construção e veiculação de textos e imagens, tal como provocaram o surgimento da fotografia, do cinema, da televisão e da informática. (PCN, 2006, p. 185, destaque nosso).

Em outra passagem, o cinema é relacionado a mídias cênicas, ao lado de "vídeo, internet e outros" (PCN, 2006, p. 185). E mais uma vez como mídia contemporânea: “televisão, vídeo, cinema, computador.” (PCN, 2006, p. 198).

Na parte 3 - "Exigências Didáticas nas Diversas Linguagens", dos PCN, o cinema é especialmente mencionado como arte, ainda que de modo insuficiente:

Também é desejável adotar uma perspectiva multicultural, em que a Literatura de um obtenha a parceria de outras áreas, sobretudo artes plásticas e cinema, não de um modo simplista, diluindo as fronteiras entre elas e substituindo uma coisa por outra, mas mantendo as especificidades e o modo de ser de cada uma delas, pois só assim, não pejorativamente escolarizados, serão capazes de oferecer fruição e conhecimento, binômio inseparável da arte (PCN, 2006, p. 74).

Não se sabe se o cinema aí é tomado como arte visual. 0 mais importante, contudo, é a apresentação da proposta expressa pelo termo "multicultural", "diluindo as fronteiras", mas "mantendo as especificidades e o modo de ser" de cada uma das artes. Desse modo, espera-se que a escola produza "fruição e conhecimento". Ainda que o cinema seja aí auxiliar da Literatura - "(...) em que a Literatura obtenha a parceria de outras áreas, sobretudo artes plásticas e cinema" -, ele parece adquirir nessas poucas linhas a consideração de suas especificidades como arte.

Nas outras passagens que encontramos nos PCN, o cinema (ou o audiovisual) é apenas mencionado como a lembrar de que algo aí se diferencia das artes visuais, como na seguinte passagem: "No que concerne à leitura, contempla pedagogicamente suas várias modalidades: a visual (mídia, cinema), a informática (digital), a multicultural e a crítica (presente em todas as modalidades)." (PCN, 2006, p. 98, destaques nossos). Ou nesta: "Pode-se dialogar em uma aula de Educação Física com outras linguagens, como a escrita ou a linguagem audiovisual" (PCN, 2006, p. 218). 
0 mesmo tratamento - o que não deixa de ser dissonante quanto ao cinema como Arte Visual - de lembrar que o cinema guarda diferenças em relação às artes visuais é encontrado na Proposta, como na passagem: "Inserida na área de Linguagens, Códigos e suas Tecnologias, aparece além de música, artes visuais, dança e teatro, as artes audiovisuais." (Proposta, 2008, p. 44). Contudo, em termos formais, o cinema é uma arte visual:

0 que faz com que cada arte tenha sua própria linguagem e seus modos e meios próprios de se fazer enquanto linguagem, para ir chegando cada vez mais perto da natureza específica do que nomeamos de artes visuais, teatro, música, dança ou cinema (Proposta, 2008, p. 41, destaques nossos).

Visto ter sido no mesmo documento destacado que há diferença entre as artes visuais e o audiovisual, parece ser, pois, de forma consciente que se deixa o cinema de fora dessas habilidades. Há, nesse sentido, um silêncio.

Sabe-se o quanto o "visual" de Artes Visuais é insuficiente para contemplar o cinema que, pois se trata de imagem em movimento, o som não é apenas acrescido, mas fundido à imagem. Ademais, o projeto $O$ Cinema vai à escola não é mencionado na Proposta nem no Currículo.

A carta da então secretária de Educação publicada na Proposta parece clara quando diz ser objetivo deste documento "atender à necessidade de organização do ensino em todo o estado." (Proposta - Arte, p. 05). Entende que sua importância é a de estabelecer para todo o estado de São Paulo referências que até então seriam sugestivas, contudo, na prática, tais sugestões têm força de lei já antes mesmo de sua passagem a Currículo, dois anos depois. A seguir, ela é mais clara quanto a esse ponto da organização e da função de um currículo para o estado: "A criação da Lei de Diretrizes e Bases (LDB), que deu autonomia às escolas para que definissem seus próprios projetos pedagógicos, foi um passo importante. Ao longo do tempo, porém, essa tática descentralizada mostrou-se ineficiente". A autonomia da escola não é prevista no Código da Educação do Estado de São Paulo, de 1933, ainda que a do professor seja citada apenas uma vez, como lembra José Mário Pires Azanha (1993, p. 34). Azanha ainda lembra que, apesar de as LDB (Lei no. 4.024/61 e Lei no. 5.692/71) não usarem a palavra "autonomia", elas prescreviam que as escolas públicas e privadas deveriam "organizar-se por meio 
de regimento próprio" (AZANHA, 1998, p. 34). Apenas na LDB no. 9.394/96, pela primeira vez, a

autonomia escolar e projeto pedagógico aparecem vinculados num texto legal. 0 Art. 12 (inciso I) estabelece como incumbência primordial da escola a elaboração e execução de sua proposta pedagógica, e os artigos 13 (inciso I) e 14 (incisos I e II) estabelecem que essa proposta ou projeto é uma tarefa coletiva, na qual devem colaborar professores, outros profissionais da educação e as comunidades escolar e local (AZANHA, 1998, p. 35).

Ao contrário de Azanha, que festeja ("representa um extraordinário progresso", p. 35) em seu texto o aparecimento do termo "autonomia" relacionado à escola, a declaração "ineficiente" da secretária de educação do Estado de São Paulo na ocasião do lançamento da Proposta parece selar a postura do estado diante da organização das escolas quanto ao currículo. Diferente teria sido se o termo usado fosse, por exemplo, "insuficiente". A lei a que a secretária se refere é a Lei no. 9.394, de 20 de dezembro de 1996103, em seu Art. 15, promulgada pelo então presidente Fernando Henrique Cardoso, em que atribui autonomia pedagógica às unidades escolares como se pode constatar:

Os sistemas de ensino assegurarão às unidades escolares públicas de educação básica que os integram progressivos graus de autonomia pedagógica e administrativa e de gestão financeira, observadas as normas gerais de direito financeiro público (BRASIL, 1996, Art. 15, caput, Lei no. 9.394/96).

Em outro Artigo dessa mesma lei, faz-se referência à base comum pedagógica nacional que todas as instituições de ensino superior responsáveis pela formação de profissionais de educação deverão manter. A lei, pois, não se refere apenas às unidades escolares do ensino básico como podemos constatar a seguir:

Art. 64. A formação de profissionais de educação para administração, planejamento, inspeção, supervisão e orientação educacional para a educação básica, será feita em cursos de graduação em pedagogia ou em nível de pós-graduação, a critério da instituição de ensino, garantida, nesta formação, a base comum nacional (BRASIL, 1996, Lei no. 9.394/96, grifo nosso).

${ }^{103} \mathrm{http} / /$ www.planalto.gov.br/CCIVIL_03/leis/L9394.htm 184 
Ora, cada escola, sabemos, tem singularidades que precisam ser contempladas em cada currículo, do contrário o ensino se descontextualiza. A LDB teria considerado tal idiossincrasia ao delegar a cada escola possibilidade dessa organização interna. Assim, caracterizar a possibilidade de tal autonomia como ineficiente parece pouco preciso quando se quer ressaltar a importância de uma Proposta com a pretensão de organizar o ensino, ainda que no parágrafo posterior, o tom seja diminuído cujo objetivo, então, seria o de "organizar melhor" o sistema educacional do estado de São Paulo.

Nesse sentido, o primeiro desacerto desse documento talvez seja exatamente o de pretender-se universalizante indo na contramão da autonomia escolar. Na carta do secretário de Educação, o engenheiro Herman Voorwald, publicada apenas na versão impressa do Currículo, o intento da publicação da nova edição do Currículo é logo revelado nas primeiras linhas: "Esta secretaria manifesta a expectativa de que as orientações didático-pedagógicas nele [no Currículo] contidas contribuam para que se efetivem situações de aprendizagem em cada disciplina (...)”. (Currículo, São Paulo, 2012, p. 03, versão impressa). Mais uma vez a questão da aprendizagem aparece forte de saída, alimentando o tom técnico do texto.

Curioso que numa carta à comunidade escolar, o secretário de educação adote um tom técnico, ressaltando o "ensino de qualidade" como o grande responsável pelo aprendizado e como o intento maior desta nova edição, que ele assina. Mais uma vez, salta a crença na relação causal direta entre ensino e aprendizagem. Assim, basta que se tenha um ensino de qualidade para se obter, por consequência, um bom aprendizado. 0 objetivo do material é que seja utilizado como instrumento a fim de "alavancar o ensino de qualidade". Mais uma vez, a ênfase é dada ao ensino.

A seguir, acrescenta que os cadernos do Currículo ("Cadernos do Professor") foram elaborados por "especialistas de cada área do conhecimento, com a valiosa participação crítica e propositiva dos profissionais do ensino". (p. 03). Sobre a participação dos professores na elaboração da Proposta, segundo o site da FDE (notícia de 06/12/2007), a SEE-SP recebeu em um mês e meio cerca de 
três mil ideias dos professores ${ }^{104}$, que seriam publicadas no ano seguinte. Será a primeira vez que o estado de São Paulo terá na rede estadual, um guia unificado de conteúdos curriculares para as escolas. Ainda de acordo com o site, a proposta curricular é uma demanda dos professores, especialistas e famílias dos alunos. Quanto à participação na elaboração ou revisão do Currículo não encontramos nenhuma referência à participação dos professores.

A secretária de Educação na ocasião da elaboração da Proposta, a socióloga Maria Helena Guimarães de Castro, diz acerca da participação dos professores para a Proposta: "As sugestões de professores são fundamentais para a formação das propostas curriculares. É importante a participação de toda a rede de educação do Estado", afirma o site, sugerindo legitimidade do material em questão por meio da participação dos professores.

Pelas declarações oficiais da SEE-SP e pela divulgação de informações sobre a Proposta entende-se que a participação dos professores se dá também pelo planejamento anual que acontece em dois dias nas próprias escolas. Assim, "todos os professores da rede estadual passaram por dois dias de planejamento, nesta segunda e terça-feiras. (sic)”. E em 2007, “cerca de quarenta especialistas de todo o Brasil se reuniram semanalmente com membros da Secretaria para a formulação do documento, que teve ampla participação de professores da rede"105, informa o site da FDE. Foram dois os tipos de participação. 0 primeiro geral, nos dois dias de planejamento realizado nas escolas, em que os professores organizam seus planos para o semestre letivo. 0 outro tipo foi composto por especialistas. Apesar da participação ativa de um grupo de especialistas e da participação diluída dos professores na elaboração da Proposta, a SEE-SP assegura a dimensão da autonomia do trabalho do professor. Assim, "todos os novos livros são complementares aos materiais didáticos, que continuam na rede. E os professores seguem com autonomia para complementar a proposta e definir as melhores formas de ensinar." E a seguir, parecendo contradizer o processo de decisão e de

\footnotetext{
104 O site não oferece nenhuma informação sobre o teor dessas ideias. De acordo com o site da SEESP (http://www.educacao.sp.gov.br/portal/institucional/a-secretaria/, acesso no dia 20 de outubro de 2015), a rede estadual de Ensino de São Paulo é composta por um contingente de 230 mil professores, o maior do país.

105 http://www.fde.sp.gov.br/PagesPublic/Noticias.aspx?contextmenu=buscaspub\&noticia=612, acesso dia 11 de setembro de 2015 .
} 186 
elaboração coletiva do documento: “O governo do Estado já implantou106 expectativas de aprendizagem para as séries do $1^{\mathrm{o}}$ ciclo do Ensino Fundamental $\left(1^{\mathrm{a}} \text { a } 4^{\mathrm{a}}\right)^{\prime \prime} 107$.

O material, que teria tido "valiosa participação dos profissionais do ensino", é apresentado como resultado do trabalho de poucas pessoas (especialistas). Considerando que a Rede Estadual de Ensino de São Paulo corresponde a aproximadamente 230 mil professores ${ }^{108}$, constituindo-se como a maior do país, perguntar-se-ia se o trabalho realizado teria força de representação já que ele passa de uma Proposta Curricular a Currículo. Isto é, assume tom oficial e obrigatório para os professores com quem, diz o secretário ainda na mesma carta, "contamos com o acolhimento e a colaboração". É nesse sentido que Marcos Napolitano indica como o principal problema do projeto $O$ cinema vai à escola o fato de ele não ter sido "bem utilizado na ponta"109. Para ele, a SEE-SP/FDE deveria ter dado atenção especial para a formação e sensibilização de diretores e coordenadores das escolas quanto ao material do projeto e fomentado entre os professores o seu uso. Acreditou-se que a adesão à aplicação do projeto se daria naturalmente, o que não veio a se confirmar.

Se por um lado, não fica claro se houve participação do professor e como teria se dado tal participação na elaboração da Proposta, por outro, quanto aos demais trabalhos (livros didáticos, Currículo, projeto $O$ cinema vai à escola etc.), certo é que ela é praticamente nula. Salvo espaço para Registro de Experiências no site da SEE-SP, não se tem mais nenhum outro indicador. É flagrante e significativa a expressão "o governo do Estado já implantou expectativas", sintoma de hierarquização, mesmo em projetos de apelo popular, como é o caso d'O cinema vai à escola, tanto na elaboração do material em formato escrito, quanto nos vídeos ou na seleção dos filmes.

\footnotetext{
1060 tom aqui não parece corresponder ao anterior, pois o modo de anunciar que o "governo do Estado já implantou expectativas (...)", é contrastado ao que imediatamente antes o mesmo texto falara em autonomia, entre o governo garantir a autonomia dos professores e ele próprio "implantar" expectativas parece haver uma contradição.

107http://www.fde.sp.gov.br/PagesPublic/Noticias.aspx?contextmenu=buscaspub\&noticia=612, acesso dia 11 de setembro de 2015, grifo nosso.

108Fonte: http://www.educacao.sp.gov.br/portal/institucional/a-secretaria/, acesso em 23 de agosto de 2015.

${ }^{109}$ Entrevista concedida por Marcos Napolitano ao autor, em 16 de maio de 2016.
} 
Parece não ser pouco relevante, enfim, que os professores não participem nem mesmo de consulta quanto aos filmes a serem fornecidos pela SEE-SP/FDE ou em pesquisas sobre que filmes comumente veem a fim de serem montadas estratégias pedagógicas. Se pensarmos que tais professores executarão a tarefa diária de apresentar e desenvolver junto aos estudantes conteúdos e temas curriculares, parece razoável que esses profissionais tenham espaços qualificados para discussão e escuta. No entanto, a participação dos professores a que se refere o secretário diz respeito a sugestões pontuais dos docentes, enviadas ao site da SEE-SP. Não se trata, pois, da seleção dos temas nem dos pormenores das atividades nos cadernos, atividades de cunho didático.

Não se sabe exatamente o que dessas sugestões dos professores foi aproveitado para a elaboração da Proposta Curricular. Os critérios para participação são pouco transparentes. É possível que as ideias que teriam sido sugeridas por professores como participação procure gerar a sensação de que os professores poderiam participar da concepção do material, caso quisessem, apresentando sugestões, o que geraria, por consequência, um sentimento de coautoria do material.

Contudo, esse alheamento do professor quanto ao processo de produção de seu próprio material de trabalho, que teria a ver com suas escolhas e com a constituição do discurso no exercício da profissão, certamente implicará em quanto o currículo produzirá marcas de significação no professor e, por consequência, nos alunos. Desnecessário dizer o quanto a presença ou não de marcas de subjetividade do professor implica seu trabalho. Assim, torna-se difícil esperar que o professor acolha a pluralidade de sentidos em que se constitui a experiência do cinema ${ }^{110}$, se ele, em certo sentido, está ausente.

\footnotetext{
110 Ideia presente na palestra proferida pelo Prof. Marcos Napolitano, em 06 de maio de 2010, em evento - Cultura é currículo: análise de filmes em sala de aula - promovido pela FDE como orientação técnica - Em cena: o cinema, o teatro e a dança - dentro do programa Cultura é Currículo. 0 vídeo encontra-se disponível em https://www.youtube.com/watch?v=n1UTnjFnBws. Acesso dia 05 de fevereiro de 2016. 188
} 


\section{5- A Disciplina Arte na Proposta Curricular e no Currículo do Estado de São Paulo}

Neste item, interessa-nos tratar da concepção da disciplina Arte na Proposta Curricular do Estado de São Paulo e no Currículo do Estado de São Paulo, levando em conta o agrupamento que aí se faz das artes. Para isto é importante o uso que a Proposta e que o Currículo fazem das concepções de arte e de cinema e o modo como essas concepções aparecem no projeto $O$ cinema vai à escola.

A Proposta segue a divisão das áreas de conhecimento estabelecida pelos PCN (2010): 1) Ciências da Natureza e suas Tecnologias, 2) Matemáticas e suas Tecnologias, 3) Ciências Humanas e suas Tecnologias e 4) Linguagens, Códigos e suas Tecnologias. A disciplina Arte está situada nesta última, juntamente com Língua Portuguesa, Literatura Estrangeira Moderna (LEM) e Educação Física. A disciplina Arte - entendida como "modos de intervenção artística e seus processos de criação" (Currículo, p. 216) - compreende Artes Visuais, Dança, Música e Teatro; por sua vez, Artes Visuais compreendem fotografia, artes plásticas e cinema.

Considerando essa configuração em que se encontram as artes na Proposta, dois problemas se apresentam. 0 primeiro trata-se de uma desconfiança que se confirma com a verificação da distribuição das atividades nos Cadernos do Professor e nos Conteúdos destinados à disciplina Arte na Proposta e no Currículo, qual seja, a de que o tempo das três artes que constituem as Artes Visuais (25\% do total destinado às Artes em geral) seria dividido equitativamente em três para serem atendidas igualmente em sala de aula.

O segundo problema diz respeito ao estatuto propriamente ontológico do cinema, uma vez que a designação "visual”, de Artes Visuais, é adequado à fotografia e às Artes Plásticas, mas não ao cinema111. Não é que atenda em parte por ser apenas insuficiente, pois que o cinema como uma arte parcialmente visual seria algo da ordem do visual + sonoro. Ora, o cinema não se constitui nessa operação de justaposição de imagem e som, mas de um todo, amálgama audiovisual: áudio e visual em movimento articulados de tal maneira que um

111 Sobre o "estatuto ontológico do cinema", conferir p. 47 deste trabalho. 
recondiciona o outro, embora não se possa afirmar que o que o termo "audiovisual" designe seja o que é próprio do cinema. A falta desse cuidado quanto ao uso do termo "artes visuais" para o cinema parece já expressão de menor atenção dada a essa arte.

Assim, o fato de o cinema, junto com fotografia e artes plásticas, compor as chamadas Artes Visuais, parece ser relevante para notar seu apagamento diante das outras, desmerecida mesmo diante da fotografia e das artes plásticas. Considerando essas ponderações, não seria o caso de o cinema, e também da fotografia e das artes plásticas, aparecer de modo autônomo, como o são Dança, Música e Teatro - uma vez que como já foi explicitado o cinema não é uma arte puramente visual?

Teoricamente, a Proposta pretende promover o mapeamento de territórios da arte que se articulam entre si, propondo conceitos geradores de processos educativos (São Paulo. Proposta: Arte, 2008, p. 41). A arte aí é entendida como "uma linguagem de potência estranha" (São Paulo. Proposta: Arte, 2008, p. 41), ainda que cada arte tenha sua especificidade. Curioso, todavia, que o cinema não seja mesmo mencionado na "Situação de Aprendizagem 7", do Caderno do Professor da 2ª . Série do Ensino Médio, referente à discilina "Arte", que trata das Artes Visuais.

O destaque dado ao termo linguagem talvez justifique o esforço teórico por parte da Proposta ao definir o que é a linguagem, referida às quatro artes mencionadas, seguindo a definição que consta dos PCN de 2006:

Linguagem é a capacidade humana de articular significados coletivos em sistemas arbitrários de representação, que são compartilhados e que variam de acordo com as necessidades e experiências da vida em sociedade. A principal razão de qualquer ato de linguagem é a produção de sentido (Proposta - Arte, p. 37).

0 texto indica a linguagem como característica humana de articular significados. Essa abertura, no entanto, não é suficiente para contemplar a chave anunciada na expressão "estética da sensibilidade", presente nos PCN, na Proposta 
e no Currículo. A passagem acima destaca a linguagem como a articulação de "significados coletivos" e como "ato de produção de sentido", considerando arte aquela própria do sistema das artes, do academicismo. Vale destacar, que será essa a predominância no uso pensado para os filmes em sala de aula no projeto $O$ cinema vai à escola, qual seja, a produção de sentido e não a compreensão da arte como processo, em que a experiência se presentifica e cujo significado é, por vezes, secundário (como acontece com o teatro pós-dramático ou com a música seriada de Erik Satie ou nos filmes de Antonioni).

A multiplicidade das linguagens é assim compreendida na Proposta: “À medida que ele [o homem] se torna mais competente nas diferentes linguagens, torna-se mais capaz de conhecer a si mesmo, assim como a sua cultura e o mundo em que vive." (Currículo do Estado de São Paulo - Linguagens, Códigos e suas Tecnologias, 2012, 2ª . edição, p. 27). A relação entre ser competente quanto às habilidades indicadas pelas linguagens (leitura, escrita, artes, ciências etc.) e o "conhece-te a ti mesmo" não é direta nem automática. Como se sabe, a relação platônica de implicação direta entre ser filósofo e ser virtuoso já não se sustenta. Aliás, o que é confirmado pela psicanálise ao colocar sob suspeita a racionalidade do discurso para a compreensão que as pessoas fazem de si mesmas.

Determinadas expressões presentes na Proposta, entre as quais apresentamos algumas a seguir, denotam compreensão da linguagem como meio de aquisição de conhecimentos. São expressões que encontramos nas seguintes passagens: “(...) a experiência escolar tranforma-se em uma vivência que permite ao aluno compreender as diferentes linguagens e usá-las como meios de organização da realidade (...) em um processo centrado nas dimensões comunicativas da expressão, da informação e da argumentação." (Proposta - Arte, p. 37, destaques nossos); "O conhecimento de natureza enciclopédica, sem significação prática, é substituído por conteúdos e atividades que possibilitam não só a interação do aluno com sua sociedade, mas também o aumento do seu poder como cidadão" (Proposta- Arte, p. 37, destaques nossos). Em outro parágrafo, o texto afirma que

utilizar-se da linguagem é saber colocar-se como protagonista do processo de produção/recepção. É também entender os princípios 
das tecnologias da comunicação e da informação, associando-os aos conhecimentos científicos e às outras linguagens, que lhes dão suporte (Proposta - Arte, p. 37).

Podemos flagrar nessas passagens o uso instrumental que se faz da linguagem ("utilizar-se da linguagem"), um modo de não se dizer que tudo ocorre na linguagem, fazendo-se uso dela. 0 texto não estabelece conexão entre linguagem e pensamento na constituição do sujeito. Assim, a Proposta parece crer na assimilação do objeto pelo sujeito como o único processo de conhecimento. É sintomática dessa crença a expressão utilizada por professores "passar conteúdo" tão comum no meio escolar. Ela denota a simplificação da compreensão do processo de produção de sentido, isto é, entendendo que se pudesse, em tal processo, depositar o conteúdo na mão de alguém. 0 mesmo se dá com outra expressão também corrente no meio escolar: "dar aulas". Não parece de nossa parte preciosismo tomar tais expressões para reforçar uma crítica a essa concepção de linguagem, mas para indicar como essas expressões espelham uma prática fundada em uma concepção de sujeito inteiro, não clivado. Pois dar aulas pressupõe, de um lado, alguém que tome o "conteúdo" de uma aula como substância e, de outro, alguém, idealizado, que pode receber tal substância. Essa passagem, essa entrega da substância, dar-se-ia num trânsito sem ruídos, cuja comunicação, com certos procedimentos de zelo pedagógico, pode ajudar a eliminar. Nesse caso, o lugar do fundamento está bem definido. De outro modo, o papel da educação seria, como afirma Safatle, colocar o fundamento em um nãolugar, vale dizer, em "posição problemática." (SAFATLE, 2006, p. 26) e não definitiva.

Assim, há na Proposta uma vontade totalizante, uma vontade de completude. Para esse documento, os alunos estão "se preparando para assumir plenamente sua cidadania" (Proposta, p. 16). O negativo, esse não-lugar, apontado por Hegel e por Lacan, de acordo com Safatle, ao contrário, confronta as ilusões de completude. Ao contrário do sujeito clivado apontado pela psicanálise e por vários filósofos, desde Hegel a Foucault, o Currículo pensa um sujeito previamente formado e que precisa de experiências junto a exterioridades heterônomas para que passe a integrá-las. Vejamos a seguinte passagem: 
Para destacar o fato de que se trata de sujeitos que se movimentam em contextos concretos, com significações e intencionalidades, tem-se utilizado a expressão 'Se-Movimentar'. 0 'Se', propositadamente colocado antes do verbo, enfatiza o fato de que o sujeito (aluno) é autor dos próprios movimentos, que estão carregados de suas emoções, desejos e possibilidades, não resultando apenas de referências externas, como as técnicas esportivas, por exemplo. Estamos nos referindo ao movimento próprio de cada aluno. Por isso, um aluno pode gostar de movimentar-se em certo contexto, mas não em outro, embora os movimentos/gestos possam ser os mesmos (por exemplo, dançar) (Currículo, p. 224-225).

A princípio parece se tratar de uma formulação interessante a que acabamos de ler acima, pois a proposta de pensar aí a movimentação dos alunos em diversos contextos, possibilitando a vivência nesses contextos distintos; por consequência, produziria certa tolerância quanto ao diferente, entendendo que cada pessoa possuiria seu repertório cultural e que precisaria experimentar outros com vistas a sua ampliação, conforme se lê logo adiante: "Ora, a educação escolarizada visa a aumentar o repertório dos alunos, influir em suas vidas, mobilizar seus desejos e potencialidades, possibilitando a tomada de consciência de suas vinculações socioculturais." (Currículo, p. 225). No entanto, como atesta Tomaz Tadeu da Silva (2009), o que se produz aí não se trata da diferença, mas da diversidade. Interessa considerar, diz ele, como a diferença e a identidade são produzidas. Portanto, não se trata apenas de vivenciar a diversidade tão somente, no sentido de ampliar matematicamente ("aumentar o repertório") o repertório cultural.

Para a Proposta, a via de realização da "plenitude cidadã" é tornar a "aprendizagem (...) o centro da atividade escolar." (Proposta, p. 18). Nesse sentido, todo o esforço escolar se dará para compor um ensino que gere determinado aprendizado. Trata-se da conhecida relação causal ensino-aprendizagem.

A seguinte fórmula é expressão dessa noção de acabamento:

A lei determina ${ }^{112}$ um prazo generoso para que os alunos aprendam o 'significado das ciências, das artes e das letras': começa na educação infantil, prossegue nos anos do Ensino Fundamental e tem mais três anos no Ensino Médio. Durante mais

112 A única alteração no texto da Proposta está na substituição da palavra "dá", "A lei dá um prazo (...)" (p. 21) para "A Lei determina um prazo (...)” (p. 22), no Currículo. 
de doze anos deverá haver tempo suficiente para alfabetizar-se nas ciências, nas humanidades e nas técnicas entendendo seus enfoques e métodos mais importantes, seus pontos fortes e fracos, suas polêmicas, seus conceitos e, sobretudo, o modo como suas descobertas influenciam a vida das pessoas e o desenvolvimento social e econômico (Currículo, p. 22).

Estranha formulação essa, principalmente no que diz respeito à expressão "prazo generoso", como se se tratasse de uma concessão, de um favor. 0 que mais chama atenção é, todavia, o que vem a seguir: "para que os alunos aprendam o 'significado das ciências, das artes e das letras'”. Tal como formulada, a ideia parece que o cronômetro disparou e que os alunos têm um determinado tempo (que é de sobra, pois generoso) para que eles concebam uma única coisa: o significado das disciplinas. A impressão que se tem é a de que se trata mesmo de uma substância, de unidades autônomas de sentido ou a descoberta de um tesouro: o significado das ciências. Chama atenção ainda a continuidade do texto, que assegura que, "durante mais de doze anos deverá haver tempo suficiente para alfabetizar-se nas ciências, nas humanidades e nas técnicas entendendo seus enfoques e métodos mais importantes (...)". Curioso que esse parágrafo, que procura dar conta da missão educativa da escola não faça menção à vida que corre para fora dos muros ou mesmo dentro deles. Referimo-nos à língua propriamente em seu uso cotidiano que, como se sabe, é em muito diversa da que se estuda na escola; a matemática, que não é utilizada para entender e projetar a economia doméstica ou para entender a gestão do erário público, e assim por diante. Não seria exatamente no currículo o lugar dessas afirmações ou do tratamento de tais questões? Ora, o enunciado de que o tempo atribuído para a alfabetização nas várias áreas de que trata o ensino não parece inócuo?

Quanto às artes, o texto chama atenção para que seu ensino não se dê de modo estritamente histórico, desvinculado da produção de sentido da diferença, da potência da linguagem:

Como manifestações culturais, a Literatura e a Arte não devem ser reduzidas a meras listagens de escolas, autores e suas características. 0 ensino de Arte não pode equivaler nem ao conhecimento histórico, nem à mera aquisição de repertório, e 
muito menos a um fazer por fazer, espontaneísta, desvinculado da reflexão e do tratamento da informação (Proposta, p. 38).

Em seguida, o texto faz menção à importância da contextualização dos assuntos abordados em sala de aula, pois que é assim que os alunos seriam mais facilmente despertados para o assunto. 0 texto apresenta três tipos de contextualização: sincrônica, diacrônica e a interativa. A primeira delas diz respeito à relação do assunto com o tempo que o gerou, as condições de receptividade da época. A segunda procura elucidar de que modo o assunto foi registrado na história do pensamento, o que nela o conduziu à história, como ele foi apropriado por outros autores. A terceira procura responder a perguntas como: de que modo o texto é visto hoje, sua atualidade, por que se deve estudá-lo.

A Proposta faz um histórico das concepções de Arte presente na escola brasileira. Lembra que ela era considerada uma atividade e que passa a se constituir como componente curricular na LDB, em 1996. (Proposta: Arte, 2008, p. 43). Ressalta que, ainda que os processos artísticos sejam abertos, nos PCN há uma expectativa de aprendizado em cada modalidade artística (Proposta: Arte, 2008, p. 43). Pergunta-se se esses processos educativos permitem uma apropriação dos alunos em relação às obras de arte, fazendo com que eles participem de uma experiência cultural educacionalmente relevante: "Quais processos educativos são desencadeados nas escolas para que os bens materiais e imateriais da cultura produzam em crianças e jovens o sentimento de pertencimento?" (Proposta: Arte, 2008, p. 42). Pergunta-se ainda sobre os modos de provocar esta aproximação dos sujeitos que compõem o ambiente escolar com a arte e "com quais campos de arte se faz um pensamento curricular para a área (....)." (Proposta: Arte, 2008, p. 43)? Preocupações fundamentais a serem consideradas para se projetar o papel da arte no ensino básico.

Como se percebe pelas citações acima, a concepção de arte na escola mudou desde a Lei de Diretrizes e Bases da Educação, Lei no. 5.692/71113, implantada durante a ditadura militar, em que a Educação Artística passa a ser disciplina obrigatória, juntamente com Educação Moral e Cívica, Educação Física e

113 A Proposta fez referência equivocada, quando apresenta a Lei N. 5.691/73 (p. 43), sendo corrigida no Currículo, Lei N. 5.692/71 (p. 187). 
Programas de Saúde. Educação Moral e Cívica já havia sido implantada pela Lei n. 869 de 12 de setembro de 1969. Os cursos de formação de professores de Educação Artística eram de curta duração; habilitando-os para ensino no Ensino de 1ํ. Grau, da 1aa à 8ª série, conforme Art. 30, alínea b da lei (para ser professor do ensino de 1o. Grau, de 1a. à 4⿳a a série bastava ter o $2^{\circ}$. Grau). Contudo, esse profissional com Licenciatura Curta poderia lecionar até a $2^{a}$. série do $2^{\circ}$. Grau se adicionasse a seus estudos um ano ${ }^{114}$ de complementação. Segundo o texto da Proposta (Arte), uma proposta da Coordenadoria de Estudos e Normas Pedagógicas - CENP - nos anos 1990, muda esse cenário do ensino das artes. A proposta da CENP para o antigo 1‥ Grau, segundo a Proposta Curricular de 2008, não dizia respeito à diluição de campos de cada arte, caso da compreensão da LDB de 1971, conforme vimos, mas a de afirmação das diferenças dos campos distintos de arte pela centralização "numa só linguagem ou estimulando a passagem de uma para outra." (Proposta: Arte, 2008, p. 43). Para o 2‥ Grau, ainda segundo a Proposta, tratou-se de evidenciar "a multiplicidade e interdependência entre as dimensões da arte. (...) Expressão, construção e representação (...)." (Proposta: Arte, 2008, p. 43).

Nesse sentido, como já dito, a arte deixa de ser uma atividade informal e passa a ser uma disciplina, com a complexidade comum de uma organização epistemológica: "a investigação da Arte na escola como um saber, um conhecimento (...)." (Proposta: Arte, 2008, p. 45).

Para a Proposta, e também para o Currículo, são três os eixos em que se anuncia se basear o ensino da Arte na rede estadual de ensino: "1) Criação/produção em Arte - o fazer artístico; 2) Fruição estética - apreciação

114 “Art. 30. Exigir-se-á como formação mínima para o exercício do magistério:

a) no ensino de $1^{0}$ grau, da $1^{\text {a }}$ à $4^{a}$ séries, habilitação específica de $2^{\circ}$ grau;

b) no ensino de $1^{\underline{o}}$ grau, da $1^{\text {a }}$ à $8^{\underline{a}}$ séries, habilitação específica de grau superior, ao nível de graduação, representada por licenciatura de $1^{\text {o }}$ grau obtida em curso de curta duração;

c) em todo o ensino de $1^{\text {o }}$ e $2^{\circ}$ graus, habilitação específica obtida em curso superior de graduação correspondente a licenciatura plena.

$\S 1^{\mathrm{o}}$ Os professôres a que se refere a letra a poderão lecionar na $5^{\underline{a}}$ e $6^{\underline{a}}$ séries do ensino de $1^{\mathrm{o}}$ grau se a sua habilitação houver sido obtida em quatro séries ou, quando em três mediante estudos adicionais correspondentes a um ano letivo que incluirão, quando fôr o caso, formação pedagógica. $\S 2^{\mathrm{o}}$ Os professôres a que se refere a letra b poderão alcançar, no exercício do magistério, a $2^{\mathrm{a}}$ série do ensino de $2^{\circ}$ grau mediante estudos adicionais correspondentes no mínimo a um ano letivo. $\S 3^{\circ}$ Os estudos adicionais referidos nos parágrafos anteriores poderão ser objeto de aproveitamento em cursos ulteriores." Disponível em http://www.planalto.gov.br/CCIVIL_03/leis/L5692.htm. 196 
significativa da Arte e do universo a ela relacionado; leitura; crítica; 3) Reflexão: a Arte como produto da história e da multiplicidade de culturas." (Proposta: Arte, 2008, p.46). Nesse ponto, o texto parece atento ao imprevisível da arte. Sua tonalidade estende-se, por exemplo, à relação pouco definida entre obra e espectador. Afirma que há um olhar de volta da obra, quando a olhamos e esse olhar provoca ressonâncias em quem olha, "abrindo fissuras em nossa percepção, arranhando a nossa sensibilidade por meio de seus signos artísticos." (Proposta: Arte, 2008, p. 47). É nesse sentido que Jorge Coli (2009) afirma que a obra é sujeito, pois ela emite sinais, elementos que são captados ou não pelo espectador. O texto da Proposta sugere que, a partir dessa sensibilização da percepção, das fissuras provocadas nos modos de olhar a obra, o professor, ao selecionar aquelas obras que serão utilizadas com os alunos, assume ele próprio o lugar de curador.

Vale destacar que raros são os momentos nesses documentos em que o professor é apontado como central no processo educativo. Sabe-se, o seu papel não deve se limitar à seleção das obras, mas também ser o de escolher os meios de apresentação das artes em diversos ambientes: escolas, museus, cinemas, igrejas, ruas, dentre vários outros. Além disso, no caso da exibição de um filme, cabe ao professor avaliar as condições de sua projeção, pois com frequência há inúmeros fatores que prejudicam-na na escola a ponto de inviabilizá-la. Isso em razão de única fonte de som provir da televisão e a ausência de blackout, por exemplo. Nessas condições, a curadoria do professor pode ser ineficaz, já que o que se vê e se ouve nesses casos é outro filme, não aquele que seria visto em condições ideias. Assim, o professor poderá optar pela exibição de trechos previamente selecionados por ele e apresentá-los para pequenos grupos por vez, para que se assegure de que os alunos tenham contato com a obra o mais próximo possível do original. Tais trechos, ao contrário do que a ortodoxia cinéfila prescreve, podem se constituir em índice da obra, fazendo com que os estudantes se sintam estimulados pelo aperitivo apresentado. Ao exibir o filme inteiro em más condições de projeção, o professor pode estar exigindo demasiadamente do aluno-espectador um comportamento idealizado e provocando uma experiência exaustiva.

De um jeito ou de outro o lugar que o professor ocupa na sala de aula e na escola é fundante. Para ressaltar a importância desse lugar a ser ocupado pelo 
professor - como aquele que, apesar de não participar ativamente da constituição do currículo pode, contudo, interferir significativamente na seleção e no modo de como e o que deve ser tematizado e problematizado na escola - tal passagem da Proposta parece configurar a "esquizofrenia" de um documento que tira o lugar do professor, quando lhe confere o papel de aplicador de um programa entregue a ele do "exterior", e, numa determinada passagem, ensaia devolver-lhe o lugar.

Os conteúdos e conceitos a serem desenvolvidos pelo professor são sugeridos pela Proposta para a organização do ensino da $5^{\mathrm{a}}$. série até a $2^{\underline{a}}$. do Ensino Médio. Tomaremos as duas primeiras do Ensino Médio por se tratar da circunscrição do projeto $O$ cinema vai à escola, que é voltado para escolas de Ensino Médio da rede estadual.

As sugestões de conceitos e conteúdos a serem trabalhados são organizadas por bimestre para cada ano. Assim, tem-se: 
Quadro 1 - Conteúdo curricular da disciplina de Arte nas 1a․ e 2a․ séries do Ensino Médio, 1ํ․ Bimestre.

\begin{tabular}{|c|c|}
\hline 1a série & $2^{\text {a Série }}$ \\
\hline $1^{\circ}$ bimestre & $1^{\circ}$ bimestre \\
\hline $\begin{array}{l}\text { Cidade, cultura e práticas culturais } \\
\text { - patrimônio cultural imaterial e material; } \\
\text { tradiçăo e ruptura; arte contemporânea; } \\
\text { educação patrimonial } \\
\text { - arte pública; intervençōes urbanas } \\
\text { - paisagem sonora; músicos da rua } \\
\text { - joncola de samba; tambor de crioula; } \\
\text { dança contemporanea; dança popular } \\
\text { - tartes circenses; circo tradicional; circo } \\
\text { contemporâneo; palhaço/clow e a } \\
\text { tradiçăo cômica; folia de reis; palhaços } \\
\text { de hospital } \\
\text { - pré-projetos de intervençáo na escola }\end{array}$ & $\begin{array}{l}\text { O encontro entre arte e público } \\
\text { - aproximaçăo entre arte e público; } \\
\text { curadoria educativa; conceitos e } \\
\text { curadoria de Festivais } \\
\text { - obras interativas; espaços institucionais e } \\
\text { alternativos; modos de expor; diferentes } \\
\text { públicos; arte e comunicação visual na escola } \\
\text { - festivais dionisiacos e teatro grego; } \\
\text { sagrado e profano; ressonâncias entre } \\
\text { espetáculo e espectador } \\
\text { - espaços convencionais e alternativos; } \\
\text { intervençáo do espectador no espetáculo } \\
\text { de dança; dança-público/quarta-parede } \\
\text { - mediaçoes para a a escuta; interpretaçoes } \\
\text { diversas; repertório pessoal e cultural; } \\
\text { bandas; coretos; espaços para concerto } \\
\text { - pré-projetos de poética pessoal ou } \\
\text { colaborativa }\end{array}$ \\
\hline
\end{tabular}

Fonte: Proposta_ART_COMP_red_md_15_01_2010,p. 58

Como se pode notar no Quadro 1 há referências à Música (músicos de rua, escola de samba, bandas, coretos, espaços para concerto, paisagem sonora), à Dança (tambor de crioula, intervenção do espectador no espetáculo de dança, dança/público/quarta parede) e ao Teatro (festivais dionisíacos, teatro grego). Não há nenhuma referência ao estudo do cinema ou do audiovisual. 
Quadro 2 - Conteúdo curricular da disciplina de Arte nas 1a. e 2a․ séries do Ensino Médio, 2o․ Bimestre.

\begin{tabular}{|c|c|}
\hline 1 a Série & $2^{a}$ Série \\
\hline $2^{\circ}$ bimestre & $2^{\circ}$ bimestre \\
\hline $\begin{array}{l}\text { Intervenção em arte: projetos poéticos na } \\
\text { escola } \\
\text { - intervenção em arte } \\
\text { - modos de intervenção nas diferentes } \\
\text { linguagens artísticas } \\
\text { - relação arte-público } \\
\text { projetos poéticos de intervençáo na escola } \\
\end{array}$ & $\begin{array}{l}\text { A poética da matéria no território das } \\
\text { linguagens da arte } \\
\text { - a materialidade na linguagem da fotografia } \\
\text { do bordado, da pintura, entre outras } \\
\text { - a materialidade do texto na construçáo da } \\
\text { obra cênica } \\
\text { - o corpo e a pesquisa de movimento } \\
\text { - a matéria-som, ruido, silêncio e palavra } \\
\text { - projetos de poética pessoal ou colaborativa }\end{array}$ \\
\hline
\end{tabular}

Fonte: Proposta_ART_COMP_red_md_15_01_2010, p. 59.

No segundo bimestre, tanto da $1^{\underline{a}}$ quanto da $2^{\mathrm{a}}$. série, conforme se pode notar no Quadro 2, aborda-se a prática da arte, abrindo-se a possibilidade de o cinema, assim como qualquer outra linguagem artística, ser tematizado no item "intervenção em arte" ou em "modos de intervenção nas diferentes linguagens artísticas, mas também aí o cinema não é abordado. Das Artes Visuais, apenas fotografia e artes plásticas (Pintura) são mencionadas. 


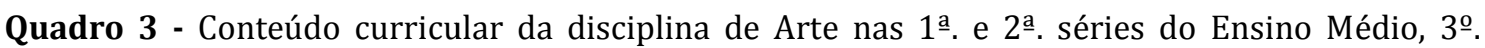
Bimestre.

\begin{tabular}{|c|c|}
\hline $1^{\text {a }}$ Série & $2^{\text {a Série }}$ \\
\hline $3^{\circ}$ bimestre & $3^{\circ}$ bimestre \\
\hline 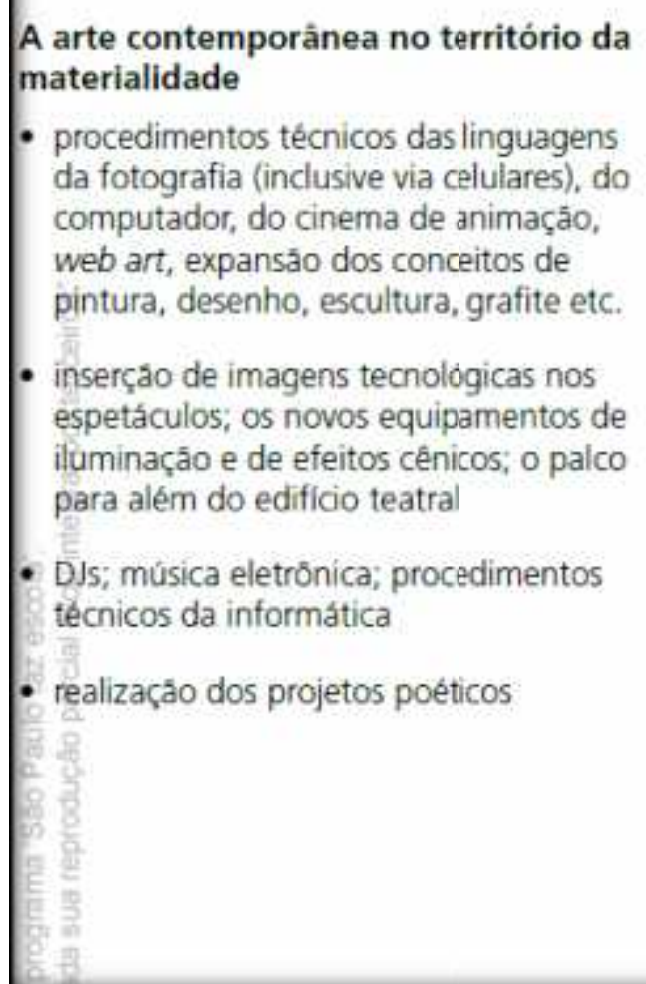 & $\begin{array}{l}\text { Projeto de contaminação de linguagens } \\
\text { no território das linguagens artisticas } \\
\text { - land art, arte pública; performance; } \\
\text { instalaçào; apropriação de imagens; } \\
\text { colagem; computaçáo gráfica; } \\
\text { contaminaçăo de linguagens; fotografia; } \\
\text { grafite; livro de artista; objeto; videoarte } \\
\text { - intervençoes urbanas; performance; teatro } \\
\text { pós-moderno } \\
\text { - dança de rua, as experiências } \\
\text { contemporâneas de movimento } \\
\text { - intervençoes sonoras; sons de celulares; } \\
\text { rádios comunitárias } \\
\text { - invençăo de açoes culturais (intervençoes } \\
\text { visuais, sonoras, corporais; curadorias } \\
\text { educativas gerando novos contatos com as } \\
\text { linguagens da arte) } \\
\text { Intervenções urbanas e ambientais como } \\
\text { projeto poético }\end{array}$ \\
\hline
\end{tabular}

Fonte: Proposta_ART_COMP_red_md_15_01_2010, p. 60.

No terceiro bimestre da $1^{a}$. série é sugerido o estudo dos procedimentos técnicos, dentre outros (fotografia, computador, pintura, desenho, escultura, grafite), o estudo do cinema de animação. No terceiro bimestre da $2^{\underline{a}}$. série, na coluna da direita, também é sugerido o "videoarte" como parte do projeto de "contaminação de linguagens artísticas". O cinema é contemplado indiretamente em "videoarte" e "cinema de animação", ainda assim, este como "procedimento técnico" e aquele como "linguagem artística contaminada", não como linguagem em si. 
Quadro 4 - Conteúdo curricular da disciplina de Arte nas 1a․ e 2ª̣. séries do Ensino Médio, 4o․ bimestre

\begin{tabular}{|c|c|}
\hline 1a Série & $2^{\text {a série }}$ \\
\hline $4^{\circ}$ bimestre & $4^{\circ}$ bimestre \\
\hline $\begin{array}{l}\text { Ressonâncias da arte do passado na arte } \\
\text { contemporânea } \\
\text { - a apropriaçăo e a citaçăo na produçăo em } \\
\text { artes visuais, dança, teatro } \\
\text { - citaçōes de obras de outras épocas (sejam } \\
\text { melódicas, harmônicas, instrumentaçōes...), } \\
\text { nas composiçōes de compositores eruditos, } \\
\text { da MPB e do jazz } \\
\text { - continuidade de projetos poéticos } \\
\text { individuais ou coletivos nas linguagens } \\
\text { artisticas }\end{array}$ & $\begin{array}{l}\text { Modos de pensar e olhar a arte } \\
\text { - Historia da Arte; Filosofia da Arte - Estética; } \\
\text { Critica de Arte; Sociologia da Arte; Psicologia } \\
\text { da Arte; Antropologia Cultural; Semiótica da } \\
\text { Cultura; Mercado da Arte etc. } \\
\text { - finalizaçáo dos projetos poéticos de } \\
\text { intervençós individuais ou colaborativas } \\
\text { com fundamentaçăo teórica a partir do } \\
\text { contato com os saberes estéticos e culturais }\end{array}$ \\
\hline
\end{tabular}

Fonte: Proposta_ART_COMP_red_md_15_01_2010,p. 61.

No quarto e último bimestre da 1a․ série, a atenção principal é dada à Música, que ganha especificações (citações melódicas, harmônicas, instrumentações), propondo-se ainda o estudo de composições eruditas, da MPB e do Jazz. Não são especificadas, quanto às Artes Visuais, quais delas e o que se estudará. Falta especificação também quanto aos conteúdos relacionados à Dança e ao Teatro. Ao mesmo tempo, sugere-se a continuidade de "projetos poéticos" que terão sido gerados antes. Quanto ao último bimestre da $2^{2}$. série, é curioso que, depois de dois anos sejam atribuídos a este bimestre o estudo teórico em vários campos como História da Arte, Filosofia da Arte - Estética, Crítica de Arte, dentre outros. Curioso se se considerar que este é o último bimestre a se estudar Arte no Ensino Médio, uma vez que tal disciplina não é oferecida na 3a․ série. Concomitante a este estudo, propõe a finalização dos "projetos poéticos (...) com fundamentação teórica" a partir desses campos de conhecimento citados.

Da Proposta (2008) para o Currículo (2010), ocorreram poucas mudanças. Quanto às sugestões de conteúdos e conceitos há, por exemplo, no primeiro bimestre da $1^{\mathrm{a}}$. série, o acréscimo de três conceitos no primeiro tópico. São eles: "heranças culturais", "estética do cotidiano" e "ligação arte e vida". E no 202 
segundo tópico acrescenta "pichação e grafite", além de "monumentos históricos". Sugere ainda o estudo de "conservação e reparo" e de "políticas culturais".

Percebe-se, com o uso da arte no cotidiano dos jovens ("pichação", "grafite", "estética do cotidiano", "ligação arte e vida"), uma preocupação predominante com o respaldo prático das artes, conforme resumo abaixo:

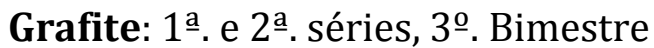

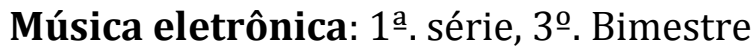

Dança de rua: $2^{\text {a }}$. série, $3^{\circ}$. Bimestre

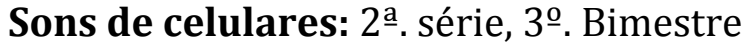

Rádios comunitárias: $2^{\mathrm{a}}$. série, $3^{\circ}$. Bimestre

Dança popular: $1^{a}$. série, $1^{\circ}$. Bimestre

Jongo, roda de samba, frevo, forró, folia de reis: $1^{a}$. série, 1o․ Bimestre.

Artes circenses: $1^{\mathrm{a}}$. série, $1^{\circ}$. Bimestre.

Da observação desses quadros, ressaltamos a importante guinada que o ensino básico no Brasil deu desde a concepção de arte adotada a partir da Lei de Diretrizes e Bases da Educação no. 5.692/71 até hoje, de modo que a arte passa a incorporar aspectos do cotidiano como as modalidades acima mencionadas, dentre elas, as chamadas "intervenções urbanas". Certo é que tais expressões de arte produzem eco nos estudantes, que geralmente tomam ciência de sua existência só por meio da mídia ou de intervenções na cidade, às vezes participando da prática de pichações (essa expressão de desobediência civil ainda é pouco estudada), grafitagem e de dança de rua, para citar algumas mais comuns. A escola, pois, as incorpora.

A expansão da arte assim entendida lança um olhar para as expressões muito comuns em grandes centros urbanos como São Paulo, em que, diferentemente de pequenos centros, onde a sociabilidade é mais controlada, como diz José Guilherme Magnani (2016), há várias formas de expressão de sociabilidade que ocupam o espaço público adquirindo, por vezes, o status de arte, caso da grafitagem. Segundo Magnani (2016), esses modos de expressão das 
pessoas nos grandes centros urbanos têm a ver com a saturação do projeto modernista que separava a cidade em moradia, trabalho, circulação, lazer e espaço público (p. 14); que, por sua vez, tem a ver com a diluição dos espaços antes reservados à arte, caso de museus e galerias. Agora, um bairro pode promover vários desses lugares, fomentando e marcando produções artísticas como a chamada "literatura marginal", por exemplo. Ainda segundo esse fenômeno de saturação do projeto modernista de cidade, as formas de organização dos jovens nas chamadas tribos urbanas, ou como diz Magnani (2016), manchas urbanas, evidenciam vivências como o Largo do Arouche, em São Paulo. Região do Centro bastante frequentada por homossexuais, impõe-se no cenário urbano de modo que as outras pessoas são obrigadas a respeitar o modo de ser desses usuários. Magnani aponta o circuito dos cinéfilos, também em São Paulo, como exemplo de outra mancha urbana (2016, p. 13). De longe, parecem manchas sem definição, mas, de perto e por dentro, diz ele, notam-se regularidades no funcionamento desses espaços.

Chamamos atenção para o modo como a Proposta incorpora o fenômeno das ruas apresentado por Magnani. Nos quadros acima, em várias ocasiões, a expressão que faz referência a esse fenômemo, a essas "intervenções urbanas", é "projetos de intervenção na escola" ou apenas "intervenção em arte". Ora, o fenômeno das "intervenções urbanas", por parte principalmente de jovens, é expressão de certa recusa de uma oficialidade. A escola, no entanto, utiliza-se de tal prática, propondo que esta virulência seja projetada ("projetos de intervenção da arte na escola"), calculada a fim de obter um produto artístico. Não se trata de afirmarmos que o tema é impossível no ambiente escolar, apenas chamar atenção para a perda do processo como o principal aspecto em questão. Do jeito que se apresenta nos Quadros ("projetos poéticos de intervenção na escola", 1ํa série, 1ํ․ Bimeste), sem legendas que indiquem as ponderações necessárias, a Proposta incorpora as intervenções urbanas como processo e produto pedagógicos, domesticados. Como já se disse, trata-se de fumar cigarro sem nicotina ou de tomar café sem cafeína. De outro modo, não se trataria de objetivar o produto final, mas de entender os processos em jogo das intervenções urbanas. Assim, como "intervir" na escola por via da oficialidade? Quanto ao cinema, pode-se entender aí 
que ele responda pouco a esse fenômeno de intervenção urbana ou ao modo de apropriação por parte da Proposta como expressão (principalmente) de atores jovens com os quais os estudantes tenderiam a se identificariam mais diretamente. Desconsiderando as intervenções de projeção de filmes em paredes das cidades, geralmente atreladas a algum outro evento mais central, como a que ocorre anualmente no vão livre do MASP (Museu de Arte de São Paulo), como parte da programação da Mostra Internacional de Cinema de São Paulo, o cinema é, por excelência, uma atividade interna, cuja projeção é feita entre quatro paredes, em sala, de preferência, escura.

Todos os conteúdos arrolados nesses quadros que apresentamos correspondem à programação da disciplina Arte, no amplo leque em que a se compreende (Visuais, Teatro, Dança, Música). Contudo, no Ensino Médio, ela é oferecida apenas nos dois primeiros anos. Com isso, há nos bimestres, conforme se pode notar, uma alta densidade de temas. 0 primeiro bimestre das duas primeiras séries do Ensino Médio, por exemplo, tem vários itens e em cada item, vários temas.

O texto da Proposta não especifica o desenvolvimento dos "modos de intervenção nas diferentes linguagens artísticas" (Proposta: Arte, 2008, p. 59), nem as "habilidades" e "competências" para o desenvolvimento dos "conceitos" e "conteúdos" apresentados por ela. Já no Currículo, as "habilidades" são sugeridas para um determinado conjunto de conteúdos, conforme se pode observar no Quadro 5. Os conteúdos apresentados na Proposta são utilizados no Currículo e, por vezes, alterados, e neste acrescido das habilidades.

Para cada bimestre, o Currículo reúne um conjunto de "habilidades" que, espera-se, sejam desenvolvidas pelo professor da disciplina "Arte" junto aos alunos. Assim, para o primeiro bimestre da 1르. série do Ensino Médio, tem-se o seguinte: 
Quadro 5 - Habilidades da disciplina Arte, 1a․ série do Ensino Médio, 1ํ․ Bimestre.

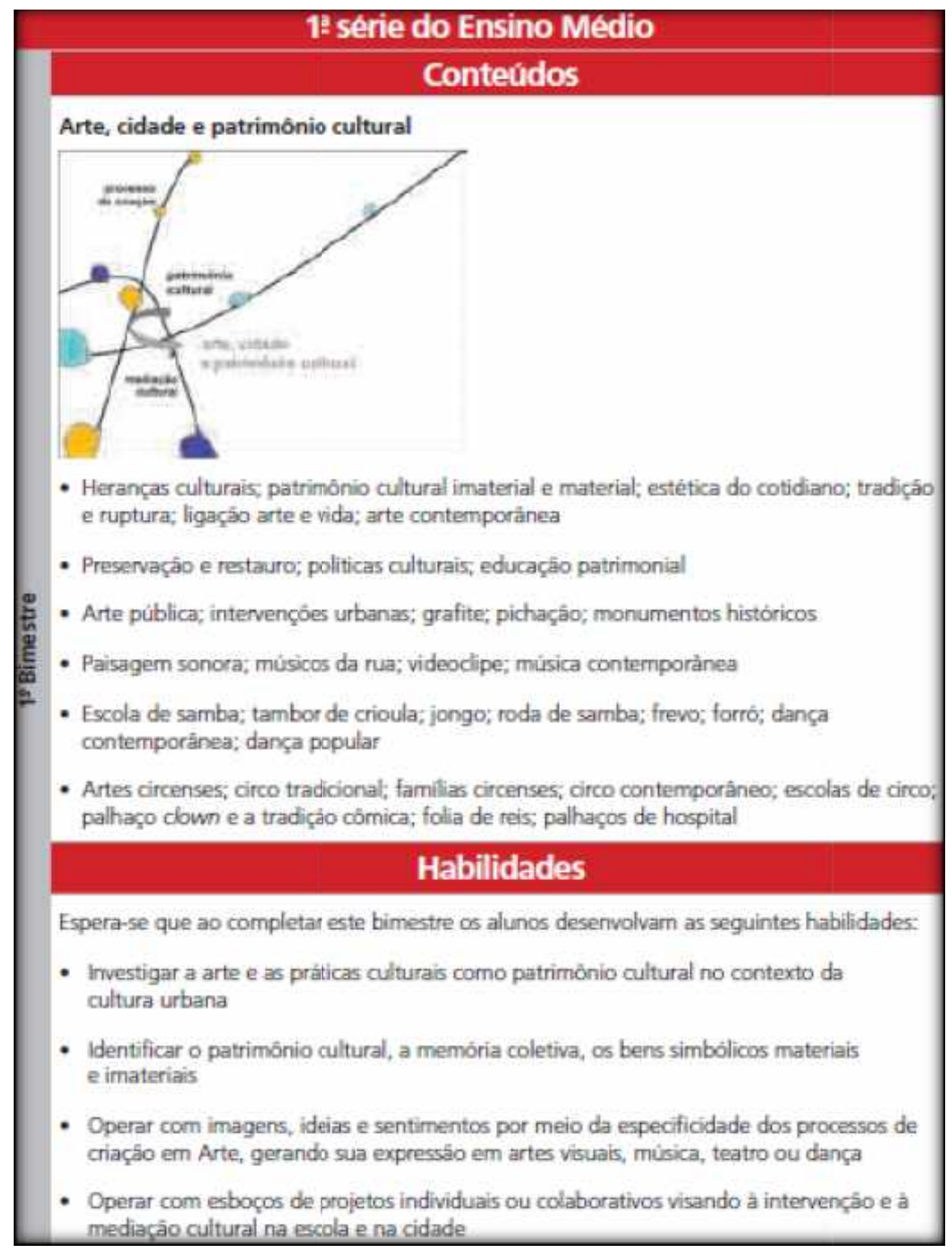

Fonte: Currículo do Estado de São Paulo, Linguagens Códigos e suas Linguagens, p. 215. 
A primeira habilidade a ser desenvolvida no primeiro bimestre da $1 \underline{a}$. Série do Ensino Médio ("Investigar a arte e as práticas culturais como patrimônio cultural no contexto da cultura urbana", Currículo, p. 215) vincula o estudo da arte ao contexto urbano. Contudo, no destaque ao "patrimônio cultural no contexto da cultura urbana" não fica claro se esse patrimônio cultural deve ser também considerado artístico ou se esses aspectos serão investigados separadamente. A segunda habilidade ("Identificar o patrimônio cultural, a memória coletiva, os bens materiais e imateriais") é condição para a primeira, por se tratar da identificação do que vem a ser patrimônio cultural. A terceira ("Operar com imagens, ideias e sentimentos...") e a quarta ("Operar com esboços de projetos individuais ou colaborativos...") preveem a exposição dos alunos à materialidade propriamente das artes, inclusive com o objetivo de exercício de produção artística individual e colaborativa, na escola e na cidade. 
Quadro 6 - Habilidades da disciplina Arte, 1a․ série do Ensino Médio, 2º․ Bimestre.

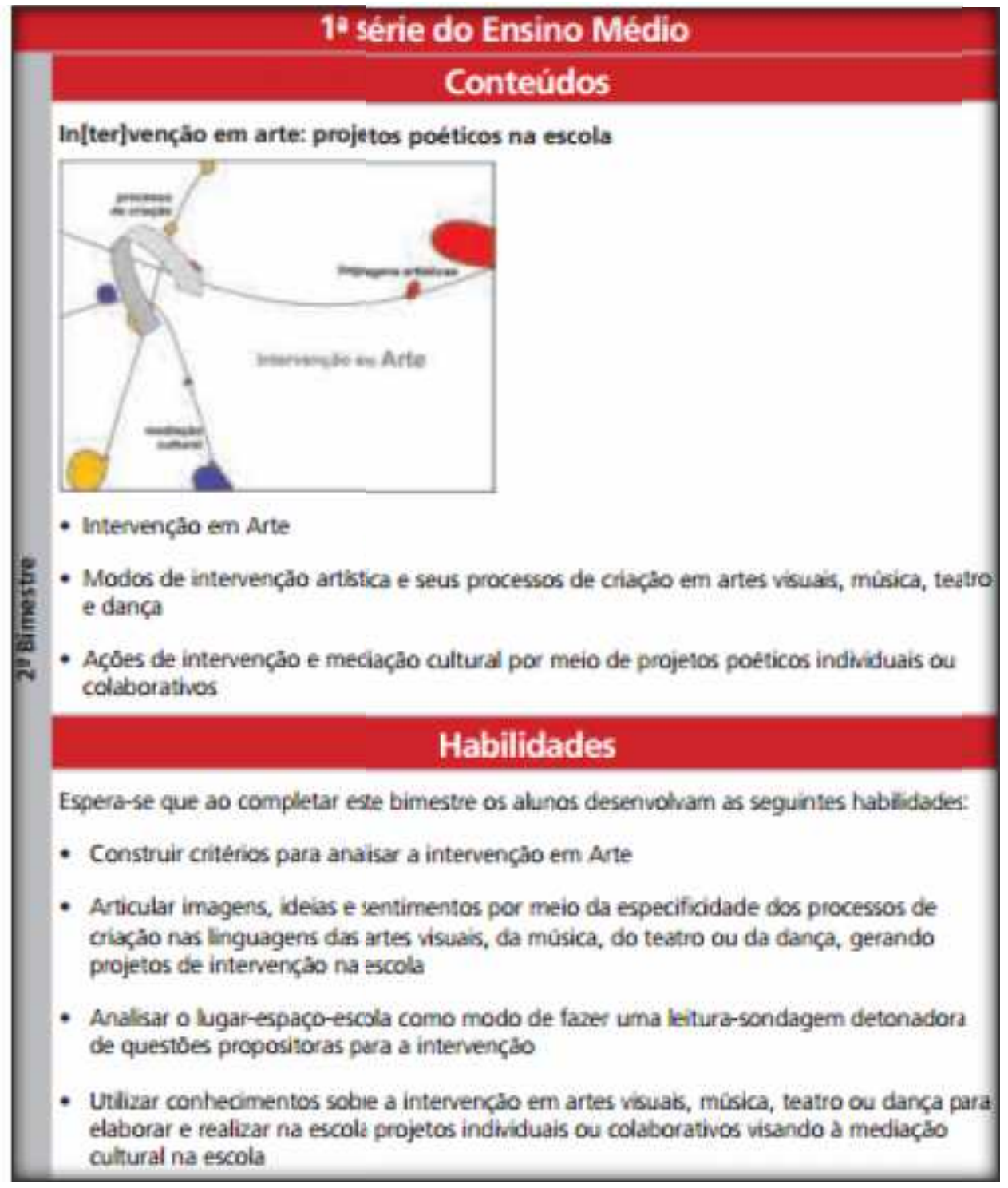

Fonte: Currículo do Estado de São Paulo, Linguagens Códigos e suas Linguagens, p. 216.

As habilidades do segundo bimestre da 1a. série estão relacionadas a práticas de intervenção artística expressas nos conteúdos ("intervenção em arte", “Modos de intervenção artística...”, “Ação de intervenão...”). A primeira delas ("Construir critérios para analisar a intervenção da arte") refere-se vagamente aos critérios para análise de intervenção em arte. Ocorre-nos apontar que em vez de "construir" critérios seria o caso de identificá-los e de perceber quais efetivamente entram em jogo na constituição do que seja artístico. De qualquer forma, parece bastante pertinente a proposição de pensar os critérios para a composição de 208 
processos artísticos. A segunda habilidade ("Articular imagens..."), que já fora apresentada no primeiro bimestre, é citada novamente, porém sem a indicação de que se trata de dar continuidade ao seu desenvolvimento, o que parece ser o caso. A terceira habilidade ("Analisar o lugar-espaço-escola como modo de fazer uma leitura-sondagem detonadora de questões propositoras para a intervenção") visa a que o aluno tome a escola como lugar de "intervenções artísticas" adequadas para a análise do espaço escolar. Aqui, como em outros bimestres, o termo "analisar" aparece de modo impreciso, sem indicação de quais questões do espaço escolar seriam evidenciadas pelas intervenções. A quarta habilidade diz respeito à aplicação ou "utilização" dos conhecimentos em arte, adquiridos anteriormente na elaboração e na realização de projetos "individuais ou colabotativos" de intervenção em artes. 
Quadro 7 - Habilidades da disciplina Arte, 1a․ série do Ensino Médio, 3o․ Bimestre.

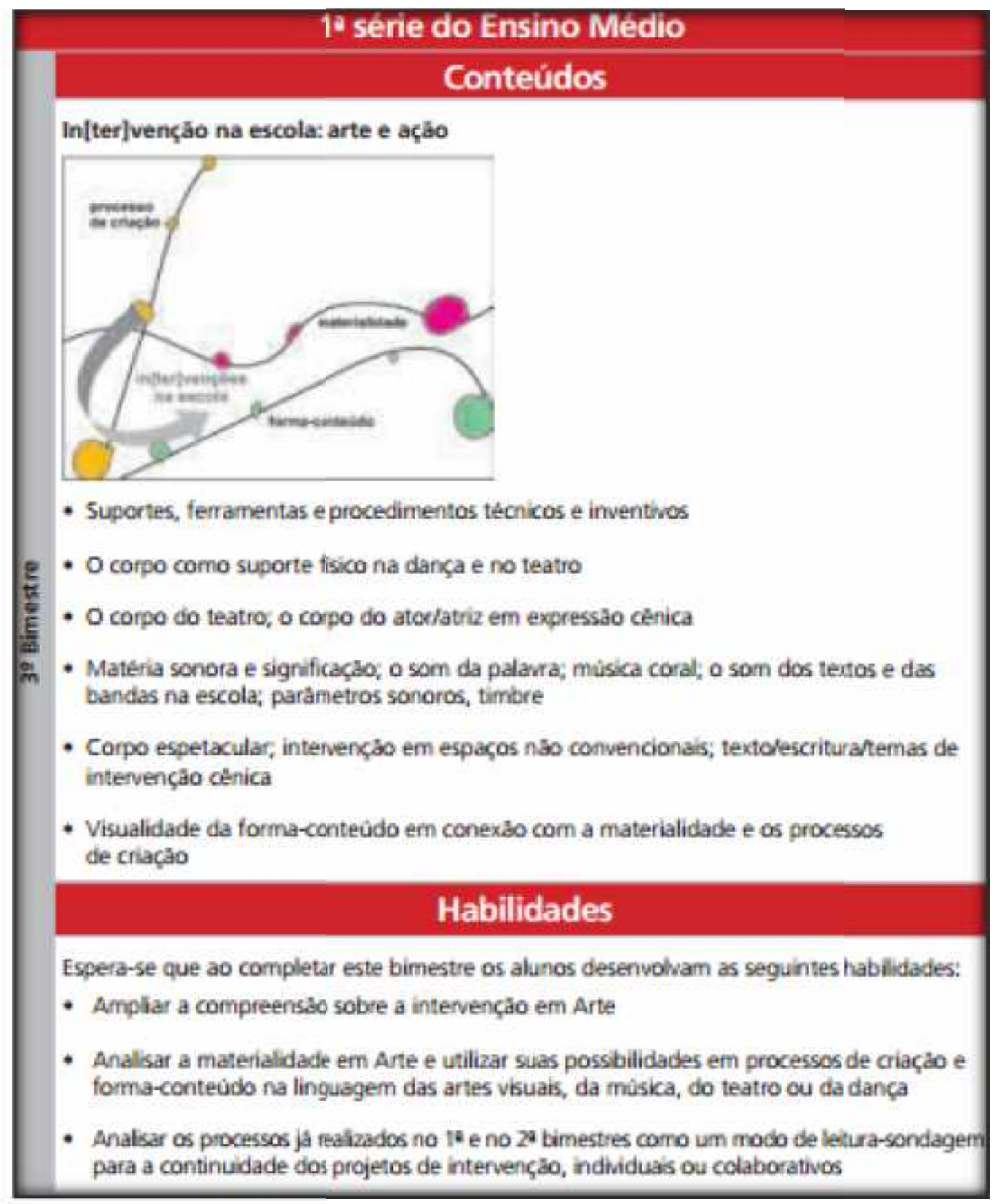

Fonte: Currículo do Estado de São Paulo, Linguagens Códigos e suas Linguagens, p. 217.

No terceiro bimestre, a única referência feita pela Proposta ao cinema (de animação), desaparece no Currículo. 0 “cinema de animação" fazia parte dos procedimentos técnicos a serem estudados. No Currículo, os "procedimentos técnicos" não são especificados e são acrescentados a eles os "procedimentos inventivos". A partir dos conteúdos desse bimestre, bastante dedicado à materialidade dos processos artísticos ("Suportes, ferramentas e procedimentos 
técnicos e inventivos”, “O corpo...”, "Visualidade da forma-conteúdo...”), espera-se "ampliar a compreensão sobre a intervenção em arte" e "Analisar a materialidade em Arte...”, além de dar continuidade ("Analisar os processos já realizados...”) às análises dos projetos de intervenção dos bimestres anteriores. A segunda e a terceira habilidades (mais uma vez, na ânsia de detecção da essência dos fenômenos artísticos) utilizam-se do termo "analisar", mas sem especificar os meios de como isso se daria. Parecem utilizarem-se do termo como se ele por si só indicasse a ação a que se refere. Pensamos no professor que toma esse documento como referência para seus trabalhos em sala de aula. Como ele procederá à "análise", quais parâmetros utilizará, o que se buscará com tal análise?

Quadro 8 - Habilidades da disciplina Arte, 1ํa série do Ensino Médio, 4ํ․ Bimestre

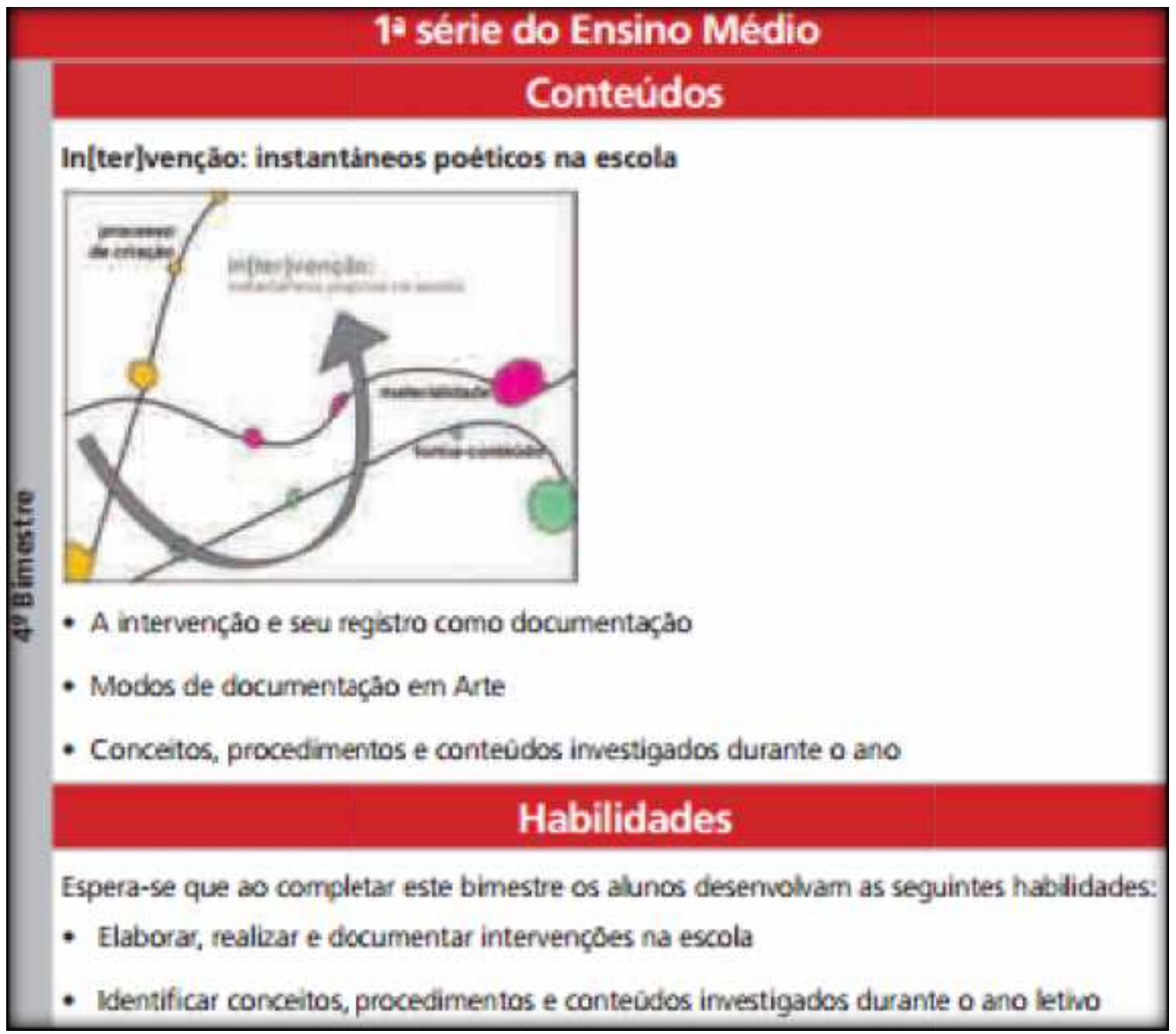

Fonte: Currículo do Estado de São Paulo, Linguagens Códigos e suas Linguagens, p. 218. 
O quarto bimestre foi aquele que mais sofreu alterações nos conteúdos na passagem da Proposta para o Currículo. A Proposta sugere o estudo da citação e da apropriação nas Artes Visuais, na Dança, no Teatro e principalmente na Música. No Currículo, a sugestão resume-se praticamente à questão dos "modos de documentação em arte", sendo, para tanto, esperadas que sejam desenvolvidas as habilidades relacionadas à elaboração, realização e documentação de intervenções de arte na escola. Na Proposta, são sugeridos estudos sobre a citação principalmente na música, mas também no teatro, nas artes visuais e na dança.

Quadro 9 - Habilidades da disciplina Arte, 2ª série do Ensino Médio, 1ํ․ Bimestre.

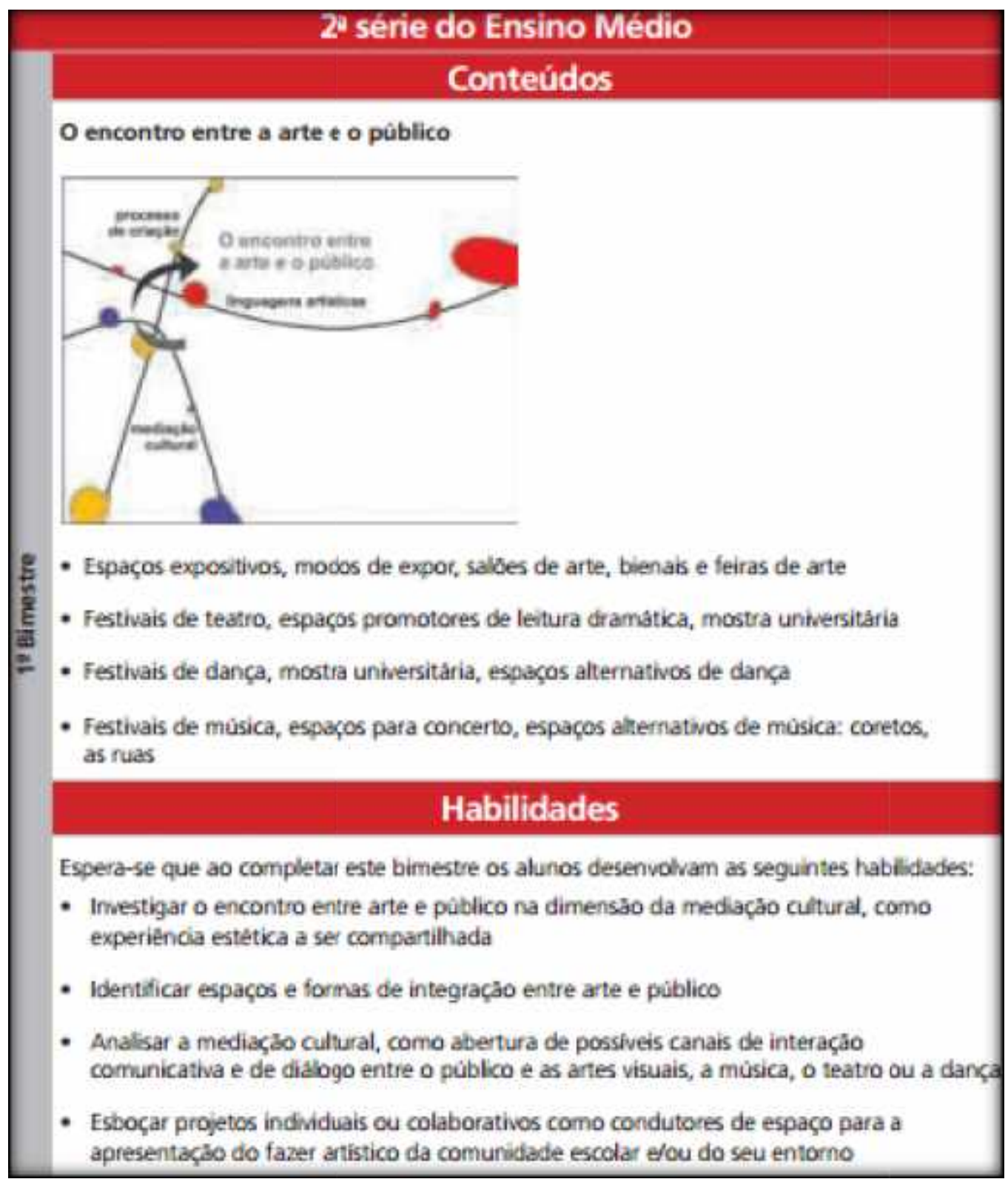


Fonte: Currículo do Estado de São Paulo, Linguagens Códigos e suas Linguagens, p. 219.

No primeiro bimestre da 2ª . série do Ensino Médio, no Currículo, as sugestões de estudo praticamente resumem-se aos "espaços expositivos" e aos "festivais" (de música, de teatro e de dança), ressaltando, desse modo, a relação do espectador com a obra e os lugares de sua exposição. Para tanto, as habilidades indicadas a serem desenvolvidas pelos alunos dizem respeito à investigação do "encontro entre arte e público na dimensão da mediação cultural” e à identificação de "espaços e formas de integração entre arte e público". Contudo, tal investigação parece pouco precisa. Não é possível identificar o que se pede nela. 0 mesmo é aplicável à terceira habilidade indicada ("Analisar a mediação cultural, como abertura de possíveis canais de interação comunicativa e de diálogo entre o público e as artes visuais, a música, o teatro ou a dança"), que não especifica a que análise se refere. Por fim, após a identificação de "espaços e formas de integração entre arte e público", deve-se "esboçar projetos individuais ou colaborativos..." para a apresentação do fazer artístico. Mais uma vez o cinema não é mencionado.

Ressaltemos que os quadros acima apresentados - e os que ainda serão apresentados - demonstram, por parte de seus proponentes, ansiedade em dar conta de um conjunto bastante amplo de conteúdos. Se considerarmos que a disciplina Arte, além de ser oferecida apenas nos dois primeiros anos do Ensino Médio ${ }^{115}$, cada turma por série tem apenas uma aula por semana, a concentração de conteúdos e expectativa aumentam.

\footnotetext{
115 No ano de 2016 a SEE-SP elaborou um documento (Matriz de Avaliação Processual, 2016), que apresenta proposta de Conteúdos, Competências/habilidades para a disciplina Arte, desta vez também para a terceira série do Ensino Médio. Diferente dos quadros aqui apresentados na Proposta e no Currículo, a Matriz de Avaliação Processual (2016) apresenta um item chamado "Avaliação Processual", que consiste basicamente em transformar as Competências/habilidades disciplinares dos bimestres em ações indicadas por verbos. Assim, se a Competência/habilidade do 1‥ Bimestre da 3a . série indica "Usar a rede de internet como meio de pesquisa e saber sobre a ética deste uso.". A "Avaliação Processual" correspondente a este item é "Compreender o processo de construção do conhecimento.". Outro exemplo para o mesmo bimestre: Competência/habilidade: "Identificar funções necessárias para a realização de um projeto artístico.". "Avaliação Processual" correspondente: "Estabelecer as diversas funções a serem exercidas pelos indivíduos, dentro de um projeto."
} 
uadro 10 - Habilidades da disciplina Arte, 2ª . série do Ensino Médio, 2o․ Bimestre.

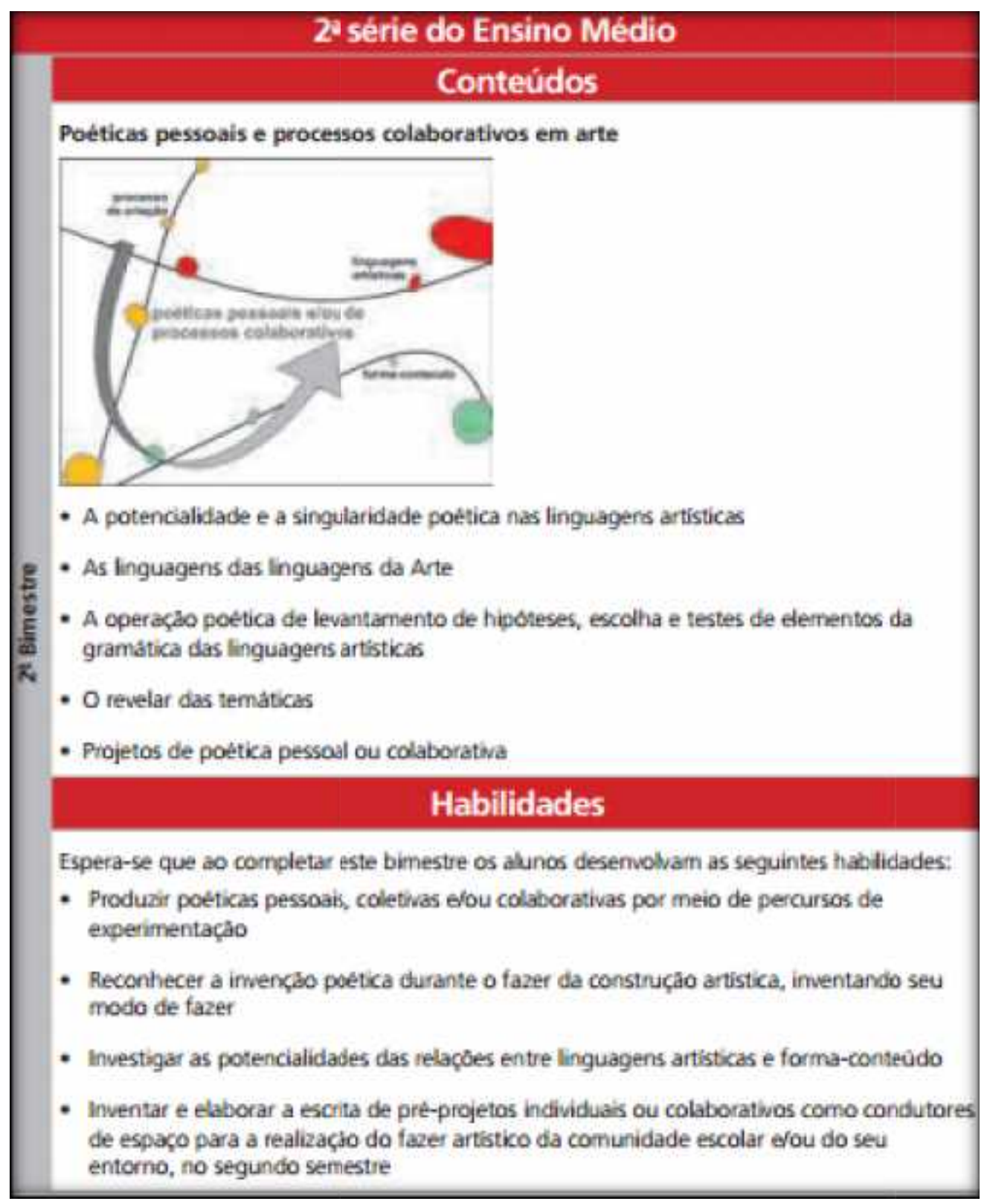

Fonte: Currículo do Estado de São Paulo, Linguagens Códigos e suas Linguagens, p. 220.

No segundo bimestre, a mudança da Proposta para o Currículo é significativa, pois enquanto aquela sugeria o estudo da materialidade da fotografia, do bordado, da pintura, "entre outras", o Currículo sugere "a potencialidade e a singularidade poética nas linguagens artísticas" e o incompreensível tópico chamado de "o revelar das temáticas". Quanto à materialidade das linguagens (o corpo e a pesquisa de movimento, a matéria-som, ruído, silêncio e palavra), o Currículo a substitui pelo sentido poético das linguagens a partir da "gramática das linguagens artísticas", calcado no fazer artístico, como fica claro nas quatro 214 
habilidades indicadas: "Produzir poéticas pessoais...". A terceira habilidade parece genérica e pouco clara quando sugere a investigação das "potencialidades das relações entre linguagens artísticas e forma-conteúdo".

Quadro 11 - Habilidades da disciplina Arte, 2ª . série do Ensino Médio, 3ํ․ Bimestre.

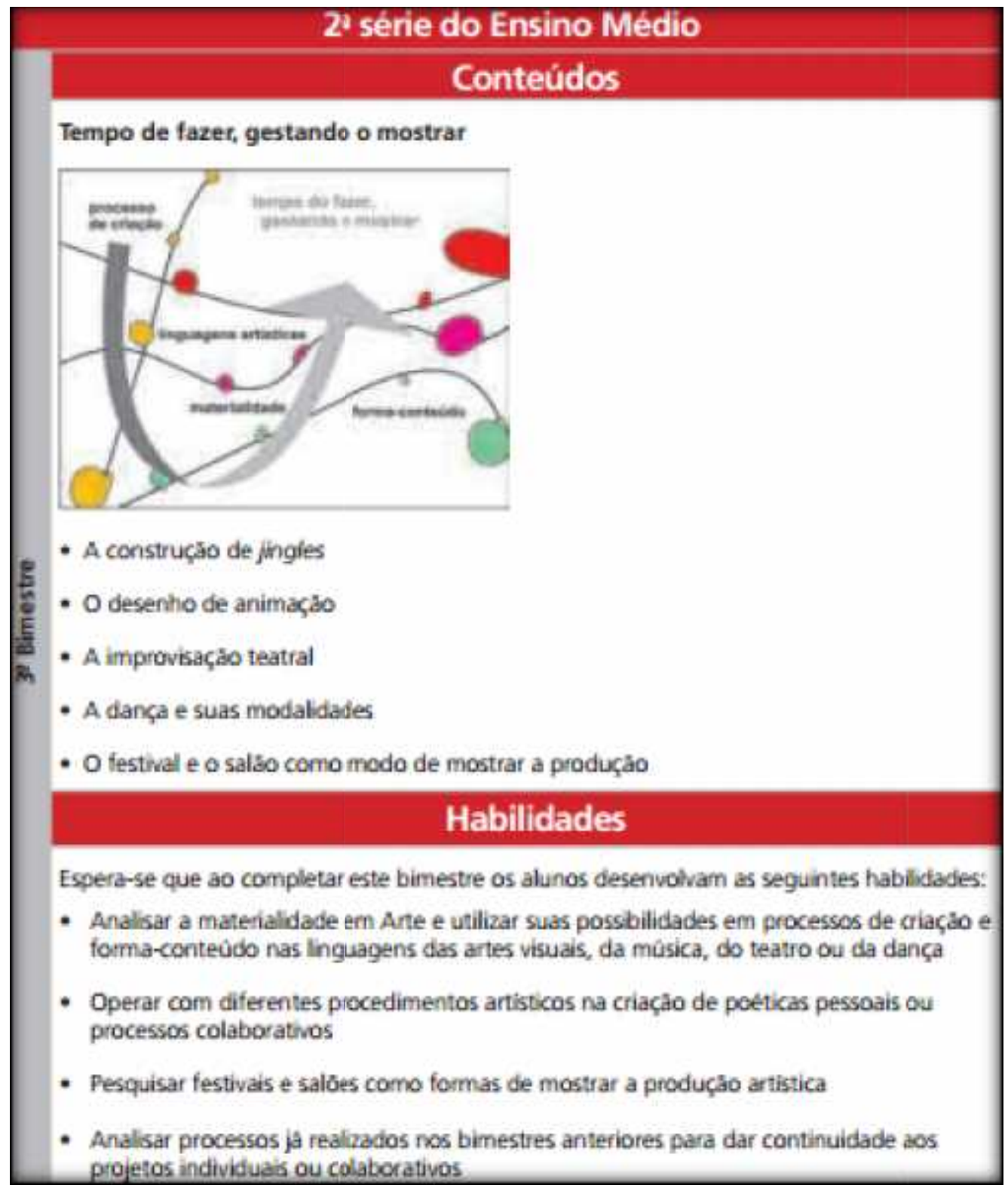

Fonte: Currículo do Estado de São Paulo, Linguagens Códigos e suas Linguagens, p. 221.

No terceiro bimestre (Currículo) são sugeridos como conteúdos "a construção de jingles”, “o desenho de animação”, “a improvisação teatral”, “dança e suas modalidades" e "o festival e o salão como modo de mostrar a produção artística". É curioso que nas habilidades não se façam referência ao desenho 
animado (não se sabe exatamente a abordagem ou o que do cinema de animação seria destacado); mas apenas aos outros conteúdos. 0 emprego do termo "salão" (entendido aqui como mostra de arte, exposição) parece expressar, mais uma vez, a concepção de arte como obra e não como processo. A referência à pesquisa de "festivais e salões" é vaga e pouco sugere ao professor que pretenda estudar esses espaços. Assim, mostrar o que da "produção artística"? Apesar da referência feita às "obras de arte", a justaposição de várias atividades independentes sugeridas como "jingles", "desenho animado", "dança e suas modalidades", assim como "intervenções", dentre várias outras, aponta para outro sentido de concepção de arte e de processos artísticos. Não se identifica, ainda fazendo ponderações às habilidades e conteúdos apresentados, que tais procedimentos estejam vislumbrados segundo uma dada perspectiva, por exemplo, a construtivista, o que, de certa forma, justificaria pensar na possibilidade de entrada em expressões artístico-culturais ("jingles", "desenho animado") para depois centrar-se oportunamente na construção de conhecimentos.

Mais uma vez a quarta habilidade diz respeito à análise de "processos já realizados nos bimestres anteriores", mas não especifica como deverá se dar essa análise. Mais confuso ainda em razão de o objetivo da análise indicar que seja dada continuidade aos trabalhos em desenvolvimento. 
Quadro 12 - Habilidades da disciplina Arte, 2ª - série do Ensino Médio, 4ํ․ Bimestre.

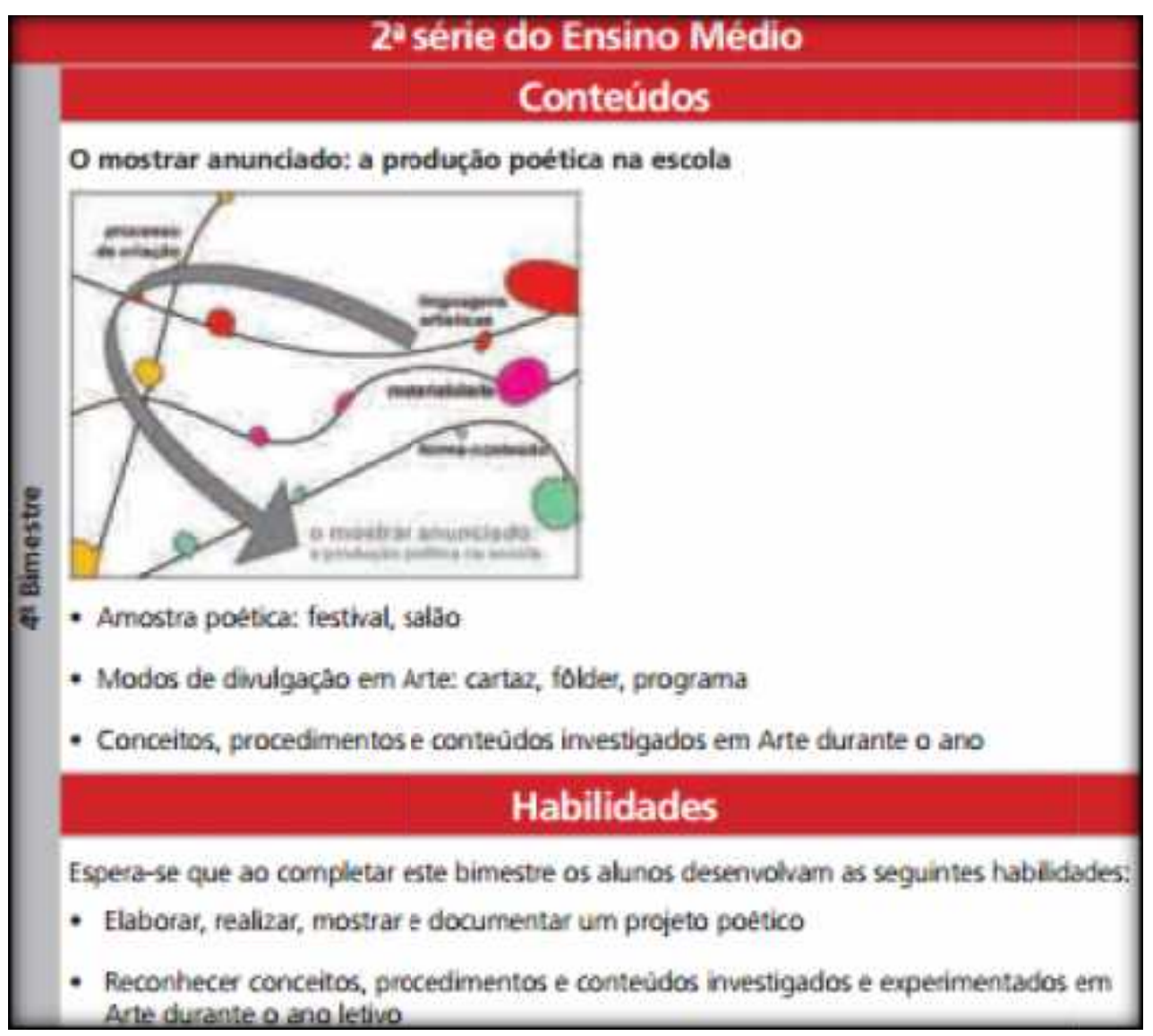

Fonte: Currículo do Estado de São Paulo, Linguagens Códigos e suas Linguagens, p. 222.

Como aconteceu no segundo bimestre, no quarto a mudança da Proposta para o Currículo é também evidente. A Proposta sugere o estudo de disciplinas como Sociologia da Arte, Psicologia da Arte, dentre outras, enquanto no Currículo é proposto que sejam estudados os modos de divulgação da arte como "cartaz, folder e programa", sugerindo ainda "amostra poética: festival, salão". A primeira habilidade sugerida a ser desenvolvida neste bimestre tem em vista a elaboração, realização, mostra e documentação de um projeto poético, isto é, todo o processo que envolve o fazer artístico, desde sua elaboração à divulgação do produto realizado, quando é o caso. No entanto, como se pode perceber, tal habilidade não mostra com clareza como mobilizaria os conteúdos sugeridos. É predominante o modo genérico com que os conteúdos e as habilidades são 
apresentados, de maneira que, a partir desses quadros, o professor terá dificuldade de se situar, planejar seu curso e executá-lo.

Vale notar que em toda a extensão da Proposta ou do Currículo, no que diz respeito à disciplina Arte, a despeito de voltar-se para uma "sensibilidade do cotidiano", não se apresenta em momento algum a ideia de "ação cultural" (exceto no primeiro bimestre da $1^{a}$. Série do Ensino Médio, que sugere o exercício de produção artística individual e colaborativa, na escola e na cidade, e no primeiro bimestre da $2^{\text {a }}$. série do Ensino Médio, que após a identificação de "espaços e formas de integração entre arte e público", propõe o esboço de "projetos individuais ou colaborativos...”), parecendo aí ensaiar a conexão da Arte com a sociedade. No entanto, o Currículo retira da Arte sua dimensão pulsante, e atual numa sociedade que é dinâmica. Sua compreensão parece longe de contemplar a arte contemporânea cujo gesto do artista é o principal elemento na definição do artístico. Desse modo, a expressão "intervenção", entendida como artística e política, é traduzida para apenas "intervenção em arte", extraindo-se, assim, o sentido político. Tal tradução parece ruidosa, já que as sugestões de abordagem da disciplina limpam-na de seu sentido original, estético, social, e político. Ao contrário, originalmente o termo "intervenção" diz respeito ao propósito de mudar algo que está ritualizado nas artes ou na política.

Se na Proposta ou no Currículo há pouca precisão no desenvolvimento das sugestões dos temas a serem trabalhados em sala de aula pelos professores, como se pode perceber, o Caderno do Professor será o lugar que produzirá esse desenvolvimento, propondo um passo a passo, desde a sensibilização ao tema, passando por sua contextualização até o seu estudo especificamente.

\section{6- Caderno do Professor: a disciplina Arte}

Visando à consolidação dos processos previstos pelo Currículo na rede estadual de São Paulo, o programa São Paulo Faz Escola criou o material de apoio ao professor denominando-o de Caderno do Professor (não confundir com o Caderno de Cinema do Professor, material este do projeto O cinema vai à escola), 218 
que toma como base as sugestões de conteúdo do Currículo a fim de homogeneizar o trabalho das várias disciplinas oferecidas pela rede estadual de ensino nas mais de 5 mil escolas. Apresentam-se ao professor caminhos possíveis de desenvolvimento dos temas presentes na Proposta ou no Currículo. O objetivo, segundo o site oficial, é "garantir uma base comum de conhecimento e competências para todos os professores e alunos."116. Os Cadernos são organizados por bimestre, série e por matéria.

A apresentação do Caderno do Professor (Arte, vol. 1, SÃO PAULO, SEESP, 2014) feita pelo Secretário da Educação do Estado de São Paulo, acentua a posição dos professores como "colaboradores": "A Secretaria da Educação do Estado de São Paulo sente-se honrada em tê-los como colaboradores nesta nova edição do Caderno do Professor (...).” (p. 03). Essa posição fica clara na frase seguinte: "[a nova edição do Caderno do Professor] realizada a partir dos estudos e análises que permitiram consolidar a articulação do currículo proposto" com o que se encontrava em vigência. Os estudos e análises foram realizados pela equipe designada para tanto sobre a qual já nos detemos no item anterior. Assim, "colaboradores" parece dizer respeito à utilização do material em sala de aula ou nos termos do próprio secretário: "Contamos com nosso Magistério para a efetiva, contínua e renovada implementação do currículo". (p. 03).

O secretário ressalta a seguir que o material teria sido resultado dos trabalhos "em parceria com os Professores Coordenadores de Núcleo Pedagógico PCNP - e com os professores da rede de ensino" a partir do programa Educação Compromisso de São Paulo117. Em visitas seguidas ao site do referido programa, pode-se constatar a ausência de informação quanto aos cursos, estudos e análises a que se referiu o secretário. Depois de ler, no site, sobre estatísticas dando conta de que a rede estadual paulista é a maior do país, e de outras evidências já repisadas em outras páginas oficiais da SEE-SP, o site promete a disponibilização dos Cadernos do Professor, isto é, ressalta sua importância e diz que a disponibiliza no site. Não sem dificuldade, consegue-se chegar finalmente a um título "Fazer

\footnotetext{
116 http://www.educacao.sp.gov.br/sao-paulo-faz-escola. Acesso em 27 de outubro de 2015. 117 http://www.educacao.sp.gov.br/compromisso-sp. Acesso 08 de janeiro de 2016.
} 
download das edições do Caderno do Aluno e Caderno do Professor". E logo abaixo: "Acesse aqui a ferramenta". Clica-se aliviado em "aqui" e uma página se abre, porém com a resposta "Não é possível acessar esse site". Como o link permite a abertura de outra página, pensa-se que o problema é temporário, mas voltamos a repetir a operação semanas e meses depois, porém, com o mesmo resultado. Quanto à acessibilidade e uso do texto da Proposta e do Currículo, chamamos atenção para a curiosa marca d'água em todas as páginas da versão da Proposta, que informa ao leitor ser proibida a reprodução do texto, parcial ou integral (ver Quadros 1, 2, 3 e 4, lado esquerdo). Acima da ficha catalogal da Proposta, no entanto, a informação é de que a SEE-SP autoriza a reprodução do material apenas pelas demais secretarias de educação na condição de que sejam mantidas a integridade e a autoria da obra. A marca d'água desaparece no Currículo. Contudo, acima da ficha catalogal, somos informados de que a reprodução parcial ou integral do texto deve ser negociada diretamente com os autores, sendo livre, no entanto, para as demais secretarias de educação do país. É curioso, pois, que um texto que visa à organização e unificação do Ensino Básico público, e também do privado, por consequência, restrinja sua divulgação.

No parágrafo seguinte, o então Secretário de Educação Herman Voorwald diz serem as orientações do Caderno do Professor complementares à Matriz Curricular. Imediatamente depois diz que tais orientações "podem ser complementadas por outras que julgarem pertinentes ou necessárias (...)", isto é, parecendo considerá-las, na verdade, eixo, obrigatórias, e não complementares como afirmara. O site do programa São Paulo Faz Escola, contudo, afirma que tais Cadernos são complementares ao livro didático.

Com o título Encontros escritos com professores de arte, o Caderno do Professor (Arte), volume 1 (SÃO PAULO, SEE-SP, 2014), inicia a apresentação do material anunciando ser ele resultado do trabalho de muitos encontros. A expectativa gerada no leitor do Caderno pelo título "Encontros escritos com professores de arte, o Caderno do Professor" não é atendida, pois o que se segue não é a confirmação do título. Os encontros seriam de "várias naturezas": "entre nós, professores autores", isto é, entre os membros da equipe destinada a escrever o 
material de arte; o encontro com a arte e o encontro simbólico com Gilles Deleuze e Félix Guattari cuja concepção de rizoma118 teria inspirado o "pensamento curricular em Arte imaginado para o andamento da composição deste Caderno." (p. 05, grifos originais). 0 encontro com o professor que ministra a disciplina Arte na rede estadual, indicado no enunciado do Caderno, mais uma vez, não acontece.

A seguir, o Caderno do Professor enuncia sua base de desenvolvimento para as sugestões das atividades. Elas são de três ordens: 1) Proposição para sondagem; 2) Situações de aprendizagem; 3) Nutrição estética. Para o primeiro ponto, como sugere o nome, o objetivo é levar imagens disparadoras relacionadas às linguagens das artes que serão abordadas em sala de aula a fim de que os alunos se impliquem, que reconheçam e se coloquem nas discussões. 0 segundo ponto diz respeito propriamente aos conteúdos e conceitos das linguagens estudadas. 0 terceiro se propõe a retomar alguns aspectos conceituais para aprofundamento.

A exemplo do que se passou com a disciplina "Arte", na Proposta e no Currículo, a experiência, isto é, a dimensão prática da disciplina Arte, é uma tônica desse material, que têm os PCN como referência:

A prática administrativa e pedagógica dos sistemas de ensino e de suas escolas, as formas de convivência no ambiente escolar, os mecanismos de formulação e implementação de políticas, os critérios de alocação de recursos, a organização do currículo e das situações de aprendizagem, os procedimentos de avaliação deverão ser coerentes com os valores estéticos, políticos e éticos que inspiram a Constituição e a LDB, organizados sob três consignas: sensibilidade, igualdade e identidade (BRASIL, 2010, PCN Ensino Médio, p. 62).

Sobre o primeiro elemento indicado na citação anterior, que nos interessa mais particularmente, a estética da sensibilidade, afirmam que:

Como expressão do tempo contemporâneo, a estética da sensibilidade vem substituir a da repetição e padronização, hegemônica na era das revoluções industriais. Ela estimula a criatividade, o espírito inventivo, a curiosidade pelo

\footnotetext{
118 Cada quadro apresentado neste item, em que constam as habilidades indicadas por bimestre, traz também, cada um deles, um desenho projetado a fim de expressar visualmente a concepção de rizoma de Deleuze e Guattari. Contudo, se a apresentação visual seja por mapa, seja por gráfico, tem o objetivo de tornar mais compreensível ou "visível" os esquemas apresentados, podendo-se perceber de forma abrangente algo que se encontra disperso, tais esquemas tornam praticamente impossível e inútil a tradução da concepção dos filósofos.
} 
inusitado, a afetividade, para facilitar a constituição de identidades capazes de suportar a inquietação, conviver com o incerto, o imprevisível e o diferente.

Diferentemente da estética estruturada, própria de um tempo em que os fatores físicos e mecânicos são determinantes do modo de produzir e conviver, a estética da sensibilidade valoriza a leveza, a delicadeza e a sutileza. Estas, por estimularem a compreensão não apenas do explicitado mas também, e principalmente, do insinuado, são mais contemporâneas de uma era em que a informação caminha pelo vácuo, de um tempo no qual o conhecimento concentrado no microcircuito do computador vai se impondo sobre o valor das matérias-primas e da força física, presentes nas estruturas mecânicas (BRASIL, 2010, PCN Ensino Médio, pp. 62-63).

Nesta passagem, o texto dos PCN mostra preocupação em vincular a prática pedagógica às sensibilidades contemporâneas, procurando distanciar-se do que ele chama de "estética estruturada" - ou a Estética, simplesmente - cuja obra é única, autêntica, de valor transcendente e irrepetível. Ao contrário, o aprendizado seria potencializado pela ressonância entre o que se estuda e o que se vive.

O texto do Caderno do Professor também destaca a noção de experiência como fundamental para o desenvolvimento das atividades em sala de aula com as artes no mesmo sentido dos PCN. No entanto, parece tomá-las redutivamente quando secundariza a frequentação de quadros, da música, da dança e de peças de teatro (o cinema não é mencionado). Parece propor o direcionamento do olhar para o mundo, mas um olhar genérico, já que a tônica da experiência seria a prática, isto é, a experiência da vida cotidiana. Portanto, o aluno é deslocado da experiência contemplativa para uma experiência contingente. Tal deslocamento pela aposta benjaminiana na reprodutibilidade da obra de arte, o que introduz aí o aspecto da política, atacando sua unicidade e autenticidade - pode, inclusive, contribuir para que o espectador contemporâneo tenha menos preconceito na relação com a obra de arte do passado.

Essa ênfase no processual que identificaria a arte contemporânea parece ser a tônica do Caderno do Professor. Contudo, a despeito de acompanhar tais transformações, joga fora a própria obra de arte, concentrando-se no fazer artístico, na abstrata expressão "inventividade" - e “criatividade" -, que, aliás, é também uma tônica das atividades com o cinema na escola, como se verá no item correspondente ao projeto $O$ cinema vai à escola. 
O Caderno do Professor apresenta as sugestões de desenvolvimento dos conteúdos e das habilidades presentes no Currículo nas chamadas "Situações de Aprendizagem". Tomamos como exemplo para análise o Caderno do Professor (Arte) da 2ª série, vol. 1: as "Situações de Aprendizagem" relacionadas às Artes Visuais são a 1 e a 7. Antes, porém, o Caderno propõe uma sondagem sobre os espaços culturais que os alunos conhecem e que frequentam, além de perguntar por suas necessidades culturais. Para tanto, propõe que o professor promova perguntas como: “Quais espaços culturais você conhece?”, “Quais museus ou teatros você já visitou?", "Para você, qual é o significado da numeração do nome dos eventos de arte: 28a․ Bienal Internacional de São Paulo, 34ํ․ Salão Internacional de Humor de Piracicaba, 32‥ Festival de Teatro de Pindamonhangaba, 38으. Festival Internacional de Inverno de Campos do Jordão, 5o․ Projeto Dança em Pauta?". Curioso que a conhecida Mostra Internacional de Cinema de São Paulo não seja mesmo citada, considerando-se ainda que essa Mostra tem várias sessões destinadas às escolas e ao público jovem, com exibição gratuita.

O objetivo da sondagem, segundo o Caderno, é "dar voz aos alunos e escutá-los (...) para aproximá-los do foco de estudos sobre a mediação cultural." (Caderno, p. 12). No entanto, na atenção dada à "voz dos alunos" parece evidente que se trata de um cumprimento protocolar apenas, visto que visa, na verdade, à sensibilização do tópico seguinte, a proposta Entre gritando, de Luciano Mariussi, realizada em 2005 no Museu de Arte Moderna, em São Paulo, que, por sua vez, será o mote para o início da "Situação de Aprendizagem 1", que passa ao comentário de dois quadros, um de Giuseppe Castiglione, e outro de Diego Velázquez e, a seguir, de Marcel Duchamp, Fonte (1917). A “Situação de Aprendizagem 7" é a outra, neste Caderno, que se ocupará das Artes Visuais, no caso utilizando-se de trabalhos de fotografia de Cristiano Mascaro e de Vik Muniz, mas também de dois quadros de Caravaggio.

Os textos até aqui analisados (Proposta, Currículo, Caderno do Professor) tratam da Arte como matéria central e não complementar ao Currículo; portanto, dizem respeito diretamente ao que os professores dessa disciplina 
tematizarão em suas aulas de Arte. Curioso, todavia, é que o cinema não seja sequer mencionado nessas duas "Situações de Aprendizagem", que tratam das Artes Visuais, ainda que como opção, como complemento, enfim. Parece mesmo tratar-se de um apagamento.

Ora, a escola é o lugar para a transmissão, entre outras coisas, do legado de gerações passadas. Fora desse ambiente, o aluno, em geral, não terá outra oportunidade de exposição a esse legado senão indiretamente e de modo bastante fragmentado. A apreciação das obras ${ }^{119}$ (eixo, segundo a Proposta Curricular do Estado de São Paulo) é parte desse legado. Antes ou paralelamente à chamada inventividade, que remete a atividades práticas, o estudo (e a exposição às obras) dos muitos modos de ser da arte na história não é dispensável. Nesse sentido, veremos como o projeto $O$ cinema vai à escola tratará do cinema como legado e como recurso pedagógico.

\section{7- 0 projeto o cinema vai à escola}

O Projeto O cinema vai à escola apresenta-se num contexto de oficialização do currículo unificado para o Estado de São Paulo. Nasce, pois, dessa paternidade que lhe impõe determinadas concepções e modos de funcionamento, apesar de o cinema, como se viu nos intens anteriores, ser notoriamente apagado do Currículo. Chegamos a cogitar a possibilidade de esse apagamento ter sido consciente, uma vez que seria atribuída ao Projeto a responsabilidade de realizar a entrada sistematizada do cinema no contexto escolar. Porém, o Teatro é também contemplado com um projeto similar ao do cinema e não se verifica seu apagamento. À secundarização do cinema, acrescentem-se as dificuldades próprias do uso dessa forma de arte em sala de aula, visto não ser comum o seu estudo no ambiente escolar, as más condições técnicas de exibição de filmes (e o fato de o

\footnotetext{
${ }^{119}$ Conforme citado anteriormente, a Proposta Curricular do Estado de São Paulo estabelece como um de seus três eixos em que baseia o ensino da Arte na rede estadual de ensino: 1"Criação/produção em Arte - o fazer artístico; [2] Fruição estética - apreciação significativa da Arte e do universo a ela relacionado; leitura; crítica; [3] Reflexão: a Arte como produto da história e da multiplicidade de culturas." (São Paulo, Proposta: Arte, 2008, p.46).
} 
cinema ser matéria complementar ao currículo), tudo isso se apresentaria como entrave para sua incorporação como matéria central na escola.

O nome completo do projeto é $O$ cinema vai à escola - a linguagem cinematográfica na educação, criado junto com outros dois (Lugares de aprender a escola sai da escola e Escola em cena), lançados em 2008 pelo programa Cultura é Currículo, como se pode ver na Figura 8. Esta apresenta a primeira página que aparece ao internauta que pesquisa sobre o programa Cultura é Currículo. Na linha superior consta o nome dos três projetos que compõem o programa. 0 projeto $O$ cinema vai à escola é o segundo, como se pode perceber.

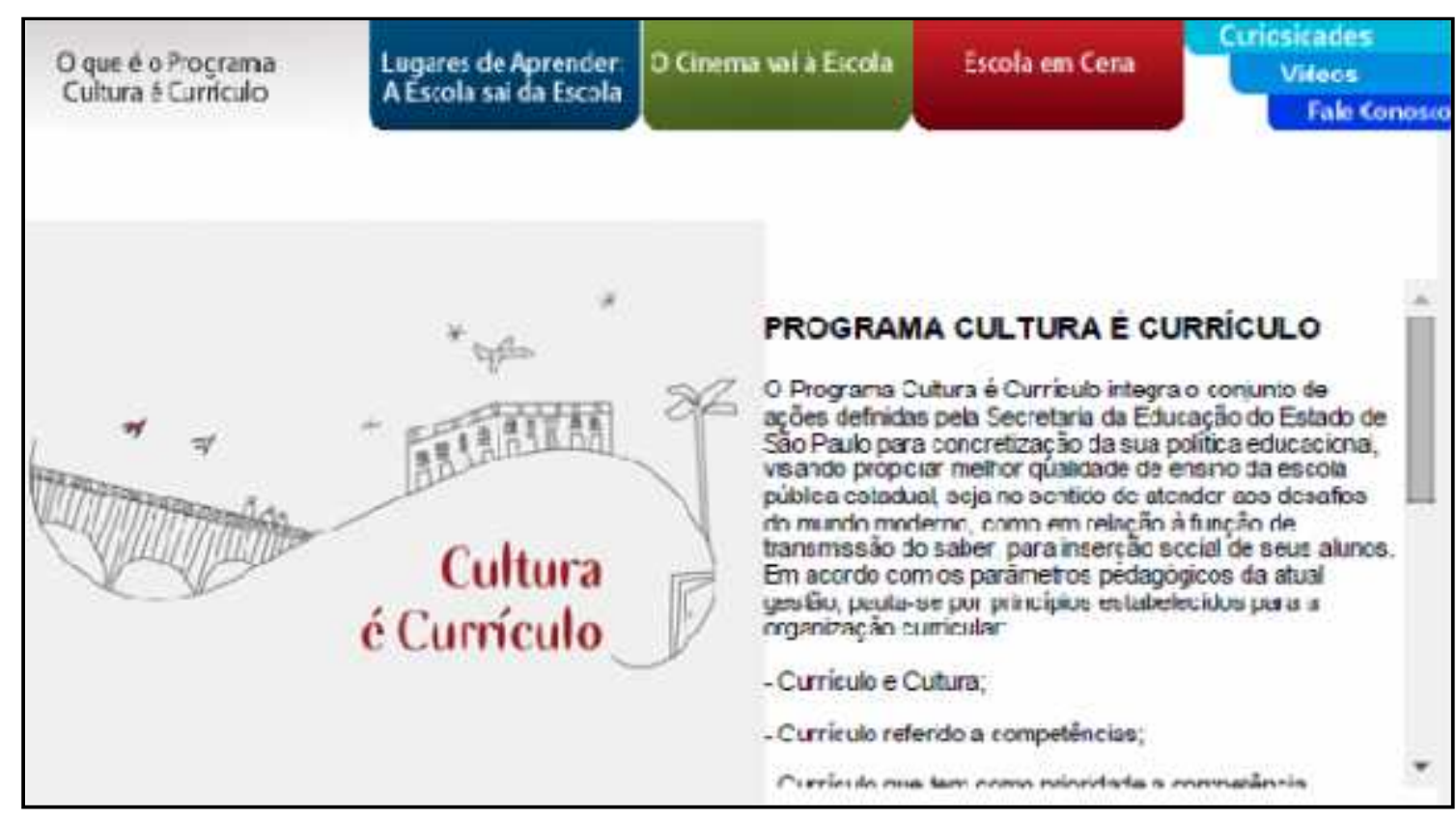

Figura 8: 0 que é o Programa Cultura é Currículo. Fonte: http://culturaecurriculo.fde.sp.gov.br/programa.aspx

Clicando-se no nome do projeto $O$ cinema vai à escola, aparece a imagem que consta na Figura 9. 0 projeto aparece no site da SSE-SP/FDE120 $\mathrm{com}$ a seguinte estrutura: $O$ que é o projeto, Justificativa, Objetivo geral, Objetivos específicos, Público-alvo, Produção de materiais de apoio didático, Seleção do conjunto de 20 filmes em DVD. Do lado esquerdo, um pouco para baixo, encontramse disponibilizados alguns "links" que, clicando-se neles, uma nova página é aberta com o conteúdo correspondente. Diferentemente do projeto Currículo +, que visa à instrumentalização de professores quanto ao uso de tecnologias digitais nas aulas, o projeto $O$ cinema vai à escola tem uma vocação espectatorial.

120 http://culturacurriculo.fde.sp.gov.br/Cinema/Cinema.aspx?projeto=3 


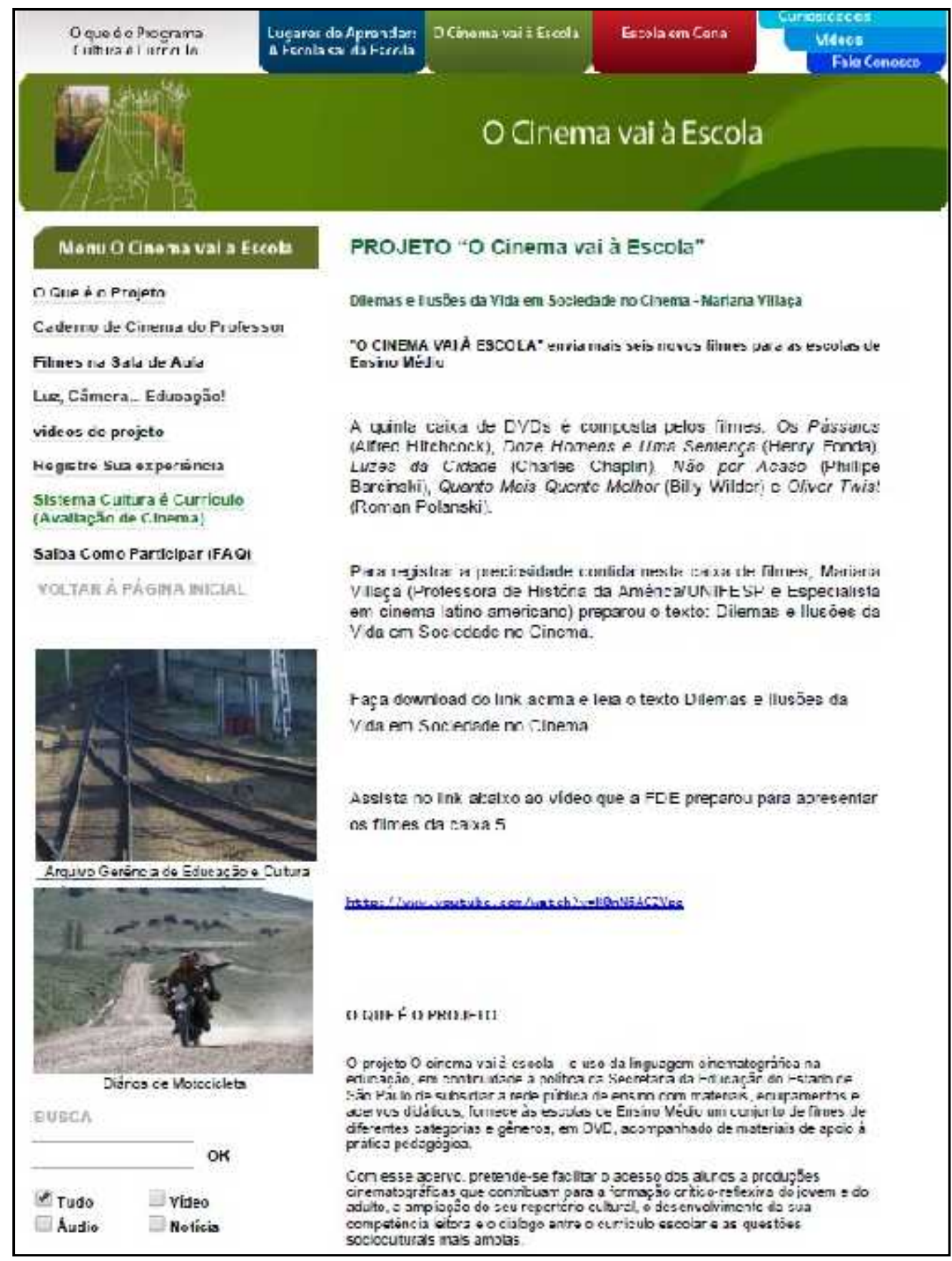

Figura 9- Apresentação do projeto $O$ cinema vai à escola no portal eletrônico da SEESP/FDE.

Fonte: http://culturaecurriculo.fde.sp.gov.br/Cinema/Cinema.aspx?menu=13\&projeto=3. $\quad 0$ conteúdo do projeto encontra-se originalmente no Anexo I, item B, da Resolução SE 19, de 1303-2009, que oficializa o funcionamento do programa Cultura é Currículo, acessível em http://siau.edunet.sp.gov.br/ItemLise/arquivos/19_09.HTM?Time=30/01/2016\%2000:44 $: 30$. 


\begin{tabular}{|c|c|}
\hline JUSTIFICATIVA & PIIRI ICO-AI vo \\
\hline 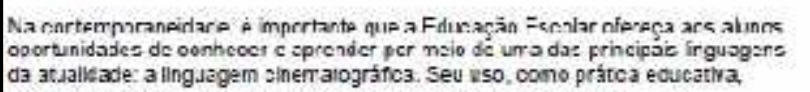 & $\begin{array}{l}\text { Aluros de trano hedo das y1 Uratoras de trsino da Hede tsiadua de Sisa } \\
\text { Paun }\end{array}$ \\
\hline \multicolumn{2}{|l|}{$\begin{array}{l}\text { faclita s gnifcatvanene o dálogo entre cs conteúdcs curriculares e os } \\
\text { conhesimertos ras derais. }\end{array}$} \\
\hline \multirow{3}{*}{ 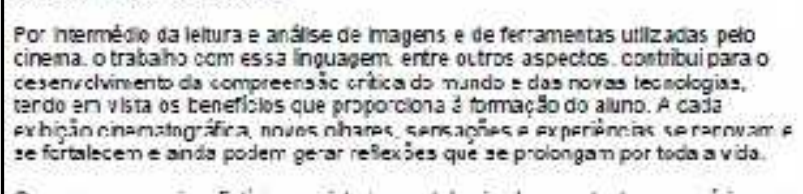 } & PRODUÇÄO DE MATERIAIS DE APCIO D DÁTICO \\
\hline & 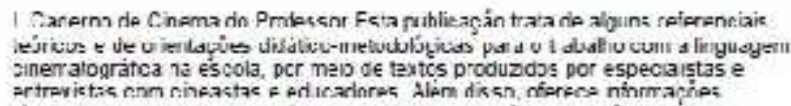 \\
\hline & 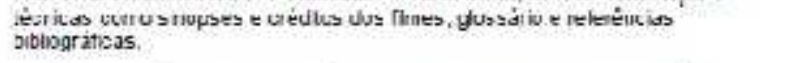 \\
\hline $\begin{array}{l}\text { Qs unversos reas of ficticos projetados iz tola simular contestes o conj́rios que } \\
\text { retatam valores ndhiousis e coletivos, que poderio ser ciacutidos e amplados } \\
\text { por melo co datate con a comunibade escolar. }\end{array}$ & 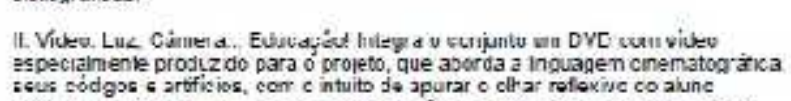 \\
\hline \multirow[t]{2}{*}{ 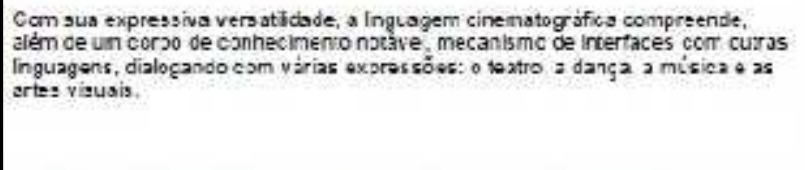 } & 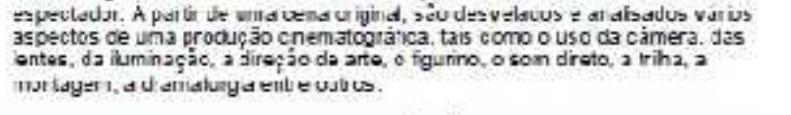 \\
\hline & 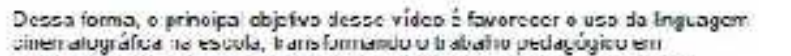 \\
\hline 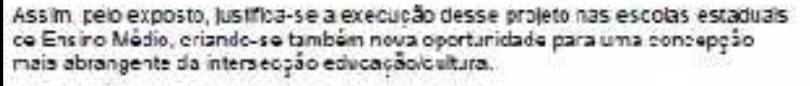 & $\begin{array}{l}\text { oportandaces oara que os alunos possam aptence: unia das prncipas } \\
\text { ingusgonc que fascm pario da sutars sonbemporinca. }\end{array}$ \\
\hline \multirow[t]{2}{*}{$\begin{array}{l}\text { Vae regsitar que c projstc potera ser ampliads com as ą̧öes conjuntas que vöm } \\
\text { sendo reaizadas com a Jec retaria Latedual da Culturs. }\end{array}$} & SELEÇÄO DO CONJJNTO DE $2 C$ FILMES EM DVD \\
\hline & 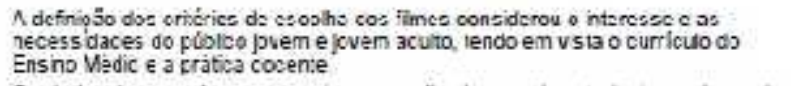 \\
\hline \multirow[t]{2}{*}{ 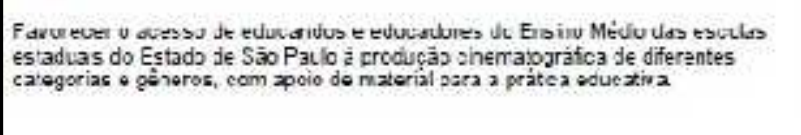 } & 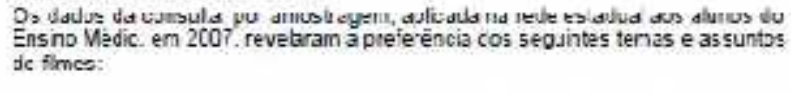 \\
\hline & - etica e cicadana \\
\hline \multirow{4}{*}{ 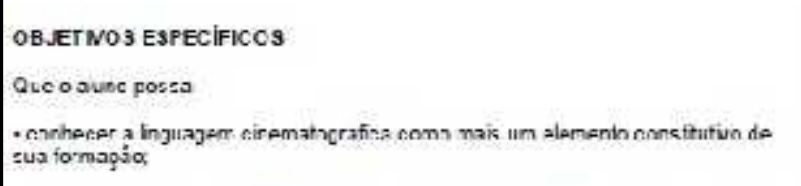 } & - melo amblente \\
\hline & sekwalidade \\
\hline & - ediluexionnas \\
\hline & - orogas \\
\hline \multirow{2}{*}{ 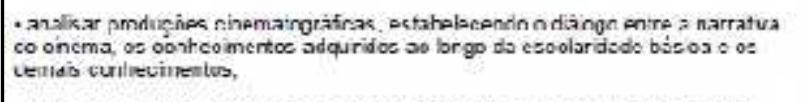 } & - vicléncia \\
\hline & - hietaricee \\
\hline \multirow{9}{*}{ 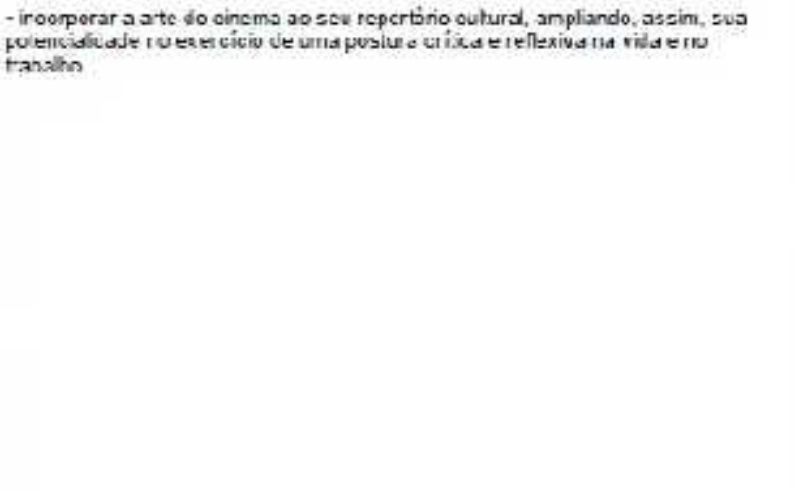 } & - preconceto \\
\hline & - confitos cs adolescéncis \\
\hline & - retexbes sobre a roaldade \\
\hline & - sad́te e cualdade de vida \\
\hline & Alän dis ss tambén feram cansiderados alguns principios nortesdores: \\
\hline & - procuçdes de distintas épocas e escolas cnematcgráncas; \\
\hline & $\begin{array}{l}\text { - diversidsde ds géneros: documertério, fic ģäo, cinebiograla, corédia, trama, } \\
\text { sispense. etc. }\end{array}$ \\
\hline & - procuç б̈es cinemaiográfeas ce dferenies peises: \\
\hline & - fimes náo sxbides ex zustivaruento pala televis żo. \\
\hline
\end{tabular}

Figura 9- (cont.) Apresentação do Projeto 0 cinema vai à escola no portal eletrônico da SEE-SP/FDE. Fonte: http://culturaecurriculo.fde.sp.gov.br/Cinema/Cinema.aspx?menu=13\&projeto=3(editado por nós)

Abaixo, o Quadro 13 apresenta o material que compõe o projeto $O$ cinema vai à escola. 
Quadro 13 - Material do projeto $O$ cinema vai à escola

\begin{tabular}{|l|l|}
\hline \multicolumn{1}{|c|}{$\begin{array}{c}\text { Material do Projeto O cinema vai à } \\
\text { escola }\end{array}$} & \multicolumn{1}{|c|}{ Descrição do material } \\
\hline 1-Luz, câmera...Educação & $\begin{array}{l}\text { Um DVD. Contém um curta-metragem } \\
\text { ficcional com explicações sobre a linguagem } \\
\text { do cinema: planos, luz, atores. Também } \\
\text { disponível no site da SEE-SP/FDE. }\end{array}$ \\
\hline 2-Caixas de Filmes & $\begin{array}{l}\text { No total, foram 6 caixas distribuídas nos 8 } \\
\text { anos que durou o projeto. Cada uma possuía } \\
\text { uma quantidade de filmes que dependia da } \\
\text { seleção feita no momento. Ao todo foram } \\
\text { distribuídos 71 filmes. A última caixa de } \\
\text { filmes foi distribuída em julho de 2015. } \\
\text { (http://www.fde.sp.gov.br/PagesPublic/Noti } \\
\text { cias.aspx?contextmenu=buscaspub\&noticia= } \\
\text { 7774, acesso 11 de setembro de 2015). }\end{array}$ \\
\hline 3-Cadernos de Cinema do Professor & $\begin{array}{l}\text { São 4 volumes impressos e também } \\
\text { disponíveis para download no site do } \\
\text { programa Cultura é currículo. Contêm } \\
\text { discussões sobre cinema e educação em } \\
\text { forma de artigos e entrevistas, além de 41 } \\
\text { Roteiros de Atividades para uso dos filmes } \\
\text { em sala de aula. }\end{array}$ \\
\hline 4-Roteiros de Atividades & $\begin{array}{l}\text { São 41 Roteiros de Atividades com } \\
\text { publicação impressa nos volumes 1 e 4 dos } \\
\text { Cadernos de Cinema do Professor, mais 30 } \\
\text { Roteiros de Atividades com publicação } \\
\text { apenas em site da SEE-SP/FDE. Estes foram } \\
\text { escritos depois da publicação dos 4 volumes } \\
\text { dos Cadernos de Cinema do Professor. }\end{array}$ \\
\hline
\end{tabular}

Se voltarmos à estrutura do projeto ("Introdução", "Objetivos" etc.), teremos algumas impressões da função pensada pela SEE-SP/FDE para o cinema no contexto escolar. Assim, o projeto é apresentado como continuidade à política da Secretaria de Educação de subsidiar as escolas de sua rede com materiais didáticos e de apoio pedagógico, com vistas a

(...) facilitar o acesso dos alunos a produções cinematográficas que contribuam para a formação crítico-reflexiva do jovem e do adulto, a ampliação do seu repertório cultural, o desenvolvimento da sua competência leitora e o diálogo entre o currículo escolar e as questões socioculturais mais amplas. (Projeto SEE-SP, destaques nossos). 
Os filmes das caixas de DVDs distribuídos pelo projeto são pensados para uso quase estritamente em sala de aula. Em momento algum o projeto se refere à possibilidade de uso dos filmes por parte dos alunos, que tomariam a iniciativa, seja coletiva (por meio de Grêmio, por exemplo), ou individualmente, para vê-los na biblioteca ou em casa. Como é esperado que o professor faça uso dele em sala de aula, os filmes acabam ficando na sala das coordenações das escolas ou nas secretarias das mesmas; mas raramente na biblioteca, como pude constatar em visita a algumas escolas.

A expressão "formação crítico-reflexiva" do texto acima parece indicar a que concepção pedagógica se filia o projeto. Parece ser a expressão de que o cinema entra no rol das matérias que contribuem para o aguçamento da cognição, do pensamento lógico e da compreensão crítica da chamada realidade, habilidades exigidas pelos estudos científicos previstas no Currículo. Desse modo, o cinema é, antes, matéria crítico-reflexiva, só depois é feito referência à sua dimensão cultural ao falar de ampliação do "repertório cultural" dos jovens e adultos, mas sem qualquer referência à dimensão propriamente estética, e também política do cinema. Pois que tipo de cultura elabora o cinema? Como a Alain Bergala (2007, p. 46), parece-nos que a ênfase na formação crítica do aluno parte de uma ilusão pedagógica de que os assuntos diligentemente escolhidos seriam imediatamente formativos. Mas o valor formativo do cinema não proviria da assimilação direta, necessariamente, do conteúdo articulado na aula. A concepção pedagógica que procede assim (isto é, que se utiliza insuficientemente do cinema para desenvolvimento do chamado espírito crítico), "proviene de una concepción del cine como mal objeto." (BERGALA 2007, p. 48).

Estamos chamando atenção para esse modo de anunciação do cinema por meio de termos a que ele estaria a serviço como "crítico-reflexivo", porque talvez seja possível, também, por aí, flagrar concepções de sujeito ao pretender que o cinema cumpra determinadas funções no contexto escolar. Assim, o cinema não é um convidado que pode sapatear à vontade, como se diz informalmente, mas é chamado ao contexto escolar, porque se pensa que ele tem função específica no Currículo, ainda que tal papel específico seja apenas de funcionar como suporte temático de outras disciplinas. 0 texto anuncia a seguir que "é importante que a 
Educação escolar ofereça aos alunos oportunidades de conhecer e aprender por meio de uma das principais linguagens da atualidade: a linguagem cinematográfica" (Projeto SEE-SP).

Como se pode perceber, o projeto apresenta o cinema como "uma das principais linguagens", mas retira-lhe esse estatuto na medida em que o coloca como auxiliar, como facilitador do "diálogo entre os conteúdos curriculares e os conhecimentos mais gerais". Assim, o cinema assume a função de linguagem orientada para determinados conteúdos - no caso, os conteúdos definidos pelo Currículo, vale dizer, conteúdos voltados para aqueles que não dizem respeito ao tratamento específico do cinema, visto que ele não é citado como "conteúdo" nem como "habilidade", que foram pensados para os três anos da disciplina Arte. No entanto, os procedimentos didáticos para o uso que se pensa fazer do cinema em sala de aula, no projeto, não são especificados, apenas se diz que ele integra uma "prática educativa".

Por intermédio da leitura e análise das imagens e de ferramentas utilizadas pelo cinema, o trabalho com essa linguagem, entre outros aspectos, contribui para o desenvolvimento da compreensão crítica do mundo e das novas tecnologias, tendo em vista os benefícios que proporciona à formação do aluno (Projeto SEE-SP, destaque nosso).

A passagem acima reforça a ideia de formação de um aluno crítico que adviria da "leitura e análise" de imagens do cinema. 0 filme é entendido como um sucedâneo, um curinga, com o qual se pode humanizar as pessoas, uma vez que ele retrataria "valores individuais e coletivos, que poderão ser discutidos e ampliados por meio do debate com a comunidade escolar". Essa humanização está na base do que o projeto chama de "os benefícios que [o cinema] proporciona à formação do aluno". Além disso, parece-nos problemática a forma de se referir ao termo leitura quanto às imagens do filme. A menção ao termo sem qualquer indicação de diferença entre a leitura de textos e a "leitura" de imagens, parece colocar a segunda nos moldes da prática comum de decodificação a que os alunos são sumetidos no estudo da gramática, exigindo que eles dêem respostas que encontrariam na imagem como as que encontram nos textos escritos. 
Contudo, sendo o cinema uma arte amplamente consumida ("espontaneamente") pelos alunos cotidianamente, diferentemente da literatura, o projeto busca estabelecer uma certa legitimidade fundada supostamente no "gosto" dos alunos e em suas supostas "necessidades", como é mostrado no item do projeto Seleção do conjunto de 20 filmes em DVD. Consta ali que a seleção dos filmes teria levado em conta os "interesses e as necessidades do público jovem e jovem adulto, tendo em vista o currículo do Ensino Médio e a prática docente" a partir de consulta aos alunos do Ensino Médio, em 2007. O site, no entanto, não divulga quais foram a amostragem, os critérios ou métodos empregados na pesquisa. Dentre os temas selecionados estão: ética e cidadania, meio-ambiente, sexualidade (não é indicada a questão de gênero), educação, drogas, violência. Além disso, para a seleção dos filmes, a FDE levou em consideração alguns outros critérios: "produções de distintas épocas e escolas cinematográficas, diversidade de gênero (documentário, ficção, cinebiografia, comédia, drama, suspense etc.), produções cinematográficas de diferentes países e filmes não exibidos exaustivamente pela televisão". Com esse conjunto de critérios o projeto pretendeu possibilitar a professores e alunos o acesso a uma grande diversidade de filmes com vistas a apresentar diferentes modos de entrada no cinema mundial e brasileiro.

As orientações gerais de uso dos filmes estão distribuídas nos vários textos do projeto. Elas podem ser específicas como as que analisaremos nos Cadernos de Cinema do Professor, sendo bastante simples ou, por vezes, imprecisas, confusas, como a seguinte: "Lembretes Importantes: após a exibição para os alunos, procurar saber as impressões que eles tiveram sobre o filme assistido". "Procurar saber as impressões" denota imprecisão e ao mesmo tempo inadequação de objetivos quanto ao uso do filme em sala de aula, pois imaginemos o que das impressões dos alunos poderia ser concatenado com uma aula de história ou de geografia, por exemplo. Essa indicação ao professor de que sonde as impressões dos alunos quanto ao filme é, antes, expressão de certo pudor de não começar a falar do filme sem "pedir autorização" aos alunos. Dessa forma, a sondagem parece atender à necessidade de que os alunos sintam que participaram da aula, que se expressaram. 
$\mathrm{Na}$ parte referente a documentários, o texto mais uma vez sofre de imprecisão, não considerando questões básicas sobre as noções de ficção ou de documentário e com citações vagas como esta creditada a John Grierson: "Os princípios do documentário são de que o potencial do cinema para observar a vida pode ser explorado em uma nova forma de arte, em que o ator 'original' e a cena 'original' são melhores do que seus pares de ficção para interpretar o mundo moderno."

0 projeto procura se justificar também pelas "oportunidades de conhecer e aprender por meio de uma das principais linguagens da atualidade: a linguagem cinematográfica". "Conhecer" e "aprender" pelo cinema. Essa relação nos remete a Adorno (1969b), quando este autor aponta que a arte teria desaparecido dos filmes devido ao acento excessivo na informação. 0 documento segue: "Seu uso [do cinema], como prática educativa, facilita significativamente o diálogo entre os conteúdos curriculares e os conhecimentos mais gerais" (Projeto SEE-SP, destaque nosso), o que parece reforçar a ideia do cinema como apêndice escolar.

Sabe-se, contudo, que os filmes podem suscitar nos estudantes reações imprevistas ao que é esperado pelo professor, visto que, como obra de arte, pode produzir o deslocamento do sujeito, desterritorializando-o. Assim, nas atividades sugeridas no Caderno de Cinema do Professor, volume 1, quanto ao filme Palavra (En)Cantada (2009), de Helena Solberg, é proposto que a turma seja dividida em grupos. Cada grupo deve fazer a "análise de uma das canções selecionadas" (p. 130), além de comparar este filme com um outro, também distribuído pela SEESP/FDE, Língua, Vidas em Português (2004), de Victor Lopes. 0 primeiro filme, um documentário sobre música brasileira, no entanto, pode "tomar" o estudante de um modo (considerando para tanto que o som do aparelho de exibição do filme possibilite uma reprodução técnica adequada ao ambiente) não previsto por tais atividades. Excetuando-se a dificuldade de exibição de dois filmes (a considerar o formato de aula de 50 minutos) para cumprimento da atividade sugerida de comparação entre os dois (uma das atividades sugere ainda que para a comparação entre os dois filmes seja visto também o making off de cada um), contudo, parece-nos uma atividade praticamente irrealizável nas condições do 
Ensino Médio em São Paulo, a intenção de identificação e distinção entre os dois filmes exige um salto fundamental para o estudante. Busca-se na comparação a identificação de intencioanlidade das obras, revelando sua constituição como produto ficcional. Em contato com as músicas e com os depoimentos dos artistas, os alunos podem ser tomados pela matéria prima do filme - as músicas - que certamente inviabilizaria o plano inicial do professor. Então, como fazer para que o professor esteja atento ao efeito identificatório nos estudantes causado na relação com as músicas? Como potencializar a fala "errante" (eivada de desvios da norma culta) de Lenine e tentar percebê-la em sua música ou a recusa de Chico Buarque à condição de poeta, quando alguém no filme assim a ele se refere.

Pelas atividades descritas no Caderno de Cinema do Professor, percebese a intenção de fazer com que o professor tenha um roteiro de ações bem claras e de tarefas também claras para os alunos. Mas, no caso da atividade do parágrafo anterior, não seria o contato com o legado que representam as músicas o aspecto principal dessa atividade? Nesse sentido, como se dará a receptividade às músicas especialmente? 0 roteiro não trata de como o professor deve acolher situações concretas e espontâneas dos alunos. A propósito, no caso de os alunos solicitarem a repetição dessa ou daquela música, o professor deverá conceder de bom grado ou deverá dar continuidade ao seu plano? Como lidar com essas reações?

Não se pode esquecer que o cinema é uma "disciplina" complementar. 0 projeto $O$ cinema vai à escola, conforme salientamos, reforça esse lugar do cinema ao considerá-lo auxiliar das outras disciplinas. Pensamos, no entanto, se não seria o caso de ele ser tomado de modo autônomo nos currículos, tal como ocorre com a literatura. Seria um passo importante para aquilo que pretendemos denominar de uma (des)educação? Tal mudança situaria os atores da escola frente à apreciação do filme em si mesmo, e não como instrumento ilustrativo de conteúdos disciplinares? 0 termo (des)educação consta no título deste trabalho, e não (contra)educação ou (anti)educação, em razão de pretendermos, a partir da estrutura que pensa o estatuto do cinema na escola, indicar e analisar os modos de subjetivação aí compreendidos e não propor uma fórmula que anule essas relações pela substituição simples de uma concepção outra. Assim, a entrada na grade curricular constituiria uma instância formal de reflexão sobre o cinema enquanto 
arte? $\mathrm{O}$ fato é que no formato atual, o cinema tem entradas pontuais na dinâmica escolar. Com uma presença mais central e contínua passar-se-ia, então, de uma vacuidade ao lugar de problematização estético-crítica da arte na escola? É o que parece sugerir a CEB (Câmara de Educação Básica) do CNE (Conselho Nacional de Educação), no 3, que promulga em sua Resolução de junho/1998, Artigo 3:․ “A Estética da Sensibilidade [...] deverá substituir a da repetição e padronização, estimulando a criatividade, o espírito inventivo, a curiosidade pelo inusitado [...]". Contrariamente, nas escolas - e reforçado inclusive pelo projeto $O$ cinema vai à escola - ainda se espera que o cinema seja subsidiário para as disciplinas, sendo a perspectiva da comunicação pura e simples, da justaposição de ideias e não da problematização dos vários elementos postos em jogo, de modo que o imponderável próprio ao cinema, enquanto arte, acaba desaparecendo.

0 interesse crescente pelas coisas da arte, motivado talvez pela crença de que ela é um modo privilegiado de comunicação e de conhecimento da realidade, por vias transversas, também obscurece a ideia de que a arte, contrariamente ao que frequentemente se espera dela, não é para ser entendida, não é conhecimento, mas uma espécie de enigma, ou um acontecimento, de imediato impenetrável, que pede para ser elucidado (FAVARETTO, 2013, p. 70).

Não é por acaso que os filmes tomados para as atividades de mediação de conteúdo das disciplinas, principalmente os ditos figurativos ou narrativos que, com frequência, parecem acentuar a infantilização dos sujeitos, buscando-se neles respostas fáceis, "pedagogizáveis": "As crianças sofrem uma infantilização que não é delas" (DELEUZE apud FOUCAULT, 1988, p. 73). Os filmes são, em grande medida, selecionados pela vocação de superfície de auxiliarem na comunicação de uma "moral", de uma "informação" que se quer anunciar em aula. Crash, no limite (Crash, 2004) é um exemplo, que procura atender expressamente a questão do uso de drogas, do racismo e da xenofobia.

Para que filmes com cenas de violência ou com sugestão de ato sexual (ou ainda qualquer situação que pode remeter à relação dos alunos entre si, não provoque indisposições entre eles, inviabilizando as atividades, em razão disso) o projeto faz indicações quanto ao devido uso de tais obras por parte dos professores. Assim, o educador deve ver todo o filme antes de exibi-lo para os 
alunos e aconselha a seleção de sequências para ênfase em determinados assuntos, considerando que o tempo da aula é curto para exibição de um longa: "O professor explora o potencial pedagógico do filme, com vistas ao desenvolvimento de competências e habilidades relacionadas à disciplina ou área de conhecimento".

Como se pode perceber em uma passagem apresentada na Figura 9, a "justificativa" do projeto se sustenta pela necessidade de "ler e analisar imagens", que contribuiria "para o desenvolvimento da compreensão crítica do mundo e das novas tecnologias, tendo em vista os benefícios que proporciona à formação do aluno". A herança da escrita escolar parece se estender para o cinema. Não se trata apenas de preciosismo notar o uso repetido dos termos "leitura" e "análise", pois são termos que expressam a vocação histórica até então predominante no ambiente escolar da palavra organizada em discursos racionalizantes.

Analisemos um "Roteiro de Atividade" junto com o relato de uma professora sobre a utilização do Roteiro desse filme para ver como essa concepção aparece na prática. Do total de 71 filmes distribuídos às escolas pela SEE-SP/FDE, 41 deles têm "Roteiros de Atividades" sugeridos com os filmes nos Cadernos de Cinema do Professor (publicação impressa, volumes 1 e 4) e também com disponibilização em site. Os outros 30 "Roteiros de Atividades" dos filmes posteriores estão disponíveis no site, com a mesma estrutura dos primeiros, mas sem publicação impressa.

Exemplo é o filme Honeydripper, do blues ao rock (Honeydripper, EUA, 2007), de John Sayles, cuja experiência publicada no site da SEE-SP, no canal "Registre sua Experiência”, pela professora de língua inglesa Janaína Alves, dentre as poucas 15 ocorrências, pareceu-nos a que obteve melhores resultados. Ela dividiu o que chamou de projeto em três partes, não informando, no entanto, de quantas aulas precisou. Antes da exibição do filme, a professora escolheu um tema ("o racismo e a desigualdade social na época da colonização") e trabalhou com os alunos a partir de textos como preparação do "terreno", estímulo para que os alunos se sentissem contextualizados quanto ao ambiente e às circunstâncias de que se tratava o filme. A segunda parte consistiu em discussão sobre a história da música. A terceira, na exibição do filme e a quarta, em "comentários sobre a apreciação do filme”. 
O Roteiro começa com a ficha técnica do filme, como se pode ver na figura abaixo.

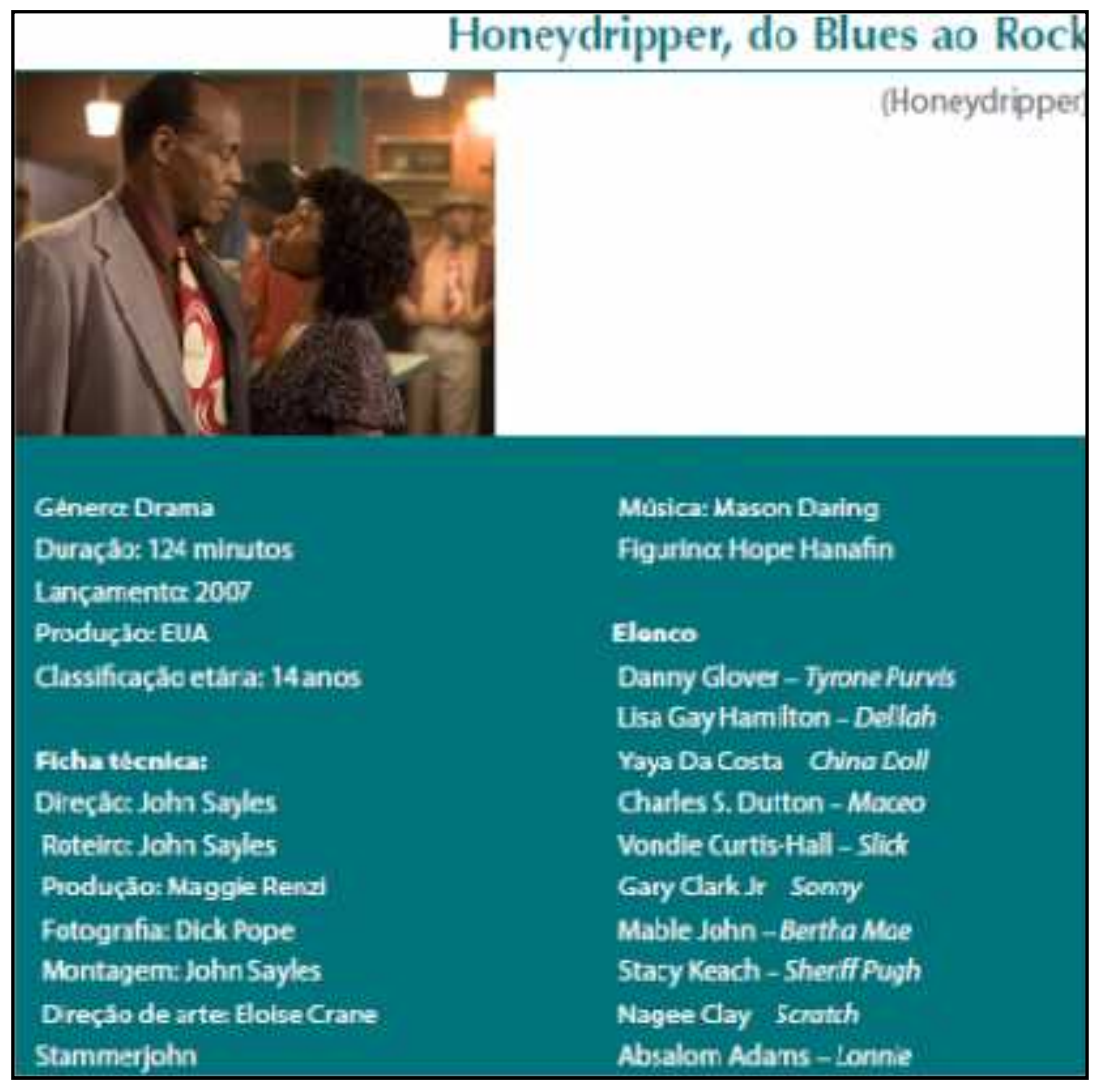

Figura 10: Roteiro - Caixa 3 - Honeydripper, do blues ao rock. Fonte: http://culturaecurriculo.fde.sp.gov.br/administracao/Anexos/Documentos/32012060 1170055HONEYDRIPPER,\%20DO\%20BLUES\%20AO\%20ROCK.pdf.

A seguir, o Roteiro apresenta o enredo do filme e algumas curiosidades, dentre elas, a de que foram contratados para o elenco alguns moradores mais jovens da região em que o filme foi realizado e que eles tiveram que aprender alguns hábitos com os moradores mais antigos como colher algodão. 


\begin{abstract}
O filme
Alabama, 1950. Enquanto a lei americana diz que todos sáo livres, os campos de algodáo que cercam a cidade de Harmony estáo repletos de máo de obra escravizada pelo xerife local, que prende os negros por vadiagem e propóe a eles uma troca: em lugar da cadeia, as plantaçóes.

Tyrone Purvis é um dos poucos negros empreendedores da regiáo e mesmo assim seu negócio, o bar Honeydripper, está em plena decadéncia. Ameaçado por credores e à beira da falência, tenta dar uma última cartada promovendo um show com um guitarrista famoso de Nova Orleans.

\section{Curiosidades}

- Algumas parceirias săo feitas para durar. E o caso do diretor John Sayles com o compositor Mason Daring. Desde 1980, quando se conheceram, até Honeydripper, foram dez filmes trabalhando juntos.

- Gary Clark Jr, que fazo papel de Sonny, năo é propriamente um ator, mas um dos mais promissores guitarristas do soul e do blues da atualidade. Em 2011, ele esteve no Brasil abrindo os shows do guitarrista Eric Clapton.

- Para o elenco, foram chamados moradores da regiáo, que tiveram que aprender alguns hábitos com os mais velhos, como o de colher algodáo manualmente.
\end{abstract}

. O filme foi rodado em Greenville, Georgiana, Anniston e Midway, quatro lo-
calidades do sul do Alabama.
Ganhou o prêmio de melhor roteiro no Festival de San Sebastian, em 2007.
Algumas possibilidades de trabalho com o filme
Honeydripper - do b/ues ao rock
- Areas curricul ares: Ciências Humanas e Linguagens e Códigos
- Sugestăo de disciplinas: Sociologia, História, Lingua Portuguesa, Lingua
- Temas: Etica e Pluralidade Cultural: respeito mútuo, direitos humanos, o
que nos torna humanos: da diferença à desigualdade (etnias, classes sociais,
gênero, geraçăo), democracia, mundo no pós-guerra, desumanizaçăo e coi-
sificaçăo, figura de linguagem (ironia), outras linguagens.

Figura 10(cont.): Roteiro Honeydripper, do blues ao rock. Fonte: http://culturaecurriculo.fde.sp.gov.br/administracao/Anexos/Documentos/32012060 1170055HONEYDRIPPER,\%20DO\%20BLUES\%20AO\%20ROCK.pdf, editado por nós.

Mais adiante, o Roteiro indica os procedimentos para o uso do filme em sala de aula. Contextualiza o enredo, contando sobre a história dos EUA da 
primeira metade do século XX, por exemplo, algumas diferenças entre o Sul e o Norte daquele país, no caso o tipo de colonização dessas duas regiões, sendo que esta teve uma colonização de povoamento enquanto a daquela foi de exploração. E a seguir, sugere passo a passo procedimentos a serem seguidos pelo professor.

Assim:

\section{Orientações preliminares}

(...)

Redija na lousa os principais resultados da pesquisa dos alunos.

É recomendável também a participação de diferentes disciplinas no trabalho com este filme. Nas aulas de Língua Inglesa, o professor trabalharia, por exemplo, algumas letras das músicas que aparecem no filme. Dessa forma, os alunos poderiam ampliar seu repertório musical e compreender melhor a trilha sonora, sobretudo durante a exibição do filme.

Como se pode perceber, as orientações dividem o Roteiro em antes da exibição (o que se costuma chamar de sensibilização para a entrada no tema do filme), durante (que é propriamente a projeção do filme em questão) e depois, com a sistematização dos elementos apresentados no filme e a impressão que os alunos tiveram. O Roteiro faz a indicação de que várias disciplinas poderiam trabalhar com este filme. Para tanto, sugere que o professor de inglês se utilize das letras das músicas a fim de ampliar o repertório musical dos alunos, mas não sugere nada específico. Assim:

\footnotetext{
Atividades

Momentos antes da exibição, comente com os alunos que o filme Honeydripper - do blues ao rock mostra o contexto da disseminação do novo gênero, o rock and roll, e uma visão da sociedade do sul dos Estados Unidos do período. Oriente-os para prestarem atenção especial aos seguintes trechos do filme:

- a imagem dos dois garotos e seus "instrumentos" (DVD 19seg e 1h55min8seg);

- o momento em que Bertha Mae se apresenta (peça para que percebam um exemplo do que é o blues, que acompanhem o ritmo da música e do que a letra fala: da pobreza, das dificuldades, da vida e do amor - DVD 3min50seg até $7 \mathrm{~min} 41 \mathrm{seg}$ );

- a presença da música na comunidade negra do Mississipi e no sul dos EUA nos anos 1950, em igrejas e bares, por exemplo;

- o trabalho nas plantações de algodão, quem o realizava e como esse trabalho era feito (tenha em mente que este é o local do nascimento do blues).
} 
E após a projeção do filme:

Após a exibição, recupere com os alunos a narrativa do filme e as impressões e sentimentos que tiveram durante e depois da exibição. Deixe que teçam seus comentários a respeito e tente saber por que eles gostaram ou não do filme. Dando sequência, converse com os alunos sobre o que conhecem de artistas e grupos como Pearl Jam, Nirvana, U2, Paralamas do Sucesso, Scorpions, Queen, Raul Seixas, Rolling Stones, Celly Campello, Beatles, Elvis Presley, Bill Halley e Little Richard. Comente que todas essas referências, embora façam parte de décadas, estilos e projetos artísticos distintos, possuem raízes que remetem ao blues. Uma possibilidade para explorar as diferenças de estilo é analisar, por exemplo, as músicas Bohemian Rhapsody, Rock Around the Clock e Unforgateble Fires.

Além da temática musical destacada pelo Roteiro, logo a seguir, ele indica que o professor chame atenção dos alunos para temas como corrupção e rebeldia, indiciados no filme e associados ao rock.

Mais adiante, tem-se a indicação para outras aulas da distribuição e trabalho de textos afins com o filme, conforme passagem a seguir:

Em outro momento, apresente aos alunos textos que falem sobre os direitos civis, respeito às diferenças, corrupção, etc. Após a leitura e discussão em pequenos grupos, seria interessante que eles desenvolvessem sua competência escritora, neste caso por meio de um artigo de opinião, que poderá compor uma revista ou ser hospedado em um site, uma vez que este gênero permite uma conversa sobre assuntos conhecidos, os quais se quer defender, com base em argumentos.

É inegável que o professor tenha em Honeydripper: do blues ao rock um conjunto de temáticas importantes, cujo desenvolvimento em sala de aula pode ser bastante profícuo. "Blues", "rock" etc. são temas caros ao Brasil e ao estado de São Paulo, já que este apresenta estatísticas conhecidas de opressão aos negros, principalmente nas periferias dos grandes centros paulistas, especialmente na capital. Contudo, o filme é, em muitos aspectos, um produto comercial. Lamentável, nesse sentido, que aborde questões importantes de um modo reducionista, sem o devido cuidado, mantendo o tratamento de temas a que os jovens estão acostumados nas novelas brasileiras. São várias evidências dessa relação do filme com a teledramaturgia. Ambos apresentam soluções já indicadas no início. 0 
forasteiro que chega à cidade, com jeito calmo de bom moço, será a salvação do bar que leva o nome do filme, Honeydripper. 0 filme, pois, possui os principais elementos que o fazem comercial: romance hetero, final feliz, star system (Danny Glover, Lisa Gay Hamilton e Charles S. Dutton), as ações (dívida do dono do bar, que vai perdê-lo se em poucos dias não pagar o que deve. Para cobrar tal dívida, dois homens "mal encarados" tratam de deixar clara a situação) não são gratuitas, elas são causa, desencadeiam novos eventos. Para acentuar o drama existencial do protagonista, o xerife do distrito (que é branco) enuncia ameaçadoramente, olho no olho, o assassinato que Tyrone cometera para dizer que ali quem manda é ele, o xerife. Este aviso ao espectador serve para introduzir já quase no final do filme o flash back que faz com que Tyrone separe a briga entre dois outros homens que certamente acabaria em morte. Tyrone segura os dois pelas mãos e os força a depositar, cada um, as armas que já haviam empunhado: um revólver e um canivete. Essa ação, bem pontuada com o flash back, serve para redimir o protagonista da culpa no passado; poupando ao menos uma vida ele estaria quite com a justiça divina, esta representada pela esposa religiosa. De saúde frágil, sua filha é outro ponto que amarra a história bem contada no filme, não deixando ponta solta. O cantor e guitarrista forasteiro, em pleno show (em que é ovacionado) anuncia que cantará uma música que compôs enquanto cortava o cabelo na mesma tarde do show cujo título traz o nome da donzela, China Doll. 0 assistente de Tyrone, Maceo, também encontra seu par, uma senhora que já havia demosntrado interesse por ele, mas este a evitava em virtude de ela ter se vingado de um ex-namorado, que a teria traído, jogando-lhe água quente no sexo. Quem conta essa história é o próprio Maceo, que se deitará com a senhora. Na ocasião, todos riem. A morte da senhora, que vemos cantar blues, num bar para apenas um cliente presente, simboliza o fim de um ciclo, o do blues, para a chegada de outro, o do rock, que vem acompanhado da guitarra elétrica, numa encenação bastante esquemática, anunciando o final feliz do filme.

Ao final do Roteiro de Atividades constante do Caderno para este filme, há indicação de filmes de mesma temática e também a sugestão ao professor de que lembre aos alunos da existência do Museu Afro Brasil, situado no Parque Ibirapuera, em São Paulo, capital, mas sem nenhuma outra orientação. O Roteiro 
ainda sugere uma atividade cultural com eventuais bandas de música na escola. Neste Roteiro especificamente não há indicação de referências bibliográficas para o trabalho com o filme, diferente de outros, como no caso do Roteiro de Lixo extraordinário (2010), por exemplo.

O espaço no site da SSE-SP (Registre sua experiência, abaixo, Figura 11) de onde colhemos o relato de experiência com o filme Honeydripper é a área reservada para registro de relatos de experiências das escolas quanto à utilização dos materiais do projeto $O$ cinema vai à escola. Podem utilizá-lo coordenadores, diretores e professores. Tem-se aí um importante instrumento no sentido de materializar e partilhar as diversas maneiras de trabalhar com o cinema na escola com relatos práticos. Os relatos têm análises prévias feitas pela SEE-SP para seleção do que é pertinente para então publicação do registro. Contudo, são poucas as experiências disponíveis para leitura (15 registros). Em 2014 há apenas uma, ainda assim enviada pelo coordenador, sem que o mesmo mencione trabalhos desenvolvidos; apenas elogia a iniciativa da SEE-SP pela disponibilização do material, que permitirá o maior acesso a um acervo diversificado do cinema. Em 2013 houve seis. Em um deles a professora se utilizou do filme $O$ povo brasileiro, uma série de TV, iniciada em 2000. Relata que se utilizou do filme como disparador para a discussão sobre o tema proposto. 0 objetivo fora estimular a participação dos alunos para, em seguida, propor que respondessem a questões previamente pensadas pela professora. 


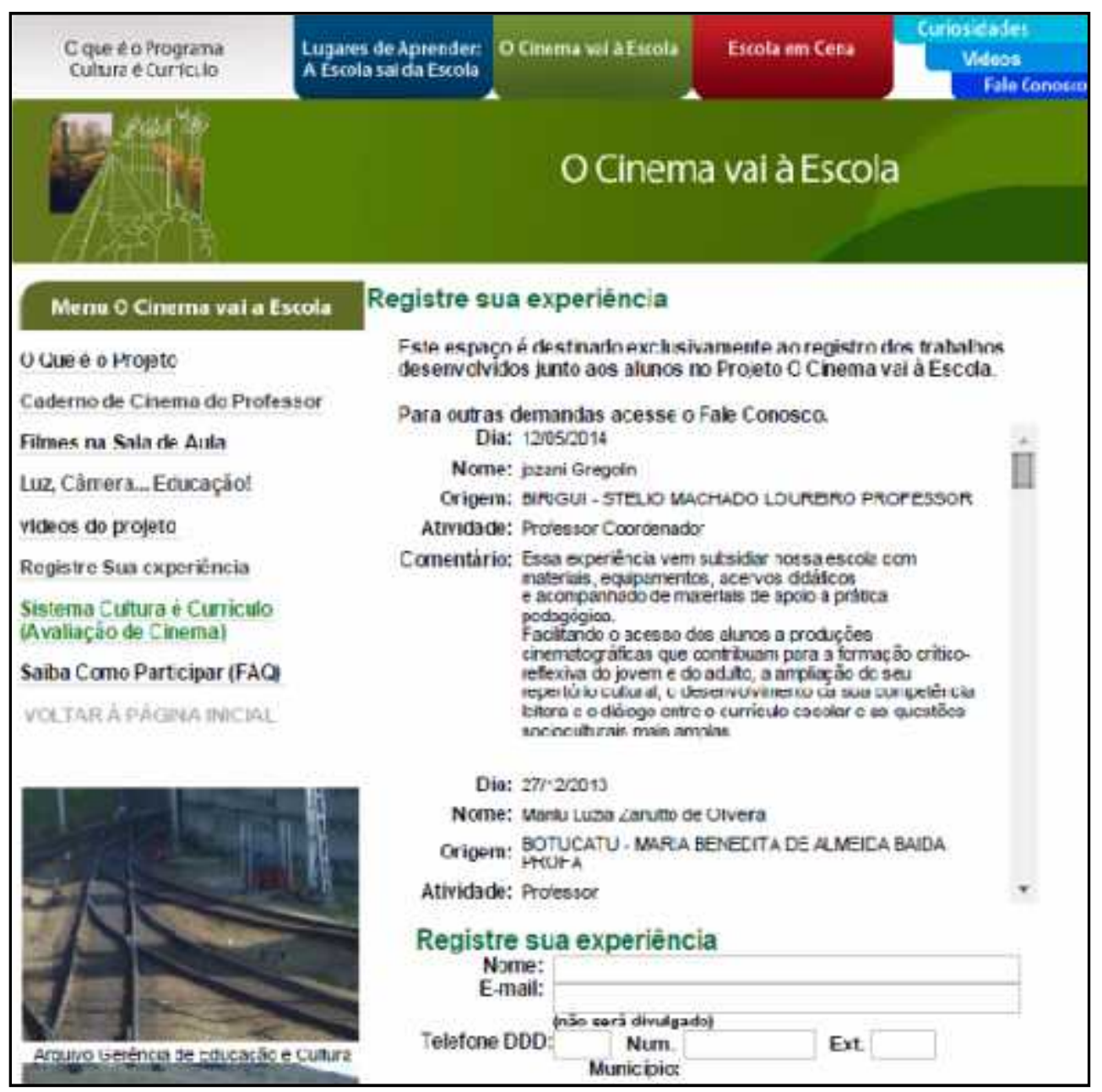

Figura 11-"Registre sua experiência", espaço de registro de experiências no site da SEE-

/FDE.Fonte:http://culturaecurriculo.fde.sp.gov.br/cinema/Sua_Experiencia.aspx?men $\mathrm{u}=53$ \&projeto $=3$

Há ainda no mesmo ano, uma experiência de realização de documentário desenvolvido pelos alunos que visitaram uma instituição (APAE) e que prepararam a exibição do documentário na escola. De 2012 tem quatro registros e o mesmo número em 2011. Em 2012, há um registro no qual o professor relata ter privilegiado o filme Lixo extraordinário (Br/Eng, 2010), de Lucy Walker, João Jardim e Karen Harley, mas não informa o modo de sua utilização, contudo, dá a entender que houve exibição e, a seguir, discussão em roda de conversa. Outra escola fez o que chamou de atualização do curta Ilha das flores (1989), de Jorge Furtado, para o Lixo extraordinário.

No entanto, essa participação, a partir de "registros de experiência", parece responder a uma perspectiva de que as contribuições dos professores são 
periféricas, visto que são pensadas como instrumentos de ajuste ao processo, sendo, portanto, apenas coadjuvantes, peças adicionais da estrutura. Observemos a fala de um professor disponibilizada no espaço Registre sua experiência, no site da SEE-SP:

Essa experiência [a do projeto O cinema vai à escola] vem subsidiar nossa escola com materiais, equipamentos, acervos didáticos e acompanhado de materiais de apoio à prática pedagógica, facilitando o acesso dos alunos a produções cinematográficas que contribuem para a formação críticoreflexiva do jovem e do adulto, a ampliação do seu repertório cultural, o desenvolvimento da sua competência leitora e o diálogo entre o currículo escolar e as questões socioculturais mais amplas.

A fala acima enuncia a importante dimensão formal do projeto, amparada em recursos materiais (filmes, vídeos, material didático). No entanto, sendo um espaço de registro de experiência, falta-lhe o verbo que dê à formalidade, a dimensão da experiência. Vale notar que mais da metade da citação acima é retirada do Projeto $O$ cinema vai à escola, quando deveria ser expressão de uma experiência com filmes do Projeto.

A partir da citação acima, onde se lê: “(...) facilitando o acesso dos alunos a produções cinematográficas que contribuem para a formação críticoreflexiva do jovem e do adulto (...)”, a dimensão da experiência estaria contemplada se à enunciação da formalidade do "contribuem" a escrita, por exemplo, se apresentasse da seguinte forma: “(...) pois tem facilitadofacilitando o acesso dos alunos a produções cinematográficas que tem contribuídocontribuem para a formação crítico-reflexiva do jovem e do adulto (...)”. (as partes em itálico são acrescentadas ao texto por nós e as riscadas são para facilitar a visualização daquilo que estamos supondo uma possível substituição).

A ideia de que o cinema facilita o aprendizado parece imbuída do engodo de que esse processo se dá de modo imediato à exposição do filme. "Sintoma" desse pensamento, encontramos no site da própria SEE-SP (Figura 12, abaixo), o anúncio do projeto $O$ cinema vai à escola, associado ao prazer que os filmes proporcionariam aos estudantes. Ali, lemos: "Aulas cada vez mais atrativas" e "Pensando em deixar as aulas cada vez mais atrativas, a Secretaria da Educação 
tem estimulado as escolas a exibirem filmes relacionados ao conteúdo do currículo e levarem seus alunos a espetáculos culturais".

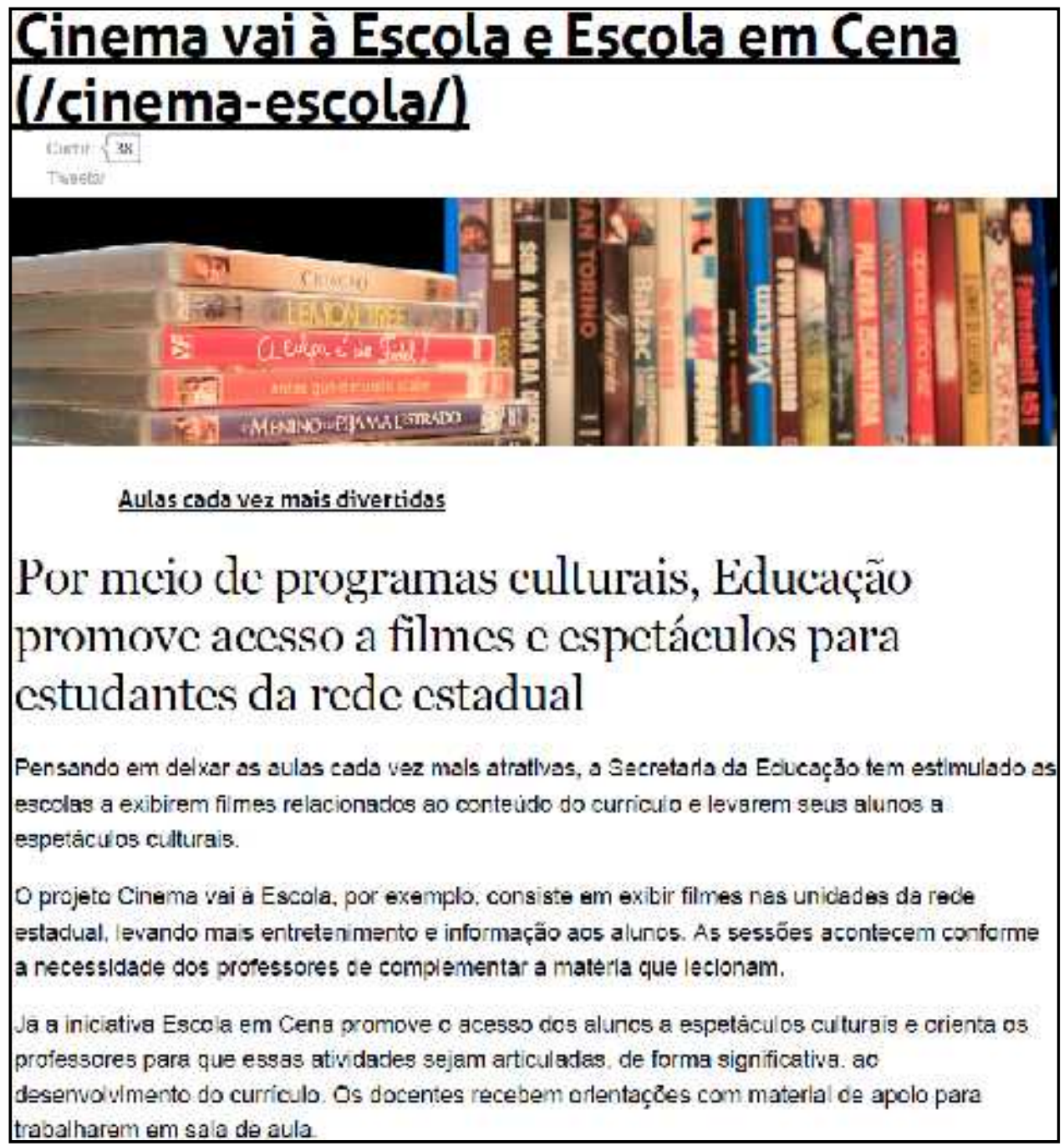

Figura 12- "Aulas cada vez mais divertidas". Fonte: http://www.educacao.sp.gov.br/cinemaescola/

Dessas passagens, podemos perceber dois aspectos. 0 primeiro, mais evidente, refere-se à diversão que seria usar o filme como produto auxiliar na condução dos conteúdos da aula. 0 filme tornaria mais leve e atrativa (porque divertida, leve) a aprendizagem dos conteúdos. 0 segundo aspecto refere-se ao filme como auxiliar dos conteúdos do currículo. Mais uma vez é rassaltado pela SEE-SP o papel do cinema no processo ensino-aprendizagem. Ora, se o filme não ensina (ainda que se aprenda com ele), ele estaria fora do eixo sério em que se baseia obsessivamente a escola, que é o chamado processo ensino-aprendizagem.

Ainda nessa perspectiva de "facilitar" o aprendizado, o site da SEE-SP apresenta "dicas" de filmes para uso em sala de aula (Figura 13) sem indicar o 
material elaborado pela FDE para a mesma função, qual seja, a orientação de uso de filmes em sala de aula.

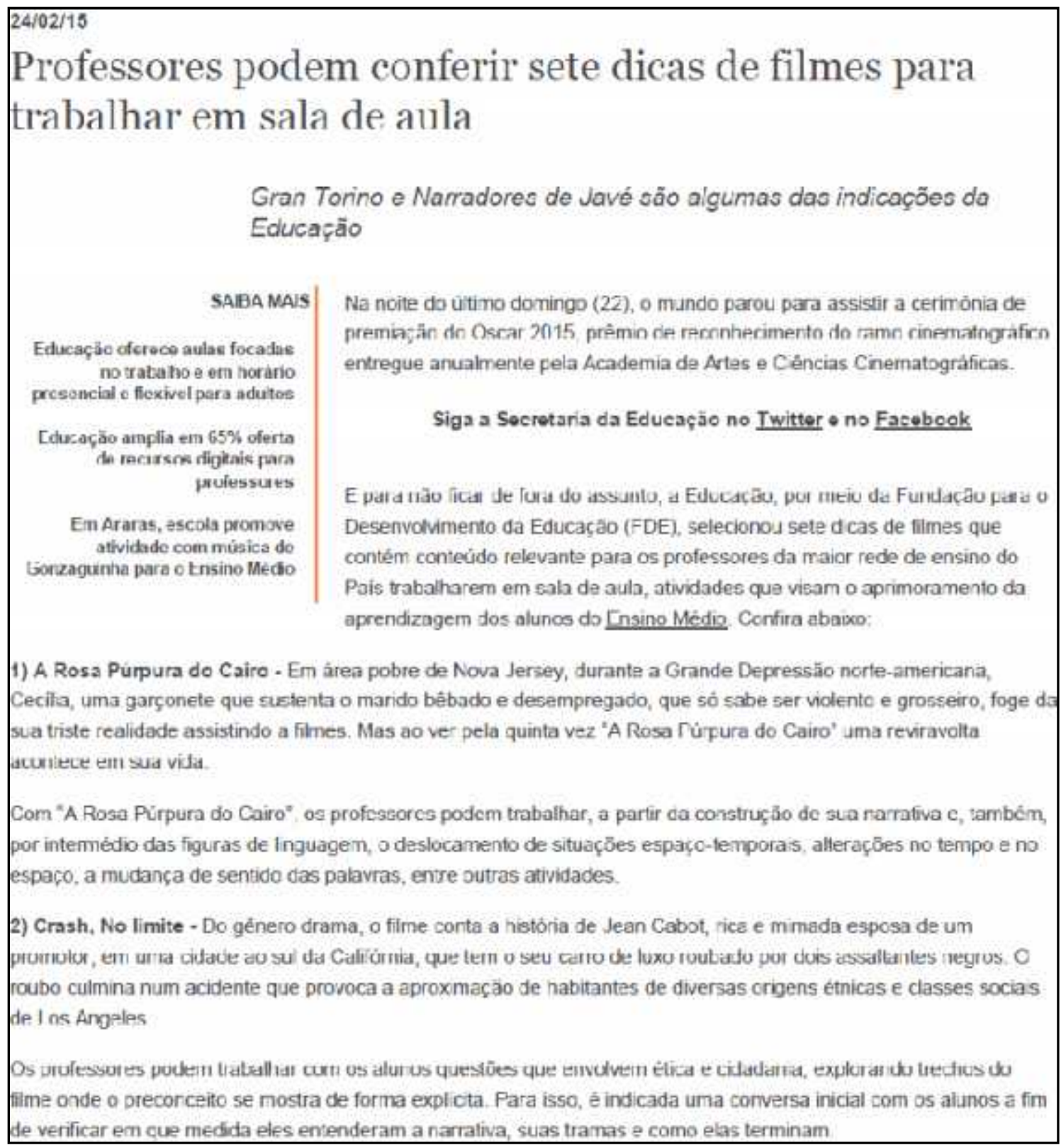

Figura 13 - Dicas para os professores se utilizarem dos filmes. Fonte: http://www.educacao.sp.gov.br/noticias/confira-sete-dicas-da-educacao-de-filmes-para-assistirneste-fim-de-semana

Como parte do Projeto, a SEE-SP/FDE ofereceu alguns cursos a fim de preparar o professor para lidar com o audiviosual, dentre eles o curso de produção de vídeos (Figura 14). Nessse curso, os professores tiveram aula sobre "fundo", "centramento" e de como lidar com câmeras de celular para montagem de vídeo- 
aulas. É interessante notar a natureza desse curso. Ele visa à apreensão da técnica de vídeo. É, sem dúvida, importante que o professor entenda, minimamente, a partir do exercício de captação de imagem pela câmera, a posição de quem compõe a imagem e como (angulação, luz, estrutura de roteiro etc.). Contudo, é curioso que haja uma desatenção especial ao "repertório" de professores e alunos. Ora, o fundamental do espectador é situar-se diante da projeção do filme. 0 que se ver quando se vê um filme? É curioso que a SEE-SP não ofereça curso nesse sentido, isto é, no sentido de promover no professor o aprimoramento quanto à apreciação do cinema, em especial, dos filmes distribuídos às escolas, mas também de vários outros representativos da história do cinema no mundo e no Brasil. Tal capacitação também poderia contemplar aspectos como a percepção de diversos planos e a análise da montagem, a partir da exibição exaustiva de trechos dos filmes, procurando fazer com que o professor aprendesse a ver detalhes dos planos observando-os demoradamente como a uma pintura a fim de identificar seus componentes e seus possíveis sentidos. No entanto, predomina a ilusão de domínio do palpável, do visível, que é a técnica, em detrimento do impoderável da arte, como já se falou. 


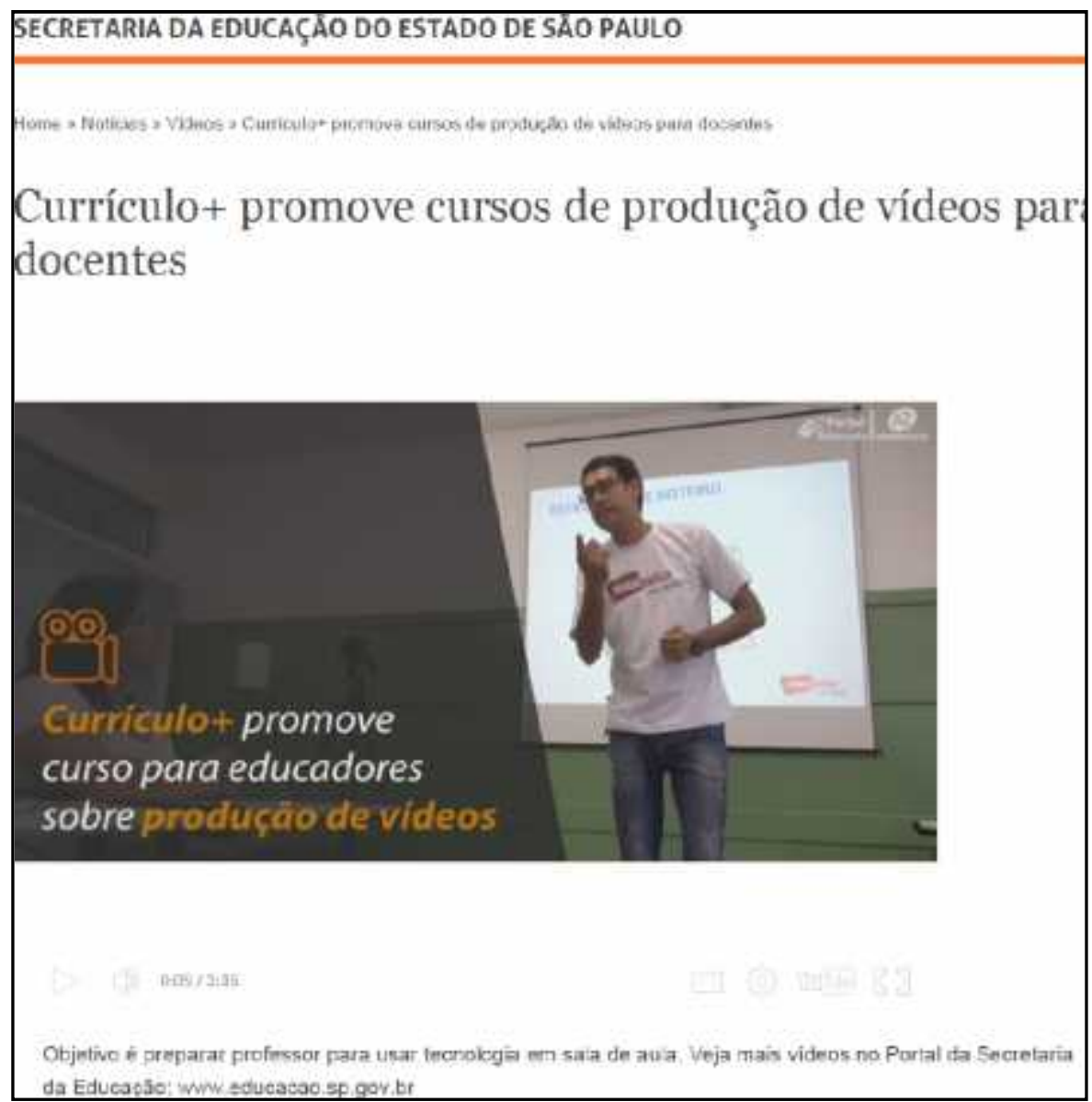

Figura 14 - Dicas para os professores se utilizarem dos filmes Curso de vídeo-aula promovido pela SEE-SP. Fonte: http://www.educacao.sp.gov.br/video.php?vid=wHoz5KGHLbE

Com essa e outras indicações, o referido projeto define o papel dos filmes como apoio pedagógico. Apesar dessa restrição do uso do filme como suporte às disciplinas, um pouco mais adiante o texto apresenta como possibilidades que o professor desenvolva pesquisas sobre o filme entre os alunos, o que consiste na seleção de cenas e em debates. Parece-nos que, no que diz respeito principalmente à seleção de cenas, os alunos são levados a investigar mais pormenorizadamente o filme (como se faz com um texto escrito), lendo e relendo trechos de parágrafos a fim de entender a que cada expressão se refere ou o que eles estão dizendo. A seleção de cenas parece um exercício poderoso em que os alunos são convocados a eleger partes de um todo que lhes seja representativo. Assim, a depender dos critérios e das discussões acerca desses critérios, bem como 
da realização desse processo, pode o professor possibilitar um excelente encaminhamento de análise da obra e de "razões" menos objetivas para a seleção de trechos, importante para situar o aluno subjetivamente na experiência estética.

Ao contrário do que aqui defendemos, Laís Bodanzki e Luiz Bolognesi, conhecidos pela parceria (direção e roteiro, respectivamente) como em filmes Bicho de sete cabeças (2001), Chega de saudade (2007) e As melhores coisas do mundo (2010), não acreditam que a entrada do cinema deva se dar pela grade curricular. Apesar de um importante trabalho de divulgação do cinema por um projeto que leva a projeção de filmes a cidades onde não há espaços de exibição, os dois premiados artistas não acreditam que colocar o cinema na grade curricular ajudaria. Ao contrário, atrapalharia, dizem eles (apud RIZZO, 2015):

Acreditamos muito que [o] audiovisual pode transformar a escola. Mas não acreditamos que ele deva entrar pela grade curricular. Deve entrar dando a câmera na mão dos meninos, para que façam o que quiserem, brinquem de filmar. Depois, você passa um filme do (Sergei) Eisenstein. Se passa antes, eles falam: 'que saco' (http://revistaeducacao.uol.com.br/textos/215/dez-anos-nateladocumentario-registra-uma-selecao-de-12-curtas-3391021.asp, acesso dia 07 de abril de 2015).

Considerando que o cinema entre na grade curricular, ao contrário do que sustentam os autores de Chega de saudade, poder-se-ia afirmar que a ocupação desse lugar pelo cinema se daria de modo que a problematização estético-crítica da arte na escola se daria mais detidamente? Isto é, pode-se pensar numa adequação crítica do cinema como disciplina na escola sem restringi-lo ao caráter de espetáculo? Ou ainda, como assegurar que o cinema na escola seja contemplado como arte e não apenas como um suporte linguístico que conta uma história? Isto estaria contemplado no horizonte da CEB (Câmara de Educação Básica), nº 3, quando promulga em sua Resolução de junho de 1998, Artigos 3º, alínea I, abaixo?

A Estética da Sensibilidade [...] deverá substituir a da repetição e padronização, estimulando a criatividade, o espírito inventivo, a curiosidade pelo inusitado [...], bem como facilitar a constituição de identidades capazes [...] de conviver com o incerto e o imprevisível; [e também no Artigo 8o, alínea I, quando diz que a interdisciplinaridade] partirá do princípio de que todo 
conhecimento mantém um diálogo permanente com outros conhecimentos ${ }^{121}$.

Perguntamo-nos se na escola esse diálogo é possível a partir do cinema; mas não só isso, perguntamo-nos se ele é desejável pelo sistema escolar tal como se encontra; é possível o debate sobre a experiência estética? Na condição de auxiliar de outras disciplinas no ambiente escolar o que do cinema continua cinema e o que deixa de sê-lo (ou como ele continua sendo arte nessa configuração)? A arte como exceção deixa de sê-la, nos termos de Godard, e passa à regra?122 Como evitar a "repetição", tal como pronunciado pelo artigo acima, quando os filmes do projeto que ora estudamos tenha selecionado em sua quase totalidade filmes "bem estruturados em termos clássicos" (XAVIER, 2003, p. 132)?

O documento Orientações Curriculares para o Ensino Médio, da Secretaria de Educação Básica/MEC, parece encaminhar uma resposta a essa questão. Assim, no capítulo referente à disciplina Sociologia, no item "Cinema, Vídeo ou DVD, e TV”, apesar de não ser feita alusão à inclusão desses recursos na grade curricular, parece entendê-los, no entanto, como primordiais para o cumprimento dos objetivos espraiados na maioria dos documentos oficiais (que tratam da necessidade, por exemplo, da consideração de uma "educação para a vida" ou uma "estética da sensibilidade"). Assim:

Trazer a TV ou o cinema para a sala de aula não é apenas buscar um novo recurso metodológico ou tecnologia de ensino adequados aos nossos dias, mais palatáveis para os alunos - e o público -, que são condicionados mais a ver do que a ouvir, que têm a imagem como fonte do conhecimento de quase tudo. Trazer a TV e o cinema para a sala de aula é submeter esses recursos a procedimentos escolares - estranhamento e desnaturalização. Não se pode entender uma "educação para a vida", de que tantos

\footnotetext{
121 Citação em parte já mencionada anteriormente, mas importante aqui para ressaltar aspectos da "estética da sensibilidade". Os PCN, que são do ano de 2000 (dois anos depois do texto da CEB) têm praticamente a mesma redação do texto em questão, como se pode constatar no item 3.1 (BRASIL, PCN, 2000, p. 62): "O currículo do ensino médio observará o disposto na Seção I deste Capítulo e as seguintes diretrizes (...) 3.1 A estética da sensibilidade. Como expressão do tempo contemporâneo, a estética da sensibilidade vem substituir a darepetição e padronização, hegemônica na era das revoluções industriais. Ela estimula acriatividade, o espírito inventivo, a curiosidade pelo inusitado, a afetividade, parafacilitar a constituição de identidades capazes de suportar a inquietação, conviver com oincerto, o imprevisível e o diferente.".

122 Estamos nos referindo à contraposição simples que Godard faz, colocando de um lado a cultura, como regra, e a arte, do outro, como exceção a ela. Em outro momento deste texto, fazemos a citação completa de Godard. Contudo, para ver mais, cf. BERGALA, op. Cit., p. 34.
} 
falam, como simples reiteração dos fatos da vida na escola, isto é, repetição dos fatos da vida e vagos comentários - clichês convencionados - acerca desses. Não é porque se fala de problemas sociais e políticos na escola - corrupção, fome, favela, desemprego, etc. - que se está cumprindo essa obrigação de trazer a vida para a escola e com isso "preparar para a vida". Do mesmo modo, a TV e o cinema na escola têm essa dupla disposição: entrar e se chocar com as formas tradicionais do ensino, incorporando as imagens ao ensino predominantemente auditivo; mas entrar na escola para sair de outro modo: sair da escola para se chocar com as formas convencionais da assistência. Assim como os diversos aspectos da vida entram na escola na forma de disciplinas Sociologia, História, Geografia, Física, Língua, etc. - e sofrem aí uma releitura científica, passando a constituir uma visão de mundo, uma perspectiva diante da vida, a formação do homem não pode ocorrer como se quer - crítica e cidadã - se não concorrer para uma perspectiva crítica e cidadã dos meios de comunicação. Ver TV e filmes em sala de aula é rever a forma de vê-los na sala de estar, de jantar ou nos quartos de casa e nas salas de cinema dos shopping centers (BRASIL, 2006, p. 129).

0 texto acima sugere que sejam levadas à escola linguagens que estão cotidianamente interagindo com as pessoas, caso da programação diária da TV e do cinema para, assim como se faz em disciplinas como Sociologia, História, Física etc., esses meios de comunicação sofrerem uma releitura dentro de uma "perspectiva crítica e cidadã". Para o texto, a escola teria a função de produzir estranhamento e desnaturalização no modo convencional de ver filmes e programas de TV. Entretanto, não apresenta meios de como, em aulas ou em eventos, se daria tal inserção ou intervenção. A sugestão de levar à escola meios de comunicação como a TV e o cinema é interessante, porque não pretende instrumentalizar o uso desses recursos como acontece frequentemente em propostas curriculares, sendo apresentada por disciplina o passo a passo que deve seguir o professor na realização dos planos de aula.

É possível que Bodanzki e Bolognesi estivessem se referindo à escolarização ou didatização ou ainda à codificação do cinema nos moldes tradicionais das disciplinas canônicas como História ou Geografia. Sua preocupação talvez seja a de que o cinema na escola conserve o componente que faz as pessoas se interessarem por ele fora dela, o que não se daria se sua utilização fosse obrigatória. Por outro lado, o fato de ele não habitar o currículo parece fazer com que os professores o tomem apenas casualmente. 
$\mathrm{Na}$ relação estabelecida pelo professor entre filme e conteúdo da disciplina há, de saída, uma hierarquização entre a obra fílmica e esse conteúdo, como se a participação da arte estivesse submetida ao sentido cientificizante do currículo. Uma vez que o cinema não é uma ciência, no jogo com as disciplinas no contexto escolar, ele é secundarizado. "Há no racionalismo e no cientificismo docente e curricular uma resistência e uma tendência a alinhar a cultura e a estética a uma certa visão irracional da realidade, a um trato pouco sério do conhecimento e da docência." (ARROYO, 2003, p. 128). Essa parece ser uma concepção comum dos discursos que circulam no contexto escolar. De outro modo, "a arte não isola, um a um, os elementos da causalidade, ela não explica, mas tem o poder de nos 'fazer sentir'. Isso, evidentemente, não quer dizer que a arte substitui a causalidade científica, nem que ela se encontra em oposição à ciência" (COLI, 2006, p. 110). E, no entanto, a escola desconfia do professor que não submeta o filme ao "conteúdo curricular", como se esse conteúdo fosse algo rígido e que excluísse o imprevisível. A arte não se prende a objetivos claros, e, no entanto, é geralmente levada a responder aos objetivos das disciplinas. Assim, o cinema visaria atender a eixos disciplinares, mas não se constituindo ele mesmo um desses eixos.

A concepção cientificizante do "conteúdo curricular" parece determinar a subjetivação do professor no exercício profissional, relegando-a ao tempo livre, justamente o tempo que, segundo Adorno, é especialmente preenchido pela indústria cultural ${ }^{123}$. O uso dos filmes associado aos conteúdos de teor

\footnotetext{
${ }^{123}$ É sabido que "tempo livre" não corresponde àquele disponível ao tempo do trabalhador fora das horas voltadas ao desempenho de suas funções trabalhistas. Interessa-nos aqui, porém, a ideia de tempo livre como qualquer tempo fora do trabalho, tempo este em que ele estará exposto ao contato com as mídias, seja o cinema ou quaisquer outras. Chama atenção que o professor, a partir da TV, dos jornais e demais mídias, diante de toda sorte de exposição de intencionalidade moral nesses veículos, portanto, diante de uma espécie de "pedagogização da vida" (AQUINO, 2013), não leve esse tipo de experiência para a sala de aula. Pode-se sentir que a pedagogização da vida se intensificou como estratégia de mercado não só no ensino formal, mas também a partir das propagandas de televisão, por exemplo. Comparemos duas propagandas de décadas diferentes para procurar perceber como as referências mudam de uma para a outra. Na propaganda da margarina "Saúde" (https://www.youtube.com/watch?v=ibJa41KwNbk), lançada em 1969, com duração de 59 segundos, um garoto sentado num banco de uma praça (ou da escola), desenrola um pão e começa a comê-lo. Um professor se aproxima, sentando-se ao seu lado. 0 menino, ainda que hesite, oferece um pedaço a ele. Em princípio, o professor recusa, mas devido à insistência do garoto, e por se
} 
cientificizante visível nos Roteiros parece submeter a própria subjetividade do professor, já que lhe resta pouco poder de escolha na seleção de temas a serem abordados. Vale lembrar Adorno, quando este se refere à ciência esvaziada de vida e arrastada pela esfera do mero consumo. (ADORNO, 1993, p. 07).

Deve-se, diz o Projeto, partir do gosto, por meio de uma intervenção que não é dada senão à educação, promover esse corte, esse salto (do mero consumo) para a experiência estética. Mas é interessante acentuar que Adorno diz ser o gosto uma referência ultrapassada.

Se perguntarmos a alguém se 'gosta' de uma música de sucesso lançada no mercado, não conseguiremos furtar-nos à suspeita de que o gostar e o não gostar já não correspondem ao estado real, ainda que a pessoa interrogada se exprima em termos de gostar e não gostar. (...); gostar de um disco de sucesso é quase exatamente o mesmo que reconhecê-lo. (...) Tal indivíduo já não consegue subtrair-se ao julgo da opinião pública (ADORNO, 1991, p. 79).

Na verdade, não se trata de afirmar que o gosto está ultrapassado, mas é ele, talvez mais que nunca, o termômetro da produção em escala industrial do audiovisual. Nesse sentido, imaginamos que também o professor seja tomado pelo emudecimento de sua subjetividade quando se submete ao gosto da opinião pública, seja pela eleição canônica de filmes apresentada pelas revistas

tratar de um pedaço pequeno, aceita. Prova o pedaço e em seguida vê-se em seu rosto uma expressão de prazer desesperado, acentuada por um zoom, que se mostra impressionado pelo sabor da margarina que fora passada no pão. Pergunta pelo nome do produto e pede mais um pedaço, ao que lhe é negado. 0 professor olha para um lado, para o outro, e, apercebendo-se de que ninguém se encontra por perto, toma o pão do garoto, passando a comê-lo avidamente. Uma voz off entra com a imagem em detalhe do produto: "Há uma nova Saúde com um novo e irresistível sabor e sua qualidade é inalterável." Logo no início, o garoto do comercial, ao desenrolar o pão, desfaz-se do papel, que cai no chão. Dificilmente se veria tal atitude nos comerciais atuais, porque é exatamente o que não se quer vincular ao produto, um comportamento "não-ético" ao sujar espaços públicos. A atenção do comercial é dada ao sabor da margarina e ao bem que ela proporcionaria à saúde. A propaganda da margarina "All Day" (https://www.youtube.com/watch?v=0EwPVfKreks), de 1994, com duração de 30 segundos, põe em evidência vários sentimentos que, a princípio, pouco teriam a ver com o referido produto. São eles: pais heterossexuais, família feliz e bem sucedida, visto se tratar de um farto café da manhã e numa casa ampla e bem aparentada, em que as pessoas sorriem o tempo todo. 0 comercial começa com um garoto ligando uma música, que ele acompanha com efusão: "Oh, happy day, oh, happy day". Ao fundo, um casal (homem e mulher) se esquiva para não intimidar o garoto, que segue cantando "Happy day, happy day..." e preparando a refeição para ele mesmo e para os pais. Coloca pães de forma na tostadeira, e, claro, pega a margarina, em plano detalhe. 0 garoto chama os pais de criança, convidando-os para o café, numa inversão de papéis, já que tudo parece tão prazeroso e fácil até para uma criança. Sentam-se à mesa, exultantes. Uma voz off anuncia o que se lê na tampa da margarina, fechando o comercial: "Chegou o seu dia de ser mais feliz.". Não se trata apenas de um café numa manhã qualquer, mas da celebração da sagrada felicidade, apenas possível em família. 
especializadas ou pela adaptação ao suposto gosto dos alunos a fim de atender suas expectativas ruidosas. Esses procedimentos, contudo, situam-se numa das três maneiras de abordar o cinema que encontramos na prática das escolas ou nos documentos verificados - inclusive o projeto $O$ cinema vai à escola - que buscam orientar professores quanto à utilização de filmes em sala de aula ou na escola. Analisando esses documentos, percebemos três formas de tratamento do cinema no contexto escolar. Em geral, elas se cruzam, mas há a predominância de um tipo em cada escola.

1- Realização de filmes. Esse modo de inserir o cinema na escola investe mais na formação técnica, tanto em relação à feitura de filmes (captação de imagens, edição, roteirização etc.), quanto à linguagem do cinema, correspondendo ao estudo de uma "gramática do cinema" (planos, movimentos de câmera etc.). É comum nesse formato a utilização de trechos de filmes para identificação técnica de tipos de planos ou de possibilidade de filmagem com vistas à realização. Os professores, em geral, mostram-se favoráveis a essa dimensão da realização de filmes, porque acreditam que os alunos, mais versados em tecnologias informáticas do que eles próprios, são protagonistas das atividades propostas, tomando a frente dos trabalhos ${ }^{124}$.

A despeito de nesses casos o cinema se apresentar aí como forma de "expressão" e não como arte ou como uma experiência estética, principalmente pela produção de autoimagens, imagens narcísicas, é interessante não perder de vista que esses trabalhos com a imagem/som podem (também) representar muito significativamente a fabricação (ensaios) da imagem (de si próprios) de jovens. Destacamos essa questão em virtude do que um trabalho de realização de filmes pode movimentar da subjetividade reificada de seus participantes, não esquecendo, é claro, dos limites desse tipo de atividade.

2- Apreciação de filmes, que diz respeito principalmente à formação de espectadores a partir da exposição de filmes, a maioria com comentários do professor, antes ou depois do filme. Nessa abordagem existe a possibilidade da criação de cineclubes e mostras de filmes de modo que essa atividade pouco se

124 Quanto a essa questão, ver Relatório do Comitê de Adaptação do Currículo da UNESCO para Formação em Alfabetização Midiática e Informacional (SOUSA \& MARTINS, 2015). 
adéqua ao formato de sala de aula, em razão do tempo de 50 minutos ser insuficiente para a exibição dos longas-metragens e à prática pouco comum nas escolas, tanto da exibição de curtas, quanto da exibição de trechos selecionados de longas.

3- Interpretação dos filmes exibidos. Aqui o filme é considerado um texto como nas várias disciplinas: Matemática, História, Geografia etc., no qual deve ser encontrado um sentido temático. A intenção é utilizar o audiovisual como um suporte para ilustrar assuntos estudados em sala de aula.

Dentre essas três possibilidades de uso do filme na escola, constata-se que a mais comum nesses documentos é a terceira (o filme como ilustração), que apresenta o filme como auxiliador dos objetivos das disciplinas, inclusive estimulado pelo projeto $O$ cinema vai à escola. Isso por várias razões, uma delas é que, não sendo conhecedor do cinema, pensa-se que o professor se sinta pouco à vontade para considerar o filme em si mesmo, o que o leva a buscar relacioná-lo sempre ao conteúdo da disciplina. É possível mesmo que o professor pense não ser necessário se deter seriamente no estudo sobre o cinema por este consolidar-se em seu imaginário como algo voltado apenas ao entretenimento - o que talvez se comprove pela predominância absoluta de filmes oriundos do cinema hollywoodiano nas salas brasileiras de cinema e nas TVs.

O problema maior não parece ser exatamente o uso do filme como ilustração pelo professor, mas que a escola não tenha um projeto próprio para o cinema (apesar de ser de conhecimento de todos a existência do projeto $O$ cinema vai à escola) e, por isso, fique a cargo de cada professor incluí-lo, do modo que lhe aprouver, nos seus planos de aula. Nesse sentido, pode-se dizer que o professor usufrui de liberdade para tentar atribuir um estatuto para o trabalho com o cinema na escola. Contudo, tendemos a considerar que o cenário é mesmo de relativa despreocupação para com o tema. Estamos chamando de projeto próprio a clareza na seleção de filmes. Assim, a responsabilidade de inserção desse cinema ficaria facultada ao professor. 
Nesse trabalho "espontâneo" do professor, a despeito da relação dos 71 filmes enviados às escolas pela SEE-SP/FDE, não é pouco comum que em seu cotidiano ele busque reproduzir a relação com os filmes que vê em casa, exibindoos na escola, entusiasmado por encaixá-los tematicamente e justificando que os do projeto não o atendem. Assim, filmes como 300 de Esparta (300, 2006, EUA), de Zack Snyder (observação feita numa das duas escolas pesquisadas) ${ }^{125}$, para tematizar a entrada da História na racionalidade e na democracia, corroborando, assim, a pesquisa que aponta que os gostos de professores e de alunos pelos produtos culturais nunca estiveram tão parecidos ${ }^{126}$.

É raro que aconteça, entretanto, algo que contrarie essa similaridade entre a posição do professor e a do aluno, expressão da passividade desses sujeitos diante do produto da indústria cultural. Tal seria outra posição do professor que procedesse como aponta Zizek que, partindo de um filme comumente visto por alunos e professores, ressalta um aspecto importante presente em 300 de Esparta, que é a defesa da liberdade, associada pelo filósofo ao ideal do Iluminismo. Ele analisa esse filme adivinhando nele uma ambiguidade que não estaria sendo identificada pelos críticos vorazes da suposta obviedade do maniqueísmo Ocidente-Oriente. Assim, na declaração final do filme de que a Grécia é contra um reino místico e tirano, e que marcha, dessa forma, para um futuro promissor, seria interpretado por Zizek como uma declaração iluminista e até comunista (ZIZEK, 2012, p. 88). Acrescenta a essa passagem a recusa de Leônidas à previsão dos oráculos, que proibiam que a Grécia entrasse em guerra contra os persas, quando se fica sabendo que os persas haviam subornado os sarcedotes. Com isso, Zizek conclui que o filme promove a ideia de uma nação laica. Contudo, parece-nos que, não obstante a laicidade sugerida por Zizek, não é contra a religião em si, mas é pela honestidade fundada no heroísmo que se impõe como valor supremo. E somente o déspota é que poderia portar tal honestidade. Trata-se de uma monarquia, apesar de o filme bradar a liberdade. Não se deve esquecer ainda que

125 Visitei duas escolas (uma do Estado e outra privada) por duas vezes para visualizar seu ambiente de modo geral e para verificar se elas dispunham de sala de vídeo, bem como observar aulas cujo professor se utilizaria de filmes.

126 Pesquisa desenvolvida pelo professor da ECA-USP, Adilson Citelli, e publicada em forma de livro, Comunicação e Educação. A Linguagem em Movimento (2004), em que aponta que o repertório cultural - quanto a programas de televisão e filmes - de professores e alunos nunca esteve tão próximo. 
toda a caracterização dos espartanos funciona como uma antítese dos persas, visto serem estes os inimigos a serem derrotados, a representação do que há de mais atrasado. Vê-se o filme sob a visão dos heróis.

No delírio pontual de Zizek quanto a essas declarações, parece flagrante, para além da desconsideração do cinema como arte, uma adesão, geralmente inconsciente, do professor a ideologias (no caso, ao orientalismo ${ }^{127}$ ) de que o filme é investido. Mais uma vez o entusiasmo para com o filme pressupõe sua adequação e submissão ao tema disciplinar.

A secundarização do cinema como arte na escola em razão de sua utilidade "pedagogizável", nesse sentido, é já uma questão educacional importante, pois o que os alunos experimentarão é um recorte sobre a arte que a toma como matéria menos importante do que as outras disciplinas. Na exposição de filmes hollywoodianos é mesmo a reprodução dessa linguagem clássica que se objetiva em geral, pela eliminação de sombras, protagonista bem intencionado "como principal agente causal" (BORDWELL, 2005, p. 279), narração descritiva ou orgânica, para usar a terminologia de Deleuze (1990, p. 157), com ênfase nos protagonistas, acentuação dos elementos cênico-motores e do cenário, como espaço avolumado, cuja câmera envolve os objetos de cena, conferindo-lhes volume (BORDWELL, 2005), além de uma marcação muito intensa de elementos causais (e de efeitos), como o do sangue que corre em câmera lenta e em plano detalhe por trás das máscaras gregas, embalado por música épica (no caso de 300 de Esparta citado anteriormente) -, apelando, assim, para a identificação do espectador com os protagonistas, procurando entorpecê-lo. Tal conjunto de procedimentos "verborrágicos" compõe a linguagem que ficou conhecida como cinema clássico, em que se procura tudo dizer, eliminando dualidades e apresentando a defesa de apenas um ponto de vista. Além disso, o filme é reforçado pela vocação do verdadeiro (DELEUZE, 1990, p. 157), com certa reverência ao verdadeiro. Psicose (Psycho, 1959), de Alfred Hitchcock, sela a consolidação da "linguagem clássica" do cinema na medida em que preenche a visão ávida do espectador com elementos pretensamente lógicos, ao tempo que cria semelhanças arbitrárias, como a fusão do plano do ralo da banheira com o

127 Temos como referência a discussão empreendida por Edward Said em Orientalismo: o oriente como invenção do ocidente. São Paulo: Companhia das Letras, 2007. 
plano de um dos olhos da vítima, por exemplo. Analisando a conhecida sequência da banheira em que há um assassinato, percebemos o nível de exposição dos elementos de cena, que têm a função de marcar iconicamente a intensidade da sequência, o que faz de Psicose o vértice discursivo hegemônico que marcará o cinema mundial daí em diante, passando a constituir suicídio comercial e mesmo "erro" gramatical um filme não obedecer a tal estrutura narrativa.

A história, nessa concepção clássica, é entendida como um palco de eventos localizados no passado, exatamente oposto à concepção de Benjamin, ainda que também se trate de uma elaboração desse passado. A linguagem desse cinema clássico esforça-se por ser "fiel" a essa história passada. Ainda que se refira a um acontecimento recente, o importante nesse caso é que a referência feita no caso hollywoodiano é a um tempo que "passou", isto é, que se fixou no passado. Curioso que amplamente difundido (com 594.669 acessos em 28 de agosto de 2014) pelo Youtube, a "Mentegatilhada Documentarios" apresente o filme 300 de Esparta com comentários de especialistas em história antiga, acentuando ainda mais a ideia de se tratar, senão de um documentário, ao menos de certa verdade documental. 0 narrador comenta a guerra de Termópilas como aquela que selaria o destino da democracia no mundo. Expressões como "corajosos guerreiros" são usadas para qualificar os espartanos.

A lógica que autoriza o uso de um filme na escola, como o citado $300 \mathrm{de}$ Esparta, nos termos que apresentamos, parece predominante nos discursos que sustentam geralmente o sistema escolar. É possível flagrar a secundarização do filme na configuração das disciplinas também no modo de abordar, de mencionar ou ainda de se referir a filmes em livros didáticos. Tomamos como exemplo o livro voltado para o Ensino Médio História Geral, de Gislane Campos e Reinaldo Seriacopi (2005). À medida que desenvolve os temas históricos, os autores sugerem alguns filmes. Assim, quando trata da Grécia Antiga, sugere que os alunos vejam o filme Tróia (2004), de Wolfgang Petersen, porém, sem nenhum encaminhamento problematizante. Mais adiante sugere que seja visto o filme Alexandre (2004), de Oliver Stone (p. 61) e também A Missão (1986), de Roland Joffé (p. 228), sem nenhuma recomendação ou pontuação acerca da relação entre filme e livro. Todos os filmes, enfim, são indicados no sentido de reforçar o 
conteúdo das unidades estudadas. Por isso, a ausência de problematização da relação livro-filme, pois o filme parece apenas "acrescentar" algo (a imagem?), não sendo estrutural para a disciplina. Essa postura não se dá de modo isolado; ao contrário, é representativa de como o cinema é recebido nas escolas.

O livro didático citado e o projeto $O$ cinema vai à escola parecem proceder como as publicações lembradas por Aumont quando dos primeiros textos - que datam dos anos 1930 - que visavam à interpretação dos filmes, de como organizar a experiência fílmica e, por consequência, de como usá-los na escola. 0 primeiro deles, segundo Jacques Aumont (1995, p. 166), foi Gramática do filme, de 1935, do britânico Raymond J. Spottiwoode. Aumont também cita outros como André Berthomieu (Essai de grammaire cinématographique, 1946) e Robert Bataille (Grammaire cinématographique, 1947). 0 objetivo desses manuais era enquadrar os filmes, sistematizá-los de modo a compreendê-los como uma obra de "bons autores" (AUMONT, 1995, p. 166), uma obra como "deve ser" (comme il faut), dissecando o filme em unidades a fim de prescrever a receita de como se evitar erros num filme e, por consequência, como fazê-lo "corretamente", respeitando uma determinada gramática que primasse pela "naturalidade" do filme, isto é, pelo apagamento da anunciação.

Esse "respeito" à gramática é apenas um modo de conceber e interpretar o cinema, mas que é ainda o predominante na escola, isto é, a concepção que toma o cinema naturalista como modelo.

Passamos a seguir à lista dos filmes distribuídos, entre 2008 e 2015, pela SEE-SP/FDE às escolas da rede estadual com Ensino Médio, a fim de analisar se os critérios anunciados para a seleção se efetivaram e, sobretudo, se dentre tais critérios, houve a preocupação de aquilatar uma seleção de filmes que fosse diversificada quanto à época e à escola cinematográfica, às nacionalidades e ao gênero. 


\section{Lista de filmes da SEE-SP/FDE - Ao todo são 71 filmes}

1‥ caixa, acompanhada do vídeo Luz, câmera...educação!, produzido pela FDE e pela TV Cultura. O Caderno de Cinema do Professor no 1 foi lançado em evento (Orientação Técnica para Professores Coordenadores das Oficinas Pedagógicas), realizado no SESC Ipiranga, no dia 29 de outubro de 2008, e disponibilizado em vídeo no site da FDE.

Quadro 6 - Lista de filmes da 1a. caixa (entregue às escolas em 2008)

\begin{tabular}{|c|c|c|}
\hline Título do Filme & $\begin{array}{c}\text { País/Duração/Indicação } \\
\text { de idade }\end{array}$ & Direção/Ano \\
\hline $\begin{array}{l}\text { 1-A cor do paraíso/Rang-E- } \\
\text { Khoda }\end{array}$ & Irã/86min./Livre & Majid Majidi/1999 \\
\hline $\begin{array}{l}\text { 2-A rosa púrpura do Cairo/The } \\
\text { purple rose of Cairo }\end{array}$ & EUA/72min./12 anos & Woody Allen/1985 \\
\hline $\begin{array}{ll}\text { 3-Arquitetura } & \text { da } \\
\text { destruição/Undergangens } & \\
\text { arkiektur } & \\
\end{array}$ & Ale/121min./14 anos/Doc. & Peter Cohen/1989 \\
\hline 4-Bendito fruto/Bendito fruto & Bra/90min./10anos & Sérgio Goldenberg/2004 \\
\hline 5-Billy Elliot/Billy Eliot & Ing/111min/12 anos & Stephen Daldry/2000 \\
\hline $\begin{array}{l}\text { 6-Cantando na chuva/Singin' } \\
\text { in the rain }\end{array}$ & EUA/118min/Livre & $\begin{array}{l}\text { Stanley Doney e Gene } \\
\text { Kelly/1952 }\end{array}$ \\
\hline $\begin{array}{ll}\text { 7-Cinema, aspirinas } & \text { e } \\
\text { urubus/Cinema, aspirinas } & \text { e } \\
\text { urubus } & \end{array}$ & Bra/90min/14anos & Marcelo Gomes/2005 \\
\hline 8-Crash, no limite/Crash & EUA/112min/14 anos & Paul Haggis/2004 \\
\hline $\begin{array}{l}\text { 9-Crianças invisíveis/All the } \\
\text { invisible children }\end{array}$ & Itália/116min/Livre & $\begin{array}{l}\text { Diversos diretores } \\
\text { nacionalidades } \\
\text { diferentes } / 2005\end{array}$ \\
\hline $\begin{array}{l}\text { 10-Diários de motocicleta/The } \\
\text { motorcycle diaries }\end{array}$ & EUA,Bra/128min/12 anos & Walter Salles/2004 \\
\hline $\begin{array}{l}\text { 11-Final fantasy/ Final } \\
\text { fantasy: the spirits within }\end{array}$ & EUA/106min/Livre/Animação & Hironobu Sakaguchi/2001 \\
\hline 12-Frankenstein/Frankenstein & EUA/70min/12 anos & James Whale/1931 \\
\hline $\begin{array}{lll}\text { 13-Língua, vidas } & \text { em } \\
\text { português/Língua, vidas } & \text { em } \\
\text { português } & & \\
\end{array}$ & Bra/105min/Livre & Victor Lopes/2004 \\
\hline $\begin{array}{l}\text { 14-Narradores } \\
\text { Javé/Narradores de Javé }\end{array}$ & Bra/102min/Livre & Eliane Caffé/2003 \\
\hline $\begin{array}{l}\text { 15-0 fim e o princípio/0 fim e } \\
\text { o princípio }\end{array}$ & Bra/110min/Livre/Doc. & Eduardo Coutinho/2005 \\
\hline $\begin{array}{l}16-0 \text { pagador de promessas } / 0 \\
\text { pagador de promessas }\end{array}$ & Bra/95min/12 anos & Anselmo Duarte/1962 \\
\hline $\begin{array}{l}17-0 \text { planeta branco/La } \\
\text { planète blanche }\end{array}$ & Fra,Can/86min/Livre/Doc. & $\begin{array}{lll}\text { Jean Lemire, } & \text { Thierry } \\
\text { Piantanida e } & \text { Thierry } \\
\text { Ragobert/2006 } & \\
\end{array}$ \\
\hline $\begin{array}{l}\text { 18-Putz! A coisa tá feia/The } \\
\text { ugly duckling and me! }\end{array}$ & $\begin{array}{l}\text { Fra-Ale-Irl-Ing- } \\
\text { Din/89min/Livre/Animação }\end{array}$ & $\begin{array}{l}\text { Michael Hegner e Karsten } \\
\text { Kiilerich/2006 }\end{array}$ \\
\hline
\end{tabular}




\begin{tabular}{|l|l|l|}
\hline $\begin{array}{l}\text { 19-Terra de ninguém/No } \\
\text { man's land }\end{array}$ & $\begin{array}{l}\text { Bélgica-Bósnia-Fra-Itália- } \\
\text { Ing/98min/14 anos }\end{array}$ & Danis Tanovic/2001 \\
\hline $\begin{array}{l}\text { 20-Vida de menina/Vida de } \\
\text { menina }\end{array}$ & Bra/101min/Livre & Helena Solberg/2004 \\
\hline
\end{tabular}

\section{2‥ caixa}

Quadro 7 - Lista de filmes da 2ª . caixa (entregue às escolas em 2009)

\begin{tabular}{|c|c|c|}
\hline Título do Filme & $\begin{array}{l}\text { País/Duração/Indicação de } \\
\text { idade }\end{array}$ & Direção/Ano \\
\hline $\begin{array}{l}\text { 1- A general/The } \\
\text { general }\end{array}$ & EUA/75min./Livre & $\begin{array}{l}\text { Buster Keaton/Clyde } \\
\text { Bruckman/1927 }\end{array}$ \\
\hline 2- A partida/Okuribito & Japão/130min./10anos & Yojiro Takita/2008 \\
\hline $\begin{array}{l}\text { 3- Apenas uma } \\
\text { vez/Once }\end{array}$ & Irlanda/85min./12anos & John Carney/2006 \\
\hline $\begin{array}{l}\text { 4- Balzac e a } \\
\text { Costureirinha } \\
\text { chinesa/Balzac et la } \\
\text { petite tailleuse chinoise }\end{array}$ & China,Fra/116min./12anos & Dai Sijie/2002 \\
\hline $\begin{array}{l}\text { 5- Bem-vindo a São } \\
\text { Paulo/Bem-vindo a São } \\
\text { Paulo }\end{array}$ & Bra/100min./12anos & $\begin{array}{l}\text { Diversos diretores de } \\
\text { nacionalidades } \\
\text { diferentes / } 2007\end{array}$ \\
\hline $\begin{array}{l}\text { 6-Donkey xote/Donkey } \\
\text { xote }\end{array}$ & Itália,Esp./90min./Livre/Animação & Jose Pozo/2007 \\
\hline $\begin{array}{l}\text { 7-Em busca da terra do } \\
\text { nunca/Finding } \\
\text { neverland }\end{array}$ & EUA/106min./Livre & Marc Foster/2004 \\
\hline $\begin{array}{ll}\text { 8-Fahrenheit } & 451 / \\
\text { Fahrenheit } 451\end{array}$ & Reino Unido,Fra/112min./12anos & $\begin{array}{l}\text { François } \\
\text { Truffaut/1966 }\end{array}$ \\
\hline $\begin{array}{ll}\text { 9-Gran } & \text { Torino/Gran } \\
\text { Torino } & \end{array}$ & Austrália,EUA/116min./14anos & Clint Eastwood/2008 \\
\hline 10-Inocência/Inocência & Bra/115min./14anos & Walter Lima Jr./1983 \\
\hline $\begin{array}{lr}\text { 11-Ladrões } & \text { de } \\
\text { bicicleta/Ladri } & \text { di } \\
\text { biciclette } & \\
\end{array}$ & Itália/90min./12anos & Vittorio De Sica/1948 \\
\hline 12-Mutum/Mutum & Bra/95min./Livre & Sandra Kogut/2007 \\
\hline $\begin{array}{l}\text { 13-Nas montanhas dos } \\
\text { gorilas/Gorillas in the } \\
\text { mist }\end{array}$ & EUA/129min./Livre & Michael Apted/1988 \\
\hline $\begin{array}{l}\text { 14-0 banheiro do } \\
\text { Papa/El baño del Papa }\end{array}$ & Bra,Fra,Uru/97min./10anos & $\begin{array}{l}\text { César } \\
\text { Charlone,Enrique } \\
\text { Fernández/2007 }\end{array}$ \\
\hline $\begin{array}{l}15-0 \text { povo brasileiro/0 } \\
\text { povo brasileiro }\end{array}$ & Bra/280min./Livre & $\begin{array}{l}\text { Isa } \quad \text { Grinspum } \\
\text { Ferraz/2000 }\end{array}$ \\
\hline $\begin{array}{l}16-0 \quad \text { sonho de } \\
\text { Cassandra/Cassandra's } \\
\text { dream }\end{array}$ & Ing.,Fra,EUA/108min./14anos & Woody Allen/2007 \\
\hline $\begin{array}{l}\text { 17-Palavra (en)cantada/ } \\
\text { Palavra (en)cantada }\end{array}$ & Bra/86min./Livre/Doc. & Helena Solberg/2009 \\
\hline
\end{tabular}




\begin{tabular}{|l|l|l|}
\hline $\begin{array}{l}\text { 18-Rebobine, por } \\
\text { favor/Be kind rewind }\end{array}$ & EUA/102min./Livre & Michel Gondry/2008 \\
\hline $\begin{array}{l}\text { 19-Sob a névoa da } \\
\text { guerra/The fog of war: } \\
\text { eleven lessons from the } \\
\text { life of Robert S. } \\
\text { McNamara }\end{array}$ & EUA/95min./12anos/Doc. & Errol Morris/2003 \\
\hline $\begin{array}{l}\text { 20-Trem da vida/Train } \\
\text { de vie }\end{array}$ & Fra,Bélg.,Holanda/12anos & $\begin{array}{l}\text { Radu } \\
\text { Mihaileanu/1998 }\end{array}$ \\
\hline $\begin{array}{l}\text { 21-Um beijo } \\
\text { roubado/My blueberry } \\
\text { nights }\end{array}$ & $\begin{array}{l}\text { China,Fra,Hong } \\
\text { Kong/90min./10anos }\end{array}$ & Won Kar-Wai/2007 \\
\hline
\end{tabular}

\section{3‥ caixa}

Quadro 8 - Lista de filmes da 3a . caixa (entregue às escolas em 2010)

\begin{tabular}{|c|c|c|}
\hline Título do Filme & $\begin{array}{c}\text { País/Duração/Indicação } \\
\text { de idade }\end{array}$ & Direção/Ano \\
\hline $\begin{array}{l}\text { 1-Antes que o mundo } \\
\text { acabe/ Antes que o } \\
\text { mundo acabe }\end{array}$ & Bra/97min./10anos & Ana Luíza Azevedo/2009 \\
\hline $\begin{array}{l}\text { 2-A culpa é do Fidel/La } \\
\text { faute à Fidel }\end{array}$ & Fra/99min./14anos & Julie Gravas/2006 \\
\hline 3-Criação/Creation & Reino Unido/108min./10anos & Jon Amiel/2009 \\
\hline $\begin{array}{ll}\text { 4-Honeydripper, } & \text { do } \\
\text { blues } & \text { ao } \\
\text { rock/Honeydripper } & \\
\end{array}$ & EUA/124min./14anos & John Sayles/2007 \\
\hline $\begin{array}{l}\text { 5-Lemon tree/Lemon } \\
\text { tree }\end{array}$ & Israel,Ale,Fra/106min./14anos & Eran Riklis/2008 \\
\hline $\begin{array}{l}\text { 6-Lixo } \\
\text { extraordinário/Lixo } \\
\text { extraordinário }\end{array}$ & Bra,Reino Unido/90min./Livre & $\begin{array}{lr}\text { Lucy } & \text { Walker,João } \\
\text { Jardim,Karen Harley/2010 }\end{array}$ \\
\hline $\begin{array}{l}\text { 7-0 menino do pijama } \\
\text { listrado/The boy in the } \\
\text { stripped pyjamas }\end{array}$ & EUA/94min./14anos & Mark Herman/2008 \\
\hline $\begin{array}{l}\text { 8-Sombras de } \\
\text { Goya/Goya's Ghosts }\end{array}$ & Esp.,EUA/113min./14anos & Milos Forman/2006 \\
\hline $\begin{array}{l}\text { 9-Sobre futebol e } \\
\text { barreiras/Sobre futebol } \\
\text { e barreiras }\end{array}$ & Bra/110min./10anos/Doc. & Arturo Hartmann/2011 \\
\hline $\begin{array}{l}\text { 10-Uma noite em } \\
\text { 67/Uma noite em } 67\end{array}$ & Bra/93min./Livre/Doc. & $\begin{array}{ll}\text { Renato } & \text { Terra,Ricardo } \\
\text { Calil/2010 } & \\
\end{array}$ \\
\hline
\end{tabular}




\section{4⿳亠口冋. caixa}

Quadro 9 - Lista de filmes da 4ạ. caixa (entregue às escolas em 2013)

\begin{tabular}{|l|l|l|}
\hline \multicolumn{1}{|c|}{ Título do Filme } & $\begin{array}{c}\text { País/Duração/Indicação } \\
\text { de idade }\end{array}$ & \multicolumn{1}{|c|}{ Direção/Ano } \\
\hline $\begin{array}{l}\text { 1-A montanha dos } 7 \\
\text { abutres/Ace in the hole }\end{array}$ & EUA/111min./Livre & Billy Wilder/1951 \\
\hline $\begin{array}{l}\text { 2-Filhos do } \\
\text { paraíso/Bacheha-Ye } \\
\text { aseman }\end{array}$ & Irã/88min./Livre & Majid Majidi/1997 \\
\hline $\begin{array}{l}\text { 3-Matar ou morrer/High } \\
\text { noon }\end{array}$ & EUA/93min./12anos & Fred Zinnermann/1952 \\
\hline $\begin{array}{l}\text { 4-O Brasil da pré- } \\
\text { história/O Brasil da pré- } \\
\text { história }\end{array}$ & Bra/53min./Livre/Doc. & $\begin{array}{l}\text { Maurício Dias,Túlio } \\
\text { Schargel,Dominique } \\
\text { Lecuivre/2007 }\end{array}$ \\
\hline $\begin{array}{l}\text { 5-Os melhores dias de } \\
\text { nossas vidas/Inside I'm } \\
\text { dancing }\end{array}$ & $\begin{array}{l}\text { Irlanda,Reino Fra/104min./12anos Unido, } \\
\text { 6-O visitante/The visitor }\end{array}$ & EUAmien O'Donnell/2005 \\
\hline
\end{tabular}

\section{5‥ caixa}

Quadro 10 - Lista de filmes da 5a . caixa (entregue às escolas em 2014)

\begin{tabular}{|l|l|l|}
\hline \multicolumn{1}{|c|}{ Título do Filme } & $\begin{array}{c}\text { País/Duração/Indicação } \\
\text { de idade }\end{array}$ & \multicolumn{1}{|c|}{ Direção/Ano } \\
\hline $\begin{array}{l}\text { 1-12 Homens e uma } \\
\text { sentença/12 angry men }\end{array}$ & EUA/93min./14anos & Sidney Lumet/1957 \\
\hline $\begin{array}{l}\text { 2-Luzes da cidade/City } \\
\text { lights }\end{array}$ & EUA/87min./Livre & Charles Chaplin/1931 \\
\hline $\begin{array}{l}\text { 3-Não por acaso/Não por } \\
\text { acaso }\end{array}$ & Bra/102min./10anos & Philippe Barcinski/2006 \\
\hline $\begin{array}{l}\text { 4-Oliver Twist/ Oliver } \\
\text { Twist }\end{array}$ & $\begin{array}{l}\text { Fra,Reino Unido,Itália,Rep. } \\
\text { Tcheca/130min./12anos }\end{array}$ & Roman Polanski/2005 \\
\hline 5-Os pássaros/The birds & EUA/119min./12anos & Alfred Hitchcock/1963 \\
\hline $\begin{array}{l}\text { 6-Quanto mais quente } \\
\text { melhor/Some like it hot }\end{array}$ & EUA/120min./Livre & Billy Wilder/1959 \\
\hline
\end{tabular}


6‥ Caixa- Para apresentação desta caixa de filmes a FDE preparou um vídeo com depoimentos de alunos e professores de uma escola da Diretoria de Ensino de Caieiras, que viram os filmes. 0 vídeo se chama Oito convites para Oito filmes e contém 12 minutos, aproximadamente, disponibilizado no site da FDE.

Quadro 11 - Lista de filmes da 6⿳a . caixa (entregue às escolas em 2015)

\begin{tabular}{|c|c|c|}
\hline Título do Filmel & $\begin{array}{l}\text { País/Duração/Indicação de } \\
\text { idade }\end{array}$ & Direção/Ano \\
\hline $\begin{array}{l}\text { 1-0 último dançarino } \\
\text { de Mao/Mao's last } \\
\text { dancer }\end{array}$ & Austrália/117min./10anos & Bruce Beresford/2009 \\
\hline $\begin{array}{l}\text { 2-Moça com brinco de } \\
\text { pérola/Girl with a pearl } \\
\text { earring }\end{array}$ & Ing.,Luxembrugo/99min./12anos & Peter Webber/2003 \\
\hline $\begin{array}{l}\text { 3-A invenção de Hugo } \\
\text { Cabret/Hugo }\end{array}$ & EUA/127min./Livre & Martin Scorsese/2012 \\
\hline $\begin{array}{l}\text { 4-As neves do } \\
\text { Kilimanjaro/Les } \\
\text { du Kilimanjaro }\end{array}$ & Fra/107min./12anos & $\begin{array}{l}\text { Robert } \\
\text { Guédiguian/2011 }\end{array}$ \\
\hline $\begin{array}{l}\text { 5-Corra } \\
\text { corra/Lola rennt }\end{array}$ & Ale/81min./14nos & Tom Tykwer/1998 \\
\hline $\begin{array}{l}\text { 6-Contos da noite/Les } \\
\text { contes de la nuit }\end{array}$ & Fra/84min./Livre & Michel Ocelot/2011 \\
\hline $\begin{array}{l}\text { 7-A vida em um } \\
\text { dia/Life in a Day }\end{array}$ & EUA/95min./Livre & Kevin MacDonald/2012 \\
\hline $\begin{array}{l}\text { 8-0 enigma da } \\
\text { pirâmide/Young } \\
\text { Sherlock Holmes }\end{array}$ & EUA/109min./12anos & Barry Levinson/1985 \\
\hline
\end{tabular}

Dos 71 filmes acima listados é possível fazer algumas observações, dentre elas, o fato de haver 26 produções estadunidenses, 20 brasileiras (ver Tabela 4) e de 36 serem faladas em língua inglesa, o que corresponde a mais da metade. 0 fato, em especial, de se tratar de uma seleção de filmes apresentada para o ensino básico da rede pública esperar-se-ia uma proporção maior de produções brasileiras e menos estrangeiras? Se considerarmos os ecos da militância de Paulo Emílio Sales Gomes (1986, p. 259), que insistiu muitas vezes "que uma situação normal exigiria que pelo menos $50 \%$ dos filmes exibidos no Brasil fossem brasileiros", certamente responderíamos pelo sim. A guerilha empreendida em textos pelo crítico entendia que era uma questão nacional a do cinema e afirmava que o espectador desta arte era mais exigente que o de teatro, que não possuía uma escala ampla de comparação, enquanto o espectador do filme brasileiro era o 
mesmo que dias antes teria ido ver "Sonhos de uma Noite de Amor, de Ingmar Bergman e que logo depois verá Noites de Cabiria, de Fellini." (GOMES, 1981, p. 40).

Abaixo, a Tabela 4 agrupa os filmes por nacionalidade.

\begin{tabular}{|c|r|}
\hline Nacionalidade & $\begin{array}{c}\text { Quantidade de } \\
\text { Produção }\end{array}$ \\
\hline Alemanha & 4 \\
\hline Austrália & 2 \\
\hline Bélgica & 2 \\
\hline Bósnia & 1 \\
\hline Brasil & $\mathbf{2 0}$ \\
\hline Canadá & 1 \\
\hline China & 2 \\
\hline Dinamarca & 1 \\
\hline Espanha & 2 \\
\hline EUA & $\mathbf{2 6}$ \\
\hline França & $\mathbf{1 3}$ \\
\hline Holanda & 1 \\
\hline Hong Kong & 1 \\
\hline Inglaterra & 4 \\
\hline Irã & 2 \\
\hline Irlanda & 3 \\
\hline Israel & 1 \\
\hline Itália & 5 \\
\hline Japão & 1 \\
\hline Luxemburgo & 1 \\
\hline Reino Unido & 4 \\
\hline Rep. Tcheca & 1 \\
\hline Uruguai & 1 \\
\hline Total & $\mathbf{9 9}$ \\
\hline
\end{tabular}

Tabela 4 - Quantididade de produção de filmes por nacionalidade (nacionalidade aparece em quantidade maior do que a quantidade de filmes em virtude de co-produções).

Convertendo-se os dados acima em percentual, tem-se o seguinte: 
Gráfico 5 - Percentual da Produção por Nacionalidade dos filmes distribuídos pela SEE-SP/FDE

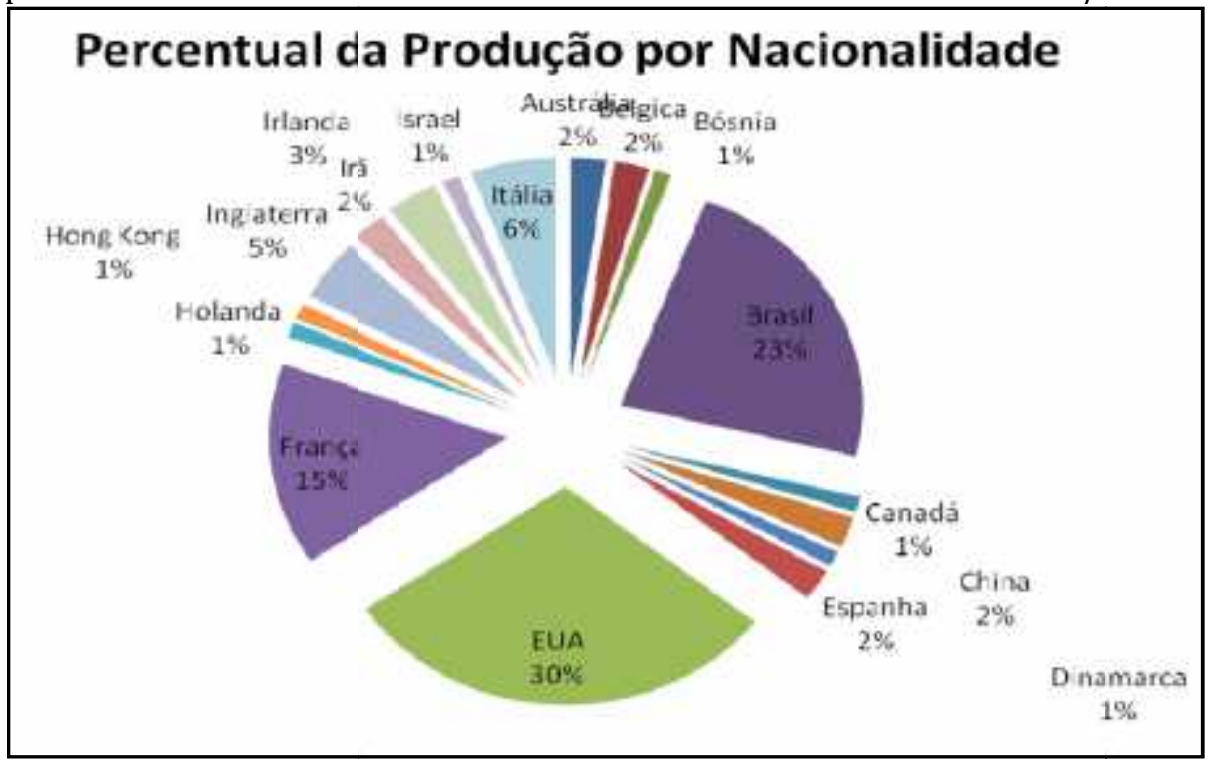

As três maiores produções são estadunidenses, brasileiras e francesas, conforme apresentado na Tabela 5 abaixo:

\begin{tabular}{|r|r|r|r|}
\hline \multicolumn{1}{|c|}{$\begin{array}{c}\text { Produções } \\
\text { Estadunidenses }\end{array}$} & $\begin{array}{c}\text { Produções } \\
\text { Brasileiras }\end{array}$ & $\begin{array}{l}\text { Produções } \\
\text { Francesas }\end{array}$ & \multicolumn{1}{c|}{$\begin{array}{c}\text { Produções de } \\
\text { outras } \\
\text { nacionalidades }\end{array}$} \\
\hline 26 & 20 & 13 & 40 \\
\hline
\end{tabular}

Tabela 5 - Quantidade de produção de filmes estadunidenses, brasileiros, francesese de outras nacionalidades de filmes da SEE-SP/FDE

O Gráfico 6 mostra de modo mais direto a distribuição das nacionalidades. 
Gráfico 6 - Quantidade das três maiores incidências de nacionalidades de filmes

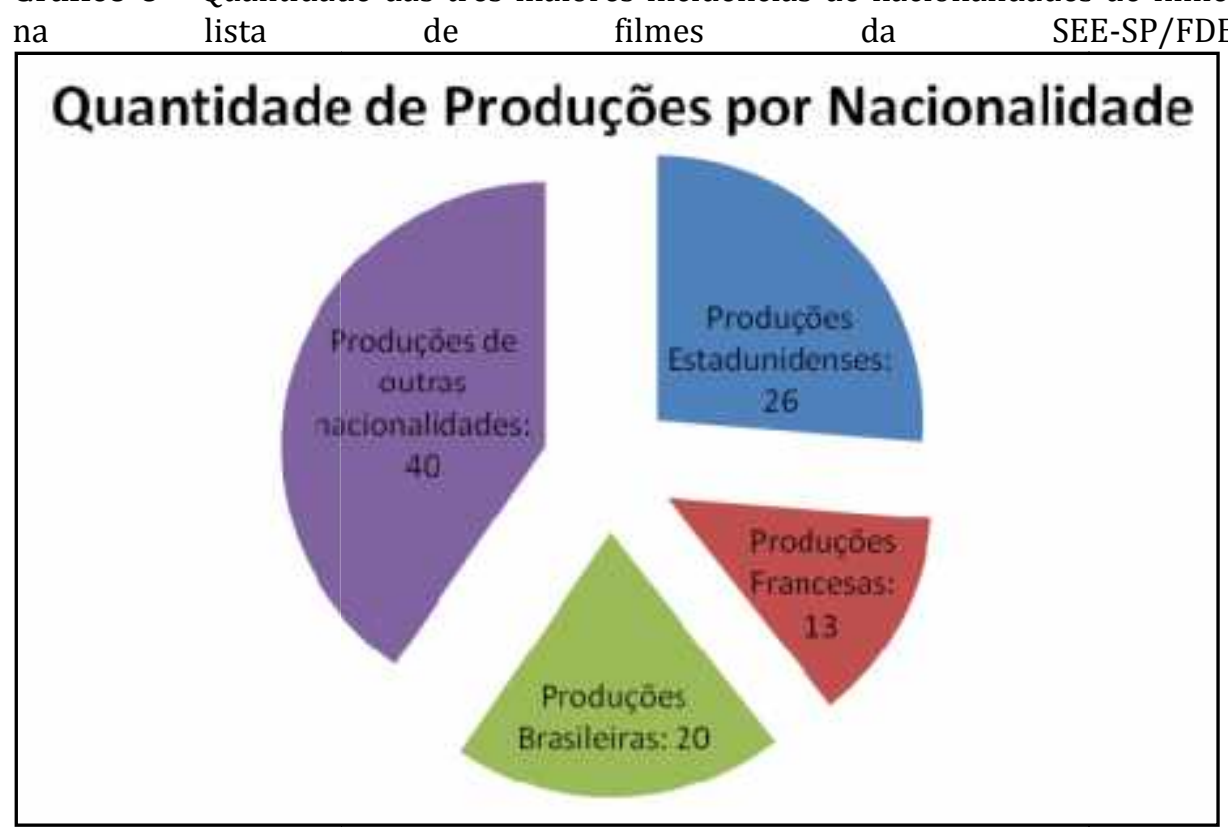

Os Gráficos 3 e $4^{128}$ apresentam a distribuição de nacionalidade de longas-metragens, seriados e minisséries, em TV aberta, que servirão agora de parâmetro para analisarmos os números do projeto $O$ cinema vai à escola, para que os dados referentes a este (apresentados pelos Gráficos 5 e 6) não ficassem isolados, em absoluto. Os Gráficos 3 e 4 nos informam que o percentual de filmes estadunidenses exibidos em TV aberta equivale a 78\% do total, o que significa quase 8 filmes a cada 10. 0 percentual dos filmes brasileiros equivale a 1 , no mesmo universo.

Quanto ao Projeto, o Gráfico 5 nos informa que, dentre os 71 filmes distribuídos pela SEE-SP/FDE às escolas de Ensino Médio do estado de São Paulo, o percentual de filmes estadunidenses é de aproximadamente $30 \%$, o que equivale a dizer, que a cada 10 filmes, quase 3 são dos EUA. Para a língua falada, no caso da inglesa, esse percentual é de 50\%. Quanto às produções brasileiras, a participação proporcional aumenta. Se pelos Gráficos 3 e 4, percebemos que o Brasil tem, aproximadamente, um filme a cada dez (equivalendo a 11,4\% do total), pelas caixas da SEE-SP/FDE, esse percentual aumenta para $23 \%$.

$\mathrm{Na}$ comparação entre os dados percentuais dos Gráficos 3 e 4 (referentes ao ano de 2009) com os do Gráfico 5 (referentes aos anos 2008 a

128 Os Gráficos 3 e 4 se encontram na página 165 deste trabalho. 266 
2015), observamos uma diferença na proporção de filmes estadunidenses, já que o predomínio destes em TV aberta é de mais que o dobro (de 78 para 30\%). A comparação também aponta um significativo aumento de filmes brasileiros (de 11,4 para $23 \%$ ), quase o dobro.

A redução do predomínio do cinema estadunidense e o aumento da presença de filmes brasileiros na lista de filmes da SEE-SP/FDE são indicadores de maior diversidade de filmes e de maior estímulo à produção nacional, ao menos quando a comparação é feita com a TV e as salas de cinema. 0 aumento da presença de filmes brasileiros e a diminuição de filmes estadunidenses indica maior inserção do cinema brasileiro diante do cinema estrangeiro e, principalmente, um maior respiro quanto às reivindicações de setores do cinema nacional pela regulamentação e consolidação de uma indústria nacional frente ao cinema produzido nos EUA, que tem seus filmes massivamente veiculados e festejados no Brasil ${ }^{129}$. Os casos analisados tratam de referências (fontes) distintas (Filme em TV x Filme em Escola) e de séries históricas também distintas. Chamamos atenção, no entanto, para a questão de que o cinema destinado à TV não tem a exigência de possuir certo teor pedagógico. Ele é uma mercadoria cuja vocação é ser vendida, consumida. Sua função é a de atender ao gosto do espectador. 0 filme aí não tem os propósitos que têm numa escola, em que da seleção de filmes é exigida uma justificativa plausível e pedagógica, o que pode torná-lo chato para os estudantes. A televisão, como lembra Orozco-Gómez (In: CITELLI \& COSTA, 2011, p. 252), fala no nível da emoção, enquanto a escola segue insistindo num currículo todo ele marcado por ideários iluministas calcados na ideia de informação, centrada, por sua vez, nos ideários da razão. 0 educativo está mais na recepção que na emissão, pois ainda segundo Orozco-Gómez, "a

\footnotetext{
129 Os meios de comunicação de massa no Brasil com frequência festejam sucessos estrondosos de bilheteria de filmes hollywoodianos, caso do jornal de TV SBT Brasil de 30 de janeiro de 2016, que celebra o lançamento de Star Wars: o despertar da força (Star wars: Episode VII - The force awakens, 2015), de J. J. Abrams. Com correspondente brasileira (Cleide Klock) do jornal em Los Angeles, entrevista os atores e anuncia com sorriso nos lábios e brilho no olhar que na estreia, só nos EUA, o filme arrecadou a cifra de R $\$ 220$ milhões, vaticinando o mesmo para a estreia no Brasil. Entusiasmo semelhante é destinado a outro filme, Pai em dose dupla (Daddy's home, 2015). 0 âncora do jornal o anuncia como uma das melhores comédias dos últimos tempos nos EUA como um selo de qualidade, e que se trata, portanto, de "diversão garantida para toda a família". 0 filme é apresentado como moderno por tratar de um assunto "atual", que é o da separação dos cônjuges. 0 ator Will Ferrell diz à correspondente Cleide Klock, sem pudores psico-pedagógicos, que espera que o filme leve ao público brasileiro a mensagem de que ter dois pais na mesma família pode ser muito divertido e positivo para todos, principalmente para as crianças.
} 
possibilidade de aprender é muito mais ampla que a possibilidade de ensinar." (In: CITELLI \& COSTA, 2011, p. 247). Contudo, para Orozco-Gómez (In: CITELLI \& COSTA, 2011), a noção de "educativo" que as crianças adquirem na escola é aquela do mesmo tipo que é reconhecido nos programas educativos da TV; quando estes são exibidos, elas trocam de canal. Frequentemente, os currículos e documentos, como a LDB n. 5.692/71, que introduz um apelo de tipo publicitário aos materiais didáticos e no Currículo, insistem na importância do uso de recursos midiáticos na escola. No horizonte deste uso está a vontade de facilitação do aprendizado, mas, ao mesmo tempo, que se deixa seduzir pela "facilitação", a escola prioriza a "Informação", não abrindo mão da ciência e da razão científica, o que acaba, muitas vezes, reproduzindo estratégias tão criticadas e comumente em uso nas salas de aula, só que transposta para o suporte televisivo. Trata-se, nesse sentido, de ilusão pedagógica o esforço de uso do suporte midiático com as mesmas estratégias de uma aula que priorize a "Informação". O recurso à "facilitação do aprendizado", nesse sentido, ocorre não segundo critérios pedagógicos adequados, mas segundo a sedução à "facilitação" que os meios de comunicação de massa sugerem.

A sedução ao canto da "facilitação" a que recorre a escola é a mesma do papel de que é imbuído o cinema na escola pelo projeto $O$ cinema vai à escola. A entrada do cinema na escola alimenta o desejo de facilitação, de suavização do chamado processo ensino-aprendizagem. É por isso que os professores têm a tendência de ensinar em "oposição à televisão" (Orozco-Gómez In: CITELLI \& COSTA, 2011, p. 247), ainda que se utilizando dela.

Nesse sentido apontado por Orozco-Gómez, o estrito uso do filme em sala de aula com fins de auxílio das disciplinas mostra seu frágil lastro quando restringe o filme ao aspecto puramente instrumental. Mas, pode-se perguntar: será que, utilizando-se do filme como um bem cultural e artístico, numa mostra de filmes, por exemplo, sem a veiculação direta às disciplinas, ter-se-ia a oportunidade de "ampliação de repertório" por parte dos alunos - conforme objetivo do Projeto - e de possibilitar mais propriamente a experiência estética?

Além dos filmes das caixas da SEE-SP/FDE, conforme sugere o documento Using Films in Schools: a practical guide (2010) ${ }^{130}$ quanto ao uso da

130 Cf. páginas 127-129 deste trabalho. 268 
internet para exibição de filmes na escola, a mostra de filmes poderia ter como suporte a internet, por meio da qual é possível acessar uma infinidade de filmes liberados ao uso público. Para tanto, a ideia de curadoria precisaria se alargar, atribuindo-se aos professores - e também aos alunos, gradualmente - esse papel da seleção de filmes. Como numa mostra profissional, tem-se aí a atribuição de papéis. A seleção do repertório a ser exibido e a ordem e horários dessa exibição é um trabalho que exige experimentação dos longas e curtas-metragens candidatos, com discussão entre os participantes. Caberia ao professor a mediação no estabelecimento das regras dessa atividade. Nesse sentido, poder-se-ia organizar uma curadoria participativa, entre alunos e professores, mediados pela SEESP/FDE, que analisaria a proposta das escolas, sugerindo material de apoio para a escolha dos filmes. Contudo, a ideia de uso da dimensão cultural e artística do cinema encontra entrave na concepção de cinema na escola, que é central no Projeto; qual seja, o de que ele deve auxiliar as disciplinas e, por isso, sua inserção no cenário escolar é direcionada às aulas, com duração de 50 minutos. Daí que o Projeto não articula o valor possível dos filmes e da participação dos estudantes.

A experimentação ou frequentação dos filmes parece fundamental para expor os alunos a uma diversidade de gêneros, de nacionalidades e de cineastas que pouco se vê na TV ou na internet (através de acesso a vídeos em canais como YouTube). Se tomarmos em consideração o que diz Walter Lima Junior, em depoimento ao Caderno de Cinema do Professor (vol. 3), sobre a educação dos brasileiros a partir das imagens, teremos maior noção da contradição travada entre regimes de imagens antagônicas. 0 público no Brasil foi "educado com o Parque dos Dinossauros (1994), ET - o extraterrestre (1982), ambos de Steven Spielberg, ou com Os dez mandamentos (1956), de Cecil B. DeMille, com a produção comercial do cinema e, de repente, é obrigado a conviver com uma suposta imagem sua que não corresponde ao seu ideal de espectador." (LIMA. In TOZZI, 2009, p. 104).

Regimes antagônicos de imagens, porque a do cinema comercial de Hollywood, por assim dizer, em geral remodela a chamada realidade, limpando-a para que ela caiba na fantasia do espectador. Nesse sentido, "não interessa aos americanos [propagadores, por excelência, do cinema cuja imagem é por definição, 
espetáculo] a existência de um cinema brasileiro" (LIMA. In TOZZI, 2009, p. 105) que concorra com suas imagens. É a ideia de imagem-espetáculo de Guy Debord. Essa imagem responde a uma sociedade que tem no espetáculo, isto é, na ficção ideológica, o seu funcionamento, confirma e fomenta o seu alienamento dos vários processos. Isto não quer dizer que a questão do espetáculo se restrinja a que as pessoas assistam a um conjunto de imagens espetaculares e que a relação social entre as pessoas se dê apenas pela mediação das imagens (DEBORD, 2003), mas que, em grande medida tais imagens confirmam-se como mediadoras preponderantes das relações das pessoas pela circulação intensa dessa natureza de imagem em aparelhos individuais portáteis (virtuais domésticos).

Nesse sentido, $O$ cinema vai à escola não parece ter preocupação com a constituição de um percurso do cinema nacional ou do mundial, ou com os registros diferentes e antagônicos de imagens a que se referiu Walter Lima Junior. A preocupação maior parece ser a de elencar filmes considerados previamente com teor pedagógico, isto é, que possam ser tematizados em sala de aula, e que prendam a atenção dos alunos e, por consequência, auxiliem no chamado processo de ensino-aprendizagem. Filmes de enredo, cuja história torna todo o resto refém da ação de contar uma história. Como num texto acadêmico, no Projeto o encadeamento dos acontecimentos deve se dar de forma causal, secundarizando o que não se apresentar para a justificação do enredo.

Essa ideia de espetáculo da imagem está presente em todos os filmes entregues pela SEE-SP/FDE na medida em que são narrativos, no sentido clássico já por nós tratado anteriormente ${ }^{131}$. Um conjunto de filmes que parece ter como propósito maior contar bem uma história.

Os filmes são sugeridos, como dissemos, a fim de que possam ser justapostos a um plano pedagógico pelo assunto que aborda e como o aborda. Assim, em alguma medida, compromete-se com essa ideia de espetáculo, que evita a desorientação, o deslocamento do sujeito, os significados do ruído e do riscado nas imagens. O espetáculo passa a caber adequadamente na concepção de pedagógico e, por isso, pode-se compreender que os filmes comerciais sejam maioria, os inventores e disseminadores da linguagem clássica, efetivada pelos

${ }^{131}$ Cf. nota 27 deste trabalho. 270 
filmes de Hollywood até o final da década de 1950, já que tais filmes colocam em circulação o discurso vigente, afirmando a perspectiva ilusória de uma transparência ${ }^{132}$, isto é, o cinema que prima ideia de naturalidade na passagem entre os planos. No Roteiro de Os filhos do paraíso (1997), no conjunto de "curiosidades", o Projeto fala que o cinema iraniano ganhou espaço nos festivais internacionais e nas salas de exibição do ocidente na década de 1990, primeiro com Abbas Kiarostami e Mohsen Makhmalbaf, "mas foi Majid Majidi, com o filme Filhos do Paraíso, o primeiro cineasta iraniano a ser indicado para um Oscar de melhor filme estrangeiro."133 A referência ao Oscar introduzida pelo "mas" e a omissão da Palma de Ouro, no mesmo ano, a Gosto de cereja (1997), de Abbas Kiarostami, é um indicativo de desvalorização de um Festival pela valorização de outro, este massificado.

Ao contrário, a seleção de filmes cujo regime de imagem em muito destoasse do de um Jurassic Park: o parque dos dinossauros (Jurassic park, 1993), de Steven Spilberg, por exemplo, parece exigir dos coordenadores e dos professores das escolas uma ideia muito própria de cinema, além de uma espécie de aposta e uma crença na militância de um regime outro de imagens.

Da lista da FDE, acreditamos que alguns filmes fujam à ideia de boa imagem, de imagem espetáculo, como Cinema, aspirinas e urubus (2005), de Marcelo Gomes, e Terra de ninguém (No man's land, 2001), de Danis Tanovic. Contudo, ainda que o filme seja um componente importante na atividade em sala de aula, o uso que se faz dele pode "desvirtuar" ou acrescentar informações para além daquilo que lhe constitui como arte. Assim, Filhos do paraíso (Bacheha-Ye aseman, 1997), de Majid Majidi, pode servir ao propósito de entender a sociedade iraniana como empobrecida e de pessoas dóceis, que devem ser ajudadas. 0 Roteiro desse filme, por exemplo, sugere a seguinte atividade: "a implantação da República Islâmica do Irã (1979), o vínculo entre Estado e religião sob a regência do Alcorão". E a seguir: "a intervenção do fundamentalismo islâmico na produção de filmes no Irã e sua relação com a experimentação e construção de uma

\footnotetext{
132 Transparência aqui no sentido que aponta Ismail Xavier (2005), característico do cinema clássico hollywoodiano que prima pela continuidade entre os planos, isto é, pela transparência. Cf. página 106 deste trabalho.

${ }^{133} \mathrm{http}: / /$ culturacurriculo.fde.sp.gov.br/administracao/Anexos/Documentos/320130610130942Fi lhos\%20do\%20Para\%C3\%ADso.pdf.
} 
linguagem cinematográfica própria". Na verdade, sabemos que se trata de um recorte executado pelo filme e que a sociedade iraniana é bastante complexa. Ao mencionar o termo "fundamentalismo", o Roteiro revela desconhecer as causas históricas que redundaram na ascendência do poder religioso no país e emite julgamento em relação à sociedade iraniana para além do filme.

Lidar com o cinema na escola é sempre transitar pela linha tênue entre a ousadia do puro deleite estético e o uso convencional e "garantido" de filmes com aprovação prévia do público estudantil. As escolhas implicam uma intenção. Nesse caso, pensamos que a seleção dos filmes, indica majoritariamente a intenção de "boa" receptividade dos alunos. Contudo, queremos crer que filmes como Cinema, aspirinas e urubus (2005), de Marcelo Gomes, e Terra de ninguém (No man's land, 2001), de Danis Tanovic, em alguma medida, fujam ao mainstream em virtude de resistirem, apesar de serem eles também narrativos, à higienização da imagem e do som. 0 primeiro apresenta corajosamente um Brasil aparentemente distante, isolado, empobrecido, em ritmo lento, em que um brasileiro e um alemão se encontram. 0 outro também tematiza diferenças entre países em conflito que deixa de fazer sentido quando acontece de pessoas desses países se encontrarem. Ambos se dão sem a superposição extrema de trilha sonora verticalizante a fim de acentuar a vilanização de personagens ou de fazer caírem lágrimas no espectador. Contudo, o uso, digamos autêntico que se pode fazer de filmes, depende do professor acentuar ou, negativamente, deixar de acentuar aspectos pouco desenvolvidos no filme ou de chegar a generalizações teóricas que vão para além do filme. Assim, tanto a postura que superestima a possibilidade de o filme por ele próprio ser suficiente para realizar a atividade em sala de aula, provocando o que chamamos de experiência estética (na relação pura e simples com o filme) e "dispensando" a mediação do professor. Por outro lado, há ainda a aposta no efeito messiânico da palavra do professor, que, por si só seria capaz de reorganizar o pensamento e a sensibilidade dos alunos, dispensa preocupação com o tipo de filme a ser exibido e, por consequência, toda a rede de possibilidade de articulações que ele poderia suscitar.

Assim, exige-se a consideração da complexidade que é a proposição de determinado conjunto de filmes a um grupo. Apesar de um conjunto de 
característica que identificam a população brasileira, há aspectos que são próprios de alguns espaços e que podem ser levados em conta na seleção dos filmes. Surpreende, pois, que tendo o estado de São Paulo o maior contingente de professores e alunos do país, haja uma padronização dos filmes e do material didático para todas as escolas. Parece ser a evidência da desconsideração do singular nas estratégias pedagógicas, espelhada na prática cientificizante da eleição de princípios universais.

Se pensarmos que a população estudantil, como se sabe, vê massivamente televisão, e que cinco de cada dez crianças brasileiras reconhecem que fazem as tarefas de casa assistindo à televisão ${ }^{134}$, sem o acompanhamneto de um adulto135, e que essa programação, conforme apontou o Gráfico 2, é marcada predominantemente por produções estadunidenses, então tal população estará em franca exposição a seus temas e modos de pensar e de ver (o que nos faz encontrar paralelo na situação da produção e distribuição cinematográfica nos EUA no início do século $\mathrm{XX}$, quando o cinema dava seus primeiros passos rumo à industrialização). Na ocasião, os EUA veem os filmes estrangeiros impondo-se como mercadoria e a tematizar o cotidiano da população, que cada vez mais frequentava os salões de projeção de filmes. Para determinados grupos essa situação ameaçava o projeto de nacionalidade "americana". Quanto a este ponto, $\operatorname{diz}$ Xavier (2004, p. 10):

No plano político, dá-se nova ênfase à contribuição de tais experiências [do cinema] para a unidade nacional nos países que estavam no centro da era do imperialismo e também no centro da produção de filmes. É conhecido o papel desempenhado pelo cinema no processo de 'cimentação' nacional dos Estados Unidos, aclimatando os imigrantes na nova sociedade urbano-industrial e veiculando, reiteradamente, os valores e as práticas comerciais tomados como alicerce da nova nação.

\footnotetext{
${ }^{134}$ A pesquisa Geração Interativa na Ibero-América: crianças e adolescentes diante das telas, lançada pela Fundação Telefônica e realizada em parceira com a Universidade de Navarra, na Espanha, foi desenvolvida em vários países da América Latina, com uma amostragem de 25.467 estudantes de escolas públicas e privadas. No Brasil, ela foi feita em São Paulo, com 4.205 estudantes, também de escolas públicas e privadas. Para saber mais, consultar SOARES, 2011, p. 27 ss.

135 Embora saibamos que o adulto, em geral, desestrumentalizado para conversar sobre os meios de comunicação, legitima a submissão dos jovens a esses meios.
} 
Parece que temos uma questão importante, uma vez que se trata da consolidação de um plano de unidade nacional a que respondem o cinema e a educação.

(...) o componente vital nesse processo de americanização era a educação, 'qualquer modo concebível de educação' (...) 'era visto como uma contribuição potencial'. (...) em 1908 e 1909, de acordo com o testemunho de reformadores morais como Simon Patten, Jane Addams, John Collier e outros, a educação incluía o cinema, em especial os nickelodeons populares, que, segundo o New York Times, agora atraía semanalmente talvez metade da população dos Estados Unidos (ABEL In: CHARNEY \& SCHWARTZ, 2004, p. 236).

"A educação incluía o cinema”, mas não qualquer cinema. A princípio, não se tratava da qualidade especificamente do produto cinematográfico que estava em questão. 0 mercado de cinema nos Estados Unidos do início do século XX estava majoritariamente nas mãos da produtora francesa Pathé-Frères. Contudo, percebeu-se logo que o cinema teria que ser "nacionalizado".

De acordo com o artigo de Richard Abel, de onde as passagens acima foram retiradas, os produtores estadunidenses travaram uma luta bastante tensa contra a produtora francesa Pathé-Frères, que possuía nos arredores de Paris três estúdios para cenas internas, enquanto as concorrentes dos Estados Unidos (Edison, Biograph, Vitagraph), possuíam apenas um, cada. Também já possuía um tipo de produção industrial, "as unidades de diretores", que mantinham os diretores trabalhando todos ao mesmo tempo. Isso fez com que ela, nos anos 1905 a 1909, chegasse a dominar o mercado de filmes dos Estados Unidos em 60\%. A censura nesse país ganhou regularização e atuação constante e determinada também em razão do plano de americanização, que implicava a eliminação da concorrente estrangeira. As empresas produtoras de cinema, lideradas pela Edison, estabeleciam regras para a atuação nesse mercado. Cláusulas da Motion Picture Patents Company (MPPC) restringiram "cada produtora licenciada a um máximo de 1.200 metros (ou quatro rolos) de novas cópias por semana" (ABEL In: CHARNEY \& SCHWARTZ, 2004, p. 227), constituindo-se claramente em restrição da atuação da Pathé.

Além dessa restrição de produtos no mercado pela regulamentação de que falamos acima, a criação do conselho responsável pela censura, o National 274 
Board of Censorship, criado em 1909, começou a complicar a vida da concorrente francesa de modo mais contundente. Os filmes da Pathé foram muito mais censurados que todas as outras empresas dos Estados Unidos. Abel dá um exemplo.

Em maio de 1909, (...) o conselho 'condenou' dois títulos da Pathé que havia pedido para serem alterados (Le parapluie d'Anatole e Le Boucher de Meudon), mas aceitou Two Memories, da Biograph, após as mudanças terem sido feitas. Um mês depois, nada menos do que seis de treze títulos da Pathé foram rejeitados ou recomendados para que fossem alterados. No fim de fevereiro de 1910, o conselho considerou Moulin maudit, de Alfred Machin, tão ofensivo que, em vez de eliminar as cenas de adultério, assassinato e suicídio, ordenou que a Pathé simplesmente cortasse a segunda metade do filme (ABEL In: CHARNEY \& SCHWARTZ, 2004, p. 233).

Esse protecionismo pragmático da Censura à indústria de cinema nacional e o desfavorecimento aos filmes da Pathé encarecia a produção desta, alvo principal do conselho. Outro fator que, segundo o artigo de Abel apresenta como a diminuição do poder de mercado da concorrente francesa, foi a atuação dos jornais da época, que criticavam com frequência diária as produções francesas, como se elas fosse indecentes e impróprias para seu público principal, formado por mulheres e crianças, além de faltar a esses filmes, um tema propriamente "americano".

Disputava-se um novo espaço dentro da esfera pública. 0 cinema, como um mecanismo da modernidade, já que ele era a novidade tecnológica que servia de entretenimento nas grandes cidades, levava as pessoas a essas grandes salas e tematizava o cotidiano, impunha o seu modo de tematizar. Era preciso estar atento a essa tematização.

É curioso, pois, que o domínio francês do mercado cinematográfico dos EUA no início do século XX, que era de 60\%, tenha alarmado os empresários e o governo dos EUA a ponto de eles se mobilizarem para mudar esse cenário, e que no Brasil, conforme pesquisa anteriormente citada, o domínio dos filmes dos EUA seja de quase $80 \%$ nas salas de cinema e na TV. Num projeto específico de cinema, esse domínio cai para 30\%, mas ainda assim é maior do que a presença de filmes 
nacionais, que é de $23 \%$. Todavia, em se tratando de um projeto de cinema, esse percentual deveria ser diferente? Dever-se-ia esperar uma proporção diferente?

No Brasil, junto com o rádio, o cinema era uma potente forma de educar as massas iletradas. 0 entusiasmo de utilização do cinema como meio educativo esteve presente já na década de 1920, ocasião em que não existia um "sistema organizado de educação pública no país" (SCHWARTZMAN, 1984, p. 52). Além disso, acreditava-se que a educação podia "moldar a sociedade a partir da formação das mentes e da abertura de novos espaços de mobilidade social e participação." (SCHWARTZMAN, 1984, p. 51). Segundo Schwartzman, contudo, na década de 1930, ficaria muito mais clara que a educação seria um campo de batalha entre os que defendiam a escola pública e os que defendiam a escola privada, sendo esta defendida pela Igreja Católica e aquela, dentre outros, defendida pela Associação Brasileira de Educação (ABE), fundada em 1924 por Heitor Lira, que já se incumbia de estabelecer o debate em torno de um projeto de educação para o Brasil por meio da realização de congressos, publicações de textos sobre o assunto e a realização de cursos (SCHWARTZMAN, 1984, p. 52) - pelo Movimento da Escola Nova, que tinha em John Dewey sua inspiração maior.

No entanto, a Igreja Católica já havia realizado dois congressos de educação em nível nacional: um na Bahia, em 1900, e outro no Rio de Janeiro, no ano seguinte. Como consequência desses encontros, a Ordem dos Beneditinos de São Paulo funda a primeira faculdade de filosofia, ciências e letras do Brasil. A faculdade trazia consigo um instituto de educação (KULLOK, 2000, p. 37). Para Maisa Gomes Brandão Kullok, o Brasil defendia a posição de uma universidade de tipo utilitário e restrito às profissões, negligenciando a formação da cultura e das ciências (KULLOK, 2000, p. 38). Em 1920, dois decretos em São Paulo, realizados pelo pedagogo Antonio de Sampaio Dória, dão novos rumos para a educação. Responsável pela Reforma de 1920, conhecida como Reforma Sampaio Dória, ela previa principalmente a erradicação do analfabetismo. Essa reforma reduz os estudos do primário de 4 para 2 anos e, com isso, ganha severas críticas. Contudo, como afirma Louisa Campbell Mathieson (2012, p. 19), ele o torna obrigatório e, com isso, gratuito. Ainda segundo Mathieson, a Reforma Sampaio Dória mudava a perspectiva educacional que até então vigorava desde a Reforma Caetano de 
Campos, em 1891, que tinha a "concepção educacional de ensinar tudo a todos, formando os alunos de maneira lenta e ampla." (2012, p. 20). A reforma de Dória passou a representar para os estudiosos da educação, como lembra Mathieson (p. 20), "ponto de viragem nos debates relativos à universalização do ensino brasileiro."

Essa noção de universalização da educação é tomada pelo movimento escolanovismo no Brasil, como lembra Schwartzman (1984, p. 52), que para esse movimento, "a educação deveria ser proporcionada para todos, e todos deveriam receber o mesmo tipo de educação. Ela criaria, assim, uma igualdade básica de oportunidades (...).”.

Esse caráter universalista é percebido também nos textos de Fernando de Azevedo, quando este, elogiando a reforma de 23 de janeiro de 1928, no Distrito Federal, expressa pelo Decreto 3.281, tem a expectativa de que tal reforma proporcionará "uma educação mais eficiente" e esperava que essa nova educação estendesse a todos, “(..) reagindo contra os fins puramente individualistas da escola antiga". E a seguir, afirma que "por essa reforma (...) pretendeu-se alcançar (...) aquela 'educação universal' a que se refere J. Dewey e que põe ao alcance de todos as suas vantagens e satisfaz à imensa variedade das exigências sociais e das necessidades e aptidões individuais (...)." (AZEVEDO, 2010, p. 704).

Se, quanto à educação, a dimensão pública foi se definindo como obrigação do Estado, o mesmo não se passou quanto ao rádio e à televisão. Apesar de o Rádio nascer estatal, como atesta o Decreto no. 3.296, de 10 de julho de 1917, que declara se tratarem de "exclusiva competência do Governo Federal os serviços radiotelegraphico e radiotelephonico no território brazileiro", ele se torna de gestão eminentemente privada, com interesse privado predominante, o que significa que a educação não foi e não segue sendo sua prioridade.

É nesse sentido que o projeto $O$ cinema vai à escola parece atender certo caráter público quando, na rede pública de ensino, no mínimo, oferece a formação de um acervo predominantemente composto por filmes fora do circuito exclusivamente comercial, com títulos nacionais e internacionais. Assim, soma-se ao importante papel desempenhado pelas bibliotecas, um acervo pouco comum nas escolas. No sentido do atendimento dessa demanda, um acervo disponível na 
própria escola pode facilitar o trabalho de planejamento que incorpore o cinema. Em termos governamentais, ações têm sido tomadas no país para a maior inserção de filmes nas escolas como a Lei no 13.006/2014, que as obriga à exibição de filmes de produção nacional em suas instalações. Essa lei acrescenta ao Art. 26 da LDB No. 9.394/96, o seguinte parágrafo: “§ 8º A exibição de filmes de produção nacional constituirá componente curricular complementar integrado à proposta pedagógica da escola, sendo a sua exibição obrigatória por, no mínimo, 2 (duas) horas mensais." (NR) ${ }^{136}$, preocupação já sentida quando o cinema era o meio de comunicação mais comum, depois da imprensa (SIMIS, 2015, p. 26), e que sua participação junto à escola é regulamentada em 1933, na Lei no 5.884 , de 21 de abril, que institui o Código de Educação do Estado de São Paulo, conforme referência feita anteriormente.

Identificamos nesses documentos o papel secundário reservado ao cinema. No entanto, perguntamo-nos se não seria o caso de ele oferecer-se muito mais a um processo de transmissão do que de auxiliar no ensino propriamente, uma vez que a arte não se apreende ao modo de um objeto científico. Epstein nos ajuda a pensar a respeito quando aponta que "é porque permanece sempre precisa e magnificamente concreta que a imagem cinematográfica se presta mal à esquematização que permitiria a classificação rigorosa, necessária a uma arquitetura lógica [...]" (EPSTEIN, Jean apud MARTIN, 2011, p. 23).

Ainda que a disciplinarização do cinema ameaçasse sua constituição como arte tal como ocorre com a literatura, esvaziada pela escola de seu sentido em si (TODOROV, 2009), quando a utiliza como suporte de metáforas e elipses, dentre outras figuras de linguagem, não seria vantagem ter o cinema como disciplina autônoma? Considerando a observação de Todorov quanto ao ensino da literatura, o mesmo se passaria com o cinema? Pensamos que, bem ou mal, pela disciplina Literatura, os alunos passam por autores brasileiros e estrangeiros. Na ausência do cinema na escola é possível que os alunos nunca cheguem a conhecer obras como Limite (1931), Ganga Bruta (1933), Matar ou Correr (1954), Rio 40 graus (1954), o grande momento (1958), Deus e o Diabo na terra do sol (1963), O

\footnotetext{
${ }^{136} \mathrm{http}: / /$ pesquisa.in.gov.br/imprensa/jsp/visualiza/index.jsp?jornal=1\&pagina=1\&data=27/06/2 014, acesso em 1․ de outubro de 2015). 
bandido da luz vermelha (1968), Bang bang (1971), para citar alguns títulos importantes do cinema nacional.

Para muitos é premente que a educação formal contemporânea acolha questões de seu tempo, como a entrada do cinema na escola, mas o de outros audiovisuais também como a televisão. É o caso de Martín-Barbero: "São muitos os temas que não chegam ao adolescente e ao jovem pelo lado da escrita: livros, jornais, revistas. Mas que podem chegar pela televisão, (...) que pode agendar temas importantes para o país e o mundo." Poderia ainda "mostrar-se para a escola como uma chave do aprendizado de toda a sofisticação que hoje passa pela experimentação audiovisual." (MARTÍN-BARBERO. In CITELLI \& COSTA, 2011, pp. 208-209). Martín-Barbero está sugerindo a televisão, o vídeo e o cinema na escola não apenas como comunicação que faz circular informação, como suportes que armazenam informação, mas como desvendamento do modo de produzi-la. A resistência dessa instituição, no entanto, apresenta-se na departamentalização da entrada do audiovisual na escola, que responde a uma forma "escolar" de ensinoaprendizagem "linear, completamente segmentada, em termos de pacote de saber (...).". Para ele, esse modo de tratar os temas na escola "é desconhecer todos os outros modos de organização, de difusão, de contato com o conhecimento que o adolescente está adquirindo." (MARTÍN-BARBERO. In CITELLI \& COSTA, 2011, p. 208).

Mesmo considerando um projeto específico de cinema na escola, como é este que ora analisamos, faz-se necessário cumprir com o cinema uma equação de comunicação com os temas abordados pelas disciplinas a partir dos filmes. Isto é, os filmes são suportes pedagógicos para os temas maiores das disciplinas. "A chamada Ideia abrangente é um classificador que serve para estabelecer ordem, mas não conexão" (ADORNO \& HORKHEIMER, 2006, p. 104).

Na escola o ensinar é estrutural (ensignar, pôr em signos), cujo fim é, em primeira instância, o de comunicar, acentuando o imperativo das ordens e buscando, com isso, sintomaticamente, restaurar na contemporaneidade a perda da perspectiva histórica única (FAVARETTO, 1993), domesticando (FOUCAULT, 1988) a subjetividade do espectador. Esse vazio que resiste à perspectiva da histórica única é a alforria do filme evitando a moldura da fetichização. 
Ao se recusar às promessas redentoras da totalidade, da teleologia dos sistemas de pensamento, enfim dos sistemas de representação, as continuidades como, por exemplo, aquela que prevalece atualmente, a da informação e da comunicação, a aposta que se tem que fazer é a de não se render à tentação de colmatar o vazio que então se instala, mas, o que é, repito, uma aposta, descobrir e trabalhar nos interstícios (na falha, na brecha) do vazio (FAVARETTO, 2011, p. 102-103).

Contudo, a identificação dos filmes que se constituiriam desse vazio ou que melhor permitiriam o trabalho "nos interstícios do vazio" não é tão simples. Além dos aspectos propriamente estéticos de um filme, há outros a serem considerados, que podem destacá-lo na medida em que ele atenda à demanda social de um determinado debate, situando-se e determinando o debate. Exemplo disso de que estamos falando são as obras premiadas em grandes festivais que tematizam o holocausto dos judeus na II Guerra Mundial como A Vida é Bela (La vita è bella, 1997), de Roberto Benigni, de humor fácil. Tais filmes passam a ser exibidos com certa regularidade, em grande medida, pelo debate que produz, não por serem exatamente "arte". Na indústria cultural, "o cinema e o rádio não precisam mais se apresentar como arte" (ADORNO \& HORKHEIMER, 2006, p. 100). Adorno e Horkheimer ressaltam o problema da eleição do filme como confirmação da identidade.

Na mesma chave, lembramos o recente caso do filme Aquarius (2016), do diretor Kleber Mendonça Filho, que (apesar de apresentar problemas de ritmo e uma interpretação solene dos atores, entre outros), ao final da sessão (como foi comum nas primeiras semanas de exibição do filme) os espectadores aplaudiam fervorosamente ao embalo de "Fora Temer"137, menção às passeatas ocorridas no Brasil em favor da saída do então presidente do país, empossado depois da confirmação polêmica de "impedimento" da antes presidenta eleita Dilma Roussef. O filme foi preterido por defensores da chamada extrema direita no Brasil. Reinaldo Azevedo, por exemplo, escreveu na revista Veja: “Assim que 'Aquarius' estrear no Brasil, o dever das pessoas de bem é boicotá-lo"138, frase que o cineasta,

\footnotetext{
137 http://www1.folha.uol.com.br/ilustrada/2016/08/1807546-exibicao-de-aquarius-emgramado-comeca-com-gritos-de-fora-temer.shtml.

138 http://veja.abril.com.br/blog/reinaldo/geral/assim-que-aquarius-estrear-no-brasil-o-deverdas-pessoas-de-bem-e-boicota-lo-que-os-esquerdistas-garantam-a-bilheteria/. Acesso dia 11 de setembro de 2016. 280
} 
como provocação e, ao mesmo tempo, demarcando seu espaço ideológico, levou ao cartaz oficial do filme. Outro caso com grande repercussão social no Brasil foi o filme Que horas ela volta (2015), da cineasta Anna Muylaert que, tematizando a relação entre patrão e empregado, abre uma ferida no Brasil, que é o trabalho doméstico. A exibição do filme em vários CEUs - Centro Educacional Unificado, em São Paulo, causou grande reação no público, que aplaudia e vibrava principalmente quando a empregada doméstica (personagem interpretada por Regina Casé) dá a notícia que sua filha foi aprovada no vestibular, enquanto o filho da patroa não havia logrado êxito no mesmo exame.

Esses dois filmes têm o mérito de dialogar com problemas brasileiros, além de marcarem suas posições político-ideológicas sem o abandono de cuidados "artísticos" da forma. É sem dúvida uma perda o fato de a escola não conseguir acolher essa discussão por meio do cinema. A escola parece não se sensibilizar para aparelhar-se dessa discusão.

Mas, na escola, o cinema não precisaria se apresentar como arte? A crítica ao filme seria suficiente? Fica evidente no projeto $O$ cinema vai à escola, que não. Prova disso são os critérios do Projeto para seleção dos filmes. Contudo, a tradição logocêntrica - reforçada paradoxalmente no Projeto - que caracteriza o ensino escolar secundariza o que não for fundado no lógos. Assim, o cinema entra na configuração escolar como auxiliador dos trabalhos pedagógicos, como entretenimento, a fim de ajudar o trabalho duro, "verdadeiramente" escolar, que se baseia em textos das várias ciências. Se lembrarmos que Eric Rohmer ${ }^{139}$ usou este pseudônimo para não escandalizar a classe de professores de literatura da qual fazia parte em razão de ele passar a escrever sobre cinema, não estaríamos, hoje, tão distante dessa atmosfera.

Para atender a esse apelo da palavra, os filmes comerciais são os mais indicados, aqueles moldados pela linguagem clássica hollywoodiana predominatemente "falados" - cujos atores do star system (com grande bilheteria), em geral, são arautos da identidade. Seus personagens falam o que já se sabe, o que já se diz antes de ele falar, porque eles vestem as palavras do tom que já outros tantos usaram, e que tal roupa, antes de desgastada, atualiza-se como a um paletó

139 Para saber mais, consultar COUTINHO, Mário Alves. Escrever com a câmera: a literatura cinematográfica de Jean-Luc Godard. Belo Horizonte: Ed. Crisálida, 2010, p. 38. 
que se adéqua ao corpo com o passar do tempo. Eles falam com a garantia de que o público entenderá o que sai de sua boca. Para Adorno e Horkheimer, esse falar reduziu a linguagem ao silêncio (ADORNO \& HORKHEIMER, 2006, p. 106).

A obra medíocre, como denominam Adorno e Horkheimer, sempre se ateve ao apelo da identificação com o público, tentativa de eliminação da problemática relação entre exterior e interior, indivíduo e sociedade, na redução da referência ao signo, e que a grande obra sempre se recusou (ADORNO \& HORKHEIMER, 2006, p. 108). E, no entanto, a obra de arte não precisa de justificativa, a não ser aquela de definir-se como forma, pois ela "não é meio para exposição de um conteúdo." (BENJAMIN, 1999, p. 84). 0 cinema divertiria o sujeito e, na diversão, como fuga da realidade, seria um meio de escapar ao enrijecimento do trabalho dentro da lógica capitalista. Promoveria a fuga do mecanicismo do capitalismo. Para Adorno e Horkheimer, até na diversão, e firmemente aí, a lógica da indústria cultural seria perversa, pois ela formata os meios de interação entre as pessoas. Tenta-se escapar ao processo mecanizado do trabalho por meio da diversão, mas o riso é a caricatura da felicidade. Rir é como o estalar da engrenagem da fábrica: "Um grupo de pessoas a rir é uma paródia da humanidade" (ADORNO \& HORKHEIMER, 2006, p. 116). Na indústria cultural, o riso é valorizado em detrimento do trágico, que é expurgado. 0 riso nos espetáculos da indústria cultural é a manifestação da expulsão do trágico. 0 cinema torna-se uma instituição de aperfeiçoamento moral, de tentativa de controle desse trágico. (Cf. ADORNO \& HORKHEIMER, 2006, p. 126).

\begin{abstract}
A liquidação do trágico confirma a eliminação do indivíduo. $\mathrm{Na}$ indústria, o indivíduo é ilusório não apenas por causa da padronização do modo de produção. Ele só é tolerado na medida em que sua identidade incondicional está fora de questão. Da improvisação padronizada no jazz até os tipos originais do cinema, que tem de deixar a franja cair sobre os olhos para serem reconhecidos como tais, o que domina é a pseudoindividualidade (ADORNO \& HORKHEIMER, 2006, p. 127-128).
\end{abstract}

O cinema parece ser convocado pela escola para ressaltar essa pseudoindividualidade de que falam Adorno e Horkheimer ou, nos termos de Elizabeth Roudinesco (2000), individualidade e menos subjetividade. É nesse sentido que o 282 
cinema na escola teria o propósito de sustentar-se como veículo de informação, acrescido do plus da leveza do espetáculo a que é associado e investido. Sua função, enfim, certamente não seria a de provocar rupturas. 0 projeto $O$ cinema vai à escola endoça esse lugar do cinema.

O filme comercial rendido à identificação não deixa liberdade para o espectador passear livremente pelo quadro fílmico; é feito de tal forma que exige presteza de bom observador, mas, ao mesmo tempo, não permite uma desenvoltura intelectual nem sensível em razão do desfile de imagens e de recursos como a música e ruídos para acentuar um aspecto no quadro fílmico:

[Os filmes] São feitos de tal forma que sua apreensão adequada exige, é verdade, presteza, dom de observação, conhecimentos específicos, mas também de tal sorte que proíbem a atividade intelectual do espectador, se ele não quiser perder os fatos que desfilam velozmente diante de seus olhos (ADORNO \& HORKHEIMER, 2006, p. 104-105).

Ainda se considerarmos o DVD, quando geralmente tentamos pará-lo, não é pouco frequente que tentemos voltar ao ponto exato de onde paramos. Diferentemente do livro, que se pode fechar a seu bel prazer, o filme transcorre e os olhos têm que se adequar ao tempo do filme.

As instruções que o observador recebe dos jornais ilustrados através das legendas se tornarão, em seguida, ainda mais precisas e imperiosas no cinema, em que a compreensão de cada imagem é condicionada pela sequência de todas as imagens anteriores (BENJAMIN, 1996a, p. 175).

E isso não se dá por esforço de cada filme, mas resulta de um formato adquirido por outros filmes e produtos culturais diversos. Segundo Adorno e Horkheimer, os produtos gerais da indústria cultural deixam o espectador familiarizado com os desempenhos exigidos dele na audiência de um filme. Para Martín-Barbero, Adorno e Horkheimer engessam a discussão sobre "o popular na cultura", tomando-o apenas como produto industrial. A entrada de Benjamin em 
cena muda esse cenário ${ }^{140}$. Para Benjamin, ao contrário de Adorno, a técnica aliada às massas seria capaz de emancipar a arte. Benjamin esboça "algumas chaves para pensar o não-pensado: o popular na cultura não como sua negação, mas como experiência e produção" (MARTÍN-BARBERO, 2006, p. 72), discussão não contemplada pela teoria de Adorno. Como se sabe, quanto à aura da obra de arte, para Benjamin, a técnica desvincula a arte da tradição. A cada reprodução de uma obra torna-se mais impossível o irrepetível aurático. 0 agente mais poderoso nessa transformação técnica é o cinema, que se relaciona

intimamente com os movimentos de massa, em nossos dias. [...]. Sua função social não é concebível, mesmo em seus traços mais positivos, e precisamente neles, sem seu lado destrutivo e catártico: a liquidação do valor tradicional do patrimônio da cultura (BENJAMIN, 1996a, p. 169).

Benjamin identifica a passagem de um tempo (o da produção aurática da obra de arte) a outro, o da produção política da obra de arte. Se a obra de arte nesse período a que poderíamos denominar de aurático - a obra de arte estava ligada a rituais -, na época política ou da reprodutibilidade técnica contemporânea, assume um status social outro: "Em vez de fundar-se no ritual, diz Benjamin, ela passa a fundar-se em outra práxis: a política." (BENJAMIN, 1996a, p. 171-172).

O filme já nasce não-aurático, uma vez que o aspecto da reprodutibilidade é a ele, mais que à fotografia, intrínseco, diferente da literatura ou da pintura, cuja "condição [é] externa para sua difusão maciça." (BENJAMIN, 1996a, p. 172), ainda que essas duas últimas, também não escapem a essa nova dimensão em que passa irremediavelmente a se situar a arte no mundo atual.

Assim, se a obra de arte, restrita ao modelo original, não podia ser reconhecida pelas massas, configurando-se aí seu valor de culto, com a reprodutibilidade técnica contemporânea tem-se uma circulação consideravelmente maior da obra de arte pela cidade, passando a ser conhecida pelos citadinos. A questão que se coloca aí é a de que o valor de exposição é, agora, substrato da obra de arte.

${ }^{140}$ Apoiando-se em Habermas, Ricardo Teixeira diz ter a indústria cultural efeitos paradoxais. "Por isso acho que Habermas tem razão, o efeito da indústria cultural é às vezes ambivalente, e no caso da coleção Os Pensadores foi ambivalente." (TERRA, 2012, p. 344). 
Como pensar a experiência na escola senão elegendo a inevitabilidade do valor de exposição da obra de arte? Talvez caiba à escola como tarefa histórica, na sombra de Benjamin, "fazer do gigantesco aparelho do nosso tempo [o cinema] o objeto das inervações humanas [...]." (BENJAMIN, 1996a, p. 174).

O Cinema vai à escola se insere num contexto maior de busca de interação entre educação e arte cinematográfica. É o que se pode observar em projetos similares desenvolvidos no mesmo período em outros estados brasileiros, caso dos estados do Rio de Janeiro e de experiências com a realização de audiovisual e de formação de pessoal no caso do Instituto de Arte e Cultura do Ceará - IACC, mais conhecido por seu nome de fantasia "Instituto Dragão do Mar", em Fortaleza, criado na década de 1990, onde são ministrados cursos com acesso gratuito de pintura, artesanato, música, fotografia e audiovisual, dentre outros. No caso do Rio de Janeiro, a parceria entre as secretarias do Estado da Cultura e da Educação criaram o Programa Cinema para Todos, que consiste na entrega de vales-ingresso a estudantes, que poderão, com acompanhante, frequentar quaisquer salas de cinema conveniadas, em qualquer dia da semana e horário, inclusive em feriados e nas férias, para ver filmes nacionais. 0 programa ainda abriu concurso entre as escolas estaduais pelo qual aquelas selecionadas passariam a ter um cineclube e receberiam um kit de equipamentos de áudio e vídeo, acervo de filmes com direitos autorais liberados, além de uma oficina de capacitação para manutenção do equipamento e do espaço. Trinta escolas foram contempladas. Todas as escolas do estado também concorrem para participarem de oficinas de vídeo promovidas pela equipe pedagógica do Programa. O cinema vai à escola não tem um braço com salas de cinema, nem com uma configuração específica para produção de filmes. Sua atuação é fundamentalmente em sala de aula, junto às disciplinas, com os filmes das caixas. 


\section{8- Os Cadernos de Cinema do Professor do projeto 0 cinema vai à escola}

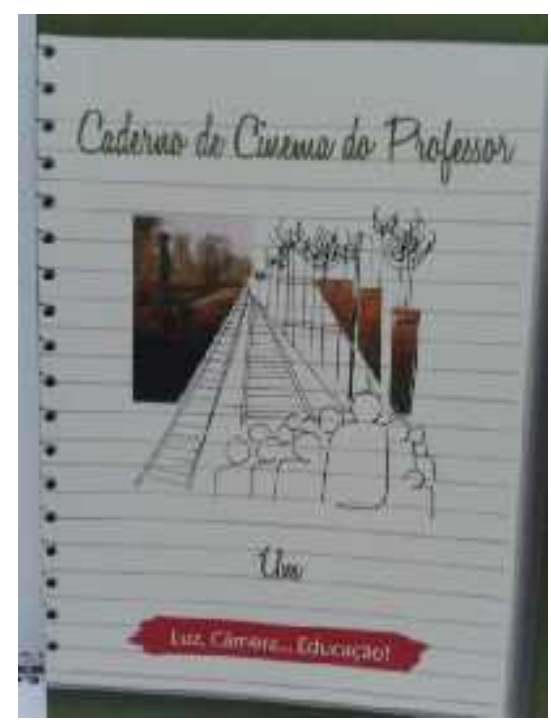

Figura 16- Foto do Caderno de Cinema do Professor (vol. 1).

Apresentamos a foto (Figura 16) do Caderno de Cinema do Professor 1, porque nos parece importante chamar atenção para a imitação que se faz pela lombada do Caderno, imitando um caderno a fim de fazer jus ao nome que ele leva. Isso também, pela finalidade de tornar o caderno mais acessível ao professor.

A publicação do primeiro volume dos Cadernos de Cinema do Professor se dá simultaneamente ao lançamento do programa Cultura é currículo, isto é, no ano de 2008, sendo os outros publicados em anos subsequentes. São 26 títulos, sendo que todos foram enviados às escolas, a maioria com sinopses, curiosidades sobre os filmes e propostas de uso pedagógico de tais filmes. Um deles traz quatro artigos que resolvemos comentar para que o leitor possa ter ideia do material destinado às escolas.

1- 0 primeiro deles ${ }^{141}$, lançado em 2008, escrito apenas por Devanil Tozzi, consiste em orientações gerais sobre o cinema na primeira parte e em panorama sobre as razões para a escolha dos filmes que compuseram as caixas que

141Disponível em http://culturaecurriculo.fde.sp.gov.br/administracao/Anexos/Documentos/320090708123630cad erno_cinema1_web.pdf. Acesso em 10 de outubro de 2015. 286 
foram enviadas às escolas. Dentre as razões, Tozzi indica que foi considerada a necessidade de professores e alunos conhecerem filmes de diversos países, de épocas e de escolas diferentes, e que também os filmes não tivessem sido apresentados exaustivamente na televisão. A seguir o primeiro Caderno tem a seguinte estrutura:

- "Os filmes" - Comentários sobre 30 filmes distribuídos nas caixas de DVDs. Os comentários consideram os filmes como suporte pedagógico para uso em sala de aula, sugerindo formas de elaboração de uma proposta. Nessa parte há uma ficha técnica de cada filme comentado.

- "Algumas marcas do projeto" - Aqui, os organizadores dos Cadernos falam das dificuldades de selecionar os filmes do projeto e agradecem a várias escolas por servirem de consulta na escolha dos filmes, que teve um total de mais de 1000 títulos antes da seleção final.

- "Frases sobre cinema" - Consiste na disposição de várias frases de realizadores e pessoas que escreveram sobre o cinema.

- "Mais filmes, outras descobertas..." - Consiste numa lista de indicação de 100 filmes, de A a Z, para o professor aumentar seu repertório, pois várias das indicações, alerta o texto, não são apropriadas para o uso em sala de aula.

2- 0 segundo volume do Caderno de Cinema do Professor ${ }^{142}$, lançado em 2009, apresenta um texto de quatro autores. São eles:

- Cinema: experiência cultural e escolar, de Marcos Napolitano.

- A linguagem do cinema no currículo do Ensino Médio: um recurso para o professor, de José Cerchi Fusari.

- Uma história do cinema: movimentos, gêneros e diretores, de Eduardo Morettin.

- A linguagem cinematográfica, de Eduardo Ramos.

O primeiro dos textos, do prfessor da USP Marcos Napolitano, apresenta o cinema como arte das massas, desde o início do século XX, mas também a TV,

\footnotetext{
142 Disponível em http://culturaecurriculo.fde.sp.gov.br/administracao/Anexos/Documentos/320090708123643cad erno_cinema2_web.pdf. Acesso em 10 de novembro de 2015.
} 
"como espaços de lutas sociais, culturais e políticas, objetos de disputas econômicas, veículos de inculcação ideológica e de projeções de utopias e sentimentos." (NAPOLITANO, 2009, p. 11). Sugere alguns modos de uso de filmes em sala de aula como o de projetar dois filmes que tratem da mesma temática. Segundo ele, os contrastes sobre o mesmo tema pode enriquecer a leitura. Dois filmes sobre gladiadores, por exemplo, Spartacus (Spartacus, 1960), de Stanley Kubrick, e Gladiador (Gladiator, 2000), de Ridley Scott, apresentam versões bem distintas. 0 primeiro faz uma leitura da Roma Antiga sob a perspectiva das lutas políticas do século XX (democracia, revolução, ditadura). 0 segundo, sob o individualismo e os valores neoliberais do final do século XX (NAPOLITANO, 2009).

Napolitano ainda afirma que em si a projeção de um filme já é formativa, mas que a escola pode adensar essa experiência. Assim, uma "análise fílmica começa quando conciliamos o olhar que capta o resultado final de um filme e a reflexão sobre as escolhas, recursos e processos que estão por trás destes resultados." (NAPOLITANO, 2009, p. 18). Na lista de filmes, o professor pode ir além das obviedades dos títulos para adolescentes de "baixo nível". Ele pode se utilizar de filmes "mais difíceis", como diz Napolitano, pois se o professor não acreditar nessa via, tornam-se menores as chances dos alunos de também acreditarem. Para tanto, é preciso que o professor não pense o filme como "ilustração" de alguma matéria dada. E sugere duas possibilidades: 1) 0 filme como um "texto" gerador de debate sobre temas que o professor seleciona antecipadamente. $\mathrm{O}$ outro modo de uso do filme 2) é este ser tomado como um documento em si, considerando os valores, conceitos, atitudes e representações que ele veicula sobre a sociedade, a ciência, a política e a história. Napolitano ainda destaca a necessidade de apresentar os elementos que compõem a obra como os temas, a roteirização, recursos de câmera, trilha sonora, montagem, dentre outros. Como também a recepção da crítica especializada à obra (NAPOLITANO, 2009).

Lembra ainda que o mau uso do filme gera preconceitos como o de não parecer haver aula, porque o professor vai passar um filme. Por isso, Napolitano destaca a importância de o professor se preparar bem para os elementos apresentados no filme, inclusive as partes polêmicas, se for o caso. 
A seguir, Napolitano destaca que para a seleção de filmes a serem exibidos no ano letivo, é importante sondar a cultura audiovisual dos alunos com um questionário que aborde questões como: 1) "Quantos filmes você viu no último ano? Quais os filmes de sua preferência? Você assiste a filmes no cinema ou na TV?" (NAPOLITANO, 2009, p. 27). De posse dessas informações, o professor poderá projetar os filmes que, a princípio, serão de interesse dos alunos, como poderá analisar o repertório audiovisual, criando hipóteses sobre as possibilidades desses alunos analisarem uma determinada obra fílmica.

O segundo texto desse volume é de José Cerchi Fusari, também professor da USP, que começa abordando a importância do currículo na definição das experiências de uma escola e sua tradução em Projeto Político Pedagógico PPP. Para esse autor, o PPP, ao contrário do currículo formal, é dinâmico e expressa mais amplamente a comunidade, a escola e a sociedade, cabendo a essa instância pensar a entrada do cinema e o modo que se daria essa entrada. Ainda de acordo com Fusari os filmes podem contribuir para o desenvolvimento de conhecimentos, habilidades, atitudes e saberes "para uma aprendizagem de cidadania pautada pela consciência de prática de direitos e deveres, na perspectiva do bem comum, além de facilitar vivências culturais diferenciadas." (FUSARI, 2009, p. 37).

Diferentemente de Napolitano, Fusari especifica o destino dos usos do cinema na escola: a cidadania, entendida aí como usufruto de direitos e cumprimento de deveres. A vivência cultural parece ter sua importância diminuída. Além disso, estabelece a conscientização como via de materialização desses objetivos. Parece que Fusari se encontra no esquema já bem consolidado do binômio ensino-aprendizagem.

Sugere a seguir alguns cuidados que o professor deve tomar antes, durante e após a exibição de um filme. Antes, o professor deve, por exemplo, informar-se sobre a linguagem cinematográfica voltada para o ensino, "identificar nexos e sentidos nas diferentes áreas e disciplinas escolares", "assistir ao filme selecionado antes da experiência com os alunos, planejando sua abordagem (...), garantindo, porém, espaço para as manifestações criativas que o filme poderá provocar." (FUSARI, 2009, p. 38). Durante a projeção o professor deve estar atento 
às reações dos alunos, possíveis indicadores "daquilo que é mais denso e do que é mais leve no filme e o sentimento que provoca em cada um (...)" a fim de proporcionar uma troca de ideias e informações. Sugere, por fim, que as impressões dos alunos sejam acolhidas pelo professor a fim de que a maioria expresse seus pensamentos e emoções; procurar fazer análises fílmicas, evitando o maniqueísmos.

O terceiro texto, de Eduardo Morettin, traça a história do cinema desde a polêmica quanto à paternidade deste invento (Thomas Edson, com seu quinetoscópio, nos EUA, e Max Skladanowsky, com seu bioscópio, na Alemanha), passando pela fase inicial, o "primeiro cinema", que era marcada pela "falta de preocupação em contar histórias, dado que o interesse estava nas próprias imagens, pensadas como 'atrações'” (MORETTIN, 2009, p. 48) até os dias atuais. A partir de 1906 os filmes de ficção começaram a sobrepujar os "documentários", com aumento do interesse do público, o que se chega a gerar espaços grandes para exibição desses filmes, chamados de nickelodeon. Os filmes se tornam cada vez mais narrativos, como são exemplos, na França, as obras Fantômas (1914) e Les Vampires (1915), de Louis Feuillade. Na Itália, Giovanni Pastrone com seu Cabiria (1914). Mas é com David Griffith, nos Estados Unidos, diz Morettin, que os filmes ganharão maior extensão, por exemplo. Pois sua duração até 1908 costumava ser de no máximo 15 minutos. Em 1911 os filmes chegam a 30 minutos. 0 trabalho de montagem aparece como fundante do filme ficcional. Importava

\footnotetext{
determinar a ligação entre os planos filmados, marcando seu ritmo, construindo um espaço e um tempo próprios. Além disso, no chamado cinema silencioso, recorria-se aos intertítulos entre um plano e outro, com o intuito de fornecer ao espectador as informações complementares necessárias ao entendimento da história (MORETTIN, 2009, p. 50).
}

O filme, como uma história contada, começa, pois, a caracterizar esses filmes. Em 1913, diz Morettin, a Biograph se recusa a comercializar seu Judith de Betúlia (Judith of Bethulia, 1914) em razão de acreditar que o público não permaneceria sentado por uma hora, tempo de duração do filme (MORETINN, 2009, p. 51). Mas os nickelodeons já eram prova de que o público aumentava cada vez mais, tornando o cinema um entretenimento de massa. 
Contudo, como faz notar Morettin, é em 1915, com Nascimento de uma nação (The birth of a nation, 1915), com duração de duas horas e meia, que se consolidaria o chamado cinema clássico. Curioso que tal filme fosse uma apologia ao racismo, enaltecendo os feitos do conhecido grupo Ku Klux Kan.

À consolidação da chamada narrativa clássica, houve tentativas de rupturas, como aquelas promovidas pelas vanguardas. Estas

procuraram construir alternativas consideradas mais apropriadas ao meio visto como fruto e parte integrante da modernidade. Nos anos 1910 e 1920, esses artistas queriam afastar o cinema de uma tradição passadista (representação calcada na realidade e na aproximação feita à arte dramática, entre outros elementos criticados), supervalorizando a visualidade em seu poder revelador e superando as convenções da linguagem verbal (MORETTIN, 2009, p. 53-55).

Morettin aponta o filme Gabinete do Dr. Caligari (The cabinet of Dr. Caligari, 1920), de Robert Wiene, como marco dessa tentativa de ruptura promovida pelas vanguardas, em virtude de sua ampla aproximação de seus planos com as artes plásticas.

Outra tentativa de ruptura com a narrativa clássica acontece na União Soviética, com Greve (Stanchka, 1925), Encouraçado Potemkin (Bronenosets Potemkin, 1925) e Outubro (Oktyabr, 1928), todos de Sergei Eisenstein, para quem, diz Morettin (2009), os processos é que deveriam ser representados, não os eventos. A ele, interessa o conflito, não a passagem leve de um plano a outro.

Assim, procurava conferir um estatuto outro à montagem, por meio da interrupção do fluxo dos acontecimentos e da intervenção do sujeito no discurso por meio da inserção de planos que destroem a continuidade espaço-temporal do cinema clássico (...). O que interessa a Eisenstein é (...) o conflito (MORETTIN, 2009, p. 56).

Da União Soviética, Dziga Vertov, apresenta Um homem com a câmera (Chelovek s kino-apparatom, 1929), sem uso de letreiros, que buscou "criar uma linguagem internacional e absoluta do cinema baseada na total separação entre cinema e texto e literatura." (VERTOV apud MORETTIN, 2009, p. 57). 
Enquanto isso, o estadunidense Robert Flaherty, em 1922, faz Nanook, o esquimó (Nanook of the North, 1922), "instituiu um padrão para o tratamento conferido ao outro, pautado pela tentativa de recuperação das experiências primordiais da sociedade e da cultura retratadas." (MORETTIN, 2009, p. 57).

Morettin lembra que nesse período, no Brasil, os anos 1920 foram marcados pelos ciclos regionais, dentre eles, Recife, Pelotas, Campinas, Cataguases, de onde sairia Humberto Mauro, que chegou a fazer cerca de 300 filmes (entre curta e média-metragem) pelo INCE, o Instituto Nacional de Cinema Educativo.

Antes da criação do INCE, a chegada do som ao cinema havia gerado grande impacto no cinema do Brasil, pois encareceu a produção e o ciclo regional não conseguiu dar continuidade. O INCE foi resultado da presença do Estado na cultura e na educação a fim de fomentar e retomar a produção de filmes.

Dessa intervenção do Estado, tem-se como resultado a Legislação protecionista, a censura no âmbito federal (Decreto No. 21.240, de 4 de abril de 1932), conforme já citamos anteriormente, e a obrigatoriedade de exibição de um curta-metragem brasileiro antes das projeções dos longas da programação normal.

De acontecimentos importantes ainda na década de 1930, Morettin cita a criação nesse ano da Cinédia por Adhemar Gonzaga. São dessa produtora os filmes Ganga Bruta (1933), de Humberto Mauro, e O Ébrio (1946), de Gilda Abreu e também os musicais com participação da Carmen Miranda.

A Atlântida, por sua vez, é fundada em 1941, e será até o final dessa década a maior produtora brasileira. São delas as chanchadas estreladas por Grande Otelo e Oscarito, e no ano de 1954, com dois grandes sucessos: Nem Sansão nem Dalila (1954) e Matar ou Correr (1954), ambos dirigidos por Carlos Manga aliás, ano em que fechava as portas a Vera Cruz, fundada em 1949, e responsável por produções como $O$ cangaceiro (1953), de Lima Barreto, e filmes estrelados por Mazzaropi. Segundo Morettin, a Vera Cruz, criada pela burguesia paulistana a fim de modernizar São Paulo, que em 1950 completaria 400 anos, para fazer filmes com equipamentos de ponta e em estúdios (à Hollywood), não atentou para a distribuição e a exibição, "dois suportes do tripé industrial" (MORETTIN, 2009, p. 62), controladas por empresas estadunidenses. 
Enquanto isso, o poderio dos EUA seguia forte. Mas no pós II Guerra Mundial, já no ano de 1945, Roberto Rossellini apresenta a obra Roma, cidade aberta (Roma, città aperta, 1945), parte do que viria a se denominar o Neo Realismo italiano, movimento do qual também fará parte Vittorio De Sica, com Ladrões de Bicicleta (Ladri di biciclette, 1948) e Umberto D (Umebrto D, 1952). Em 1943, Luchino Visconti já fizera Obsessão (Ossessione, 1943), mas que não tinha as características do movimento. Trata-se de uma grande resistência ao cinema estadunidense e inspirará vários outros movimentos no mundo, como o Cinema Novo, no Brasil, que tem seu precursor em Nelson Pereira dos Santos, com Rio, 40 graus (1955) e Rio, zona norte (1957). "Feito fora dos estúdios e privilegiando um enfoque marcado pelos debates em torno do nacional e do popular", influenciaria Roberto Santos, com O grande momento (1958), dentre outros, como o cineasta ícone, Glauber Rocha. Este também seria influenciado pela Nouvelle Vague francesa. Filmes como Os incompreendidos (Les quatre cents coups, 1959) e Acossado (À bout de souffle, 1960), de baixo orçamento e feitos em locação, fora de estúdios. Contudo, vale lembrar que a relação do Cinema Novo brasileiro com a crítica francesa tem sua dívida com $O$ cangaceiro, que "foi o primeiro filme brasileiro a atingir o mercado internacional. O filme impressionou o crítico dos Cahiers du Cinéma, Jacques Doniol-Valcroze (...).” (FIGUEIRÔA, 2004, p. 38).

É daí que o Cinema Novo de Glauber Rocha, Paulo César Saraceni, Cacá Diegues, Leo Hirszman, David Neves, Joaquim Pedro de Andrade, dentre outros, tiram sua inspiração maior.

Diferente da seriedade do cinema novo, o cinema marginal ou cinema do lixo terá no deboche sua marca maior. São nomes como Rogério Sganzerla, com $O$ bandido da luz vermelha (1968), Júlio Bressane, Andrea Tonacci, Ozualdo Candeias e Carlos Reichenbach.

Na década de 1990, diz Morettin, os filmes são agrupados no que se chamou "cinema da retomada", que tem os filmes Central do Brasil (1998), de Walter Salles, e Cidade de Deus (2002), de Fernando Meirelles, dentre outros, como aqueles que tiveram grande aceitação de crítica e de público. 
O quarto e último artigo, de Eduardo Ramos, cineasta e roteirista, define a linguagem cinematográfica como o jeito de o filme tratar e mostrar determinado tema, e que o espectador é "alfabetizado" nessa linguagem sem que se dê conta. 0 cinema sempre tem algo a dizer ao espectador e o meio pelo qual o faz é o filme. Este, cada vez mais sofisticado, tem estratégias das quais o espectador deve se apropriar para que possa entender melhor o filme. Ao dizer que o cinema "mostra" Ramos não se refere ao próprio objeto. Ele cita Christin Metz, que diz que o cinema opera com a imagem dos objetos e não com eles próprios. Fala do cinema como uma linguagem que dialoga com outras, como a música, por exemplo. Ela tem que estar concatenada "com os ruídos da cena, entre as falas de personagens e narradores." (RAMOS, 2009, p. 76). Da fotografia, o cinema toma "a noção de enquadramento: a forma, o tamanho, a composição e os limites ao emoldurar uma cena ou uma paisagem pela lente da câmera." (RAMOS, 2009, p. 76).

A seguir, o autor define vários elementos da linguagem do cinema como elipse, movimento de câmera, ritmo, montagem, ruídos, silêncio, fade out, fade in, decupagem, a relação entre filme e o digital. Ressalta o espectador como o fim da obra, que se completa com a audiência. 0 tipo da audiência que se quer atingir já é definido no roteiro.

E no final do artigo, define a função dos profissionais do cinema, dentre eles, diretor, roteirista, produtor executivo, diretor de produção, diretor de fotografia, primeiro assistente de câmera, diretor de arte, cenógrafo, montador, editor de áudio e diretor musical.

3- 0 terceiro volume ${ }^{143}$, também lançado em 2009, apresenta uma conversa informal com críticos de cinema como Inácio Araújo e cineastas como Walter Lima Jr., Anselmo Duarte e Eduardo Coutinho, com o diretor da Cinemateca Brasileira, Carlos Magalhães, e com dois professores da rede estadual de ensino, Godofredo Bonadies e Sandra Haddad, que relatam suas experiências com o cinema em sala de aula. Estas conversas ficaram assim organizadas:

143 Disponível em http://culturaecurriculo.fde.sp.gov.br/administracao/Anexos/Documentos/320100701185037cad erno_cinema3_web.pdf. Acesso em 15 de novembro de 2015. Acesso em 20 de novembro de 2015. 294 
- O Complexo mundo do cinema - entrevista com Inácio Araújo.

-Fazer um filme é como contar uma história num bom bate-papo - entrevista com Anselmo Duarte.

-Encontros e mediações de um filme - entrevista com Eduardo Coutinho.

-Cinema: passado e presente - entrevista com Carlos Magalhães.

-O cinema como prática educativa - entrevista com Sandra Haddad.

-Cinema e escola: olhar, descobrir e ensinar - entrevista com Gofredo Bonadies.

-Depoimento de Walter Lima Jr.

Para Inácio Araújo, o cinema, em seu aparecimento, é aquele que coloca toda a arte em crise. Assim, a semelhança com o mundo exterior já não seria objeto das artes plásticas. Diz ser o cinema uma arte impura, pertencendo ao domínio das imagens, das letras e da indústria; e cara, diferente das artes plásticas e da literatura.

Respondendo à pergunta sobre o fundamento de uma escola cinematográfica, Araújo aponta para a história. Ele diz que sem a derrota da Alemanha na I Guerra Mundial não teria havido expressionismo. No caso do Cinema Novo brasileiro, havia uma vontade de mostrar o "homem brasileiro", a "realidade brasileira" (ARAÚJO, 2009, p. 11).

Fala da potência da imagem do cinema como registro documental, ainda que se dê numa ficção. Dessa forma, o professor, que se utiliza do filme como ilustração, deve salientar que o filme contém sempre uma versão do evento estudado (portanto, passível de discussão), não podendo, com isso, ser entendido como a materialização deste evento. No entanto, o filme antigo, num plano de rua consegue informar como as pessoas se vestiam, por exemplo, e vários outros costumes. Nesse sentido, o desaparecimento de filmes como Alô, alô carnaval e Favella dos meus amores é uma grande perda, pois possibilitavam a oportunidade de ver as pessoas "tal como eram". Quanto a esse aspecto do cinema de mostrar, documentar, diz Araújo que é por essa razão que, no Brasil, há uma repressão ao documentário, porque ele levaria para as telas os negros, os pobres, os desdentados, isto é, o contrário de uma imagem que se queria criar, um Brasil 
branco, “'sofisticado', bem vestido, que ia ao clube Fluminense, essas coisas." (ARAÚJO, 2009, p. 15).

Araújo diz que, apesar de o cinema ter uma linguagem universal, que chega a todos e que é possível legendar as diferentes línguas, ao mesmo tempo, ele é "tremendamente local". Assim, um filme nordestino é em muito diferente de um filme feito em São Paulo.

O jornalista estende esse mesmo raciocínio à crítica, afirmando que esta não existe, havendo o que ele chama de "críticas", no plural. Mas quando o faz, talvez deixe de fora aquela crítica vinculada a grandes meios de comunicação, muitas vezes destinadas a promover determinados tipos de filmes, em geral, comercial e de produção vinculada ao próprio veículo, como, por exemplo, os títulos produzidos pela "Globo Filmes" e das críticas publicadas nos diversos veículos do grupo.

A segunda entrevista é com Anselmo Duarte, diretor de $O$ pagador de promessas (1962). Para ele, um filme deve saber contar bem uma história, não entregando ao espectador informações que só deveriam vir mais adiante, além de saber posicionar bem uma câmera e movimentá-la. Esse saber se sobrepõe ao equipamento, ainda que o cinema seja uma arte industrial.

Para Duarte, o cinema mundial se divide em dois: cinema comercial e o cinema de autor. No entanto, a seguir, fala que o Brasil apresenta filmes comerciais, que são aceitos no circuito comercial mundial, com "toque artístico" (DUARTE, 2009, p. 27, caso de Central do Brasil, exemplifica ele. Para ele, no caso brasileiro, a falha na indústria cinematográfica é de responsabilidade governamental.

Perguntado sobre 10 filmes indispensáveis para a escola, cita os seguintes:

1-Sem novidades no front (All Quiet on The Western Front), de Lewis Milestone (1930)

2-Limite, de Mário Peixoto (1931)

3-Romeu e Julieta (Romeo and Juliet), de George Cukor (1936) 
4-Tempos modernos (Modern Times), de Charles Chaplin (1936)

5-Cidadão Kane (Citizen Kane), de Orson Welles (1941)

6-Carnaval no fogo, de Watson Macedo (1949)

7-Vizinhos (Neighbours), de Norman McLaren (1952)

8-Moby Dick (Moby Dick), de John Huston (1956)

9-West side story, de Robert Wise (1961)

10-O pagador de promessas, de Anselmo Duarte (1962)

O terceiro entrevistado é o documentarista Eduardo Coutinho. “O documentário mostra o sistema... é o que eu sinto", diz ele. Coutinho diz que fazer documentário é mais complicado que fazer ficção em razão do compromisso ético, porque no documentário se tem de tratar com pessoas reais. No caso da ficção, uma personagem pode matar quantos quiser, diz ele, comparando com as personagens reais do documentário.

Para ele, um dos problemas do cinema no Brasil é a concorrência imbatível do cinema estadunidense, que é o cinema dominante. Todo o resto vai mal diante desse cenário. 0 outro grande problema é a televisão brasileira, que é muito forte e que sobrepuja o cinema.

Perguntado sobre que filmes ele indicaria para serem projetados em escolas, ele responde que o filme é indiferente, até o pior deles é indicado ou blockbusters. A diferença quem faz é o "animador" (que pode ser um professor), que tem que "saber o que discutir" (COUTINHO, 2009, p. 33).

A seguir, ele fala de como foi fazer seu filme $O$ fim e o princípio (2005). Disse que foi à Paraíba sem saber exatamente o que fazer e que, por sorte, uma mulher da Pastoral da Criança os levou a uma comunidade não atingida pela televisão. Eram pessoas idosas, tal qual ele, o que teria facilitado sua relação com os entrevistados. E, finalmente, diz que a relação da escola com o cinema está em se ensinar a ver, não importando o tema propriamente, mas o modo de ser o mundo, e isso seria o que interessaria em Capitu, não pela traição, mas pelo modo de apresentar essa traição. 
O quarto entrevistado é Carlos Magalhães, diretor da Cinemateca Brasileira desde 2002. 0 fato de ocupar tal cargo em uma importante instituição de preservação e difusão do audiovisual brasileiro, além de significativos títulos do cinema mundial, justifica sua escolha como entrevistado e suscitado a tratar sobre o assunto.

Magalhães fala da dificuldade da fundação de uma instituição dessa natureza no Brasil, ocorrida em 1946. Ainda que tenha havido certo reconhecimento de sua importância, não surgiram soluções concretas para seu efetivo estabelecimento, diz ele. Lembra os três incêndios ocorridos na instituição, que devastaram obras sem que tenham restado qualquer cópia.

Devido ao alto custo de sua manutenção, desde 1984 a Cinemateca está vinculada ao governo federal, contando ainda com o apoio dos governos estadual e municipal de São Paulo.

Magalhães lembra que a função da instituição é a de recolher e conservar o audiovisual brasileiro sem julgá-lo, tendo em vista que "o julgamento que cada época emite sobre si mesma não é o mais objetivo e por isso o critério é guardar o máximo de acervo possível." (MAGALHÃES, 2009, p. 39).

A legislação federal prevê que todo filme produzido com algum tipo de recurso público, orçamentário ou por meio de lei de incentivo, destine uma cópia à Cinemateca Brasileira.

A instituição mantém sessões regulares nas quais utiliza, tanto títulos de seu acervo, como outros de fora, além de alguns projetos para divulgação do cinema, como Cine Educação, voltado para alunos do Ensino Fundamental, em parceria com a Via Gutemberg e com as Secretarias Municipais de Ensino e a SEESP, e o Maior Idade, projeto voltado para pessoas da terceira idade, em parceria com a Via Gutenberg e Uma História do Cinema na Cinemateca, para interessados em geral na história do cinema, desenvolvido em pareceria com o Departamento de Cinema, Rádio e Televisão da Escola de Comunicações e Artes da USP.

O site da Cinemateca disponibiliza grande parte de seu acervo por meio da ferramenta Banco de Conteúdos Audiovisuais, que consiste em acervo de imagens em movimento, isto é, os filmes, e também fotografias. 
Magalhães destaca a figura de Paulo Emílio na fundação da Cinemateca Brasileira e na produção intelectual do cinema e da cultura brasileiros bem como na fundação do Clube de Cinema, em 1940, que viria a se tornar a Cinemateca Brasileira. Ressalta ainda o papel decisivo na constituição de um campo de estudos em cinema no Brasil, sendo professor da Universidade de Brasília e na Universidade de São Paulo. Tem muitos textos publicados, mas dois se destacam pelo tempo dedicado a esses trabalhos. Um deles é sobre Humberto Mauro e o outro sobre Jean Vigo, este escrito em francês, em Paris, que ganharia o prêmio Armand Tallier, concedido ao melhor livro de cinema publicado na França, em 1958, como informa Lygia Fagundes Telles ${ }^{144}$.

Para Magalhães, assim como na literatura ou na alfabetização, todos devíamos aprender a ver imagens desde cedo. Devíamos "aprender a ver as imagens, o que elas mostram, o que elas escondem, que tipo de modelo de representação elas expõem." (MAGALHÃES, 2009, p. 44). Magalhães dá tal importância a esse trabalho com as imagens, porque, segundo ele, "a imagem possui papel fundamental e o cinema surge como uma espécie de laboratório para a sociedade do espetáculo em que vivemos." (MAGALHÃES, 2009, p. 44).

A seguir, o Caderno de Cinema do Professor entrevistou Sandra Haddad e Gofredo Bonadies, dois professores da rede estadual de Ensino, direcionando a eles as mesmas perguntas.

Para Sandra Haddad, o cinema na escola sensibiliza os alunos a fazerem uma leitura crítica do mundo, na medida em que podem, por meio do cinema, perceberem-se produtores e transformadores da realidade.

Para Haddad, as práticas do professor têm que possibilitar ao aluno "a redescoberta do espaço escolar como o lugar do pensar e do agir com autonomia." (HADDAD, 2009, p. 47). Enquanto Haddad não especifica o uso do cinema em sala de aula, Gofredo Bonadies o faz. Para ele, o uso das novas tecnologias em sala de aula responde a uma demanda atual. Dentre elas, o cinema, com várias "ótimas produções (...) com múltiplas possibilidades de aproveitamento pedagógico" (BONADIES, 2009, p. 57), que dependerá do repertório do professor e do jeito que

144 Texto em homenagem a Paulo Emílio, disponível em site da Cinemateca Brasileira: http://www.cinemateca.gov.br/pauloemilio/. Acesso em 15 de janeiro de 2016. 
este conduzirá o processo de ensino-aprendigem. Bonadies coloca no horizonte a dimensão prática do ensino, apontando para "os bens culturais [ao lado dos] conhecimentos produzidos pela humanidade" como suporte para tanto. Como Haddad, afirma ser necessário mudar a realidade. E para ele, a escola é esse lugar que proporciona essa mudança.

Segundo Haddad, o trabalho com o cinema deve se dar de modo interdisciplinar, "compartilhado pelo coletivo" (HADDAD, 2009, p. 48). Para ela, todo o trabalho na escola deve ter essa premissa, a de ser respaldada no coletivo. 0 momento de desenvolver as estratégias para um trabalho coletivo é o planejamento escolar, em que se deve assumir "propostas de trabalho pedagógico diferenciadas e criativas" (HADDAD, 2009, p. 48). Peça chave no desenvolvimento desse trabalho é o coordenador pedagógico, mediador do diálogo entre os professores.

Quanto à seleção dos filmes a serem utilizados pelos professores em sala de aula, Bonadies diz que dependerá do professor proceder à seleção tentando ver nos filmes potencial pedagógico que mobilize a atenção dos alunos e que seja capaz de emocionar sem ser banal (BONADIES, 2009, p. 58-59). Bonadies diz não ser correto usar o cinema para ilustração dos conteúdos das disciplinas, mas sugere "que a escolha de um filme [seja subordinada] ao conteúdo que se pretende ensinar e à adequação à faixa etária." (BONADIES, 2009, p. 59).

Para ambos, o cinema é um meio prazeroso e facilitador de aquisição de conhecimentos, o que explicaria a boa receptividade a ele. Como professor, Bonadies utiliza várias fontes de informação sobre os filmes antes de projetá-lo, para que os alunos se interessem pelo que vão ver. Depois de exibido o filme, confronta com os alunos o que a obra "defende" em relação a outras fontes, como livros didáticos e paradidáticos. Mas no início, assume, usava o filme como ilustração. Com o tempo percebeu que ele era uma linguagem autônoma.

O confronto do repertório de cinema exibido na TV que os alunos têm com a proposta da escola deve se dar pela proposição de "bons filmes", diz Haddad. Para Bonadies esse trabalho de confrontação é o pressuposto, pois não se pode partir sem considerar que os alunos já têm conhecimento prévio do cinema, ainda que seja majoritário o chamado cinema comercial, pela TV. Dessa forma, a escola 
deve promover essa transição, ou seja, promover a passagem da apreensão do cinema como mero meio de entretenimento (saber advindo da relação do aluno com a TV) para um conhecimento mais sofisticado, que considere as várias dimensões do filme (estética, cognitiva, social e psicológica), inclusive de expressão de ideias e de sentimentos com vistas ao desenvolvimento da "leitura de diferentes textos em diferentes linguagens." (BONADIES, 2009, p. 62).

Haddad pontua que o professor não precisa ser especialista em cinema, bastando que atente para a consideração de algumas etapas básicas para a utilização do filme:

1) Planejamento ou "plano de aulas", que consiste na seleção de conteúdos.

2) Pesquisa ou "a escolha", que consiste na escolha de um filme com consequente pesquisa sobre tal filme. 0 objetivo na escolha é que o filme contribua para o enriquecimento das discussões sobre conteúdo disciplinar.

3) Sensibilização ou "preparativo", que consiste na forma como o professor vai propor o trabalho com os alunos, visando à motivação destes.

4) Execução ou "a exibição", que consiste na projeção do filme, devendo o professor estar atento às reações dos alunos, antes, durante e depois da projeção. Depois da projeção, deve pedir que os alunos façam apreciações orais sobre o filme.

5) Debate e reflexão, ou "pensando o filme", que consiste na mediação do professor das discussões em torno do filme.

6) Registros ou "finalizando a atividade escolar", que consiste em aprofundar o nível de informação sobre o filme visto, com produção de ficha técnica e pesquisando em sites e livros que contribuam nesse trabalho de aprofundamento da compreensão do filme.

7) Produção de texto, que consiste na produção de síntese por escrito, bem como escrita de peça para encenação em sala de aula, produção de curtametragem, organização de depoimentos e entrevistas.

E sugere alguns filmes para uso em sala de aula: 
1) Uma verdade inconveniente (An inconvenient truth, 2006), de Davis Guggenheim

2) Anos de chumbo: 1939-1945(1998) ${ }^{145}$

3) Arquitetura da destruição (Undergangens arkiektur, 1989), de Peter Cohen

4) Tiros em columbine (Bowling for Columbine, 2002), de Michael Moore

5) O encouraçado potemkin (Bronenosets Potemkin, 1925), de Sergei Eisenstein

6) Roma, cidade aberta (Roma, città aperta, 1945), de Roberto Rossellini

7) Hotel Ruanda (Hotel Rwanda, 2004), de Terry George

8) Ladrões de bicicleta (Ladri di biciclette, 1948), de Vittorio De Sica

9) Escritores da liberdade (Freedom writers, 2007), de Richard La Gravanese

10)A vida é bela (La vita è bella, 1997), de Roberto Benigni

11) A lista de Schindler (Schindler's list, 1993), de Steven Spielberg

12) Cidade de Deus (2002), de Fernando Meirelles

13)Eles não usam black-tie (1981), de Leo Hirszman

14) Olga (2004), de Jayme Monjardim

15) O quatrilho (1995), de Fábio Barreto

16) O que é isso, companheiro? (1997), de Bruno Barreto

17)Deus e o Diabo na terra do sol (1964), de Glauber Rocha

18)Cinema paradiso (Nuovo Cinema Paradiso, 1988), de Giuseppe Tornatore

A indicação de filme feita por Bonadies foi a seguinte:

1) Cabra marcado para morrer (1985), de Eduardo Coutinho

2) Pra frente, Brasil (1982), de Roberto Farias

145 Não conseguimos enocntrar informação sobre a direção dessa série. 302 
3) Domésticas (2001), de Nando Olival e Fernando Meirelles

4) Un poquito de agua (1995), de Camilo Tavares, Francisco Zapata Betancourt

5) A obra de Martin Scorsese, com destaque para The blues (2003-)

6) À beira da loucura (In the mouth of madness, 1994), de John Carpenter

7) Os pássaros (The birds, 1963), de Alfred Hitchcock

8) Quando Nietzsche chorou (When Nietzsche wept, 2007), de Pinchas Perry

9) O pequeno príncipe (The little prince, 1974), de Stanley Donen

10) O nome da rosa (Der name der rose, 1986), de Jean-Jacques Annaud

11) A missão (The mission, 1986), de Roland Joffé

12) Carlota Joaquina: princesa do Brazil (1995), de Carla Camurati

13)1492 - A conquista do paraíso (1492 - Conquest of paradise, 1992), de Ridley Scott

14) A guerra do fogo (La guerre du feu, 1981), de Jean-Jacques Annaud

15) Giordano Bruno (Giordano Bruno, 1973), de Giuliano Montaldo

16)300 de Esparta $(300,2006)$, de Zack Snyder

17)O último rei da Escócia (The last king of Scotland, 2006), de Kevin Macdonald

18) Orgulho e preconceito (Pride and prejudice/1940, Pride \& prejudice, 2005), versão de 1940 de Robert Z. Leonard e a de 2005, de Joe Wright

19)Lutero (Luther, 2003), de Eric Till

20) Os títulos da série Harry Porter. O primeiro lançado foi Harry Poter e a pedra filosofal (Harry Porter and the sorcerer's stone, 2001), de Chris Columbus

21) Harry Porter e o cálice do fogo (Harry Porter and the globet of fire, 2005), de Mike Newell

22) Harry Porter e as relíquias da morte I (Harry Porter and the deathly hallows I, 2010), de David Yates 
23) Harry Porter e o enigma do príncipe (Harry Porter and the half-blood Prince, 2009), de David yates

24) Harry Porter e as relíquias da morte II (Harry Porter and the deathly hallows II, 2011), de David Yates

25) A obra de Michael Haneke, começando por A professora de piano (La pianiste, 2001), de

26) O tempo do lobo (Le temps du loup, 2003), de Michael Haneke

27) O vídeo de Benny (Benny's video, 1992), de Michael Haneke

28)Violência gratuita (Funny games, 1997), de Michael Haneke

29) 71 fragmentos de uma cronologia do acaso (71 fragmente einer chronologie des Zuffals, 1994), de Michael Haneke

30)Código desconhecido (Code inconnu: récit incomplet de divers voayges, 2000), de Michael Haneke

31) Caché (Caché, 2005), de Michael Haneke

Por último, o Caderno de Cinema do Professor (vol. 3) traz um texto com o diretor e professor Walter Lima Jr., que a FDE chamou de Depoimento. 0 texto é uma junção de trechos de uma conversa que ele teve com professores, em 1993, em evento promovido pela própria FDE, e de uma entrevista concedida à mesma FDE, em 1994.

Walter fala de seu tempo de criança, quando não havia coca-cola, nem calça jeans. Tudo isso apareceu primeiro pelo cinema, conta ele. Mais tarde, já com 16-17 anos, fundou o primeiro cineclube de Niterói, depois outros no Rio de Janeiro.

Ver o mundo por meio do cinema tirou o país do isolamento, fazendo-o perceber o que podia ser aspirado de bom para si a partir das outras culturas. Contudo, essa abertura para o outro gerou, por consequência, alheamento de nós mesmos (LIMA JUNIOR, 2009, p. 72).

Walter Lima Jr. cita Limite (1930), de Mário Peixoto, e Ganga Bruta (1933), de Humberto Mauro, como exemplos de filmes sérios que não se prestavam ao puro entretenimento. Seu "cinemês" teria sido adquirido vendo muitos filmes, o que o levou a escrever críticas de cinema. 
Para Walter Lima Jr. não é possível imaginar a vida senão pelo cinema, uma vez que ele não viveu o período anterior a esta arte. Desde criança ele vê o mundo pelo olhar do cinema, que era uma expressão de modernidade, já que era pelo cinema que o Brasil saía de seu isolamento quanto ao resto do mundo.

Teve a oportunidade de ser terceiro assistente de diretor de Adolfo Celi, italiano, que fez alguns filmes (Caiçara, em 1950, Tico-Tico no Fubá, em 1951, e $O$ Álibi, em 1968) pela Vera Cruz, em São Paulo. Mais tarde, em razão de Vladimir Herzog não poder ser assistente de Glauber Rocha, este o chama para ocupar a posição. 0 filme era Deus e o Diabo na terra do sol (1964).

Ele lembra que o cinema foi apresentado também em parques de diversão, por meio de máquinas em que se colocavam moedas para ver os filmes. A produção industrial de filmes surgiu com os musicais de Wallace Downey, criador da chanchada carnavalesca, que dirigiria Coisas nossas (1931), Alô, alô, Brasil (1934) e Abacaxi azul (1943). Em seguida, a Atlândida teria esse caráter industrial cujo maior acionista era Luiz Severiano Ribeiro Jr. Essa empresa foi responsável por grandes sucessos como Matar ou correr (1954), Nem Sansão nem Dalila (1955), O homem do Sputnik (1959), todos dirigidos por Carlos Manga. Para Walter Lima Jr. o que a Atlândida fazia era "imitação do cinema que se fazia lá fora. (...) um cinema ingênuo, apesar de toda a informação política que ele traz." (LIMA Jr., In TOZZI, 2009, p. 75-76).

Contudo, aponta ainda Walter Lima Jr., há filmes com inspiração moderna, caso de Ganga bruta (1933), de Humberto Mauro, que, no meio de uma história idílica, apresenta um ato sexual, mas que também é um processo do amor, sugerindo esse ato pelos movimentos de cilindros de uma usina (LIMA Jr. In TOZZI, 2009, p. 76).

A geração do entrevistado também buscou a modernidade pelo cinema. O cinema que esta geração fez não dialogava muito com o público, constata ele. E, no entanto, "o cinema não existe sem o público. O cinema é uma arte do entretenimento." (LIMA Jr. In TOZZI, 2009, p. 76).

Para ele, o cinema nasce da presença do público justificando a produção de filmes que, sem ele, essa produção não se sustentaria. A tendência é que nas grandes salas de cinema sejam exibidas apenas grandes produções e que os "filmes 
B" sejam exibidos na televisão. Ainda segundo Walter Lima Jr., o aparecimento da televisão tirou de circulação grande parte dos cineclubes. Ela

\begin{abstract}
democratizou a relação do espetador com a imagem: você pode trocar de canal e mudar a imagem, clarear, escurecer, colocar mais cor, tirar a cor, ir até o banheiro e interromper essa relação até então sagrada com a imagem, que o dominava e agora você dispõe dela. Com o videocassete mais ainda: você pode voltar e investigar o filme. No cinema, você saía de casa e confraternizava com outro espectador, mesmo sem conhecê-lo. Havia uma troca de energia dentro daquela grande sala.

Com o videocassete, você fica totalmente isolado: pega uma fita, vai para o seu espaço, vê o filme, parando quantas vezes quiser; depois você devolve a fita. A coisa extraordinária no cinema é ele provocar, no público, esse conhecimento comum, que é uma espécie de grande lixo, os clichês do cinema que já foram assimilados pelos espectadores, então nós temos uma cultura cinematográfica comum. (...) É interessante que é aí que o cinema nasce. Na troca entre as pessoas (LIMA Jr. In TOZZI, 2009, p. 77).
\end{abstract}

Os filmes de baixo orçamento como os do Cinema Novo brasileiro, inspirado no Neo Realismo italiano, que deram grande contribuição para o mundo, são exemplos de inventividade para contornar o problema de orçamento, quanto à falta de refletores, por exemplo. Para as cenas noturnas de Roma, cidade aberta (Roma, città aperta, 1945), Rosselini filmava-as de dia. Tal procedimento, segundo Walter Lima Jr., já era feito em $O$ nascimento de uma nação (The birth of a nation, 1915), de David W. Griffith, que, segundo conta, todas as cenas noturnas foram feitas durante o dia.

A seguir, Walter Lima Jr. retoma a questão do público para dizer que o Cinema Novo brasileiro ganhou status de arte (em torno de 50 prêmios internacionais), reconhecido principalmente na França e na Itália, mas afastou o público. Exemplo disso é Roberto Farias, que fez um filme misto de seriedade e de emoção (Walter aqui se utiliza desse sentimento para resumir aquilo que o público espera de um filme, emocionar-se), obtendo sucesso de crítica e de bilheteria: $O$ assalto ao trem pagador (1962). No entanto, entusiasmado com filmes como Vidas secas (1963), de Nelson Pereira dos Santos, e Deus e o diabo na terra do sol (1963), de Glauber Rocha, faz um filme sério, Selva trágica (1964), mimetizando imagens do filme de Nelson Pereira dos Santos e se utilizando do mesmo uniforme de 
Antônio das Mortes, do filme do Glauber, inclusive o ator. 0 filme é um grande fracasso de bilheteria.

Walter dá bastante ênfase à relação do cinema (mesmo aquele voltado para a televisão) com o público. Fala da necessidade de voltar-se para o mercado, de aproveitar o know-how da televisão brasileira em prol dessa produção. Em 1994, faz $O$ monge e a filha do carrasco, que é voltado para essa perspectiva do mercado internacional, reforçando ainda que a produção de filmes mudou atualmente. Assim, pensa-se num banco de imagens para alimentação da realização de filmes. Quando um filme é vendido, todas as imagens feitas para o filme vão juntas. Isso para o caso de se fazer uma minisérie. Para ele, a televisão no Brasil trabalha num ritmo bastante acelerado sem concorrência em nível mundial, pois sua produção equivale a aproximadamente três longas-metragens por semana, se juntados todos os capítulos das novelas no ar. Por isso, defende que o Brasil seja esse sorvedor de imagens em que se constitui a televisão.

Walter passa a contar as razões que o levaram a filmar Menino de engenho (1965). Para ele, a história desse livro de José Lins do Rego dizia respeito à infância no Brasil, mas sentia-se particularmente conectado ao livro por ter pais nordestinos e morar numa casa que lembrava a do engenho. A narrativa do livro "é meio horizontal, não tem nenhuma verticalidade. Não existe uma relação de causa e efeito." (LIMA. In TOZZI, 2009, p. 89). Para Walter, adaptar um livro famoso é um grande desafio, porque o compromete com o leitor do livro. Você pode decepcionar o leitor, diz ele. Contudo, continua, se o cineasta identificar o que o autor do livro quis dizer, sendo fiel a essa proposta, ele pode ter certa liberdade para criar. Para Walter, o maior trabalho de adaptação é traduzir do texto literário o sentimento desse texto para o filme. Essa tradução será avaliada na bilheteria.

Sobre sua obra Inocência (1983), adaptada do romance de Visconde de Taunay, teve um percurso atordoado. Primeiro, foi dissuadido por um cinasta que o procurou e pediu que ele não fizesse o filme, porque era parente do Viscone de Taunay e que gostaria ele próprio de fazê-lo. Era o cineasta Carlos Alberto Souza Barros, que havia adaptado A nova Califórnia, de Lima Barreto e dirigida por César Memolo. A obra se chamou Osso, amor e papagaio (1956). Dirigiu Jerry, a grande parada (1967), As alegres vigaristas (1974) e Um soutien para papai (1975). 
Depois de algum tempo, Walter procura Lima Barreto, quando soube que estava hospitalizado como indigente. Conversa sobre o roteiro de Inocência, que ficou sabendo que Barreto tinha, dentre outros. A situação de indigência do escritor e diretor deixa Walter indignado, pois tratava-se de alguém que tinha dirigido o filme que mais tinha dado bilheteria no Brasil, 0 cangaceiro (1953), pela Vera Cruz, que teria falido em razão de a Columbia Pictures, segundo Walter, ter roubado a bilheteria do filme.

Lima Barreto indica o baú onde estão os roteiros que ele fizera e também um bilhete do cineasta Akira Kurosawa, em que estava escrito em um cartão que entregara ao escritor: "Pela terceira vez, volto ao cinema onde fui ver o seu filme $O$ Cangaceiro e continuo maravilhado." (apud LIMA. In TOZZI, 2009, p. 94).

Segundo Walter Lima Jr., o livro Inocência era muito visual em razão de Taunay ter formação em pintura. "Ele fala de luz, descreve os ambientes; parece que você está lendo um roteiro." (LIMA. In TOZZI, 2009, p. 94). 0 roteiro de Lima Barreto do romance de Taunay era literário, desconsiderando os aspectos visuais. Para Walter, isso se deve a algum drama vivido pelo escritor para escrever o roteiro, com o agravante de querer fazer o filme falado em esperanto.

Walter compra os direitos de fazer o filme e o termina mais rapidamente do que os outros que chegara a fazer. Durante a feitura do filme, lê uma entrevista de Humberto Mauro, dizendo que sempre quis filmar Inocência e não pôde. Walter descobre que parte do roteiro que Lima Barreto havia feito para Inocência tinha sido escrito com Humberto Mauro, que morre antes de Walter terminar seu filme. Walter o dedica a ele.

Fala a seguir da parceria com o fotógrafo Pedro Farkas, com quem trabalha desde Inocência, e de como é importante essa parceria, um fotógrafo atento à realização visual de uma concepção de cena em parceria com o diretor.

Walter se preocupa com o espectador na medida em que ele próprio também se vê como espectador. Procura apresentar para o espectador uma “compreensão de vida" (LIMA. In TOZZI, 2009, p. 100). Sendo em sua concepção a "prática do cinema muito ligada à possibilidade de me emocionar." (LIMA. In TOZZI, 2009, p. 100). Para Walter, é triste que o espectador saia do cinema alheio 
ao que foi projetado. Fala ainda que a curiosidade do público é algo com o que tem que se saber lidar.

Eu não acredito nesse cinema de laboratório, que se justifica com argumentos de semiologia, de um universo cultural mais sofisticado, mas ao mesmo tempo distante do público. (...) A questão básica, no cinema narrativo, é a credibilidade. Você [o público] tem que acreditar que aquilo é real, produzindo uma ilusão de você ter participado daquilo.

É o contrário do teatro, no qual, ao entrar em sala, você vê, imediatamente, uma simulação: já é a ilusão de que aquelas pessoas são os personagens, de que aquilo é uma casa. 0 teatro te leva à credibilidade. 0 cinema é o contrário, você parte da credibilidade para chegar à ilusão. Por isso, não posso prescindir da posição do espectador (LIMA. In TOZZI, 2009, p. 100-101).

Para Walter Lima Jr., o cineasta deve atingir determinados espectadores sem rasurar a obra, tornando-a incomunicável. Deve "falar para todos ao mesmo tempo e depois afinar aquilo que você [o cineasta] disse para um tipo de espectador. (...) Você não pode ser um espectador para um só público." (LIMA. In TOZZI, 2009, p.101).

Nas passagens acima, Walter parece entender que o cinema deva se voltar para a compreensão de uma história, que deve satisfazer a necessidade do público de se emocionar, fazendo-o compreendê-la, pois deve o espectador sair do cinema, compreendendo algo e não alheio ao que acabara de ver. Essa não preocupação com a posição do espectador pode levar a um "processo de desintegração" da obra, que é o que deve ter acontecido ao Glauber Rocha, especula Walter.

Para Walter (o ano em que ele dá essa entrevista é 1994), o Brasil vive uma crise de autoestima. Nesse sentido, ao se ver na tela num filme, ele reaje contra. Já na novela, não, porque a novela é entretenimento e emoção ao mesmo tempo. "A nossa imagem não nos é simpática", diz ele. Isso se deve à educação pelos filmes estadunidenses como Jurassic park: o parque dos dinossauros (Jurassic park, 1993), ET - O extraterrestre (E.T - The extra-Terrestrial, 1982), ambos de Steven Spielberg, Os dez mandamentos (The ten commandments, 1956), de Cecil B. DeMille. E, quando submetido a uma imagem que se dintigue desse padrão, o 
espectador a rejeita. Assim, falta converter o espaço cultural brasileiro em espaço político.

Nesse cenário, os curtas-metragens no Brasil, para Walter, são prova de que a criação artística respira. Enquanto os longas estão comprometidos com a indústria, os curtas podem se diferenciar. Para os longas, falta financiamento organizado. Sendo um dos principais mercados para o filme hollywoodiano, não interessa aos EUA que haja um cinema brasileiro forte. Isso quem dizia era Alberto Cavalcanti, lembra Walter. Então, se o Brasil apresenta problemas na estrutura industrial do cinema isso se deve a uma política de desmonte. Um dos primeiros atos do presidente Fernando Collor de Melo quando assume o poder é desmanchar a EMBRAFILME, enfraquecendo mais ainda o cinema no país. Assim, confrontando as duas imagens, a de Hollywood e a de filmes brasileiros, o espectador sente numa o mundo desenvolvido, isto é, o que deu certo, e, em outra, a do fracasso.

4- 0 quarto volume ${ }^{146}$, lançado em 2010 , tem como objetivo comentar os 21 filmes da segunda caixa de filmes distribuídos nas escolas, com indicação de possibilidades de uso desses filmes em sala de aula. Traremos mais adiante alguns exemplos em que identificamos o modo de apreensão e papel do cinema na escola.

5- A seguir, cada um dos 30 Roteiros publicados (apenas no site) traz comentários e indicações de uso pedagógico de apenas um filme em sala de aula. Cada um desses tem em torno de 5 páginas.

Com a reunião dos vários textos listados acima com fins pedagógicos, a expectativa oficial desses documentos parece ser a de que o cinema cumpra a função de levar informação e, sobretudo, espetáculo para a escola, algo da ordem do festivo, que celebra o belo como atestam as palavras de Fábio Bonini Simões de Lima, presidente da FDE: “Acreditamos que, tanto pela qualidade dos filmes selecionados, como do material de apoio, alunos e professores poderão desfrutar e

\footnotetext{
146 Disponível emhttp://culturaecurriculo.fde.sp.gov.br/administracao/Anexos/Documentos/320100701185051 caderno_cinema4_web.pdf. acesso em 25 de novembro de 2015.
} 
aprender com muita emoção, suspense e aventura!" (TOZZI, 2008, p. 06). Ou que o cinema possa tornar as pessoas melhores, nas palavras da então secretária de educação, Maria Helena Guimarães de Castro: "Como a literatura, o cinema também é capaz de nos tornar seres humanos melhores." (TOZZI, 2008, p. 04). De modo contrário pensa Jorge Coli para quem "a viagem ao mundo da arte não 'melhora' nossa relação com nosso mundo. Mas o fato é que, se não melhora, ela transforma essa relação, tornando-a mais complexa, mais rica." (COLI, 2006, p. 111).

Sandra Haddad, professora da rede estadual, todavia, em entrevista aos Cadernos de cinema do professor (n. 03), confirma a concepção acima, quando aponta o fascínio pelo cinema e que ele serviria para "discutir" questões importantes. Afirma ainda que há uma boa receptividade dos filmes entre os alunos, e que isso "é explicável porque a linguagem audiovisual pode ser um meio diferenciado e muito prazeroso de aprender, as informações visuais e auditivas são mais fáceis de estimular, sistematizar e assimilar o conhecimento" (HADDAD, p. 49).

0 poder da imagem e da sua representação desperta a curiosidade e o fascínio dos alunos. O cinema, além de diversão e entretenimento, quando bem utilizado pelo professor, pode se tornar uma ferramenta interessante para discutir questões importantes e fazer a diferença na aprendizagem dos alunos (2009, p. 50, destaque nosso).

De acordo com a citação acima, o cinema serviria para "diversão", "entretenimento" e para "discutir questões importantes". Como "ferramenta" ele não se presta à análise por si só, estando sempre vinculado a conteúdo a ele exterior. Ainda nesse sentido, Godofredo Bonadies, também professor da rede estadual de ensino, em entrevista ao mesmo Caderno de cinema do professor. (n. 03), diz que:

(...) os filmes precisam ser dosados e apresentados aos alunos depois de um trabalho prévio de preparação do professor para que compreendam que, a partir de um roteiro, os movimentos da câmera, os enquadramentos, os closes são definidos por um diretor que pretende transmitir uma emoção, por exemplo (BONADIES, 2009, p. 59, destaque nosso). 
Entendemos a que o professor esteja se referindo, quando procura se utilizar da emoção, mas essa associação sem a consideração de outras dimensões não seria restringir demasiadamente o papel do cinema? Pois o que dizer de filmes que buscam mobilizar o pensamento ou que se apresentam de modo "seco", que elimina elementos (clichês, mas não apenas eles, como também uma lágrima que é omitida de certa personagem em determinado momento como em A Lição, Urok, The Lesson, 2014, de Kristina Groseva e Petar Valchanov. Aqui, a personagem principal segue tentando resolver os problemas que lhe aparecem sem expressar movimentos corporais de explosão ou mesmo aumentando a voz) que, em tese, emocionariam, caso de filmes mais "formais" como A Chinesa (La Chinoise, 1967), de Godard, por exemplo, ou Em busca da vida (Still life, 2006), de Jia Zhang-ke, em que parece não haver pretensão clara de causar emoção (na verdade, o filme não se utiliza dos clichês que costumam causar determinadas emoções no espectador. Sabemos que, na verdade, o espectador já vai assistir ao filme contando com essas indicações de ordem: chore, ria, relaxe!)? Por outro lado, essa dimensão unilateral, digamos, festiva e espetacular do cinema, é contrastada com comentários bastante contundentes na entrevista concedida por Inácio Araújo ao mesmo Caderno de cinema do professor, quando ele fala da dimensão industrial do cinema e aponta a necessidade de certa concessão da sociedade para a existência do cinema. "De certa forma, ela necessita de uma concordância da sociedade para existir." (ARAÚJO, 2009, p. 10), referindo-se à diferença do cinema em relação à pintura quanto ao custo de sua produção, o que faz com que o cinema se torne espetáculo para atrair público. Araújo lembra, no entanto, que a ambiguidade do cinema como indústria e arte é uma riqueza que o caracteriza e o distingue de outras artes. Outro entrevistado que não comunga com essa dimensão unilateral festiva e espetacular do cinema é Carlos Magalhães (2009, p. 44), diretor da Cinemateca Brasileira, quando sugere que "deveríamos, desde cedo, aprender a ver imagens, o que elas mostram, o que elas escondem, que tipo de modelo de representação elas expõem.". Tal sugestão se refere a algo mais que se utilizar das imagens a fim de facilitar a apreensão dos conteúdos disciplinares. Parece voltar-se mais para uma espécie de alfabetização visual. Mais: 
Para servir de ferramenta para a educação, o cinema deve ser entendido nas suas especificidades. Por exemplo, não basta exibir um filme cujo tema se relaciona com a reforma agrária e exigir que os alunos argumentem sobre a questão. É preciso discutir a maneira como o filme a apresenta, qual discurso ele privilegia, de qual linguagem ele se serve para desenvolver o tema. 0 cinema retém de maneira flagrante o mundo histórico do qual faz parte (MAGALHÃES, 2009, p. 44).

Carlos Magalhães chama atenção para os recursos dos quais um determinado filme exibido na escola venha a fazer uso. Assim, ele se utiliza de cores para ressaltar atos de heroísmo, por exemplo, luz ou sombra, plongé e contra-plongé? Quem narra a história? Se a história fosse narrada por outra personagem o filme ganharia outra concepção sobre a questão tratada? Provavelmente.

\section{9- Os vídeos do projeto $O$ cinema vai à escola}

O projeto $O$ cinema vai à escola disponibiliza em seu site vários vídeos que correspondem ao propósito de formação dos professores quanto à linguagem audiovisual, com palestras e debates, bem como vídeos institucionais que apresentam o material de cinema aos professores, além de outros feitos a partir da experiência de algumas escolas que se utilizaram dos filmes das caixas distribuídas às escolas ou que promoveram alguma atividade relacionada ao cinema. Passamos a seguir a comentar cada um deles, selecionando o que nos pareceu mais relevante, ora confirmando as diretrizes do Projeto, ora negando-as.

\subsubsection{Vídeos institucionais da FDE para promoção do Projeto}

\section{- Luz, Câmera...Educação!, 13min.}

O vídeo “Luz, câmera... educação!" é composto de um curta-metragem e de comentários teóricos sobre a linguagem do cinema. Esses comentários são 
feitos por Jairo Mattos a partir de planos do curta e de sua estrutura de modo geral. Pode-se considerar que o curta cabe no gênero da comédia e do suspense, atendendo bem ao propósito de ilustração. Bem realizado, com final surpreendente, consegue chamar atenção do espectador, permitindo a visualização dos movimentos de câmera, planos, montagem, fotografia e dos bastidores de um set de filmagem. 0 curta começa com dois homens pulando o muro de um casarão, à noite. Logo se fica sabendo que se trata de um roubo. Um dos ladrões mata o cachorro da casa. A indicação da morte do cachorro se dá pela saída de um dos ladrões de cena, enquanto a câmera permanece parada e logo se ouve o gemido do cachorro ao levar o golpe mortal. 0 ladrão volta ao enquadramento e diz para o outro: “Satisfeito?”. Essa passagem será explorada nos comentários de Jairo Mattos ao se referir ao som como elemento narrativo. Os ladrões conversam entre si antes de avançar para o interior da casa. Ao se direcionar para a porta da casa o curta tem alguns movimentos de câmera e de planos, que também serão explorados por Mattos em seus comentários. Enquanto um dos ladrões tenta abrir a porta com uma chave de fenda, o outro faz a guarda. Ao abri-la, o outro se junta ao primeiro e ambos se encontram diante da porta aberta quando a luz de dentro se acende e um grupo, por volta de 15 pessoas, canta parabéns pelo aniversário em uma sala bastante clara, em contraste com o exterior, escura, dominado pelo suspense do primeiro momento do filme. Os amigos do dono da casa - que deveria ter chegado no lugar dos ladrões - cantam parabéns pelo universário do dono da casa efusivamente quando começam a perceber o problema. Um deles, que não conhecia o aniversariante, pergunta qual dos dois era ele, enquanto enche um balão para estourá-lo. Os outros, em silêncio e assustados, não respondem, apenas levantam as mãos em susto pelo estouro do balão.

Mattos comenta no vídeo que, ao contrário do que as pessoas falam sobre a ideia de magia do cinema, o que há, na verdade, é muito trabalho. Ele se refere a todo o trabalho intelectual de vários profissionais envolvidos no projeto do filme, dentre eles, o planejamento do filme, além de questões técnicas e de prazo, custo, dentre vários outros. Se há mágica, esta deve ser buscada como efeito no espectador a partir da coordenação de todos esses elementos na feitura do filme. A produção de uma espécie de magia seria a de anular a dureza do trabalho 
por trás das câmeras. Há, pois, certa expectativa de espetáculo em relação ao cinema. Nesse sentido, o comentário de Mattos frustra a ideia de espetáculo fortemente presente no Projeto, mas reforça-a ao mesmo tempo, na medida em que apresenta um curta-metragem com viés comercial.

\section{- “Orientação sobre o projeto", 7”}

Este vídeo oferece orientação às escolas que promoveram atividades com filmes das caixas entregues a elas para preenchimento de questionário avaliativo como condição para que recebessem a caixa seguinte, contendo 21 filmes. No entanto, apesar dessa condição consta que todas as escolas receberam as caixas seguintes. Não há, contudo, um vídeo ou texto que analise os resultados que teriam sido obtidos com os questionários.

\subsubsection{Vídeos sobre atividades desenvolvidas nas escolas}

Chamamos de "Vídeos sobre atividades desenvolvidas nas escolas" aqueles vídeos produzidos pela FDE em escolas estaduais de São Paulo a fim de promover atividades com os filmes das caixas. São também, nesse sentido, institucionais, pois não há neles espaço para debates senão falas elogiosas para dar visibilidade às atividades que teriam sido bem sucedidas. Porém, diferentemente dos vídeos do item anterior - "5.9.1 Vídeos institucionais da FDE para promoção do Projeto" -, estes não foram atividades promovidas pela FDE. As escolas desenvolveram tais atividades por iniciativa própria a partir de estímulo das Diretorias de Ensino (DE) a que elas são ligadas. A FDE promoveu a cobertura dessas atividades por meio do vídeo. São seis experiências.

1 - De acordo com o vídeo realizado na E. E. Profa. Luiza Hidaka, da Diretoria de Ensino de Suzano, os professores de Filosofia e de Geografia planejaram juntos as aulas, que teriam a exibição de um mesmo filme, Arquitetura da destruição, com o objetivo de ilustração do tema a ser desenvolvido em suas aulas. 0 tema da aula de 
Filosofia foi “Questões ideológicas" e o de Gegrafia, "O que é Nação, Estado e Imperialismo Europeu no Século XIX". No vídeo são mostrados trechos curtos das aulas de Filosofia e de Geografia. Num desses trechos, o professor de Filosofia afirma que o filme em questão serviu de "propaganda nazista, instrumento de dominação. A ideologia acaba fazendo com que o indivíduo se perca, os indivíduos acabam de transformando em sujeito da massa". Quanto à exibição do filme, uma aluna diz que é uma forma de reforçar o aprendizado. 0 trecho que apresenta o professor de Geografia mostra-o falando apenas sobre o tema da aula e, a seguir, em entrevista, falando que o filme é importante, porque é uma linguagem mais acessível. Para a coordenadora, o cinema representa cultura e é função da escola promovê-la.

2 - 0 vídeo que cobriu a atividade na E. E. Prof. Antônio Zanluchi, da Diretoria de Ensino de Sumaré, mostra como os alunos montaram um teatro musical na escola sobre a história do cinema. Os cinemas da Itália e da França teriam sido fortes antes da II Guerra Mundial, uma aluna chega a dizer, mas a ênfase é dada ao cinema de Hollywood. Todo o restante do vídeo promove a ideia de espetáculo que proporciona o filme comercial. Mais uma vez, o trabalho de ampliação de repertório parece esbarrar no leque de filmes comerciais hollywoodianos, caindo no lugar comum da representação das figuras de Chaplin e de Marilyn Monroe. Nada é dito quanto à exibição de filmes. Nota-se que houve muita dedicação dos alunos para a elaboração e realização da atividade.

3 - Na cidade de Cananéia, sob a Diretoria de Ensino de Registro, o terceiro vídeo que aqui comentamos apresenta alunos e professores falando sobre a experiência da escola com a realização de filmes. Os alunos fizeram um curta que se chamou $O$ homem cobra, pertencente aos gêneros policial e terror. São exibidos trechos desse curta. A E.E. Dinorah Silva dos Santos fez dois filmes e produziram textos. O PCOP de Arte, Silva Ramalho, lembra que houve escolas em que os alunos viram o filme Frankenstein com som e uma outra vez sem som. O vídeo ainda cita um documentário feito pela E. E. Frutuoso Pereira de Moraes. 0 enredo do filme realizado pelos alunos teria sido inspirado no filme exibido, Frankenstein? Como na 
atividade anterior, nesta também não é mencionado se foram exibidos outros filmes (além de Frankenstein) como parte da atividade.

4 - Pela Diretoria de Ensino de Itaquaquecetuba é realizado em 2009 o "I Festival de Cinema de Itaquaquecetuba", um festival de curtas com formação de jurado para avaliação dos trabalhos e com premiação. Segundo a PCOP de Arte Adriana Silvestre, da Diretoria de Ensino de Itaquaquecetuba, na primeira edição do festival, 20 escolas finalizaram e enviaram trabalhos. São citadas no vídeo: E. E. José Olympio Pereira Filho, E. E. Dr. Ervin Horvath, E. E. Profa. Helena Loureiro Rossi, E. E. Jorn. Paulo E. Olintho Rehder, E. E. Bertha Corrêa de Castro, E. E. Helena Loureiro Rossi, E. E. Eliseu Jorge e E. E. Jardim Odete III. O vídeo apresenta a partir da fala da PCOP como se deu o festival de curtas mencionado, exibindo trechos dos curtas realizados pelos alunos. Os curtas têm direção de cena e roteiros muito simples, todos com gêneros muito bem definidos (comédia, suspense, terror ou documentário).

Na categoria "Documentário" o vídeo vencedor foi Amizade, da E. E. José Olympio Pereira Filho. Dele, vemos apenas um plano em que um grupo de quatro colegas diz que "eles curtem a vida de modo saudável". Na categoria Ficção/Aventura o primeiro lugar ficou com o curta $O$ túnel, da E. E. Dr. Ervin Horvath. Também dele, o vídeo apresenta poucos planos. Vê-se um grupo de garotos e garotas chegando até a boca de um túnel, onde repentinamente aparecem "zumbis", que os assustam. Antes, um dos garotos diz: "Não viemos aqui atrás de novas aventuras?”. A seguir, os "zumbis" aparecem assustando todo mundo. Para uma aluna foi importante participar da realização deste curta, porque ela ganhou novas amizades e se aproximou de várias pessoas com quem não conversava, fazendo com que ela aprendesse a lidar com várias pessoas. Uma história de superação é um documentário da E. E. Jorn. Paulo E. Olintho Rehder com depoimentos de um aluno cego da escola, que conta que andar de bicicleta foi um grande momento de superação. A PCOP diz que teve a ideia de um festival de cinema, porque pensou que os alunos participariam "não só como espectadores, debatendo, dando opiniões, mas produzindo um filme". Curioso como a atividade espectatorial é diminuída com a expressão "não só". Da maneira que é enunciado parece se tratar 
de duas atividades desvinculadas entre si. 0 trecho do curta A caixa, da E. E. Profa. Helena Loueiro Rossi, apresentado no vídeo mostra uma mulher mascarada - uma heroína - segurando dois garotos (também fantasiados) pela camisa, indicando seus superpoderes, e perguntando com tom empostado: "Quem são vocês e para onde vão?". No plano seguinte, um dos garotos luta desajeitadamente com a suposta heroína. Identidade, documentário da E. E. Bertha Corrêa de Castro. 0 trecho de Magnólia, da E. E. Profa. Helena Loureiro Rossi, é muuito curto de modo que não dá para saber qual o tema do curta. 0 mesmo se passa com $O$ poder, da E. E. Jardim Odete III, e com O caminho somos nós que trilhamos, da E. E. Prof. Eliseu Jorge. Curioso que um professor que participou das atividades de uma dessas escolas fale que "o professor é a figura chave para descobrir os talentos".

Antes da realização do festival foi feita uma oficina para a qual foram convidados de cada escola, o coordenador e mais um professor, que podia ser de Arte ou de qualquer outra cujo professor se interessasse. Para a PCOP responsável pela oficina foi necessária a instrumentalização dos professores participantes para que eles desenvolvessem a ideia junto aos alunos.

A realização do festival poderia confirmar os objetivos do Projeto quanto à ampliação de repertório de filmes, mas o vídeo não informa se tal trabalho foi contemplado. Fala-se apenas da realização dos curtas.

5 - Segundo o PCOP de Arte Djalma Abel Novaes, a Diretoria de Ensino de Guaratinguetá sugeriu entre as escolas sob sua jurisdição, que uma vez por mês, ao menos, fosse feita a exibição de um filme com acompanhamento de alguma atividade pedagógica. Nesse sentido, apesar da timidez do trabalho com os filmes promovidos por esta Diretoria de Caieiras parece ter sido a Diretoria de Ensino que mais se deteve à ideia original e principal do Projeto, que é a de ampliação de repertório de filmes dos alunos. As escolas da diretoria mencionadas no vídeo são: E.E. Geraldo Costa, na cidade de Campos de Cunha, exibiu Vida de Menina, E.E. Hilda Roca, na cidade de Cruzeiro, exibiu Billy Elliot, E. E. Luiz Menezes, na cidade de Guaratinguetá, exibiu $A$ cor do paraíso, E. E. Clotilde Ayello, cidade de Guaratinguetá, exibiu Crash. Quanto às escolas E. E Prof. Francisco Gonçalves Vieira e E.E. Armando Sestini não foram mencionados os filmes exibidos. 
Não é certamente tarefa fácil a da inclusão do cinema no cotidiano escolar por um projeto que tenta abrager todo o estado, principalmente sendo São Paulo bastante populoso. Algumas falhas são sentidas, Sentimos que cada exibição exige dos professores e coordenadores das escolas um grande esforço. É o caso da presente DE, que para cada escola apresenta uma única exibição.

6 - "Oito convites para oito filmes", $12 \mathrm{~min}$.

Este vídeo cobre a atividade de exibição de oito filmes em duas escolas da Diretoria de Ensino de Caieiras (E.E Prof. Francisco Gonçalves Vieira e E.E. Armando Sestini). O vídeo não oferece informações sobre a quantidade de alunos participantes, mas pela repetição dos comentários de alguns deles e pelas panorâmicas na sala onde foram exibidos os filmes parece ter se restringido a um grupo de no máximo 40 alunos. Ao todo foram exibidos oito filmes das caixas distribuídas pela FDE. A relação de filmes foi a seguinte:

1- $A$ vida em um dia

2- Moça com brinco de pérola

3- O último dançarino de Mao

4- As neves do Kilimanjaro

5- Contos da noite

6- Corra, Lola, Corra

7- A Invenção de Hugo Cabret

8- $O$ enigma da pirâmide

Depois da exibição de cada filme alunos e professores foram entrevistados. Os recortes selecionados para o vídeo são elogiosos aos filmes e ao Projeto. Num deles, uma professora diz que, na preparação que antecedeu a atividade, ela havia sugerido que os alunos observassem "a edição e a montagem do filme”, mas não especificou que elementos destacar. Apesar da importante preocupação da professora de fazer os alunos atentarem para os processos de feitura do filme, a orientação é generalizante e imprecisa. A mesma professora 
teria perguntado aos alunos o que eles "tiraram" para suas vidas, em particular, dentro de uma perspectiva utilitarista. Para uma aluna, o filme teria sido um complemento do que ela teria tido em aulas de Língua Portuguesa e em Arte, pois determinado filme é ambientado na Idade Média e eles estudaram o Barroco.

O último dançarino de Mao é um filme verídico, motivacional, inspirador, diz outra aluna. Um terceiro aluno diz ter gostado do filme, porque pensa em estudar Direito na universidade e o filme aborda a questão do socialismo e do capitalismo. Para uma quarta aluna, o filme apresenta a superação de problemas, importante para os alunos se motivarem a também superarem suas dificuldades. A despeito das motivações sentidas a partir da identificação com personagens dos filmes, sabe-se, contudo, que as coisas que "tiramos" da Arte frequentemente não se dão a ver. A relação não se dá pela imediaticidade, nem com vistas ao melhoramento moral ou ético dos sujeitos.

A realização dessa atividade de projeção de filmes, segundo a outra professora, aproximou mais os alunos entre si e dos profesores, pois eles teriam se tornado mais amigos, o que é confirmado por uma aluna.

Como se pode perceber, os alunos e os professores apresentam muitas impressões sobre os filmes que não são desenvolvidas, marcando o vídeo de um caráter testemunhal moralizante e de propaganda do Projeto.

Os trechos dos curtas e das falas dos professores e alunos apresentados nos seis vídeos comentados acima levam à identificação muito clara da intensa predominância de uso de técnicas do cinema que, notoriamente, buscam imitar o tipo de enredo do filme comercial. Mais uma vez, a ênfase é dada ao produto em detrimento do processo. Nesses curtas feitos nas escolas, apesar dos poucos recursos, busca-se atingir a arte bem acabada, em que a beleza se encontra, por assim dizer, muito evidente, desenhadas com traços bem definidos. Busca-se, enfim, contar uma história completa. Também ficou evidente a opção pela produção de vídeos e muito pouca ênfase à exibição de filmes.

Nas exibições que ocorreram predominou o caráter comercial dos filmes, caso dos oito exibidos e indicados no vídeo 6 ("Oito convites para oito filmes"). Além disso, as falas dos professores e alunos passam a impressão de que a 
exibição de filmes é insuficiente, devendo a escola dedicar-se à realização de filmes.

\subsubsection{Palestras sobre Audiovisual organizadas pela FDE}

As palestras a professores da rede estadual de Ensino aconteceram no Sesc Vila Nova, em São Paulo, ou no Centro Cultural São Paulo (entre 2009 e 2013), e foram todas reproduzidas em vídeo, que passaremos a comentar.

\section{1-“Do enredo à trilha sonora: os desafios da linguagem cinematográfica"}

Inicialmente, a professora de História da América, Mariana Martins Villaça, na palestra "Do enredo à trilha sonora: os desafios da linguagem cinematográfica", aponta a expectativa primeira que teria o aluno diante do filme: "vou conhecer uma história". E a seguir sugere aos professsores que o próprio aluno "tente recontar a história". O aluno pode recontar como esse filme se passa, considerando a função narrativa da música, atentando para seu lugar na narração, pois ela pode ser gradiloquente, minimalista, lírica. Essa perspectiva parte, de saída, eliminar outra noção de filme que não seja narrativo. Significa conformar a ideia predominante de cinema. Nesse sentido, a palestrante confirma a ideia recorrente no Projeto de dar ênfase à narração de cada filme.

Sugere que os professores se apropriem da indicação de Ismail Xavier de que todo filme (simplificando) teria uma estrutura trina: 1) apresentação do tema, 2) clímax (ou ponto de virada) e o 3) desfecho. Assim, Villaça fala que esse exercício de identificar essas partes no filme é importante para que eles passem a entender como o filme se estrutura.

A seguir, elenca elementos do filme sobre os quais destaca a importância de que o aluno tenha noção de sua função na obra do cineasta, como plano, sequência/cena, fotografia, iluminação. Importante, porque, no caso do plano, vale saber que ele orienta o olhar do espectador, frequentemente possibilitando que o espectador se identifique com aspectos de determinado 
personagem, ria ou chore em virtude de elementos destacados nos planos. Tendo em vista todos os elementos que compõem um filme, ela ressalta que é importante lembrar aos alunos que o cinema é uma obra coletiva. Nesse sentido, passa a falar da trilha sonora como um elemento que também compõe a obra fílmica, que para muitos se trata apenas da música (trilha musical). Na verdade a trilha sonora é toda a parte audível do filme, e também o que não se ouve, o silêncio. A música, segundo a palestrante, entra no cinema, dentre outras razões, porque nos primórdios do cinema a maquinaria de filmagem e de projeção era barulhenta e a música amenizava esse incômodo, mas, sobretudo, porque a música era o que, basicamente, conferia as emoções, que traduzia para o espectador os momentos de emoção numa cena romântica ou de suspense etc. É um índice de como se comportar diante do filme, um guia ao espectador. Ainda que geralmente não se perceba a presença da trilha sonora no filme, sua importância narrativa é, em geral, imprescindível. Ela estabelece uma paisagem sonora; pode nos identificar o tempo e local. Barulho de carruagem e de sino, por exemplo. Contudo, hoje em dia pode se ter um filme de época com rock, para causar estranhamento mesmo.

No chamado cinema mudo, em vez de trilha musical, Villaça destaca que é mais adequado se referir a "acompanhamento musical". Em tais acompanhamentos, começa-se a perceber que determinadas músicas tinham mais efeito em determinados espectadores que em outros. Daí a ideia de leitmotiv, uma música que, quando aparece, o espectador já identifica uma situação ou personagem. Com a proliferação das exibições, fica inviável o acompanhamento musical em todas elas. A Warner Bros cria, então, um aparelho chamado "Vita phone", que procura sincronizar imagem e música, uma revolução na constituição da chamada gramática do cinema.

\section{2-“Do mundo das palavras e do mundo do cinema"}

A palestrante Helena Solberg é cineasta e tem dois filmes de sua direção na caixa de filmes da FDE (Vida de menina e Palavra (en)cantada). Começou a trabalhar no "Cinema novo" como continuísta. Afirma que, por essa experiência, ela percebeu que para filmar tem que se ter uma história para contar, com um conflito. 
Fala de seu caso em Vida de menina (2004), que parte do diário de uma adolescente. 0 diário não tinha um drama e que ela e a roteirista tiveram que criar um. Fala da necessidade de uma convicção de unidade do roteiro, mas que o diretor tem que estar aberto às mudanças no roteiro como as de falas dos atores, percebidas inclusive pelos próprios atores, que frequentemente percebem quando o texto não é natural.

No documentário, cada personagem pode mudar o rumo da história contada. Para ressaltar esse elemento da imprevisibilidade, diz que em seu filme Terra proibida (The forbiden Land, 1990), por exemplo, entrevistou um homem que estava numa prisão em Teresina por suspeita de assassinato de um padre. Vendo a movimentação da equipe de filmagem e a câmera, o homem entusiasma-se e confessa o crime pela primeira vez. Tal confissão é usada oficialmente contra ele. Apesar desse importante evento que aparece no documentário, o tom do filme, segundo Solberg, é dado na edição.

A seguir, conta da dificuldade de fazer A entrevista (1966), pois tratavase de um documentário com entrevistas sobre sexo, religião, dentre outros temas delicados. As mulheres entrevistadas eram burguesas, com preocupação com suas posições sociais e não queriam aparecer no filme, porque suas declarações comprometiam a imagem de "mulher feliz em família". Lembrando o papel da edição, Solberg diz que a solução encontrada por ela foi colocar imagens de uma noiva sendo preparada para o casamento ao tempo que as falas das entrevistas descontruíam essas imagens.

\section{3- "Olhar de novo: o prazer de descobrir na escola"}

Maria Clara Wasserman, professora com mestrado em História da Música, ressalta a ideia de que os filmes distribuídos pela FDE constituem um acervo a ser catalogado e sugere formas de utilizá-lo, ainda que cada escola, diz ela, deva encontrar os melhores modos de utilização desses filmes: empréstimos, catalogação, modos de conservação. Propõe a reunião de filmes a serem exibidos por tema, porque permitiria a integração de várias disciplinas, por exemplo: artes (Arquitetura da destruição, Goya), cinema dentro do cinema (Cinema, aspirinas e 
urubus, Rosa púrpura do cairo), música (Rosa Púrpura do Cairo, Uma noite em 67, Honeydripper).

Para Wasserman, em toda exibição de filme, dentre outros aspectos, é indicado observar:

-Local e época da ação;

-Ficha técnica: figurino, direção de arte;

-Sinopse: roteiro original, adaptação.

Quanto à utilização dos filmes em sala de aula, Wasserman propõe que o professor não exiba apenas trechos, porque seria desperdiçar a proposta do filme. Lembramos aqui, como já dissemos anteriormente, que a seleção de um trecho pode ser indicialmente interessante e potencializador na medida em que pode ser o aperitivo de que o aluno precise para se sentir estimulado a buscar vêlo na íntegra, em casa ou com amigos. 0 trecho pode gerar a impressão de que há algo ali no filme que vale a pena ser visto. 0 que está na origem da preocupação de Wasserman é que não se oportunize a suposta proposta do filme, que se apresenta no filme por completo, contudo, ela parte do pressuposto de que a exibição do filme diz respeito apenas à duração da projeção, desconsiderando as condições técnicas para tanto. Pois ao desconsiderar tais condições, pode-se projetar uma imagem e um som muito distintos do original. Pensamos que esse "respeito" à obra de que trata Wasserman sacraliza-a, impedindo que seu uso considere o ambiente escolar em que se dá a projeção e, com isso, deixando de estabelecer as adequações possíveis ao ambiente.

\section{4- Vídeo Palestra: "Análise de filmes em sala de aula"}

O professor de história Marcos Napolitano, que já escreveu um livro sobre cinema na escola (NAPOLITANO, 2003), começa a palestra lembrando a premissa de que o filme não deve ser usado para substituir o livro ou apresentado para aqueles que "não gosta de ler". As atividades com filmes e livros caminham juntas, diz ele. Para Napolitano, o filme é subjetivo, mas também objetivo, pois há uma história que é transmitida e comprendida pelo espectador. Ele está se 
referindo à maioria dos filmes, que são, por assim dizer, narrativos. Fala do efeito de realidade que a sala escura potencializa e que não morre depois da exibição do filme; ele continua e é importante considerá-lo do ponto de vista pedagógico.

Em grande medida o efeito de realidade depende das escolhas tomadas pela equipe que trabalha num filme, sobretudo o diretor ou o produtor, no caso de filmes comerciais, a exemplo de Honneydripper; Nas montanhas dos gorilas; Crash, no limite; Billy Eliot; Final fantasy, por exemplo, que constam da lista da FDE. Para Napolitano, o trabalho de cinema na escola está em identificar e documentar essas escolhas. Existe uma expectativa de que um documentário reforce algo que o professor apresentou em sala de aula. Essa aposta é muito maior no documentário que na ficção. Quanto à intenção do diretor do filme de dizer ou de ter querido dizer algo, Napolitano afirma que é menos importante, pois o que se tem de mais concreto e importante é a obra, o filme. Ele dá o exemplo do filme Tropa de Elite (2007), em que José Padilha, seu diretor, disse publicamente que não quis fazer apologia da violência. Os críticos, contudo, identificaram vivo apelo à violência.

Para fazer a análise dos filmes é preciso entender a linguagem em que se constitui o cinema. São regras flexíveis. Napolitano propõe um olhar inquiridor para o filme: o que o filme defende sobre o tema, como ele tratou o tema. Ressalta, por em, que o roteiro e a montagem são as partes mais importantes do filme.

A escolha do gênero define o tipo de narrativa. Assim, um melodrama acentua a dicotomia entre bem e mal, por exemplo, enquanto num drama realista tira-se $o$ acento das tensões entre bem e mal.

Destaca a importância de atentar-se para o marketing na promoção do filme, que pode chegar a representar dois ou três quartos do orçamento do filme, caso de Titanic (1997). Napolitano lembra que o filme comercial estadunidense é peça de propaganda de estilo de vida e que o professor deve atentar para isso.

O uso de filme como documento cultural tende a eliminar o preconceito pelo meio do qual o aluno festeja a obra em detrimento da aula expositiva e o professor que exibe um filme, em razão de estar cansado. Napolitano afirma que, com o uso contínuo do cinema em sala de aula, a tendência é gerar uma cultura desse uso. Ele sugere o uso do filme também como "tema gerador" como atividade interdisciplinar, temas transversais ou relacionados a temas das disciplinas 
envolvidas. Deve-se fazer um levantamento do potencial pedagógico do filme. 0 que ele oferece que reforce os objetivos da aula do professor? Será que o aluno vai absorver o filme tal como o professor espera?

Napolitano, ao contrário de Alain Bergala (2007), diz que, em geral, não se pode partir no trabalho com o cinema na escola de um cineasta como Akira Kurosawa, pois tal entrada pode servir, frequentemente, para consolidar preconceitos, já que faltariam aos alunos elementos para se situarem diante de algo completamente estranho. Contudo, chama atenção para a necessidade de ampliação gradual de repertório dos alunos, começando de filmes menos "autorais". Como fizemos notar no capítulo dedicado a Bergala, o autor não acredita que o professor que parte de um filme bastante comercial, que ele o faça de modo que chegue a provocar o salto a que se refere Napolitano. Ao contrário, prefere apostar no estranhamento da exibição de filmes não comerciais. Bergala não acredita, pois, no acesso gradual à arte, como se tivesse que haver uma espécie de acumulação de certa capacidade prévia.

Por fim, o professor e historiador sugere que o cinema seja trabalhado também não só na sala de aula, mas em semanas culturais, fora da sala de aula, mesmo que uma vez ou duas por ano. Esta obsevação é a única feita dentre os palestrantes quanto ao uso do filme fora da sala de aula, sem preocupação de relacioná-lo a uma atividade "pedagógica". Aqui, a exibição do filme é entendida como evento cultural. 0 Projeto, ao contrário, pensa o uso do filme a partir de sua inserção em sala de aula, vinculado a uma disciplina.

\section{5- Vídeo Palestra: "O lugar do audiovisual no mundo contemporâneo"}

Para Luis Buñel, segundo o crítico de cinema Sérgio Rizzo, o cinema é mais parecido com a mente humana em estado de sonho. Nesse sentido, o professor deve buscar seu próprio jeito e se formar para incorporar o cinema em suas aulas, em geral, por interesses pessoais mesmo. 0 lugar do audiovisual no mundo contemporâneo deve ter como ponto de partida a preocupação de identificar que lugar ele ocupa na vida das pessoas: "O que o audiovisual faz na sua vida ou o que eu faço do audiovisual". Lembra que Ítalo Calvino declarou que, 
durante a Segunda Guerra Mundial, em que viveu sua adolescência, o cinema era o seu refúgio, uma forma de sobreviver, de alimentar a esperança. Segundo Rizzo, Calvino tem consciência da negação da realidade pelo cinema, mas ressalta como os filmes possibilitavam a ele a suspensão da dura realidade em que a Europa se encontrava. Do mesmo modo, consciente dessa potência do cinema de suspender as referências imediatas do espectador, o professor possa apostar que os filmes provoquem inadvertidamente a tensão de lugares comuns a que os alunos estão acostumados.

Para tanto, diz ele, não adianta "brigar" com o repertório dos alunos; deve-se partir dele. Nesse sentido, Rizzo concorda com Napolitano, inclusive pela ampla democratização digital, em que qualquer um pode fazer um filme. Antes disso, as salas de cinema mantinham o monopólio da exibição. Agora, as redes virtuais possibilitam a ampliação gigantesca dessa socialização do audiovisual. Essa democratização passa também para a produção e a escola deve dedicar-se a esse fenômeno. 


\section{CONCLUSÃO}

O programa Cultura é currículo é oficializado por uma Resolução da Secretaria de Educação, a SE no. 19, de 13 de março de 2009147, quando, na prática, este já existia (como projeto piloto) desde 2008, sendo suspenso por meio de ofício emitido em 03 de agosto de 2015 pela mesma Secretaria. Neste ofício, consta que o programa não seria renovado nesse ano a que se refere em virtude de cortes no orçamento. Com tal procedimento, a SEE-SP gerou nas pessoas que trabalham na FDE a expectativa de que a qualquer instante o programa poderia voltar a receber o aval para que fosse retomado, o que não se cumpriu.

Enquanto isso, o programa sobrevive de um braço no "Escola da Família", aos finais de semana, com poucos filmes retirados das 6 caixas que foram distribuídas no tempo de funcionamento do projeto O cinema vai à escola. Os Roteiros de Atividades sugeridos a partir dos filmes são refeitos, simplificando-se em razão da heterogeneidade do público e das pessoas que projetam os filmes - a cargo de dois estagiários por escola, que são beneficiados com o "Bolsa Universidade" e que se comprometem, como contrapartida, a trabalhar nos finais de semana como monitores. A princípio, a FDE foi procurada para indicar para cada dia de exibição de filme no "Escola da Família" três dos 71 títulos distribuídos às escolas para que cada escola escolhesse um. Segundo a FDE, os monitores são orientados pelos coordenadores e supervisores das diretorias de ensino.

Tomando as experiências com projeção de filmes nas escolas e também a necessidade de inserção do audiovisual presente nos discursos de pedagogos e profissionais do cinema, não há dúvida de que existe certa receptividade à ideia de que a instituição escolar deva incorporar os meios de comunicação de massa (TV, jornais, mídias em geral) ao rol de suas preocupações. Mas ainda insuficientemente para impedir o cancelamento de um projeto como O cinema vai à escola, configurando-se como um sintoma na tensão entre forças políticas (ideológicas, e

\footnotetext{
147 www.educacao.sp.gov.br. Estando o site em manutenção o que é comum, deve-se digitar no Google: "Resolução da Secretaria de Educação, a SE 19, de 13 de março de 2009" e o primeiro link disponibilizado é um arquivo em Word organizado pela CENP (2009), que possui a referida resolução. Vale observar que, apesar da referida resolução ser de 2009 o programa Cultura é currículo funciona desde 2008.
} 
educacionais também) ainda resistentes, especialmente às artes. Prova da existência dessa receptividade foi exposta na discussão que fizemos em capítulos anteriores quando apontamos o aparecimento do cinema em documentos oficiais como os PCN, a Proposta Curricular do Estado de São Paulo e o Currículo do Estado de São Paulo, para citar os mais recentes, e o próprio uso "espontâneo" do professor desvinculado de projetos da exibição de filmes em atividades nas escolas, professor este pressionado a fazer a inclusão das "novas linguagens" sem o devido tratamento para a questão.

Espremido na inadequada designação "Artes Visuais”, junto com Artes Plásticas e Fotografia, o Cinema é, surpreendentemente, "apagado" dos documentos, inclusive das propostas de atividades em sala de aula no caso dos Cadernos do Professor, como se pôde verificar. Nos vários documentos analisados nesta tese, destacamos a Lei 13.006/14, que obriga as escolas à exibição de, pelo menos, duas horas mensais de filmes brasileiros, e pela própria existência do projeto $O$ cinema vai à escola, ainda que ele tenha sido suspenso em 2015. Assim, nota-se relativo movimento para a inclusão do cinema no contexto escolar, ainda que, como destacamos, o cinema seja aí considerado complemento curricular associado a algum conteúdo disciplinar.

De modo geral, ainda que considerada inferior às outras disciplinas, a arte é tomada como fonte de conhecimento, o que lhe confere um lugar no currículo. Já o cinema, ainda que seja uma arte, embora contando com certa receptividade, não chega a adquirir a mesma importância que as disciplinas institucionalizadas. Quanto a essa questão, diz Rosália Duarte, que “o cinema não é visto pelos meios educacionais como fonte de conhecimento (...), pois estamos impregnados da ideia de que cinema é diversão e entretenimento." (DUARTE, 2009, p. 70-71), dentre outros motivos, em razão da grande imersão de filmes comerciais nas salas de cinema e na televisão brasileiras. Além do mais, não se pode esquecer que o lugar da arte na produção do conhecimento mudou, a partir das vanguardas, por exemplo, com Duchamp e Maliévitch. A escola, no entanto, em geral, busca reforçar o lugar de uma arte ainda sustentada pela separação entre "objeto de arte" e espectador, cuja relação deste com aquele se daria pela 
contemplação, enquanto na arte contemporânea fala-se mais em "objeto de pensamento" (FAVARETTO, 2015, p. 20).

Em conformidade com a exigência mínima de exibição de filmes brasileiros nas escolas - a fim de conter a defasagem dessas produções em relação às de filmes estrangeiros, sobretudo, estadunidenses comerciais -, há experiências singulares no Brasil nesse sentido, valendo destacar aquela desenvolvida pela escola privada Carlitos, que oferece os ensinos Infantil, Fundamental I e II, em São Paulo, que incorporou à sua grade curricular o ensino do cinema. Lê-se em seu site:

A presença do Cinema no currículo da Escola Carlitos em todas as etapas escolares afirma o respeito da instituição pela sétima arte. Esse respeito e admiração pela arte cinematográfica já são manifestados no nome da Escola, homenagem ao personagem imortal de Charles Chaplin, representante do humanismo do século $\mathrm{XX}^{148}$.

Contudo, é curioso que mesmo o caso raro de uma escola notoriamente interessada na inserção do cinema em seu currículo (note-se o nome da escola, que homenageia um personagem do cinema), que haja aí, apesar da valorização notável ao cinema se comparado ao quadro geral do país, um papel secundário dessa arte. Quanto à relação com o cinema, a preocupação destacada em seu site é a de análise dos filmes programados para as crianças, que são três por ano.

Como parte do currículo dessa área, o aluno assiste a três filmes por ano, em salas de cinema parceiras da Escola, e analisa-os no ambiente escolar. Os filmes são escolhidos com a intenção de colocá-lo em contato com obras do cinema próprias para o exercício de reflexão à face da imagem em movimento, contribuindo para a formação de um espectador ativo ${ }^{149}$.

Como se depreende do texto acima, o objetivo da escola com o cinema é o de que ele sirva à "reflexão". "Os filmes são escolhidos com a intenção de colocálo [o aluno] em contato com obras do cinema próprias para o exercício de reflexão [...]". As obras escolhidas têm que ser "próprias à reflexão", como declara expressamente o site. No entanto, em outra parte do site, pode-se ler uma relação

148 Texto disponível em http://www.escolacarlitos.com.br/projetos/aprendizdecinema.html. Acessado em 21 de maio de 2013.

149 Texto disponível em http://www.escolacarlitos.com.br/index.php/vivencias/aprendiz-decinema. Acesso em 12 de Julho de 2014. 
considerável de livros didáticos e de literatura nas línguas portuguesa, francesa, inglesa e espanhola, além dos outros referentes a cada disciplina como História, Geografia etc. Para termos ideia da relação de livros de uma disciplina, tomemos a Literatura em língua portuguesa para o 9oa ano, que apresenta a seguinte relação: Morte e Vida Severina, de João Cabral de Melo Neto, Vidas Secas, de Graciliano Ramos, $O$ Visconde partido ao meio, de Ítalo Calvino, As intermitências da morte e $O$ conto da ilha desconhecida, ambos de José Saramago, A metamorfose, de Franz Kafka e Cem anos de solidão, de Gabriel García Márquez. São sete livros. No entanto, nenhuma menção é feita à filmografia em nenhum dos nove anos a que se dedica a escola.

Em razão dessa secundarização do cinema, torna-se mais notável ainda a atenção que Benjamin concede a essa arte. Ainda que questões como as mutações perceptivas - provocadas na espectatorialidade nas duas últimas décadas pela internet e aplicativos via aparelhos eletrônicos portáteis - devam ser melhor pensadas, contudo, pelo menos no século XX, como bem assinala Benjamin, que trata da análise do empobrecimento da experiência na modernidade, o cinema é "a grande expressão dos novos tempos". Para ele, "o filme serve para exercitar o homem nas novas percepções e reações exigidas por um aparelho técnico cujo papel cresce cada vez mais em sua vida cotidiana." (BENJAMIN, 1996a, p. 174). Por isso, não deixa de ser curioso que nas escolas contemporâneas a consciência "pedagógica" da tematização e da problematização das tecnologias que veiculam imagens não passem ao ato. Na verdade, sabe-se que a materialização dessa consciência implicaria o rearranjo dos lugares ocupados entre as disciplinas, na posição que assume o saber científico entre elas.

\begin{abstract}
A hegemonia da imagem na cultura-mundo de hoje ameaça não o livro, senão ao seu estatuto de eixo da cultura, deslocando-se do centro. E este deslocamento problematiza o saber próprio dos intelectuais, recoloca suas atividades profético-pedagógicos, exigindo um esforço de relocalização social e cultural que muitos não estão dispostos a fazer (MARTÍN-BARBERO apud CITELLI, 2006, p. 19).
\end{abstract}

No trecho acima citado, Martín-Barbero se refere a dois tipos de hegemonia. A existência pragmática da imagem no cotidiano das pessoas, 
inundadas a todo instante por elas, seja na própria escola ou fora dela, pela televisão, internet ou nas ruas. Não obstante essa marcante presença da imagem, o outro tipo de hegemonia diz respeito à importância concedida não à imagem, mas à palavra, que, na escola, recheia as aulas e os livros didáticos, sendo a grande referência na (re)produção do saber "escolar". Essa insuficiência no tratamento que a escola dispensa às imagens resulta noutro problema. Sabe-se que nos grandes centros urbanos a escola - principalmente as de "Tempo Integral" - "priva" a criança e o jovem do convívio com o adulto, gerando a incomunicabilidade pela separação física entre eles, o que acaba relegando esse contingente imenso de alunos à sorte de mediações em que eles próprios pautam entre si seus interesses, utilizando-se da internet e de aplicativos em celulares e, ainda fortemente, da televisão aberta. Hoje, essa separação parece inevitável, dadas as demandas de um mundo cada vez mais administrado em que pais, mães e demais responsáveis pelos estudantes trabalham fora de casa e, por isso, precisam passar parte considerável do dia afastados. A escola, no entanto, ao se isentar quanto à acolhida de temas recorrentes entre os estudantes, acaba contribuindo para a cristalização da deriva na formação desse contingente ou apenas confirmando a tônica da indústria cultural em suas vidas.

Essa crítica feita à escola, quanto ao fomento da incomunicabilidade desses mundos paralelos, toma por base a ideia de que é necessário que o jovem conviva e desenvolva atividades com seus pares na comunidade em que vive, inclusive com os adultos, para que se sinta partícipe de todo um modo de ver, de sentir e de pensar, que contribui para a integração ao lugar. Curioso como esse distanciamento, de alguma forma, ao menos tecnicamente, pode ser encurtado com a explosão de janelas virtuais (internet, com vídeos e charges, textos, aplicativos de chats de celulares, séries de TV, filmes etc.). Tal explosão provocou um salto expressivo quanto à assimilação de um maior número de informação sobre o que se passa no globo terrestre. Com isso, mudou-se a concepção de distância geográfica que se tinha. Hoje, não raro, no entanto, sabe-se muito mais intensamente de acontecimentos que se dão no mundo inteiro do que sobre a realidade do bairro em que se vive. É nesse sentido que a escola deixa de ser a detentora única do saber e, por consequência, o professor - seu maior 
representante - perde esse lugar antes quase exclusivo. Nessa nova configuração de acesso ao saber, caberia à escola e ao professor mediar, instalar-se no meio dessa enxurrada de produção de informação para orientar os alunos na produção de sentidos.

Sabe-se o quanto tal "horizontalidade" na acessibilidade da informação não é suficiente para a promoção do diálogo entre os mundos adulto e juvenil. Antes, frequentemente, concorre para inviabilizá-lo. Assim, se o modo de a escola apreender e de conceber os universos adulto e infantil não é causa da separação ou do silêncio entre as gerações, a escola é, no mínino, sintoma. 0 audiovisual nos celulares, na TV, na internet ou no cinema, com produções mais comerciais ou menos, faz hoje parte da cultura informal da sociedade, de modo que não ter visto determinado filme ou vídeo pode significar ficar fora da roda de conversa. Assim, a visitação a determinados produtos se impõe no meio informal entre os alunos à parte da formalidade escolar.

Considerando que a escola, pois, deva tratar dessa questão para que não fique ela de fora da roda, é que nos propusemos o estudo do material que promove essa entrada do cinema (e do audiovisual) na escola, tentando analisar as estratégias utilizadas oficialmente e com lastro considerável no estado de São Paulo via projeto $O$ cinema vai à escola, além de outros materiais de orientação quanto ao uso do cinema na escola.

Assim, entendendo que essa discussão deva ser situada na disciplina de Arte, buscamos nos documentos da SEE-SP identificar e analisar as noções de arte, de cinema e de sujeito, inclusive considerando o projeto "Currículo +" da SEE-SP, que objetiva exclusivamente fazer uso instrumental da tecnologia, oferecendo "ao professor recursos pedagógicos digitais e formação na utilização destes recursos para complementar o desenvolvimento da sua aula e aprimorar a sua prática"150. No entanto, é surpreendente que no Currículo do Estado de São Paulo, também da SEE-SP, na disciplina Arte, o termo "artes audiovisuais" seja citado apenas uma única vez, ainda assim tais artes não são contempladas nos quadros que sugerem conteúdos e habilidades a serem desenvolvidos na disciplina de Arte ou como há

150 Cf. http://curriculomais.educacao.sp.gov.br/sobre-o-curriculo/, acesso em 08 de janeiro de 2015. 
em História e Geografia, por exemplo. O Cinema não é incluído. Por isso, denominamos essa ausência do cinema de "apagamento".

Tal apagamento coloca-se na via contrária da receptividade ao audiovisual de que falamos anteriormente. Caberia à escola pensar modos de incorporação desse cinema tradicionalmente excluído e, ao mesmo tempo, não dispensar de todo a exposição e debate de filmes comerciais já conhecidos pelos alunos. A questão parece não se restringir a problematizar os temas a partir dos filmes, mas situar o cinema como arte, pois, como se sabe, o filme é usado como suporte emergencial na falta de professores ou ainda para ilustrar coadjuvantemente conteúdos de disciplinas ou sintomaticamente como momento de atividade, supostamente, lúdica, a fim de gerar apenas prazer. Tais filmes pouco operam nos estudantes a entrada na experiência do pensamento, em razão, talvez, de priorizarem espetacularizar a vida por meio da promoção da identidade com personagens e situações que reforçam lugares-comuns. Os filmes utilizados se não são narrativos (de circuito comercial como Honeydripper, Nas montanhas dos gorilas, Billy Eliot, Em busca da terra do nunca, dentre outros que constam da lista de filmes distribuídos às escolas), isto é, filmes que contam explicitamente alguma história e geralmente apelam para os efeitos mirabolantes da técnica e de montagem rápida para entreter o espectador ávido; são filmes que, amparados e orientados por Roteiros de Atividades, servem de ilustração para assuntos abordados pelo professor, que, por sua vez, seleciona nele o que interessa para a disciplina.

Contudo, por outro lado, é possível dizer que o projeto $O$ cinema vai à escola mudou esse cenário na medida em que promoveu uma seleção mais diversificada de produções e propôs, ainda que como auxiliar das disciplinas, vez outra, a abordagem de aspectos técnicos do cinema.

Para o projeto $O$ cinema vai à escola, o papel do cinema é pensado em termos daquilo que ele pode suscitar a partir da reflexão nas aulas junto às disciplinas, isto é, uma mediação em muito conduzida pela palavra, que demarca posições de sujeito diante da materialidade da arte no que diz respeito à condução de interpretação dos filmes e, com isso, à implementação e acomodação dessa arte na escola. "Un decir es del orden del acontecimento" (ALEMÁN, 2013, p. 166). 0 
Roteiro de Ladrões de bicicleta (Ladri di biciclette, 1948) do Caderno de Cinema do Professor, por exemplo, sugere como primeira orientação ao professor, que peça aos alunos para que identifiquem cenas do filme que mostrem a situação de pobreza dos personagens principais. E a seguir: "O que o emprego de Antonio representava para a família?". O Roteiro parece querer nomear o que já se apresenta visualmente. Trata-se, pois, de apontar para a mesa e dizer: me-sa; para a cadeira e dizer: ca-dei-ra! Nesse sentido, com esse modo de "soletrar" a arte perde-se a oportunidade de deixar que o filme "fale" a seu modo. Vive-se o império do sentido, ou melhor, do significado.

Ademais, se lembrarmos que, em tese, os Roteiros são destinados para uso de todos os professores de todas as disciplinas, temos que admitir que essas indicações não serão apenas alternativas a partir de um Roteiro próprio, "pessoalmente" elaborado pelo professor. Sem formação específica em cinema, se o professor não passar o filme apenas como entretenimento, certamente ele seguirá o Roteiro como um manual e, nesse sentido, eliminará o acontecimento a que se referia Alemán na citação do parágrafo acima. Esse uso verticalizado, imposto ao professor é expressão da dessubjetivação de seu lugar no exercício de sua função de educador.

Inácio Araújo (2009, p. 19), em entrevista ao projeto O cinema vai à escola, fala sobre essa ideia do uso do filme como auxiliar das disciplinas:

Me parece que, com muita frequência, os professores usam os filmes como ilustração de determinadas coisas. É um procedimento válido. Você pode obter informações sobre a Revolução Francesa, por exemplo, tanto vendo certos filmes como lendo certos livros. Me parece, porém, que na maior parte das vezes o cinema é usado como um "facilitador", porque é uma espécie de "prova" do acontecido. E, nesse sentido, pode ser até mesmo nocivo. Se o aluno for ver um filme como 0 Cangaceiro, por exemplo, pode presumir que os cangaceiros não passavam de grupos de arruaceiros cruéis que viviam no sertão nordestino. Não sei se eram só isso. Com certeza, a história que os envolve é mais complexa do que isso. Então me parece que 0 Cangaceiro explica muito sobre a maneira como a elite paulista de 1950 (representada na Vera Cruz, a produtora do filme) via o cangaço. Isso é que precisa ficar muito claro. O cinema é uma fonte histórica, sem dúvida, mas quem vê um filme precisa estar consciente de que o fato de mostrar algo não significa que ele diz a verdade sobre aquele fato. Ele é a visão de alguém (um diretor), 
de uma época, de um povo sobre um determinado acontecimento (ARAÚJO, 2009, pp. 19-20).

Esse modo de o cinema auxiliar as disciplinas, de ser um "facilitador", pode guardar como pressuposto a simplificação pela imagem. Assim, Ladrões de bicicleta seria uma "espécie de 'prova' do acontecido", espécie de prova de que "na Itália era assim". Em certa medida, o filme é, sim, um documento, mas chamamos atenção para a perda da dimensão da ficção.

Apesar de vários textos, desde a década de 1940, dentre eles os de Walter Benjamin, já considerarem o cinema uma arte, é bem mais tarde que ele será tomado como tal, mas ainda assim não sem certa desconfiança. Para Inácio Araújo, crítico e roteirista, o cinema só será considerado arte nas décadas de 1950 e 1960. "No início, o cinema é uma diversão de feira. Só será plenamente aceito como arte, como a arte por excelência do século 20, lá pelos anos 50, 60." (ARAÚJO, 2009, p. 09).

Considerando essa condição inferiorizada do cinema frente a outras artes na escola, no início do século XX, é curioso que tenha havido tentativas de agregar prestígio a ele, então considerado atração de feira, diferentemente do romance ou da música erudita, artes burguesas. Em 1908, pois, quando é criada na França a Sociedade do Filme de Arte (AUMONT, 1995), procura-se literalizar o cinema, torná-lo mais cerebral, adaptando-se obras como Macbeth (SOUSA, 2012). A concepção dominante era de que a arte deveria estar impregnada pela letra, que esta fosse a tônica na relação com a imagem.

Noutra chave,

É preciso antecipar um cinema [...] incompleto, de modo que o espectador possa intervir para preencher os vazios, as lacunas. A estrutura do filme, em vez de sólida e impecável, deveria ser enfraquecida, tendo em conta que não se deve deixar (sic) escapar os espectadores! [...]. Creio que muitos filmes mostram demais (KIAROSTAMI, 2004, p. 182-183).

Esse cinema de que fala o cineasta iraniano é fundamentalmente diferente daquele que costuma ser exibido nas escolas (o projeto $O$ cinema vai à escola, contudo, garante certa representação do cinema mundial), que mais parece responder a uma necessidade profilática. Está ali pela insuficiência atual do ensino 
pautado nas letras e no ideal da ciência, que se arvora de determinado conteúdo, cuja vocação é central. No mesmo sentido de Kiarostami, diz Wim Wenders: "Hoje, não consigo suportar filmes que preencham todo o espaço com suas histórias. Eles não deixam muito espaço para a imaginação. 0 que você vê é aquilo que você leva nada mais. Preciso ser capaz de entrar na narrativa, preciso dos espaços vazios." (WENDERS In CAKOFF, 2011, p. 14). Dada a predominância mundial desse cinema que "preenche todos os espaços", ele não tem cumprido na escola o papel de sucedâneo profilático que viria juntar-se a outras estratégias pontuais como festas, apresentações de coral, teatro de final de ano etc. ${ }^{151}$, a fim de suprir com certa leveza a couraça gerada por um regime "sério", duro, lógico, em que se constitui o ensino cientifizante?

Assim, pensando na subalternização do cinema no contexto escolar não é pouco comum que as pessoas digam em conversas informais que o livro é sempre "mais profundo que o filme". Quem já não ouviu diversas vezes essa assertiva mesmo de cinéfilos, que, ao que parece, envergonhados de sua dedicação "estranha" ao cinema, consagre-se também a ler os livros antes de ver os filmes? Tal "verdade" reverbera imponente no contexto escolar. 0 audiovisual entra na escola enviesado, estranho ao ambiente, como se falasse uma língua estrangeira, sem legendas. Por isso, a necessidade de se repensar os lugares e os tipos de saber da educação contemporânea. 0 presente trabalho tentou cumprir tal papel.

151 Não estamos procurando diminuir a importância dessas atividades para a dinâmica escolar, mas apenas apontar o pouco valor que é atribuído a elas nesse contexto. 


\section{REFERÊNCIAS}

ABEL, Richard. "Os perigos da Pathé ou a americanização dos primórdios do cinema americano". In: CHARNEY, Leo \& SCHWARTZ, Vanessa R. $O$ cinema e a invenção da vida moderna. $2^{\mathrm{a}}$. ed, trad. Regina Thompson. São Paulo: Cosa \& Naify, 2004, p. 215-256.

ADORNO, Theodor. Correspondência, 1928-1940: Theodor W. Adorno/Walter Benjamin. 2a ${ }^{a}$. ed., trad. José Marcos Mariani de Macedo. São Paulo: UNESP, 2012.

ADORNO, Theodor \& HORKHEIMER, Max. "A Indústria Cultural: o esclarecimento como mistificação das massas". In: Dialética do Esclarecimento. Trad. Guido Antonio de Almeida. Rio de Janeiro: ed. Zahar, 2006a.

ADORNO, Theodor. Educação e Emancipação. Trad. Wolfgang Leo Maar, 4⿳亠丷a. ed. Rio de Janeiro: Paz e Terra, 2006b.

ADORNO, Theodor. "O Artista como representante". In: Notas de Literatura I. Trad. Jorge de Almeida. São Paulo: Duas Cidades/ Ed. 34, 2003, pp. 151-164.

ADORNO, Theodor. "O Curioso Realista". In: Revista Novos Estudos, N.85, Nov., 2009, p. 05-22. Trad. Laura Rivas Gagliardi e Vicente A. de Arruda Sampaio.

ADORNO, Theodor. "Notas sobre o filme". In COHN, Gabriel (Org.). Theodor W. Adorno. São Paulo: Ática, 1994, p.100-107.

ADORNO, Theodor. Minima Moralia. Trad. Luiz Eduardo Bicca. São Paulo: Ática, 1993.

ADORNO, Theodor. "O fetichismo na música e a regressão da audição". In: Horkheimer e Adorno: Textos Escolhidos. São Paulo: Ed. Nova Cultural, 1991. Trad. de Luiz João Baraúna e revisão de João Marcos Coelho.

ADORNO, Theodor. "Prólogo a la Televisión". In: Intervenciones. Trad. para o espanhol: Roberto J. Vernengo. Caracas/Venezuela: Monte Avila Editores C. A., 1969a, p. 63-74.

ADORNO, Theodor. "La televisión como ideología”. In: Intervenciones. Trad. para o espanhol: Roberto J. Vernengo. Caracas/Venezuela: Monte Avila Editores C. A., 1969b, p. 75-89.

AGAMBEN, Giorgio. Infância e História. 2ª ed., trad. Henrique Burigo. Belo Horizonte: UFMG, 2012a.

AGAMBEN, Giorgio. "O que é o contemporâneo?" In: $O$ que é o contemporâneo? e outros ensaios. Trad. Vinícius Nicastro Honesko. Chapecó/SC: Argos, 2012b.

ALEA, Tomás Gutiérrez. Dialética do Espectador. Trad. Itoby Alves Correa Júnior. São Paulo: Summus, 1984. 
ALEMÁN, Jorge. "Jacques Lacan y el debate posmoderno". In: Jacques Lacan y el debate posmoderno. Madrid: Filigrana, 2013.

AMBRÒS, Alma \& BREU, Ramón. Cine y Educación: El cine en el aula de primaria y secundaria. Madrid: Graó, 2007.

AQUINO, Julio Groppa. Pedagogização do Pedagógico: sobre o jogo do expert no governamento docente. In: Educação (Porto Alegre, impresso), vol. 36, n. 2, p. 201209.c, 2013.

AQUINO, Júlio Groppa. "O pensamento como desordem: repercussões do legado foucaultiano". In: Revista Pro-Posições, maio/ago, 2014, vol. 25, n. 02 (74), p. 83101.

ARANTES, Otília Beatriz Fiori; FAVARETTO, Celso Fernando; SUZUKI JUNIOR, Matinas. (Coord.). Revista Arte em Revista. São Paulo. Ano 1, n. 01, jan-mar, 1979. Disponível em: https://www.facebook.com/groups/918301211532935/files/.

ARAÚJ0, Inácio. In: Caderno de Cinema do Professor (vol. 03). Secretaria de Educação (Estado), 2009.

ARAÚJO, Inês Lacerda. Foucault e a Crítica do Sujeito. 2ª . ed. Curitiba: Ed. UFPR, 2008.

ARAÚJ0, Thaissa Helena de Barros \& CHAUVEL, Marie Agnes. Estratégias de Promoção no Lançamento de Filmes Norte-Americanos no Mercado Brasileiro: um estudo de caso. Revista Interdisciplinar de Marketing, v. 3, n. 01, pp. 22-39, Jan./Jun., 2004.

ARBOUSSE-BASTIDE, Paul \& MACHADO, Lourival Gomes. Notas de rodapé. In: Discurso sobre as ciências e as artes. In: ROUSSEAU, vol. II, 1988.

ARENDT, Hannah. "Crise na educação". In: ARENDT, Hannah. Entre o passado e o futuro. 7ạ. Ed. Trad. Mauro W. Barbosa. São Paulo: Perspectiva, 2013, pp. 221-247.

ARENDT, Hannah. Lições sobre a filosofia política de Kant. Trad. André Duarte de Macedo. Rio de Janeiro: Relume-Dumará, 1993.

ARROYO, Miguel G. "Uma celebração da colheita". In: TEIXEIRA, Inês Assunção de Castro \& LOPES, José de Sousa Miguel (Orgs.). A escola vai ao cinema. Belo Horizonte: Autêntica, 2003, p. 125-135.

ARTAUD, Antonin. O teatro e seu duplo. Trad. Teixeira Coelho. São Paulo: Martins Fontes, 1999.

AUMONT, Jacques et al. A Estética do filme. Trad. de Marina Appenzeller. São Paulo: Papirus, 2011.

AUMONT, Jacques. Moderno? Porque o cinema se tornou a mais singular das artes. Trad. Eloisa Araújo Ribeiro. Campinas, SP: Papirus, 2008. 
AUMONT, Jacques. O Olho interminável. Trad. Eloisa Araújo Ribeiro. São Paulo: Cosac\& Naif, 2007.

AUMONT, Jacques \& MARIE, Michel. Dicionário Teórico e Crítico de Cinema. Trad. de Eloisa Araújo Ribeiro. Campinas, SP: Papirus, 2003.

AZANHA, José Mário Pires. Proposta pedagógica e autonomia da escola. Cadernos de História e Filosofia da Educação. São Paulo, FEUSP, vol.1, no1, 1998. Disponível em: http://www3.fe.usp.br/secoes/inst/novo/acervo_jmpa/PDF_SWF/78.pdf. Acesso dia 18 de agosto de 2016.

AZEVEDO, Fernando de [et al]. Manifesto dos Pioneiros da Educação Nova (1932) e dos Educadores (1959). BRASIL. Ministério da Educação. Ed. Massangana, 2010.

AZEVEDO, Fernando de. A Cultura Brasileira. São Paulo: EDUSP, 2010.

BAECQUE, Antoine de. Cinefilia: invenção de um olhar, história de uma cultura. Trad. André Telles. São Paulo: Cosac Naify, 2010.

BARTHES, Roland. Escritores, intelectuais, Professores. In: Escritores, intelectuais, Professores. Lisboa: Presença, 1975, p. 25-61.

BASTOS, Hermenegildo. "Inferno, alpecarta: trabalho e liberdade em Vidas Secas". In: RAMOS, Graciliano. Vidas Secas. Rio de Janeiro: Record, 2013.

BAZIN, André. O Cinema. Trad. Eloisa de Araújo Ribeiro. São Paulo: brasiliense, 1991.

BAZIN, André et all. A Política dos autores. Trad. Isabel Maria Lucas Pascoal. Lisboa: Assírio \& Alvim, 1976.

BAXANDALL, Michel. O Olhar Renascente. Pintura e Experiência Social na Itália da Renascença. Trad. Maria Cecília Preto da Rocha de Almeida. São Paulo: Paz e Terra, 1991.

BENJAMIN, Walter. "Experiência". In: Sobre a criança, o brinquedo e a educação. Trad. Marcus Vinicius Mazarri. São Paulo: Duas Cidades, 2011.

BENJAMIN, W. Passagens. Trad. Irene Aron e Cleonice Paes Barreto Mourão. Belo Horizonte: UFMG; São Paulo: Imprensa Oficial do Estado, 2007.

BENJAMIN, W. O conceito de crítica de arte no Romantismo alemão. Márcio Suzuki. São Paulo: Iluminuras, 1999.

BENJAMIN, W. "A Obra de arte na era de sua reprodutibilidade técnica". In: Walter Benjamin: Magia e técnica, arte e política (Obras Escolhidas). Trad. Sergio Paulo Rouanet. São Paulo: brasiliense, 1996a.

BENJAMIN, W. "Experiência e Pobreza". In: Walter Benjamin: Magia e técnica, arte e política (Obras Escolhidas). Trad. Sergio Paulo Rouanet. São Paulo: brasiliense, 1996b. 
BENJAMIN, W. "Sobre o Conceito de História”. In: Walter Benjamin: Magia e técnica, arte e política (Obras Escolhidas). Trad. Sergio Paulo Rouanet. São Paulo: brasiliense, 1996c.

BENJAMIN, W. "O Narrador". In: Walter Benjamin: Magia e técnica, arte e política (Obras Escolhidas). Trad. Sergio Paulo Rouanet. São Paulo: brasiliense, 1996d.

BENJAMIN, W. "Franz Kafka”. In: Walter Benjamin: Magia e técnica, arte e política (Obras Escolhidas). Trad. Sergio Paulo Rouanet. São Paulo: Brasiliense, 1996e.

BENJAMIN, W. "Pequena história da fotografia". In: Walter Benjamin: Magia e técnica, arte e política (Obras Escolhidas). Trad. Sergio Paulo Rouanet. São Paulo: brasiliense, $1996 f$.

BENTES, Ivana (Org.). Glauber Rocha: cartas ao mundo. São Paulo: Companhia das Letras, 1997.

BERGALA, Alain. La hipótesis del cine: pequeño tratado sobre la transmissión del cine en la escuela y fuera de ella. Trad. do francês para o espanhol: Núria Aidelman e Laia Colell. Barcelona: Laertes, 2007.

BERGALA, Alain. Nadie como Godard. Trad. do francês para o espanhol: Jos Oliver. Barcelona: A \& M Gràfic, 2003.

BÍBLIA. “Apocalipse”. In: A Bíblia de Jerusalém. São Paulo: Paulinas, 1985.

BIRAL, Daniel. "Alunos de escolas ocupadas querem usar aula voluntária para abonar dias letivos". Entrevista concedida à Empresa Brasil de Comunicação S/A ECB, disponível em: http://agenciabrasil.ebc.com.br/educacao/noticia/201511/alunos-de-escolas-ocupadas-querem-usar-aula-voluntaria-para-abonar-dias.

Site consultado em 10 de dezembro de 2015.

BORDWELL, David. "O cinema clássico hollywoodiano: normas e princípios narrativos". In: RAMOS, Fernão Pessoa (Org.). Teoria contemporânea do cinema: documentário e narratividade ficcional. Trad. Fernando Mascarello. São Paulo: SENAC, 2005, vol. II.

BORGES, Jorge Luis. “O outro”. In: O livro de areia. São Paulo: MEDIAfashion, 2012.

BORGES, Jorge Luis. "Pierre Menard, Autor de Quixote”. In: Ficções. Trad. Carlos Nejar. Porto Alegre: Globo, 1972.

BOURDIEU, Pierre. A distinção: crítica social do julgamento. Trad. Daniela Kern e Guilherme J. F. Teixeira. São Paulo: EDUSP; Porto Alegre: Zouk, 2008.

BRASIL, 2006. Orientações Curriculares para o Ensino Médio. Brasília. Ciências Humanas e suas Tecnologias, vol. 3. Ministério da Educação, Secretaria de educação Básica (MEC/SEF), 133 p.

BUCCI, Eugênio \& KEHL, Maria Rita. Videologias. São Paulo: Boitempo, 2009. 
CABRERA, Julio \& TIBURI, Marcia. Diálogo/Cinema. São Paulo: SENAC, 2013.

CAKOFF, Leon. Os filmes da minha vida (vol. 3). São Paulo: Imprensa Oficial do Estado de São Paulo; Mostra Internacional de São Paulo, 2011.

CAMARGO, Luis F. Espíndola \& AGUIAR, Fernando. "Foucault e Lacan: o sujeito, o saber e a verdade". In: Rev. Filos.: Curitiba, 2009, vol. 21, n. 29, pp. 531-544.

CAMARG0, Paula de. "Mal-estar docente". Revista Escola Pública, 2015, ed. 47, Out/Nov., $2015 . \quad$ Disponível em: http://revistaescolapublica.com.br/textos/35/mal-estar-docente-300042-1.asp.

Acesso dia 09 de junho de 2016.

CAMPOS, GISLANE \& SERIACOPI, Reinaldo. História Geral. São Paulo: Ática, 2005.

CANGUILHEM, Georges. O normal e o patológico. Trad. Mana Thereza. Rio de Janeiro: Forense Universitária, 2002.

CARMO, Paulo Sérgio do. Merleau-Ponty: uma introdução. São Paulo: EDUC, 2000.

CAZUZA/FREJAT. Maior Abandonado. Música. Som Livre, 1984. Álbum Maior Abandonado. Estúdios da Sigla, Rio de Janeiro.

CHAUI, Marilena. Convite à Filosofia. São Paulo: Ática, 1997.

CHAUI, Marilena et all. A criação histórica. Porto Alegre: Artes e Ofícios, 1992.

CHAUI, Marilena. Resistência e Conformismo: aspectos da cultura popular no Brasil. São Paulo: Brasiliense, 1985.

CIRINO, Oscar. Psicanálise e Psiquiatria com crianças: desenvolvimento ou estrutura. Belo Horizonte: Autêntica, 2001.

CITELLI, Adilson. "Imagens e representações dos professores: situando o problema”. Imagens do professor na mídia. In: CITELLI, Adilson (Org.). São Paulo: Paulinas, 2012, pp. 09-17.

CITELLI, Adílson Odair \& COSTA, Maria Cristina Castilho. (Org.). Educomunicação: construindo uma nova área de conhecimento. São Paulo: Paulinas, 2011.

CITELLI, Adilson. Palavras, meios de comunicação e educação. São Paulo: Ed. Cortez, 2006.

COELHO, J. T. apud Americanos sabem jogar com as paixões positivas. Folha de São Paulo. Disponível em: http://www1.folha.uol.com.br/folha/mundo/ult94u29275.shtml. Acessado em: 10/04/2016.

COLI, Jorge. "A espiritualidade da arte". Debate como parte de atividade Café Filosófico. São Paulo, 30 de novembro de 2009. Disponível em: http://www.institutocpfl.org.br/cultura/2009/11/30/integra-a-espiritualidade- 
da-arte-jorge-coli/.

COLI, Jorge. O que é arte. 15a . ed. São Paulo: brasiliense, 2006.

DANEY, Serge. "O therrorisado: pedagogia godardiana". In: DANEY, Serge. $A$ Rampa: cahiers du cinema. Trad. Marcelo Rezende. São Paulo: Cosacnaify/Mostra Internacional de Cinema, 2007.

DEBORD, Guy. A sociedade do espetáculo. Trad. http://www.terravista.pt/sociedade. Projeto Periferia, publicação digital. Editoração eBook e eBookBrasil.com, disponível em: http://www.cisc.org.br/portal/biblioteca/socespetaculo.pdf, acessado em 30 e janeiro de 2016.

DELEUZE, Gilles. Empirismo e Subjetividde. 2ª ed. Trad. Luiz B. L. Orlandi. São Paulo: 34, 2012.

DELEUZE, Gilles. Lógica do Sentido. Trad. Luiz Roberto Salinas Fortes. São Paulo: Perspectiva, 2007a.

DELEUZE, Gilles. Francis Bacon: lógica da sensação. Trad. (Coord.) Roberto Machado. Rio de Janeiro: Zahar, 2007b.

DELEUZE, Gilles. Conversações. Trad. Peter Pál Pelbart. São Paulo: Ed. 34, 2004.

DELEUZE, Gilles. "As potências do falso". In: Imagem-Tempo. Trad. Eloisa de Araújo Ribeiro. São Paulo: Brasiliense, 1990, p. 155-188.

DEWEY, John. Arte como experiência. Trad. Vera Ribeiro. São Paulo: Martins Martins Fontes, 2010.

DUBOIS, Philippe. Cinema, vídeo, Godard. Trad. Mateus Araújo Silva. São Paulo: CasacNaify, 2004.

DUNKER, Christian Ingo Lenz\& RODRIGUES, Ana Lucilia. "Fazer cinema, fazer psicanálise”. In: DUNKER, Christian Ingo Lenz \& RODRIGUES, Ana Lucilia. (Org.), 2ª . ed.. Coleção Cinema e Psicanálise. São Paulo: nVersos, 2015, p. 13-27.

DUNKER, Christian Ingo Lenz. "Zizek: um pensador e suas sombras". In: Marx: a criação destruidora. Curso de Introdução à obra de Slavoj Zizek. São Paulo: Boitempo, 2013, p. 37-63.

DUNKER, Christian Ingo Lenz. As transformações do sofrimento psíquico. Palestra proferida em 22 de outubro de 2012. Programa Café Philosofico, TV Cultura. Disponível em: http://www.institutocpfl.org.br/cultura/2012/10/22/christiandunker-as-transformacoes-do-sofrimento-psiquico-2/. Acesso dia 04 de julho de 2016.

DUVE, Thierry de. Sintoma e intuição. Edição e tradução de Tina Montenegro. Entrevista de Thierry de Duve a Afonso Luz, Thais Rivitti, Tiago Mesquita e Tina 
Montenegro. Revista Novos Estudos. n. 79, Novembro de 2007, p. 211-226.

EAGLETON, Terry. Ideologia. Trad. Silvana Vieira e Luís Carlos Borges. São Paulo: Boitempo/UNESP, 1997.

FARIA, Ernesto. Dicionário Escolar Latino-Português. Rio de Janeiro: MEC/Artes Gráficas Gomes de Souza S/A, 1962.

FAVARETTO, Celso Fernando. Ensino de filosofia: por uma mediação filosófica. Educabrasil.com: entrevista concedida a Ebenezer Takuno Menezes e publicada em 02 de outubro de 2001. Disponível em: http://www.educabrasil.com.br/ensinode-filosofia-por-uma-mediacao-pedagogica/. Acesso em 19 de maio de 2016.

FAVARETTO, Celso Fernando. "Arte e conhecimento". In: CUNHA, Daiane S. S. da; MELO, Desirée Paschoal de; GOMES, Érica Dias; CEBULSKI, Márcia Cristina. (Orgs.) Arte na Atualidade. Jundiaí-SP: Paco editorial, 2015, p. 19-33.

FAVARETTO, Celso Fernando. "Arte contemporânea - opacidade e indeterminação". Revista Rapsódia 8. São Paulo: FFLCH - Departamento de Filosofia - USP, 2014.

FAVARETTO, Celso Fernando. Por entre rastros e restos. Cadernos Benjaminianos, Número especial. Belho Horizonte, 2013, p. 70-76.

FAVARETTO, Celso Fernando. "Deslocamentos: entre a arte e a vida". In: Revista ARS, Ano 8, n. 18, pp. 95-109, 2011.

FAVARETTO, Celso Fernando. "Educar e Avaliar: uma perspectiva contemporânea". In: Revista Educação e Avaliação: série Educação para a Cidadania. Dezembro de 1993.

FAVARETTO, Celso Fernando. "Pós-Moderno na Educação". In: Revista da Faculdade de Educação. São Paulo: EDUSP, vol. 17, p. 121-127, jan./dez./1991.

FERRARA, Lucrecia D 'Alessio. Olhar Periférico. São Paulo: Edusp/Fapesp, 1993.

FILHO, Kléber Mendonça. Crítico, 2008, documentário.

FOUCAULT, Michel. A ordem do discurso. 21a. ed., trad. Laura Fraga de Almeida Sampaio. São Paulo: Loyola, 2011.

FOUCAULT, Michel. "O que é um autor?". In: MICHEL, Foucault. Estética: Literatura e Pintura, Música e Cinema. Ditos \& escritos III. 2ª edição, trad. Inês Autran Dourado. Rio de Janeiro: Forense Universitária, 2009, p. 264-298.

FOUCAULT, Michel. História da Sexualidade: a vontade de saber. 18aㅜ ed., trad. Maria Thereza da Costa Albuquerquee J. A. Guilhon Albuquerque, vol. I. São Paulo: Graal, 2007.

FOUCAUlT, M. “Os intelectuais e o Poder”. In: Microfísica do Poder. , 7a. ed., trad. Roberto Machado. Rio de Janeiro: Graal, 1979. 
FRANÇA, 2001. "Le plan pour des arts et laculture à l'école". Paris: Ministério da Educação da França e Ministério das Comuicações e da Cultura da França, 2001.

FRANCO, Marilia. "Hipótese-Cinema: múltiplos diálogos". Rio de Janeiro: UFRJ, disponível em: http://www.educacao.ufrj.br/artigos/n9/2_hipotese_cinema_e_seus_multiplos_dia logos_8_a_3.pdf, acessado em 10 de setembro de 2014.

FREIRE, Paulo. "A importância do ato de ler". In: FREIRE, Paulo. A importância do ato de ler: em três artigos que se completam. São Paulo: Autores Associados: Cortez, 1981, 23a . edição.

FREITAG, Bárbara. A Teoria Crítica: ontem e hoje. São Paulo: Brasileinse, 2004.

FREITAG, Bárbara. Escola, Estado \& Sociedade. São Paulo: Moraes, 1980, 6ª edição.

FRESQUET, Adriana \& MIGLIORIN, Cezar. "Da obrigatoriedade do cinema na escola: notas para uma reflexão sobre a lei 13.006/14". In: (Org.) FRESQUET, Adriana. Cinema e educação: a Lei 13.006: reflexões, perspectivas e propostas. Disponível em: http://www.redekino.com.br/wpcontent/uploads/2015/07/Livreto_Educacao10CineOP_WEB.pdf

FREUD, Sigmund. "Os que fracasam pelo êxito". In: Freud, Sigmund. Freu: Arte, literatura e os artistas. Trad. Ernani Chaves. Belo Horizonte: 2015 , pp. 233-253.

FREUD, Sigmund. $O$ mal-estar na civilização. Trad. José Octávio de Aguiar Abreu. Rio de Janeiro: Imago, 1997.

GAGNEBIN, Jeanne Marie. "Walter Benjamin não pode ser mais um fetiche cultural". Entrevista concedida ao Diário Oficial do estado de Pernambuco, 26 de janeiro de 2015, disponível em: http://www.suplementopernambuco.com.br/entrevistas/1343-walter-benjaminnao-pode-ser-mais-um-fetiche-cultural.html.

GAGNEBIN, Jeanne Marie. "Do Conceito de Mímesis no Pensamento de Adorno e Benjamin". In: Sete Aulas sobre Linguagem, Memória e História. Rio de Janeiro: Imago, 2005.

GAGNEBIN, Jeanne Marie. "Walter Benjamin ou a História Aberta" (prefácio). In: Walter Benjamin: Magia e Técnica, Arte e Política. São Paulo: Ed. Brasiliense, 1996, vol. I, p. 07-19.

GALLO, Silvio. Subjetividade, ideologia e educação. Florianópolis: Revista Perspectiva, vol. 16, n. 29, p. 133-152, jan./jun. de 1998.

GARCIA, Janaina Pires. Aproximação entre teorias do currículo e cinema. Publicação de julho de 2011. ISSN: 1984-6290. Disponível em: http://www.educacaopublica.rj.gov.br/biblioteca/educacao/0296.html. Acesso em 04 de janeiro de 2016. 
GODARD, Jean-Luc. Godard, Jean-Luc. (Org.) ROSEMBERG, Luis Filho. Rio de Janeiro: Taurus, 1986.

GOMES, Paulo Emílio Sales. Jean Vigo. São Paulo: Cosac Naify / SESC-SP, 2009.

GOMES, Paulo Emílio Sales. Cinema: trajetória no subdesenvolvimento. São Paulo: Paz e Terra, 1996.

GOMES, Paulo Emílio Sales. In: (Org.) CALIL, Carlos Augusto \& MACHADO, Maria Teresa. Paulo Emílio: um intelectual na linha de frente. São Paulo/Rio de Janeiro: EMBRAFILME/Ministério da Cultura, 1986.

GOMES, Paulo Emílio Sales. Crítica de cinema no suplemento literário II. Rio de Janeiro: Paz e Terra/EMBRAFILME, 1981.

GOMBRICH, E. H. Arte e ilusão: um estudo da psicologia da representação pictórica. Trad. Raul de Sá Barbosa. São Paulo: Martins Fontes, 1986.

GUÉRON, Rodrigo. Da imagem ao clichê, do clichê à imagem: Deleuze, cinema e pensamento. Rio de Janeiro: NAU, 2011.

HABERMAS, Jürgen. Técnica e ciência como ideologia. Trad. Artur Morão. Lisboa: Edições 70, 1987.

HORKHEIMER, Max. "O Conceito de iluminismo". In: Textos escolhidos: HORKHEIMER \& ADORNO. Trad. Zeljko Loparic e Andréa Maria Altino de Campos Loparic. São Paulo: Nova Cultural, 1991.

IAVELBERG, Rosa. $O$ ensino das artes nas escolas do século XXI. Entrevista conceida a Marcus Tavares. Revista Pontocom. Disponível em: http://revistapontocom.org.br/edicoes-anteriores-entrevistas/o-ensino-da-artenas-escolas-do-seculo-xxi. Acesso em 23 de maio de 2016.

IBSEN, Henri. Casa de Bonecas. São Paulo: Nova Cultura, 2003.

INGLATERRA. Using film in schools: a practical guide. Londres: UK Film, Council, FilmClub, Media Education Wales, 2010. Introdução de Adam Cooper e demais textos de Tom Barrance.

JIMENEZ, Marc. O que é estética? Trad. Fulvia M. L. Moretto. São Leopoldo, RS: UNISINOS, 1999.

JIMENEZ, Marc. Para ler Adorno. Trad. Roberto Ventura. Rio de Janeiro: Francisco Alves, 1977.

KANT, Immanuel. "Resposta à Pergunta: Que é Esclarecimento?" In: Immanuel Kant: Textos Seletos. 2a . edição. Trad. Floriano de Sousa Fernandes. Petrópolis-RJ: Vozes, 1985, p. 100-117.

KEHL, Maria Rita. Mulheres em Transformação e homens em crise. Palestra dentro da programação do Café Filosófico. São Paulo: TV Cultura. Disponível em: 346 
https://www.youtube.com/watch?v=b_K5BEdxCAc. Acesso dia 09 de janeiro de 2015a (não encontrei esse vídeo no site oficial).

KEHL, Maria Rita. $O$ Capitalismo como religião. Palestra de lançamento do livro $O$ Capitalismo como religião. São Paulo: Ed. Boitempo, 2013. Disponível em: https://www.youtube.com/watch?v=4st9V8wnayY, acesso dia 11 de janeiro de 2015b.

KEHL, Maria Rita. Seminários promovidos pela II Trupe de Choque, no CAISM Philippe Pinel. Parte do processo Corpos Acumulados. São Paulo, 11 setembro de 2009b. Disponível em: https://www.youtube.com/watch?v=l1iJvo7V3oQ. Acesso em 15 de julho de 2015c.

KEHL, Maria Rita. O tempo e o cão: a atualidade das depressões. São Paulo: Boitempo, 2009.

KEHL, Maria Rita. Sobre Ética e Psicanálise. São Paulo: Companhia das Letras, 2002, 5‥ Edição.

KIAROSTAMI, Abbas. Abbas Kiarostami: duas ou três coisas que sei de mim. Trad. de Alvaro Machado. São Paulo: Cosac Naify; Mostra Internacional de São Paulo, 2004.

KRACAUER, Siegfried. "As pequenas balconistas vão ao cinema". In: O Ornamento da massa: ensaios. Trad. Carlos Eduardo J. Machado e Marlene Holzhausen. São Paulo: Cosac Naif, 2009a, p. 311-326.

KRACAUER, Siegfried. "Sobre os escritos de Walter Benjamin". In: O Ornamento da massa: ensaios. Trad. Carlos Eduardo J. Machado e Marlene Holzhausen. São Paulo: Cosac Naif, 2009b, p. 279-285.

KULLOK, Maisa Gomes Brandão. Formação de Professores para o próximo milênio: novo lócus? São Paulo: Annablume, 2000.

KUPFER, Maria Cristina. “O Sujeito na Psicanálise e na Educação: bases para a educação terapêutica". In: Educação \& Realidade. Revista de jan/abr de 2010, p. 265-281.

LACAN, Jacques. O Seminário XI: os quatro conceitos fundamentais da psicanálise (1964). Trad. M. D. Magno. Rio de Janeiro: Zahar, 2008.

LACAN, Jacques. Seminário X: A Angústia (1962-1963). Trad. Vera Ribeiro. Rio de Janeiro: Jorge Zahar, 2005.

LACAN, Jacques. "Para além do 'Princípio de realidade'”. In: Escritos. Trad. Vera Ribeiro. Rio de Janeiro: Jorge Zahar, 1998.

LACAN, Jacques. O Seminário VIII: A Transferência (1960-1961). Trad. D. D. Estrada. Rio de Janeiro: Jorge Zahar, 1992.

LAJONQUIÈRE, Leandro de. Figuras do Infantil. São Paulo: Vozes, 2010. 
LAJONQUIÈRE, Leandro de. "(Psico) Pedagogia, Psicanálise e Educação: uma aula introdutória”. São Paulo: Revista Estilos da Clínica. Vol. 3, N. 5, 1998, p. 120-134.

LANG, Jack. Discours public: les discours dans l'actualité. Conferência à imprensa sobre as orientações para uma política das artes e da cultura na escola (Conférence de presse sur les orientations pour une politique des arts et de la culture à l'école à Paris le 14 décembre 2000). Paris, 14 de dezemebro de 2000. Disponível em: http://discours.vie-publique.fr/notices/003003427.html. Acesso em 18 de maio de 2016.

LASCH, Christopher. O mínimo eu: sobrevivência psíquica em tempos difíceis. Trad. João Roberto Martins Filho. São Paulo: brasiliense, 1986.

LAZARSFELD, Paul F. \& MERTON, Robert K. “Comunicação de massa, gosto popular e ação social organizada". In: COHN, Gabriel (org.). Comunicação e indústria cultural: leituras de análise dos meios de comunicação na sociedade contemporânea e das manifestações de massa nessa sociedade. São Paulo: Cia. Editora Nacional e Editora da USP, 1971. p. 232-253.

LEBRUN, J-P. Um Mundo sem Limite. Rio de Janeiro: Companhia de Freud, 2004, pp. 71 ss.

LOPES, Alice Casimiro. Discursos nas políticas de currículo. Revista: Currículo Sem Fronteiras, v. 6, n. 2, pp. 33-52, jul/Dez 2006, disponível em SSN 1645-1384 (online) www.curriculosemfronteiras.org. Acesso em 5 de dezembro de 2015.

LYOTARD, Jean-François. O pós-moderno explicado às crianças. Trad. Tereza Coelho, 2ª . edição. Lisboa: Publicações Dom Quixote, 1993.

MACIEL, Kátia. "A Última imagem". In: PARENTE, André (Org.). A Imagem Máquina: a era das tecnologias do virtual. Rio de Janeiro: Ed. 34, 1993.

MCLUHAN, Marshal. Os meios de comunicação como extensões do homem. Trad. de Décio Pignatari. São Paulo: Cultrix, 2009.

MARTÍN-BARBER0, Jesús. Dos meios às mediações: comunicação, cultura $e$ hegemonia. 4⿳亠丷a . edição, trad. de Ronald Polito e Sérgio Alcides. Rio de Janeiro: UFRJ, 2008.

MATHIELSON, Louisa Campbell. $O$ militante e o pedagogo Antonio de Sampaio Doria: a formação do cidadão republicano. Dissertação de mestrado - Faculdade de Educação - Universidade de São Paulo, 2012.

MERLEAU-PONTY, Maurice. O olho e o espírito. Trad. Paulo Neves e Maria Ermantina Galvão Gomes Pereira. São Paulo: Cosac \& Naif, 2004.

MOGADOURO, Claudia. Educomunicação e escola: o cinema como mediação possível (desafios, práticas e propostas). Tese de doutorado - Escola de Comunicações e Artes - ECA, Universidade de São Paulo, 2011, 428p. 
MORETTIN, Eduardo. Humberto Mauro, cinema, história. São Paulo: Univesp, 2013.

NAPOLITANO, Marcos. Como usar o cinema na sala de aula. São Paulo: Contexto, 2003.

NASIO, J.-D. 5 Lições sobre a teoria de Jacques Lacan. Trad. Vera Ribeiro. Rio de Janeiro: Jorge Zahar, 1993.

NOMA, Amélia Kimiko. "A Pesquisa Histórica em Educação com Fontes Audiovisuais". In: (org.) SCHELBAUER, Anabele Regina et al. Educação em Debate. Campinas-SP: Ed. Autores Associados, 2006, p. 257-275.

OITICICA, Hélio. Encontros: Hélio Oiticica. Rio de Janeiro: ed. azougue, 2009.

OTTE, Georg. "Vestígios da experiência e índices da modernidade". In: SEDLMAYER, Sabrina \& GINZBURG, Jaime (Orgs.). Walter Benjamin: rastro, aura e história. Belo Horizonte: UFMG, 2012, p. 61-85.

PASOLINI, Pier Paolo. In: BERTOLUCCI, Giuseppe. Pasolini Próximo Nosso (Pasolini Prossimo Nostro). Filme. Itália/França, 2006, cor, 63 min., entrevista com Pasolini.

PIAGET, Jean. Psicologia e Pedagogia. SP/RJ: Editora Forense, 1970.

POUND, Ezra. $A B C$ da Literatura. Trad. Augusto de Campos e José Paulo Paes. São Paulo: Cultrix, 2013.

PIRES, Eloíza Gurgel. "Experiência e linguagem em Walter Benjamin". In: Educação e Pesquisa. Revista de Educação da Faculdade de Educação da USP, vol. 40, n. 03, Julho/Setembro de 2014, pp. 813-828. Disponível em: http://www.scielo.br/scielo.php?pid=S1517-

97022014000300015\&script=sci_arttext. Acesso em 05 de abril de 2015.

RANCIÈRE, Jacques. "Mouchete e os paradoxos da língua das imagens". In: As Distâncias do cinema. Trad. Estela dos Santos Abreu. Rio de Janeiro: Contraponto, 2012, p. 53-81.

RIZZO, Sérgio. Documentário registra uma seleção de 12 curtas realizados por alunos de escolas públicas. In: Revista Educação. Março de 2015. Disponível em: http://revistaeducacao.uol.com.br/textos/215/dez-anos-na-teladocumentarioregistra-uma-selecao-de-12-curtas-339102-1.asp, acesso dia 07 de abril de 2015.

ROCHA, Glauber. Revisão crítica do cinema brasileiro. São Paulo: Cosac \& Naif, 2003.

ROMANELLI, Otaíza Oliveira. História da Educação no Brasil: 1930/1973. 8ª . ed. Petrópolis: Vozes, 1986.

ROSE, Nikolas. "Governando a alma: a formação do eu privado." In: SILVA, Tomaz Tadeu da (org.). Liberdades Reguladas. Petrópolis: Vozes, 1988, p. 30-45.

ROUDINESCO, Elizabeth. Por que a Psicanálise. Trad. Vera Ribeiro. Rio de Janeiro: Jorge Zahar, 2000. 
ROUSSEAU, Jean-Jacques. "Discurso sobre as ciências e as artes". In: Rousseau (vol. II). Trad. Lourdes Santos Machado. São Paulo: Nova Cultural, 1988, p. 133-156.

SAFATLE, Vladimir. Introdução à experiência Intelectual de Gilles Deleuze, Primeiro semestre de 2012, Total de 11 aulas exibidas pelo Departamento de Filosofia da USP e publicada no site do mesmo departamento (http://filosofia.fflch.usp.br/docentes/safatle/aulas_grad). Acesso em 12 de Agosto de 2014.

SAFATLE, Vladimir. A paixão do negativo: Lacan e a dialética. São Paulo: UNESP, 2006.

SALIBA, Elias Thomé. "A produção do conhecimento histórico e suas relações com a narração fílimica". In: SÃO PAULO. Secretaria de Educação do Estado de São Paulo. 2 ${ }^{a}$. edição. Coleção Lições com cinema. A produção do conhecimento histórico e suas relações com a narração fílimica. São Paulo: FDE, 1993.

SALLES, João Moreira. "Elogio da superfície”. In: CAKOFF, Leon (Org.). Os filmes da minha vida 3. São Paulo: Imprensa Oficial do Estado de São Paulo / Mostra Internacional de Cinema de São Paulo, 2011, p. 72-101.

SÃO PAULO (ESTADO). Secretaria da Educação. Currículo do Estado de São Paulo: Linguagens, códigos e suas tecnologias / Ensino Fundamental - ciclo II e Ensino Médio, Secretaria de Educação - SE; Coordenação geral: Maria Inês Fini; coordenação de área: Alice Vieira, 2012. São Paulo: Secretaria de Educação. 2a edição, 260 p.

SÃO PAULO (ESTADO). Material de apoio ao Currículo do Estado de São Paulo: caderno do professor; arte, ensino médio. 1a. série / Coordenação geral, Maria Inês Fini; equipe, Geraldo de Oliveira Suzigan, Gisa Picosque, Jéssica Mami Makino, Miirian Celeste Martins, Sayonara Pereira. São Paulo: Secretaria de Educação - SE, 2014, vol. 1, 88 p.

SÃo PAUlO (ESTADO). Censo escolar do Estado de São Paulo: Informe 2012. Secretaria da Educação do Estado de São Paulo. Centro de Informações Educacionais, Anos: 2012, 2013 e 2014.

SÃO PAUlO (ESTADO). Proposta Curricular do Estado de São Paulo - Arte: Ensino Fundamental Ciclo II e Ensino Médio. Secretaria da Educação do Estado de São Paulo, 2008.

SÃO PAULO, Cadernos de Cinema do Professor. Secretaria da Educação do Estado de São Paulo, 2008 e 2010.

SARAIVA, Luiz Alex Silva; SOLANGE, Maria Pimenta \& Maria Laetitia Corrêa. Dimensões dos discursos em uma empresa têxtil mineira. Revista de Administração Contemporânea - RAC. Rio de Janeiro: v. 8, n. 4, Out./Dez., 2004, p. 57-79. 
SARAMAGO, José. Janela da Alma. Filme dirigido por João Jardim e Walter Carvalho. Ano: 2001. Europa Filmes.

SARAMAGO, José. O conto da ilha desconhecida. São Paulo: Companhia das Letras, 1998.

SARTRE, Jean-Paul. “Que é escrever?”. In: SARTRE-, Jean-Paul. Trad. Carlos Felipe Moisés. Que é literatura? Petrópolis, RJ: Vozes, 2015, p. 15-37.

SARTRE, Jean-Paul. Esboço para uma teoria das emoções. Trad. Paulo Neves. Porto Alegre: L\&PM, 2007.

SCHVARZMAN, Sheila. Humbero Mauro e as imagens do Brasil. São Paulo: UNESP, 2004.

SCHWARTZMAN, Simon; BOMENY, Helena Maria Bousquet \& COSTA, Vanda Maria Ribeiro. Tempos de Capanema. Rio de Janeiro: Paz e Terra; São Paulo: EDUSP, 1984.

SERRANO, Jonathas; VENÂNCIO FILHO, Francisco. Cinema e educação. São Paulo: Cayeiras, 1930.

SILVA, Tomaz Tadeu. "A produção social da identidade e da diferença". In: SILVA, Tomaz Tadeu (Org.). Identidade e Diferença. São Paulo: Vozes, 2009, p. 73-102.

SIMIS, Anita. Estado e cinema no Brasil. São Paulo: Unesp, 2015.

SOCINE, 2010, Bruno Hingst, Filme histórico: novas formas de circulação $e$ ampliação de público.

SOARES, Ismar de Oliveira. Educomunicação: o conceito, o profissional, a aplicação. São Paulo: Paulinas, 2011, 2ª edição.

SOUSA, Daniel Marcolino Claudino de \& MARTINS, Ferdinando Crepalde. Relatório do Comitê de Adaptação do Currículo da UNESCO para Formação em Alfabetização Midiática e Informacional, 2015.

SOUZA, C. R. de. (Org.) Catálogo Filmes produzidos pelo INCE. Rio de Janeiro: Fundação Cinema Brasileiro, Ministério da Cultura, 1990. (Série Documentos).

STAM, Robert. Introdução à teoria do cinema. Trad. Fernando Mascarello. Campinas: Papirus, 2003.

TARKOVSKI, Andrei. Esculpir o tempo. Trad. Jefferson Luiz Camargo e Luís Carlos Borges. São Paulo: Martins Fontes, 1990.

TEIXEIRA, Anísio. Educação não é privilégio. Rio de Janeiro: José Olympio, 1957.

TERRA, Ricardo. A questão filosófica mais importante é sempre uma questão do presente. Entrevista. Revista Idéia: UNICAMP, 2012, v. 3, n. 1 (4), pp. 334-356. 
TODOROV, Tzvetan. A Literatura em Perigo. 2ª ed., Trad. Cairo Meira. Rio de Janeiro: DIFEL, 2009.

TODOROV, Tzvetan. O Espírito das luzes. Trad. Mônica Cristina Corrêa. São Paulo: Barcarolla, 2008.

TOZZI, Devanil et al (org.). Caderno de Cinema do Professor. São Paulo: Secretaria de Educação, FDE, 2008, vol. 1.

TOZZI, Devanil et al (org.). Caderno de Cinema do Professor. São Paulo: Secretaria de Educação, FDE, 2009, vol. 2.

TOZZI, Devanil; DANTAS, Eva Maragarth\& BOCALINI, Marilena(org.). Caderno de Cinema do Professor. São Paulo: Secretaria de Educação, FDE, 2009, vol. 3.

TOZZI, Devanil \& DANTAS, Eva Maragarth (org.). Caderno de Cinema do Professor. São Paulo: Secretaria de Educação, FDE, 2010, vol. 4.

VANOYE, Francis \& GOLIOT-LÉTÉ, Anne. Ensaio sobre a Análise Fílmica. Trad. Marina Appenzeller. Campinas, SP: Papirus, 1994.

VEIGA-NETO, Alfredo. "Michel Foucault e Educação: há algo de novo sob o sol?". In: Crítica Pós-Estruturalista e Educação. Porto Alegre: ed. Sulina, 1995, p. 9-56.

VICENTIN, Marcelo. 0 cinema vai à escola: um papel para diferentes personagens (relações entre currículo(s), cultura(s) e identidade(s)). Dissertação de mestrado, 2013. Universidade São Francisco, Itatiba, São Paulo. 175p.

VIEIRA, Carlos Eduardo. "O Discurso da modernidade na I Conferência Nacional de Educação (Curitiba, 1927)”. In: Sociedade Brasileira de História da Educação, 2004. III Congresso Brasileiro de História da Educação. Disponível em: http://sbhe.org.br/novo/congressos/cbhe3/Documentos/Individ/Eixo3/244.pdf. Acesso em 29 de Dezembro de 2014.

VOLTOLINI, Rinaldo. "O Conhecimento e o Discurso do Capitalista: a Despsicologização do Cotidiano Social”. In: Estilos da Clínica. São Paulo, 2012, 17(1), 106-121, p. 108.

VOLTOLINI, Rinaldo. Lacan e a educação. Col. Pensadores e a Educação. São Paulo: ed. ATTA, 2011. Vídeo instrucional (duração de 33 min.).

VOLTOLINI, Rinaldo. "A síndrome da D'existência: o educador em tempos de fracasso". In: MARIGUELA, Márcio, CAMARGO, Ana Maria Faccioli de \& SOUZA, Regina Maria de. (Orgs.). Que Escola é Essa?São Paulo: Alínea e Átomo, 2009.

VOLTOLINI, Rinaldo. "Ensino e Transmissão: duas posições na linguagem". In: BEHARES, Luiz Ernesto \& GIMÉNEZ, Raumar Rodríguez (org.). Cuerpo, Lenguaje y Enseñanza. 2008, p. 181-192. CIDADE: Universidad de la República, 2008.

VOLTOLINI, Rinaldo. "Psicanálise e inclusão escolar: direito ou sintoma?". In: Revista Estilos da Clínica: 2004, vol IX, n. 16, p. 92-101. 
WENDERS, Wim. "Amo filmes que deixam lacunas entre as imagens". In: CAKOFF, Leon (Org.). Os filmes da minha vida 3. São Paulo: Imprensa Oficial do Estado de São Paulo / Mostra Internacional de Cinema de São Paulo, p. 10-33.

WÖLFFLIN, Heinrich. Conceitos Fundamentais da História da Arte. Trad. João Azenha Jr. São Paulo: Martins Fontes, 2006

XAVIER, Ismail. $O$ discurso cinematográfico: a opacidade e a transparência. São Paulo: Paz e Terra, 2005, 3a. edição.

XAVIER, Ismail. Prefácio à edição brasileira. In: CHARNEY, Leo \& SCHWARTZ, Vanessa R. O cinema e a invenção da vida moderna. Trad. Regina Thompson. 2. ed. São Paulo: Cosac Naify, 2004, p. 9-15.

XAVIER, Ismail. O olhar e a cena. São Paulo: Cosac \& Naify, 2003

XAVIER, Ismail. 0 cinema brasileiro moderno. 2ª ed. São Paulo: Paz e Terra, 2001.

XAVIER, Ismail. Sétima Arte: um culto moderno. São Paulo: Perspectiva, 1978.

ZIZEK, Slavoj. Bem-Vindo ao Deserto do Real. Trad. Paulo Cezar Castanheira. São Paulo: Boitempo Editorial, 2003. Também disponibilizado pela editora em: http://controversia.com.br/wp-content/uploads/2015/04/ZIZEK-Slavoj.-BemVindo-Ao-Deserto-Do-Real.pdf.

ZIZEK, Slavoj. Em defesa das causas perdidas. 2ª. ed., trad. Maria Beatriz de Medina. São Paulo: Boitempo, 2012.

ZIZEK, Slavoj. Eles não sabem o que fazem: o sublime objeto da ideologia. Trad. do francês: Vera Ribeiro. Rio de Janeiro: Jorge Zahar, 1990. 
